\title{
Punitive damages: the civil remedy in American law, lessons and caveats for continental Europe
}

Citation for published version (APA):

Meurkens, R. C. (2014). Punitive damages: the civil remedy in American law, lessons and caveats for continental Europe. [Doctoral Thesis, Maastricht University]. Wolters Kluwer Business. https://doi.org/10.26481/dis.20141219rm

Document status and date:

Published: 01/01/2014

DOI:

10.26481/dis.20141219rm

Document Version:

Publisher's PDF, also known as Version of record

\section{Please check the document version of this publication:}

- A submitted manuscript is the version of the article upon submission and before peer-review. There can be important differences between the submitted version and the official published version of record.

People interested in the research are advised to contact the author for the final version of the publication, or visit the DOI to the publisher's website.

- The final author version and the galley proof are versions of the publication after peer review.

- The final published version features the final layout of the paper including the volume, issue and page numbers.

Link to publication

\footnotetext{
General rights rights.

- You may freely distribute the URL identifying the publication in the public portal. please follow below link for the End User Agreement:

www.umlib.nl/taverne-license

Take down policy

If you believe that this document breaches copyright please contact us at:

repository@maastrichtuniversity.nl

providing details and we will investigate your claim.
}

Copyright and moral rights for the publications made accessible in the public portal are retained by the authors and/or other copyright owners and it is a condition of accessing publications that users recognise and abide by the legal requirements associated with these

- Users may download and print one copy of any publication from the public portal for the purpose of private study or research.

- You may not further distribute the material or use it for any profit-making activity or commercial gain

If the publication is distributed under the terms of Article $25 \mathrm{fa}$ of the Dutch Copyright Act, indicated by the "Taverne" license above, 


\section{Punitive Damages}

The Civil Remedy in American Law, Lessons and Caveats for Continental Europe 



\section{PUNITIVE DAMAGES}

The Civil Remedy in American Law, Lessons and Caveats for Continental Europe

\section{PROEFSCHRIFT}

ter verkrijging van de graad van doctor aan de Universiteit Maastricht, op gezag van de Rector Magnificus, prof. dr. L.L.G. Soete, volgens het besluit van het College van Decanen, in het openbaar te verdedigen op vrijdag 19 december 2014 om 14.00 uur

door

Renée Charlotte Meurkens

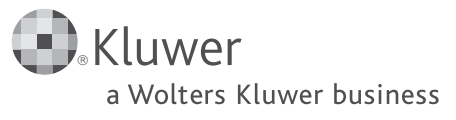

Deventer - 2014 


\section{Promotores:}

Prof. mr. T. Hartlief

Prof. mr. G.E. van Maanen

\section{Beoordelingscommissie:}

Prof. dr. M.G. Faure (voorzitter)

Prof. mr. C.C. van Dam (King's College London/Universiteit Utrecht)

Prof. mr. J.H.M. van Erp

Prof. mr. I. Giesen (Universiteit Utrecht)

Prof. mr. J.M. Smits 


\section{TABLE OF CONTENTS}

\section{Chapter One \\ Introduction}

1.1 The Subject Matter

1.2 Problem Statement and Research Questions

$\begin{array}{ll}1.3 & \text { Limits of the Research } \\ \end{array}$

1.4 Scope of the Research 6

1.5 General Overview of the Structure 8

\section{Chapter Two}

The Punitive Damages Remedy in American Law: Background

$\begin{array}{lll}2.1 & \text { Introductory Remarks } & 13\end{array}$

2.2 The American Setting 14

2.2.1 The Complexity of American Law 14

2.2.2 The Importance of American Law for this Research 14

2.2.2.1 The American Governmental, Legislative and Judicial System 20

2.2.2.2 The Role of the Civil Justice System 23

2.2.3 The American Civil Justice System Put into Context 29

2.2.3.1 An Excessive Litigation System? 30

2.2.3.2 Adversarial Legalism 31

$\begin{array}{lll}2.2 .3 .3 & 32\end{array}$

$\begin{array}{ll}2.2 .3 .4 & 32 \\ 2.2 .3 .5 & \text { Litigation Costs }\end{array}$

$\begin{array}{lll}2.2 .3 .5 & \text { Legal Aid } & 34\end{array}$

2.2.3.6 Class Actions $\quad 34$

$\begin{array}{lll}2.2 .3 .7 & \text { Liability Insurance } & 38\end{array}$

2.2.4 The Position of Punitive Damages in American Law 39

2.3 History, Theory and Purposes of Punitive Damages 41

2.3.1 Short Historical Overview 41

2.3.2 Nature and Theory 42

2.3.3 Purposes 45

2.3.4 Punitive Damages from a Law and Economics Perspective 49

2.4 Concluding Remarks 53

\section{Chapter Three}

The American System of Awarding Punitive Damages: When and How

3.1 Introductory Remarks $\quad 55$

3.2 Liability Criteria for Punitive Damages 55 
3.2.1 Types of Actions in Which Punitive Damages May Be Recovered: General Remarks

3.2.2 Exploring the Popular 'Punitive Damages Categories' 57

3.2.3 Nature of Conduct for Which Punitive Damages May Be Awarded

3.2.4 Requirement of Actual Damage 64

3.3 Assessment and Amount of Punitive Damages 65

3.3.1 Discretion of the Jury 65

3.3.2 Judge and Jury Compared 66

3.3.3 Amount of Punitive Damages $\quad 68$

$\begin{array}{lll}\text { 3.3.3.1 Judicial Control of Jury Awards } & 71\end{array}$

$\begin{array}{ll}\text { 3.3.4 Relation to Criminal Punishment } & 71\end{array}$

3.3.5 Persons Entitled to and Liable for Punitive Damages 73

3.3.5.1 Persons Entitled to Recover 73

$\begin{array}{lll}\text { 3.3.5.1.1 Multiple Plaintiffs } & 74\end{array}$

3.3.5.1.2 Sharing or Split-Recovery of Punitive Damages Awards 76

3.3.5.2 Persons Liable $\quad 79$

3.3.5.2.1 Vicarious Liability of the Employer 79

$\begin{array}{ll}\text { 3.3.5.2.2 Multiple Defendants } & 81\end{array}$

$\begin{array}{lll}3.4 & \text { Insurability } & 82\end{array}$

3.5 Concluding Remarks $\quad 86$

\section{Chapter Four}

Acceptance and Control of Punitive Damages in the

American Legal System

4.1 Introductory Remarks $\quad 91$

4.2 Acceptance and Application of Punitive Damages 92

4.2.1 Acceptance in Forty-Five States 92

4.2.2 Application: Is Excessiveness the Key Word? 93

4.2.2.1 American Punitive Damages Awards are not Extreme nor Common 96

$\begin{array}{lll}4.3 & \text { Critique } & 99\end{array}$

4.3.1 Civil Punishment? A Controversial Issue, Also in

the American Legal System

4.3.2 Further Points of Criticism 101

4.3.2.1 Civil Punishment: Lack of Criminal Procedural Safeguards 101

4.3.2.2 Vagueness of Liability Standards Leads to Unpredictable and Excessive Awards 103

4.3.2.3 The 'Windfall-Effect' of Punitive Damages 104

$\begin{array}{lll}\text { 4.3.2.4 Ineffective Deterrence? } & 105\end{array}$

4.3.2.5 Relation to Litigation Costs 106

4.4 Legislative and Judicial Control of Improper Punitive Damages Awards 107

4.4.1 Statutory and Common Law Control 107

4.4.2 Judicial Review: General Remarks 111 
4.4.3 The Constitutionality of Punitive Damages

4.4.4 Punitive Damages Decision-Making by the U.S. Supreme Court

4.4.4.1 The Late 1980s and Early 1990s Decisions

4.4.4.2 The 'Trilogy' of Due Process Cases (Plus One) Decided Between 1996 and 2007

4.4.4.2.1 BMW of North America, Inc. v. Gore 119

4.4.4.2.2 Cooper Industries, Inc. v. Leatherman Tool Group, Inc. 121

4.4.4.2.3 State Farm Mutual Automobile Insurance Co. v. Campbell 123

4.4.4.2.4 Philip Morris USA v. Williams 126

4.4.4.3 The 2008 Decision: Exxon Shipping Co. v. Baker 129

4.5 Concluding Remarks

\section{Chapter Five}

The Punitive Damages Remedy in American Law: a Mid-Term Review

5.1 Introductory Remarks

5.2 A Civil Justice System

5.3 Criticism Has Led to Control Mechanisms 138

$\begin{array}{ll}5.4 & \text { Allegations Concerning Excessiveness Exaggerated } \\ 5.5 & 140\end{array}$

$\begin{array}{ll}5.5 \text { Concluding Remarks } & 144\end{array}$

\section{Chapter Six}

Reasons for the Non-Existence of Punitive Damages in

\section{Continental Europe}

6.1 Introductory Remarks

6.2 There is the Traditional Function of Tort Law... 146

$\begin{array}{lll}6.2 .1 & \text { The Starting Point } & 146\end{array}$

6.2.2 The Functions of Tort Law 150

6.2.2.1 Some Remarks on the Legal History of Tort Law 151

6.2.2.2 Compensation as the Traditional Function 155

6.2.2.3 An Important Additional Function: Deterrence 159

$\begin{array}{lll}\text { 6.2.2.4 Loss-Spreading } & 161\end{array}$

6.2.2.5 Other Functions of Tort Law? 162

6.2.2.6 The Functions of Tort Law According to the PETL and the DCFR 164

6.3 The Division between Public Law and Private Law 168

6.3.1 Undesirable Consequences for the Prosecution Policy 172

6.3.2 Compatibility of Punitive Damages with Criminal Procedural Safeguards 174

6.3.2.1 Compatibility of Punitive Damages with Article 6 ECHR 178

6.3.2.1.1 Blake v. The United Kingdom 180

6.3.2.1.2 When is an Offence a Criminal Charge under Article 6 ECHR? 
6.3.2.1.3 Applying the Three Criteria to the Imposition of Punitive Damages

6.3.2.1.4 Concluding Remarks with regard to Article 6 ECHR 184

6.4 The Role of Government

6.4.1 The Citizen as a Private Attorney General? 189

6.4.2 The Influence of Other Compensation Mechanisms on Civil Litigation

6.4.2.2 Social Security and Social Insurance 191

6.4.3 The Influence of Government Regulation on $\begin{array}{ll}\text { Civil Litigation } & 195\end{array}$

6.4.3.1 An Example from Products Liability Law 195

6.4.3.2 Values Are Influenced by Culture 198

6.4.3.3 The View on Own Responsibility 199

6.4.4 The Influence of Procedural Law Aspects on
Civil Litigation

6.5 Other Reasons for the Non-Existence of Punitive Damages 202

$\begin{array}{ll}\text { 6.5.1 Some Common Additional Reasons against Punitive } & \\ & \text { Damages }\end{array}$

$\begin{array}{lll}\text { 6.6 Concluding Remarks } & 204\end{array}$

Chapter Seven

Private Enforcement and Powerful Civil Sanctions: Causes of the Increased European Interest in Punitive Damages

$\begin{array}{lll}7.1 & \text { Introductory Remarks } & 207\end{array}$

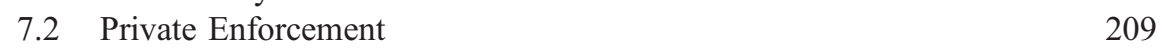

$\begin{array}{lll}\text { 7.2.1 Origin of the Concept } & 210\end{array}$

7.2.2 Increased Attention for Private Enforcement in Europe 213

7.2.3 The Court of Justice of the European Union Takes the Lead...

7.2.4 ...And the European Commission Carries the Work Forward

$\begin{array}{lll}\text { 7.2.4.1 } & \text { The Ashurst Report } & 221 \\ \text { 7.2.4.2 } & \text { The Commission Green Paper } & 224\end{array}$

$\begin{array}{lll}\text { 7.2.4.3 The Commission White Paper } & 226\end{array}$

7.2.4.4 Private Enforcement of Competition Law: Current State of Affairs 230

7.2.5 European Attention for Private Enforcement outside the Field of Competition Law 231

7.2.6 Final Remark 234

$\begin{array}{lll}7.3 \text { Calls for Powerful Civil Sanctions } & 235\end{array}$

$\begin{array}{lll}\text { 7.3.1 Introduction } & 235\end{array}$

7.3.2 Punitive Damages in Specific Tort Situations: Intentional, Calculative and Grave Misconduct 238 
7.3.3 The (Changing) Functions of Tort Law: Compensation is Still the Primary Function 242

7.3.3.1 But... the Deterrent Function of Tort Law Steps In 244

7.3.3.2 Prevention in 'European' Tort Law 245

$\begin{array}{lll}7.4 & \text { Concluding Remarks } & 246\end{array}$

\section{Chapter Eight}

The Status Quo of Punitive Damages Rejection in Europe:

Towards More Liberalness?

8.1 Introductory Remarks

8.2 Punitive Damages Are Not Awarded by the European Court of Human Rights

8.3 The Uncertain and Inconsistent Position of the EU Legislator

8.4 The Court of Justice of the EU Demands 'Effective, Proportionate and Dissuasive' Sanctions

8.5 Punitive Damages from a Private International Law Perspective: Signs of Liberalness

8.6 Concluding Remarks

\section{Chapter Nine}

\section{Existing Civil Sanctions in Four European Legal Systems}

9.1 Introductory Remarks

9.2 Defining the Topic

9.2.1 Relevance in View of the Problem Statement 281

9.2.2 Civil Sanctions

9.3 A General Perspective of Monetary Damages: Compensatory or Non-Compensatory

9.3.1 Compensatory Damages

9.3.2 Damages That Are Not Exclusively Based on Compensation

9.4 Civil Sanctions: an Overview per Legal System

9.4.1.1 Basic Principles of the Law of Damages 290

9.4.1.2 Immaterial Damages 292

9.4.1.3 Disgorgement of Profit 299

9.4.1.4 Contractual Penalty Clause 300

9.4.1.5 Other Non-Compensatory Mechanisms 301

9.4.2 Germany 303

9.4.2.1 Basic Principles of the Law of Damages 303

9.4.2.2 Immaterial Damages 305

9.4.2.2.1 General Legal Basis 308

9.4.2.2.2 Das Allgemeine Persönlichkeitsrecht 310

9.4.2.2.3 Difference between Personality Right Infringements and Personal Injury Cases 
9.4.2.3 Disgorgement of Profit 314

9.4.2.4 Contractual Penalty Clause 314

9.4.2.5 Other Non-Compensatory Mechanisms 315

9.4.3 France 316

9.4.3.1 Basic Principles of the Law of Damages 316

9.4.3.2 Immaterial Damages 320

9.4.3.3 Disgorgement of Profit 322

9.4.3.4 The Concept of Peine Privée 322

9.4.3.5 Punitive Damages Developments in the Legislative Field 326

$\begin{array}{lll}\text { 9.4.4 England } & 329\end{array}$

9.4.4.1 Basic Principles of the Law of Damages 329

9.4.4.2 Immaterial Damages and Aggravated Damages 331

9.4.4.3 Punitive Damages in English Law 333

9.4.4.3.1 Punitive Damages for Torts: the Categories Test 333

9.4.4.3.2 Other Relevant Factors in the Assessment of Punitive
Damages

9.4.4.3.3 Punitive Damages for Breach of Contract? 339

9.4.4.3.4 English Government Rejects Suggestions to Reform

Punitive Damages Law

9.5 A Comparison Scale of the Legal Systems: From

Compensation to Punishment 342

9.5.1 The Position of the American Legal System on the Scale 343

9.5.2 The Position of the Four European Legal Systems on the Scale

\section{Chapter Ten}

Does the Punitive Damages Remedy Have a Future in

Continental Europe?

10.1 Introductory Remarks

10.2 There is Resistance to, but also Interest in, Punitive

Damages in Continental Europe $\quad 350$

10.2.1 Relevant Aspects of the European Resistance 350

10.2.1.1 The Reasons for the Non-Existence of Punitive Damages: Prohibitive Objections or Not? 350

10.2.1.1.1 Problems Relating to the Traditional Functions of Tort Law 351

10.2.1.1.2 Problems Relating to the Public-Private Divide 352

10.2.1.1.3 Problems Relating to the Role of Government 354

10.2.1.2 What is the Status Quo of Punitive Damages Rejection in Europe? 356

10.2.1.3 What about the Fact that the Punitive Damages Remedy is Deemed to be Alien to the European System? 359

10.2.2 Relevant Aspects of the European Interest 360

10.2.2.1 Private Enforcement 360 
10.2.2.2 Calls for Powerful Civil Sanctions 362

10.2.3 Conclusion 364

10.3 Misperceived Ideas of American Punitive Damages Law: Lessons for Continental Europe

10.3.1 Lesson One: Powerful Civil Sanction in a Civil Justice System

10.3.2 Lesson Two: The Truth about Excessiveness 367

10.3.3 Lesson Three: Punitive Damages are Generally Awarded with Great Caution

10.3.4 Lesson Four: Insurability of Punitive Damages, Cause for Concern?

10.3.5 Conclusion

10.4 Concluding Remarks: Punitive Damages in Continental Europe and Gazing into a Crystal Ball

Nederlandse samenvatting

Kenmerken van het Amerikaanse punitive damages-recht 378

Afwezigheid van punitive damages in continentaal Europa 381

Toegenomen Europese interesse in punitive damages 383

5 Afwijzing van punitive damages in continentaal Europa: de status quo

6 Bestaande civiele sancties in het Nederlandse, Duitse, Franse en Engelse recht

$\begin{array}{lll}7 & \text { Concluderende opmerkingen } & 389\end{array}$

Bibliography

Table of Cases 



\section{LIST OF ABBREVIATIONS}

\begin{tabular}{|c|c|}
\hline AA & Ars Aequi \\
\hline ABGB & $\begin{array}{l}\text { Allgemeines bürgerliches Gesetzbuch } \\
\text { (Austrian Civil Code) }\end{array}$ \\
\hline $\mathrm{AcP}$ & Archiv für die civilistische Praxis \\
\hline ALI & American Law Institute \\
\hline Ala Code & Alabama Code \\
\hline Ala L Rev & Alabama Law Review \\
\hline Alaska Stat & Alaska Statutes \\
\hline ALR & American Law Reports \\
\hline Am Bus L J & American Business Law Journal \\
\hline Am J Comp L & American Journal of Comparative Law \\
\hline Am J Juris & American Journal of Jurisprudence \\
\hline Am Jur & American Jurisprudence \\
\hline Am U L Rev & American University Law Review \\
\hline Annals AAPSS & $\begin{array}{l}\text { Annals of the American Academy of Political and } \\
\text { Social Science }\end{array}$ \\
\hline Annu Rev Law Soc Sci & Annual Review of Law and Social Science \\
\hline Ariz Const & Arizona Constitution \\
\hline Ariz J Int'l \& Comp L & $\begin{array}{l}\text { Arizona Journal of International and Comparative } \\
\text { Law }\end{array}$ \\
\hline Ariz L Rev & Arizona Law Review \\
\hline ASL & Air and Space Law \\
\hline ATRA & American Tort Reform Association \\
\hline AV\&S & Aansprakelijkheid, Verzekering \& Schade \\
\hline Baylor L Rev & Baylor Law Review \\
\hline BGB & Bürgerliches Gesetzbuch (German Civil Code) \\
\hline BGH & Bundesgerichtshof \\
\hline Brook J Int'l L & Brooklyn Journal of International Law \\
\hline Buff Crim L Rev & Buffalo Criminal Law Review \\
\hline Buff L Rev & Buffalo Law Review \\
\hline BVerfG & Bundesverfassungsgericht \\
\hline BW & Burgerlijk Wetboek (Dutch Civil Code) \\
\hline $\mathrm{CA}$ & California \\
\hline Cal Civ Code & California Civil Code \\
\hline Cal Civ Code Ann & California Civil Code Annotated \\
\hline Cal L Rev & California Law Review \\
\hline Cato Sup Ct Rev & Cato Supreme Court Review \\
\hline $\mathrm{Cc}$ & Code civil (French Civil Code) \\
\hline Charleston L Rev & Charleston Law Review \\
\hline
\end{tabular}




\begin{tabular}{|c|c|}
\hline Chi-Kent L Rev & Chicago-Kent Law Review \\
\hline CJEU & Court of Justice of the European Union \\
\hline CJS & Corpus Juris Secundum \\
\hline CJSSC & Civil Justice Survey of State Courts \\
\hline Clev St L Rev & Cleveland State Law Review \\
\hline CMLR & Common Market Law Review \\
\hline Colum J Transnat'1 L & Columbia Journal of Transnational Law \\
\hline Colum L Rev & Columbia Law Review \\
\hline Colo Rev Stat & Colorado Revised Statutes \\
\hline Conn Gen Stat & Connecticut General Statutes \\
\hline Conn Gen Stat Ann & Connecticut General Statutes Annotated \\
\hline Conn L Rev & Connecticut Law Review \\
\hline Cornell L Rev & Cornell Law Review \\
\hline DAJV Newsletter & $\begin{array}{l}\text { Deutsch-Amerikanischen Juristen-Vereinigung } \\
\text { Newsletter }\end{array}$ \\
\hline DCFR & Draft Common Frame of Reference \\
\hline DCJ & Defense Counsel Journal \\
\hline DePaul L Rev & DePaul Law Review \\
\hline DES & Diethylstilbestrol \\
\hline $\mathrm{DM}$ & Deutsche Mark \\
\hline $\mathrm{EC}$ & European Communities \\
\hline ECHR & European Convention of Human Rights \\
\hline ECJ & European Court of Justice \\
\hline ECtHR & European Court of Human Rights \\
\hline ECLR & European Competition Law Review \\
\hline ECTIL & European Centre of Tort and Insurance Law \\
\hline ECU & European Currency Unit \\
\hline EIPR & European Intellectual Property Review \\
\hline EJLS & European Journal of Legal Studies \\
\hline EJCL & Electronic Journal of Comparative Law \\
\hline ELR & European Law Review \\
\hline Emory L J & Emory Law Journal \\
\hline ERCL & European Review of Contract Law \\
\hline ERPL & European Review of Private Law \\
\hline ETL & Institute for European Tort Law \\
\hline EU & European Union \\
\hline Eur J L \& Econ & European Journal of Law and Economics \\
\hline FF & Franc Français \\
\hline Fla L Rev & Florida Law Review \\
\hline Fla Stat Ann & Florida Statutes Annotated \\
\hline Ga Code & Georgia Code \\
\hline Ga Code Ann & Georgia Code Annotated \\
\hline Ga J Int'1 \& Comp L & $\begin{array}{l}\text { Georgia Journal of International and Comparative } \\
\text { Law }\end{array}$ \\
\hline
\end{tabular}




\section{GDP}

\section{GEMA}

\section{Geo L J}

Geo Wash L Rev

\section{GLJ}

Harv L Rev

Hastings Int'l \& Comp L R

Hastings L J

HR

Hum Rts Q

ICCPR

ILSA J Int'l \& Comp L

Int'l Bus Law

Int'l Rev L \& Econ

Iowa L Rev

IPRax

J Empirical Legal Stud

JEP

JETL

$\mathrm{J}$ Int Arb

J Int'l L \& Pract

JITE

J L Econ \& Pol'y

J Legal Analysis

J Legal Stud

J L \& Com

$\mathrm{J}$ L \& Econ

JRI

JSAL

Kan Stat Ann

KLJ

Ky Const

Law \& Contemp Probs

La L Rev

Law \& Hum Behav

Law \& Soc'y Rev

LG

L J Student B Ass'n Ohio St U
Gross Domestic Product

Gesellschaft für musikalische Aufführungs- und mechanische Vervielfältigungsrechte

Georgetown Law Journal

George Washington Law Review

German Law Journal

Harvard Law Review

Hastings International and Comparative Law

Review

Hastings Law Journal

Hoge Raad der Nederlanden

Human Rights Quarterly

International Covenant on Civil and Political Rights International Law Students Association Journal of International and Comparative Law

International Business Lawyer

International Review of Law and Economics

Iowa Law Review

Praxis des Internationalen Privat- und Verfahrensrechts

Journal of Empirical Legal Studies

Journal of Economic Perspectives

Journal of European Tort Law

Journal of International Arbitration

Journal of International Law and Practice

Journal of Institutional and Theoretical Economics

Journal of Law, Economics and Policy

Journal of Legal Analysis

Journal of Legal Studies

Journal of Law and Commerce

Journal of Law and Economics

Journal of Risk and Insurance

Journal of South African Law

Kansas Statutes Annotated

King's Law Journal

Kentucky Constitution

Law and Contemporary Problems

Louisiana Law Review

Law and Human Behavior

Law \& Society Review

Landgericht

Law Journal of the Student Bar Association Ohio State University 
LGDJ

Loy Consumer L Rev

Loy L A Int'l \& Comp L J

Loy L A L Rev

Loy U Chi L J

L \& Phil

Md L Rev

Mich L Rev

Minn J Int'1 L

Minn L Rev

MJ

MLR

M\&M

$\mathrm{MN}$

Mo L Rev

Mo Rev Stat

Mont Code Ann

$\mathrm{NC}$

NCAs

N D Cent Code

Nev Rev Stat Ann

NGOs

NIPR

NJB

N J Stat Ann

NQHR

NTBR

Nw U L Rev

N Y Int'l L Rev

ODCC

Ohio St L J

OJLS

OLG

Or

Or L Rev

PETL

PIL

PIV-Bulletin

QJE

$\mathrm{Rb}$.

Rev Litig
Librairie générale de droit et de jurisprudence

Loyola Consumer Law Review

Loyola of Los Angeles International and

Comparative Law Review

Loyola of Los Angeles Law Review

Loyola University Chicago Law Journal

Law and Philosophy

Maryland Law Review

Michigan Law Review

Minnesota Journal of International Law

Minnesota Law Review

Maastricht Journal of European and Comparative

Law

Modern Law Review

Markt en Mededinging

Minnesota

Missouri Law Review

Missouri Revised Statutes

Montana Code Annotated

North Carolina

National Competition Authorities

North Dakota Century Code

Nevada Revised Statutes Annotated

Non-Governmental Organisations

Nederlands Internationaal Privaatrecht

Nederlands Juristenblad

New Jersey Statutes Annotated

Netherlands Quarterly of Human Rights

Nederlands Tijdschrift voor Burgerlijk Recht

Northwestern University Law Review

New York International Law Review

Osservatorio del Diritto Civile e Commerciale

Ohio State Law Journal

Oxford Journal of Legal Studies

Oberlandesgericht

Oregon

Oregon Law Review

Principles of European Tort Law

Private International Law

Stichting Personenschade Instituut van

Verzekeraars-Bulletin

The Quarterly Journal of Economics

Rechtbank

Review of Litigation 


\begin{tabular}{|c|c|}
\hline RHDI & Revue Hellénique de Droit International \\
\hline RLDA & Revue Lamy Droit des Affaires \\
\hline RLE & Review of Law and Economics \\
\hline RM Themis & Rechtsgeleerd Magazijn Themis \\
\hline Rv & $\begin{array}{l}\text { Wetboek van Burgerlijke Rechtsvordering (Dutch } \\
\text { Code of Civil Procedure) }\end{array}$ \\
\hline RW & Rechtskundig Weekblad \\
\hline San Diego L Rev & San Diego Law Review \\
\hline S Cal L Rev & Southern California Law Review \\
\hline $\mathrm{S} \mathrm{Ct}$ & Supreme Court \\
\hline S D Codified Laws & South Dakota Codified Laws \\
\hline Stan L Rev & Stanford Law Review \\
\hline Suffolk U L Rev & Suffolk University Law Review \\
\hline Sup Ct Econ Rev & Supreme Court Economic Review \\
\hline TCR & Tijdschrift voor Civiele Rechtspleging \\
\hline Tenn L Rev & Tennessee Law Review \\
\hline Tex Const & Texas Constitution \\
\hline Tex L Rev & Texas Law Review \\
\hline TFEU & Treaty on the Functioning of the European Union \\
\hline TMA & $\begin{array}{l}\text { Tijdschrift voor Milieuschade en } \\
\text { Aansprakelijkheidsrecht }\end{array}$ \\
\hline Tul Eur \& Civ L F & Tulane European and Civil Law Forum \\
\hline Tul L Rev & Tulane Law Review \\
\hline TPR & Tijdschrift voor Privaatrecht \\
\hline $\mathrm{TvC}$ & $\begin{array}{l}\text { Tijdschrift voor Consumentenrecht en } \\
\text { Handelspraktijken }\end{array}$ \\
\hline TVP & Tijdschrift voor Vergoeding Personenschade \\
\hline U Cin L Rev & University of Cincinnati Law Review \\
\hline UCSB & University of California Santa Barbara \\
\hline UK & United Kingdom \\
\hline UMKC L Rev & University of Missouri-Kansas City Law Review \\
\hline U Pa L Rev & University of Pennsylvania Law Review \\
\hline U.S. & United States of America \\
\hline USA & United States of America \\
\hline USC & United States Code \\
\hline USCA & United States Code Annotated \\
\hline U.S. Supreme Court & Supreme Court of the United States \\
\hline USF L Rev & University of San Francisco Law Review \\
\hline U St Thomas L J & University of St. Thomas Law Journal \\
\hline Utah L Rev & Utah Law Review \\
\hline Val U L Rev & Valparaiso University Law Review \\
\hline Vill L Rev & Villanova Law Review \\
\hline Va L Rev & Virginia Law Review \\
\hline VR & Verkeersrecht \\
\hline
\end{tabular}


Washburn L J

Willamette L Rev

Wis L Rev

WC

WCAM

WMPC

Wm \& Mary L Rev

WODC

WPNR

Wyo Const

Yale L J

YEL

ZEuP
Washburn Law Journal

Willamette Law Review

Wisconsin Law Review

World Competition: Law and Economics Review

Wet Collectieve Afhandeling Massaschade

Wet Marktpraktijken en Consumentenbescherming

William and Mary Law Review

Wetenschappelijk Onderzoek-en

Documentatiecentrum

Weekblad voor Privaatrecht, Notariaat en

Registratie

Wyoming Constitution

Yale Law Journal

Yearbook of European Law

Zeitschrift für Europäisches Privatrecht 


\section{CHAPTER ONE}

\section{INTRODUCTION}

\subsection{The Subject Matter}

Conventional wisdom tells us that what happens in the United States will not stay there and that American trends can also predict our future. The United States is considered to be a forerunner in several fields, and there is a certain tendency in Europe and other parts of the world to copy American traditions. Although, as with all conventional wisdom, it would be unwise to hold this one as a universal truth, ${ }^{1}$ we can learn something from it nevertheless. Perhaps most importantly, this wisdom teaches us not to close our eyes to what happens on the other side of the Atlantic Ocean. Information regarding the American approach to certain situations and (legal) problems might one day come in handy. This idea also forms the thread of this book on punitive damages, a civil remedy that is already widely discussed in American law and receives growing attention in Europe. ${ }^{2}$ Does this civil remedy have a future in continental Europe? Or should we, by definition, reject it, for example due to the often heard fear of the development of a so-called compensation culture or of exorbitant civil damages awards resulting from an excessive use of civil litigation? The following definition of this particular civil remedy can be found in American law: ${ }^{3}$

(1) Punitive damages are damages, other than compensatory or nominal damages, awarded against a person to punish him for his outrageous conduct and to deter him and others like him from similar conduct in the future.

(2) Punitive damages may be awarded for conduct that is outrageous, because of the defendant's evil motive or his reckless indifference to the rights of others. In assessing punitive damages, the trier of fact can properly consider the character of the defendant's act, the nature and extent of the harm to the plaintiff that the defendant caused or intended to cause and the wealth of the defendant.

In other words, punitive damages are monetary damages that may be awarded to the plaintiff in a civil lawsuit apart from and in addition to compensatory damages. Several purposes have been attributed to such damages, most importantly punishment and deterrence of the defendant for wrongfully harming the plaintiff. ${ }^{4}$ This

1 A quick search on the internet shows that Americans similarly see Europe as a trendsetter, for example in light of the financial and economic crises. See www.cbn.com/cbnnews/finance/2012/ May/Warning-What-Happens-in-Europe-Wont-Stay-There/.

Hartlief 2009a, p. 67-68.

Restatement of Torts, $\S 908$.

Ellis 1982, p. 3. 
explains why this form of damages is seen as a sanction in private law (hereafter: civil sanction). The punitive damages doctrine, traditionally a common law doctrine that originates in England and the United States, is nowadays merely accepted in common law countries but until now it is alien to continental European legal systems. ${ }^{5}$ Policymakers and legal scholars in Europe, however, increasingly exchange ideas about the potential advantages of punitive damages. The interest in this civil sanction runs parallel to two developments. Before pointing out these developments, note that they should be seen in the context of present-day societal trends: more articulate citizens, ${ }^{6}$ diminished trust in the government and hierarchic structures, an increased desire to call governmental bodies - not in the last place the judicial branch - or fellow citizens to account, calculating citizens and lawyers, ${ }^{7}$ increased attention for victims of wrongdoing rather than a sole focus on wrongdoers, ${ }^{8}$ and calls for an accessible and transparent judiciary. There is, as it were, an enhanced consciousness of rights and therefore an important role for, in the words of Von Jhering and Magnus, der Kampf ums Recht. ${ }^{9}$ This can be illustrated by the simple example that, for instance, doctors, judges, bankers, schools, the church, and government institutions are increasingly subjected to civil or even criminal litigation, which used to be a different story until late in the previous century. ${ }^{10}$

In recent years, legal mechanisms that allow citizens to fight for their rights in court have become a topic of much debate, for example in Dutch legal doctrine. Not surprisingly, these legal mechanisms are well known in the American legal system where more importance seems to be attached to the right to sue than in European legal systems. ${ }^{11}$ Think of 'no cure, no pay' arrangements and class actions: the first mechanism is not allowed in Dutch law but has been signaled as a

5 Although it is generally accepted in continental Europe that the function of punishment should nowadays be primarily left to criminal law, historically tort law did have a clear punitive character in addition to its compensatory function in both common law and civil law systems. As will be further explained in section 6.2.2.1, in ancient Roman law there was no real division between public law and private law, and a mixed system of criminal law existed. Modern civil law systems have at least theoretically - surrendered the punitive function of tort law, whereas common law systems have retained it in the form of punitive damages.

6 Hartlief 2007a, p. 915. Note in this respect that the European Union declared the year 2013 'The European Year of Citizens', thereby inviting citizens to join the debate and encouraging dialogue between government, civil society and business on the rights that come with EU citizenship, see europa.eu/citizens-2013/.

7 This was the theme of the Annual congress of the Dutch Bar in 2010 (Nederlandse Orde van Advocaten, Jaarcongres 2010, Claimcultuur: Calculerende burgers en advocaten, 24 September 2010, Rotterdam).

8 Akkermans et al. 2008.

9 Magnus 2010, p. 109, referring to 'Der Kampf ums Recht', a lecture held by Rudolf Von Jhering in 1872.

10 Take, for instance, the Roman Catholic church sex abuse cases in the past decade. See also the following Dutch dissertation on civil liability of schools: Paijmans 2013.

11 Centner 2008, p. 3-4. 
means of improving access to justice, ${ }^{12}$ whereas a mechanism that resembles the class action is available in Dutch law since 2005. ${ }^{13}$ Also in the United Kingdom, class actions are on the legislator's agenda: in 2013 the government announced plans to introduce opt-out class actions in competition law cases. ${ }^{14}$ It has been suggested that the introduction of the class action to effectively deal with the contemporary expansion of civil claims is the first step leading to a compensation culture, but that we should take the positive aspects of this system into account rather than focus on the feared negative impact. ${ }^{15}$ In the Netherlands, this idea is not only shared by legal scholars but also by the media, as there seems to be a recent tendency of positive opinions about the American compensation culture. ${ }^{16}$ Moreover, it is important to keep in mind that well-founded opinions on the correctness of the negative allegations about the American system can hardly be found in European literature. ${ }^{17}$ These two examples are mainly matters of procedural law, but there is also increased attention for the punitive damages remedy which forms part of the law of damages, i.e. a substantive law matter and the subject matter of this book. This follows, for example, from the recent dissertation of Nordin. ${ }^{18}$ In the following paragraphs, the two developments that explain the increased European interest in this civil remedy will be addressed. These developments are derived from legal texts. ${ }^{19}$

First, there is more and more attention for the theory of private enforcement, which means law enforcement through private law mechanisms, such as tort damages. ${ }^{20}$ A related development is the European attention for public interest litigation: civil procedures - initiated by citizens and NGOs - with a public interest

12 A 'no cure, no pay' experiment for personal injury lawyers started on 1 January 2014 and will take five years, see further section 2.2.3.4. See Faure \& Hartlief 2012; Faure, Fernhout \& Philipsen 2010; Van Boom \& De Jong 2014.

13 Due to the Act on Collective Settlements Mass Damages (Wet Collectieve Afhandeling Massaschade or WCAM) of 2005, which is incorporated in the Dutch civil code (articles 7:907 to 7:910 $\mathrm{BW}$ ) and in the Dutch code of civil procedure (articles 1013 to $1018 \mathrm{Rv}$ ). The developments concerning the WCAM will be explained in section 2.2.3.6. A recent book on class actions in Europe is Backhaus, Cassone \& Ramello 2012.

14 See Higgins \& Zuckerman 2013

15 Franken 2009, p. 2008. See also Schirmeister 1996, p. 4.

16 See: decorrespondent.nl/1311/waarom-wij-de-amerikaanse-claimcultuur-moeten-importeren/ 82019870130-1521b9f4; www.nrc.nl/nieuws/2013/10/23/kijken-de-meest-onbegrepen-rechtszaakooit-in-amerika/.

17 Tzankova, Plomp \& Raats 2013, p. 180.

18 Nordin 2014. This book pays limited attention to Nordin's dissertation as the finalising stages of both manuscripts ran almost analogously. In her book, Nordin explores the compensation and law enforcement function of civil damages in, mostly Belgian, liability law. She thereby focuses on contract law and competition law, and pays considerable attention to punitive damages. On comparison, comparative law plays a more important role in this book, which explores American punitive damages law and the European punitive damages debate, in order to find an answer to the question whether the civil remedy has a future in continental Europe.

19 In this respect, I am aware of the fact that caution is required: it is of course difficult to derive an increased interest purely from legal texts, as this probably also requires research in other fields such as social sciences.

20 Kilpatrick 2000, p. 2 
that are at the interface of privatisation and globalisation and that deal with problems relating to, for instance, climate change, depletion of natural resources, corruption, and violations of human rights. ${ }^{21}$ Second, and in line with the previous development, there are calls for powerful civil sanctions to improve the enforcement of tort law standards and to deal with situations of serious wrongdoing. Compensation for damage, traditionally regarded as the main purpose of tort law, is no longer the sole purpose. ${ }^{22}$ Under the influence of law and economics and civilology, i.e. the study of civil law using other disciplines such as economics, psychology and sociology, growing attention is paid to the instrumental and sanctioning function of tort law. ${ }^{23}$ The idea is that tort law, if equipped with apt legal remedies, could be used as a mechanism to influence behaviour, deter wrongdoers and enforce legal rules. Inspired by the American experience, European policymakers and legal scholars wonder whether the powerful punitive damages remedy could contribute to realising this ambition. ${ }^{24}$ As pointed out by Koziol in $2009:^{25}$

In academic circles, one can observe that quite a number of continental European scholars are in favour of punitive damages, although most of them prefer a more restrictive system than the American one.

Because there is an extensive amount of American punitive damages law and practice, and the Americans have much experience with the punitive damages remedy, in this book reference is especially made to American law. Understanding of the American savoir faire with regard to punitive damages is useful when examining the pros and cons of this civil remedy for continental Europe. Therefore, this book is divided into two parts: chapters two to five provide an overview of aspects of American punitive damages law that are relevant for Europe, whereas chapters six to nine explore the so-called European punitive damages debate. ${ }^{26}$ Chapter ten gives concluding observations in light of the central issue whether the punitive damages remedy has a future in continental Europe. Before exploring the limits, scope and structure of this book further, the next paragraph will set out the problem statement and research questions.

21 Rijnhout et al. 2013; Enneking \& De Jong 2014.

22 Deakin, Johnston \& Markesinis 2008, p. 52.

23 Koziol 2012, p. 17; Van Boom, Giesen \& Smit 2012, p. 202. See also Van Boom, Giesen \& Verheij 2013.

24 Hartlief 2007a, p. 915. A relevant example is the development in the field of EU competition law. The European Commission has suggested the use of damages actions in private law to fight breaches of EU antitrust rules. See Green Paper 2005; Annex to Green Paper 2005; White Paper 2008; Annex to White Paper 2008; Annex to White Paper 2008: Impact Assessment.

25 Koziol 2009, p. 288.

26 Other publications on the punitive damages debate in Europe include, e.g., Coderch 2001; Georgiades 2005; Rouhette 2007; Koziol 2008; Koziol \& Wilcox 2009; Berch 2010; Nagy 2012; Meurkens \& Nordin 2012; Fausten \& Hammesfahr 2012; Nordin 2014. 
First and foremost, the objective of this book is to increase the understanding of the punitive damages remedy as such. Only proper knowledge of the facts relating to this civil remedy creates the possibility to participate in the current European debate on punitive damages and private enforcement in a fair manner. This warning should especially be read in light of the largely negative approach that many Europeans seem to have towards punitive damages, whereas certain indications in American law support the idea that this is an unfounded attitude. The negative judgment seems to be one of the reasons that the introduction of punitive damages in continental Europe is considered undesirable. What prevails is fear of an excessive use of civil litigation leading to a compensation culture, fear of exorbitant civil damages, fear that civil judges will act in the criminal sphere, and so on. One could define this attitude as fear of the unknown, whereas we all know that fear is a bad adviser. It is at least conspicuous that when such claims are made, they are hardly ever accompanied by facts and figures. The negative perception of American punitive damages law could very well be based on preconceived ideas and lack of information. American legal scholars have done quite some (empirical) research into the acceptance of punitive damages. This research improves understanding of the punitive damages remedy by explaining relevant aspects of American punitive damages law and explores the question whether this powerful civil remedy has a future in continental Europe. The problem statement is formulated as follows: does the punitive damages remedy have a future in continental Europe? In order to analyse this problem statement adequately the following research questions need to be answered:

(1) What are the main characteristics of American punitive damages law, such as the functions of and conditions for awarding punitive damages?

(2) What are the underlying reasons for the non-existence of punitive damages in continental European legal systems?

(3) (a) Which developments illustrate the increased European interest in punitive damages?

(b) How can these developments be explained?

(4) What is the status quo of the rejection of punitive damages in Europe? Are there signs of a more liberal approach to the civil remedy?

(5) Which existing civil sanctions, especially sanctions that bear a resemblance to the punitive damages remedy, can be distinguished in four European legal systems, i.e. the Netherlands, Germany, France and England?

This book is helpful for those in Europe who are developing ideas concerning private enforcement and powerful civil sanctions, such as policymakers, legislators, but also victims, insurers, personal injury lawyers and judges. Based on the American experience with punitive damages, the results of the research will include lessons and caveats that should be kept in mind by European punitive damages supporters and policymakers, as well as a number of recommendations on the possible use of this civil remedy in continental Europe. 
This book is not going to provide an answer to the question whether the punitive damages remedy is an effective private enforcement mechanism or a useful civil sanction, although an overview of (dis)advantages of this civil remedy will be given on the basis of existing American legal literature. More importantly, this research takes up the recurring suggestion in Europe to strengthen the existing array of tort remedies with punitive damages and starts from the viewpoint that the deterrent and law enforcement function of this civil remedy is evident. It is rather difficult to measure effectiveness and usefulness, as that would require, for instance, a comparison with other available public and private law mechanisms. This also means that the research does not involve law and economics, nor does it include empirical analyses in this respect. However, as it is primarily law and economics scholars and empiricists who focus on the deterrent and law enforcement function of punitive damages, this book cannot - and will not - completely ignore law and economics and empirical studies. The description of these studies will however be concise. The same applies to empirical studies relating to the alleged law enforcement deficiency in continental Europe. This research elaborates on legal literature in which the law enforcement deficiency is considered present, although there are authors who consider empirical research into the law enforcement deficiency necessary. ${ }^{27}$ Van Boom for example suggests that, in order to find out whether such a deficiency really exists, a research method and measuring instrument to assess effects, effectiveness and efficiency is needed. ${ }^{28}$ A final limit is that, as will be further explained in the next section, the comparative approach of this book in principle does not entail more than a study of the American legal system on the one hand and four national legal systems in Europe on the other hand. Developments on a broader European level that specifically relate to punitive damages and private enforcement will however be taken into account, especially in light of research questions two to four concerning the European reasons for the non-existence of punitive damages, the developments illustrating the increased interest in punitive damages and the status quo of punitive damages rejection.

\subsection{Scope of the Research}

In addition to the limits, an important aspect that should be explained concerns the scope of the research. This book takes a comparative approach. Attention will be paid in particular to the punitive damages remedy in relation to the black-letter law, the (changing) functions of tort law, the division between public and private law, and the view on the role of government. As explained above, five research questions will be dealt with in separate chapters in order to be able to analyse the problem statement adequately. Chapters two to five explore the main characteristics of the punitive damages remedy in American law. American punitive

27 See on this subject in Dutch literature Scheltema 2012; Van Boom, Giesen \& Smit 2012.

28 Van Boom 2008, p. 765. 
damages law is of particular interest as the Americans are most experienced with this civil remedy. Not only the punitive damages remedy in isolation, but also the American setting in which punitive damages are available, such as the policy and procedural context, deserves fair consideration. Attention will also be paid to criticism and problems relating to the punitive damages doctrine.

The issues in chapters six to nine will be addressed from a European perspective. Firstly, the reasons for the non-existence of punitive damages in continental Europe are in fact applicable to all (European) civil law systems (chapter six). Secondly, the two causes for the growing European interest in punitive damages, i.e. private enforcement and calls for powerful civil sanctions, seem to be noticeable in the juridical debate throughout Europe (chapter seven). Thirdly, the status quo of punitive damages rejection in Europe is dealt with from the perspective of the European Court of Human Rights, the legislator of the European Union, the Court of Justice of the European Union, and private international law (chapter eight). Hence, up to and including chapter eight, the American approach to punitive damages will be contrasted to the general European approach.

In chapter nine, the legal comparison is narrowed down. Chapter nine explores the final research question in relation to already existing civil sanctions, especially sanctions that bear a resemblance to the punitive damages remedy, which can be distinguished in a number of private law systems within Europe. The nature of this research question is different from the previous three, as the focus is not so much on the general European approach but rather on the approach of national legislators and courts within Europe. As it is practically impossible to include all legal systems within Europe, four legal systems will be dealt with: the Netherlands, Germany, France and England. It should be noted at this point that research with regard to punitive elements in private law in a number of other European countries, such as Hungary, Italy, Norway, Sweden, Denmark, Spain, Estonia, and Switzerland, has been published elsewhere. ${ }^{29}$

The choice of the four legal systems can be explained as follows. A number of influential European authors who have already compared European liability systems have indicated that the German, French and English legal systems are the three most important systems within Europe. ${ }^{30}$ Chapter nine will also deal with these three systems in addition to the Dutch legal system. The Netherlands has been added because I am Dutch and most familiar with this legal system, which is highly influenced by the French legal tradition. This also explains why, with regard to the European punitive damages debate, legal doctrine from Dutch authors plays a relatively important role in this book. Of the four legal systems, the Dutch, German and French legal systems form part of continental Europe, whereas the English legal system does not. Nevertheless, the English legal system is especially interesting as it is a common law system within Europe that explicitly accepts the punitive damages remedy, albeit in a more restricted form than in the United States.

29 E.g. Koziol \& Wilcox 2009; Meurkens \& Nordin 2012. See also Shelton 2005, p. 42; Lemmens 2003, p. 403; Georgiades 2005, p. 156; Lahe 2011.

$30 \quad$ Van Gerven et al. 1998; Van Gerven, Lever \& Larouche 2000, p. 2; Van Dam 2013a, p. 9. 
As will be explained in chapter nine, all four legal systems recognise - to a certain extent - civil sanctions and a non-compensatory function of private law. Furthermore, the punitive damages debate is quite alive in the Netherlands, starting with a preliminary advice on the possible incorporation of punitive damages in the Dutch legal system and the topic of powerful civil sanctions to deal with serious wrongdoing receives increased attention here. ${ }^{31}$ Also, in Germany and France, punitive elements in private law and punitive damages are topics on the legal agenda, as is clear, for example, from publications of Ebert, Koziol, Carval and Jault. ${ }^{32}$ As stated above, English law is interesting in respect of the theme of this book as England is one of the few countries in Europe that recognises a restricted form of punitive damages. To conclude, three legal families are represented in this research, namely the Roman legal family (the Netherlands and France), the German legal family (Germany), and the common law legal family (the United States and England).

\subsection{General Overview of the Structure}

Apart from the introducing observations in this chapter, this book consists of nine chapters. As stated above, chapters two to five concern a selection of relevant aspects of American punitive damages law, whereas chapters six to nine explore the European punitive damages debate. Chapter ten contains concluding observations. A brief description of each chapter will be given at this point.

\section{Chapter Two}

Punitive damages are predominantly awarded in the American legal system. For this reason, the first four chapters of this book address the approach to punitive damages there and give an overview of relevant aspects of American punitive damages law. Chapter two gives background information on the punitive damages doctrine and basically addresses the question what the underlying reasons for awarding punitive damages are, or, in other words, why punitive damages are awarded. It sets out the American context in which punitive damages are available, including some of the main characteristics of the American (tort) system, in order to give a general idea of the position of punitive damages in the law. Furthermore, a short historical overview, as well as an explanation of the theory and purposes of punitive damages, is given in this chapter.

31 Bolt \& Lensing 1993. See on the topic of private enforcement in Dutch literature e.g. Engelhard et al. 2009; Adriaanse 2007; Adriaanse et al. 2008; Van Boom 2006a; Van Boom 2007b; Van Boom 2008; Kortmann 2009; Kortmann \& Sieburgh 2009.

32 Ebert 2004, see for an extensive overview of punitive elements in German private law especially part C thereof; Koziol 2012, p. 50-57; Jault 2005; Carval 1995; Mahé 2012; Magnus 2012. 


\section{Chapter Three}

Chapter three is about the questions when and how punitive damages are awarded according to American law. It gives an overview of the liability criteria for punitive damages, it goes into the assessment and amount of punitive damages, and it addresses the specific topic of insurability of punitive damages. This leads to some concrete and useful examples, such as the types of actions in which punitive damages may be recovered, the nature of conduct for which punitive damages may be awarded and the persons entitled to and liable for punitive damages.

\section{Chapter Four}

Chapter four concerns the acceptance and control of punitive damages in the American legal system. Many Europeans seem to have a rather condemnatory judgment of both the American use of punitive damages and the suitability of the civil remedy for their own legal system (fear of an excessive use of civil litigation leading to a compensation culture, fear of exorbitant civil damages, fear that civil judges will act in the criminal sphere and so on). It is questionable whether this opinion is realistic and based on true figures. Information concerning the acceptance and application of punitive damages in the United States should help to put the negative perception of punitive damages into perspective. Nevertheless, also in the legal system that is most experienced with the civil remedy, punitive damages awards are considered controversial. The main points of critique are summarised in this chapter, which is valuable information - especially in respect of the main focus of this book - that draws our attention to a number of problems, such as the imposition of punitive damages in the absence of criminal procedural safeguards. To conclude, it is interesting to look into the American methods of dealing with problems and obstacles relating to punitive damages. This chapter therefore also explores the legislative and judicial control of punitive damages awards in the United States.

\section{Chapter Five}

Chapter five forms a mid-term review with regard to the punitive damages remedy in American law. In this chapter, the main findings of the American law part will be pointed out. This chapter concretises a number of aspects of American punitive damages law that are relevant for the European punitive damages debate. Chapter five therefore not only provides concluding observations relating to the American law part, but it also forms a connection with chapters six to nine on the European punitive damages debate.

\section{Chapter Six}

The second part of the book, which includes chapters six to nine, concerns the European punitive damages debate. There is more and more European attention for punitive damages. However, this does not mean that this civil remedy is consistent with the legal traditions in continental Europe. This punitive damages remedy is not an accepted civil remedy in continental European legal systems. The only countries 
in Europe that do accept a restricted form of punitive damages are England and Wales, Ireland and Cyprus, which are not situated on the European continent and have a common law or mixed legal system. In chapter six, some plausible reasons for the non-existence of punitive damages on the European continent will be given.

\section{Chapter Seven}

European legal scholars have shown more interest in the punitive damages remedy as a new means of private enforcement and as a way to deal with serious wrongdoing. These developments are visible enough to form the reason for this research; if there were no such developments there would have been no point in conducting this research. Chapter seven provides an answer to two questions. Firstly, which developments have led to the idea that punitive damages may form a useful addition to the already existing tort remedies in continental Europe and, secondly, how can these developments and the increased European interest be explained?

\section{Chapter Eight}

Chapter eight describes the status quo of the rejection of punitive damages in Europe and gives four concrete examples of the contemporary approach to punitive damages there. Although the general idea is that the punitive damages remedy is irreconcilable with continental European legal traditions, some signs of liberalness can be pointed out. This chapter explores the views of the European Court of Human Rights, the legislator of the European Union, and the Court of Justice of the European Union on punitive damages. Furthermore, the European punitive damages approach will be analysed from a private international law perspective.

\section{Chapter Nine}

Because the punitive damages remedy is assumed to be alien to continental European legal systems (systeemvreemdheid ${ }^{33}$ ), there seem to be no definite answers yet as to what role this civil remedy could play in these legal systems. The central objective of this book is to find out if the punitive damages remedy has a future in continental Europe. An important research question in this regard is which, if any, civil sanctions already exist there. The focus in this chapter will be tort law, as American punitive damages awards are in principle - but not only - recoverable for tort actions and are part of private law for that purpose. The approach of three European civil law systems, i.e. the Netherlands, Germany and France, will be compared to that of the United States which is most familiar with a punitive function of private law. As England is a common law system in Europe that explicitly accepts the punitive 
damages remedy, although in a more restricted form, some remarks will also be made about English law. The idea is to provide a so-called comparison scale of all legal systems. The purpose of this scale is to make clear to what extent the legal systems already approve of civil sanctions. The American legal system, which is obviously on the most punitive side of the scale, will be compared to the other four legal systems. In particular, the existence of civil sanctions that bear a resemblance to the punitive damages remedy could be indicative for participants in the European punitive damages debate, in the sense that their existence renders often heard arguments against punitive damages such as the compensatory function of tort law and the division between public law and private law unfounded.

\section{Chapter Ten}

The research results will be combined in the concluding chapter ten. An important conclusion of this book is that the possibility and desirability of introducing punitive damages continues to raise questions in the European debate. But it is difficult - particularly because of resistance to punitive damages felt throughout continental Europe - to say anything meaningful about the distant future. Two reasons for this resistance can be pointed out. The negativity is primarily caused by a number of obstacles that are intrinsic in the civil law tradition. These obstacles can, on the one hand, be seen as prohibitive objections to punitive damages that form part of the continental European legal tradition for a good reason. On the other hand, it is possible to put each single objection into perspective. However, as it is currently unlikely that punitive damages opponents will accept these qualifications, at this point in time the introduction of this civil remedy in continental Europe does not seem to be a workable proposal. Careful judgment is needed in deciding whether the punitive damages remedy should have a future in continental Europe. Participants in the European punitive damages debate could thereby start with themselves. Apart from the above-mentioned obstacles, the European resistance to punitive damages is largely based on an incorrect perception of the American reality and therefore on inaccurate arguments. The lessons and warnings provided in chapter ten should help to improve the understanding of the punitive damages remedy so that the required careful judgment can be made in a fair manner. Rather than to focus on the often believed negative effects of this civil remedy, it seems worthwile to have an open attitude towards the punitive damages remedy and focus on the positive effects that the remedy might have. In line with the American approach, if awarded with caution, this punitive damages remedy can be used to complement public enforcement mechanisms and to deal with specific situations of intentional, calculative and grave misconduct. Chapter ten therefore provides a number of recommendations with regard to the possible use of the civil remedy in continental European legal systems.

This research was closed on 16 July 2014. Only small changes have been made after that date. 



\section{CHAPTER TWO}

\section{THE PUNITIVE DAMAGES REMEDY IN AMERICAN LAW: BACKGROUND}

\subsection{Introductory Remarks}

Together with chapters three, four and five, this chapter gives an introduction into American punitive damages law. Punitive damages law is a complex area of law that can hardly be described in a nutshell. ${ }^{1}$ For that reason, the word introduction is used intentionally. This chapter will focus on the general characteristics of the law along with the main points of discussion in American legal literature. The idea of this introduction is not to give a complete description of the law relating to punitive damages. Rather, the selection of information provided should be read in light of the problem statement, i.e. does the punitive damages remedy have a future in continental Europe? For each of the following chapters, it will therefore be pointed out why the information provided is relevant in view of that theme.

The structure of this chapter is as follows. Section 2.2 will set out the American context in which punitive damages are available. This includes some of the main characteristics of the American (tort) system to give a general idea of the position of punitive damages in the law. Although this might be thought of as superfluous information, because it goes further than the doctrine of punitive damages as such, it is essential to include this information because the American experience with punitive damages should first of all be judged from the American setting, which clearly differs from the continental European setting. ${ }^{2}$ It is difficult to understand this particular civil sanction if we do not know the setting in which it is available.

A short historical overview, as well as a description of the rationale and purposes of punitive damages, will be given in section 2.3. It is simply impossible to get a clear idea of this common law doctrine without knowing its underlying reasons and functions. Furthermore, based on their long experience with the civil remedy, authors from the United States and also England recommend that Europe should get the theory right before introducing it. ${ }^{3}$ Section 2.4 contains some concluding remarks.

1 The following handbooks give a profound overview of American punitive damages law: Blatt, Hammesfahr \& Nugent 2008; Kircher \& Wiseman 2000a; Kircher \& Wiseman 2000b; Schlueter 2005a; Schlueter 2005b. I have also relied on two important encyclopaedias of American law: American Jurisprudence and Corpus Juris Secundum, as well as the legal database American Law Reports, which are all available through the online database of Westlaw International.

Six 2006, p. 3; Franken 2009, p. 261.

Sebok 2012, p. 145; Morgan 2012, p. 204. 


\subsection{The American Setting}

\subsubsection{The Complexity of American Law}

Doing research into American law is a fairly difficult mission. The complexity of the law is caused by several factors, most importantly the multifaceted governmental structure of the United States. ${ }^{4}$ Due to the division of legislative and judicial powers between the federal government and the states, some legal fields remain under state control, whereas others are regulated on a federal level. Another aspect of American law that adds to its complexity is the relevance of both common law and statutory law. Regardless of these difficulties, research into American law is useful for understanding the concept of punitive damages. And this is in itself essential to analyse the problem statement adequately. As will be demonstrated below, punitive damages have traditionally and primarily been an issue of state common law. This section will first make some general remarks on the American legal system, in general, and the civil justice system, in particular. Furthermore, explanations for the widespread use of punitive damages relating to the civil justice system are provided.

\subsubsection{The Importance of American Law for this Research}

What would happen if a group of Europeans, composed of both lawyers and nonlawyers, were asked in which country punitive damages are typically awarded? Their first reaction would most probably not be 'England' or 'New Zealand', notwithstanding the fact that the doctrine is also accepted in those common law countries. An obvious answer to such a question would be 'the United States', where punitive damages are a well-established part of the legal tradition. ${ }^{5}$ Although punitive damages are available in several legal systems in the world, ${ }^{6}$ it is common knowledge that the most widespread use of the civil remedy is in the United States where the amount of case law, doctrine and legislation on the subject is still growing apace. ${ }^{7}$ American punitive damages awards are known, and even feared, not only because of the perceived number of awards, but also because the amount of money that is sometimes involved in such awards provokes consternation all over the world. A well-known and illustrative example is the McDonald's case, a products liability case in which the plaintiff received substantial punitive

Von Mehren \& Murray 2007, p. 23.

Blatt, Hammesfahr \& Nugent 2008, p. 40.

6 E.g. Canada, England and Wales, Australia, New Zealand, India, Uganda. Punitive damages are generally not found in civil law or socialist systems, however, note the availability of punitive damages in South Africa, Brazil and Ethiopia which have mixed influences. See Shelton 2005, p. 42. For an overview of punitive damages law in South Africa, see Mukheibir 2007.

7 Schlueter 2005b, p. 666; Nagy 2012, p. 4; Owen 2005, p. 1120. 
damages for her injuries that arose from spilling McDonald's coffee. ${ }^{8}$ This is a typical example of an American punitive damages case that has practically evolved into a horror story, which is primarily the result of people being badly informed and unaware of what has actually happened. ${ }^{9}$ According to Koenig and Rustad: ${ }^{10}$

The media's mischaracterization of the McDonald's hot coffee case has done more than any other tort horror story to create a climate of distrust about tort law and its remedies.

Galanter refers to the case as 'the best known contemporary legal legend' and states that the misinformation surrounding it partly explains the enactment of tort limitations statutes by state legislators. ${ }^{11}$ Generally, it appears that the majority of 'tort tales' cited by tort reformers such as the American Tort Reform Association (ATRA) originate in the mass media, which shows the enormous influence that the media may have. However, interesting background information about the $\mathrm{McDo}$ nald's case is that knowledge of the true facts induced the Supreme Courts of Ohio and Illinois to overturn tort reform statutes, and a number of other state courts struck down tort reforms based on the state constitution. ${ }^{12}$

An example of a fact that is often ignored is that the actions of McDonald's resulted in injuries to Mrs. Liebeck, the plaintiff, that were far worse than most people believe. During and long after the lawsuit, the media made an icon of Mrs. Liebeck and a tort tale of her case. ${ }^{13}$ But there have also been attempts to portray the case accurately. Filmmaker Susan Saladoff has done an excellent job by making the documentary 'Hot Coffee', ${ }^{14}$ which reveals information about the McDonald's case and the American civil justice system in general that a layman

8 Liebeck v. McDonald's Restaurants, P.T.S., Inc., 1995 WL 360309 (N.M. Dist. 1994). This citation leads only to the final judgment; the opinion is not published. However, in addition to the final judgment, Westlaw International gives access to the motions, pleadings and filings of the case. Some of these documents have been referred to below in the following order: McDonald's case, name of document, source.

9 Rustad 1998, p. 15-16. See also section 4.1.

10 Rustad \& Koenig 2001, p. 6.

11 Galanter 1998b, p. 731

12 Haltom \& McCann 2004, p. 155.

13 Haltom \& McCann 2004, p. 185. These authors have devoted an entire chapter to the (un)truth about the McDonald's case in their book Distorting the law. Politics, Media and the Litigation Crisis (chapter six: 'Java Jive: Genealogy of a Juridical Icon', p. 183-226).

14 Hot Coffee, a 2011 documentary by Susan Saladoff (hereafter: Hot Coffee 2011). Saladoff‘s film has won several prices, for example the 'Best Documentary' at the Seattle International Film Festival 2011. The short summary of the documentary on the website reads as follows: 'Is Justice Being Served? Seinfeld mocked it. Letterman ranked it in his top ten list. And more than fifteen years later, its infamy continues. Everyone knows the McDonald's coffee case. It has been routinely cited as an example of how citizens have taken advantage of America's legal system, but is that a fair rendition of the facts? Hot Coffee reveals what really happened to Stella Liebeck, the Albuquerque woman who spilled coffee on herself and sued McDonald's, while exploring how and why the case garnered so much media attention, who funded the effort and to what end. After seeing this film, you will decide who really profited from spilling hot coffee.' Retrieved via: www. hotcoffeethemovie.com. 
would normally miss out on. To illustrate, in one of the opening scenes, two Americans give their somewhat unsubstantial opinion: ${ }^{15}$

"The woman, she purchased the coffee and she spilled it on herself. I mean... it wasn't like the McDonald's employee took the coffee, do it on her. Now, that in itself, then she would have had a lawsuit."

And:

"It's just... people just are greedy and want money, and they'll do anything to get it."

Consequently, two legal experts respond:

"I think many Americans have a fundamentally wrong perception of the civil justice system; they think that the system is flooded with frivolous lawsuits".

And:

"Lawsuit lottery and jackpot justice and frivolous lawsuits, these were bumper sticker phrases that were easy to market and used to move public sentiment away from a strong civil justice system".

In 1992, Mrs. Liebeck was a 79-year-old lady who ordered a cup of coffee at a McDonald's drive-through in Albuquerque, New Mexico. According to her daughter, at that time she was still very active for her age. ${ }^{16}$ For instance, she had a fulltime job as a sales clerk and, as stated in the Complaint for Damages, was a 'healthy, robust, and gainfully employed person'. ${ }^{17}$ Mrs. Liebeck's life took a tragic turn due to a cup of excessively hot coffee. Unlike what has been suggested, not only by 'people on the street' but even by a newsreader at the time of the first court decision, ${ }^{18}$ Mrs. Liebeck was not driving her car while drinking the coffee but sitting in the passenger seat. She spilled the scalding coffee into her lap after her grandson had pulled over and stopped the car completely so that she was able to put cream and sugar in her cup. ${ }^{19}$ The coffee appeared to be so hot that it caused second- and third-degree burns to her upper inner thighs, buttocks, groin and other areas of her body. ${ }^{20}$ Not only does the documentary show terrible pictures of the burns, Mrs. Liebeck also gives her comment: ${ }^{21}$

"Excruciating pain. I was burned so severally that they didn’t think I would live".

15

16

McDonald's case, Amended Complaint for Damages, at VII, 1993 WL 13651163 (N.M. Dist.).

8 Hot Coffee 2011, at 00:43.

Koenig \& Rustad 2001, p. 7.

20 McDonald's case, Motion for Summary Judgment, at 3, 1994 WL 16777830 (N.M. Dist.). See also Baker, Kritzer \& Vidmar 2008, p. 16; Ryan 2003, p. 77; Koenig \& Rustad 2001, p. 7.

21 Hot Coffee 2011, at 06:31 
The Complaint for Damages also illustrates how grave Mrs. Liebeck's injuries were: ${ }^{22}$

The burns consisted of both second and third degree burns and were of such severity as to require debridement and skin grafting, causing enormous conscious pain and suffering, mental anguish, and loss of life's enjoyment, for which she seeks damages.

Mrs. Liebeck wanted McDonald's to take care of her medical costs. Her family wrote a letter to McDonald's with this request, also telling McDonald's that their coffee was probably too hot, that this must be an aberration of their machine and that, if selling coffee at this temperature was their policy, they should worry about that policy as more people could get injured. McDonald's replied that it would not offer more than $\$ 800$, whereas, at that point, the medical bill was already $\$ 10,000 .^{23}$ Mrs. Liebeck then decided to consult a lawyer. The lawyer's request of $\$ 90,000$ for medical costs and pain and suffering was refused, as well as a later offer to settle the case for $\$ 225,000$. Thus, several initiatives had been taken by Mrs. Liebeck before she went to court.

During the trial, it appeared that McDonald's had failed to comply with industry standards. ${ }^{24}$ The court agreed with Mrs. Liebeck's statement that the coffee was defectively manufactured due to excessive heat. ${ }^{25}$ The coffee was sold at a temperature between 180 and 190 degrees Fahrenheit and was therefore able to cause third-degree burns in two to seven seconds, ${ }^{26}$ whereas an expert had testified that Mrs. Liebeck's injuries could have been sustained at temperatures as low as 130 degrees. $^{27}$ The reason for selling the coffee at this extreme temperature does not become clear from the case documents, but it is likely that it has to do with keeping the coffee fresh for a longer period.

Furthermore, McDonald's did not warn their customers about the risks of buying coffee at this temperature. ${ }^{28}$ The company could for example have used containers with a proper warning as regards its content. A simple warning, as can be found nowadays on containers of, for example, the coffee company Starbucks ('Careful, the beverage you're about to enjoy is extremely hot'), would have been sufficient. Moreover, the company had already received 700 other complaints about the temperature of their coffee and had also compensated earlier claims. A witness for McDonalds even testified that the dangers were considered irrelevant and that there was no plan to change the coffee policy. The policy not to warn customers was therefore seen as a conscious decision. This eventually led to a punitive damages award of $\$ 480,000$. The outcome of the lawsuit is another point about which many

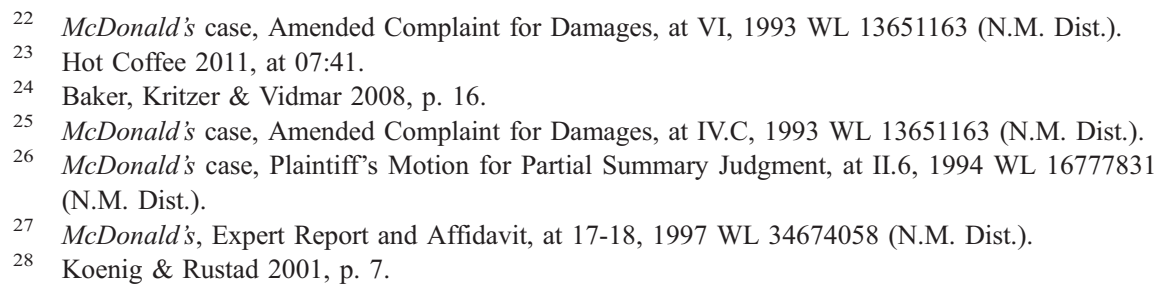


people have misperceived ideas. The punitive damages that were awarded by the jury amounted $\$ 2.7$ million, but the award was substantially reduced by the trial judge to $\$ 480,000$. The jury came to the initial award after Mrs. Liebeck's lawyer had explained that the daily profit made by McDonald's from selling coffee was $\$ 1.35$ million, and that the profit of two days would be a reasonable punitive damages award for Mrs. Liebeck. ${ }^{29}$ The total award, as reduced, was \$ 640,000 consisting of $\$ 480,000$ in punitive damages and $\$ 160,000$ in compensatory damages. McDonald's appealed, but the case was eventually settled for an undisclosed, but in all probability reduced, amount of money. ${ }^{30}$ Taking into account the worldwide sales of this multinational, the payment to Mrs. Liebeck was almost certainly nothing but a trifle to McDonald's.

Controversial or not, this decision has set an example to McDonald's and also other restaurants in the world not to serve coffee that is too hot and to warn customers about dangers: ${ }^{31}$

McDonald's coffee is now sold at temperatures similar to other restaurants. Despite the abuse heaped on Mrs. Liebeck's case, McDonald's customers are safer as a result today.

Gottlieb, who wrote a White Paper for the Center for Justice and Democracy in New York, also refers to punitive damages as a mechanism to make society safer. She gives many examples of punitive damages cases that have led to improvement in this respect. These cases relate to consumer products, drugs and medical devices, hate crimes, patient care, transportation and the workplace. ${ }^{32}$ Some people refer to the McDonald's case as an excess of the American system, an urban legend or even a horror story. ${ }^{33}$ But the case can also be considered as an example upholding the American civil justice system, even though this system can be 'enormously threatening to actual and potential defendants'. ${ }^{34}$ And this observation does not apply exclusively to the McDonald's case: there are countless other examples of American punitive damages cases that can be viewed as excessive horror stories on the one hand or as necessary examples to uphold civil justice on the other. Take for instance the case of Rachel Barton, a promising violinist, twenty years of age, who was involved in a terrible accident. ${ }^{35}$ When Rachel stepped off a train, the violin case that she was carrying together with her purse, briefcase and food bag got stuck. The train doors suddenly closed, pinning Rachel to the train, and started moving. Rachel was dragged along in a half-sitting

29

Koenig \& Rustad 2001, p. 8; Baker, Kritzer \& Vidmar 2008, p. 16.

Baker, Kritzer \& Vidmar 2008, p. 16.

Gottlieb 2011, p. 6-8.

Koenig \& Rustad 2001, p. 6, 173.

4 Kagan 2010, p. 133.

35 Barton v. Chicago and North Western Transp. Co., 325 Ill.App.3d 1005, 757 N.E.2d 533, 258 Ill. Dec. 844 (Ill.App. 1 Dist. 2001). See on this case also Rustad 2008. 
position for several feet, which resulted in life-threatening injuries. ${ }^{36}$ Her left leg had to be amputated, as well as the toes of her right foot. Rachel testified that her recovery included '25 surgeries, 223 medical appointments, 122 prosthetics appointments and 170 physical rehabilitation sessions'. ${ }^{37}$ She had medical costs of $\$ 672,570.97$. As the railroad failed to have a proper procedure to prevent the doors from closing and the train from leaving when passenger's luggage or limbs were in the way, the trial court decided that, although Rachel was $4.5 \%$ at fault, she was entitled to a damages award of almost \$ 29 million, including $\$ 859,500$ in punitive damages. ${ }^{38}$ This decision was affirmed by the appeal court. ${ }^{39}$ The McDonald's case and the Barton case are only two of many examples that are easy targets of criticism, fruits of the excessive American civil justice system, not in the last place for European outsiders. ${ }^{40}$ Another striking real-life example is that of a four-year-old plaintiff who got severely burned, i.e. second- and third-degree burns over $20 \%$ of her body resulting in permanent disfigurement, because her flannelette pajamas caught fire. The manufacturer had to pay the little girl $\$ 1$ million in punitive damages for failing to use flame retardants and using unreliable tests in the production process. ${ }^{41}$

It is important to carefully weigh these two viewpoints - horror story or necessity to uphold civil justice - of punitive damages judgments. Doroshow, executive director of the Center for Justice and Democracy, explains in Hot Coffee why the American civil justice system works as it does: ${ }^{42}$

"When you are hurt by somebody, harmed in some way, and the person or the company that harms you is negligent or does this intentionally, you have a right to hold that wrongdoer accountable. And those are the civil courts that handle those kinds of cases, and that is our civil justice system. It's a fundamental right that we have, it stems from the Constitution, from the Bill of Rights."

The McDonald's case, the Barton case and the many other available punitive damages judgments also support the idea that the punitive damages doctrine is, in

36 Barton case, at 541.

37 Barton case, at 543.

38 Barton case, at 549. The compensatory damages award was composed as follows: $\$ 9$ million for disability, $\$ 8$ million for disfigurement, \$ 8 million for pain and suffering, \$ 3 million in future pain and suffering, \$20,250 in lost wages, \$104,370 in future lost wages, \$ 672,570.97 in medical expenses and $\$ 1,293,018$ for future medical expenses. The jury also awarded punitive damages of $\$ 900,000$. After a reduction of $4.5 \%$, the total of the awards was $\$ 28,736,149.57$ and $\$ 859,500$ respectively.

39 Rachel Barton Pine never stopped playing the violin. She has built a successful career and has her own website: www.rachelbartonpine.com

40 Rustad 2008, p. 465.

41 Gryc v. Dayton-Hudson Corp., 297 N.W.2d 727 (Minn. 1980).

42 Hot Coffee 2011, at 08:06. 
itself, generally linked to the United States. ${ }^{43}$ It is for that reason explainable that, in order to analyse the problem statement adequately, reference is made to American punitive damages law. To give a better understanding of the context of American punitive damages law, some background information about the American governmental, legislative and judicial system, as well as the important role of the civil justice system, will be provided before exploring substantive punitive damages law.

\subsubsection{The American Governmental, Legislative and Judicial System}

The government of the United States was officially established by the Constitution of 1789 , its structure being primarily characterised by the principles of separation of powers - based on Montesquieu's idea of trias politica - and federalism. ${ }^{44}$ The separation of powers principle aims at a true division between the three branches of federal government laid down in the Constitution: the legislative, the executive and the judicial branch. In an ideal situation the three branches control each other, and prevent the one from becoming more powerful than the other. In practice, the separation of powers principle is interpreted as a balancing of powers, a system of 'checks and balances'. ${ }^{45}$ Federalism means that powers are shared between different levels of government that all have substantial autonomy. In the United States, powers are shared between the central government and 50 state governments. Because of its federalist structure, the country is in fact made up of 51 different governments that all have legislative, executive and judicial autonomy. Federalism has a considerable effect on the American legal system. To be precise, it is not entirely accurate to speak of the American legal system. The United States is in fact divided into 51 separate legal systems.

All state governments plus the central government have the power to pass legislation, and numerous courts throughout the country produce judicial precedent. The United States is a common law system, which means that legal reasoning is primarily based on judicial decisions, in particular so far as private law is concerned. ${ }^{46}$ Thus, the judiciary is able to create legal rules through decisions in individual cases. Judicial precedent, or judge-made law, is a very important source of law in the United States. In fact, together with statutes, ${ }^{47}$ the common law is the source of law that is most often encountered. ${ }^{48}$ The underlying basis of the

43 Although the three examples mentioned in this section concern personal injury, punitive damages are awarded - relatively - rarely in personal injury cases. The main reason for this is that they should not be imposed when the harm is caused accidentally. Punitive damages are mostly awarded in the United States for intentional torts, defamation and financial torts. The popular punitive damages categories will be further explained in section 3.2.2.

44 Burnham 2006, p. 1.

45 Burnham 2006, p. 9

46 The common law system, one of the two great legal traditions of the Western world, differs from the Roman law based civil law systems in continental Europe. See Von Mehren \& Murray 2007, p. 27.

47 Statutes are sets of legislation enacted by state and federal legislative bodies. The collection of federal statutes is called the 'United States Code', whereas collections of state statutes are known as 'compiled laws' or 'compiled statutes'. See Burnham 2006, p. 38.

48 Burnham 2006, p. 38. 
doctrine of precedent is the principle of stare decisis, i.e. the necessity to abide by former case law when the same points arise in future litigation. ${ }^{49}$ All jurisdictions within the United States, with the exception of Louisiana, have a common law tradition. The extensive body of case law that has already been developed by American courts is still growing every day. There are two types of case law: common law case law, meaning the body of law developed solely through judicial decisions, and case law interpreting enacted law, meaning judicial decisions interpreting a source of law. ${ }^{50}$ As a source of law, case law interpreting enacted law follows the hierarchical level of the enacted law that it interprets and, for that reason, has a higher place in the hierarchy than common law case law. ${ }^{51}$ As for the law created by the legislator, such as statutes, both state governments and the federal government have the power to pass legislation, except as limited by the federal and state constitution. The legislative powers of Congress are listed in the Constitution. ${ }^{52}$ These express powers of Congress include the right to levy taxes, coin money and declare war. Federal and state governments may have concurrent powers to pass legislation on a certain subject. If, in that case, the federal government chooses to legislate, federal law prevails over conflicting state law under the Supremacy Clause and the U.S. Supreme Court's doctrine on preemption. ${ }^{53}$ Powers that are not specified by the Constitution are under state control, meaning that legal fields such as tort, contract, property, family and commercial law remain within the ambit of the state: ${ }^{54}$

The powers not delegated to the United States by the Constitution, nor prohibited by it to the States, are reserved to the States respectively, or to the people.

What does the division between federal and state governments mean for punitive damages law? As will be explained below, punitive damages are, for the most part, awarded in tort cases involving certain aggravating circumstances such as intentional or reckless behaviour. ${ }^{55}$ Tort law is in essence not an issue of federal law and is therefore primarily regulated by the states. ${ }^{56}$ Although primary sources are essential for researching punitive damages law, a lot of information may also be

50 Burnham 2006, p. 167

51 Burnham has structured the sources of law in the United States as follows: (1) the federal Constitution, (2) federal statutes, treaties and court rules, (3) federal administrative agency rules, (4) federal common law, (5) state constitutions, (6) state statutes and court rules, (7) state agency rules, and (8) state common law. See Burnham 2006, p. 41.

52 Constitution, article I $\S 8$.

53 Constitution, article VI clause 2: 'This Constitution, and the Laws of the United States which shall be made in Pursuance thereof; and all Treaties made, or which shall be made, under the Authority of the United States, shall be the supreme Law of the Land; and the Judges in every State shall be bound thereby, any Thing in the Constitution or Laws of any State to the Contrary notwithstanding'. The doctrine of preemption is derived from the Supremacy Clause.

54 Amendment $X$ to the Constitution (1791), cited in Burnham 2006, p. 30.

55 Von Mehren \& Murray 2007, p. 179; Burnham 2006, p. 241. See section 3.2.

56 Burnham 2006, p. 425. 
derived from secondary sources of American law. For example, punitive damages law of all American states has been summarised in legal encyclopedias such as American Jurisprudence and Corpus Juris Secundum. Another important secondary source is created by the American Law Institute (ALI). ${ }^{57}$ The ALI was established in 1923 to clarify, simplify and improve the law and its administration, because early $20^{\text {th }}$ century American law was both uncertain and complex. ${ }^{58}$ The uncertainty followed from the lack of agreement on common law principles, whereas the complexity was a result of the legal diversity within the different jurisdictions. The ALI does research into several legal fields, including torts, and produces so-called restatements of the law. Restatements summarise the existing state of American law and provide explanatory comments. Although restatements are not official statements of the law and have only persuasive authority, they are highly influential and are used as guidelines by legislators and courts. ${ }^{59}$ State legislators and courts are entitled to adopt restatements in whole or in part at their discretion. American punitive damages law has been summarised and commented in the Restatement (Second) of Torts 1979 (hereafter: Restatement of Torts). ${ }^{60}$

The American judicial system is characterised by adversarial legalism and jury trials, and it is known for its 'unique legal style'. 61 The foundation for the adversary procedure was laid by the use of juries to decide disputes. The rise of the jury trial slowed down the development of an inquisitorial process as it enabled the judge to be passive and neutral. ${ }^{62}$ In American civil cases, the right to a trial by jury is guaranteed through the Constitution ${ }^{63}$ and state constitutions. ${ }^{64}$ The jury cooperates with the judge and is in principle responsible for deciding issues of fact, whereas the judge decides issues of law. ${ }^{65}$ The adversarial system holds the parties responsible for producing the evidence upon which the decision will be based. ${ }^{66}$ Furthermore, the procedure is highly structured into different phases, i.e. pre-trail,

57 All members - with a maximum of 3,000 - of the ALI have a legal background. The members, primarily judges, practitioners and scholars, elect a director and a council, who in turn appoint reporters for specific legal subjects.

58 See www.ali.org.

59 Von Mehren \& Murray 2007, p. 21.

60 Restatement of Torts, $\S 908$ ('Punitive Damages') and $\S 909$ ('Punitive Damages Against a Principal').

61 Kagan 2001, p. 7; Kagan 2007, p. 45.

62 Kagan 2010, p. 10, 122.

63 Amendment VII to the Constitution: 'In Suits at common law, where the value in controversy shall exceed twenty dollars, the right of trial by jury shall be preserved, and no fact tried by a jury, shall be otherwise re-examined in any Court of the United States, than according to the rules of the common law'.

64 E.g. Constitution of Massachusetts, articles XII and XV.

65 Burnham 2006, p. 87; Von Mehren \& Murray 2007, p. 2.

66 Verkerk 2010, p. 279-280; Kagan 2001, p. 11. 
trial and post-trial, which are all governed by an elaborate set of rules. ${ }^{67}$ For comparison: in most continental European legal systems the judicial process is essentially inquisitorial, an approach that adversarialism is usually contrasted with. ${ }^{68}$ The most important actor in an inquisitorial process is the judge, who is actively committed to the search for material truth. ${ }^{69}$ According to Kagan, American adversarial legalism is the result of tension between two factors: ${ }^{70}$

First, a political culture (or set of popular political attitudes) that expects and demands comprehensive governmental protections from serious harm, injustice, and environmental dangers - and hence a powerful, activist government - and, second, a set of governmental structures that reflect mistrust of concentrated power and hence that limit and fragment political and governmental authority. Adversarial legalism helps resolve the tension. In a "weak," structurally fragmented state, lawsuits and courts provide "nonpolitical," nonstatist mechanisms through which individuals can demand high standards of justice from government.

The powerful punitive damages remedy is an example of a mechanism through which high standards of justice can be demanded, as 'strong legal penalties' are an important characteristic of adversarial legalism. ${ }^{71}$ Although the American system of adversarial legalism is said to facilitate litigant activism, litigation is also considered a costly burden and therefore claimants are enticed to resolve disputes before trial, for example by settling a civil case or by relying on alternative dispute resolution. $^{72}$ To conclude, what is important is that in comparison to Europe adversarial legalism is far more common in the United States, where it has a powerful influence on both governmental and legal processes. ${ }^{73}$

\subsubsection{The Role of the Civil Justice System}

The role of the American state is generally characterised by notions of individualism, laissez-faire and the like. Compared to most continental European countries, the United States is a reactive rather than an activist state. The reactive state traditionally fulfils a relatively reserved role in society and attaches great value to the individual's own responsibility, whereas the activist state tends to improve

67 Landsman 1988, p. 2. Burnham gives a more extensive explanation of the adversarial system by adding two characteristics: '(1) the proceeding is concentrated, uninterrupted and otherwise designed to emphasize the clash of opposing evidence and arguments presented by the parties, (2) the parties have equal opportunities to present and argue their cases to the decision-maker', see Burnham 2006, p. 81.

68 Cf. Von Mehren \& Murray 2007, p. 166, stating that 'almost all systems of private civil litigation in the modern democratic world are more or less adversarial, in that parties generally initiate law suits, parties control the scope of the issues to be decided, parties proffer and identify the sources of factual proof to be received, and parties can terminate the litigation by agreement'. See also Verkerk 2010, p. 280.

69 Landsman 1988, p. 38

70 Kagan 2010, p. 15-16.

71 Kagan 2001, p. 9.

72 See section 2.2.3.1 below.

73 Kagan 2007, p. 46-47. 
economic and social life and implements policies accordingly. ${ }^{74}$ The idea of a reactive state corresponds to the classical liberal theory that is favourable to individual rights and freedoms, a free market and limited governmental intervention. Freedom is a highly respected value in the United States. The Bill of Rights protects each individual's right to be free of superfluous interference from the state. The idea that citizens should not interfere with each other's rights is primarily protected by private law, including tort law. ${ }^{75}$ The impact that classical liberalism has had on the United States can be explained by the substantial influence of John Locke, a well-known classical liberal. In contrast, continental Europe was principally influenced by collectivistic theories with a focus on society, for example the theory of Jean-Jacques Rousseau. ${ }^{76}$

Obviously, the United States is not a purely reactive state. The federal and state governments have intervened in a number of policy areas and are increasingly doing so. In addition to legislation in all sorts of legal fields, current examples of state interference are the support of the federal government relating to the (global) financial and economic crises that started on the American housing market by the end of 2006. ${ }^{77}$ Another example relates to Obama's initiatives to organise health care and health insurance. ${ }^{78}$ Different views on the role of the state undoubtedly influence the way in which a state is organised. This may help to explain the rise of the Welfare State in Western Europe in contrast to the near absence of a safety net in the United States. ${ }^{79}$ The role of the state also affects the objectives of judicial proceedings. ${ }^{80}$ Von Mehren and Murray put it as follows: ${ }^{81}$

In the United States, the civil justice system frequently performs functions that are discharged in other modern jurisdictions by other governmental institutions.

In the words of Kagan: ${ }^{82}$

The United States has been less aggressive than many countries in mobilizing governmental resources to provide alternatives to litigation and to reduce the private costs of civil justice. The American system is shaped more by an exceptionally large, entrepreneurial, and politically assertive legal profession, and less by national ministries of justice.

The United States is a country in which public policy is to a great extent privately enforced, in the sense that the enforcement of public norms is entrusted to private litigants and their lawyers. ${ }^{83}$ It is common practice that important political, social

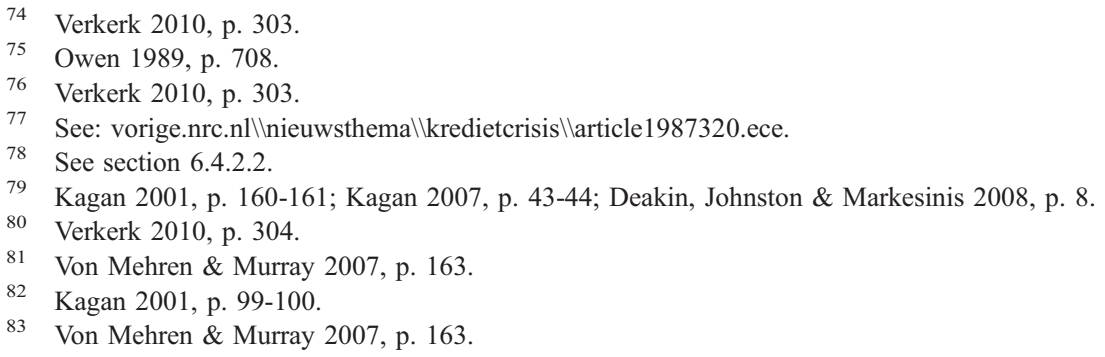


and economic issues are subjected to case-by-case decisions initiated by the people. The United States is known as a legal system in which civil litigation works as a policymaking mechanism. ${ }^{84}$ Due to this importance attached to civil litigation, the United States is also sometimes called a compensation culture. ${ }^{85}$ This approach to policymaking shows the American laissez-faire attitude, the rather reserved and non-active role of government in developing policy. For example, in cases of accidentally-caused personal injury, Americans rely more easily on civil litigation than on social security to obtain compensation of medical expenses. In other modern European countries, such as the Netherlands, Denmark, Sweden, Germany, and France, victims of similar accidents do not principally rely on court proceedings but rather on the established system of social security. ${ }^{86}$ According to Faure and Hartlief, the difference in social security levels between Europe and the United States is an important determinant for the difference in compensation culture. ${ }^{87}$ For example, there has always been a demonstrable difference between the way in which victims of asbestos-related diseases are compensated in the United States and in the Netherlands. In 1991, almost 200,000 asbestos tort claims had been filed in the United States against less than 10 in the Netherlands. ${ }^{88}$ One plausible explanation for this difference seems to be the reliance of the Dutch on the well-organised social security system. ${ }^{89}$ The figures mentioned, however, refer to 20 to 30 years ago. It should be made clear that, in recent years, the number of asbestos tort claims has increased in the Netherlands, which goes hand-in-hand with the increased awareness of the dangers as well as the need for victim protection. In 1999, the Netherlands got its own institute for asbestos victims (Instituut Asbestslachtoffers). ${ }^{90}$ Furthermore, from 1 January 2005, the European Union forbids the use of or trading in asbestos in all the Member States. ${ }^{91}$ Nevertheless, despite the increase in cases in Europe, the United States has a leading role in asbestos litigation, which has been called 'unique' and 'the archetypal mass tort litigation': the expectation is that by 2049 another 668,363 asbestos claims will have been filed. ${ }^{92}$

Civil litigation started to play a role in American policymaking in the eighteenth century. Prior to the American Revolution of 1775, the British colonial administration was considered inaccessible and later on all forms of central authority were mistrusted. ${ }^{93}$ By the end of the eighteenth century, ideas of popular democracy

84

Kagan 2001, p. 16; Verkerk 2010, p. 304; Melnick 2005, p. 79

Deakin, Johnston \& Markesinis 2008, p. 6.

Von Mehren \& Murray 2007, p. 163; Kagan 2001, p. 11, 242; Kagan 1997, p. 168; Ginsburg \& Kagan 2005, p. 5; Cavaliere 2004, p. 307.

Faure \& Hartlief 1999, p. 2015.

Kagan 2001, p. 126.

Kagan 2001, p. 126; Kagan 2007, p. 44.

See www.asbestslachtoffers.nl. See also the following dissertation on asbestos and developments in liability law: De Kezel 2013.

Directive 1999/77/EC.

Schoenbrod et al. 1996, p. 477; Connor 2000, p. 31.

Von Mehren \& Murray 2007, p. 165. 
received considerable attention. Legitimacy was lent to decisions in individual cases that were decided by both judge and jury. Today, the American legal system is still highly democratic, at least when compared to other legal systems. ${ }^{94}$ In controversial issues such as abortion, wrongful birth and wrongful life, gay marriage and the death sentence, politicisation of the law is deep. ${ }^{95}$ The same applies to punitive damages, which are considered a charged political question: ${ }^{96}$

Punitive damages has become an issue like gun control or abortion, generating heated rhetoric and an unwillingness to undertake sustained and dispassionate analysis.

The high level of democracy is demonstrated by judges and juries with popular political legitimacy, which results in the politicisation of legal decisions and contributes to the policymaking role of civil litigation. Judges are appointed by politicians from the executive branch or are elected directly by the electorate, whereas juries are randomly chosen from all citizens. ${ }^{97}$

The transfer of public policy powers from the government to civil litigation is another important aspect of adversarial legalism that characterises the American legal system. ${ }^{98}$ As pointed out by Von Mehren and Murray: ${ }^{99}$

A fragmentation of authority and relatively weak hierarchical control in the United States have led to policy making and dispute resolution through formal legal contestation of individual cases initiated by active private litigants to an extent not known in other modern democracies.

The adversarial system, representing the 'value of autonomy', is the adjudicatory branch of the American political system which considers democracy and liberalism of great importance. ${ }^{100}$ Also according to Kagan, the American system of adversarial legalism has created an 'alternative channel of political action on behalf of the politically weak' and facilitates private enforcement of public policy: ${ }^{101}$

Adversarial legalism has called attention to social problems that political elites had declined to recognize, such as sexual harassment in the workplace, prison crowding, or the inequity (for children in tax-poor municipalities) of funding public education primarily through local property taxes. Adversarial legalism is useful for challenging bureaucratic indifference or callousness or cultural bias, and for bringing procedural regularity to a wide range of governmental decisions, [...].

As pointed out by Melnick, private lawsuits are currently the primary method for the interpretation and enforcement of American federal regulation of state and local governments. ${ }^{102}$ According to Ginsburg and Kagan, apart from the structure

94 Kagan 2010, p. 15

95 Deakin, Johnston \& Markesinis 2008, p. 7

96 Galanter 1998a, p. 14.

97 Von Mehren \& Murray 2007, p. 166; Six 2006, p. 4.

98 Von Mehren \& Murray 2007, p. 165; Kagan 2010, p. 304.

99 Von Mehren \& Murray 2007, p. 165.

100 Redish \& Mathews 2004, p. 24.

101 Kagan 2001, p. 242.

102 Melnick 2005, p. 74. 
of political power, there is another reason for the relatively large role for civil litigation in the United States: economic liberalisation. ${ }^{103}$ In contrast to European economies, the United States has a far more decentralised and competitive market. Important services - the authors mention telecommunications, electricity, health care, working class housing, transportation systems, and financial services - are primarily privately owned rather than dominated by government monopolies. As a result, regulation of these services also does not primarily take place at governmental level: ${ }^{104}$

Regulation of commercial relations in the United States, accordingly, has been left more fully to the realms of contract law, private litigation, common law policymaking by courts, and more legalistic modes of regulation. In recent decades, as globalization has intensified competitiveness of markets, the rate of litigation among businesses has increased, further drawing courts into a policy-making role.

Thus, the influence of litigation on policymaking in the American legal system is evident. However, adversarial legalism cannot solve all problems of civil rights and mass justice: ${ }^{105}$

Civil rights litigation has had only limited success, at best, in integrating the suburbs and improving inner-city housing, schools, and mental health services. Substantively, the United States lags well behind the welfare states of Western Europe in providing for the basic needs of the poor and of single mothers.

Kagan also thinks that adversarial legalism and civil litigation is probably not the most powerful method of reducing social inequality in all situations. Rather, he suggests that high quality education, job training, and social welfare programs should be improved by more generous governmental funding: better social welfare provision would reduce the incentive to turn to adversarial legalism to influence policy and challenge individual decisions. ${ }^{106}$

As regards punitive damages, the subject matter of this book, the widespread use of the civil remedy in the United States in comparison to other countries may well be explained by the modest role of the American state and the importance of the civil justice system. Furthermore, generally speaking, American law imposes more severe civil, regulatory and criminal sanctions when compared to Western European countries. ${ }^{107}$ In essence, the punitive damages remedy is a mechanism that serves as an incentive for potential plaintiffs to initiate civil litigation as socalled private attorneys general. ${ }^{108}$ According to Posner, judge in the Court of

103 Ginsburg \& Kagan 2005, p. 8.

104 Ginsburg \& Kagan 2005, p. 9.

105 Ginsburg \& Kagan 2005, p. 242.

106 Kagan 2001, p. 242.

107 Kagan 2007, p. 44, 60 .

108 Zipursky 2012, p. 1771; Hay 2005, p. 70; Mallor \& Roberts 1999, p. 1003; Redish \& Mathews 2004, p. 2. 
Appeals for the Seventh Circuit (covers Illinois, Indiana and Wisconsin) ${ }^{109}$ and law and economics scholar: ${ }^{110}$

Punitive damages relieve the pressures on the criminal justice system. They do this not so much by creating an additional sanction, which could be done by increasing the fines imposed in criminal cases, as by giving private individuals - the tort victims themselves - a monetary incentive to shoulder the costs of enforcement.

Punitive damages awards ought to contribute to the enforcement of public norms as well as the punishment and deterrence of wrongdoers. The view that such awards are considered a useful complement to other forms of enforcement in the United States is for example shown by the inclusion of a punitive damages remedy in the 1991 amendments to the Civil Rights Act. ${ }^{111}$ According to Von Mehren and Murray: ${ }^{112}$

The relatively weak public apparatus for regulation by detailed administrative norms and for investigation and prosecution of crime is complemented by motivated private litigants and their lawyers. Safeguards are provided through the structure of legal rules enforced by the trial judge and the appellate process. The citizen jury provides the democratic legitimation that is provided by prosecuting officials in many other regimes.

Private litigants stay 'motivated', because potential punitive damages awards function as a 'vehicle by which private individuals enforce public values'. ${ }^{113}$

The punitive damages remedy is not the only mechanism that gives an incentive to private litigants to start a lawsuit. ${ }^{114}$ The American legal system offers other mechanisms that motivate potential plaintiffs or facilitate civil litigation. These will be summarised in the next section.

109 Due to the influence of federalism, the American court system is structured into federal courts and state courts. Both court systems consist of first instance courts ('trial courts') and appellate courts. There are generally two layers of appellate courts: intermediate appellate courts ('the Courts of Appeals') and a court of final resort ('the Supreme Court'). Each state has its own closed court system, meaning that the court of final resort has the last word as far as state law is concerned. For example, the Supreme Court of California has a final say in the interpretation of California Law. Federal courts have jurisdiction over federal law claims, which may arise in state and federal courts, and state law claims that involve parties from different states. The courts of first instance in the federal court system are the United States District Courts, situated in ninety-four judicial districts throughout the country. The judicial districts are organised into thirteen Circuits in which the thirteen federal Courts of Appeals are located. For example, the Court of Appeals for the Tenth Circuit covers Colorado, Kansas, New Mexico, Oklahoma, Utah, and Wyoming. The U.S. Supreme Court serves as the court of last resort in cases appealed from the federal Courts of Appeals. Furthermore, the highest federal court has jurisdiction over questions of federal law that have arisen in state courts. See 29 USCA $\S \S 81-144 ; 28$ USCA § 41; Burnham 2006, p. 167, 174. See also www.uscourts.gov.

110 Kemezy v. Peters, 79 F.3d 33, 64 USLW 2578 (C.A.7 (Ind.) 1996), at § 35 (no. 6). This case gives a clear overview of the functions of punitive damages according to both majority and minority views.

11142 USC \& 1981a, see on this provision section 7.2.5; Mallor \& Roberts 1999, p. 1003.

112 Von Mehren \& Murray 2007, p. 181.

113 Redish \& Mathews 2004, p. 38.

114 Verkerk 2010, p. 304. 


\subsubsection{The American Civil Justice System Put into Context}

The rationale of the American civil justice system is that tort litigants, among others, not only try to get compensation for their losses, but they also serve the public interest by revealing and deterring dangers in society. Koenig and Rustad put it as follows: ${ }^{115}$

Tort law, like sunlight, acts as a disinfectant by exposing hidden threats to the public welfare.

These authors also take the view that American tort law generally has two functions: a manifest function and a latent function. The first is the generally accepted function of tort law to restore plaintiffs to the position they would be in without the wrongful injury, while the latter refers to the public role tort law plays in addressing misconduct without needing a 'rigid government bureaucracy'. 116 As already mentioned above, the United States is known for its compensation culture, litigious culture or blame culture. ${ }^{117}$ Apart from the structure and underlying principles of the legal system, this is also the result of other views on responsibility. The attitude of legally blaming others for problems is accepted in American society. Putting the blame on someone else might sometimes be fair, at other times it might not. But the question whether suing someone else is the right thing to do is not the point to be made here. What is important to realise is that the right to sue and trying to hold others responsible is emphasized more in the United States than in Europe. Centner, for example, writes about 'America's "love affair" with the right to sue'. ${ }^{118}$ Americans and Europeans seem to have contrasting approaches to liability. Americans put less emphasis on personal responsibility and more on deterring accidents and keeping others safe. ${ }^{119}$ As a result, American and European tort systems have developed differently. It would go beyond the scope of this book to explain the basics of substantive American tort law. ${ }^{120}$ Some aspects will anyhow become relevant in the following parts on punitive damages law. It is far more interesting at this point to look into certain features of procedural law that are inherent to the American legal system and that have an impact on civil litigation, especially tort claims. According to Magnus: ${ }^{121}$

115 Koenig \& Rustad 2001, p. 3.

116 Koenig \& Rustad 2001, p. 1-2.

117 Centner 2008, p. 3, 5.

118 Centner 2008, p. 4.

119 Centner 2008, p. 20. See on this topic also section 6.4.3.3.

120 For an easy-reference summary of American tort law see Burnham 2006, chapter XI, p. 424-459. For an extensive overview see Keeton et al. 1984.

121 Magnus 2010, p. 110. This article of Magnus explains the characteristics of American tort law in comparison to the European approach to tort law and has been used as a main source for this section. See generally on legal differences between American and European Law Grabher \& Gamper 2009. 
More than in other legal systems specific procedural peculiarities of the US legal system influence the application and effects of tort law. These peculiarities are not tort-specific, but in tort they are especially relevant.

These procedural law aspects, some of which have already been pointed out, differentiate the American civil justice system from those in continental Europe. It is especially interesting to see how such aspects support civil litigation, make access to court easier and facilitate the awarding of punitive damages. But before going into these procedural aspects, some remarks will be made about the believed 'litigation explosion' in the United States. ${ }^{122}$

\subsubsection{An Excessive Litigation System?}

As explained in section 2.2.2.2, civil litigation plays an important role in American society, especially - and this is important - when compared to other legal systems. ${ }^{123}$ But there is a lot of debate on the exact meaning of this role. Contrary to what is often believed, empirical research shows that the American tort system is not characterised by excessiveness or abuse: tort cases form a relatively small percentage of civil lawsuits and tort damages are modest in amount. ${ }^{124}$ Contract cases, disputes over mortgages, domestic relations, and other civil matters are prevailing. The majority of tort cases concern automobile accidents. ${ }^{125}$ Excluding these automobile accidents, it appears that a rather small part of accidental deaths and injuries get compensated through the tort system. ${ }^{126}$ According to Bornstein et al. 'only a very small percentage of cases actually go to trial' and tort cases are in fact relatively rare. ${ }^{127}$ Merritt and Barry also point out that relatively few lawsuits are being filed compared to the incidence of personal injury, meaning that most persons who suffer personal injuries never file a lawsuit. ${ }^{128}$ Furthermore, the majority of tort claims are settled, and these settlements usually do not compensate the plaintiff completely. ${ }^{129}$ Cohen, for instance, estimates that in 2005 only $4 \%$ of all tort cases were disposed of by trial. ${ }^{130}$ In the area of medical malpractice, which is often believed to be a major area of tort law, only a small percentage of persons who have received seriously unsatisfactory medical care start a lawsuit, and only in $30 \%$ of these lawsuits the plaintiff actually wins. ${ }^{131}$ Also, in the majority of

122 Burnham 2008, p. 457

123 As will be further explained in section 3.2.2, punitive damages are mostly - but not only - awarded in tort cases. The sections hereafter will therefore keep referring to civil litigation rather than tort litigation.

124 Centner 2008, p. 21. See section 4.2.2.

125 Cohen 2009, p. 2; Centner 2008, p. 21; Burnham 2008, p. 457; Galanter 2000, p. 663; Sugarman 2000, p. 2428.

126 Burnham 2008, p. 458; Goldberg 2008, p. 1264.

127 Bornstein et al. 2008, p. 10.

128 Merritt \& Barry 1999, p. 317. See also Galanter 2000, p. 663, who states that claims were put forward in only about ten percent of all accidental injuries, thereby citing a national survey of claiming behaviour from the 1980s.

129 Baker 1998b, p. 212; Koenig 1998, p. 171, 208.

130 Cohen 2009, p. 1.

131 Burnham 2008, p. 458. See also Bornstein et al. 2008, p. 13; Cohen 2009, p. 2. 
products liability trials, only a small percentage of claims are filed and plaintiffs either lose or the verdict is modest. ${ }^{132}$ Moreover, the number of tort cases peaked in the 1980s and has been decreasing since the 1990s. ${ }^{133}$ The notion that the American litigation system is not excessive has also been signaled in Dutch literature by Faure and Hartlief. ${ }^{134}$ Based on a Rand report from 1991, they make clear that 90 out of 100 American personal injury victims never make a claim; only two of the ten victims who do make a claim file a civil claim.

Several American tort reform initiatives, such as imposing caps on damages, have played a role in the restriction of civil litigation. Another important characteristic of the American legal system is the availability of a wide range of alternative dispute resolution instruments, such as arbitration and mediation. ${ }^{135}$ Claimants may, for various reasons, prefer to rely on such instruments, which has an impact on civil litigation. Note that punitive damages are also available in arbitration. ${ }^{136}$ So where does this misperceived idea of excessive civil litigation in the American legal system come from? A topic that keeps popping up in legal doctrine is that the image is caused by a lack of objective analyses of the litigation system, especially through mass media. ${ }^{137}$ The media is not always citing correct information, and much about the litigation system remains unknown to the public and even to politicians. ${ }^{138}$ It is, however, important to keep in mind that although the system is in practice not as excessive as is often believed, there is a noticeable difference between the United States and Europe when it comes to civil litigation. As stated above, the right to sue is an ingrained right in American society that has always been considered more important there than in Europe.

\subsubsection{Adversarial Legalism}

A fundamental characteristic of the American legal system is the above-mentioned system of adversarial legalism. The outcome of a legal procedure is to a large extent influenced by the parties' lawyers (in a criminal procedure: prosecutor and defense) who have to reveal the truth, in contrast to continental European legal systems where the judge has an inquisitorial role and needs to reveal the truth actively. ${ }^{139}$ The American legal system is noticeably built upon this principle of adversarial legalism. An example is the procedural mechanism of discovery, which offers the plaintiff the possibility to gather information from the defendant in a way that is not allowed in continental European legal systems. ${ }^{140}$ More general aspects

132 Merritt \& Barry 1999, p. 317; Cohen 2009, p. 2.

133 Centner 2008, p. 21; Geistfeld 2005, p. 1093; Burnham 2008, p. 457.

134 Faure \& Hartlief 2012, p. 158, referring to Hensler et al. 1991.

135 Magnus 2010, p. 117.

136 See on this topic Lew 2007; Noussia 2010.

137 Centner 2008, p. 22; Galanter 1998b, p. 723.

138 Burnham 2008, p. 458; Centner 2008, p. 22; Bailis \& MacCoun 1996, p. 424

139 Kagan 2001, p. 105.

140 Magnus 2010, p. 116. 
of adversarial legalism are policy and decision-making by civil litigation, fragmented authority, weak hierarchical control, and political judges. ${ }^{141}$ As mentioned in section 2.2.2.1 above, strong legal penalties such as punitive damages, through which high standards of justice can be demanded, are also an important characteristic of adversarial legalism.

\subsubsection{Juries}

Another feature of the American legal system unknown in continental European legal systems is the use of juries that are composed of laymen. As a passive decision maker, the jury fits well in an adversarial system. ${ }^{142}$ Jury trials are considered a 'vehicle for obtaining civil justice'. ${ }^{143}$ The jury has substantial influence in civil litigation as it may decide on issues of fact and is able to influence the amount of damages awarded without having to motivate its decision. Opponents of punitive damages are concerned about the competences of juries as they fear that juries are easily persuaded by victims asking for compassion and they award outrageous amounts of (punitive) damages as a result. However, as will be shown in section 3.3.2, empirical studies that investigate decision-making of judges and juries in respect of punitive damages awards show that this assertion is incorrect. The difference between judge and jury awards is not as striking as often thought. ${ }^{144}$

\subsubsection{Litigation Costs}

The American litigation system is the most expensive in the world: in 2009, it cost about \$ 248 billion per year, which is about \$ 808 per person. ${ }^{145}$ The American tort system is more than twice as expensive as that of other major industrialised nations. ${ }^{146}$ The number of practicing lawyers in the United States is six times higher than in the Netherlands. ${ }^{147}$ These differences most likely have to do with the importance attached to the American civil justice system, despite the abovementioned notion that tort cases are in fact relatively rare. What about the costs of starting a lawsuit? The sometimes difficult decision for a victim of whether or not to start expensive proceedings may become easier due to the American rule on litigation costs in connection with the system of contingency fees or remuneration of lawyers on the basis of 'no cure, no pay'. The American rule implies that the parties in a civil lawsuit have to pay for their own legal costs, no matter what the outcome of the lawsuit is. ${ }^{148}$ An effect of the American rule is that it may influence the amount of punitive damages awarded, as juries will usually take litigation costs into account. Punitive damages awards are indeed used to evade the American rule

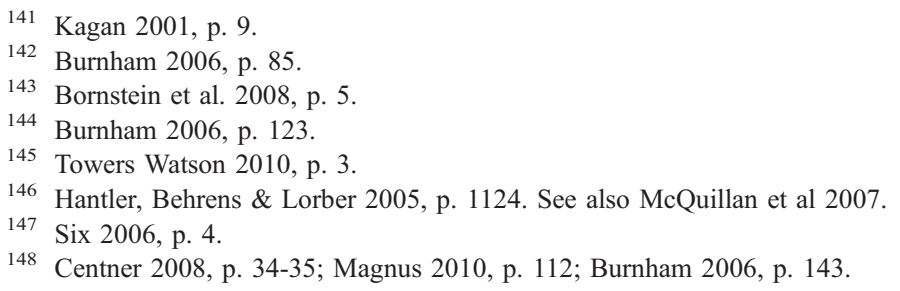


of adjudicating costs, ${ }^{149}$ although not all American states allow these costs to be considered in awarding punitive damages, as this would lead to compensation of the plaintiff rather than punishment of the defendant. ${ }^{150}$ However, because each party should in principle pay its own attorneys' fees, it is generally considered appropriate to award something more than pure compensatory damages. Furthermore, the risk of having to pay a considerable amount of litigation costs is taken away by the possibility of contingency fees or 'no cure, no pay' arrangements, which oblige the client to pay the lawyer only if the case has been won. In that way, even people who cannot afford a lawsuit are able to find a lawyer, simply because, according to Howells, 'there is no deterrent to trying one's luck in an American court'. 151

Thus, the American rule combined with contingency fees facilitates access to court for everyone and gives an incentive to initiate civil proceedings; claimants do not have to be afraid of litigation costs. The contingency fee system allows lawyers, who will have an economic incentive in each case, to refuse unmeritorious or doubtful claims. ${ }^{152}$ In other words, lawyers function as gate keepers who reject claims that do not have a chance of success. This practice certainly does not stimulate an excessive litigation culture. Nevertheless, an often heard point of critique is that the system enables so-called ambulance chasers, i.e. (persons paid by) lawyers who make every effort to bring in clients. ${ }^{153}$ In contrast, continental European legal systems apply the European rule which means that the losing party also has to pay for the litigation costs, usually determined by a fixed rate, of the winning party. This will also prevent most claimants from bringing doubtful or risky cases before the court. ${ }^{154}$ Claimants are not able to exclude the risks of having to pay litigation costs in the same way as Americans can, as contingency fees arrangements are illegal in most continental European legal systems where lawyers should stick to fixed hourly rates in order to uphold their independence, incorruptibility and integrity. ${ }^{155}$

The American rule in connection with contingency fees in a way stimulates the compensation culture in the United States, as it may make the sometimes difficult decision of a plaintiff whether or not to start expensive proceedings easier. One important final remark is that the American system seems to be an inspiration to others: the Dutch legislator is currently exploring the possibility of introducing a 'no cure, no pay' system in order to guarantee effective access to court. In this respect, the Minister of Safety and Justice prepared an experiment for personal

149 Behr 2003, p. 122

150 Schlueter 2005a, p. 36; Kircher \& Wiseman 2000a, p. 5-169. See section 4.3.2.5.

151 Howells 2000, p. 307.

152 Faure \& Hartlief 2012, p. 160; Magnus 2010, p. 114.

153 Schirmeister 1996, p. 121; Koenig \& Rustad 2001, p. 42-43; Kagan 2001, p. 133.

154 Magnus 2010, p. 112.

155 See Beer 2008, p. 136-139; Magnus 2010, p. 113-114. 
injury lawyers together with the Dutch bar. ${ }^{156}$ In his letter to the Lower House, the Minister makes clear that he is not afraid that an excessive claim culture will result from introducing 'no cure, no pay' arrangements, for example because the Netherlands has a well-developed system of subsidised legal aid, privately financed legal aid and legal aid insurance. ${ }^{157}$ Furthermore, he points out, the Dutch judge pursues a moderate policy with regard to awarding civil damages as most damages claims are settled out of court and punitive damages are not allowed. Time will tell whether 'no cure, no pay' arrangements have a real future in the Dutch legal system.

\subsubsection{Legal Aid}

A characteristic of the American legal system that is closely attached to the American rule is the absence of legal aid from public funds. Legal aid is considered unnecessary because of the American rule and contingency fees which enable even the poorer people to start a civil procedure. ${ }^{158}$ With regard to Europe, the already explained European rule has made legal aid from public funds necessary. In Europe, a poorer person is usually only entitled to financial support if his claim has reasonable prospects of success. ${ }^{159}$ Thus, legal aid is used to filter out claims of little value or importance. ${ }^{160}$

\subsubsection{Class Actions}

Another feature of American law that facilitates civil litigation is the class action or collective civil litigation. Under both federal and state law, a group of plaintiffs may bring a common civil action that is based on common questions of fact and law and, in so doing, each individual plaintiff avoids the relatively high costs of legal proceedings in the United States. ${ }^{161}$ The Federal Law basis for class actions is Rule 23 of the Federal Rules of Civil Procedure. American class actions, especially the combination with punitive damages, have been criticised and referred to as 'the mass tort monster'. ${ }^{162}$ A contrary view is that the class action

156 The experiment started on 1 January 2014 and will take five years, see www.advocatenorde.nl/729/ consumenten/contact-algemeen-incl-persberichten.html\#resultaat gerichte beloning. See, on the experiment, Van Boom \& De Jong 2014.

157 See Kamerstukken II 2012/13, 31 753, nr. 62.

158 Note that another reason for the absence of legal aid is that many alternatives to costly litigation are available. For example, workers' compensation systems to compensate injured employees have replaced most civil litigation, and no-fault automobile insurance policies may offer the possibility to settle tort claims without individual lawsuits. Also think of the 9/11 Victim Compensation Fund, which has distributed government money to compensate (relatives of) victims of the terrorist attacks: around $\$ 7$ billion has been paid to compensate around 5,600 persons, which is $97 \%$ of the individuals who might otherwise have filed civil claims. See Centner 2008, p. 22-23; Burnham 2006, p. 458-459; Final Report of the Special Master for the September $11^{\text {th }}$ Victim Compensation Fund of 2001, retrieved via: www.justice.gov/final_report.pdf.

159 See for Dutch law article 12 Wet op de Rechtsbijstand.

160 Magnus 2010, p. 114.

161 Von Mehren \& Murray 2007, p. 182.

162 Connor 2000, p. 3. See on the combination class action and punitive damages also McGovern 2010. 
fits into the role that is assigned to the American civil justice system, as it improves access to justice and contributes to law enforcement. The possibility to join a class of claimants forms an incentive for individual victims who would otherwise refrain from initiating a civil claim because of rational lack of interest, i.e. when the damage is too small. ${ }^{163}$ Also in respect of the theme of this book, it is interesting how Kortmann points out that the American class action mechanism is not totally in conformity with the compensatory principle: ${ }^{164}$

On a conceptual level, there is no reason why a class action system would necessarily elicit a deviation from the compensatory principle. In practice, however, the American class action has led to a significant departure from that principle. Class actions are now frequently allowed in circumstances where there is no reasonable expectation of the action resulting in compensation for individual victims.

And:

Clearly, where class actions are allowed to proceed without a credible prospect of providing redress to individual class members, it can no longer be maintained that their purpose is compensatory. Instead, they have become an instrument to enforce the underlying principles of substantive law.

Most European legal systems do not have a mechanism that is similar to the American class action, although in recent years the European interest in class actions has increased. ${ }^{165}$ For example, recent developments in the United Kingdom should be mentioned: in 2013 the government announced plans to introduce opt-out class actions in competition law cases. ${ }^{166}$ Furthermore, the coming into force of the Dutch Act on Collective Settlements Mass Damages (Wet Collectieve Afhandeling Massaschade or WCAM) in 2005 has had a considerable impact. ${ }^{167}$ The WCAM is incorporated into book 7 of the Dutch civil code (articles 7:907 to 7:910 BW) and in the Dutch code of civil procedure (articles 1013 to $1018 \mathrm{Rv}$ ). It provides the possibility to judicially declare a collective settlement agreement, made between an organisation that acts in the interests of a number of injured parties on the one hand and the liable party or parties on the other hand, binding for the entire group of victims. ${ }^{168}$ Although American class actions have served as a model for the WCAM, Dutch WCAM procedures are not entirely similar to American class actions. As explained by Frenk, one essential difference between the two is that in the Dutch procedure the parties mentioned have already reached

163 Magnus 2010, p. 116.

164 Kortmann 2009, p. 9-10.

165 Cauffman 2009, p. 690-708.

166 See Higgins \& Zuckerman 2013. Other European countries with collective damages actions include Germany, Belgium, France and Portugal. See Memorie van Toelichting Wetsvoorstel Afwikkeling Massaschade in een Collectieve Actie (consultatieversie juli 2014), p. 5, retrieved via: www. internetconsultatie.nl/motiedijksma.

167 Hartlief 2007b, p. 2595. See on WCAM-procedures in the Netherlands also Tsankova 2007; Frenk 2007; Van der Heijden 2010; Tzankova \& Lunsingh Scheurleer 2009; Ozmiz \& Tzankova 2012; Tzankova 2012; Ten Wolde \& Peters 2013.

168 Frenk 2007, p. 215. 
agreement about the claim settlement, after which they ask the judge to declare this agreement binding for all victims, whereas in the American procedure a lawyer asks the judge to condemn a liable party to pay damages to a class of claimants. A disadvantage of the American procedure is that after consideration of the joint legal issues, the exact amount of damages for each individual victim needs to be assessed. The contributory fault of a particular victim may for instance reduce the amount of damages he is entitled to. In order to circumvent this problem, American class actions in practice often result in a settlement. The Dutch legislator found the costly and time-consuming American procedure undesirable and has for that reason opted for another approach that resembles the American practical method of using settlements. ${ }^{169}$

Since 2006, a number of Dutch cases have fallen under the WCAM regime. In these cases, a collective settlement agreement has been declared binding by the Court of Appeal of Amsterdam, which is the only Dutch court that has jurisdiction in WCAM cases (article 1013 lid 3 Rv). The following six cases can be mentioned: ${ }^{170}$ (1) the worldwide famous case of the so-called DES daughters, i.e. women who suffer from various forms of rare cancer because, from the 1940s onwards, the drug DES (diethylstilbestrol) was prescribed to their mothers to prevent miscarriage, ${ }^{171}$ (2) the case of Dexia, a bank that has caused financial damage to many consumers by selling illicit margin financing products; ${ }^{172}$ (3) the case of Vie d'Or, a company selling life insurance that got into financial trouble and had to compensate its assureds; ${ }^{173}$ (4) the case of Shell, which had to compensate shareholders for misinforming them about Shell's oil and gas reserves; ${ }^{174}$ (5) the Vedior case, which is about financial damage to shareholders due to insider trading; ${ }^{175}$ and (6) the Converium case, in which shareholders suffered financial damage due to unfounded announcements of the company with regard to its (expected) financial results. ${ }^{176}$ This shows that, since 2006, there is a noticeable increase in mass damages claims in the Netherlands, especially in the field of financial products and services leading to damage to consumers or shareholders. Only one of the six Dutch settlement agreements, i.e. the DES case, involved personal injury claims. ${ }^{177}$

Note that this is the current situation in the Netherlands. The Dutch WCAM procedures may however have international effect: in some of the Dutch cases mentioned above, the settlement agreement was also made on behalf of foreign injured parties. Especially the cases of Shell and Converium had a substantial international scope because the majority of the claimants were not residing in the

169 Frenk 2007, p. 216.

170 Ten Wolde \& Peters 2013, p. 3; Tzankova 2012, p. 558.

171 Hof Amsterdam 1 juni 2006, NJ 2006/461 (DES).

172 Hof Amsterdam 25 januari 2007, NJ 2007/427 (Dexia).

173 Hof Amsterdam 29 april 2009, NJ 2009/448 (Vie d'Or).

174 Hof Amsterdam 29 mei 2009, NJ 2009/506 (Shell).

175 Hof Amsterdam 15 juli 2009, JOR 2009/325 (Vedior).

176 Hof Amsterdam 17 januari 2012, NJ 2012/355 (Converium).

177 Tzankova 2012, p. 558. 
Netherlands. ${ }^{178}$ The WCAM procedure is therefore also seen as a mechanism to settle international mass damages claims, although its international success depends on the question whether foreign courts will recognise and enforce the settlement agreement. This is a matter of private international law that has not yet been resolved. ${ }^{179}$ The international scope of the WCAM is currently on the agenda of the Dutch legislator, who did not expect an international effect to this extent. ${ }^{180}$

To conclude, thus far no other European country provides for a mechanism that is similar to the WCAM procedure. ${ }^{181}$ Despite the potential international scope of Dutch settlement agreements, class actions therefore still play a minor role in tort systems throughout Europe, which has been confirmed by Magnus. ${ }^{182}$ Nonetheless, the developments in the Netherlands and the fact that the topic receives increased attention in Europe are relevant observations in view of the theme of this book. The European Commission, for instance, published a communication and a recommendation concerning the future of collective redress in the European Union in June 2013 and advises the Member States 'to have collective redress systems at national level that follow the same basic principles throughout the Union'. ${ }^{183}$ The national collective redress systems should enable private enforcement of rights granted by European Union law in areas such as competition, consumer protection, financial services, investor protection, non-discrimination, environmental protection, and protection of personal data. ${ }^{184}$ The Member States should implement the principles set out in the recommendation within two years after its publication, i.e. before June 2015. ${ }^{185}$ These collective redress documents complement two other measures created by the Commission to facilitate private enforcement: the proposal for a Directive on damages actions for EU competition law infringements ${ }^{186}$ and the communication on quantifying harm in such damages actions. ${ }^{187}$

These developments show that the class action, which is seen as an important mechanism in the American civil justice system, serves as an example for mass damages settlements in Europe. Thus, as stated in chapter one, the positive aspects of this American mechanism have come to the attention of legislators in Europe. Often heard negative ideas concerning mass damages settlements, such as fear of the rise of a compensation culture, therefore come out second best, at least in this particular field.

178 Ten Wolde \& Peters 2013, p. 3; Tzankova 2012, p. 566.

179 Ten Wolde \& Peters 2013, p. 3; Tzankova 2012, p. 567-569.

180 Tzankova 2012, p. 568.

181 Tzankova 2012, p. 561; Ten Wolde \& Peters 2013, p. 3, citing Halfmeier 2012.

182 Magnus 2010, p. 116. For a recent overview of class actions in Europe see Backhaus, Cassone \& Ramello 2012.

183 COM(2013) 401/2; C(2013)3539/3, recital 10 of the Preamble. See Giesen 2013, p. 291; Tzankova, Plomp \& Raats 2013. See also section 8.3.

$184 \mathrm{COM}(2013) 401 / 2$, at $\S 1.3$; C(2013)3539/3, recital 7 of the Preamble.

$185 \mathrm{C}(2013) 3539 / 3$, recital 24 of the Preamble.

$186 \mathrm{COM}(2013) 404$ final. The proposal for a Directive on damages actions is accompanied by an impact assessment report: SWD(2013) 203 final. See section 7.2.4.4.

$187 \mathrm{C}(2013) 3440$. The communication on quantifying harm is accompanied by a practical guide: SWD (2013) 205. 


\subsubsection{Liability Insurance}

Liability insurance is not a procedural issue as such. However, as liability insurance does play a very important role in American tort law it will be briefly described here. The catalyst for the extensive use of liability insurance was the development of the automobile industry. Nowadays, many American corporations, professionals such as doctors, and individuals have liability insurance. ${ }^{188}$ According to Ellis, the function of liability insurance is twofold: ${ }^{189}$

First, it allows the insured to substitute a present, certain payment for the risk of large future losses that are contingent on claims by other persons. [...] The second function of liability insurance, and one that has become an increasingly important public policy concern, is to assure that funds will be available to provide compensation when a person is injured under circumstances that make another party liable.

The words of Ellis are not surprising, as the Americans do not have a different perspective of liability insurance than most European countries. ${ }^{190}$ The availability of liability insurance makes redress available to victims who would otherwise remain uncompensated. Liability insurance gives many people access to compensation of their losses and - like the legalisation of contingency fees - it has thereby contributed to the democratisation of American tort law. ${ }^{191}$ Without insurance, tort liability would be useless for the most part as most defendants would not be able to pay the damages imposed. ${ }^{192}$ It is simply impossible to get blood from a stone. This also means that without insurance, the above-mentioned costs of the American tort system would probably not be as high. As will be shown below in section 3.4, the issue of punitive damages insurance receives considerable attention and is rather controversial. Some American courts prohibit punitive damages insurance on public policy grounds, as these insurances undermine the punitive and deterrent purposes of punitive damages. ${ }^{193}$ The tortfeasor will have to pay the award out of its own pocket. ${ }^{194}$ However, in the majority of jurisdictions courts find that punitive damages insurance does not violate public policy and should therefore be allowed. ${ }^{195}$ Note that this public policy argument that is often heard in the debate on punitive damages insurance also used to play a role in the debate on liability insurance as such. For instance, in Europe liability insurance has for a long time been seen in a bad light: it was considered invalid and contrary to good manners. ${ }^{196}$ Nowadays, liability insurance is the order of the day, and indirect punishment and deterrence of wrongdoers via insurers who give incentives is considered normal and accepted.

188 Burnham 2006, p. 456

189 Ellis 1982 , p. 72.

190 See generally on this topic Wagner 2005; Wansink 2006

191 Goldberg 2008, p. 1268

192 Burnham 2006, p. 456

193 Owen 2005, p. 1183; Baker 1998a, p. 101.

194 Goldberg 2008, p. 1268.

195 Blatt, Hammesfahr \& Nugent 2008, p. 200

196 Van Dam 2013b, p. 163. 


\subsubsection{The Position of Punitive Damages in American Law}

The previous sections mostly give background information on the American legal system. The remainder of this chapter will be about the history, theory and purposes of American punitive damages law. But before going into that, it is useful to clarify the position of punitive damages in American law. The punitive damages remedy forms part of the law of damages and is only available in civil lawsuits. The meaning of the term damage(s) in Anglo-American law is twofold: it either refers to the harm that is suffered by a plaintiff (damage) or to money damages that are awarded to compensate him (damages). ${ }^{197}$ The mere existence of damage is not enough for damages to be awarded. The plaintiff only has a right of action if the defendant inflicted a legal wrong on the plaintiff resulting in damage. Civil damages generally arise in the field of torts or in case of breach of contract: ${ }^{198}$

A person who, tortuously or in breach of a contractual obligation, does an act which has injurious consequences is liable for the damage caused by such wrongful act.

While contract and tort are separate branches of law, both can be categorised as part of the law of obligations. ${ }^{199}$ Contract obligations are imposed by agreement, whereas tort obligations are imposed by the law. Based on the principle pacta sunt servanda (agreements are to be kept), contract law enforces legally binding agreements between parties and therefore generally protects only the parties to the contract. Tort law is based upon legal duties imposed by law and, although it primarily aims at compensation of the harmed person, it also protects society as a whole from harm to person or property. ${ }^{200}$ Perhaps more than in other legal systems, deterrence is a major objective of the American tort system. ${ }^{201}$ There are numerous types or forms of torts, but - in general - a tortious act is defined as follows: ${ }^{202}$

Commission or omission of an act by one, without right, whereby another receives an injury, directly or indirectly, in his person, property or reputation.

19722 Am. Jur. 2d Damages § 2: 'Injury is the illegal invasion of a legal right; damage is the loss, hurt, or harm that results from the injury; and damages are the recompense or compensation awarded for the damage suffered'.

19822 Am. Jur. 2d Damages § 4

19974 Am. Jur. 2d Torts $\S 1$.

20086 C.J.S. Torts, $\S 4 ; 22$ Am. Jur. 2d Damages $\S 569$. The Latin tortus literally means 'twisted'. It came to mean 'wrong', as it still does in the French language. 'J'ai tort' is the French translation of 'I am wrong'.

201 Centner 2008, p. 40.

20274 Am. Jur. 2d. Torts $\S 1$. 
Burnham gives the following definition of tort law: ${ }^{203}$

The law of torts concerns civil wrongs: wrongful acts which injure the body, property, or reputation of a person that can result in civil liability.

Nearly all remedies in the American law of damages are substitutionary as opposed to specific. The former aim at replacing harm suffered with a substitute, whereas the latter seek to 'restore directly and specifically that which the defendant has taken from the plaintiff'. ${ }^{204}$ The common substitutionary damages are money damages. The urge for money damages in civil lawsuits is not so strange. Firstly, numerous claims are related to debts, therefore a successful claim will always result in a money judgment. Secondly, in certain cases specific performance is impossible, for example if the damage is done to property that is irreplaceable or consists of personal injury. ${ }^{205}$ There are four types of money damages available in American law: ${ }^{206}$ nominal, liquidated, compensatory, and punitive damages. ${ }^{207}$ The first type of damages is rarely awarded: nominal damages are symbolic awards, usually in the amount of one dollar, that may be granted if the plaintiff's rights are breached but no real harm is suffered. Liquidated damages are fixed damages awards agreed upon by the parties to a contract for breach of the contract. Compensatory damages, also known as actual damages, aim at reimbursing the plaintiff for the damage he has suffered. Although compensatory damages are available in all kinds of civil cases, as mentioned above, they are primarily awarded in cases concerning breach of contract and tortious wrongdoing. ${ }^{208}$ In personal injury lawsuits, the standard form of damages is compensatory damages to cover different heads of damage such as medical costs, loss of earnings and pain and suffering. ${ }^{209}$ The last type of damages, punitive damages, will be explained further below. Contrary to what is often believed, in most cases both compensatory damages for pain and suffering and punitive damages awards are modest in amount. ${ }^{210}$ However, encouraged by the tort reform movement of the past twenty years, state legislators have adopted caps for the latter two types of damages. ${ }^{211}$

203 Burnham 2006, p. 424

204 Yeazell 2008, p. 268.

205 Yeazell 2008, p. 268.

206 Note that the money judgment is not the only form of relief that may be granted in a judgment resulting from a civil lawsuit. Other forms are equitable relief, declaratory relief and awards of costs. See Burnham 2006, p. 240-245.

20722 Am. Jur. 2d Damages $\S 3$. Burnham only distinguishes between three broad categories of damages: nominal, compensatory and punitive. Burnham 2006, p. 241.

208 Burnham 2006, p. 241.

209 Centner 2008, p. 36.

210 Centner 2008, p. 36; Burnham 2006, p. 458. See section 4.2.2.

211 Centner 2008, p. 36-39. See section 4.4.1. 


\subsection{History, Theory and Purposes of Punitive Damages}

\subsubsection{Short Historical Overview}

Although punitive damages have very ancient roots in the law, ${ }^{212}$ they were first adopted as a common law remedy in eighteenth century England. The early English cases were decided by juries, and it was solely within the discretion of the jury to determine whether or not the plaintiff should recover punitive damages. The jury verdict would not be disturbed by the courts, therefore, it was deemed unnecessary to give an extensive explanation of the grounds for awarding such damages. ${ }^{213}$ In 1763, the doctrine of punitive damages was recognised by the English courts in two cases concerning aggravated misconduct, namely Wilkes $v$. Wood $^{214}$ and Huckle v. Money. ${ }^{215}$ In Wilkes v. Wood, the court decided as follows: ${ }^{216}$

[Members of the] jury have it in their power to give damages for more than the injury received. Damages are designed not only as a satisfaction to the injured person, but likewise as a punishment to the guilty, to deter from any such proceeding for the future, and as a proof of the detestation of the jury to the action itself.

These cases have the same underlying cause of action and are considered the fons et origo, the source and origin of punitive damages. ${ }^{217}$ The plaintiffs, both accused of libel against the King, filed tort claims for trespass, assault and false imprisonment. Punitive damages were awarded because the substantial infringements of the plaintiff's civil rights by agents of the King - consisting in house-search, seizure of property, and imprisonment - were only based on a general warrant. The courts established the judicial precedent that punitive damages could be awarded to punish the defendant and deter future misconduct in instances of malice, oppression or gross fraud. ${ }^{218}$ In that way, the suggestion that the punitive and deterrent purposes of damages awards could be separated from their compensatory function received judicial expression. ${ }^{219}$ Nearly thirty years later, punitive damages were recognised in the United States. The earliest reported punitive damages case is

212 Forms of multiple damages remedies were available in medieval English law (e.g. the Statute of Westminster [3 Edw. I, c. 1. (1275)], awarding double damages for trespassers against religious persons, and the Statute of Gloucester [6 Edw. I, c. 5. (1278)], awarding treble damages for waste), Roman law (the Twelve Tables) and even the Bible (The Old Testament, Exodus, 22(1): 'If a man shall steal an ox, or a sheep, and kill it, or sell it; he shall restore five oxen for an ox, and four sheep for a sheep'). For an overview on the history of punitive damages, see Schlueter 2005a, p. 1-19; Owen 2005, p. 1123-1124; Owen 1976, p. 1262; Englard 2012, p. 1-14.

213 Freifield 1935, p. 6.

214 Wilkes v. Wood [1763] 98 ER 489.

215 Huckle v. Money [1763] 95 ER 768.

216 Wilkes v. Wood, at $\S 498$.

217 See Schlueter 2005a, p. 5; Owen 1995, p. 1124; Deakin, Johnston \& Markesinis 2008, p. 945

218 Schlueter 2005a, p. 6.

219 Ellis 1982, p. 14 
Genay v. Norris, decided by the South Carolina Supreme Court in $1784 .^{220}$ The plaintiff received punitive damages after becoming ill from drinking wine that contained toxic Spanish fly, added to it by the defendant. Subsequently, in 1791, the New Jersey Supreme Court decided Coryell v. Colbaugh. ${ }^{221}$ In this case punitive damages were awarded to the plaintiff, who had sued the defendant for breach of promise to marry, to serve as an example to others. ${ }^{22}$ During the eighteenth and nineteenth century punitive damages were awarded in various legal categories that all involved insult of the victim's honour, including slander, seduction, assault, malicious prosecution and false imprisonment, illegal intrusion into private dwellings and seizure of private papers, trespass onto private land in an offensive manner etc. ${ }^{223}$ In 1851, the U.S. Supreme Court explicitly recognised punitive damages in Day v. Woodworth, stating that the punitive damages doctrine had already been supported for more than a century. ${ }^{224}$

\subsubsection{Nature and Theory}

We have already seen that punitive damages are damages that may be awarded to the plaintiff in a civil lawsuit apart from and in addition to compensatory damages. $^{225}$ The Court of Appeals for the Seventh Circuit once stated: ${ }^{226}$

Punitive damages are damages awarded above and beyond what will compensate the victim for his losses.

As stated in chapter one, the Restatement of Torts defines punitive damages as 'damages, other than compensatory or nominal damages, awarded against a person to punish him for his outrageous conduct and to deter him and others like him from similar conduct in the future'. ${ }^{227}$ Thus, the theory behind punitive damages is one of punishment and deterrence and involves a blending of the interests of society in general with those of the harmed party in particular. ${ }^{228}$ Punitive damages ought to 'make the guilty defendant feel the pain of his misdeeds and to deter him and others from similar misconduct'. ${ }^{229}$

220 Genay v. Norris, 1 Bay 6, 1 S.C.L. 6, 1784 WL 26 (S.C. Com. Pl. Gen. Sess. 1784).

221 Coryell v. Colbaugh, 1 N.J.L. 77, 1791 WL 380 (N.J. 1791). See Schlueter 2005a, p. 15; Daniels \& Martin 1990, p. 7.

222 Coryell v. Colbaugh, at $\S 77$. The jury was instructed by the court 'not to estimate the damages by any particular proof of suffering or actual loss; but to give damages for example's sake, to prevent such offenses in [the] future'.

223 Ellis 1982, p. 15.

224 Day v. Woodworth, 54 U.S. 363, 1851 WL 6684 (U.S. Mass. 1851), at § 371.

225 Other terminology that has been used for punitive damages is 'smart money', 'exemplary', 'vindictive', 'punitory', 'speculative', 'imaginary', 'presumptive', or 'added' damages. See Freifeld 1935, p. 5; Schlueter 2005a, p. 22.

226 F.T.C. v. Febre, 128 F.3d 530 (C.A.7 (Ill.) 1997), at $\S 536$. See also 22 Am. Jur. 2d Damages $\S 539$.

227 Restatement of Torts, $\S 908$.

22825 C.J.S. Damages $\S 195$.

229 Von Mehren \& Murray 2007, p. 180. 
Even though their procedural setting is civil, in most states the main purpose of punitive damages is non-compensatory. ${ }^{230}$ Only three states have assigned a compensatory function to punitive damages. ${ }^{231}$ In Connecticut, punitive damages aim at compensating the plaintiff for his injuries instead of punishing the defendant for his wrongful behaviour, and in Michigan wounded feelings and injured dignity add to the amount of compensation available through punitive damages. A Michigan court once held that: ${ }^{232}$

Exemplary damages are of necessity intangible in nature and, therefore, cannot well be considered apart from those matters which are capable of exact pecuniary valuation. They may enlarge the compensatory allowance, but they are not to be considered as authorizing a separate sum by way of example or punishment.

Although the purposes of punitive damages in Texas are to punish and deter, they also serve to compensate for the plaintiff's inconvenience and attorney fees and to reimburse for losses too remote to be considered as elements of strict compensation.

Given the public interest in awarding punitive damages, the civil remedy has been described by American courts as a 'civil fine, fine or penalty for the protection of the public interest, private fine, civil penalty and quasi-criminal penalty'. ${ }^{233}$ It is often argued that punitive damages awards have criminal law objectives rather than tort law objectives. In this respect, they are even considered an 'anomaly' in the law of torts. ${ }^{234}$ The primary objective of modern tort law is compensation for actual loss suffered. ${ }^{235}$ If a person is held liable under tort law for causing harm to another, the award of damages is, as we have seen above, by far the most important remedy. Damages play a central role in serving the functions of tort law and are therefore usually compensatory. ${ }^{236}$ Quite the opposite is true for punitive damages, which provide an exception to the general rule that damages serve only to compensate the plaintiff. ${ }^{237}$ They are in essence not compensatory, but rather they seem to have objectives that resemble criminal law objectives. Criminal law aims at punishment and rehabilitation of the offender, deterrence of the offender and others from behaving similarly, and ultimately the protection of society. ${ }^{238}$ The traditional division between public law and private law - also known and hereafter referred to as public-private divide - and the belief that punishment is an aim that is best left to criminal law is the main reason why punitive elements in tort law are minimal in most civil law systems. ${ }^{239}$ The publicprivate divide therefore plays a rather important role in this book and will be

230 Mann 1992, p. 1798; Schlueter 2005a, p. 1, 16; Owen 2005, p. 1122.

231 Schlueter 2005a, p. 17; Kircher \& Wiseman 2000a, p. 4-3 to 4-8.

232 Wise v. Daniel, 221 Mich. 229, 190 N.W. 746 (Mi. 1922), at § 747

23322 Am. Jur. 2d Damages $\S 541$.

234 Kircher \& Wiseman 2000a, p. 2-5; Morris 1931, p. 1176; Schlueter 2005a, p. 79.

235 Magnus 2001b, p. 185; Deakin, Johnston \& Markesinis 2008, p. 52; Schlueter 2005a, p. 79

236 Burrows 2004, p. 29; Lindenbergh 2006, p. 234-241.

237 Yeazell 2008, p. 273.

238 Schlueter 2005a, p. 79-80.

239 Deakin, Johnston \& Markesinis 2008, p. 50; Von Mehren \& Murray 2007, p. 179. 
further explained below. ${ }^{240}$ Opponents of punitive damages argue that the sanction of punishment is traditionally a matter of criminal law that should be left to the state and that the defendant who is facing punitive damages should benefit from criminal procedural safeguards. Such procedural safeguards generally do not apply in American punitive damages law. ${ }^{241}$ Redish and Mathews put it as follows: ${ }^{242}$

The framework of punitive damages gives us the worst of both worlds: pure public power is vested in the hands of purely private actors, but those private actors do not simultaneously assume the constitutional and political restrictions traditionally imposed on those who exercise pure public power.

However, opinions on this controversial issue differ throughout the country: ${ }^{243}$

Under some authority, because exemplary damages rest on justifications similar to those for criminal punishment, they require the appropriate substantive and procedural safeguards to minimize the risk of unjust enrichment. Under other authority, an award of punitive damages based on a civil claim may not be considered a substitute for criminal punishment, or a criminal sanction to which criminal-law protections apply. Although an award of exemplary damages is punitive, it is a private remedy rather than a public criminal sanction.

Nonetheless, it is generally accepted in the United States that punitive damages are a form of penal remedy in civil law. ${ }^{244}$ As pointed out by Behr, legal systems in which punitive damages are explicitly available have a dualistic approach towards tort law, i.e. a focus on a compensatory and a punitive function of tort law, in contrast to the monistic approach in civil law systems. ${ }^{245}$

The penal elements of punitive damages are illustrated by both substantive law and rules of evidence. ${ }^{246}$ For example, mere negligence of the defendant is not sufficient for punitive damages to be awarded. ${ }^{247}$ As will be further explained in section 3.2.3, the defendant must be guilty of violating the plaintiff's rights by using aggravated conduct, meaning that 'the defendant has injured the plaintiff maliciously, intentionally, or with a conscious, reckless, wilful, wanton or oppressive disregard of the rights or interests of the plaintiff'. ${ }^{248}$ For example, in the McDonald's case, the conscious decision of McDonald's to disregard the safety of its customers by selling excessively hot coffee justified awarding of punitive damages. Furthermore, as follows from $\S 908$ of the Restatement of Torts,

240 See section 4.3 .1 and section 6.3 .

241 Owen 2005, p. 1122; Hubbard 2008, p. 386, stating that there are of course exceptions to the general rule. For example, some states have adopted the reasonable doubt standard for proving the egregious conduct necessary for imposing punitive damages. See for example Colo Rev Stat $\S 13$ 25-127 (2007). See also section 4.3.2.1.

242 Redish \& Mathews 2004, p. 4, 30

24325 Am. Jur. 2d Damages § 541.

244 Owen 2005, p. 1122

245 Behr 2003, p. 105-106

246 Yeazell 2008, p. 273

247 Burnham 2006, p. 241

248 Owen 2005, p. 1121 
some American states allow the plaintiff who claims punitive damages to introduce information concerning the wealth of the defendant, whereas this information is legally irrelevant to most other civil law issues. ${ }^{249}$ The idea is that wealthy defendants who are liable for punitive damages should be hurt and punished by substantial awards. This however does not mean that they should be financially ruined. ${ }^{250}$

To summarise: the theory of punitive damages is neither completely civil nor criminal in nature, and this mixed character is an important reason for the controversy that has always surrounded the topic.

\subsubsection{Purposes}

From the early beginning, American courts have viewed punitive damages as primarily non-compensatory in character. ${ }^{251}$ What else can be said about the functions of punitive damages? In fact, punitive damages serve more than a few functions: punishment, deterrence or prevention, preserving the peace, inducing private law enforcement, compensating victims for otherwise non-compensable losses, and paying the plaintiff's attorney fees. ${ }^{252}$ Keeping in mind the introductory observations of the American tort system described above, punitive damages seem to fit in well. According to Owen: ${ }^{253}$

In this nation, punitive damages are still considered an important remedy that checks, rectifies, and helps prevent extreme misconduct.

The meaning of 'extreme misconduct' is interpreted differently and is dependent on the concrete circumstances of the case, but it always involves an element of major aggravation. As mentioned above, the nature of conduct for which punitive damages may be awarded will be discussed in chapter three.

Most jurisdictions in the United States agree that compensation follows from the award, but is in essence not a function of punitive damages. ${ }^{254}$ Punitive damages are more about the behaviour of the defendant than the damage of the plaintiff. The remedy is based on ideas of public policy rather than individual compensation. ${ }^{255}$ In this regard, Zipursky refers to the distinction between objective punitiveness ('punitive damages are focused on the defendant's conduct and character') and subjective punitiveness ('the idea that the victim of a wrong is allowed to be punitive'). According to Zipursky, this latter theory of subjective punitiveness,

249 Von Mehren \& Murray 2007, p. 180; 22 Am. Jur. 2d Damages $\S 607$.

250 Dardinger v. Anthem Blue Cross \& Blue Shield, 98 Ohio St. 3d 77, 2002-Ohio-7113, 781 N.E.2d 121 (2002), at $\S 144$. See also section 3.3.3.

251 Kuklin 1989, p. 5.

252 The functions of punitive damages are extensively analysed in a leading article of Dorsey D. Ellis, Fairness and Efficiency in the Law of Punitive Damages: Ellis 1982, p. 4. See also Owen 2005, p. 1132-1144; Schlueter 2005a, § 2.2; Schoenbrod et al. 1996, p. 452-453.

253 Owen 2005, p. 1200.

25425 C.J.S. Damages § 195; 22 Am. Jur. 2d Damages $\S 544$.

25522 Am. Jur. 2d Damages $\S 544$. 
which he also calls 'private vengefulness', is an important reason why punitive damages are not a recognised part of tort law in many jurisdictions outside the United States and in several American states. ${ }^{256}$

In respect of objective punitiveness, which is the dominant theory in American punitive damages law, the primary purposes of awarding punitive damages are to punish the defendant, thereby deterring him and others from similar behaviour in the future. ${ }^{257}$ The idea that deterrence should be seen as the purpose of punishment has been supported by Posner and other law and economics scholars. ${ }^{258}$ Based on the theory of objective punitiveness, it does not matter whether the award goes to the plaintiff or to the state on the basis of a split-recovery statute; the only important question is whether the defendant pays the award. ${ }^{259}$ Thus, one could argue that the main purposes of punitive damages are threefold, i.e. punishment, specific deterrence, and general deterrence. Since these purposes are almost akin to each other, ${ }^{260}$ they are usually mentioned jointly. Before going further into these purposes, note that some American authors disagree with the idea that punitive damages do not have a compensatory function nor lead to subjective punitiveness. Owen is one of them: ${ }^{261}$

While American courts typically refer only to 'punishment' (meaning retribution) and 'deterrence' as the purpose of punitive damages, such damages have a third important function - providing victims with added compensation, sometimes called 'aggravated damages', for the purpose of victim vindication and redress - despite the almost universal proclamation in American law that punitive damages are 'non-compensatory'. Recently, scholars have begun to rediscover the value of punitive damages in forcing flagrant wrongdoers to fully restore the aggravated losses suffered by their victims.

Especially losses involving intangible harm, such as lost opportunities, injured feelings and dignity are often left uncompensated by compensatory damages and should be accepted by the victim as a risk of life. Although this might under normal circumstances be in fairness to injurers, Owen remarks that there is a problem when the wrongdoer intentionally injured the victim and, according to him, this problem - which he calls unjust impoverishment of the victim and unjust enrichment of the wrongdoer - could be solved by awarding an additional amount of punitive damages. ${ }^{262}$ Other interesting opinions deviating from the 'mainstream' also emphasise principally the function that punitive damages fulfil in relation to the right of the victim to seek revenge or recourse against their injuries,

256 Zipursky 2005, p. 154-155.

257 Restatement of Torts, § 908; Schlueter 2005a, p. 25; Yeazell 2008, p. 273; 22 Am. Jur. 2d Damages $\S 542, \S 544 ; 25$ C.J.S. Damages $\S 195$.

258 Kemezy v. Peters, 79 F.3d 33 (C.A.7 (Ind.) 1996), at $§ 34$. See on this case and Posner's viewpoint also section 7.3.1.

259 Romero 2008, p. 125; Zipursky 2005, p. 154. See on split-recovery section 3.3.5.1.2.

260 Schlueter 2005a, p. 29.

261 Owen 2012, p. 120-121.

262 Owen 2010, p. 186. See also the opinion of Judge Posner in the above-mentioned case Kemezy v. Peters, at $\S 34$ (no. 1). 
private retribution, and vindication. ${ }^{263}$ This is also known as the civil recourse theory, i.e. victims who seek redress from their wrongdoers via tort law. ${ }^{264}$

Notwithstanding these alternative theories, in 2008 the U.S. Supreme Court once more affirmed the primarily punitive and deterring purpose of punitive damages. ${ }^{265}$ What do these purposes entail? The term 'punishment' implies a retributive aim. Ellis refers to this aim as a 'notion of desert', a method to serve justice. ${ }^{266}$ A person who is injured by the outrageous conduct of another ought to be revenged, whereas the tortfeasor deserves to be punished. This theory is justified on the basis of general notions of public morality, that it is deemed immoral to commit a wrongful act and thereby violate the rights of another person without proper justification for it. ${ }^{267}$ Indeed, retributive justice is one of the most important aspects of punitive damages law. ${ }^{268}$ It is general belief in almost all American states that, if the conditions for awarding punitive damages are fulfilled, the defendant should be punished for the mere reason of justice. The retributive function does not only protect the interests of the harmed individual, but it also serves society as a whole. ${ }^{269}$ In this respect, punitive damages have the purpose of protecting society, although the protection of the individual can also be understood as an issue of both individual and social concern. ${ }^{270}$ Markel, for example, is strongly in favour of the idea that punitive damages should primarily be seen as a retributive sanction that serves the public interest. ${ }^{271}$ In some jurisdictions, all awards of punitive damages must be supported by a finding that the public interest will be served by punishing the wrongdoer. ${ }^{272}$

As stated by Ellis deterrence, preserving the peace, and inducing law enforcement are instrumental functions of punitive damages that look at the notion of effectiveness as opposed to the 'notion of desert'; the aim of these instrumental functions is not to impose detriment on the defendant, but rather to improve social life as a whole. ${ }^{273}$ It is argued, for example by Dobbs, that deterrence is the leading purpose of punitive damages. ${ }^{274}$ Dobbs suggests to 'trigger extracompensatory damages when it is shown that deterrence is needed': the court should

263 See e.g. Colby 2008; Sebok 2007; Galanter \& Luban 1993; Zipursky 2005; Nezar 2011. Cf. Sharkey 2003, p. 389, suggesting that punitive damages should be seen as 'compensatory societal damages assessed to redress widespread harms caused by the defendant, harms that reach far beyond the individual plaintiff before the court'.

264 Zipursky 2012, p. 1778.

265 Exxon Shipping Co. v. Baker, 554 U.S. 471, 128 S.Ct. 2605 (U.S. 2008), at $\$ 2621$.

266 Ellis 1982, p. 4. See also Owen 2005, p. 1133; Romero 2008, p. 120. In his article, Romero compares punitive damages to other forms of punishment.

267 Ellis 1982, p. 5.

268 Owen 2005, p. 1193.

26925 C.J.S. Damages $\S 195 ; 22$ Am. Jur. 2d Damages $\S 544$.

270 Harris 1989, p. 1102.

271 Markel 2009a; Markel 2009b; Markel 2010.

27222 Am. Jur. 2d Damages § 542.

273 Ellis 1982, p. 8. See on the 'preserving the peace' purpose of punitive damages Robinette 2008.

274 Dobbs 1989, p. 858. See also Owen 2005, p. 1136, and, critical of the deterrence theory, Sebok 2014. 
estimate the punitive damages award at 'the amount necessary to deter' rather than 'the amount necessary to inflict justly deserved punishment'. How can the amount that is necessary to deter be measured? Dobbs in this regard refers to torts committed by so-called calculative wrongdoers: ${ }^{275}$

For torts committed in the course of a profit-motivated activity, the deterrence measure would usually either (a) the profit or gain derived by the defendant from the activity (or in some cases the hoped for gain), or (b) the plaintiff's reasonable litigation costs, including a reasonable attorney fee based on hours reasonably invested at a reasonable hourly rate.

According to Dobbs, deterrence damages offer many advantages over punitive damages and thereby deal with all the serious criticisms of the civil remedy. ${ }^{276}$ As mentioned above, also Posner considers deterrence as the purpose of punishment. In other words, punishment is not a function of punitive damages in itself but rather a means to an end, namely deterrence. As participants in the European punitive damages debate seem to be especially interested in these instrumental functions of the civil remedy - deterrence in particular - rather than in its punitive function, Posner's theory will also play a role in chapter seven. This does not mean that the punitive function receives no attention at all in Europe, as will be further explained in section 7.3. There is for example increased attention for taking into account the degree of blameworthiness in assessing damages awards in situations of intentional, calculative and grave misconduct, which adds a punitive element to the civil damages award.

Although the effectiveness of deterrence by imposing punitive damages remains a source of discussion, it is a believed side effect of both tort law and criminal law that the imposed liability or punishment has some deterrent effect. The deterrent function of punitive damages is especially interesting with regard to potential offenders who know that misbehaviour often goes undetected and unpunished, the above-mentioned calculative wrongdoers. ${ }^{277}$ The awarding of punitive damages sends an unambiguous message that the price of getting caught is higher than the worth of committing the wrongful act; in other words that committing a tort does not pay.

The law enforcement function is instrumental in the sense that the punitive damages remedy is a procedural mechanism which serves as an incentive for potential plaintiffs to initiate civil litigation. ${ }^{278}$ As mentioned by Schlueter, this might include the exposure and punishment of minimal loss: ${ }^{279}$

Proponents of punitive damages suggest that they are an incentive for a person who has suffered only minimal damages to bring a cause of action when it may not otherwise be economically feasible or it would be unlikely that the defendant would be punished under criminal law.

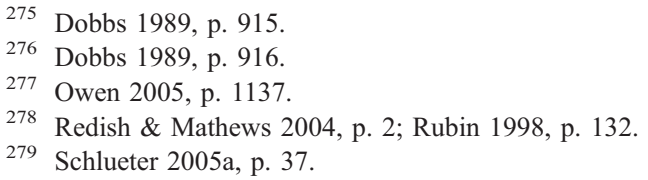


In this respect, abuse and excessive punitive damages awards can be overcome by requiring a reasonable relation to the actual loss. On the other hand, as the loss is only minimal, critics suggest that such a requirement merely imposes practical limitations on the law enforcement function of punitive damages. ${ }^{280}$ Furthermore, punitive damages awards are believed to contribute to law enforcement as they form an incentive for potential wrongdoers to obey the rules. The notions of deterrence and effectiveness explain the great attention paid to these functions, deterrence in particular, by law and economics theories.

\subsubsection{Punitive Damages from a Law and Economics Perspective}

As stated in the introduction to this book, this research does not involve a law and economics analysis. However, this book cannot ignore the fact that the punitive damages doctrine receives considerable attention from law and economics scholars. For the reason given above, the description of the law and economics perspective of punitive damages will be concise. ${ }^{281}$ Section 6.2.2.3 and section 7.3.3.1 will also pay some attention to the economic analysis of tort law.

Law and economics scholars ask themselves the question whether a punitive damages award leads to optimal deterrence. Furthermore, they look into the question whether private law enforcement, for example by means of punitive damages, is an alternative for public law enforcement. ${ }^{282}$ Compensatory and punitive damages assessed against wrongdoers in private lawsuits complement public enforcement measures in the sense that the ideal enforcement system would be a mix between public and private mechanisms. ${ }^{283}$ In general, there even is a preference for private enforcement due to lower costs, but, as private enforcement alone is not sufficient, reliance on more expensive public enforcement mechanisms is needed.

The punitive damages remedy is interesting for law and economics scholars, as given the need, according to some, to improve this controversial remedy in the American tort system - an economic analysis can provide guidelines for 'a more coherent account of punitive damages'. ${ }^{284}$ And, of course, such guidelines are useful for everyone who participates in the punitive damages debate. In the law and economics literature, the most important arguments are the deterrence-based arguments. $^{285}$ In line with Posner's idea mentioned in the previous section, it is generally accepted that (specific and general) deterrence is in itself a goal of

280 Schlueter 2005a, p. 37.

281 With regard to the law and economics theory of punitive damages, see among many others Cooter 1982; Ellis 1982; Owen 1982; Schwartz 1982; Friedman 1989; Grady 1989; Chapman \& Trebilcock 1989; Cooter 1997; Sunstein, Kahneman \& Schkade 1998; Polinsky \& Shavell 1998a; Polinsky \& Shavell 1998b; Eisenberg 1998; Boyd \& Ingberman 1999; Faure 2009; Sharkey 2012; Rhee 2012; Visscher 2012.

282 Ellis 1982, p. 1; Landes \& Posner 1975; Visscher 2012, p. 476.

283 Ellis 1982, p. 2; Dorfman 2010, p. 147; Van Boom 2006a, p. 30.

284 Cooter \& Ulen 2004, p. 374.

285 Visscher 2012, p. 475. 
punishment. ${ }^{286}$ Rhee describes the standard law and economic theory of punitive damages as follows: ${ }^{287}$

The standard law and economic theory of punitive damages advances deterrence as the normative goal. The law should optimally deter defendants who should internalize the full cost of all wrongful conduct such that the law incentivizes the optimal level of care. This basic idea originates from Learned Hand's famous exposition of the negligence standard in United States v. Carroll Towing Co. The economic theory of punitive damages is based on the idea of minimizing social cost through optimal deterrence.

According to Sharkey: ${ }^{288}$

The predominant law and economics theory of punitive damages is based upon optimal deterrence or loss internalization and focuses on the under-enforcement problem: supra-compensatory damages are needed when under-detection of harms or other factors leads to inefficiently low expected liability, which is insufficient to induce optimal care. Other contenders include gain elimination or disgorgement and inducement of voluntary transfers, also known as the property rights perspective.

Sharkey also refers to the Learned Hand formula, which she calls 'the centerpiece of economic analysis of tort law'. ${ }^{289}$ This formula was designed by the American judge Hand in 1947 to be able to determine the optimal standard of care in the tort of negligence. According to judge Hand, a tortfeasor should be held liable if the burden (B) to take adequate precautionary measures is less than the probability $(\mathrm{P})$ that an accident occurs, multiplied by the gravity of the injury (L) (thus: $B<P L$ ). The required level of care is that of a reasonable person under the given circumstances. $^{290}$

Tort liability, particularly punitive damages, may play a role in deterring wrongful behaviour. ${ }^{291}$ Ellis gives three situations in which punitive damages might produce efficient outcomes: (1) when the probability of liability is less than the probability of loss; (2) when the damages assessed are less than the value of the loss; and (3) when the subjective cost of avoidance is greater than the cost recognised by the law. ${ }^{292}$ Based on arguments made by Ellis, but also by Polinsky and Shavell, ${ }^{293}$ Visscher has summarised the main economic arguments for punitive damages from a deterrent and from a punitive perspective. ${ }^{294} \mathrm{He}$ mentions five arguments, which will be briefly explained.

Firstly, punitive damages may correct the problem that a wrongdoer does not face a hundred percent probability of being held liable, especially in cases of

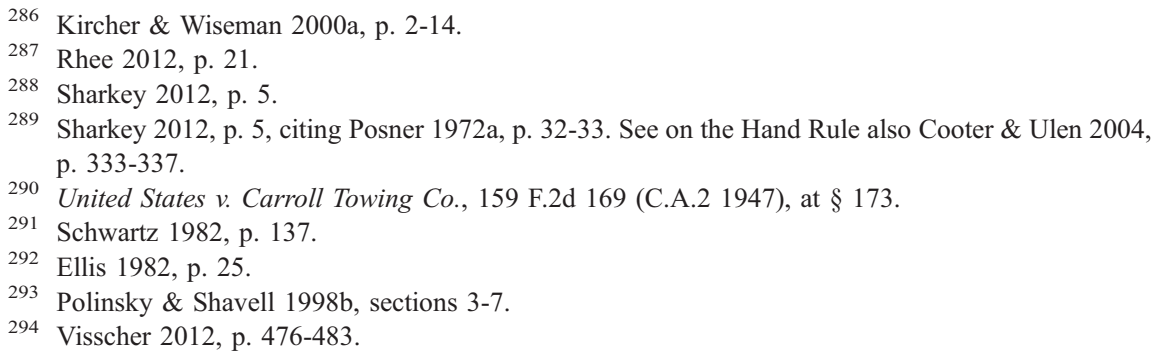


intentional torts. According to Visscher, this is the most important law and economics argument, which he explains as follows: ${ }^{295}$

Punitive damages are a way to solve the problem of a too low probability of being held liable. The potential injurer weighs his costs of precautionary measures against the reduction in expected liability they cause. Expected liability consists of the probability of being held liable, multiplied by the damages he has to pay if he is held liable. If the probability decreases, but the damages increase proportionally, it is still possible to provide the correct behavioural incentives. This implies that total damages should be determined by multiplying the amount of the losses with the reciprocal of the probability of being held liable. Hence, if this probability is $50 \%$, damages should be doubled to provide the correct incentives. If the losses of the victim would be $€ 10,000$, total damages would then consist of compensatory damages of $€ 10,000$ and punitive damages of $€ 10,000$. Expected liability of the injurer would then be $50 \% x € 20,000$, hence $€ 10,000$.

Secondly, punitive damages could solve the problem that compensatory damages may not cover all losses of the victim and that the wrongdoer is underdeterred. This especially applies if compensatory damages are difficult to assess, for example in case of immaterial loss or when the loss has a subjective nature. An example is defamation, a tort for which punitive damages are indeed often awarded, as will be shown in section 3.2.2.

Thirdly, punitive damages may solve the problem of socially unaccepted gains, which are not included in the 'normal' analysis of deciding the optimal level of care. An example is the pleasure that a wrongdoer derives from intentionally hurting someone else. Compensatory damages supposedly do not deter socially illicit behaviour completely, which especially applies in case of intentional torts, and punitive damages could improve this situation. Visscher mentions three reasons why the value of this argument is limited in his view: (1) socially illicit behaviour is often seen as criminal behaviour, which means that there are already criminal incentives available ${ }^{296}$ (2) the issue of socially illicit gains is not often relevant, because a lot of socially undesirable behaviour is not aimed at causing harm; ${ }^{297}$ and (3) it is difficult to decide which behaviour is socially desirable or not.

The fourth economic argument from a deterrent perspective is the argument that punitive damages may encourage voluntary transfers (via the market), as such damages increase the costs of involuntary transactions (via lawsuits). According to law and economics scholars, this argument relates to the so-called 'property rule liability rule framework', which decides how certain entitlements may be protected

295 Visscher 2012, p. 477.

296 Visscher 2012, p. 479, citing Schwartz 1982, p. 138. Some disagree with Schwartz on this point, for example Owen: 'Although these goals [of fairness and efficiency] could be achieved to some extent, and sometimes better, by a wider application of the criminal law, the public penal law appears to me too rigid, too expensive, and too threatening to our freedoms to expand it further to fill the gap. And so I think that punitive damages are for the best, and that they are here to stay.' See Owen 1982, p. 121.

297 Visscher 2012, p. 479, citing Polinsky \& Shavell 1998b, p. 194. 
by law. ${ }^{298}$ Protection by property rules means that an entitlement can only be transferred in a voluntary transaction, i.e. with consent of the owner. Protection by liability rules means that an entitlement can be transferred in an involuntary transaction provided that the person who takes the entitlement pays an amount of damages for it. In principle there is a preference for property rule protection, because voluntary transactions increase total welfare, whereas this is not necessarily the case with involuntary transactions, because the objectively assessed amount of damages could be lower than the subjective assessment of the victim. According to Visscher: ${ }^{299}$

In order to stimulate voluntary transactions, the sanction on involuntary transactions should outweigh the mere value of the entitlement, because otherwise a potential taker could simply convert a property rule into a liability rule.

In other words, because there is a preference for voluntary transactions, it is undesirable to have an involuntary transaction whenever voluntary transactions are in principle available. Punitive damages could prove useful, as they make the involuntary transaction more expensive and therefore the voluntary transaction more attractive. An example that is often mentioned in this regard is the violation of intellectual property law. ${ }^{300}$ Indeed, as recently confirmed by Koziol, this is a legal area in which damages that exceed compensation and could therefore be understood as punitive damages are already considered acceptable. ${ }^{301}$

The fifth and final economic argument relates to the punitive function of punitive damages as a goal in itself and not as a means of deterrence. This argument has also been described by Polinsky and Shavell: ${ }^{302}$

Having discussed the use of punitive damages to accomplish proper deterrence, let us now turn to the punishment objective. We treat this objective as deriving from the desire of individuals to have blameworthy parties appropriately punished. We equate blameworthiness with the reprehensibility of a party's conduct, that is, with its maliciousness or the extent to which it reflects disregard for the safety of others. Given the degree of a party's blameworthiness, we assume that there is a correct level of punishment, and that either higher or lower punishment detracts from satisfaction of the punishment objective.

Thus, as the punitive function of punitive damages is derived from the desire that blameworthy individuals are appropriately punished, the level of the sanction should depend on the degree of blameworthiness. As mentioned in the previous section, taking into account the degree of blameworthiness adds a punitive element

298 Visscher 2012, p. 480, citing Calabresi \& Melamed 1972. This argument is also explained by Judge Posner in Kemezy v. Peters, at §34-35 (no. 3): 'This function of punitive damages is particularly important in areas such as defamation and sexual assault, where the tortfeasor may, if the only price of the tort is having to compensate his victim, commit the tort because he derives greater pleasure from the act than the victim incurs pain'.

299 Visscher 2012, p. 480.

300 Visscher 2012, p. 481, citing Polinsky \& Shavell 1998b, p. 195.

301 Koziol 2012, p. 50.

302 Polinsky \& Shavell 1998b, section 7. 
to civil damages awards. The authors explain that the relationship between punitive damages and the objective of punishment is clearer where the defendant is an individual than where the defendant is a firm. In the latter situation, the punitive damages award might not be borne by the blameworthy individual, for example because the firm is unable to identify the wrongdoer or because the internal sanction that the firm applies in case the wrongdoer is identified is not sufficiently influenced by the punitive damages award. ${ }^{303}$ The punitive function of punitive damages in case the defendant is a company is therefore doubtful.

Although this has only been a brief introduction into the law and economics theory of punitive damages, it shows that this theory and the deterrent function receive considerable attention. Those in favour of the theory believe that its main arguments address many of the issues relating to the controversial punitive damages remedy. ${ }^{304}$

\subsection{Concluding Remarks}

To conclude, this chapter illustrated that civil litigation is an essential part of American society. Society as such, the civil justice system and the procedural organisation of the legal system are well equipped for civil litigation. This stems from the highly esteemed societal value and right that each American citizen has consistent with the Constitution - to hold a wrongdoer who negligently or intentionally hurts him accountable in a civil lawsuit. The right to sue is an essential right in American society. However, although the civil justice system is considered an important aspect of the American legal system, this does not automatically mean that it is also excessive as many Europeans suggest. It seems that the picture of the tort system painted mostly by the media and political tort reformers is not entirely representative of the American system. Although a lot of information about the tort system remains unknown, research has shown that the number of tort actions is not as excessive as is often believed.

The procedural law mechanisms that are available in American law but largely absent in continental European legal systems create a legal climate in which civil litigation is made accessible. Although the procedural aspects barely have a direct effect on the application of punitive damages awards, it is safe to state that their indirect influence cannot be neglected. For example, the American rule on litigation costs most likely influences the amount of the punitive damages award as juries will take litigation costs into account when determining this award. Procedural law mechanisms thus set up conditions and thereby indirectly facilitate the imposition of punitive damages awards.

This chapter has also made clear that the theory of punitive damages is one of punishment and deterrence and involves a blending of the interests of society in general with those of the harmed party in particular. Punitive damages awards are in essence not compensatory, but rather they seem to have objectives that resemble

303 Visscher 2012, p. 481.

304 Visscher 2012, p. 490. But compare opponents, for example Kip Viscusi 1998, p. 381. 
criminal law objectives, such as punishment and rehabilitation of the offender, deterrence of the offender and others from behaving similarly and ultimately the protection of society. In fact, although it is generally accepted in the United States that punitive damages are a form of penal remedy in civil law, the remedy is neither completely civil nor criminal in nature, and it is precisely this hybrid character that causes the controversy that has always surrounded the subject.

Questions as regards fairness, utility and constitutionality of punitive damages are very politicised aspects of the American tort reform movement. ${ }^{305}$ This movement started as a result of crises in the areas of medical malpractice and products liability in the 1970 s and 1980 s which centered on liability insurance that had become unaffordable, supposedly due to the increase in number and size of punitive damages. ${ }^{306}$ Although the punitive damages doctrine is controversial, it plays an important role in the American civil justice system. This civil remedy primarily aims at punishment, special deterrence and general deterrence. The deterrent function of punitive damages receives a lot of attention from law and economics scholars. Some consider deterrence as the leading function of punitive damages and, in this regard, see deterrence as the purpose of punishment. Punishment is in this view not a function of punitive damages, in itself, but rather a means to an end: deterrence. Note that this is an important observation in respect of the theme of this book, as participants in the European punitive damages debate also seem to be especially interested in the deterrent and law enforcement function of the punitive damages remedy, rather than in its punitive function. Of course, where the debate concentrates on taking into account the level of blameworthiness in situations of intentional, calculative and grave misconduct, the punitive element that is then added to civil damages awards cannot be ignored and does play a role. Furthermore, punitive damages serve the instrumental function of inducing private law enforcement and are considered an incentive for plaintiffs to initiate civil litigation. Other relevant functions are compensating victims for otherwise noncompensable losses, preserving the peace, and paying the plaintiff's attorney fees.

This chapter has given insight into the underlying reasons and functions of punitive damages, which is vital for understanding the civil remedy. The next chapter will focus on the questions when and how punitive damages are awarded according to American law.

305 Owen 1989, p. 705-706, Owen 2005, p. 1125.

306 Owen 2005, p. 1125. See also Moore \& Kip Viscusi 2001, p. 10. 


\section{CHAPTER THREE}

\section{THE AMERICAN SYSTEM OF AWARDING PUNITIVE DAMAGES: WHEN AND HOW}

\subsection{Introductory Remarks}

The previous chapter provided information on the background of the punitive damages remedy in American law. Having seen the underlying reasons and functions of punitive damages or, in other words, why punitive damages are awarded in the American legal system, this chapter deals with the questions when and how punitive damages are awarded according to American law. In respect of the main focus of this book, it is necessary to find out about the main conditions for awarding punitive damages in American law. The concrete examples given in this chapter on, for instance, the types of actions in which punitive damages may be recovered and the nature of conduct for which punitive damages may be awarded are useful for those who participate in the European punitive damages debate. The topics that will be addressed in this chapter are the liability criteria for punitive damages (section 3.2), the assessment and amount of punitive damages (section 3.3) and the specific and controversial topic of insurability of punitive damages (section 3.4).

\subsection{Liability Criteria for Punitive Damages}

\subsubsection{Types of Actions in Which Punitive Damages May Be Recovered: General Remarks}

The foundational requirement for a punitive damages award is the invasion of a legally protected interest. ${ }^{1}$ The underlying cause of action and the proof that is submitted in support of the claim must permit the recovery of punitive damages. Even though the rules of pleading have become more liberal in the past years, some courts may in certain situations still refuse to allow punitive damages because the cause of action alleged and proved does not support a punitive damages award. ${ }^{2}$ As a general rule, punitive damages are recoverable only for tort actions. ${ }^{3}$ The breach of a duty imposed by tort law justifies a punitive damages award for purposes of punishment and deterrence but - as will be further explained below - only in certain aggravating circumstances. All jurisdictions in which 
punitive damages are available have accepted this general rule. ${ }^{4}$ In practice, American courts impose punitive damages in all sorts of situations: ${ }^{5}$

Punitive damages are available in civil lawsuits for willful or intentional violations of common law or statutory duties.

For example, although punitive damages are in principle not available under contract law, punitive damages may in fact be awarded if a breach of contract and a tort are constituted by the same act. ${ }^{6}$ This follows from the principle that, although tortious acts are independent of contract, a tort may arise out of a contractual relationship. ${ }^{7}$ The general rule in the Restatement of Contracts, which is followed in almost every state in which the issue has been raised and resolved by court or legislator, reads as follows: ${ }^{8}$

Punitive damages are not recoverable for a breach of contract unless the conduct constituting the breach is also a tort for which punitive damages are recoverable.

The classic example of a tortious breach of contract is that of bad faith claims against insurers. ${ }^{9}$ Disputes over insurance contracts are common practice in the American legal system. Insurers are frequently held liable for punitive damages due to shortcomings in the claim handling procedure of their insureds. ${ }^{10}$ Bad faith of the insurer does not always entitle a plaintiff to punitive damages: ${ }^{11}$

The generally accepted rule is that punitive damages are not recoverable by an insured simply because he or she has established the necessary elements of the tort that allow the recovery of compensatory damages resulting from insurer bad faith.

Also in this situation certain aggravating circumstances are required, such as oppression, fraud or malice on the side of the insurer or a conscious disregard of the plaintiff's rights. ${ }^{12}$

In the past twenty years, American courts have recognised more and more exceptions to the rule that, in the absence of statutory authorisation, punitive damages are not allowed in contract cases. ${ }^{13}$ Punitive damages are also available in property cases, provided that the defendant knowingly and wilfully infringed the plaintiff's rights. ${ }^{14}$ Furthermore, punitive damages have for example been awarded in cases of medical malpractice, false arrest or imprisonment, employment law,

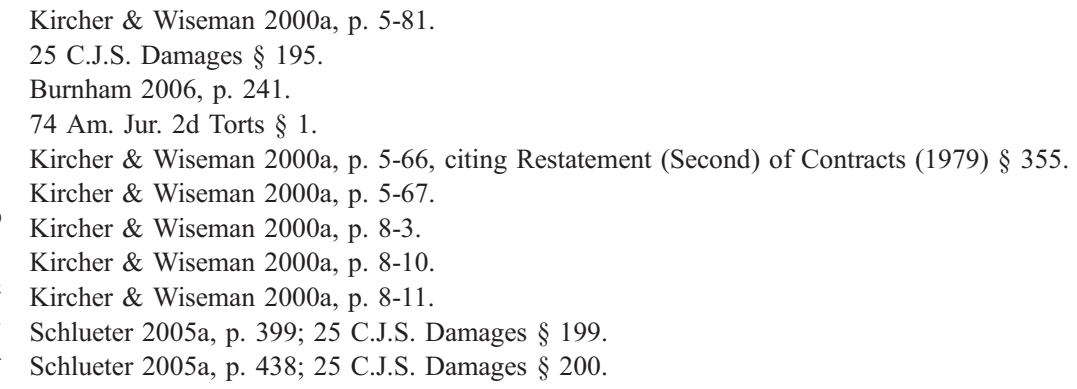


discrimination, human rights infringements, family law, aviation litigation, aids and sexually transmitted diseases. ${ }^{15}$ Thus, punitive damages are in fact available in an extensive number of actions based upon tortious behaviour, provided that the required element of major aggravation is present.

\subsubsection{Exploring the Popular 'Punitive Damages Categories'}

Luckily, there is more information available on the types of cases in which punitive damages are mostly awarded. In the next chapter, a separate section will be devoted to the American application of punitive damages, especially in relation to the frequency and excessiveness of such awards. ${ }^{16}$ At this point, some remarks will suffice. First of all, contrary to popular belief, punitive damages awards are in fact rare in medical malpractice and products liability cases. ${ }^{17}$ According to Baker, the relative increase in punitive damages awards that did occur in these legal areas has to do with the near absence of such awards earlier. ${ }^{18}$ Another already mentioned factor that most likely contributes to this misunderstanding is the media. For example, Bailis and MacCoun have done research in American media coverage of three types of tort cases: automobile negligence, products liability, and medical malpractice. ${ }^{19}$ Their article shows that the majority of cases filed - in twenty-seven state trial courts between 1984 and 1993 - were automobile cases $(60 \%)$ whereas the minority was formed by products liability cases $(4 \%)$ and medical malpractice cases $(7 \%)$. Interestingly, research into five national magazines between 1980 and 1990 shows that the products liability cases were most reported (49\%), second were the medical malpractice cases $(25 \%)$, and the least reported were the automobile accidents $(2 \%)$. This shows how the media is able to give a wrong impression of the facts. Although the article of these two authors is nearly twenty years old, the idea that many critics have a wrong impression of the frequency of punitive damages awards has been confirmed by others, for example Sebok in $2007:^{20}$

In fact, there have been concentrations of frequently awarded punitive damages, but they have not occurred where the critics of punitive damages imagined. For example, in recent years, medicalmalpractice and products liability cases have exhibited the lowest frequency of punitive damages among all types of civil actions for which punitive damages are available.

15 For a list of specific tort based causes of actions, see Schlueter 2005a, chapters eleven, twelve, thirteen, and fourteen; 22 Am. Jur. 2d Damages $\S 570$.

16 See section 4.2.2.

17 Cohen \& Harbacek 2011, p. 2; Cohen 2009, p. 6; Sebok 2007, p. 966.

Baker 1998b, p. 211-212.

Bailis \& MacCoun 1996, p. 424. See also on this topic Garber \& Bower 1999.

20 Sebok 2007, p. 966. See especially footnote 24 of Sebok's article for relevant references on this matter. 
Punitive damages are - in reality - infrequently available in cases of personal injury resulting from negligence and accidents; the main reason for this is that they should not be imposed when the harm is accidentally caused. ${ }^{21}$ Dorfman also mentions that punitive damages are rarely awarded for the tort of negligence. ${ }^{22}$ This does not mean that personal injury cases do not play any role in American punitive damages law. It is important to distinguish between personal injury resulting from negligence and personal injury resulting from intentional behaviour. In the latter category, punitive damages are relatively often awarded, whereas punitive damages awards are uncommon in the first category.

What are then the popular punitive damages categories? Of all civil actions, punitive damages are mostly awarded for intentional torts (for example battery, assault) and in cases concerning defamation (also known as slander or libel). Another area with a relatively high occurrence of punitive damages awards are certain contract cases, such as fraud, bad faith insurance, employment discrimination, real property and consumer sales. ${ }^{23}$ These contract cases are also known under the name financial torts. The following table, derived from an analysis of punitive damages application by state courts in the seventy-five most populous counties (i.e. an administrative subdivision of a state) in 2005 gives a more detailed overview of categories in which punitive damages are awarded: ${ }^{24}$ 


\section{Plaintiff winners awarded punitive damages in civil trials in state courts, by case type, 2005}

\begin{tabular}{lrc} 
Case type & $\begin{array}{c}\text { Number } \\
\text { of trials }\end{array}$ & $\begin{array}{c}\text { Percentage awarded } \\
\text { punitive damages }\end{array}$ \\
\hline All cases & 14,359 & $5 \%$ \\
Tortb & 8,519 & $3 \%$ \\
Intentional tort & 426 & 30 \\
Other or unknown tort & 299 & 5 \\
Product liabilityc & 95 & 1 \\
Medical malpractice & 567 & 1 \\
Automobile & 5,984 & 1 \\
Premise liability & 712 & $\ldots$ \\
Contractd & 5,840 & $8 \%$ \\
Fraud & 661 & 23 \\
Employmente & 447 & 22 \\
Other or unknown contract & 132 & 15 \\
Buyer plaintiff & 1,642 & 8 \\
Rental/lease & 341 & 2 \\
Seller plaintiff & 2,175 & 1 \\
\hline
\end{tabular}

Note: Table includes only those trials in which one or more plaintiffs prevailed. Data on awarding of punitive damages were available for $98.5 \%$ of all trials. Several tort and contract case categories are not shown because there were too few cases to obtain statistically reliable estimates. Detail may not sum to total due to rounding.

a Includes some trials in which litigants did not seek but were awarded punitive damages.

b Includes all tort cases, including those not listed in table.

c Includes asbestos and other product liability cases.

dIncludes all contract cases, including those not listed in table.

e Includes employment discrimination and other employment dispute cases.

...Less than $0.5 \%$.

Although it should be made clear that the figures in this table are not representative of the entire United States, as research has only been carried out on the seventy-five most populous counties, this table shows that in these counties punitive damages are mostly awarded for intentional torts (30\%), fraud (23\%) and employment cases, including employment discrimination (22\%). A similar report about punitive damages awards by state courts in the seventy-five most populous counties in 2001, reveals that the types of tort cases in which punitive damages were mostly awarded are libel and slander $(58 \%)$, intentional torts $(36 \%)$, and false arrest or false imprisonment $(26 \%)$. Of the contract cases, punitive damages were mainly 
awarded in partnership disputes (22\%), employment discrimination (18\%), and fraud cases $(17 \%)^{25}$

Thus, American punitive damages verdicts are largely dominated by intentional torts, defamation cases and financial torts, whereas personal injury resulting from negligence, automobile accidents, medical malpractice and products liability plays a relatively minor role (all 5\% or less in the table above). A plausible explanation for this result is the element of major aggravation that is required for the imposition of punitive damages. This aggravating element, which will be further explained in the next section, is probably more often present when the cause of action is an intentional tort, defamation case or financial tort than in personal injury cases resulting from negligence, automobile accidents, medical malpractice and products liability. This is explained as follows in the above-mentioned report containing data from $2005:^{26}$

The variation in punitive damage claims by case type might be influenced by the legal elements inherent in the CJSSC (i.e. Civil Justice Survey of State Courts, LM) case categories. Certain civil claims, such as intentional torts (e.g., assault or battery) or slander or libel tend to have elements of willful or intentional behavior that would be expected to support a punitive damages request. Other CJSSC case categories, such as automobile accident or premises liability, typically do not involve elements of intentional or reckless behavior that could be used to support a punitive damages award.

However, we must not forget that the relatively low percentage of punitive damages awarded in personal injury cases in comparison to the other categories obviously does not mean that punitive damages are never awarded in such personal injury cases. ${ }^{27}$ Note that further information on the acceptance and application of punitive damages in the United States will be provided in section 4.2.

To conclude, in respect of the main focus of this book, an important research result that should be emphasised at this point is that the categories of wrongful behaviour in which punitive damages could especially play a role in continental Europe are known in American law as intentional torts, defamation and financial torts. These three categories cover both intentional and grave wrongdoing, which particularly applies to the intentional torts, and calculative wrongdoing, for example defamation and fraud. This seems to be in line with the increased European attention for powerful civil remedies to improve the enforcement of tort law standards and deal with intentional, calculative and grave misconduct of tortfeasors. As will be explained in chapter seven, this is an important reason for the increased European interest in punitive damages.

\subsubsection{Nature of Conduct for Which Punitive Damages May Be Awarded}

Not only the underlying cause of action, also the nature of the tortfeasor's conduct is very important for the decision whether or not punitive damages can be awarded. According to Kircher and Wiseman: ${ }^{28}$

25 Cohen 2005, p. 1.

26 Cohen \& Harbacek 2011, p. 2. See also Cohen 2009, p. 6.

27 See for example the explanations of the McDonald's case and the Barton case in section 2.2.2.

28 Kircher \& Wiseman 2000a, p. 5-4. 
In determining whether a punitive award is justified, the focus is directed at the nature or character of the conduct of the defendant.

As we have seen, punitive damages are for example available for intentional conduct, such as the tort of battery. ${ }^{29}$ Another accepted type of conduct that may give rise to punitive damages is reckless or conscious disregard of the probability that the plaintiff will be harmed. ${ }^{30}$ Keeton et al. give the following characterisation of the behaviour needed to justify a punitive damages award: ${ }^{31}$

Something more than the mere commission of a tort is always required for punitive damages. There must be circumstances of aggravation or outrage, such as spite or "malice", or a fraudulent or evil motive on the part of the defendant, or such a conscious and deliberate disregard of the interests of others that the conduct may be called willful or wanton. There is general agreement that, because it lacks this element, mere negligence is not enough, even though it is so extreme in degree as to be characterized as "gross." Gross negligence is a term of ill-defined content, which occasionally, in a few jurisdictions, has been stretched to include the element of conscious indifference to consequences, and so to justify punitive damages. Still less, of course, can such damages be charged against one who acts under an innocent mistake in engaging in conduct that nevertheless constitutes a tort.

In each American state that allows punitive damages, the judiciary or legislator has implemented aggravated circumstances in characterising the nature of the defendant's conduct. In addition to the violation of a right, there must be an additional element of asocial behaviour beyond the kind of behaviour necessary to create a normal tort. $^{32}$

This means that punitive damages can in principle not be awarded in normal tort cases where there are no aggravated circumstances. ${ }^{33}$ In theory, the liability standards that justify punitive damages can be defined with reasonable precision and consistency. In reality, the criteria for assessing punitive damages are rather vague, which leads to legal uncertainty. The uncertainty is primarily caused by the following factors: (1) the variety and imprecision of terminology adopted by legislators and courts to describe when punitive damages are appropriate, and (2) the broad discretion that is accorded to the trier of fact - the trier of fact is normally the jury, but can also be the court sitting without a jury - in awarding such damages. ${ }^{34}$

What are then the generally accepted grounds for awarding punitive damages? As mentioned above, punitive damages are most often awarded in tort cases. In addition to violating a right and - as will be explained below - inflicting actual damage, ${ }^{35}$ a certain state of mind of the defendant is needed for punitive damages

Keeton et al. 1984, p. 9-10.

For an overview of definitions of the required conduct per state, see Kircher \& Wiseman 2000a, p. 5-4 to $5-41$.

3325 C.J.S. Damages $\S 200$.

34 Ellis 1982, p. 34; 22 Am. Jur. 2d Damages $\S 605 ; 25$ C.J.S. Damages $\S 196$. See on this topic also section 3.3 below.

3525 C.J.S. Damages $§ 198$. 
to be awarded. The Restatement of Torts emphasises, in line with the abovementioned characterisation of behaviour as defined by Keeton et al., that 'punitive damages may be awarded for conduct that is outrageous, because of the defendant's evil motive or his reckless indifference to the rights of others'. ${ }^{36}$ This formulation can be interpreted very broadly, which indeed leads to criticism as regards the vagueness of liability standards in American punitive damages law. ${ }^{37}$ Whether or not punitive damages can be imposed depends on the circumstances of each individual case, including the relationship between the plaintiff and defendant and the duties owed by them. ${ }^{38}$ The conduct and state of mind of the defendant are vital factors in determining whether punitive damages should be awarded. ${ }^{39}$ The trier of fact may, at its discretion, impose punitive damages in a number of situations. As mentioned above, something more than the mere commission of a tort is necessary: the wrongful conduct of the defendant is so extreme and exceptional that it includes an element of major aggravation. ${ }^{40} \mathrm{~A}$ high standard of misconduct is required to justify the punishing and deterring purpose of the award. One could in this respect think of the following aggravating conditions: willfulness, wantonness, malice or ill will, gross negligence or recklessness, oppression, outrageous conduct, violence, indignity or insult, fraud or gross fraud and criminal indifference. ${ }^{41}$ In most jurisdictions, one aggravating condition is sufficient to justify a punitive damages award. ${ }^{42}$ If no such condition is pleaded and proven, only compensatory damages can be awarded. Some jurisdictions only recognise certain particular aggravating conditions as grounds for punitive damages. In Arkansas for example, the characterisation of behaviour that may give rise to punitive damages is as follows: ${ }^{43}$

In order to support an award of punitive damages, the evidence must indicate the defendant acted wantonly in causing the injury or with such a conscious indifference to the consequences that malice might be inferred. Negligence alone, however gross, is not a sufficient basis to justify the award of punitive damages.

The most often encountered key concepts will be explained in short. Willful and wanton misconduct, which refers to a higher degree of culpability than negligence, is defined as highly unreasonable conduct, or an extreme departure from ordinary care, in a situation in which a high degree of danger is apparent. ${ }^{44}$ The concept has also been explained as conscious indifference. Willful and wanton behaviour is not the same as malice, also known as ill will or the intent to injure. ${ }^{45}$ Malice refers

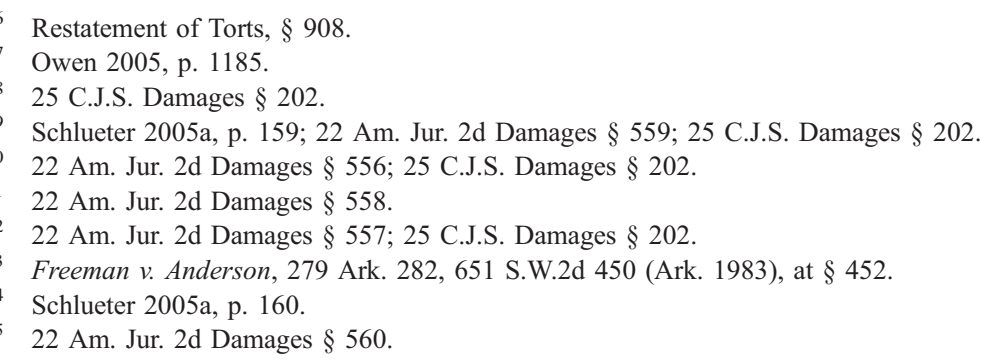


either to the situation in which a defendant intentionally commits a wrongful act without just cause (legal malice), or to the situation in which the defendant has a wrong motive by which the purpose and desire to injure is activated (actual malice or malice in fact). ${ }^{46}$ It is relatively difficult to prove malice. ${ }^{47}$ Some jurisdictions require actual malice whereas in other jurisdictions legal malice is a justified basis for punitive damages. ${ }^{48}$ A court may also award punitive damages if the defendant's conduct is aggravated by fraud and oppression. ${ }^{49}$ Furthermore, in the absence of aggravating circumstances, mere negligence does not justify a punitive damages award. ${ }^{50}$ There are states that allow punitive damages in cases of gross negligence, but then the negligence must be so gross that there was 'a conscious indifference to the rights and safety of the plaintiff' ${ }^{51}$ The Supreme Court of Massachusetts recently confirmed that, in the absence of malice or willful misconduct, gross negligence can be a sufficient basis for a punitive damages award of $\$ 18$ million. ${ }^{52}$ The claimant in this products liability case was the widower of a twenty-nine year old woman who died from injuries sustained due to a defective inflatable swimming pool slide. As shown in the previous section, the outcome of this case is extraordinary for two reasons: punitive damages awards are relatively rare in products liability cases and personal injury caused by negligent behaviour is usually not enough for a punitive damages award. Note that there are a few cases in which punitive damages have been imposed in the absence of a guilty state of mind of the defendant. ${ }^{53}$ These cases usually involve defendants who seriously abuse their position or privilege of power, for example a policeman who violates the civil rights of a suspected person.

The foregoing forms a theoretical and somewhat unclear set of aggravating conditions. Blatt et al. have made the following useful subdivision of conduct required for punitive damages to be awarded: (1) malice; (2) conduct exceeding gross negligence but not constituting malice; (3) gross negligence; and (4) various statutory requirements. More than half of the states that allow punitive damages require conduct in the second category, whereas the rest of the states require malice or gross negligence. It differs per state whether the conduct must be proved by clear and convincing evidence, by a preponderance of the evidence or beyond a reasonable doubt, although the latter criminal law standard is hardly required. ${ }^{54}$ As will be explained in section 4.4.1, most states require clear and convincing evidence for punitive damages to be awarded.

25 C.J.S. Damages $\S 205$; Schlueter 2005a, p. 162.

Schlueter 2005a, p. 161.

Aleo v. SLB Toys USA, Inc., 466 Mass. 398, 2013 WL 4849097 (Mass. 2013).

Schlueter 2005a, p. 162.

Blatt, Hammesfahr \& Nugent 2008, p. 91. 
To conclude, the mere fact that the defendant committed an unlawful act is not, of itself, a sufficient basis for a punitive damages award. ${ }^{55}$ The act complained of must not only be unlawful, but it must also involve a certain aggravating element.

\subsubsection{Requirement of Actual Damage}

There is no separate cause of action for punitive damages. Rather, a punitive damages award is an 'element of recovery, a type of relief, or an additional remedy'. ${ }^{56}$ Punitive damages cannot by itself constitute the basis of a cause of action but are incidental to the underlying cause of action. ${ }^{57}$ This means that a plaintiff must have suffered actual damage in order to obtain punitive damages and must produce sufficient evidence in this respect. ${ }^{58}$ The rationale of this requirement is that conduct that caused no measurable objective injury should not be punished, which goes hand-in-hand with the principle that private individuals should not be encouraged to start litigation if they have suffered no injury (damnum absque injuria). The common law rule that punitive damages can only be awarded if actual damage has been suffered is generally accepted, but American courts have differing opinions on the question whether the plaintiff must be entitled to nominal or compensatory damages as a basis for punitive damages. ${ }^{59}$

The majority of jurisdictions hold that the plaintiff must be entitled to at least nominal damages, which is a symbolic award of no real value as was seen in section 2.2.4 of the previous chapter. ${ }^{60}$ These jurisdictions take the view that nominal damages awards are a sufficient basis for punitive damages, because the purpose of punitive damages is to punish and deter outrageous conduct. It is also justified by the view that the defendant should not be relieved of his responsibility because an injured party (unluckily) failed to prove compensatory damages. ${ }^{61} \mathrm{~A}$ recent example is a case concerning employment discrimination, to be precise sexual harassment in which $\$ 1$ in nominal damages and $\$ 125,000$ in punitive damages were awarded to the plaintiff. ${ }^{62}$ This is an example of a case that fits into the popular punitive damages categories mentioned in section 3.2.2.

On the contrary, in some jurisdictions the mere award of nominal damages cannot serve as a basis for punitive damages. ${ }^{63}$ In this regard, punitive damages are not allowed unless the plaintiff either proves that he is entitled to compensatory damages or in fact received compensatory damages. ${ }^{64}$ The requirement of compensatory damages as a basis for punitive damages is justified for several

5525 C.J.S. Damages $\S 204$.

5622 Am. Jur. 2d Damages $\$ 551$.

57 Schlueter 2005a, p. 359.

58 Schlueter 2005a, p. 358; 25 C.J.S. Damages, § 197; 22 Am. Jur. 2d Damages § 551, 553.

59 Kircher \& Wiseman 2000a, p. 5-156; Schlueter 2005a, p. 359; 25 C.J.S. Damages, § 197.

60 Kircher \& Wiseman 2000a, p. 5-161.

6122 Am. Jur. 2d Damages $\S 553$.

62 Arizona v. Asarco Llc, 733 F.3d 882 (C.A.9 (Ariz.) 2013).

63 Hopewell Enterprises, Inc. v. Trustmark Nat. Bank, 680 So.2d 812 (Miss. 1996).

64 Schlueter 2005a, p. 361-362; 22 Am. Jur. 2d Damages $§ 553$. 
reasons: there is no separate cause of action for punitive damages; conduct which causes no measurable objective injury should not be punished; and compensatory and punitive damages should bear a reasonable relation to each other. ${ }^{65}$ The relationship between compensatory and punitive damages will be explained in section 3.3 .3 below.

It is debatable whether the Americans argue soundly when emphasising the punishing and deterring purpose of punitive damages, on the one hand, and requiring that actual damage has to be suffered by the plaintiff - like in situations where compensatory damages are involved - on the other hand. It could of course be that, even in the absence of damage, the behaviour of the defendant is still so remote as to justify punitive damages. In other words, if the theory of punitive damages is in fact solely focused on punishment and deterrence of the defendant's behaviour, the award of punitive damages in a situation where there is no actual damage should perhaps be possible. However, given the general requirement of actual damage which relates to the position of the plaintiff, it is defensible that punitive damages do serve the function of compensating the plaintiff as well. As explained in section 2.3.3, the theory that punitive damages also have an important compensatory function indeed receives support in American legal doctrine.

\subsection{Assessment and Amount of Punitive Damages}

\subsubsection{Discretion of the Jury}

Punitive damages issues are usually decided by both trial court and jury. The court determines issues of law, whereas the jury determines issues of fact. ${ }^{66}$ In its role as gatekeeper, the court must decide whether the question of punitive damages may be submitted to the trier of fact, i.e. normally the jury. For example, the question of punitive damages is not submitted to the trier of fact when punitive damages are not recoverable for the particular cause of action, such as a 'normal' contract action. Furthermore, the court must decide whether there is sufficient evidence to support a punitive damages award before the question of punitive damages may be submitted to a jury. ${ }^{67}$ The court ought to consider the evidence that is most favourable to the plaintiff. ${ }^{68}$ If the pleadings and the evidence justify punitive damages, the issue should be submitted to the trier of fact. In this respect, courts normally provide juries with jury instructions. ${ }^{69}$ Over forty states have approved so-called Model Jury Instructions, which are used to define the law in a way that jurors can comprehend. If the evidence is insufficient, most courts refuse to give jury instructions or instruct the jury not to allow punitive damages. ${ }^{70}$

65 Schlueter 2005a, p. 363.

66 Schlueter 2005a, p. 331.

6722 Am. Jur. 2d Damages § 550.

8 Schlueter 2005a, p. 332.

69 Kircher \& Wiseman 2000a, p. 5-202. For examples of appropriate jury instructions, see Schlueter 2005 a, p. 333.

70 Schlueter 2005a, p. 332, 336. 
Whether particular conduct constitutes a basis for punitive damages is not a question of law. The decision whether punitive damages are recoverable generally rests in the discretion of the trier of fact, which decides whether the defendant's conduct was egregious enough to justify punitive damages. ${ }^{71}$ In addition to the character of the defendant's act, the trier of fact may consider the nature and extent of the harm that the defendant caused, or intended to cause to the plaintiff, and consider these factors in relation to the punitive and deterring function of punitive damages. Other relevant factors are the wealth of the defendant and the possibility of criminal punishment. ${ }^{72}$

Punitive damages are not recoverable as a right. In other words, the plaintiff 'does not have an automatic right to such an award', unless awarded by statute. ${ }^{73}$ The trier of fact is not obliged to award punitive damages, even if the evidence and pleadings justify such damages, or the defendants' acts are sufficiently egregious. ${ }^{74}$ As explained in the encyclopedia American Jurisprudence: ${ }^{75}$

No matter how compelling a punitive damages award might seem to be under the facts of a given case, should the fact finder for any reason opt against making such an award, the plaintiff has no redress.

Conversely, in the absence of a clear abuse of discretion, the decision of a first instance court to award punitive damages cannot be reversed by the court of appeal. ${ }^{76}$

\subsubsection{Judge and Jury Compared}

Some authors have argued that the amount of punitive damages will be smaller if such claims are decided by judges instead of jurors. ${ }^{77}$ Jury punitive damages

71 Kircher \& Wiseman 2000a, p. 5-172; Schlueter 2005a, p. 348; 22 Am. Jur. 2d Damages $\S 550$.

72 Restatement of Torts, $\S 908$; Kircher \& Wiseman 2000a, p. 5-175.

73 Kircher \& Wiseman 2000a, p. 5-171; Schlueter 2005a, p. 27.

74 Kircher \& Wiseman 2000a, p. 5-171.

7522 Am. Jur. 2d Damages $\S 550$.

7622 Am. Jur. 2d Damages § 550

77 Critical remarks can be found, for example, in Hersch \& Kip Viscusi 2004. The abstract to their paper reads as follows: 'This paper presents the first empirical analysis that demonstrates that juries differ from judges in awarding punitive damages. Our review of punitive damages awards of \$ 100 million or more identified 63 such awards, of which juries made 95 percent. These jury awards are highly unpredictable and are not significantly correlated with compensatory damages. Using data on jury and bench verdicts from the Civil Justice Survey of State Courts, 1996, we find that juries are significantly more likely to award punitive damages than are judges and award higher levels of punitive damages. Jury awards are also less strongly related to compensatory awards. The differential effect of juries is most pronounced among the largest awards. Juries also tend to award higher levels of compensatory damages, which in turn boost the punitive damages award. The findings are robust with respect to controlling for self-selection of jury or bench trial.' In a more recent article, the same authors again support the view that jury behaviour with regard to punitive damages is unpredictable: Hersch \& Kip Viscusi 2010, p. 279. However, this has been debated by Eisenberg \& Heise, who state that the claim made by Hersch and Kip Viscusi 'seems based on Exxon-funded experiments that never reconciled their findings with real-world punitive damages data': Eisenberg \& Heise 2011, p. 326, footnote 2. 
awards are criticised because juries are believed to be more biased, irrational and emotionally in support of the plaintiff than judges. ${ }^{78}$ Several empirical studies that investigated the decision-making of judges and jurors show that this assertion is not necessarily correct. ${ }^{79}$ However, the outcomes of these studies as regards the possible differences between judges and jurors are quite mixed. ${ }^{80}$ For example, one study ${ }^{81}$ that compared a large number of civil cases over a period of ten years reveals that in some types of cases judges awarded more damages, whereas in other types of cases juries awarded more damages. ${ }^{82}$ Another study ${ }^{83}$ reveals that almost one-third of 9,000 punitive damages cases were awarded by judges. To the astonishment of the researchers, the share of punitive damages awards by judges is rather substantial when compared to 'the overwhelming focus on jury punitive awards in the literature and policy debate'. ${ }^{84}$ The study on punitive damages awards in large counties in 2001, which has already been mentioned in section 3.2 .2 above, reveals that in 6,504 civil trials plaintiffs received punitive damages in $6 \%$ of the jury trials and in $4 \%$ of the court trials. ${ }^{85}$ Furthermore, the median punitive damages awarded by juries amounted to $\$ 50,000$, whereas courts awarded $\$ 46,000$. Of the 260 jury trials in which a plaintiff obtained punitive damages, $14 \%$ resulted in an award of $\$ 1$ million or more. Punitive damages of $\$ 1$ million or more were awarded in $2 \%$ of the 79 court trials with punitive damages. These latter figures do show that juries are slightly more inclined to award large punitive damages awards than judges are.

In the case Philip Morris USA v. Williams, ${ }^{86}$ the U.S. Supreme Court was advised on jury behaviour relating to punitive damages by a group of academics. ${ }^{87}$ The advisor's arguments supporting the rational and reasonable performance of juries are the following: ${ }^{88}$

(1) juries award punitive damages infrequently; (2) punitive damages awards have not increased in frequency; (3) when adjustments are made for inflation the magnitude of such awards has not increased over the past several decades; (4) most awards are modest in size; (5) the overwhelming majority of awards show a rational proportionality between actual and potential harm caused by defendants; (6) the same proportionality relationship between compensatory and punitive damages exists in cases

78 Bornstein et al. 2008, p. 5.

79 Robbennolt 2002b, p. 336-337. For an overview of empirical research on the decision-making of judges and jurors, see Robbennolt 2002a, p. 146. See also Sharkey 1996, p. 1089-1090, footnote 5 and 6, who gives an overview of authors advocating either judicial assessment or jury assessment of punitive damages. For a general overview of the relation between juries and, e.g., punitive damages, see Developments in the Law 1997.

80 Robbennolt 2002a, p. 152.

81 Clermont \& Eisenberg 1992, p. 1134

82 The first types of cases were especially products liability, medical malpractice and motor vehicle cases, the second types of cases were especially marine and Federal Employer's Liability Act cases.

83 Eisenberg et al. 2002, p. 747-748; Robbennolt 2002a, p. 149.

84 Eisenberg et al. 2002, p. 752.

85 Cohen 2005, p. 2. See also section 4.2.2.

86 Philip Morris USA v. Williams, 549 U.S. 346, 127 S.Ct. 1057 (U.S.Or. 2007).

87 Vidmar et al. 2006.

88 Vidmar et al. 2006, p. 2. 
involving large punitive awards; (7) juries pay particular attention to the reprehensibility of defendants' conduct; (8) jury decision-making processes in punitive damages cases are similar to the decisionmaking processes used by judges in bench trials of such cases; (9) the amounts of punitive awards rendered by juries and judges are similar when adjustments are made for case types; (10) little evidence indicates that juries are biased against large businesses; (11) judges effectively exercise supervision over punitive damages in post-verdict motions or on appeal; and (12) in other instances post-verdict settlements reduce or abandon punitive awards without judicial intervention.

These arguments were put forward to the court by twenty-four academics who have all done empirical research into juries, punitive damages verdicts, or both. ${ }^{89}$ To conclude, the general outcome of all relevant studies combined is not unfavourable for juries: $:^{90}$

Juries do not appear to make decisions that clearly differ from the decisions that judges would make, certainly not to the dramatic extent that most critics of the jury suggest.

Thus, the skepticism that is surrounding jury punitive damages awards has been put into perspective. Even though this theme is not really relevant for the European debate due to the absence of a jury system in continental European legal systems, Europeans should not unquestioningly accept the idea that juries contribute to excessive punitive damages awards in the United States, nor should they be put off by it. This idea seems to be a misconception, just as many other misconceptions that are brought forward in the European punitive damages debate.

\subsubsection{Amount of Punitive Damages}

There is no fixed standard for measuring the amount of punitive damages. ${ }^{91}$ As punitive damages primarily serve to punish and deter the defendant, the court must focus on the defendant's rather than the plaintiff's conduct when fixing an appropriate amount. For that reason, courts usually reject the argument that contributory fault of the plaintiff can be used to diminish the punitive damages award. $^{92}$ The amount of a punitive damages award is determined by the trier of fact, as explained above in principle the jury, and depends on the circumstances of each individual case: ${ }^{93}$

In assessing punitive damages, the trier of fact can properly consider the character of the defendant's act, the nature and extent of the harm to the plaintiff that the defendant caused or intended to cause and the wealth of the defendant.

Vidmar et al. 2006, p. 1. For more background information about punitive damages decisionmaking by juries and psychological or legal perspectives of civil juries, see Sunstein et al. 2002 and Bornstein et al. 2008.

90 Robbennolt 2002a, p. 158.

9122 Am. Jur. 2d Damages $\S 604 ; 25$ C.J.S. Damages $\S 213$.

92 Kircher \& Wiseman 2000a, p. 5-142.

93 Restatement of Torts, $\S 908(2)$ 
The jury should determine a proper amount without being passionate, prejudiced or corrupt. ${ }^{94}$ Thus, contrary to popular belief, the discretion of the jury cannot be arbitrary or unlimited. Draconian punitive damages awards are not allowed because the amount of the award should not be disproportionate to, among other things, the defendant's ability to pay. This has been further explained by the Supreme Court of Ohio: ${ }^{95}$

The focus of the award should be the defendant, and the consideration should be what it will take to bring about the twin aims of punishment and deterrence as to that defendant. We do not require, or invite, financial ruination of a defendant that is liable for punitive damages. While certainly a higher award will always yield a greater punishment and a greater deterrent, the punitive damages award should not go beyond what is necessary to achieve its goals. The law requires an effective punishment, not a draconian one.

The award should be reasonable and should not go beyond what is necessary to achieve its goals. There are two important aspects to this. Firstly, there must be a reasonable relation between the amount of punitive damages and the (potential) harm done to the plaintiff. ${ }^{96}$ Secondly, as a general rule, there must be a reasonable relation to the amount of compensatory damages awarded. ${ }^{97}$ This rule, which relates to the generally accepted rule that punitive damages can only be awarded if actual damage has been suffered, is also known as the reasonable ratio rule. The rule has resulted in courts holding that the amount of punitive damages should bear a reasonable relation to the compensatory damages award or to the plaintiff's injury. For example, if the defendant acted with wanton disregard but with no actual intention to cause harm, the ratio of punitive damages to compensatory damages has been set at roughly five to one, whereas this ratio can be much higher if the defendant acted with evil intention. ${ }^{98}$ Note that the reasonable ratio rule is not the most straightforward rule given the mainly non-compensatory purpose of punitive damages. As mentioned in section 3.2.4, the majority of courts have therefore decided that a relationship between punitive damages and compensatory damages is not required: after all, punitive damages awards mainly relate to the defendant's behaviour rather than to the plaintiff's loss. ${ }^{99}$ These courts allow (rather large) disparities between punitive and compensatory damages awards.

A lot of empirical research has been done into the relation between punitive and compensatory damages. ${ }^{100}$ Critics of punitive damages complain about the

95 Dardinger v. Anthem Blue Cross \& Blue Shield, 98 Ohio St. 3d 77, 2002-Ohio-7113, 781 N.E.2d 121 (2002), at $\S 144$

96 Schlueter 2005a, p. 359; 22 Am. Jur. 2d Damages $\S 604$.

97 Schlueter 2005a, p. 37, 353.

22 Am. Jur. 2d Damages $\S 610 ; 25$ C.J.S. Damages $\S 213$.

9922 Am. Jur. 2d Damages $\S 612$.

100 Eisenberg \& Wells 1999; Eisenberg, Hans \& Wells 2008; Eisenberg, Heise \& Wells 2010; Sharkey 2008; Vidmar et al. 2006, p. 10-14. 
absence of such a relationship. This has however been disputed, for example by Eisenberg et al.: ${ }^{101}$

To our knowledge, no persuasive analysis of actual cases supports the absence of a relation between punitive and compensatory damages.

Eisenberg and his colleagues do remark that courts have let 'the punishment fit the crime', meaning that greater harm and resulting compensatory damages awards are accompanied by increased punitive damages awards.

As explained in section 3.3.1, the jury, or the (appellate) court that reviews the punitive damages award for excessiveness, may consider several factors in determining a proper amount. These are comparable to the factors that influence the initial decision of the jury whether punitive damages should be awarded and include the nature, reprehensibility, and duration of the defendant's conduct, the defendant's intent or motivation, the awareness of any danger the conduct has caused, and other circumstances relating to the defendant's actions. ${ }^{102}$ The trier of fact may also take the wealth of the defendant into account. Some - but not all jurisdictions allow evidence with regard to the financial position of the defendant. ${ }^{103}$ On the one hand, this relates to the general principle that punitive damages should not be draconian, that such damages do not aim at destroying the financial position of the defendant. On the other hand, a rationale for allowing such evidence is that larger awards may be necessary to punish and deter wealthier defendants. In other words, the punishing and deterring effect of a punitive damages award depends on the defendant's financial situation. ${ }^{104}$ It has also been decided that the financial position of both parties may be considered in determining the amount of punitive damages. ${ }^{105}$

In arriving at its award, the jury in considering all of the surrounding circumstances can properly take into consideration the relative financial standing of the parties.

According to this court, all facts and circumstances of the case, including the injury done to the plaintiff and the effects of this injury on his financial condition, must be considered. The financial condition of the defendant may be especially relevant: ${ }^{106}$

The financial worth of the defendant is an important factor. Punitive damages have often been referred to as 'smart' money and it takes only slight consideration to realize that an amount of damages which might 'smart' one defendant might be entirely inconsequential to another.

101 Eisenberg, Heise \& Wells 2010, p. 6.

10222 Am. Jur. 2d Damages $\S 606$.

103 Schlueter 2005a, p. 175, 297; Kircher \& Wiseman 2000a, p. 9-52; 25 C.J.S. Damages $\S 216$. For an overview of jurisdictions that admit evidence of the defendant's financial status, see Kircher \& Wiseman 2000a, p. 5-223 to 5-226.

10422 Am. Jur. 2d Damages $\S 607 ; 25$ C.J.S. Damages $\S 215$.

105 Wisner v. S.S. Kresge Co., 465 S.W.2d 666 (Mo.App. 1971), at § 669.

106 Wisner v. S.S. Kresge Co., at $\S 669$. 
Another factor that can influence the size of the punitive damages award is the fact that a defendant gained money from his wrongful act, in the sense that he obtained profits. Courts may decide that the amount should be in excess of the profit for the following reason: ${ }^{107}$

This result is based on the theory that exemplary damages are intended to inject an additional factor into the cost-benefit calculations of companies that might otherwise find it fiscally prudent to disregard the threat of liability.

As regards the costs of litigation and attorney's fees, the majority of courts take such costs into account when determining the amount of punitive damages. The rationale is that the plaintiff who has been seriously wronged should not bear the burden of litigation costs. ${ }^{108}$ This also allegedly encourages plaintiffs to take wrongdoers to court and, therefore, is in line with the law enforcement function of punitive damages. ${ }^{109}$ However, opinions differ on this, and in some jurisdictions it has been argued that a punitive damages award should not cover litigation costs because that would only serve to compensate the plaintiff rather than to punish the defendant. ${ }^{110}$

\subsubsection{Judicial Control of Jury Awards}

As previously mentioned, jury punitive damages awards can be reviewed judicially by the trial court or on appeal. This judicial control applies only to awards that seem to be excessive or inadequate. For the rest, the discretion of the jury to determine the amount of the punitive damages award is largely respected. ${ }^{111}$ The court can only set aside a jury verdict, usually on request of the defendant, on one of the following grounds: (1) the verdict exceeds what has been claimed in the complaint; (2) it is prejudiced, passionate or biased; (3) it is based on a mistake of law or fact; (4) it lacks evidentiary support, or (5) it shocks the judicial conscience. ${ }^{112}$ Judicial review of punitive damages awards is one of the mechanisms in American law to control improper awards and will be further explained in section 4.4.2.

\subsubsection{Relation to Criminal Punishment}

The wrongful behaviour that exposes a defendant to civil liability may simultaneously expose him to criminal liability. This especially applies to intentional torts or tortious behaviour with a conscious or reckless disregard for the health and safety of others. In most states, a criminal conviction does not bar the imposition of punitive damages on the defendant for the same act in a civil lawsuit, and an

10722 Am. Jur. 2d Damages $\S 607$.

108 Schlueter 2005a, p. 34-36; 22 Am. Jur. 2d Damages $\S 608$.

109 Farmers Ins. Exchange v. Shirley, 958 P.2d 1040 (Wyo. 1998).

110 Schlueter 2005a, p. 36; Kircher \& Wiseman 2000a, p. 5-169. See also sections 2.2.3.4 and 4.3.2.5.

111 Kircher \& Wiseman 2000a, p. 5-179; Kircher \& Wiseman 2000b, chapter eighteen.

112 Kircher \& Wiseman 2000b, p. 18-7. 
award of punitive damages is not considered a double jeopardy. ${ }^{113}$ According to the Maine Supreme Court: ${ }^{114}$

\begin{abstract}
"In the constitutional sense," jeopardy is a technical term that encompasses only the risk inherent in proceedings that are "essentially criminal." Accordingly, a civil action for punitive damages cannot infringe on a defendant's constitutional right to be free from double jeopardy. A claim for punitive damages is based upon a private wrong, and is clearly distinguishable from a criminal prosecution, which is brought solely on the behalf of the public. The state and federal constitutional prohibitions against double jeopardy present no bar to actions for punitive damages.
\end{abstract}

\title{
The Court continued: ${ }^{115}$
}

In the absence of constitutional compulsion, we can see no reason to bar actions for punitive damages based upon the fact that the underlying conduct is also subject to criminal prosecution. Such a step would "[fall] short of a principled approach." As we noted earlier, "the criminal system cannot always adequately fulfill its role as an enforcer of society's rules. We therefore prefer a more flexible rule, whereby the fact finder may consider any criminal punishment imposed for the conduct in question as a mitigating factor on the issue of punitive damages.

Thus, the rationale for this general rule is that the criminal sanction is mainly imposed for the wrong done to society, whereas the civil sanction is primarily imposed for the wrong done to the individual plaintiff. ${ }^{116}$ Although - as was seen in section 2.2.3 - there certainly is a public interest in awarding punitive damages, the theory that the punitive damages award should in principle be understood as punishment for the wrong done to the plaintiff rather than for public wrongs is supported by more American authors, for example Colby. ${ }^{117}$ Furthermore, according to Freifield, who wrote an article on the rationale of punitive damages in 1935 , punitive damages are originally meant to supplement the criminal law: ${ }^{118}$

Now the objective in the civil forum is basically to make the aggrieved party whole. In the criminal court, the goals may be variously stated, though en rapport: first, to punish the offender against society; secondly, to deter him and other from perpetrating similar, or any, offenses against society; and thirdly, to inspirit in the offender an approach to penitence for his wrongful act. Yet an examination discloses that, to a not inconsiderable extent, the civil tribunal acts as a supplementing, bolstering factor, to secure the objectives of the criminal forum. The subject of punitive damages $[\ldots]$ furnishes a choice example.

In other words, the general rule that a punitive damages award cannot be considered a double jeopardy allows the punitive damages remedy to function as a supplement to criminal law sanctions. The use of the word supplement

113 Kircher \& Wiseman 2000a, p. 5-136. The authors give a useful overview of states in which this is the general rule. See also Rendleman 2009, p. 3; Mallor \& Robert 1999, p. 1006

114 Tuttle v. Raymond, 494 A.2d 1353 (Me. 1985), at § 1357-1358.

115 Tuttle v. Raymond, at $\S 1358$.

116 Kircher \& Wiseman 2000a, p. 5-138.

117 Colby 2003, p. 678.

118 Freifield 1935, p. 5. 
suggests that the two forms of sanctions should be geared to one another in order to prevent excessive punishment.

The imposition of a criminal sanction should thus not affect the civil punishment. It therefore seems that the ne bis in idem principle, known as the double jeopardy rule in common law systems, which is an often heard argument against punitive damages in European civil law systems, does not have much practical value in relation to punitive damages awards in most American states. This is of course related to the fact that the public-private divide similarly does not have much practical value as it does not form an impediment to the imposition of punitive damages in the United States. ${ }^{119}$ Nevertheless, even though these arguments do not have much practical value, also in the American punitive damages debate the public-private divide and the idea that punishment is best left to criminal law is an important point of critique. ${ }^{120}$

In determining the amount of punitive damages, a court may consider any criminal punishment against the defendant; the existence of a criminal punishment may even justify a punitive damages award. Furthermore, the amount of punitive damages may be compared to the amount of criminal sanctions imposed for similar conduct. ${ }^{121}$ For example, in Ellerin v. Fairfax Sav., F.S.B. the Court of Appeals of Maryland decided as follows: ${ }^{122}$

[...] in determining whether an award of punitive damages is proportionate to the defendant's misconduct, a court may consider, inter alia, the legislative policy reflected in statutes setting criminal fines.

As explained above, in addition to criminal penalties, the amount of compensatory damages awarded may also be considered in determining the amount or excessiveness of punitive damages. ${ }^{123}$

\subsubsection{Persons Entitled to and Liable for Punitive Damages}

\subsubsection{Persons Entitled to Recover}

Only the injured person, that is the immediate person receiving the injury, is entitled to recover punitive damages from a liable defendant. ${ }^{124}$ Statutes may deviate from this generally accepted common law rule. For instance, under some survival statutes punitive damages may be recovered by the personal representative of a decedent. ${ }^{125}$

The law generally does not allow punitive damages to be granted to a person who has a derivative claim, for example for loss of consortium, as he is only

119 See section 6.3 .

120 Schlueter 2005a, p. 31, 184. See also section 4.3.2.1.

12122 Am. Jur. 2d Damages $\S 609$.

122 Ellerin v. Fairfax Sav., F.S.B., 337 Md. 216, 652 A.2d 1117 (Md. 1995), at § 242.

12322 Am. Jur. 2d Damages $\S 610 ; 25$ C.J.S. Damages $\S 213$.

124 Schlueter 2005a, p. 178; 22 Am. Jur. 2d Damages $\S 583 ; 25$ C.J.S. Damages $\S 208$.

125 Schlueter 2005a, p. 178, 630. 
indirectly injured. ${ }^{126}$ However, it has been held that a spouse may recover punitive damages based on loss of consortium of the other spouse who was injured due to willful and reckless misconduct of the defendant. ${ }^{127}$

Some parties that are entitled to recover punitive damages call for special mention. For example, a private corporation may recover punitive damages in appropriate circumstances, e.g. where a malicious and oppressive trespass is committed on its property. ${ }^{128}$ Moreover, an employer (or: principal) may recover punitive damages in a suit against his employee (or: agent), under the condition that the employee breached trust in a 'flagrant and calculated' way. ${ }^{129}$ A punitive damages award against an employee is for example justified if the employee conceals a conflict of interest from the employer or keeps profits for himself. It has also been held that a state may recover punitive damages, simply because a state is able to bring a civil suit. ${ }^{130}$ However, the California Court of Appeal has ruled to the contrary. ${ }^{131}$ This court decided that it is against public policy for a public entity to recover punitive damages from a private tortfeasor for two reasons. ${ }^{132}$ Firstly, the public body already possesses police power to punish by imposing fines and other penal remedies, whereas the only means a private party has to punish a tortfeasor is by an award of punitive damages. Secondly, California law prohibits private parties from recovering punitive damages from a public entity; to allow a public entity to recover punitive damages from a private party would therefore raise serious questions of equal protection under the law.

\subsection{Multiple Plaintiffs}

The American legal system is familiar with the phenomenon of multiple plaintiffs or, when the claims are consolidated into a single litigation, plaintiffs who seek punitive damages in a class action. ${ }^{133}$ Certain events or products may injure many plaintiffs, for example an air crash or a defectively manufactured medical drug. Especially the class action is advantageous for the average plaintiff, as it saves him a lot with regard to costs and troubles of starting legal proceedings. Two situations can be distinguished. Firstly, a single act, such as a car or airplane accident, may cause harm to a number of persons. Secondly, a single act, such as a conscious manufacturing defect, may cause separate events leading to injuries. ${ }^{134}$

As a general rule, a court's decision to award punitive damages does not depend on whether the case was brought by multiple plaintiffs or as a class action. ${ }^{135}$ The award of punitive damages to one plaintiff does not mean that all subsequent

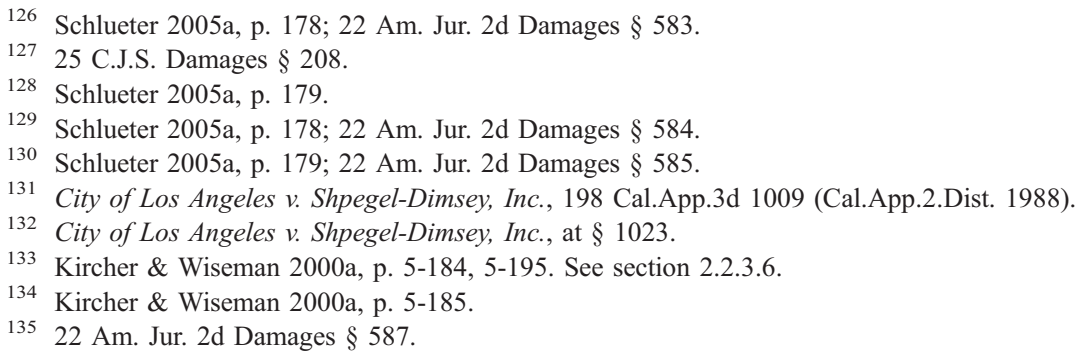


plaintiffs are precluded from recovering punitive damages, as each plaintiff in principle has an individual right to such damages. ${ }^{136}$ However, in practice, claims of multiple claimants are often considered difficult, as 'repeatedly imposing punitive damages on the same defendant for the same course of wrongful conduct may implicate substantive due process constraints'. ${ }^{137}$ Note that due process is not violated if the defendant committed several different acts of misconduct against different plaintiffs. ${ }^{138}$

Multiple plaintiff litigation is indeed considered a problematic area of American punitive damages law. It is an often contested, complex issue that also presents jurisprudential problems. ${ }^{139}$ Schlueter differentiates between legal problems and policy problems. ${ }^{140}$ Problems of the former category relate to the bankruptcy of defendants due to the size of punitive damages awards and to the anomalous result that the plaintiff in one jurisdiction obtains a larger award than the second plaintiff in another jurisdiction. A believed policy problem relates to the undesired result of 'over-punishment' or 'overkill', but opinions on this view differ. It is argued that awarding multiple punitive damages for the same wrong is unfair to the defendant and inconsistent with the punitive damages doctrine. This is rebutted by the argument that each time a person gets injured constitutes a separate wrong. In response to the 'overkill' problem, some courts have held punitive damages awards to be inappropriate in the particular class of cases. ${ }^{141}$ Another policy problem relates to multiple punitive damages awards that are in excess of any criminal penalty imposed for the same conduct. ${ }^{142}$ This problem was already observed in the 1960s, when the case of Roginsky v. Richardson-Merrell, Inc. was decided. ${ }^{143}$ The defendant had brought a defective medical drug onto the market, was aware of the defect, but failed to warn those who took the drug. Roginsky, who filed a suit just like hundreds of others did, was awarded $\$ 17,500$ in compensatory damages and $\$ 100,000$ in punitive damages. On appeal, the punitive damages award was reversed because there was insufficient evidence to warrant punitive damages. ${ }^{144}$ One of the judges of the appellate court, Judge Friendly, nevertheless showed concern about the outcome of the initial case and the problem of manufacturers who are exposed to multiple punitive damages awards: ${ }^{145}$

136 Schlueter 2005a, p. 180.

13722 Am. Jur. 2d Damages § 587.

138 Schlueter 2005a, p. 183.

139 Kircher \& Wiseman 2000a, p. 5-184; Schlueter 2005a, p. 180.

140 Schlueter 2005a, p. 180. For another extensive overview of problems relating to multiple plaintiffs, see Kircher \& Wiseman 2000a, §§ 5:27-5:34.

141 E.g. Globus v. Law Research Service, Inc., 418 F.2d 1276 (C.A.N.Y. 1969); deHaas v. Empire Petroleum Co., 435 F.2d 1223 (C.A.Colo. 1970).

142 Schlueter 2005a, p. 184.

143 Roginsky v. Richardson-Merrell, Inc., 254 F.Supp. 430 (D.C.N.Y. 1966)

144 Roginsky v. Richardson-Merrell, Inc. (appeal), 378 F.2d 832 (C.A.N.Y. 1967).

145 Roginsky v. Richardson-Merrell, Inc. (appeal), at § 839. 
The legal difficulties engendered by claims for punitive damages on the part of hundreds of plaintiffs are staggering. If all recovered punitive damages in the amount here awarded these would run into tens of millions, as contrasted with the maximum criminal penalty of 'imprisonment for not more than three years, or a fine of not more than $\$ 10,000$, or both such imprisonment and fine,' 21 U.S.C. $\S 333$ (b), for each violation of the Food, Drug and Cosmetic Act with intent to defraud or mislead. We have the gravest difficulty in perceiving how claims for punitive damages in such a multiplicity of actions throughout the nation can be so administered as to avoid overkill.

To conclude, there is no unanimity in American law on the desirability of awarding punitive damages in multiple plaintiff litigation. According to Kircher and Wiseman, there is no ideal solution for all the problems relating to multiple punitive damages awards against one defendant for a single egregious act. ${ }^{146}$ They suggest that to solve the problem, there should be legislative uniformity among the jurisdictions. This would be preferable over judicial action taking, as changes through the common law would simply take too long. Gash has put forward the practical solution of introducing a national punitive damages registry: a defendant who causes injury to multiple plaintiffs through a single act would under certain conditions be eligible to file a Prior Punitive Damages Statement. According to Gash, his proposal would fully resolve the multiple punishments problem and would advance the public policy on which the punitive damages theory is based. ${ }^{147}$

\subsection{Sharing or Split-Recovery of Punitive Damages Awards}

In some jurisdictions, the plaintiff will not be entitled to the entire punitive damages sum awarded. These jurisdictions have enacted statutes that require the plaintiff to share a part of the punitive damages award with the state treasury or a state or court-administered fund created to compensate victims. ${ }^{148}$ The rationale for such a measure is to minimise or prevent a so-called windfall for the plaintiff and to address the excessiveness problem of punitive damages awards. ${ }^{149}$ The states that have adopted split-recovery statutes include, for instance, Colorado, Florida, Georgia, Alaska, Illinois, Indiana, Iowa, Missouri, Oregon, New York, and Utah. ${ }^{150}$ An example of a split-recovery statute is $\S$ 668A.1(b) of the Iowa Code, ${ }^{151}$ which provides that if the defendant's willful and wanton misconduct is not directed specifically at the plaintiff, or at the person from which the plaintiff's claim is derived, the court should first order the payment of applicable costs and fees, after which $25 \%$ - which is a relatively small portion and therefore a rather strict rule - of the punitive damages award may be granted to the plaintiff and the remainder to a civil reparations trust fund of the state. ${ }^{152}$ The purpose of this provision has been defined in Varboncoeur v. State Farm Fire and Cas. Co.: ${ }^{153}$

146 Kircher \& Wiseman 2000a, p. 5-212.

147 Gash 2005, p. 1617-1618. See also Gash 2012.

14822 Am. Jur. 2d Damages § 586; Kircher \& Wiseman 2000b, p. 21-85; Klaben 1994, p. 106.

149 Klaben 1994, p. 157. On the windfall effect, see also section 4.3.2.3.

150 Kircher \& Wiseman 2000b, p. 21-85, 21-86.

151 Iowa Code, $\S 668$ A.1 on Punitive or Exemplary Damages.

152 See e.g. Fernandez v. Curley, 463 N.W.2d 5 (Iowa 1990).

153 Varboncoeur v. State Farm Fire and Cas. Co., 356 F.Supp.2d 935 (S.D.Iowa 2005), at § 950. 
The rationale underlying Iowa's punitive damage legislation is "that 'a plaintiff is a fortuitous beneficiary of a punitive damage award simply because there is no one else to receive it." Section 668A.1 "was designed to divert a portion of a resulting punitive damage award to a public purpose."

Larsen has annotated some cases in which American courts determined the validity, construction and application of split-recovery statutes. ${ }^{154}$ Her annotation does not include cases where judges independently allocate a percentage of the punitive damages award to a state fund or charity. ${ }^{155}$ This tells us that American courts apparently have also put split-recovery into practice in the absence of legislation. In fact, while split-recovery statutes are a rather modern phenomenon, already in 1877 the judiciary showed its preference for splitting punitive damages awards. ${ }^{156}$ However, at least one decision makes clear that in the absence of a statute, splitting punitive damages awards with a state treasury is not necessary for the prevention of windfalls. ${ }^{157}$ The introduction of split-recovery statutes has not been without a struggle; Larsen explains that the statutes have been challenged on constitutional grounds: ${ }^{158}$

These statutes have been challenged on various state and federal constitutional grounds as levying excessive fines, violating constitutional provisions against double jeopardy, denying the claimant due process and equal protection, and not affording the right to trial by jury.

Larsen also gives an overview of court decisions in which split-recovery statutes have been held valid, on the ground that the plaintiff did not have a constitutionally protected right to a punitive damages award or because allocation to a courtadministered fund did not constitute state action. ${ }^{159}$ An example cited is the case of Gordon v. State, in which the Supreme Court of Florida held that Florida Statute $\S 768.73(2)$ (Supplement 1986), on the basis of which $60 \%$ of a punitive damages award was allocated to the state, was constitutional. ${ }^{160}$ The court stated: ${ }^{161}$

We agree with the trial court that no substantive due process violation occurred. The statute under attack here bears a rational relationship to legitimate legislative objectives: to allot to the public weal a portion of damages designed to deter future harm to the public and to discourage punitive damage claims by making them less remunerative to the claimant and the claimant's attorney. We also have considered the other constitutional claims raised and suffice it to say that the statute does not violate the right to trial by jury, does not constitute a tax on judgments, does not deny equal protection and is not a special law.

154 Larsen 1993. On split-recovery statutes, see also Klaben 1994.

155 Larsen 1993, footnote 2.

156 Bass v. Chicago \& N.W. Ry. Co., 42 Wis. 654, 1877 WL 7100 (Wis. 1877), at $\S 6$.

157 Life Ins. Co. of Georgia v. Johnson, 701 So.2d 524 (Ala. 1997). See also 22 Am. Jur. 2d Damages $\S 586$.

158 Larsen 1993, § 1 .

159 Larsen 1993, \& 2, 3.

160 Gordon v. State, 608 So. 2d 800 (Fla. 1992). The statute provided that in case punitive damages were awarded for personal injury or wrongful death, the percentage should be paid to the Public Medical Assistance Trust Fund, and in other cases it should be paid to the General Revenue Fund: Gordon v. State, at $\$ 801$.

161 Gordon v. State, at $\S 802$ 
In contrast, other court decisions have overturned split-recovery statutes because punitive damages awards are seen as vested property affording the claimant a constitutionally protected right to keep the award. ${ }^{162}$ Furthermore, as regards the application of split-recovery statutes, the Oregon Supreme Court for example held that informing the jury about the allocation of a punitive damages award on the basis of Oregon Statute $\S 18.50$ (now Oregon Revised Statute $\S 31.735$ ) constituted a reversible error. ${ }^{163}$ The instruction distracts the jury from the appropriate line of analysis, i.e. furthering punishment and deterrence, which the jury should follow when awarding punitive damages. ${ }^{164}$

The U.S. Supreme Court has addressed the question whether the Excessive Fines Clause ${ }^{165}$ applies to a punitive damages award when a portion of the award is payable to a state entity. ${ }^{166}$ The Court held that despite the 'recognition of civil exemplary damages as punitive in nature, the Eighth Amendment did not expressly include it within its scope'. ${ }^{167}$ The specific question whether the clause applies when a private party brings a lawsuit in name of the state, which then shares in the punitive damages award, was left open by the court. ${ }^{168}$ If this question is answered affirmatively, each allocation of punitive damages to a state fund will be subject to the limitations that are imposed by the Excessive Fines Clause. ${ }^{169}$

Distribution of punitive damages awards to public funds receives special attention in the area of public health. According to Eggen: ${ }^{170}$

\begin{abstract}
Some states have enacted split-recovery statutes to direct a percentage of each punitive damages award to the state general treasury or a specific state fund. But from a public health standpoint, it would be sensible to require that the portion of the punitive award that the plaintiff does not receive be allocated to a state or private program that will enhance deterrence of the conduct that gave rise to the award in the particular case. States should explore an alternative to the plaintiff's windfall by enacting a split-recovery statute with a fixed percentage allocated to the plaintiff and authorizing the trial court to select a program related to the litigation and to the misconduct for which punitive damages are warranted to which the remaining percentage should go.
\end{abstract}

Eggen for instance refers to the example of a health insurer who mishandled a patient's request for a certain kind of chemotherapy which resulted in premature death, and the health insurer therefore had to pay $\$ 30$ million to a cancer research fund. ${ }^{171}$

162 E.g. Kirk v. Denver Pub. Co., 818 P.2d 262 (Colo. 1991): a statute requiring one-third of the punitive damages award to be paid to the state is considered an unconstitutional confiscation of private property without just compensation.

163 Honeywell v. Sterling Furniture Co., 310 Or. 206, 797 P.2d 1019 (Or. 1990).

164 Honeywell v. Sterling Furniture Co., at $\S 211$.

165 Eighth Amendment to the Constitution of the United States: 'Excessive bail shall not be required, nor excessive fines imposed, nor cruel and unusual punishments inflicted'. See section 4.4.3.

166 Browning-Ferris Industries of Vermont, Inc. v. Kelco Disposal, Inc., 492 U.S. 257, 109 S.Ct. 2909 (U.S.Vt. 1989).

167 Browning-Ferris, at $\S 274-275$.

168 Browning-Ferris, at $\S 276$.

169 Kircher \& Wiseman 2000b, p. 21-87.

170 Eggen 2011, p. 247.

171 Dardinger v. Anthem Blue Cross \& Blue Shield, 98 Ohio St.3d 77, 781 N.E.2d 121 (Ohio 2002). 
To conclude, the allocation of a portion of punitive damages awards to the state treasury, a state fund or charity is an accepted strategy in the United States that is supported by legislators and courts. Consequently, the plaintiff may not be the only beneficiary of a punitive damages award. This practice allegedly enhances the public purpose of punitive damages.

\subsubsection{Persons Liable}

For the reason that punitive damages are traditionally awarded to punish and deter the defendant, only the person who committed a wrong that justifies punitive damages is liable for such damages. ${ }^{172}$ Can someone else, other than the wrongdoer, be liable for punitive damages? Because of the rationale of punitive damages, it is in principle incorrect to award such damages against a person who is personally innocent. Thus, vicarious liability of one person to pay punitive damages for harm that is caused by another is limited. ${ }^{173}$ However, as will be shown in the next section, there is an important exception to this rule, namely liability by employers for acts of their employees under the doctrine of respondeat superior. ${ }^{174}$

\subsection{Vicarious Liability of the Employer}

Although a few courts have decided differently in the past, most courts nowadays hold that an employer who is liable for actual damage may also be liable for punitive damages. ${ }^{175}$ In any case, to hold the employer vicariously liable for punitive damages, the employee must have committed the acts in the line of his employment or in the scope of his authority. Furthermore, as a general rule, the employer will not be held liable for punitive damages where the employee would not be liable for punitive damages if the suit were brought directly against him. ${ }^{176}$ Schlueter points out that, apart from acting within the scope of the employment, appropriate conditions such as a malicious act of the employee must be present and that courts have followed this approach because holding the employer liable can deter such conduct and encourage employers to supervise their employees. ${ }^{177}$ Malicious conduct of the employee has however not been included as a separate requirement in the Restatement of Torts. The Restatement summarises the conditions for awarding punitive damages against an employer because of a wrongful act by an employee as follows: ${ }^{178}$

172 Schlueter 2005a, p. 192; 25 C.J.S. Damages $\S 209$

17325 C.J.S. Damages $\S 209$.

174 Kircher \& Wiseman 2000b, p. 24-2.

175 Schlueter 2005a, p. 193-194. See also Sturley 2010. For an extensive overview of the approach to vicarious liability for punitive damages see Kircher \& Wiseman 2000b, chapter eighteen.

17625 C.J.S. Damages $§ 212$.

177 Schlueter 2005a, p. 194.

178 Restatement of Torts, $\S 909$ (Punitive Damages Against A Principal). A nearly identical provision can be found in the Restatement (Second) of Agency 1957, § 217C. 
Punitive damages can properly be awarded against a master or other principal because of an act by an agent if, but only if:

(a) the principal authorized the doing and the manner of the act; or

(b) the agent was unfit and the principal was reckless in employing him; or

(c) the agent was employed in a managerial capacity and was acting in the scope of employment; or

(d) the principal or a managerial agent of the principal ratified or approved the act.

Thus, some fault of the employer is required: authorising the doing and the manner of the act, ratifying or approving the act, or recklessly employing an unfit employee. Furthermore, punitive damages can be awarded against an employer if the employee was employed in a managerial capacity and was acting within the scope of employment. This latter category, which is the key provision for vicarious liability, may for example form the basis for punitive damages in employment discrimination cases. ${ }^{179}$ Although both accidental and intentional conduct of an employee may fall within the scope of his employment, vicarious liability for punitive damages is restricted to tortious conduct that is considered as one of the normal risks of the employer; the employment must be the primary cause of the tort and so-called personal torts of the employee are thereby excluded. ${ }^{180}$ Consequently, the employer can probably not be held vicariously liable for many - but not all - intentional torts of the employee; one could in this respect try to hold the employer liable on the basis of one of the other categories such as reckless employment. Nevertheless, most punitive damages awards for which employers are held vicariously liable result from the employee's accidental conduct within the scope of employment.

The majority of jurisdictions have adopted one or more of the conditions formulated by the Restatement of Torts to hold an employer vicariously liable for punitive damages, ${ }^{181}$ whereas in other jurisdictions courts take a more liberal view in the sense that they do not require some fault of the employer but merely impose liability because the employee was acting within the scope of his employment. ${ }^{182}$

Note that in addition to liability of the employer for his employee, other forms of vicarious liability for punitive damages exist. The main example is the vicarious liability of governmental or public bodies for the acts of their agents. It is rather difficult to hold a public entity, such as a municipality, liable for punitive damages in the United States due to the generally accepted common law principle of governmental immunity. This principle is based on the historical concept that the King could do no wrong. Governmental immunity, which originally protects against governmental liability in most areas, applies to the federal, state and local government. ${ }^{183}$ For example, there is immunity for punitive damages under the Federal Tort Claims Act: ${ }^{184}$

179 Kircher \& Wiseman 2000b, p. 24-63; Sturley 2010, p. 515.

180 Sykes 1988 , p. 563, 583.

181 Kircher \& Wiseman 2000b, p. 24-5. E.g. David by Berkeley v. Pueblo Supermarket of St. Thomas, 740 F.2d 230 (C.A. Virgin Islands 1984).

182 E.g. City of Minneapolis v. Richardson, 307 Minn. 80, 239 N.W.2d 197 (MINN 1976).

183 Schlueter 2005a, p. 205; Kircher \& Wiseman 2000b, p. 24-42.

18428 USC $\S 2674$. 
The United States shall be liable, respecting the provisions of this title to tort claims, in the same manner and to the same extent as a private individual under like circumstances, but shall not be liable for interest prior to judgment or for punitive damages.

The majority of American courts indeed refuse to award punitive damages against public entities for public policy reasons. ${ }^{185}$ An important reason is that the punitive and deterrent functions of the award would not be justified against the public entity as taxpayers would bear the burden. ${ }^{186}$ However, it appears that the importance of the governmental immunity principle is decreasing as there are several exceptions to the general rule. ${ }^{187}$ First, punitive damages may be awarded to a public entity if authorised by statute. Furthermore, punitive damages have been allowed where the public entity ratified or authorised the wrongful act of its officer. ${ }^{188}$ Finally, exceptions have been made where the act of the public entity was considered intentional, willful, or raised the suggestion of actual malice. For example, punitive damages have been imposed on an officer who abused his powers and was guilty of oppression in the exercise of official duties. ${ }^{189}$

\subsection{Multiple Defendants}

Punitive damages are also available in actions against joint tortfeasors, meaning 'two or more persons who are liable to the same person for the same harm'. ${ }^{190}$ Similar to the issue of multiple plaintiffs, this topic is surrounded by controversy. Schlueter addresses the problems relating to the concepts of joint and several liability, contribution or indemnity, and apportionment of damages. ${ }^{191}$ In common law, punitive damages may only be awarded against those who have participated in, or contributed to, the act that justifies such damages. ${ }^{192}$ If a court holds separate tortfeasors jointly and severally liable for a wrong, punitive damages may be awarded against all of them. ${ }^{193}$ Depending on their culpability, joint tortfeasors are not necessarily liable for the same amount of punitive damages and the award may be apportioned between them. The different degrees of culpability among the tortfeasors must appear from the evidence. ${ }^{194}$ In the majority of jurisdictions, the trier of fact may award punitive damages against the defendant in different amounts. ${ }^{195}$ Punitive damages have also been awarded against one or more of the joint tortfeasors and not against the others. Some jurisdictions do not allow apportionment of punitive damages between tortfeasors, for the reason that they

185 For an overview of case law see Schlueter 2005a, p. 206, footnote 510

186 Schlueter 2005a, p. 199.

187 Schlueter 2005a, p. 207-208; Kircher \& Wiseman 2000b, p. 24-41.

188 Frick v. Abell, 602 P.2d 852 (Colo. 1979).

189 Runyon v. Superior Court, 187 Cal.App.3d 878 (Cal.App.4.Dist. 1986).

190 Schlueter 2005a, p. 200. See also 25 C.J.S. Damages $§ 210 ; 22$ Am. Jur. 2d Damages $\S 601$, 602, 603.

191 Schlueter 2005a, p. 200.

19225 C.J.S. Damages $\S 210$.

193 E.g. Transgo, Inc. v. Ajac Transmission Parts Corp., 768 F.2d 1001 (C.A.9 1985).

194 Schlueter 2005a, p. 203-204; 25 C.J.S. Damages § 210.

19522 Am. Jur. 2d § 601. 
are jointly and severally liable. ${ }^{196}$ For example, the Supreme Court of Kansas explained its decision not to apportion a punitive damages award among three tortfeasors with the following general rule: ${ }^{197}$

It is the generally recognized rule that there is no line of separation in the joint liability of joint tortfeasors; the tort is a thing integral and indivisible, and any claim for injuries arising therefrom runs through and embraces every part of the tort, so that the liability of one cannot be carried into any portion of the joint tort that is not followed by an equal liability of the other tortfeasors. Under this principle, either or any of the wrongdoers may be held liable for the whole of the damages resulting from their tortious acts.

To conclude, where punitive damages may be apportioned between the defendants, the so-called one-satisfaction rule does not apply. ${ }^{198}$ The rationale of this general tort rule is that a plaintiff receives no more than full compensation for his loss in case of equally liable defendants. It does not apply to punitive damages awards, as the primary purpose of such awards is not to compensate the plaintiff.

\subsection{Insurability}

This section gives attention to the important topic of punitive damages insurance, often brought forward as an argument against (the introduction of) punitive damages. It is instructive to consider the approaches to this issue taken by the various American states. ${ }^{199}$

The question whether insurance may cover liability for punitive damages is answered differently throughout the United States. The insurability of punitive damages in a particular state normally depends upon the importance that is attached to public policy considerations. ${ }^{200}$ Relevant points of public policy relate to the functions of punishment, deterrence and loss prevention, as well as economic concerns relating to the availability and costs of insurance. ${ }^{201}$ It is argued that the availability of insurance and the resulting loss spreading undermines the punitive and deterrent effect of punitive damages awards because the insurer instead of the wrongdoer pays the award; this problem is generally known as the so-called moral hazard. ${ }^{202}$ Punitive damages insurance is in that way contrary to good manners and violates public policy, which is the main argument against insurance. Another argument is that the economic impact of punitive damages insurance supposedly leads to increased costs for the insurance industry and for the public at large. ${ }^{203}$ The American insurance market has addressed this

19622 Am. Jur. 2d Damages § 602.

197 Sieben v. Sieben, 231 Kan. 372, 646 P.2d 1036 (Kan. 1982), at 378.

19822 Am. Jur. 2d Damages $\S 603$.

199 See generally Schlueter 2005b, chapter seventeen; Blatt, Hammesfahr \& Nugent 2008, chapter four; Kircher \& Wiseman 2000a, chapter seven; Schirmeister 1996, p. 162-167.

200 Blatt, Hammesfahr \& Nugent 2008, p. 197.

201 Blatt, Hammesfahr \& Nugent 2008, p. 197-198; Kircher \& Wiseman 2000a, p. 7-42.

202 See on this topic e.g. Priest 1989, p. 1029; Shavell 1979, p. 541.

203 Ellis 1982, p. 71; Chapman \& Trebilcock 1989, p. 821; Blatt, Hammesfahr \& Nugent 2008, p. 199. 
problem to a certain extent, in the sense that some insurers nowadays explicitly exclude - in full or in part - coverage for punitive damages liability. ${ }^{204}$ Insurers may for instance refuse coverage of punitive damages awarded as a result of intentional or calculative wrongdoing. Note that the prohibition of insurability of intentionally caused damage is also current practice in other modern legal systems, such as the Netherlands; in 1975 the Dutch Supreme Court decided that to allow liability insurance in this situation would violate good manners and public policy. $^{205}$

As explained in section 3.2.2, the popular punitive damages categories in American law, i.e. intentional torts, defamation and financial torts, also cover intentional or calculative wrongdoing; therefore, for insurers to allow coverage of punitive damages awards that fall within these popular categories would probably be costly. Thus, even though punitive damages insurance is accepted in a certain state, insurers may simply avoid payouts for punitive damages by excluding coverage. This started in the late 1970s, when insurers no longer wanted to pay for punitive damages whenever bodily injury had occurred. Until then, punitive damages had been included in insurance policies as 'all sums which the Insured shall become legally obligated to pay as damages because of bodily injury'. ${ }^{206}$ Then again, in order to protect insureds, an important public policy consideration is that insurers should in principle cover everything they do not explicitly exclude. As mentioned above, from the 1980s on, insurance companies started to exclude punitive damages explicitly, in which case public policy issues did not come into play. ${ }^{207}$ Another solution to the problem of increased costs is that insurers nowadays have the possibility of reinsurance, i.e. the "contractual indemnity that an insurer or reinsurer obtains, in whole or in part, from another company, which is a reinsurer'. 208

On the other hand, those in favour of punitive damages insurance see no harm in it, especially as insurance facilitates that the plaintiff who is entitled to punitive damages receives his money. The idea is that 'if victims and injurers are rendered better off by insurance, there is no need for the law to prohibit it'. ${ }^{209}$ Indeed, research from 2008 shows that the majority of American states that have dealt with this topic allow the insurability of some form of punitive damages. ${ }^{210}$ In this regard, an important distinction is made between punitive damages that are assessed directly against the insured, and punitive damages that are assessed vicariously against the assured. ${ }^{211}$ In the latter situation, the assured is held liable

204 Owen 2005, p. 1183; Schlueter 2005b, p. 21.

205 HR 30 mei 1975, NJ 1976/572, m.nt. B. Wachter.

206 Schlueter 2005b, p. 17. See also Kircher \& Wiseman 2000a, p. 7-4

207 Schlueter 2005b, p. 17, 21.

208 Blatt, Hammesfahr \& Nugent 2008, p. 220

209 Cooter 1982, p. 96

210 Blatt, Hammesfahr \& Nugent 2008, p. 200. See also Priest 1989, p. 1009. For an overview of jurisdictions that permit insurability of punitive damages, see Blatt, Hammesfahr \& Nugent 2008, p. 202; Kircher \& Wiseman 2000a, p. 7-149 to 7-166.

211 Blatt, Hammesfahr \& Nugent 2008, p. 200. 
for the wrongful conduct of another person, for example an employee. Most states, thirty-six in total, permit the insurability of vicariously assessed punitive damages, whereas twelve states leave the issue undecided. This means that in only two states vicariously assessed punitive damages are not insurable. A plausible explanation for this result is that there is no real need to prohibit vicariously assessed punitive damages as public policy considerations, especially those relating to ineffective deterrence, play a lesser role in this category than in that of directly assessed punitive damages. In contrast, the insurability of directly assessed punitive damages is - indeed - prohibited in twenty states, because the effect of a punitive damages award on the wrongdoer is almost zero if paid by an insurer. ${ }^{212}$ Insurance coverage of directly assessed punitive damages is permitted in twenty-five states; five states leave the issue undecided. ${ }^{213}$ Thus, in comparison to vicariously assessed punitive damages, insurance of directly assessed punitive damages is problematic: this form of insurance is not allowed in almost half of the American states.

Priest calls the divergence in the United States in respect of punitive damages insurance confusing. ${ }^{214}$ Blatt et al. however give a clear overview in which three approaches as regards insurability of punitive damages in the United States are distinguished. $^{215}$ Firstly, in the majority approach both directly and vicariously assessed punitive damages are insurable. The majority rule that punitive damages are insurable is clearly stated in Lazenby v. Universal Underwriters Ins. Co., a decision of the Supreme Court of Tennessee. ${ }^{216}$ Although this decision dates back to 1964 , it is still frequently cited. The Lazenby case concerns a car accident that was caused by an intoxicated driver. Punitive damages were awarded directly against the driver, who was insured. Subsequently, the court determined that Tennessee law permits punitive damages to be insurable under an automobile liability insurance policy. ${ }^{217}$ Secondly, the minority approach prohibits the insurability of punitive damages in whole or part. ${ }^{218}$ In 1962, the Court of Appeals for the Fifth Circuit determined in Northwestern National Casualty Co. v. McNulty ${ }^{219}$

212 Note that although both insurance and vicarious liability may take away the direct deterrent effect of punitive damages, indirect deterrence of wrongdoers may still occur due to sanctions imposed by the insurer on its insured and by the employer on its employees. See in this regard section 4.3.2.4.

213 Blatt, Hammesfahr \& Nugent 2008, p. 202.

214 Priest 1989, p. 1009.

215 Blatt, Hammesfahr \& Nugent 2008, p. 204-209.

216 Lazenby v. Universal Underwriters Ins. Co., 18 McCanless 639, 214 Tenn. 639, 383 S.W.2d 1 (Tenn. 1964).

217 The court interpreted the insurance contract between the company and the insured to include coverage for punitive damages: 'The language in the insurance policy in the case at bar, which is similar to many types of liability policies, has been construed by most courts, as a matter of interpretation of the language of a policy, to cover both compensatory and punitive damages. Since most courts have so construed this language in the policy, we think the average policy holder reading this language would expect to be protected against all claims, not intentionally inflicted'. See Lazenby v. Universal Underwriters Ins. Co., at § 5. See also Belli 1980, p. 15.

218 Blatt, Hammesfahr \& Nugent 2008, p. 206.

219 Northwestern Nat. Cas. Co. v. McNulty, 307 F.2d 432 (C.A.Fla. 1962). 
that public policy does not permit a liability insurer to pay the punitive damages award that was imposed against its insureds. ${ }^{220}$ Again, the case concerned a car accident that was caused by an insured intoxicated driver. The court determined as follows: ${ }^{221}$

Where a person is able to insure himself against punishment he gains a freedom of misconduct inconsistent with the establishment of sanctions against such misconduct. It is not disputed that insurance against criminal fines or penalties would be void as violative of public policy. The same public policy should invalidate any contract of insurance against the civil punishment that punitive damages represent.

Thirdly, of the states that prohibit the insurability of directly assessed punitive damages, ten states permit vicariously assessed punitive damages. ${ }^{222}$ This is the so-called hybrid approach. Despite the controversy that has always surrounded the issue, figures show that in the past years, both the availability of insurance for directly assessed punitive damages and for vicariously assessed punitive damages has grown. ${ }^{223}$

To give a better insight into the issue of insurance, based on the substantial body of case law on the matter, Widiss has outlined a number of conditions that are essential to consider in determining whether an insurance contract covers punitive damages awarded to a plaintiff by the insured. ${ }^{224}$ For example, if coverage of the insured's intentional tortious conduct is excluded by an explicit provision in the insurance policy or an implied exception that has been recognised by the courts, coverage for punitive damages awarded as a consequence of such acts is of course not within the scope of the protection afforded by liability insurance. ${ }^{225}$ Furthermore, as mentioned above, some insurers include explicit clauses in their policy for liability insurance stating that no coverage exists for punitive damages, and courts have sustained the enforceability of such provisions. ${ }^{226}$ Another condition is that there may be legislative and judicial restrictions on coverage for punitive damages. In his article, Widiss gives clear comments on these and other conditions as well as on judicial and legislative responses to disputes arising from the insurability of punitive damages.

To conclude, with regard to the European punitive damages debate, the decision whether or not to insure punitive damages will mainly be in the hands of insurers. The above shows that opinions on this matter differ throughout the United States on the basis of public policy, the type of defendant (direct or vicarious), and the type of tort (intentional or accidental). It may very well be that insurers in continental Europe also decide to refuse coverage of punitive damages if the civil remedy is

220 Schlueter 2005b, p. 22; Priest 1989, p. 1012; Belli 1980, p. 14

221 Northwestern Nat. Cas. Co. v. McNulty, at $\S 440$.

222 Blatt, Hammesfahr \& Nugent 2008, p. 208.

223 Blatt, Hammesfahr \& Nugent 2008, p. 210

224 Widiss 1994, p. 459-460. See on the debate over punitive damages insurance also: Sharkey 2005; Long 1977; Kip Viscusi \& Born 2005; Priest 1989.

225 Widiss 1994, p. 459, 462-463.

226 Widiss 1994, p. 464. 
introduced there - for example because this takes away the deterrent effect of the award or because the damages have been awarded as a result of intentional or calculative wrongdoing - which would be an understandable outcome.

\subsection{Concluding Remarks}

With regard to the liability criteria for punitive damages it was shown that the foundational requirement for a punitive damages award is the invasion of a legally protected interest. In theory, punitive damages are recoverable only for tort actions. In fact, punitive damages are available in an extensive number of actions based upon tortious behaviour, provided that the required aggravating circumstances are present. The mere fact that the defendant committed an unlawful act is not a sufficient basis for a punitive damages award. The act complained of must not only be unlawful, but it must also involve a certain element of major aggravation. Furthermore, the plaintiff must in principle have suffered actual damage in order to obtain punitive damages and must produce sufficient evidence in this regard. The rationale of this requirement is that conduct that caused no measurable objective injury should not be punished, which goes hand in hand with the principle that private individuals should not be encouraged to start litigation if they have suffered no injury. However, as explained in section 3.2.4, the majority of jurisdictions hold that a nominal damages award is a sufficient basis for punitive damages, because the purpose of the latter award is to punish and deter wrongdoers.

A final interesting point concerns the types of cases in which punitive damages are mostly awarded. Contrary to popular belief, punitive damages awards are in fact relatively rare in cases about personal injury resulting from negligence, automobile accidents, medical malpractice, and products liability. Punitive damages are mostly awarded for intentional torts, such as battery and assault, and in cases concerning defamation. Furthermore, punitive damages relatively often are awarded in cases concerning the so-called financial torts, for instance fraud, bad faith insurance, employment, discrimination, real property, and consumer sales. As was seen in section 3.2.2, a plausible explanation for this result is the element of major aggravation that is required to award punitive damages. This aggravating element is probably more often present in case of intentional torts, defamation or financial torts than in personal injury cases resulting from negligence, automobile accidents, medical malpractice, and products liability. In view of the main focus of this book, this means that punitive damages could especially be useful in continental Europe to deal with the categories of wrongdoing that are known in American law as intentional tort, defamation and financial tort.

As regards the assessment and amount of punitive damages, punitive damages issues are normally decided by both trial court and jury. The court determines issues of law, whereas the jury determines issues of fact. In its role as gatekeeper, the court must decide whether the question of punitive damages may be submitted to the trier of fact. The trier of fact is normally the jury, but it can also be the court sitting without a jury. The trier of fact is not obliged to award punitive damages, 
even if the evidence and pleadings justify doing so or the defendants' acts are sufficiently outrageous. It is generally argued that the size and amount of punitive damages will be smaller if such claims are decided by judges instead of jurors. Jury punitive damages awards are criticised because juries are believed to be more biased, irrational and emotionally in support of the plaintiff than judges. Empirical research into the decision-making of judges and jurors shows that this assertion is not necessarily correct.

In assessing the amount of the punitive damages award, the trier of fact can consider the character of the defendant's act, the nature and extent of the harm to the plaintiff that the defendant caused or intended to cause, and the financial condition of the defendant. Draconian punitive damages awards are generally not allowed. We have seen in section 3.3.2 above, for example, that a study on punitive damages awards in large counties in 2001 revealed that the median punitive damages awarded by juries amounted to $\$ 50,000$, whereas courts awarded $\$ 46,000$. Of the 260 jury trials in which a plaintiff winner obtained punitive damages, $14 \%$ resulted in punitive damages awards of $\$ 1$ million or more. Punitive damages of $\$ 1$ million or more were awarded in $2 \%$ of the 79 court trials with punitive damages. More information on the alleged excessiveness of American punitive damages awards will be provided in section 4.2.2.

The generally accepted rule is that the punitive damages award should be reasonable and should not go beyond what is necessary to achieve its goals. There must be a reasonable relation to the harm done to the plaintiff and to the potential harm. Furthermore, according to some courts the reasonable ratio rule applies, meaning that there must be a reasonable relation to the amount of compensatory damages awarded. The fact that a defendant gained money from his wrongful act can also influence the size of the punitive damages award. However, due to the mainly non-compensatory purpose of punitive damages, other courts have decided that a relationship between punitive and compensatory damages is not required. Note that, as will be explained in section 4.4.4, the U.S. Supreme Court does consider the ratio between the punitive and compensatory award a relevant factor that should be used by trial and appellate courts in evaluating whether a punitive damages award is unconstitutionally excessive.

Another important research result that can be derived from this chapter is that the double jeopardy rule, known as the ne bis in idem principle in civil law systems, does not have much practical value in relation to punitive damages awards in the United States, whereas it is often heard as an argument against the introduction of punitive damages in continental Europe. As explained in section 3.3.4, the general rule in most American jurisdictions is that a criminal conviction does not bar the imposition of punitive damages on the defendant for the same act in a civil lawsuit and that a punitive damages award is not considered a double jeopardy. The rationale for this general rule is that the civil sanction is primarily imposed for the wrong done to the individual plaintiff, whereas the criminal sanction is imposed for the wrong done to society. Moreover, this general rule allows the punitive damages remedy to function as a supplement to criminal law sanctions. As mentioned 
above, the explicit use of the word supplement suggests that the two forms of sanctioning should be geared to one another to prevent excessive punishment.

Furthermore, we have seen in this chapter that in principle only the injured person, that is the immediate person receiving the injury, is entitled to recover punitive damages. The American legal system is familiar with the phenomenon of multiple plaintiffs or, when the claims are consolidated into a single litigation, plaintiffs who seek punitive damages in a class action. Multiple plaintiff litigation is considered a rather problematic area of American punitive damages law. A policy problem relates to the undesired result of 'over-punishment', but opinions on this view differ. Another policy problem relates to multiple punitive damages awards that are in excess of any criminal penalty imposed for the same conduct.

In some jurisdictions, the plaintiff will not be entitled to the entire punitive damages sum awarded. These jurisdictions have enacted statutes that require the plaintiff to share a part of the award with the state treasury or a state or courtadministered fund created to compensate victims. The rationale that state legislators have for such a measure is to minimise or prevent a so-called windfall for the plaintiff and to address the excessiveness problem of punitive damages awards. The vicarious liability of one person to pay punitive damages for harm that is caused by another is limited by the common law. There is an important exception to this rule, namely liability by employers for acts of their employees under the doctrine of respondeat superior.

As regards the insurability of punitive damages, the question whether insurance should cover liability for punitive damages is answered differently throughout the United States. Insurability of punitive damages normally depends upon the importance attached to public policy considerations, the type of defendant (direct or vicarious) and the type of tort (intentional or accidental). Relevant points of public policy relate to the functions of punishment, deterrence and loss-prevention, as well as economic concerns relating to the availability and costs of insurance. The distinction between punitive damages that are assessed directly against the insured and punitive damages that are assessed vicariously against the assured is important. Most American states permit the insurability of vicariously assessed punitive damages; only two states prohibit this form of punitive damages. In contrast, the insurability of directly assessed punitive damages is prohibited in twenty states, because the effect of a punitive damages award on the wrongdoer is almost zero if paid by an insurer. Thus, in comparison to vicariously assessed punitive damages, insurance of directly assessed punitive damages is problematic. Despite the controversy that has always surrounded the issue, statistics show that, in the past years, the availability of insurance for both directly and vicariously assessed punitive damages has grown in the United States. Insurers in continental Europe might decide to refuse coverage of punitive damages if the civil remedy is introduced there, for example because this takes away the deterrent effect of the award or because the damages have been awarded as a result of intentional or calculative wrongdoing. 
This chapter dealt with the questions when and how punitive damages are awarded in the American legal system. The concrete examples given should improve the European perception of the civil remedy, and this will advance participation in the European punitive damages debate in a fair manner. The next chapter explores the acceptance and control of punitive damages in the American legal system further. 



\section{CHAPTER FOUR}

\section{ACCEPTANCE AND CONTROL OF PUNITIVE DAMAGES IN THE AMERICAN LEGAL SYSTEM}

\subsection{Introductory Remarks}

The previous chapters have explored the question why, when and how punitive damages are awarded. This chapter goes further into one important aspect of that theme, i.e. the acceptance and control of punitive damages in the American legal system. Given the often heard allegations concerning the excessiveness of punitive damages awards in the United States, section 4.2 will be devoted to the acceptance and application of punitive damages. As already mentioned in chapter one, many outsiders have a rather negative judgment of the American use of this civil remedy. With regard to the European punitive damages debate, this seems to be one of the reasons that the introduction of punitive damages is considered undesirable. What prevails is fear of an excessive use of civil litigation leading to a compensation culture, fear of exorbitant civil damages, fear that civil judges will act in the criminal sphere and so on. One could define this attitude as fear of the unknown, whereas we all know that fear is a bad adviser. It is at least conspicuous that when such claims are made, they are hardly ever accompanied by facts and figures. The negative perception of American punitive damages law could very well be based on preconceived ideas and lack of information. American legal scholars have done quite some (empirical) research into the acceptance of punitive damages. The next section gives an impression of the research results that have followed therefrom. The information provided should help to put the negative perception of punitive damages into perspective.

The purpose of this chapter is - however - not to waive aside all criticism relating to the punitive damages doctrine. As has been made clear in the previous chapters, in the American legal system the punitive damages remedy is also considered controversial. The main points of critique will be summarised in section 4.3. This is valuable information that draws our attention to a number of problems that Americans (have) encounter(ed) in respect of the punitive damages doctrine. Should punitive damages one day become part of the existing array of civil sanctions in continental European legal systems, it is of course best to be able to anticipate such problems.

Lastly, although prevention is indeed better than cure, it is also interesting to look into the American methods of dealing with problems and obstacles relating to punitive damages. Section 4.4 therefore deals with legislative and judicial control of improper punitive damages awards in the United States. Sections 4.3 and 4.4 provide interesting information with regard to the problem statement of this book - i.e. does the punitive damages remedy have a future in continental 
Europe? - and the related lessons and caveats that should be kept in mind by European punitive damages supporters and policymakers.

\subsection{Acceptance and Application of Punitive Damages}

American punitive damages law has developed for over two centuries. Punitive damages are currently available in almost every state but, as has been made clear in the foregoing chapters, there is variety among the states in respect of the circumstances under which such damages may be awarded. As a result, an attempt to generalise the use and regulation of punitive damages in the United States beyond some basic observations is a risky business. For example, the degree of wrongfulness of conduct that is required for punitive damages to be awarded varies per state. ${ }^{1}$ For the purposes of this introduction into American punitive damages law, it would be undoable to give an extensive overview of the law in each separate jurisdiction of the United States. It would also be unnecessary, because the purpose of this study is to provide a general overview regarding the acceptance and application of punitive damages in the United States.

\subsubsection{Acceptance in Forty-Five States}

To what extent are punitive damages actually available in the American legal system? Five jurisdictions within the United States prohibit punitive damages for all civil lawsuits, namely Louisiana, ${ }^{2}$ Massachusetts, Nebraska, New Hampshire, and Washington. ${ }^{3}$ Courts in these states have traditionally been critical of punitive damages, meaning that such damages are not allowed unless specifically authorised by statute. ${ }^{4}$ This means that the remaining forty-five states allow punitive damages to a certain extent. The punitive damages remedy is legalised partly by the judiciary and partly by the legislator: legal bases for punitive damages can be found in statutes, ${ }^{5}$ but American punitive damages law is still common law for the most part. $^{6}$ Furthermore, although punitive damages are available under both federal and state statutes, punitive damages law is primarily state law.

1 Von Mehren \& Murray 2007, p. 179. The authors also refer to variations in respect of 'the permissible size of an award in the context of the nature of the wrongdoing or the net worth of the defendant, and the rigorousness of appellate review of punitive damages awards'.

2 Louisiana is especially interesting in respect of punitive damages and conflicts of law, also for participants in the European punitive damages debate, as this is the only jurisdiction in the United States with a civil law tradition. See Janke \& Licari 2013.

3 Kircher \& Wiseman 2000a, p. 4-8 to 4-17; Owen 2005, p. 1123; Schlueter 2005a, p. 29. Schlueter cites only four states and does not mention New Hampshire. Another source also refers to only four states that do not permit punitive damages: Michigan, Nebraska, New Hampshire, and Washington, see Blatt, Hammesfahr \& Nugent 2008, p. 90.

4 Owen 2005, p. 1123; Schlueter 2005a, p. 29.

5 Owen 2005, p. 1122. For an overview of statutory law, see Owen 2005, p. 1122, footnote 19; Owen 1976, p. 1264, footnote 17.

$622 \mathrm{Am}$. Jur. $2 \mathrm{~d}$ Damages $\S 540$. If used in this sense, 'the common law' refers to a general system of law deriving exclusively from court decisions, see Martin 2003, p. 94. 
Some states have statutes providing for punitive damages, ${ }^{7}$ for example California, ${ }^{8}$ Nevada ${ }^{9}$ and South Dakota. ${ }^{10}$ Apart from general statutory provisions on punitive damages, a collection of statutes provides for punitive damages in specific situations. Such specific statutes may be adopted at the federal ${ }^{11}$ or state level. ${ }^{12}$ Punitive damages are provided for not only under state statutory law but also under state constitutional law, for example the Texas constitution. ${ }^{13}$ Furthermore, several state constitutions prohibit limitations of damages awards in cases of death or personal injury. ${ }^{14}$

\subsubsection{Application: Is Excessiveness the Key Word?}

As will be further explained in section 4.3 below, American punitive damages awards are controversial. Opponents of the civil remedy for example argue that punitive damages have 'run wild'. ${ }^{15}$ In three cases of the U.S. Supreme Court concerning punitive damages, Justice O'Connor emphasised that the frequency and amount of punitive damages awards have been 'skyrocketing'. ${ }^{16}$ Justice O'Connor in Browning-Ferris Industries of Vermont, Inc. v. Kelco Disposal, Inc.: ${ }^{17}$

Awards of punitive damages are skyrocketing. As recently as a decade ago, the largest award of punitive damages affirmed by an appellate court in a products liability case was $\$ 250,000$. Since then, awards more than 30 times as high have been sustained on appeal. The threat of such enormous awards has a detrimental effect on the research and development of new products. Some

7 Mostly Western states, as their legal systems are highly codified, including California, Montana, Nevada, North Dakota, Oklahoma, and South Dakota. See Owen 2005, p. 1122.

$8 \quad$ Cal Civ Code $\S 3294$.

$9 \quad$ Nev Rev Stat Ann $\S 42.005$.

10 S D Codified Laws $\S 21-3-2$

11 For example 15 USC $\$ 15$ a which provides for treble damages in cases of antitrust violations, and 15 USC $\S 1681 \mathrm{n}$ which provides for punitive damages in case of willful violations of consumer credit reporting law. For an overview of federal statutes expressly providing punitive damages, see Schlueter 2005b, chapter twenty-one, part I.

12 For example Cal Civ Code $\S 3340$ : 'for wrongful injuries to animals being subjects of property, committed willfully or by gross negligence, in disregard of humanity, exemplary damages may be given'.

13 Tex Const article $16 \S 26$ : 'Every person, corporation, or company, that may commit a homicide, through willful act, or omission, or gross neglect, shall be responsible, in exemplary damages, to the surviving husband, widow, heirs of his or her body, or such of them as there may be, without regard to any criminal proceeding that may or may not be had in relation to the homicide'.

14 Ariz Const article $2 \S 31$ : 'No law shall be enacted in this state limiting the amount of damages to be recovered for causing the death or injury of any person'. Cf. Ky Const $\S 54$; Wyo Const article $10 \S 4$.

15 Pacific Mut. Life Ins. Co. v. Haslip, 499 U.S. 1, 111 S.Ct. 1032 (U.S.Ala. 1991), at $§ 18$.

16 Browning-Ferris Industries of Vermont, Inc. v. Kelco Disposal, Inc., 492 U.S. 257, 109 S.Ct. 2909 (U.S.Vt. 1989); Pacific Mut. Life Ins. Co. v. Haslip, 499 U.S. 1, 111 S.Ct. 1032 (U.S.Ala. 1991); TXO Production Corp. v. Alliance Resources Corp., 509 U.S. 443, 113 S.Ct. 2711 (U.S.W.Va. 1993). Justice O'Connor's criticism has been criticised on several grounds, see Hubbard 2008, p. 395.

17 Browning-Ferris, at $\S 282$. 
manufacturers of prescription drugs, for example, have decided that it is better to avoid uncertain liability than to introduce a new pill or vaccine into the market. Similarly, designers of airplanes and motor vehicles have been forced to abandon new projects for fear of lawsuits that can often lead to awards of punitive damages. The trend toward multimillion dollar awards of punitive damages is exemplified by this case.

But opponents who criticise the incidence and size of punitive damages awards seem to take it too far. Schoenbrod et al. make clear that there is limited empirical evidence of the growth of punitive damages and mainly point out research that proves the contrary. ${ }^{18}$ Although no information is available with regard to all punitive damages verdicts in the United States, from the 1960s onwards several empirical studies ${ }^{19}$ have indeed concluded that punitive damages awards are uncommon. ${ }^{20}$ Rustad, for example, has analysed nine relevant empirical studies. On the basis of this research, he has made clear that, according to all nine studies, punitive damages verdicts are in fact rare..$^{21}$ According to Sebok, six major studies reviewing punitive damages verdicts from 1985 onwards disclose that punitive damages have been awarded in 2 to $9 \%$ of all cases that were won by the plaintiff. He also remarks that, with regard to the size of the awards, the median for punitive damages awards was between $\$ 38,000$ and $\$ 52,000$ per award. ${ }^{22}$ Furthermore, Yeazell observes that a close correlation between the amount of compensatory and punitive damages has been found, which implies that punitive damages are not as unpredictable as often believed. ${ }^{23}$

The Bureau of Justice Statistics of the U.S. Department of Justice has also made a valuable contribution to awareness about the application of punitive damages awards. Since 1995, this bureau has published civil justice surveys of state courts in the seventy-five most populous counties in the United States. Three of these reports, published in 2005, 2009 and 2011, have already been cited in section 3.2.2; the most popular punitive damages categories can be reviewed in that section. At this point, information on the frequency and amount of punitive damages awards in general will be provided. These figures fit into the general theme of this chapter, i.e. acceptance and control of punitive damages.

The 2005 report, containing data from 2001, reveals that in that year no more than $356(6 \%)$ of the 6,504 state court civil trials that were won by the plaintiff resulted in punitive damages. ${ }^{24}$ In half of the 356 trials, plaintiffs obtained a

18 Schoenbrod et al. 1996, p. 454. See for empirical data from those in favour of punitive damages reform Stocker 2003, p. 156-159.

19 For empirical data, see for example Blatt, Hammesfahr \& Nugent 2008, p. 13-25; Eisenberg et al. 2002; Eisenberg et al. 2006; Eisenberg et al. 2010; Cohen 2005; Cohen \& Harbacek 2011; Langton $\&$ Cohen 2008. See also, for an overview of empirical studies, Robbennolt 2002a, p. 160, footnote 262; Sebok 2007, p. 964, footnote 19.

20 Rubin \& Shepherd 2008, p. 598; Rustad 1998, p. 54; Hubbard 2008, p. 361; Eisenberg 1997, p. 633; Sebok 2007, p. 964-965; Daniels \& Martin 1990, p. 43; Vidmar \& Holman 2010, p. 856. Rustad 1998, p. 17, 54.

Sebok 2007, p. 964, 970.

Yeazell 2008, p. 273.

24 Cohen 2005, p. 1. The number 356 is composed of 217 tort trials, 138 contract trials, and 1 real property trial; see Cohen 2005 , p. 4 , table 2 . 
punitive damages award of $\$ 50,000$ or more. In $41(12 \%)$ of the trials resulting in punitive damages, damages that equaled or surpassed $\$ 1$ million were awarded, and in $9(3 \%)$ trials punitive damages of $\$ 10$ million or more were awarded. The report estimates the median for punitive damages for the tort cases at $\$ 25,000$ and for the contract cases at $\$ 83,000 .^{25}$ According to the 2009 report concerning state court tort trials in 2005, punitive damages were awarded in $254(3 \%)$ of the 8,763 tort trials with plaintiff winners; the median punitive damages award in these cases was $\$ 55,000 .^{26}$ A more recent report of 2011 reveals that in 2005 punitive damages were sought in $12 \%$ of the approximately 25,000 tort and contract cases that were concluded in state courts. ${ }^{27}$ Punitive damages were awarded in $700(5 \%)$ of the 14,359 cases that were won by the plaintiff. The following table shows that the median award for these 700 cases was $\$ 64,000$, whereas in $13 \%$ of the 700 cases punitive damages of $\$ 1$ million or more were awarded. ${ }^{28}$ Furthermore, the median award was again higher in contract cases than in tort cases:

Punitive damage award amounts in civil trials in state courts, by case type, 2005

\begin{tabular}{lccccccc} 
& & & \multicolumn{4}{c}{ Percentage of trials with punitive damage awards } \\
\cline { 3 - 7 } Case type & $\begin{array}{l}\text { Number } \\
\text { of trials }\end{array}$ & $\begin{array}{l}\text { Median } \\
\text { punitive award }\end{array}$ & $\begin{array}{l}\text { Under } \\
\mathbf{\$ 1 0 , 0 0 0}\end{array}$ & $\begin{array}{l}\mathbf{\$ 1 0 , 0 0 0}- \\
\mathbf{\$ 4 9 , 9 9 9}\end{array}$ & $\begin{array}{l}\mathbf{\$ 5 0 , 0 0 0}- \\
\mathbf{\$ 2 4 9 , 9 9 9}\end{array}$ & $\begin{array}{l}\mathbf{\$ 2 5 0 , 0 0 0 -} \\
\mathbf{\$ 9 9 9 , 9 9 9}\end{array}$ & $\begin{array}{l}\mathbf{\$ 1} \text { million } \\
\text { or more }\end{array}$ \\
\hline All cases & 700 & $\$ 64,000$ & $15 \%$ & $27 \%$ & $28 \%$ & $16 \%$ & $13 \%$ \\
Tort & 254 & 55,000 & 23 & 18 & 35 & 7 & 17 \\
Contract & 446 & 69,000 & 10 & 33 & 25 & 22 & 11 \\
\hline
\end{tabular}

Note: The 700 trials with punitive damages includes trials in which punitive damages were not formally requested. In some instances, statutory rules allow jury or judge to consider awarding punitive damages in cases where no formal request was made. Medians calculated from only cases in which punitive damages were awarded. Detail may not sum to total due to rounding.

This table makes clear that relatively substantial awards do exist but also that high amounts are not as often awarded as the public generally believes. ${ }^{29}$ Other interesting statistics that follow from the 2005 report relate to the ratio of punitive damages to compensatory damages. In 632 of the 700 cases, both punitive and compensatory damages were awarded. This means that in 68 cases, punitive damages were awarded in the absence of compensatory damages. ${ }^{30}$ In $76 \%$ of the 632 cases, the ratio of the punitive award to the compensatory award was 3 to 1 or less: ${ }^{31}$

25 Cohen 2005, p. 1.

Cohen 2009, p. 6.

Cohen \& Harbacek 2011, p. 1

Cohen \& Harbacek 2011, p. 5, table 8.

9 See also Yeazell 2008, p. 273.

30 Cf. section 3.2.4 and 3.3.3. These numbers confirm that, despite the generally accepted requirement of actual damages, American courts may also award punitive damages in the absence of compensatory damages.

31 Cohen \& Harbacek 2011, p. 5, table 9. 


\section{Ratio of punitive to compensatory damage awards in civil trials in state courts, 2005}

\begin{tabular}{lcrc} 
Punitive to compensatory & $\begin{array}{l}\text { Number } \\
\text { owards ratio }\end{array}$ & \multicolumn{2}{c}{ Median damage awards } \\
\cline { 3 - 4 } \multicolumn{1}{c}{ All civil trials } & 632 & Punitive & Compensatory \\
1-to-1 ratio or less & 280 & $\$ 76,000$ & $\$ 58,000$ \\
$>$ 1-to-1 ratio and $\leq$ 3-to-1 ratio & 200 & 100,000 & 76,000 \\
$>$ 3-to-1 ratio & 151 & 352,000 & 22,000 \\
\hline
\end{tabular}

Note: The number of trials with punitive and compensatory awards (632) will not equal the total number with punitive damages (700). There were 68 trials with punitive damages in which no compensatory damages were awarded. Medians calculated from only those cases in which both punitive and compensatory damages were awarded. Detail may not sum to total due to rounding.

These three reports may not be exhaustive for the overall application of punitive damages in the United States, as research has only been done into the seventy-five most populous counties, but they do give an interesting view on the matter. Gottlieb, who wrote the Center for Justice and Democracy White Paper mentioned in chapter two, subscribes to the results of the reports by making clear that punitive damages are, among other things, rarely sought, rarely awarded, and modest in amount. ${ }^{32}$ Robbennolt concludes her analysis of several empirical studies as follows: ${ }^{33}$

These studies have common findings: although there are variations across geographical area and type of case, punitive damages are not often awarded, are rarely extreme in size, are awarded in response to egregious conduct, and are not often collected in the amounts awarded by juries.

Given the figures in this section, the conclusion that both the frequency and amount of punitive damages awards are not 'skyrocketing' nor 'out of control' can be considered a plausible one. This is an important research result in light of the often heard negative perception of American punitive damages law which is allegedly surrounded by excessiveness.

\subsubsection{American Punitive Damages Awards are not Extreme nor Common}

The word excessiveness does not apply to the bulk of punitive damages awards. Exceptions do of course exist. Notorious 'blockbuster punitive damages awards' have been reported more than once; examples are the awards granted in the cases of Pennzoil Co. v. Texaco, Inc. (\$ 3 billion) and more recently Exxon Shipping Co. v. Baker (\$ 2.5 billion) as well as Cynthia Robinson v. R.J. Reynolds Tobacco Co.

32 Gottlieb 2011, p. 9-10. See section 2.2.2.

33 Robbennolt 2002a, p. 160-161. 
(\$ 23.6 billion). ${ }^{34}$ The largest punitive damages award in American history amounts $\$ 145$ billion, which was awarded to a class of plaintiffs in a procedure against a tobacco producer. ${ }^{35}$ One can quite easily see that these blockbuster awards are granted against wealthy and powerful business defendants rather than the 'common' individual defendants.

What causes the popular belief that American punitive damages awards are extreme and common? It is difficult to give a crystal-clear answer to this question, also because of the lack of 'complete' information. Nevertheless, as mentioned earlier, a number of authors equally point into the direction of misunderstandings and half-truths caused by, for example, the media. It is indeed striking that punitive damages are especially rare in legal fields that receive most public attention: products liability and medical malpractice cases in particular and personal injury cases in general. ${ }^{36}$ It is true that from the 1970 s punitive damages awards in these legal fields have increased in number and size and have reached fairly large amounts. ${ }^{37}$ However, misunderstandings as regards the real size and frequency of such awards do exist and are allegedly caused by the fact that the extreme cases are highly publicised in national and international media. ${ }^{38}$ Perhaps even more important in this respect: the media are not always right. ${ }^{39}$ A good example is illustrated by the McDonald's case introduced in the beginning of chapter two. ${ }^{40}$ But it is possibly not only the media that causes half-truths about punitive damages. Some say that the misinformation is also caused by reform groups such as the American Tort Reform Association (ATRA), already referred to in chapter two, which demolishes punitive damages on its website by characterising the remedy as excessive and arbitrary. ${ }^{41}$ ATRA expresses the problem on punitive damages as follows: ${ }^{42}$

While punitive damages awards are infrequent, their frequency and size have grown greatly in recent years. More importantly, they are routinely asked for today in civil lawsuits. The difficulty of predicting whether punitive damages will be awarded by a jury in any particular case, and the marked trend toward astronomically large amounts when they are awarded, have seriously distorted settlement and litigation processes and have led to wildly inconsistent outcomes in similar cases.

34 Blatt, Hammesfahr \& Nugent 2008, p. 13-14, citing Pennzoil Co. v. Texaco, Inc., 481 U.S. 1, 107 S. Ct. 1519 (U.S.N.Y. 1987); Exxon Shipping Co. v. Baker, 554 U.S. 471, 128 S.Ct. 2605 (U.S. 2008); Cynthia Robinson v. R.J. Reynolds Tobacco Co., 2008 CA 000098 (Fla. 2014). See for an overview of blockbuster punitive damages awards Del Rossi \& Kip Viscusi 2009, p. 35-38; Kip Viscusi \& McMichael 2013.

35 Engle v. R.J. Reynolds, 122 F.Supp.2d 1355 (S.D.Fla., 2000). See on this case Finch 2002.

36 Cohen 2005, p. 3; Eisenberg 1997, p. 633; Galanter \& Luban 1993, p. 1412. See also section 3.2.2. 7 Owen 2005, p. $1125,1129$.

38 Haltom \& McCann 2004, p. 174; Robbennolt 2002a, p. 159; Ryan 2003, p. 70; Schirmeister 1996, p. 2; Sebok 2007, p. 962; Centner 2008, p. 4, 22.

39 This has also been observed by Dutch authors, e.g. Keirse 2007, at 3.2 .

40 Liebeck v. McDonald's Restaurants, P.T.S., Inc., 1995 WL 360309 (N.M. Dist. 1994).

41 Eisenberg, Heise \& Wells 2010, p. 5, citing the ATRA website.

42 Retrieved via: www.atra.org/issues/punitive-damages-reform. 
ATRA's approach is criticised by Eisenberg, who asserts that ATRA does not rely on the available academic sources on punitive damages awards and states that it is now generally accepted that the mass of punitive damages awards have been reasonably sober, modest in size, and without significant increases over time'. ${ }^{43}$ According to Galanter, a lot of civil litigation horror stories that are emphasised by tort reformers are 'exaggerated or outright fabrications'. 44 Renowned by now are the so-called urban legends concerning American tort cases that are rife but unreal, for example the case concerning the pet in the microwave. ${ }^{45}$ Another practice in the United States that, according to some, causes misinformation is that of corporations or conservative think tanks that fund anti-punitive damages research by academics for the purpose of persuading courts not to award such damages. ${ }^{46}$ An example that - apparently - really happened is that of corporation Exxon. ${ }^{47}$ Exxon contacted a sociology professor when it faced a law procedure due to the oil spill by supertanker Exon Valdez off the coast of Alaska. As mentioned above, this procedure finally resulted in one of the largest punitive damages sums ever awarded. ${ }^{48}$ The professor, Freudenburg, was confronted by a caller who asked him to publish an article about what punitive damages do to society and thereby proposed the following: ${ }^{49}$

"Then, in the corporation's appeal, we can cite the article, and note that professor so-and-so has said in this academic journal, preferably a quite prestigious one, that punitive awards don't make much sense".

This professor did not comply with the request of the unsolicited caller, but imagine the error and confusion that can be caused by those who do cooperate. Rustad has called attention to the practice of anti-punitive damages research: ${ }^{50}$

Despite the unanimity of the social scientists, tort reformers and much of the business community continue to argue that there is a punitive damages crisis. Punitive damages is the BosniaHerzegovina of American legal remedies. The schism over punitive damages lines up both for and against the contention that the crisis is creating a crisis for American businesses. The dispute has resulted in dueling punitive damages studies. Tort reform lobbyists and lawyers have produced their own studies to change the opinion of judges and the general public about punitive damages.

He summarised and criticises three studies that were conducted by defendants of the largest punitive damages awards: Texaco, Exxon and Honda. ${ }^{51}$ Barday

44

45 (Ryanter 1998 b, p. 726.

45 Ryan 2003, p. 72-74; Klik 1989, p. 13

46 Barday 2008, p. 712

7 Eisenberg, Heise \& Wells 2010, p. 6; Eisenberg \& Heise 2011, p. 326

48 Exxon Shipping Co. v. Baker, 554 U.S. 471, 128 S.Ct. 2605 (U.S. 2008). See on this case section 4.4.4.3 below.

49 Barday 2008, p. 712

50 Rustad 1998, p. 56.

51 Rustad 1998, p. 57-65 
observed that even the U.S. Supreme Court took notice of and declines to rely on such funded studies: ${ }^{52}$

The Court is aware of a body of literature running parallel to anecdotal reports, examining the predictability of punitive awards by conducting numerous "mock juries," where different "jurors" are confronted with the same hypothetical case. Because this research was funded in part by Exxon, we decline to rely on it.

To conclude, although uncertainty and lack of clarity with regard to the entirety of American punitive damages verdicts will remain as long as there is no information available to that extent, it is safe to state that the general criticism relating to the frequency and amount of punitive damages awards is exaggerated. Misunderstandings and misleading information brought forward by media and anti-punitive damages lobbyists contribute to the negative image of the frequency and amount of American punitive damages awards.

\subsection{Critique}

\subsubsection{Civil Punishment? A Controversial Issue, Also in the American Legal System}

It would surprise me if any informative written piece on American punitive damages law, whether the author is American or not, ignores the fact that the civil remedy is controversial. Even in the legal system where the remedy is accepted, punitive damages are criticised. Criticism of punitive damages seems to be as old as the civil remedy itself, which follows for example from a decision involving punitive damages of the New Hampshire Supreme Court in $1872:^{53}$

The idea is wrong. It is a monstrous heresy. It is an unsightly and unhealthy excrescence, deforming the symmetry of the body of the law.

The primary point of critique in the United States and in the rest of the world is that punitive damages interfere with the division between criminal law and tort law or, more generally, public law and private law. ${ }^{54}$ Opponents of punitive damages consider civil punishment a 'contradiction in terms'. ${ }^{55}$ Although the availability of punitive damages might lead to a different conclusion, the public-private divide did influence American legal culture. ${ }^{56}$ This may be traced back to the liberal

52 Barday 2008, p. 712, footnote 3, citing Exxon Shipping Co. v. Baker, 554 U.S. 471, 128 S.Ct. 2605 (U.S. 2008), at $\S 2626$, footnote 17. The Court cites the following studies: Sunstein et al. 2002; Schkade, Sunstein \& Kahneman 2000; Hastie, Schkade \& Payne 1999 (for a critical examination of these authors' work see Vidmar 1999); Sunstein, Kahneman \& Schkade 1998.

53 Fay v. Parker, 53 N.H. 342, 1872 WL 4394 (N.H. 1872), at $\S 382$.

54 Owen 2005, p. 1177, providing an overview of often encountered criticism of punitive damages.

55 Rendleman 2009, p. 2. See also Schlueter 2005a, p. 30.

56 Horwitz 1992, p. 206-208. 
democratic foundation of the country that, as has been described in chapter two, attaches great value to individual freedom and personal autonomy. ${ }^{57}$ Theories of liberal democracy suggest that the goals of democracy can only be reached when individuals are encouraged and empowered to protect their own personal interests. $^{58}$ The division between public law and private law has been created to prevent that individuals are generally subjected to the restrictions that are imposed on state actors. ${ }^{59}$

Our society draws a fundamental distinction between public and private authority to assure that the private autonomy so essential to attainment of the goals of liberal democratic theory is not undermined by subjecting it to the constitutional and political structures to which the state, in the exercise of public power, is subjected.

In the United States (and elsewhere), private law was not primarily developed to regulate individual behaviour, but rather to create legal areas within which individuals can pursue their own individual goals without interference by the state and others. Public law, on the other hand, was traditionally created with the aim of policing behaviour to the extent of protecting individual rights. Subsequently, tort law was defined as private law, whereas criminal law was defined as public law. Although the public-private divide is no longer as strict as it once was, especially in comparison to civil law countries as will be shown in section 6.3 , it is still seen as one of the foundations of the American legal system. ${ }^{60}$ The Maine Supreme Court decided in the earlier mentioned case Tuttle v. Raymond that the division is neither clear nor strict. ${ }^{61}$ Rendleman stated about the court's reasoning in this case that: ${ }^{62}$

Civil courts and the civil law play a role in defining and punishing defendants' misconduct. Some things, the court continued, are wrong but not crimes. Some crimes are not prosecuted. Some criminal statutes are not enforced. Some criminal penalties are too low to deter a miscreant's breaches. Thus, the Maine court held, courts' administration of common law punitive damages plays an important role in maintaining social order.

This is in line with the idea that punitive damages are originally meant to supplement the criminal law. ${ }^{63}$ Rendleman refers to the inadequate protection of society by criminal law sanctions and the failure of the public prosecutor to act against all crimes. Not everyone agrees with the supplementary function that punitive damages could play in this regard. It is suggested that if criminal law is indeed ineffective, this should not be remedied by imposing civil punishment but rather by improving criminal justice. ${ }^{64}$ Note that this argument is also brought

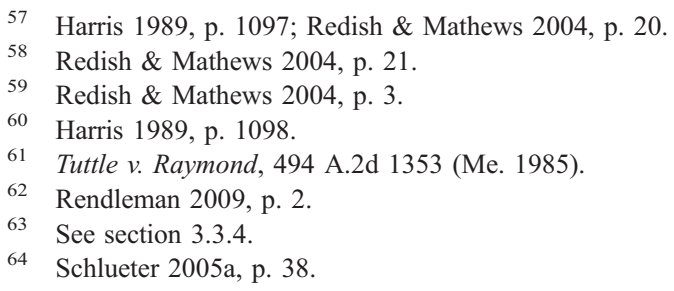


forward in the European punitive damages debate, for example by Koziol who is not in favour of introducing punitive damages in continental Europe and by Dijkshoorn who is critical of private enforcement via tort law, specifically punitive damages and class actions, and suggests that law enforcement deficiencies should be solved via public law mechanisms. ${ }^{65}$

Overall, it cannot be neglected that the availability of punitive damages in the United States is inconsistent with the classical liberal theory and weakens the public-private divide. Horwitz makes clear that punitive damages have formed a threat to the public-private divide from the 1850s onwards. ${ }^{66}$ According to Eggen, the punitive damages doctrine falls 'at the intersection of public and private law', and the public-private divide is 'a more accurate reflection of the goals and purposes of punitive damages than the older criminal-civil hybrid' ${ }^{67}$ As we know by now, rather than simply compensating harm, punitive damages primarily attempt to punish and regulate behaviour. ${ }^{68}$ Although these objectives are more closely connected to the public law domain than to the private law domain, punitive damages are available in private law. How is this justified? Along with the purposes of punitive damages explained in chapter two, the following important observations can be made here in order to answer this question. It is argued that punitive damages are justified for the mere reason that public enforcement power is vested in the hands of private litigants who function as private attorneys general. ${ }^{69}$ Furthermore, it has been suggested that punitive damages are an effective way of setting an example for the public. ${ }^{70}$ From this point of view, punitive damages law protects both private and public interests. Yet, these justifications do not seem to ease the minds of those critical of interfering with the public-private divide by means of awarding punitive damages.

\subsubsection{Further Points of Criticism}

\subsubsection{Civil Punishment: Lack of Criminal Procedural Safeguards}

The previous section makes clear that opponents of punitive damages primarily disagree with punitive damages because they interfere with the public-private divide. Punitive damages have the nature of a civil penalty and are awarded without criminal procedural safeguards. The lack of safeguards such as the principle of legality, the requirement of proof beyond a reasonable doubt, as well as protection against self-incrimination and double jeopardy is disapproved of by punitive damages opponents. ${ }^{71}$ Those in favour of punitive damages do not

65 Koziol 2012, p. 54; Dijkshoorn 2012, p. 3020-3021. See on this topic also Kortmann 2009, p. 20; Hartlief 2009b, p. 1553; Hartlief 2009d, p. 577; Giesen 2009, p. 309; Van Boom 2006a, p. 40; Bolt \& Lensing 1993, p. 83.

66 Horwitz 1992, p. 113-115.

67 Eggen 2011, p. 224.

68 Harris 1989, p. 1097.

69 Redish \& Mathews 2004, p. 21. See section 2.2.2.2.

70 Harris 1989, p. 1102.

71 Rendleman 2009, p. 2. 
seem to agree with this argument. The Supreme Court of Maine referred to above has put it as follows: ${ }^{72}$

Furthermore, the lack of certain procedural safeguards, which are required in criminal prosecutions, does not render the civil law unfit to serve this deterrent function. The statute books provide many examples where penalties, in the form of multiple damages payable to a private party, are imposed in civil actions for the purpose of discouraging undesirable conduct. The absence of these procedural safeguards presents no constitutional bar to the imposition of punitive damages in a civil action. The reason for requiring such safeguards in the criminal arena, the threat to the defendant of incarceration or other substantial stigma, does not justify their application in actions for punitive damages.

Can a civil court adequately protect the defendant in a punitive damages lawsuit? It probably differs per person whether the available protection is considered adequate, but arguments in support of an affirmative answer can be given. For example, most states require clear and convincing evidence for punitive damages to be awarded. Furthermore, the defendant is entitled to the privilege of protection against selfincrimination and the defendant who is also charged with a crime is usually protected from self-incrimination by a stay (or: suspension) of the civil procedure, which obliges the claimant to wait until the criminal proceedings are closed. ${ }^{73}$

Although - as explained in section 3.3.4 - the general rule is that a criminal conviction does not bar the imposition of punitive damages and a punitive damages award is not considered a double jeopardy, the public-private divide and the lack of criminal procedural safeguards is still the main reason why courts, critical of punitive damages, proclaim that punitive damages are not favoured in the $l a w{ }^{74}$ The encyclopedia American Jurisprudence reads as follows: ${ }^{75}$

Punitive damages are not favored because of their penal nature. Consequently, they are to be awarded with caution and within narrow or normal limits. Described as an 'extraordinary sanction', punitive damages are proper only in the most exceptional or extreme cases or cases involving the most egregious conduct.

Indeed, legislators and courts have shown endless concern about the power to grant punitive damages. As a result, they have generally taken the position that punitive damages should be awarded 'with great caution': punitive damages can be awarded, but this has to be done carefully and within certain limits so that the award is reasonable and not excessively punitive on the defendant. ${ }^{76}$ For example, in Alexander v. Meduna the Supreme Court of Wyoming emphasised that 'punitive damages are not favoured and are to be allowed cautiously within narrow limits'. ${ }^{77}$

72 Tuttle v. Raymond, at $\S 1356-1357$. See also Adar 2012, p. 338, who subscribes to the idea that there is a difference between criminal and civil punishment, and that a punitive damages verdict is far less stigmatising than a criminal conviction.

73 Rendleman 2009, p. 3. See also Mallor \& Roberts 1999, p. 1006.

74 Owen 2005, p. 1125; Schlueter 2005a, p. 27.

7522 Am. Jur. 2d Damages § 546. See also e.g. McKinnon v. Kwong Wah Restaurant, 83 F.3d 498 (C.A.1 (Me.) 1996).

76 Schlueter 2005a, p. 27.

77 Alexander v. Meduna, 47 P.3d 206 (Wyo. 2002), at $\$ 218$. 
In United States v. Halper, the U.S. Supreme Court held that a defendant who has already been punished in a criminal prosecution may not be subjected to an additional civil sanction that is disproportionate to the damage caused, as this would violate the double jeopardy principle laid down in the Fifth Amendment. ${ }^{78}$ However, although this reflects the general idea that largely disproportionate punitive damages awards should be prevented, this decision was overruled by the U.S. Supreme Court in Hudson v. United States. ${ }^{79}$ The Court decided in this case that the double jeopardy principle - indeed - cannot be invoked to prevent imposition of any additional civil sanction, as this principle only protects against the imposition of multiple criminal punishments for the same offence that occur in successive proceedings.

Punitive damages are also disapproved of for other reasons, of which the following are most often encountered.

\subsubsection{Vagueness of Liability Standards Leads to Unpredictable and Excessive Awards}

Firstly, it is argued that the vagueness and diversity of liability standards in punitive damages law deprive judges and juries of reliable methods to decide whether punitive damages should be awarded. ${ }^{80}$ In particular the characterisations of misbehaviour, such as 'malicious' or 'outrageous' behaviour, are considered imprecise and therefore problematic. ${ }^{81}$ Critics suggest that the vagueness of the law leaves room for juries to be 'arbitrary, capricious, biased in favour of plaintiffs, overgenerous, and unprincipled' when awarding punitive damages. ${ }^{82}$ In this way, imprecise rules are developed and the law becomes 'unstable and unpredictable, undermining people's ability to plan and predict'. ${ }^{83}$ In contrast, unpredictability of criminal fines is usually prevented because the amount of such fines is established by statute. ${ }^{84}$ Unpredictable and excessive punitive damages awards are seen as harmful for society. ${ }^{85}$ As we have seen in section 4.2.2 above, according to former Supreme Court Justice O'Conner, an example of an undesired result of excessive punitive damages awards is that manufacturers may be discouraged from developing new products. Critics also mention the problem of variance in the amount of punitive damages. ${ }^{86}$ Firstly, a punitive damages award might bear no resemblance to the criminal fine that can be imposed for similar misconduct. In this regard, Kircher and Wiseman cite the appeal decision of Roginsky v. Richardson-Merrell, Inc., in which the court noted that the maximum criminal fine which could be imposed against the defendant was $\$ 10,000$, whereas the plaintiff obtained

United States v. Halper, 490 U.S. 435, 109 S.Ct. 1892 (U.S.N.Y. 1989).

Hudson v. United States, 522 U.S. 93, 118 S.Ct. 488 (U.S.Okl. 1997).

Owen 2005, p. 1185.

Rendleman 2009, p. 5.

Robbennolt 2002a, p. 105.

Rendleman 2009, p. 6.

Schlueter 2005a, p. 32

Owen 1994, p. 396.

Schlueter 2005a, p. 32. 
$\$ 100,000$ in punitive damages. ${ }^{87}$ Secondly, there is no guarantee that punitive damages awarded in the same jurisdiction in two comparable cases will bear any resemblance to one another. This however does not fit with the earlier described image that the majority of punitive damages awards are not excessive. It is therefore debatable whether this is realistic and reasonable criticism.

To conclude, some say that not the weakness but the strength of punitive damages lies in their unpredictability: ${ }^{88}$

If a punitive damages award can be known with certainty in advance of the conduct, the very sort of callousness that is to be corrected by a punitive award would be facilitated; the defendant would be able to calculate his maximum exposure to liability and determine whether to disregard the interests of the plaintiff.

\subsubsection{The 'Windfall-Effect' of Punitive Damages}

Secondly, it is often asserted that punitive damages provide a windfall for the plaintiff. The original meaning of a windfall is a fruit that is blown off a tree, or a financial bonus such as an inheritance. In a technical sense, every damages award that exceeds what is necessary to compensate the plaintiff and, in the case of punitive damages, also to punish and deter the defendant can be considered an unjustified windfall. In practice, the term is used by critics to express their disapproval of punitive damages. ${ }^{89}$ The windfall effect of punitive damages is for example illustrated by a decision of the Wisconsin Supreme Court: ${ }^{90}$

It is difficult on principle to understand why, when the sufferer by a tort has been fully compensated for his suffering, he should recover anything more. And it is equally difficult to understand why, if the tortfeasor is to be punished by exemplary damages, they should go to the compensated sufferer, and not to the public in whose behalf he is punished.

Schlueter also argues that the civil fine is imposed in the form of a criminal fine, while the latter fine normally goes to the state and not to the plaintiff. $^{91}$ As explained in section 3.3.5.1.2 of the previous chapter, some American states have adopted so-called split-recovery statutes that oblige a plaintiff who obtains punitive damages to share a portion of the award with the state treasury or a special fund to minimise the windfall effect. Courts have generally upheld such statutes. ${ }^{92}$ The rationale of this measure is to minimise a windfall for the plaintiff and to address the excessiveness problem of punitive damages awards. Thus, it is unlikely

87 Kircher \& Wiseman 2000a, p. 2-30, citing Roginsky v. Richardson-Merrell, Inc. (appeal), 378 F.2d 832 (C.A.N.Y. 1967), at $\S 839$. See on this case also section 3.3.5.1.1.

88 Mallor \& Roberts 1999, p. 1003. See also Rustad \& Koenig 1993, p. 1277.

89 Schlueter 2005a, p. 33; Rendleman 2009, p. 6; 22 Am. Jur. 2d Damages $§ 545$.

90 Bass v. Chicago \& N.W. Ry. Co., 42 Wis. 654, 1877 WL 7100 (Wis. 1877), at $\S 6$.

91 Schlueter 2005a, p. 32

92 E.g. Evans ex rel. Kutch v. State, 56 P.3d 1046 (Alaska 2002); Gordon v. State, 608 So.2d 800 (Fla. 1992); Ford v. Uniroval Goodrich Tire Co., 267 Ga. 226, 476 S.E.2d 565 (Ga. 1996); Cheatham v. Pohle, 789 N.E.2d 467 (Ind. 2003); Fust v. Attorney General for the State of Mo., 947 S.W.2d 424 (Mo. 1997); DeMendoza v. Huffman, 334 Or. 425, 51 P.3d 1232 (Or. 2002). See also 22 Am. Jur. 2d Damages $\S 586$. 
that courts will use the existence of split-recovery statutes as a justification to award higher punitive damages sums.

It is doubtful whether the windfall effect is as problematic as often asserted. Several safeguards to confine windfalls exist, such as the prerequisite of actual damage and the requirement - in some jurisdictions - of a reasonable relation to the amount of compensatory damages awarded. ${ }^{93}$

Furthermore, it is debatable whether the windfall effect is actually wrong, or whether it is a necessity in relation to the many purposes of punitive damages. ${ }^{94}$ In addition to the punishment and deterrence of the defendant, the punitive damages award has other functions: preserving the peace, law enforcement, compensating victims for otherwise non-compensable losses such as pain and suffering or emotional distress, and paying the plaintiff's legal fees. These functions, which are of course relevant from the victim's perspective and might justify a windfall for that reason, are also important in view of the public interest. As the system gratefully relies on victims to serve the common good, it should not criticise that a windfall falls into the hands of the victim. In other words, the advantages of the punitive damages award outweigh any disadvantages that follow from the windfall.

\subsubsection{Ineffective Deterrence?}

The third point of critique is that it is uncertain whether the deterrent function of punitive damages is really effective. ${ }^{95}$ Kircher and Wiseman note the fact that they found no empirical research about the issue whether punitive damages play an important role in the deterrence of antisocial conduct, and therefore they analyse this critique from the standpoint of common sense. ${ }^{96}$ The main argument in this category is that the misdirection of punitive damages undermines the punishing and deterrent effect of punitive damages. ${ }^{97}$ According to critics, misdirection may for instance occur in situations where liability for punitive damages is insured or where not the employee but the employer is held vicariously liable. However, while insurance and vicarious liability may take away the direct deterrent effect of punitive damages, indirect deterrence of wrongdoers may still occur. The liability insurer will probably impose sanctions on its insured, such as increases of the insurance premium or cancellation of insurance coverage, whereas the employer could take disciplinary measures to supervise his employees more effectively. ${ }^{98}$

Furthermore, punitive damages may not have a deterrent effect similar to criminal fines, because punitive damages are not known to individuals in the same manner as criminal sanctions are. ${ }^{99}$ According to Kircher and Wiseman: ${ }^{100}$

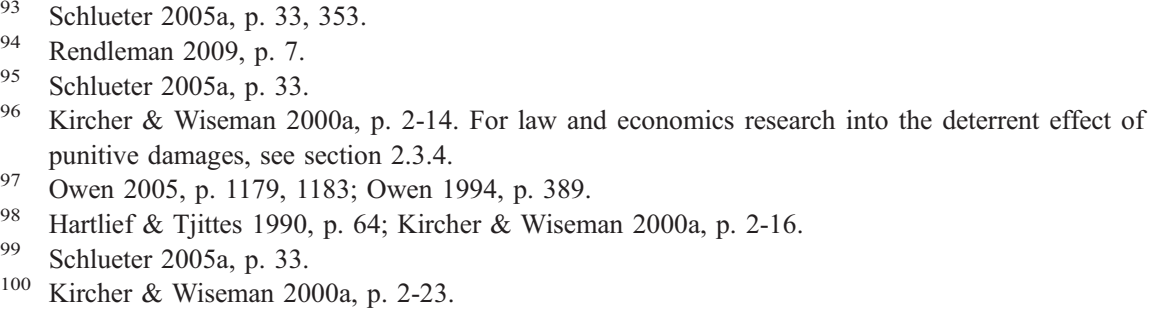


Do members of the general public receive the same deterrent message from the civil law's use of punitive damages as they do from the operation of the criminal law? It is highly unlikely that this is the case.

And: ${ }^{101}$

It is highly unlikely that a person who never served on a jury in a civil case involving punitive damages, or who was never a litigant in such as case, would know when his conduct may be such as to warrant the imposition of punitive damages. It is much more likely that the average person's conduct would be restrained because of his own moral code, or the fear of criminal prosecution, than it would because of the potential of punitive damages.

Then again, the authors also make clear that punitive damages send a deterrent message to 'the more sophisticated members of the public', such as manufacturers, insurers and employers. ${ }^{102}$ It is likely that these parties will, as stated above, indirectly influence others in society.

Another argument is that ineffective deterrence or under-punishment of business defendants follows from the fact that these defendants might profit from lenient tax legislation as they are allowed to deduct the award for tax purposes. ${ }^{103}$ Finally, deterrence may be ineffective because civil law already has an adequate instrument to deter continued wrongdoing of the defendant, namely injunctive relief. ${ }^{104}$

\subsubsection{Relation to Litigation Costs}

The last argument that is often brought forward by critics is that punitive damages should not be used to offset the plaintiff's litigation costs. ${ }^{105}$ Due to the American rule explained in section 2.2.3.4, the parties in a civil lawsuit have to pay for their own litigation costs. However, as mentioned earlier, it is generally accepted that the plaintiff's litigation costs are considered an element of the punitive damages award. Reimbursing the plaintiff's litigation costs is a function of punitive damages. The idea behind this general rule is that the plaintiff should not bear the costs of bringing a wrongdoer to court, costs which he would never have made had it not been for the grave infringement of his rights. ${ }^{106}$ Not all American states allow litigation costs to be considered in awarding punitive damages, as this would compensate the plaintiff rather than punish the defendant. ${ }^{107}$ Critics suggest that it is unfair to limit the offset of litigation costs only to cases in which the plaintiff obtains punitive damages. The idea is that if litigation costs are to be reimbursed, they should be recovered by all successful plaintiffs and not only by those who obtain a punitive damages award. ${ }^{108}$

101 Kircher \& Wiseman 2000a, p. 2-24.

102 Kircher \& Wiseman 2000a, p. 2-24.

103 Polsky \& Markel 2010, p. 1359; Gottlieb 2011, p. 12.

104 Schlueter 2005a, p. 33-34

105 Kircher \& Wiseman 2000a, p. 2-27; Schlueter 2005a, p. 34.

106 Schlueter 2005a, p. 34-35.

107 Schlueter 2005a, p. 36.

108 Kircher \& Wiseman 2000a, p. 2-27; Schlueter 2005a, p. 37. 
Having provided an overview of the acceptance and application of punitive damages as well as critique of the civil remedy in the United States, the next section will explore existing mechanisms in American law to control punitive damages awards.

\subsection{Legislative and Judicial Control of Improper Punitive Damages Awards}

In the aftermath of the so-called punitive damages crisis, as referred to by Rustad in section 4.2.2.1 above, American punitive damages law has been affected by two important developments. ${ }^{109}$ Firstly, the law has been subjected to legislative reforms to put an end to excessive and improper awards. Secondly, punitive damages awards are controlled by judicial review. Judicial review of punitive damages is a topic of much debate, particularly since the tort law reform movement that even attracted the attention of the U.S. Supreme Court. From the late 1980s, the Court has analysed the constitutionality of punitive damages in a number of decisions that give a warning to courts to review punitive damages awards thoroughly. ${ }^{110}$ These two developments are driven by the notion that punitive damages are 'out of control', by which critics usually mean that there has been an increase in the frequency, size and unpredictability of awards. ${ }^{111}$

\subsubsection{Statutory and Common Law Control}

In the past years, there has been a trend towards the reform of American punitive damages law. These reforms have been initiated by state legislators and courts and are part of the general tort reform movement in the United States. ${ }^{112}$ An attempt of the federal legislator to pass the so-called Fairness in Punitive Damage Awards Act (S. $1554,105^{\text {th }}$ Congress) failed in $1997 .{ }^{113}$ Several state legislators have already enacted, or have under consideration, a number of measures to control and limit the imposition of improper punitive damages awards. ${ }^{114}$ The most important measures will be discussed in this section.

One of the first general reform measures that has been taken by legislators and courts relates to the clarification of vague standards in punitive damages law. As explained in the previous section, this is an important point of critique of punitive damages. Several states have, for example, specified standards relating to measurement, liability, and misconduct to prevent inappropriate awards. ${ }^{115}$

109 Mallor \& Roberts 1999, p. 1002.

110 Schlueter 2005a, p. 346.

111 Sebok 2007, p. 962; Ellis 1982, p. 55; Cooter 1989, p. 1145; Robbennolt 2002a, p. 159.

112 Owen 2005, p. 1200. See, for an overview of state tort reforms in the United States between 1980 and 2012, Avraham 2014.

113 Dawkins 2008, p. 84. See, for the text of the Act, www.govtrack.us/congress/bills/105/s1554/text.

114 Mallor \& Roberts 1999, p. 1006; McKown 1995, p. 436. For examples of statutes see $B M W$ of North America, Inc. v. Gore, 517 U.S. 559, 116 S.Ct. 1589 (U.S.Ala. 1996), at § 615-616.

115 Owen 2005, p. 1201. 
Another important measure is the statutory cap on awards to prevent excessive punitive damages. ${ }^{116}$ For example, in Colorado the maximum punitive damages award cannot exceed the amount of compensatory damages. ${ }^{117}$ Connecticut caps punitive damages in products liability cases at twice the amount of compensatory damages. ${ }^{118}$ In North Dakota, punitive damages awards may not exceed two times the compensatory damages award, or a maximum of $\$ 250,000$. $\$ 32-03.2-11$ (4) of the North Dakota Century Code reads as follows: ${ }^{119}$

If the trier of fact determines that exemplary damages are to be awarded, the amount of exemplary damages may not exceed two times the amount of compensatory damages or two hundred fifty thousand dollars, whichever is greater; provided, however, that no award of exemplary damages may be made if the claimant is not entitled to compensatory damages. In a jury trial, the jury may not be informed of the limit on damages contained in this subsection. Any jury award in excess of this limit must be reduced by the court.

In Kansas, the maximum amount may not exceed the defendant's annual gross income, or $\$ 5$ million. ${ }^{120}$ These are only a few examples of several states that limit punitive damages awards, generally ranging from $\$ 50,000$ to $\$ 5$ million. $^{121}$ Interestingly, the tort reform movement also inspired legislators to adopt caps for compensatory damages. ${ }^{122}$ This development is primarily supported by the medical community.

Furthermore, state legislators have enacted statutes permitting the payment of (part of) the award to the state or state agencies instead of to the plaintiff. See in this regard also section 3.3.5.1.2. The proportion of the award to be paid to the state ranges from 35 to $100 \%$. It is argued that this reform measure diminishes the windfall effect of punitive damages, reduces the incentive for plaintiffs to file a claim for punitive damages and contributes to the prevention of excessive awards. ${ }^{123}$ Arizona law, for instance, instructs courts to allocate punitive damages to a victims' fund in certain circumstances. ${ }^{124}$ Subject to statutory exceptions, $75 \%$ of punitive damages awarded in Indiana are paid to a compensation fund for victims of violent crimes. ${ }^{125}$ Kansas apportions $50 \%$ of punitive damages in

116 See Klick \& Sharkey 2009. In another article, these authors are critical of punitive damage caps: 'Using data from the National Center for State Courts, we show, in various specifications, that compensatory awards are higher when states cap punitive damage awards and the effect is generally statistically significant'. This leads them to the conclusion that 'caps alone are a poor way to constrain damages awards'. See Sharkey \& Klick 2007, p. 1, 20.

117 Colo Rev Stat $\S \S 13-21-102(1)(a)$ and (3) (1987).

118 Conn Gen Stat $\S 52-240 b$ (1995).

119 N D Cent Code $\S 32-03.2-11(4)$ (Supp.1995).

120 Kan.Stat.Ann. §§ 60-3701(e) and (f) (1994).

121 Mallor \& Roberts 1999, p. 1006.

122 Centner 2008, p. 36.

123 Owen 2005, p. 1210; Mallor \& Roberts 1999, p. 1006.

124 HR. 2279, 42d Leg., 1st Reg. Sess. (introduced Jan. 12, 1995).

125 HR 1741, 109th Reg. Sess. (enacted Apr. 26, 1995). 
medical malpractice cases to the state treasury. ${ }^{126}$ Again, more states allow state recovery of punitive damages awards. ${ }^{127}$

States have also enacted legislation relating to so-called bifurcated trials, in which questions of liability and compensation are separated from punitive damages issues. ${ }^{128} \mathrm{~A}$ trial may be bifurcated automatically or upon the request of (one of) the parties. It is believed that the reason for bifurcated trials is to prevent improper punitive damages awards that might result from having access to knowledge about the defendant's financial position during the liability phase of a trial. Note that, as explained in section 3.3.3, some jurisdictions already allow the fact finder to take the financial position of the defendant into account when determining the punitive damages award. This is to make sure that the award has a sufficient deterrent and punitive effect. It is nonetheless argued that, by separating phases of a trial, courts promote 'just punishment and deterrence while avoiding prejudice and bias'. ${ }^{129}$ For example, statutes in California, Georgia, Kansas, Missouri, and Montana ask the trier of fact to determine - in bifurcated proceedings - first whether the defendant is liable for punitive damages and then the amount of punitive damages. ${ }^{130}$ Other states, such as New Jersey and North Dakota, require separate proceedings for the determination of compensatory and punitive damages. ${ }^{131}$

Some states, for example Connecticut and Kansas, ${ }^{132}$ have legislation that attributes the responsibility for determining the amount of punitive damages awards to the court rather than to the jury in order to prevent biased juries rendering awards that are 'out of control'. ${ }^{133}$

Furthermore, a small number of states have enacted so-called one-bite reform legislation in order to limit punitive damages awards to one punishment for a single act or course of conduct. ${ }^{134}$ This form of legislation has been created to solve the problem of multiple punishment addressed in section 3.3.5.1.1, i.e. a defendant who is subjected to punishment over and over again for a single wrong, for instance in products liability litigation. For example, Georgia law limits punitive damages awards in products liability cases to one award without exception. ${ }^{135}$

Another measure to limit improper punitive damages awards is the heightened burden of proof. This control mechanism will filter out claims in which the

126 Kan Stat Ann $\S 60-3402(e)$ (1994).

127 The Supreme Court gives an overview of these and other state legislator reform measures in $B M W$ of North America, Inc. v. Gore, 517 U.S. 559, 116 S.Ct. 1589 (U.S.Ala. 1996), at § 615-619.

128 See on trial bifurcation also Landsman et al. 1998; Greene, Woody \& Winter 2000; Shea Adams \& Bourgeois 2006.

129 McKown 1995, p. 446, 448; Mallor \& Roberts 1999, p. 1006.

130 Cal Civ Code Ann § 3295(d) (West Supp.1995); Ga Code Ann § 51-12-5.1(d) (Supp.1995); Kan. Stat.Ann. §§ 60-3701(a) and (b) (1994); Mo Rev Stat $\S \S 510.263(1)$ and (3) (1994); Mont Code Ann $\S 27-1-221(7)(1995)$.

131 N J Stat Ann $\S \S 2 A: 58 C-5(b)$ and (d) (West 1987); N. D. Cent. Code $\S 32-03.2-11(2)$ (Supp.1995).

132 Conn Gen Stat Ann § 52-240b; Kan Stat Ann § 60-3701(a).

133 Owen 2005, p. 1214. See on this topic also section 3.3.2.

134 Owen 2005, p. 1214.

135 Ga Code $\S 51-12-5.1(\mathrm{e})(1)$ 
evidence cannot justify a punitive damages award. The ordinary standard of proof that is required in civil litigation is preponderance of the evidence, but several courts and legislators have raised the standard of proof for punitive damages claims, because such damages are 'extraordinary and harsh'. ${ }^{136}$ A number of states have enacted a procedural rule that punitive damages must be established by clear and convincing evidence. ${ }^{137}$ In Colorado, a punitive damages award may only be based on proof beyond a reasonable doubt, which is in fact a criminal law requirement. ${ }^{138}$ Even in the absence of legislation, many courts require a higher standard of proof for the recovery of punitive damages than the ordinary standard. ${ }^{139}$ For example, in the products liability case Wangen v. Ford Motor Co. the Wisconsin Supreme Court determined as follows: ${ }^{140}$

The issue of whether the defendant acted maliciously or in willful or reckless disregard of the plaintiff's rights, justifying recovery of punitive damages, falls within the "certain classes of acts" for which stigma attaches and is a more serious allegation than the ordinary factual issue in a personal injury action. Therefore, for all punitive damages claims we adopt the middle standard for the burden of proof for the issue of whether the defendant's conduct was "outrageous".

The court also explains what it means to require a middle burden of proof: ${ }^{141}$

This burden of proof, referred to as the middle burden of proof, requires a greater degree of certitude than that required in ordinary civil cases but a lesser degree than that required to convict in a criminal case.

In Hodges v. S.C. Toof \& Co., the Tennessee Supreme Court adopted a clear and convincing standard of proof for punitive damages awards: ${ }^{142}$

Because punitive damages are to be awarded only in the most egregious cases, a plaintiff must prove the defendant's intentional, fraudulent, malicious, or reckless conduct by clear and convincing evidence.

According to the Court, clear and convincing evidence means 'evidence in which there is no serious or substantial doubt about the correctness of the conclusions drawn from the evidence'. ${ }^{143}$ The Maine Supreme Court determined likewise in Tuttle v. Raymond: ${ }^{144}$

136 Owen 2005, p. 1203

137 Owen 2005, p. 1203; McKown 1995, p. 455, citing e.g. Ala Code § 6-11-20 (1993); Alaska Stat $\S 09.17 .020$ (1994); Cal Civ Code $\S 3294($ a) (West 1994); Fla Stat Ann $\S 768.73(1)$ (b) (West Supp. 1994).

138 Colo Rev Stat $\S 13-25-127(2)$ (1987).

139 See McKown 1995, p. 455-458.

140 Wangen v. Ford Motor Co., 97 Wis.2d 260, 294 N.W.2d 437 (Wis. 1980), at $\S 458$.

141 Wangen v. Ford Motor Co., at $\S 457$.

142 Hodges v. S.C. Toof \& Co., 833 S.W.2d 896 (Tenn. 1992), at $§ 900$.

143 Hodges v. S.C. Toof \& Co., at $\S 901$.

144 Tuttle v. Raymond, at $\S 1363$. 
[...] although punitive damages serve an important function in our legal system, they can be onerous when loosely assessed. The potential consequences of a punitive damages claim warrant a requirement that the plaintiff present proof greater than a mere preponderance of the evidence. Therefore, we hold that a plaintiff may recover exemplary damages based upon tortious conduct only if he can prove by clear and convincing evidence that the defendant acted with malice.

To conclude, a final measure to prevent excessive punitive damages awards is the already mentioned requirement of proportionality between compensatory and punitive damages. This requirement is usually expressed by the legislator as a ratio, or by state courts as a standard. ${ }^{145}$ For example, according to Florida law punitive damages may not exceed three times the actual damages, ${ }^{146}$ whereas Colorado law states that punitive damages may not exceed the actual damages except in special circumstances when they are limited to three times the actual damages. ${ }^{147}$ State courts normally do not set a fixed ratio, but they determine reasonableness on a case-by-case basis. ${ }^{148}$

\subsubsection{Judicial Review: General Remarks}

In the United States, the amount of a punitive damages award is determined by the trier of fact which, as explained in section 3.3.3, in principle is the jury. Judicial review is a method to control such jury awards. First, both trial courts and appellate courts have the power of remittitur and additur. ${ }^{149}$ Second, an appellate court that finds a jury award excessive may overturn the verdict and order a new trial.

When a court determines that a jury has rendered an excessive award, it can grant a remittitur and reduce the award. Remittitur cannot be granted without the plaintiff's consent. ${ }^{150}$ The plaintiff has the option to either accept the reduced award or seek a new trial. ${ }^{151}$ A less common form of correcting the jury's verdict is additur. When a court finds that the punitive damages award is insufficient, it can order an additur and add damages to the award. Although the power of additur is highly criticised, it gives the trial judge two interesting options: either the defendant accepts the increase in punitive damages or the judge orders a new trial. ${ }^{152}$

The grounds for one of the parties to bring an appeal generally relate to the insufficiency of evidence to justify the punitive damages award or to its excessiveness. ${ }^{153}$ Appellate courts are primarily faced with the issue of excessive

145 Mallor \& Roberts 1999, p. 1007.

146 Fla Stat Ann $\S 768.73(1)(a)$ (West Supp. 1994).

147 Colo Rev Stat $\S 13-21-102$ (1987).

148 Schlueter 2005a, p. 354.

149 Schlueter 2005a, p. 366. See on excessive and inadequate punitive damages awards Kircher \& Wiseman 2000b, chapter eighteen.

150 E.g. Thorne v. Welk Inv., Inc., 197 F.3d 1205 (C.A.8 (Mo.) 1999).

151 E.g. Beggs v. Universal C.I.T. Credit Corp., 409 S.W.2d 719 (Mo. 1966); Montoya v. Moore, 77 N.M. 326, 422 P.2d 363 (N.M. 1967).

152 Schlueter 2005a, p. 372. E.g. Micari v. Mann, 126 Misc.2d 422, 481 N.Y.S.2d 967 (N.Y.Sup. 1984).

153 Schlueter 2005a, p. 377. 
awards. Not only legislators, but also courts have created standards of review that should be considered when a punitive damages verdict is appealed. The factors on excessiveness outlined by the U.S. Supreme Court are important and will be discussed in detail below. In short, the standard of review of the U.S. Supreme Court is known as the de novo standard based on three guideposts that were developed in the case BMW of North America, Inc. v. Gore. ${ }^{154}$ The guideposts that trial and appellate courts must consider in evaluating whether a punitive damages verdict is unconstitutionally excessive relate to the reprehensibility of the conduct, the ratio between punitive and compensatory awards, and the comparison with criminal fines or civil penalties available for similar conduct. ${ }^{155}$ If no constitutional issue is raised, the appellate court may apply the abuse of discretion standard by which punitive damages are traditionally reviewed. This standard is less demanding than the de novo standard and broadly interpreted by the courts. ${ }^{156}$ In Pacific Mutual Life Insurance Co. v. Haslip, the U.S. Supreme Court endorsed the standard that had been used by the Alabama Supreme Court. ${ }^{157}$ The case, which will be discussed below, offered guidance as regards the standard to be used by lower courts. As a general rule, appellate courts may reverse or modify an award for the reason that the jury, or the court sitting as a jury, abused its discretion. As was seen in chapter three, a reasonable basis for the exercise of discretion only exists where there are aggravating circumstances to justify punitive damages. ${ }^{158}$ Punitive damages awards cannot be based on passion, prejudice or corruption of the jury. ${ }^{159}$ Furthermore, on the basis of the reasonable ratio rule, an appellate court may overturn an excessive punitive damages award that is disproportionate to the compensatory damages award. ${ }^{160}$

\subsubsection{The Constitutionality of Punitive Damages}

There have been numerous attempts to attack the punitive damages doctrine as being contrary to certain constitutional provisions that can be found in the U.S Constitution as well as state constitutions. ${ }^{161}$ The U.S. Supreme Court, to start with, has repeatedly addressed concerns over the frequency, size and predictability of particular punitive damages awards. But not only the U.S. Supreme Court, also

154 BMW of North America, Inc. v. Gore, 517 U.S. 559, 116 S.Ct. 1589 (U.S.Ala. 1996).

$155 B M W$, at $\S 576$. See Blatt, Hammesfahr \& Nugent 2008, p. 80.

156 Blatt, Hammesfahr \& Nugent 2008, p. 80; Schlueter 2005a, p. 377

157 Pacific Mut. Life Ins. Co. v. Haslip, 499 U.S. 1, 111 S.Ct. 1032 (U.S.Ala. 1991).

158 Schlueter 2005a, p. 349.

159 For an overview of case law, see Schlueter 2005a, p. 350, footnote 39.

160 Schlueter 2005a, p. 353.

161 See on the constitutionality issue in general Schlueter 2005a, chapter three; Kircher \& Wiseman 2000a, chapter three; Blatt, Hammesfahr \& Nugent 2008, chapter two. See also Sharkey 2009; Sharkey 2010; Rendleman 2009; Eisenberg, Heise \& Wells 2010; Calandrillo 2010; Gash 2004; Gash 2011; Mead 1995; Dupree 2010; Redish \& Mathews 2004; Krauss 2007; Kenefick 1987; Schwartz \& Magarian 1990; Spencer 2006; Rustad 2008; Geistfeld 2008; Seiner 2012. 
lower federal courts and state courts have addressed the constitutionality issue. ${ }^{162}$ According to Schlueter: ${ }^{163}$

\begin{abstract}
Of the many arguments advanced against punitive damages, perhaps the most compelling, but rarely successful, are those based on constitutional grounds. These constitutional arguments usually focus on the procedures by which punitive damages are imposed, especially in light of the similarity in purpose and effect between punitive damages and criminal sanctions. The argument continues that civil defendants who are exposed to punitive liability should be afforded many of the constitutional safeguards which protect criminal defendants. Additionally, arguments against assessment of punitive damages can be made on the constitutional grounds of vagueness, the right of confrontation, equal protection, double jeopardy, cruel and unusual punishment, and free speech.
\end{abstract}

From the late 1980s onwards, the U.S. Supreme Court decided a series of cases on the basis of two important constitutional challenges: the Excessive Fines Clause and the Due Process Clause. In so doing, the Court established a framework for awarding punitive damages. ${ }^{164}$ The focus of attention will be on these two constitutional provisions. However, it should be made clear that - like Schlueter Kircher and Wiseman mention other important constitutional provisions in relation to the punitive damages doctrine, namely double jeopardy, ${ }^{165}$ freedom of speech and press, ${ }^{166}$ equal protection, ${ }^{167}$ and other constitutional grounds, such as right to privacy, undue burden upon interstate commerce and violation of the Contract Clause. $^{168}$

The Excessive Fines Clause is used to challenge the constitutionality of large punitive damages awards. This clause, which is traditionally applied in criminal cases rather than civil cases, can be found in the Eighth Amendment to the U.S. Constitution: ${ }^{169}$

Excessive bail shall not be required, nor excessive fines imposed, nor cruel and unusual punishments inflicted.

The second constitutional challenge is based upon the Due Process Clause which protects two distinct rights, namely the right of procedural and substantive due process. ${ }^{170}$ This clause can be found in Section 1 of the Fourteenth Amendment to the U.S. Constitution:

162 Blatt, Hammesfahr \& Nugent 2008, p. 3-2.

163 Schlueter 2005a, p. 50.

164 Blatt, Hammesfahr \& Nugent 2008, p. 38; Owen 2005, p. 1216; Kircher \& Wiseman 2000a, p. 3-1; Schlueter 2005a, p. 49.

165 Kircher \& Wiseman 2000a, p. 3-3, citing the Fifth Amendment of the U.S. Constitution (“...nor shall any person be subject for the same offence to be twice put in jeopardy of life and limb...") and parallel provisions in the state constitutions.

166 Kircher \& Wiseman 2000a, p. 3-58, citing the First Amendment of the U.S. Constitution. The First Amendment is especially invoked in defamation cases involving punitive damages.

167 Kircher \& Wiseman 2000a, p. 3-59.

168 Kircher \& Wiseman 2000a, p. 3-82.

169 Blatt, Hammesfahr \& Nugent 2008, p. 39.

170 Colby 2008, p. 400. 
All persons born or naturalized in the United States, and subject to the jurisdiction thereof, are citizens of the United States and of the State wherein they reside. No State shall make or enforce any law which shall abridge the privileges or immunities of citizens of the United States, nor shall any State deprive any person of life, liberty or property, without due process of law; nor deny any person within its jurisdiction the equal protection of the laws.

An often heard argument is that the process of assessing the amount of punitive damages violates the Due Process Clause. Furthermore, the requirement that there must be a relationship to a legitimate purpose is - arguably - violated when the punitive damages award is not in proportion to the compensatory damages award. The rationale is that the Due Process Clause is violated when the purposes of punitive damages would be adequately served by a smaller award. ${ }^{171}$

In the next subsection, some of the most important constitutionality decisions with regard to punitive damages will be analysed in order to give an impression of the significance of this topic. The Eighth and Fourteenth Amendment have clearly played a central role in the U.S. Supreme Court decision-making.

\subsubsection{Punitive Damages Decision-Making by the U.S. Supreme Court}

The earliest U.S. Supreme Court decisions on punitive damages go back to the nineteenth century. In the Amiable Nancy decision of $1818,{ }^{172}$ the already mentioned Day v. Woodworth decision of $1851^{173}$ and the Missouri Pacific Railway Company v. Humes decision of $1885,{ }^{174}$ the U.S. Supreme Court found punitive damages to be constitutional for the reason that the remedy is 'an integral part of the American legal tradition'. ${ }^{175}$ Then, from the late 1880s until the late 1960s there have been few U.S. Supreme Court decisions on punitive damages. This is probably the result of a lack of financial incentive, as the number of punitive damages awards at that time was small. The next series of constitutional cases was decided by the U.S. Supreme Court from the 1970 s through to the early 1980s. ${ }^{176}$ These cases were primarily defamation cases focused on the constitutionality of punitive damages in light of the First Amendment on freedom of speech and press. ${ }^{177}$ It was not until

171 Blatt, Hammesfahr \& Nugent 2008, p. 40.

172 The Amiable Nancy, 16 U.S. 546, 1818 WL 2445 (U.S.N.Y. 1818).

173 Day v. Woodworth, 54 U.S. 363, 1851 WL 6684 (U.S. Mass. 1851), which is the first U.S. Supreme Court decision in which the punitive damages doctrine was considered 'constitutional': 'It is a wellestablished principle of common law, that in actions of trespass and all actions on the case for torts, a jury may inflict what are called exemplary, punitive, or vindictive damages upon the defendant, having in view the enormity of his offence rather than the measure of compensation to the plaintiff. We are aware that the propriety of this doctrine has been questioned by some writers; but if repeated judicial decisions for more than a century are to be received as the best exposition of what the law is, the question will not admit of argument.' Day $v$. Woodworth, at $\S 371$. See on this case also section 2.3.1.

174 Missouri Pac. Ry. Co. v. Humes, 115 U.S. 512, 6 S.Ct. 110 (U.S. 1885).

175 Blatt, Hammesfahr \& Nugent 2008, p. 40.

176 Blatt, Hammesfahr \& Nugent 2008, p. 44-45

177 E.g. Gertz v. Robert Welch, Inc., 418 U.S. 323, 94 S.Ct. 2997 (U.S.Ill. 1974). 
1986 that the next constitutionality case was decided. ${ }^{178}$ The cases that followed from then all considered constitutional challenges of the Eighth and Fourteenth Amendment. The U.S. Supreme Court decisions that will be addressed in this section have been categorised into the late 1980s decisions, the early 1990s decisions, the 'trilogy' of due process cases (plus one) decided between 1996 and 2007, ${ }^{179}$ and a decision from 2008. ${ }^{180}$ This is not an exhaustive enumeration of all U.S. Supreme Court decisions concerning the constitutionality of punitive damages. ${ }^{181}$ The main focus will be on cases decided from 1996 onwards, as these are the cases in which the Court for the first time struck down grossly excessive punitive damages awards as unconstitutional. First a brief insight into the cases decided prior to 1996 will be provided.

\subsubsection{The Late 1980s and Early 1990s Decisions}

In the cases that were decided between 1986 and 1989, the Court took a rather reserved stance on the constitutionality of punitive damages awards. In the first two cases, Aetna Life Insurance Company v. Lavoie and Bankers Life \& Cas. Co. v. Crenshaw, the Court did not decide on the question whether the two constitutional clauses were violated. ${ }^{182}$ However, the Court's language 'encouraged litigants to challenge punitive damages as violative of the Eighth and Fourteenth Amendments'. ${ }^{183}$ The actual development of a punitive damages framework began with the third case, BrowningFerris Industries of Vermont, Inc. v. Kelco Disposal, Inc., ${ }^{184}$ in which the Court addressed the possible violation of the Excessive Fines Clause. The Court decided that the punitive damages award of \$ 6 million for unfair business practices did not violate the Excessive Fines Clause because the action was not prosecuted by the government, and the government did not share in the award. ${ }^{185}$ In so deciding, the Court left open the possibility that awards in which governmental entities take part may be restricted by the Excessive Fines Clause. ${ }^{186}$ The due process issue was not

178 Aetna Life Ins. Co. v. Lavoie, 475 U.S. 813, 106 S.Ct. 1580 (U.S. Ala. 1986).

179 Sharkey 2010, p. 451.

180 See for a similar but more elaborate structure Blatt, Hammesfahr \& Nugent 2008, chapter two.

181 See for instance Owen 2005, p. 1216-1225.

182 Aetna Life Ins. Co. v. Lavoie, 475 U.S. 813, 106 S.Ct. 1580 (U.S. Ala. 1986); Bankers Life and Cas. Co. v. Crenshaw, 486 U.S. 71, 108 S.Ct. 1645 (U.S. 1988).

183 Blatt, Hammesfahr \& Nugent 2008, p. 47. In the concurring opinion of Bankers Life concern about the constitutionality of punitive damages was expressed: 'This grant of wholly standardless discretion to determine the severity of punishment appears inconsistent with due process. The court has recognised that "vague sentencing provisions may pose constitutional questions if they do not state with sufficient clarity the consequences of violating a given criminal statute". Nothing in Mississippi law warned appellant that by committing a tort that caused $\$ 20,000$ of actual damages, it could expect to incur a $\$ 1.6$ million punitive damages award'. See Bankers Life, at $\$ 88$.

184 Browning-Ferris Industries of Vermont, Inc. v. Kelco Disposal, Inc., 492 U.S. 257, 109 S.Ct. 2909 (U.S.Vt. 1989)

185 Browning-Ferris, at $\S 263-264$.

186 Owen 2005, p. 1217; Blatt, Hammesfahr \& Nugent 2008, p. 53. 
addressed but the Court emphasised its importance and held the door open for a constitutional challenge in an appropriate case. ${ }^{187}$

Not surprisingly, in the early 1990s decisions Pacific Mutual Life Insurance Co. v. Haslip, TXO Production Corp. v. Alliance Resources Corp. and Honda Motor Co., Ltd. v. Oberg, the Court addressed the constitutionality of punitive damages under the Due Process Clause. ${ }^{188}$ The first case of Pacific Mutual concerned insurance fraud. The award of punitive damages $(\$ 840,000)$ was more than four times the award of compensatory damages $(\$ 200,000)$. The Court decided, among other things, that the punitive damages award assessed against the insurer, although large in proportion to the insured's compensatory damages and out-of-pocket expenses, was not so disproportionately large as to violate due process. ${ }^{189}$ Although the Court expressed its concern about punitive damages that 'run wild', it refused to 'draw a mathematical bright line between the constitutionally acceptable and the constitutionally unacceptable that would fit every case'. ${ }^{190}$ The Court however stressed the need for reasonableness and adequate guidance when the amount of the award is assessed by a jury and thereby cited the words that had been used two years earlier by Owen: ${ }^{191}$

Yet punitive damages are a powerful remedy which itself may be abused, causing serious damage to public and private interests and moral values.

In determining whether the specific award violated the Due Process Clause, the Court endorsed seven factors that had been developed by the Supreme Court of Alabama to determine whether a punitive damages award is reasonably related

187 Browning-Ferris, at $\S 275-281$. According to Justice Brennan: 'Without statutory (or at least common-law) standards for the determination of how large an award of punitive damages is appropriate in a given case, juries are left largely to themselves in making this important, and potentially devastating, decision. Indeed, the jury in this case was sent to the jury room with nothing more than the following terse instruction: "In determining the amount of punitive damages, you may take into account the character of the defendants, their financial standing, and the nature of their acts." Guidance like this is scarcely better than no guidance at all. I do not suggest that the instruction itself was in error; indeed, it appears to have been a correct statement of Vermont law. The point is, rather, that the instruction reveals a deeper flaw: the fact that punitive damages are imposed by juries guided by little more than an admonition to do what they think is best. Because "[t]he touchstone of due process is protection of the individual against arbitrary action of government," I for one would look longer and harder at an award of punitive damages based on such skeletal guidance than I would at one situated within a range of penalties as to which responsible officials had deliberated and then agreed.'

188 Pacific Mut. Life Ins. Co. v. Haslip, 499 U.S. 1, 111 S.Ct. 1032 (U.S.Ala. 1991); TXO Production Corp. v. Alliance Resources Corp., 509 U.S. 443, 113 S.Ct. 2711 (U.S.W.Va. 1993); Honda Motor Co., Ltd. v. Oberg, 512 U.S. 415, 114 S.Ct. 2331 (U.S.Or. 1994).

189 Pacific Mutual, at $\S 1$. See Owen 2005, p. 1217; Schlueter 2005a, p. 59

190 Pacific Mutual, at $\$ 17-18$.

191 Pacific Mutual, at $\S 18-19$, citing Owen 1989, p. 739. 
to the goals of deterrence and retribution. ${ }^{192}$ In so deciding, the Court showed other courts how to control punitive damages awards. The Court concluded that the Due Process Clause was not violated. ${ }^{193}$

The next case concerning punitive damages and due process, TXO, involves unfair business practices. Although the Court recognised that there was a 'dramatic disparity ${ }^{194}$ between the punitive damages award (\$ 10 million) and the compensatory award $(\$ 19,000)$ under consideration, it decided not to adopt fixed standards for testing the constitutionality of the size of punitive damages awards. ${ }^{195}$ Instead, the Court reiterated its wording from the Pacific Mutual case that there is "no mathematical bright line between an award that is constitutionally acceptable and one that is constitutionally unacceptable'. ${ }^{196}$ The Court focused on the reasonable relation between the award and the harm that occurred or was likely to occur from TXO's bad faith conduct. ${ }^{197}$ It thereby referred to the decision of the Supreme Court of Appeals of West Virginia, which had affirmed the initial jury verdict against TXO on the basis of three factors relating to the question whether such a relationship existed: (1) the potential harm that TXO's actions could have caused; (2) the maliciousness of TXO's actions; and (3) the penalty necessary to discourage TXO from undertaking such endeavors in the future. ${ }^{198}$ Taking into account these factors, the Court ruled that the punitive damages sum imposed on TXO was not so grossly excessive as to violate due process. ${ }^{199}$ However, similar to Pacific Mutual, the TXO case established that there should be procedural due process limits on the size of punitive damages

192 Pacific Mutual, at $\S 21-22$ : 'The following could be taken into consideration in determining whether the award was excessive or inadequate: (a) whether there is a reasonable relationship between the punitive damages award and the harm likely to result from the defendant's conduct as well as the harm that actually has occurred; (b) the degree of reprehensibility of the defendant's conduct, the duration of that conduct, the defendant's awareness, any concealment, and the existence and frequency of similar past conduct; (c) the profitability to the defendant of the wrongful conduct and the desirability of removing that profit and of having the defendant also sustain a loss; (d) the "financial position" of the defendant; (e) all the costs of litigation; (f) the imposition of criminal sanctions on the defendant for its conduct, these to be taken in mitigation; and $(\mathrm{g})$ the existence of other civil awards against the defendant for the same conduct, these also to be taken in mitigation'.

193 Pacific Mutual, at $\$ 23-24$.

$194 T X O$, at $\S 444,462$.

$195 T X O$, at $\S 443,456$. See also Owen 2005, p. 1219.

$196 T X O$, at $\$ 457$.

197 Kircher \& Wiseman 2000a, p. 3-16.

$198 T X O$, at $\$ 453$

$199 T X O$, at $\S 443-445$. The Court added in $\S 462$ that it was reasonable for the jury to reach the verdict: 'In sum, we do not consider the dramatic disparity between the actual damages and the punitive award controlling in a case of this character. On this record, the jury may reasonably have determined that petitioner set out on a malicious and fraudulent course to win back, either in whole or in part, the lucrative stream of royalties that it had ceded to Alliance. The punitive damages award in this case is certainly large, but in light of the amount of money potentially at stake, the bad faith of petitioner, the fact that the scheme employed in this case was part of a larger pattern of fraud, trickery and deceit, and petitioner's wealth, we are not persuaded that the award was so "grossly excessive" as to be beyond the power of the State to allow.' 
awards, in the sense that due to 'a general concern of reasonableness' there should be appropriate jury instructions and meaningful judicial review. ${ }^{200}$

The last early 1990s decision, Honda Motor Co. v. Oberg, is the first case in which the Court found a violation of the Due Process Clause. The products liability case was about an all-terrain vehicle, also known as an ATV or quad-bike, which had overturned and injured Oberg, the respondent. ${ }^{201}$ Oberg brought a products liability case against the manufacturer. The Oregon Supreme Court affirmed the jury verdict consisting of a \$ 5 million punitive damages award and a \$ 900,000 compensatory damages award. The case before the U.S. Supreme Court focused on the question whether precluding - on the basis of a unique provision in the Constitution of Oregon - judicial review of punitive damages awarded by the jury 'unless the court can affirmatively say there is no evidence to support the verdict' violates the Due Process Clause. ${ }^{202}$ The Court decided that this preclusion indeed violates the Due Process Clause, for the reason that punitive damages awards should not be at the discretion of a jury without proper judicial review. ${ }^{203}$ The denial of judicial review, including review of the size of awards, was considered unconstitutional as it might lead to excessive punishment of the defendant. ${ }^{204}$

\subsubsection{The 'Trilogy' of Due Process Cases (Plus One) Decided Between 1996 and 2007}

The following decisions are also known as the 'trilogy of punitive damages cases', in which 'the U.S. Supreme Court has erected an edifice of constitutional due process review superimposed upon state common law practice of punitive damages'. ${ }^{205}$ These cases differ from the earlier cases in the sense that the Court

200 TXO, at $\S$ 443. See also Owen 2005, p. 1219.

201 Owen 2005, p. 1220; Blatt, Hammesfahr \& Nugent 2008, p. 75.

202 Honda, at $\S 415$.

203 Honda, at $\S 434-435$ : 'In support of his argument that there is a historic basis for making the jury the final arbiter of the amount of punitive damages, respondent calls our attention to early civil and criminal cases in which the jury was allowed to judge the law as well as the facts. As we have already explained, in civil cases, the jury's discretion to determine the amount of damages was constrained by judicial review. The criminal cases do establish - as does our practice today - that a jury's arbitrary decision to acquit a defendant charged with a crime is completely unreviewable. There is, however, a vast difference between arbitrary grants of freedom and arbitrary deprivations of liberty or property. The Due Process Clause has nothing to say about the former, but its whole purpose is to prevent the latter. A decision to punish a tortfeasor by means of an exaction of exemplary damages is an exercise of state power that must comply with the Due Process Clause of the Fourteenth Amendment.'

204 Honda, at $\S 416$ : 'This Court has not hesitated to find proceedings violative of due process where a party has been deprived of a well-established common law protection against arbitrary and inaccurate adjudication. Punitive damages pose an acute danger of arbitrary deprivation of property, since jury instructions typically leave the jury with wide discretion in choosing amounts and since evidence of a defendant's net worth creates the potential that juries will use their verdicts to express biases against big businesses. Oregon has removed one of the few procedural safeguards which the common law provided against that danger without providing any substitute procedure and without any indication that the danger has in any way subsided over time'.

205 Sharkey 2010, p. 451. 
for the first time used its power to strike down grossly excessive punitive damages awards as unconstitutional. ${ }^{206}$ Although this also happened in the Honda case, that decision was based on the unconstitutional preclusion of judicial review, whereas these cases focus on the unconstitutional excessiveness of punitive damages awards. One additional case that is described in this subsection does not form part of the trilogy, as Sharkey names it, but it was decided some years after the first case in the trilogy and is relatively often cited as an important U.S. Supreme Court decision on the constitutionality of punitive damages.

\subsection{BMW of North America, Inc. v. Gore}

In BMW of North America, Inc. v. Gore, ${ }^{207}$ BMW had sold a 'new' car to Gore, the respondent. Gore did not know that the car had sustained acid rain damage in transit to the United States and had been repaired and partially repainted before it was delivered to him. ${ }^{208}$ When he found out about this he felt cheated, sued BMW and claimed, among other things, that 'the failure to disclose that the car had been repainted constituted suppression of a material fact'. ${ }^{209}$ An Alabama jury initially awarded \$ 4,000 in compensatory damages and \$ 4 million in punitive damages. Because BMW had engaged in similar conduct across the country, the compensatory damages award was multiplied by a thousand, the estimated number of cars that BMW had repaired and sold as new. ${ }^{210}$ However, the Alabama Supreme Court reduced the punitive damages award to $\$ 2$ million because the jury could not properly have based the award on BMW's sales outside the state of Alabama. ${ }^{211}$ The U.S. Supreme Court found the \$ 2 million punitive damages award to be grossly excessive and therefore in violation of the Due Process Clause for the following two reasons: (1) lawful conduct by a distributor outside Alabama cannot be considered by an Alabama court in assessing a punitive damages award, and (2) a punitive damages award of $\$ 2$ million is grossly excessive given the low level of reprehensibility of conduct and the 500 to 1 ratio between the punitive damages award and the actual harm to the buyer. $^{212}$

Thus, according to the Court the jury improperly calculated the amount of punitive damages because its calculation was not limited to the conduct of BMW in Alabama. In other words, state courts cannot award punitive damages for out-of-state conduct. $^{213}$ BMW's conduct was actually legal in some other states, where legislation does not require disclosure of minor repairs of new cars. The Court determined that the Alabama jury verdict violated principles of state sovereignty and comity, and made clear that state courts cannot assess punitive damages for conduct in other

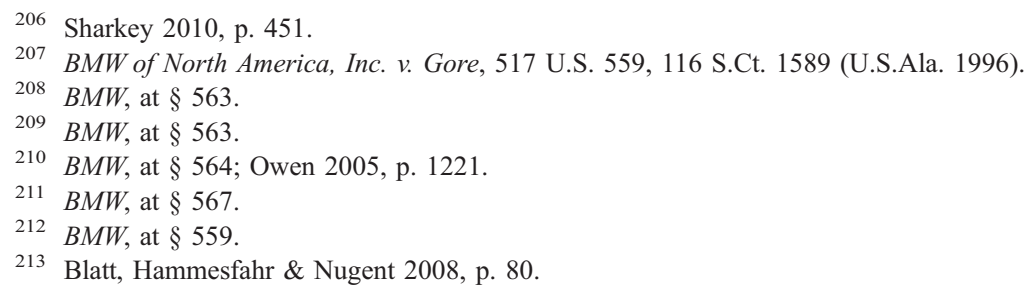


states. $^{214}$ Furthermore - and even more important - the Court provided three guideposts that should be used by trial and appellate courts in evaluating whether a punitive damages award is unconstitutionally excessive: (1) the reprehensibility of the conduct, (2) the ratio between punitive and compensatory awards, and (3) the comparison with criminal fines or civil penalties available for similar conduct. The Court reasoned as follows: ${ }^{215}$

Elementary notions of fairness enshrined in our constitutional jurisprudence dictate that a person receive fair notice not only of the conduct that will subject him to punishment, but also of the severity of the penalty that a State may impose. Three guideposts, each of which indicates that BMW did not receive adequate notice of the magnitude of the sanction that Alabama might impose for adhering to the nondisclosure policy adopted in 1983, lead us to the conclusion that the $\$ 2$ million award against BMW is grossly excessive: the degree of reprehensibility of the nondisclosure; the disparity between the harm or potential harm suffered by Dr. Gore and his punitive damages award; and the difference between this remedy and the civil penalties authorized or imposed in comparable cases.

The Court then discussed these considerations one by one. As regards the first guidepost, the nature of the conduct should be evaluated independently. ${ }^{216}$ Conduct reflecting reasonable executive decisions and an intention to comply with existing laws will not be considered reprehensible. BMW's conduct was not considered reprehensible by the Court for the following reason: ${ }^{217}$

In this case, none of the aggravating factors associated with particularly reprehensible conduct is present. The harm BMW inflicted on Dr. Gore was purely economic in nature. The presale refinishing of the car had no effect on its performance or safety features, or even its appearance for at least nine months after his purchase. BMW's conduct evinced no indifference to or reckless disregard for the health and safety of others. To be sure, infliction of economic injury, especially when done intentionally through affirmative acts of misconduct, or when the target is financially vulnerable, can warrant a substantial penalty. But this observation does not convert all acts that cause economic harm into torts that are sufficiently reprehensible to justify a significant sanction in addition to compensatory damages.

With regard to the second guidepost, the ratio between the punitive and the compensatory award of 500 to 1 was rejected. In so doing, the Court again cited Pacific Mutual and TXO. The Court started by explaining why a mathematical formula to determine the constitutionally acceptable is rejected and in which situations a higher ratio may be justified: ${ }^{218}$

Of course, we have consistently rejected the notion that the constitutional line is marked by a simple mathematical formula, even one that compares actual and potential damages to the punitive award. Indeed, low awards of compensatory damages may properly support a higher ratio than high compensatory awards, if, for example, a particularly egregious act has resulted in only a small

$B M W$, at $\S 568-574$.

$B M W$, at $\S 574-575$.

Blatt, Hammesfahr \& Nugent 2008, p. 80.

$B M W$, at $\$ 576$.

$8 B M W$, at $\S 582$. 
amount of economic damages. A higher ratio may also be justified in cases in which the injury is hard to detect or the monetary value of noneconomic harm might have been difficult to determine. It is appropriate, therefore, to reiterate our rejection of a categorical approach.

The Court continued its reasoning: ${ }^{219}$

Once again, we return to what we said ... in Haslip: 'We need not, and indeed we cannot, draw a mathematical bright line between the constitutionally acceptable and the constitutionally unacceptable that would fit every case. We can say, however, that a general concern of reasonableness ... properly enters into the constitutional calculus'.

And the Court concluded as follows on this point: ${ }^{220}$

In most cases, the ratio will be within a constitutionally acceptable range, and remittitur will not be justified on this basis. When the ratio is a breathtaking 500 to 1 , the award must surely raise a suspicious judicial eyebrow.

As regards the third guidepost, the Court found that the \$2 million punitive damages award was substantially higher than the statutory fines available in Alabama and elsewhere for similar conduct: ${ }^{221}$

\begin{abstract}
In this case the $\$ 2$ million economic sanction imposed on BMW is substantially greater than the statutory fines available in Alabama and elsewhere for similar malfeasance. [...] The sanction imposed in this case cannot be justified on the ground that it was necessary to deter future misconduct without considering whether less drastic remedies could be expected to achieve that goal. The fact that a multimillion dollar penalty prompted a change in policy sheds no light on the question whether a lesser deterrent would have adequately protected the interests of Alabama consumers. In the absence of a history of noncompliance with known statutory requirements, there is no basis for assuming that a more modest sanction would not have been sufficient to motivate full compliance with the disclosure requirement imposed by the Alabama Supreme Court in this case.
\end{abstract}

For the reasons given, the U.S. Supreme Court ruled that the punitive damages award imposed on BMW was grossly excessive and violated the Due Process Clause. The judgment of the Alabama Supreme Court was reversed and the case remanded.

\title{
4.4.4.2.2 Cooper Industries, Inc. v. Leatherman Tool Group, Inc.
}

In the next case, Cooper Industries, Inc. v. Leatherman Tool Group, Inc., ${ }^{222}$ which does not form part of Sharkey's 'trilogy' but is still worth mentioning at this point, the U.S. Supreme Court determined that U.S. Courts of Appeals should apply a de novo standard when reviewing a district court's determination of the constitutionality of a punitive damages award. Appellate courts must thereby apply the three guideposts of the $B M W$ case. ${ }^{223}$ This changed the standard of federal

$219 B M W$, at $\S 582-583$.

$220 B M W$, at $\S 583$

$221 B M W$, at $\S 583-585$.

222 Cooper Industries, Inc. v. Leatherman Tool Group, Inc., 532 U.S. 424, 121 S.Ct. 1678 (U.S.Or. 2001).

223 Cooper Industries, at $\S 424-425$. 
appellate review from abuse of discretion to a more demanding standard of review. If no constitutional issue is raised, appellate courts may use the abuse of discretion standard explained in section 4.4 .2 above. ${ }^{224}$

Cooper Industries had been sued by Leatherman, manufacturer of a multifunction tool comparable to the classic Swiss army knife. Cooper Industries nearly copied Leatherman's tool and accompanying advertisement and was sued for trademark infringement, false advertising, and unfair competition. ${ }^{225}$ A jury awarded damages for unfair competition: \$50,000 in compensatory damages and $\$ 4.5$ million in punitive damages. The Court held that the Court of Appeals for the Ninth Circuit, which upheld the jury verdict, made a mistake by applying the normal abuse of discretion standard when reviewing the award of the district court. According to the Court, punitive damages operate as a quasi-criminal private fine designed to punish a defendant rather than to assess actual damage suffered by a plaintiff: ${ }^{226}$

\begin{abstract}
Although compensatory damages and punitive damages are typically awarded at the same time by the same decisionmaker, they serve distinct purposes. The former are intended to redress the concrete loss that the plaintiff has suffered by reason of the defendant's wrongful conduct. The latter, which have been described as "quasi-criminal," operate as "private fines" intended to punish the defendant and to deter future wrongdoing. A jury's assessment of the extent of a plaintiff's injury is essentially a factual determination, whereas its imposition of punitive damages is an expression of its moral condemnation.
\end{abstract}

The Court recognises the broad discretion that States have with respect to the imposition of both criminal penalties and punitive damages, but it also makes clear that the Due Process Clause imposes substantive limits on that discretion. ${ }^{227}$ The Court then makes clear that it is convinced that appellate courts should apply the de novo standard when reviewing district courts' determinations of the constitutionality of punitive damages awards. ${ }^{228}$ According to the Court, this decision is supported by the Pacific Mutual case: ${ }^{229}$

$[\ldots]$ our decision today is supported by our reasoning in [Pacific Mutual]. In that case, we emphasized the importance of appellate review to ensuring that a jury's award of punitive damages comports with due process.

The concerns raised by Leatherman with regard to his right to trial by jury, i.e. the Seventh Amendment to the Constitution, were not subscribed to by the Court: ${ }^{230}$

224 Cooper Industries, at $\S 424$; Schlueter 2005a, p. 73.

225 Cooper Industries, at $\S$ 424; Blatt, Hammesfahr \& Nugent 2008, p. 83; Owen 2005, p. 1222

226 Cooper Industries, at $\S 432$; See Owen 2005, p. 1223.

227 Cooper Industries, at $\S 433$.

228 Cooper Industries, at $\S 436$.

229 Cooper Industries, at $\$ 436$.

230 Cooper Industries, at $\S 437$. 
Unlike the measure of actual damages suffered, which presents a question of historical or predictive fact, the level of punitive damages is not really a 'fact' 'tried' by the jury. Because the jury's award does not constitute a finding of "fact," appellate review of the district court's determination that an award is consistent with due process does not implicate the Seventh Amendment concerns raised by respondent and its amicus.

Thus, the de novo standard of appellate review is not constrained by the right to jury trial. The case was remanded, as the Court's own application of the three Gore factors 'reveals a series of questionable conclusions by the District Court that may not survive the de novo review'. ${ }^{231}$

The Cooper case has been criticised; it is argued that the decision implies a radical shift of control over punitive damages determination from juries to courts. ${ }^{232}$ However, it appears that the change in the standard of review has little practical impact on either state courts or federal courts. ${ }^{233}$ This is for example reflected by the opinion of the New Mexico Court of Appeals in Seitzinger v. Trans-Lux Corp.: ${ }^{.234}$

We do not interpret Cooper Industries, Inc. to impose de novo review as a matter of federal constitutional imperative. Rather, it appears to be an appellate procedural option for the federal courts. We are thus free to apply our own standard as a matter of constitutional law.

Likewise, a federal court decided in Todd v. Roadway Express Inc. that the Cooper decision has no bearing on how punitive damages are awarded, only on how a jury's award is reviewed. ${ }^{235}$

\subsection{State Farm Mutual Automobile Insurance Co. v. Campbell}

The U.S. Supreme Court continued to stress its due process concerns in State Farm Mutual Automobile Insurance Co. v. Campbell. ${ }^{236}$ Similar to the BMW decision, this was an 'economic harm case'. ${ }^{237}$ The Campbells had negligently caused a car accident in which one person died and another person became disabled. Nevertheless, their insurance company State Farm refused offers by the victim and the deceased's inheritors to settle the case within the policy limits of $\$ 50,000$ of Campbell's car insurance. Furthermore, despite the advice of one of its own investigators, State Farm started court procedures and - inaccurately - promised the Campbells that their personal belongings were safe, that they were not liable for the accident, that State Farm would represent their interests and that they did not need a separate counsel. ${ }^{238}$ Not surprisingly, a jury verdict of $\$ 185,849$ was awarded against the Campbells. When State Farm refused to pay at first, Campbell

231 Cooper Industries, at $\S 441$.

232 Owen 2005, p. 1223, citing Litwiller 2002.

233 Owen 2005, p. 1223.

234 Seitzinger v. Trans-Lux Corp., 40 P.3d 1012 (N.M.App. 2001), at § 1023.

235 Todd v. Roadway Exp., Inc., 178 F.Supp.2d 1244 (M.D.Ala. 2001).

236 State Farm Mut. Auto. Ins. Co. v. Campbell, 538 U.S. 408, 123 S.Ct. 1513 (U.S. 2003)

237 Sharkey 2010, p. 452.

238 State Farm, at $\S 413$. 
and his wife thought for a period of eighteen months that they had to sell their house. $^{239}$ State Farm had simply told them: ${ }^{240}$

"You may want to put for sale signs on your property to get things moving."

The Campbells sued State Farm for bad faith failure to settle, fraud and intentional infliction of emotional distress. ${ }^{241}$ They introduced evidence that State Farm worked on the basis of a fraudulent scheme (the so-called 'Performance, Planning and Review' policy) to randomly minimise claim payouts in order to maximise profits and that this fraudulent behaviour was conducted not only in their home state Utah but in numerous states for over twenty years. ${ }^{242}$ For that reason, a Utah jury awarded \$2.6 million in compensatory damages, and \$ 145 million in punitive damages, which the trial court reduced to $\$ 1$ million and $\$ 25$ million respectively. ${ }^{243}$ Both parties appealed. The Utah Supreme Court reinstated the $\$ 145$ million punitive damages award: ${ }^{244}$

Relying in large part on the extensive evidence concerning the PP \& R policy, the court concluded State Farm's conduct was reprehensible. The court also relied upon State Farm's "massive wealth" and on testimony indicating that "State Farm's actions, because of their clandestine nature, will be punished at most in one out of every 50,000 cases as a matter of statistical probability," and concluded that the ratio between punitive and compensatory damages was not unwarranted. Finally, the court noted that the punitive damages award was not excessive when compared to various civil and criminal penalties State Farm could have faced, including \$10,000 for each act of fraud, the suspension of its license to conduct business in Utah, the disgorgement of profits, and imprisonment.

Thus, in light of, among other things, the insurer's 'massive wealth' and the unlikelihood of being caught and punished due to the secret nature of its activities, State Farms fraudulent conduct was reprehensible and therefore compatible with the $B M W$ guideposts. ${ }^{245}$

State Farm appealed to the U.S. Supreme Court. According to the insurer, the verdict was excessive and violated the Due Process Clause because the Utah courts had considered conduct outside the state of Utah and had otherwise violated the $B M W$ guideposts. ${ }^{246}$ The U.S. Supreme Court agreed with State Farm. As regards the first $B M W$ guidepost on reprehensibility of conduct, the Court acknowledged the offensiveness of State Farm's fraudulent behaviour. However, the Court also made clear that due process precludes courts from basing punitive damages on misconduct that is unrelated to the respondents' harm, especially conduct outside the state. Punitive damages may not be used 'as a platform to expose, and punish,

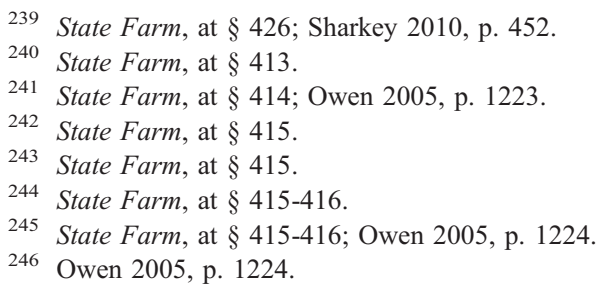


the perceived deficiencies of State Farm's operations throughout the country'. ${ }^{247}$ According to the Court: ${ }^{248}$

Lawful out-of-state conduct may be probative when it demonstrates the deliberateness and culpability of the defendant's action in the State where it is tortuous, but that conduct must have a nexus to the specific harm suffered by the plaintiff.

\section{The Court continued: $:^{249}$}

A defendant should be punished for the conduct that harmed the plaintiff, not for being an unsavory individual or business. Due process does not permit courts, in the calculation of punitive damages, to adjudicate the merits of other parties' hypothetical claims against a defendant under the guise of the reprehensibility analysis, but we have no doubt the Utah Supreme Court did that here.

Also the second $B M W$ factor, the ratio guidepost, was further refined in the State Farm decision. Although again refusing to impose a 'bright-line ratio' that punitive damages awards may not exceed, the Court warned lower courts to be careful: ${ }^{250}$

When compensatory damages are substantial, then a lesser ratio, perhaps only equal to compensatory damages, can reach the outermost limit of the due process guarantee. The precise award in any case, of course, must be based upon the facts and circumstances of the defendant's conduct and the harm to the plaintiff.

In general, the Court said that few punitive damages awards exceeding a single-digit ratio between punitive and compensatory damages will in practice satisfy due process to a significant degree. ${ }^{251}$ The Court emphasised that a punitive award should be both reasonable and proportionate to the harm and to the general damages recovered. ${ }^{252}$ The 145-to-1 ratio used in this case was not considered reasonable and proportionate: ${ }^{253}$

The compensatory award in this case was substantial; the Campbells were awarded $\S 1$ million for a year and a half of emotional distress. This was complete compensation. The harm arose from a transaction in the economic realm, and not from some physical assault or trauma; there were no physical injuries; and State Farm paid the excess verdict before the complaint was filed, so the Campbells suffered only minor economic injuries for the 18-month period in which State Farm refused to resolve the claim against them. The compensatory damages for the injury suffered here, moreover, were likely based on a component which was duplicated in the punitive award. Much of the distress was caused by the outrage and humiliation the Campbells suffered at the actions of their insurers; and it is a major role of punitive damages to condemn such conduct. Compensatory damages, however, already contain this punitive element. See Restatement (Second) of Torts § 908, Comment $c$, p. 466 (1977) ("In many cases in which compensatory damages include an amount for emotional distress, such as humiliation or indignation aroused by the defendant's act, there is no

247 State Farm, at $\S 420$.

248 State Farm, at $\S 422$.

249 State Farm, at $\S 423$.

250 State Farm, at $\S 425$.

251 State Farm, at $\S 425$

252 State Farm, at $\$ 426$.

253 State Farm, at $\S 426$. 
clear line of demarcation between punishment and compensation and a verdict for a specified amount frequently includes both").

The third guidepost on comparable civil and criminal penalties was also addressed. It appeared that the comparable penalty under Utah legislation for similar fraudulent behaviour was a $\$ 10,000$ fine. $^{254}$ Because the $B M W$ guideposts were not sufficiently taken into account, the Court concluded that the $\$ 145$ million punitive damages award was unconstitutionally excessive and violated due process, as it 'was neither reasonable nor proportionate to the wrong committed, and it was an irrational and arbitrary deprivation of the property of the defendant'. ${ }^{255}$

\subsection{Philip Morris USA v. Williams}

The last case in the due process trilogy is Philip Morris USA v. Williams. ${ }^{256}$ Unlike $B M W$ and State Farm, this is not an economic harm case but a personal injury case involving wrongful death. ${ }^{257}$ A similarity between the three cases is that they all involve 'consumer-protection punitive damages because the defendants' misconduct had caused widespread public harm'. ${ }^{258}$

Philip Morris was sued by respondent Williams for causing the death of her husband, who died of lung cancer after years of smoking Philip Morris cigarettes. Her lawyer had asked an Oregon jury to punish Philip Morris, not only for the death of Mr. Williams, but also for the harm caused to thousands of other smokers in Oregon who had been injured by smoking Philip Morris cigarettes. ${ }^{259}$ The jury found that smoking was the cause of Mr. Williams' death, that he smoked in significant part because he was taught that it was safe, and that Philip Morris had knowingly and falsely misrepresented the risks of smoking. According to the jury, Philip Morris was negligent (as was Mr. Williams) and had engaged in deceit; it therefore awarded $\$ 821,000$ in compensatory damages (of which $\$ 800,000$ was for noneconomic damage) and $\$ 79.5$ million in punitive damages. The trial judge reduced the punitive damages award to $\$ 32$ million because of its excessiveness. ${ }^{260}$ Both parties appealed. The Oregon Supreme Court then reinstated the \$ 79.5 million award, because the conduct of Philip Morris 'caused a significant number of deaths each year in Oregon' and that 'using punitive damages to punish a defendant for harm to nonparties' does not violate the Constitution. ${ }^{261}$ Colby compared this situation with the $B M W$ case decided ten years earlier: ${ }^{262}$

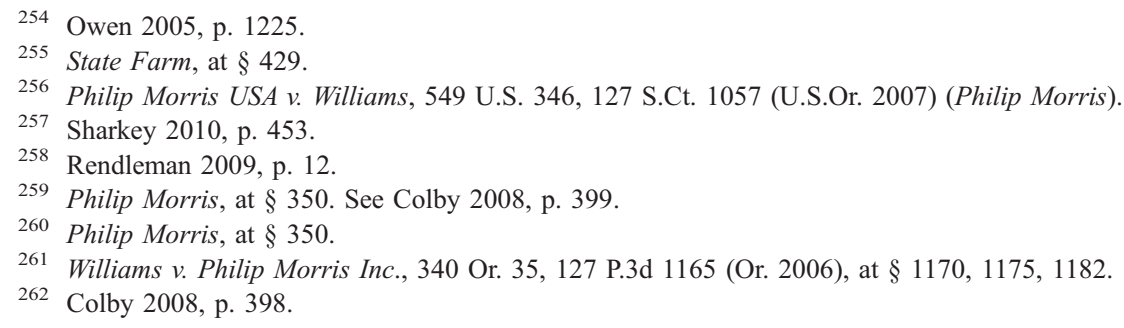


In BMW of North America, Inc. v. Gore, the Court held that federalism concerns preclude a state court from using punitive damages to punish a defendant for harm caused to out-of-state victims, at least where the defendant's conduct was legal in the other state, but the Court clearly, albeit implicitly, endorsed the notion that there is nothing wrong with allowing the jury to punish the defendant for the harm caused to all in-state victims, even those not before the court.

Indeed, there was an obvious trend toward so-called total harm punitive damages that punished the defendant for the harm caused to society, rather than the harm caused to the actual plaintiff(s). ${ }^{263}$ Then again, as was seen in the previous section, in the State Farm decision the Court determined that 'a defendant should be punished for the conduct that harmed the plaintiff, not for being an unsavory individual or business'. ${ }^{264}$ In practice, the decisions of BMW and State Farm caused uncertainty to courts across the country as to whether punitive damages for harm to nonparties were either allowed or prohibited. ${ }^{265}$ In the Philip Morris case, the Court puts an end to this uncertainty. Two questions were presented to the Court: firstly, a procedural due process question regarding punishment for harm to nonparty victims and, secondly, a substantive due process question relating to the 100-to-1 ratio used in the case. ${ }^{266}$ With regard to the first question, the Court decided as follows: ${ }^{267}$

A punitive damages award based in part on a jury's desire to punish a defendant for harming nonparties amounts to a taking of property from the defendant without due process.

According to the Court, juries may consider harm to third parties in determining the amount of punitive damages because such harm is relevant to the degree of reprehensibility of a defendant's conduct. However, they may not increase punitive damages awards to punish the defendant directly for this harm: ${ }^{268}$

We did not previously hold explicitly that a jury may not punish for the harm caused others. But we do so hold now.

In the Court's view, punitive damages cannot be used to punish a defendant for wrongful harm to a third party: ${ }^{269}$

In our view, the Constitution's Due Process Clause forbids a State to use a punitive damages award to punish a defendant for injury that it inflicts upon nonparties or those whom they directly represent, i.e., injury that it inflicts upon those who are, essentially, strangers to the litigation. For one thing, the Due Process Clause prohibits a State from punishing an individual without first providing that individual with "an opportunity to present every available defense".

263 Colby 2008, p. 397.

264 State Farm, at $\$ 423$.

265 Colby 2008, p. 399.

266 Sharkey 2010, p. 454.

267 Philip Morris, at $\S 346$.

268 Philip Morris, at $\S 356-357$.

269 Philip Morris, at $\S 353$. 


\section{The Court continued: ${ }^{270}$}

Yet a defendant threatened with punishment for injuring a nonparty victim has no opportunity to defend against the charge, by showing, for example in a case such as this, that the other victim was not entitled to damages because he or she knew that smoking was dangerous or did not rely upon the defendant's statements to the contrary. For another, to permit punishment for injuring a nonparty victim would add a near standardless dimension to the punitive damages equation. How many such victims are there? How seriously were they injured? Under what circumstances did injury occur? The trial will not likely answer such questions as to nonparty victims. The jury will be left to speculate. And the fundamental due process concerns to which our punitive damages cases referrisks of arbitrariness, uncertainty, and lack of notice - will be magnified.

The second question was not addressed by the Court, 'because the Oregon Supreme Court's application of the correct standard may lead to a new trial, or a change in the level of the punitive damages award'. ${ }^{271}$

The Philip Morris case did not end with this decision: what followed is a complicated set of procedures. In short, the U.S. Supreme Court vacated the Oregon Supreme Court's judgment and remanded the case. ${ }^{272}$ On remand, the Oregon Supreme Court adhered to its prior decision and decided that the punitive damages award was correctly awarded. ${ }^{273}$ Then, the U.S. Supreme Court dismissed the request for appeal to consider the issue again as the writ of certiorari, i.e. a request of an appellate court in which a lower court is ordered to send the record of the case for review, was carelessly granted. ${ }^{274}$ The manufacturer subsequently paid the compensatory damages award and part of the punitive damages award to the widow, but refused to pay the $60 \%$ of the punitive damages allocated to the state under a split recovery statute. ${ }^{275}$ A new verdict was therefore issued by the Oregon Supreme Court in 2011. This Court decided that $60 \%$ of the Williams punitive damages award should indeed be paid to the Oregon Attorney General under the Oregon split-recovery statute. ${ }^{276}$

Note that the U.S. Supreme Court's holding from 2007 is still the guiding principle in procedural due process issues, as follows for example from the recent district court decision Ray v. Allergan, Inc. ${ }^{277}$ In this case, Douglas Ray had filed a civil claim against manufacturer Allergan because he had become disabled due to three Botox injections that he had received to treat a dystonic movement disorder of his right hand. Mr. Ray alleged that he sustained a severe reaction to the Botox which left him disabled. Allergan alleged that Mr. Ray's injuries resulted from a pre-existing neurodegenerative condition. After the jury had imposed compensatory damages of $\$ 12$ million and punitive damages of $\$ 200$ million on Allergan

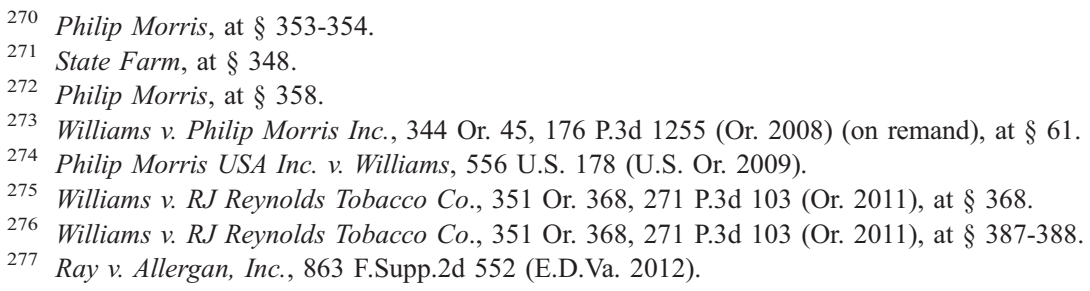


because of negligent failure to warn, Allergan moved for a new trial which was granted. ${ }^{278}$ One of the reasons for the decision of the district court to grant a new trial was that the closing argument of Mr. Ray's counsel violated the rule created by the U.S. Supreme Court in Philip Morris USA v. Williams that punitive damages cannot be used to punish a defendant for injury that it inflicted upon nonparties: ${ }^{279}$

In closing, Ray's counsel invited jurors to "think of all the Douglas Rays in the United States that were being injected with BOTOX ${ }^{\circledR}$ in 2007 for mild to moderate nonlife-threatening conditions." [...] Ray contends that his statement was made "in the context of whether the conduct was sufficiently reprehensible" to support an award of punitive damages. The Supreme Court recognized that "[e]vidence of actual harm to nonparties can help to show that the conduct that harmed the plaintiff also posed a substantial risk of harm to the general public, and so was particularly reprehensible," but it also cautioned that "a jury may not go further than this and use a punitive damages verdict to punish a defendant directly on account of harms it is alleged to have visited on nonparties."

The district court therefore decided as follows:

The argument here runs afoul of Williams, and thus the argument was improper for that reason. It also was improper because there was no evidence in the record about how many people were injected with BOTOX $^{\circledR}$ who thereafter sustained injury upon migration of the toxin to the central nervous system, much less to the brain. In other words, the contention was sheer speculation.

This is an example of a recent case in which a punitive damages due process principle introduced by the U.S. Supreme Court was applied by a lower American court.

\subsubsection{The 2008 Decision: Exxon Shipping Co. v. Baker}

The last substantive U.S. Supreme Court decision on the constitutionality of punitive damages that deserves attention is Exxon Shipping Co. v. Baker. ${ }^{280}$ Unlike the previous due process cases, in which single plaintiffs raised individual claims, the plaintiffs in the Exxon case were part of a mandatory, non opt-out class action for punitive damages. Furthermore, the Exxon case was unique in the sense that it addressed the issue of punitive damages as a common law remedy under federal maritime law. ${ }^{281}$ Due to the complexity of the case, this will be a concise description that focuses on the alleged excessiveness of the punitive damages award.

The decision forms the end of two decades of litigation resulting from the oil spill by supertanker Exxon Valdez into Prince William Sound, a part of the Bay of Alaska. The accident was caused due to a mistake made by the intoxicated captain, Joseph Hazelwood. The respondents Baker, who depended on Prince William Sound for their incomes, had brought a claim against Exxon for economic loss.

278 Ray v. Allergan, Inc., at 552.

279 Ray v. Allergan, Inc., at 565.

280 Exxon Shipping Co. v. Baker, 554 U.S. 471, 128 S.Ct. 2605 (U.S. 2008).

281 Sharkey 2009, p. 46, 53. 
The trial consisted of different phases in which the jury awarded \$287 million in compensatory damages to some of the plaintiffs (others had settled their compensatory claims for $\$ 22.6$ million), $\$ 5,000$ in punitive damages against Hazelwood and an exorbitant amount of $\$ 5$ billion against Exxon. The Court of Appeals for the Ninth Circuit granted remittitur and the punitive damages award against Exxon was reduced to the, still large, amount of \$ 2.5 billion. $^{282}$ The U.S. Supreme Court subsequently allowed the request for appeal.

The last of the three questions ${ }^{283}$ asked to the Court was whether the punitive damages awarded against Exxon in this case were excessive as a matter of maritime common law. The Court answered this question affirmatively and gave several arguments to support that conclusion. ${ }^{284}$ Most importantly, the Court focused on the problem of the unpredictability of punitive damages: ${ }^{285}$

\begin{abstract}
American punitive damages have come under criticism in recent decades, but the most recent studies tend to undercut much of it. Although some studies show the dollar amounts of awards growing over time, even in real terms, most accounts show that the median ratio of punitive to compensatory awards remains less than 1:1. Nor do the data show a marked increase in the percentage of cases with punitive awards. The real problem is the stark unpredictability of punitive awards.
\end{abstract}

According to Sharkey, the primary aim that the Court had while deciding this case was to find a solution to the problem of the unpredictability of punitive damages. ${ }^{286}$ The Court continued as follows with regard to the unpredictability issue: ${ }^{287}$

The Court's response to outlier punitive damages awards has thus far been confined by claims at the constitutional level, and our cases have announced due process standards that every award must pass. [...] Our review of punitive damages today, then, considers not their intersection with the Constitution, but the desirability of regulating them as a common law remedy for which responsibility lies with this Court as a source of judge-made law in the absence of a statute. Whatever may be the constitutional significance of the unpredictability of high punitive awards, this feature of happenstance is in tension with the function of the awards as punitive, just because of the implication of unfairness that an eccentrically high punitive verdict carries in a system whose commonly held notion of law rests on a sense of fairness in dealing with one another.

The Court found that a punitive damages award must be 'reasonable predictable in its severity'. ${ }^{288}$ It then considered three approaches towards a standard for assessing maritime punitive damages. The Court was skeptical about the first

282 Exxon, at $\S 471$.

283 Exxon, at $\S 481$. The first question whether maritime law allows corporate liability for punitive damages on the basis of the acts of managerial agents was answered affirmatively, whereas the second question whether the Clean Water Act forecloses the award of punitive damages in maritime spill cases was answered negatively. Both questions fall outside the scope of this case description.

284 Exxon, at $\S 490-515$.

285 Exxon, at \$ 497-499.

286 Sharkey 2009, p. 26

287 Exxon, at $\S 502$.

288 Exxon, at $\S 502$. 
approach, i.e. the use of verbal formulations or judicial review criteria to prevent unpredictable punitive damages awards. ${ }^{289}$ The Court also rejected the second option of quantified limits or setting a hard dollar cap on punitive damages awards. ${ }^{290}$ According to the Court, the best approach would be to use a ratio of the punitive damages to the compensatory damages: ${ }^{291}$

The question is what ratio is most appropriate. An acceptable standard can be found in the studies showing the median ratio of punitive to compensatory awards. Those studies reflect the judgments of juries and judges in thousands of cases as to what punitive awards were appropriate in circumstances reflecting the most down to the least blameworthy conduct, from malice to avarice to recklessness to gross negligence. The data in question put the median ratio for the entire gamut at less than 1:1, meaning that the compensatory award exceeds the punitive award in most cases. In a well-functioning system, awards at or below the median would roughly express jurors' sense of reasonable penalties in cases like this one that have no earmarks or exceptional blameworthiness.

Accordingly, the Court finds that a 1:1 ratio is a fair upper limit in such maritime cases.

To conclude, the Court applied the 1:1 ratio to the present case and relied on the District Court's calculation of the total relevant compensatory damages at $\$ 507.5$ million. Thus, that amount was also the maximum punitive damages award. The case was remanded for the Court of Appeals to reduce the punitive damages award accordingly. As mentioned, Exxon concerns maritime common law and is for that reason a rather specific punitive damages case. Nevertheless, as the Court established the 1:1 ratio in the context of the 'stark unpredictability of punitive awards', this case certainly gives an indication of the Court's opinion on punitive damages awards in general. ${ }^{292}$

\subsection{Concluding Remarks}

This chapter forms the third and final part of the introduction into American punitive damages law. In section 4.2, we have seen on the basis of empirical research that the rather condemnatory judgment of American punitive damages awards that many outsiders seem to have is exaggerated. In contrast to what is often believed, the frequency and the amount of punitive damages are not out of control. Although excessive and improper punitive damages have certainly been awarded by American courts, the criticism that most punitive damages awards are excessive and improper is unfounded and overgeneralised. The media and anti-punitive damages lobbyists contribute to the negative image that consists of American punitive damages awards by creating misunderstandings due to misleading information.

Criticism of punitive damages is however still part of the American punitive damages debate and cannot be neglected for the purpose of this book. In section 4.3, the main points of critique have been summarised. The main criticism of punitive

289 Exxon, at § 473, 503.

290 Exxon, at $\S 473$.

291 Exxon, at § 473-474.

292 Exxon, at $\S 472$. 
damages in the United States and in the rest of the world relates to the so-called public-private divide or the confusion of tort law and criminal law. Opponents of punitive damages primarily disagree with the civil remedy because the remedy has the nature of a civil penalty and is awarded without criminal procedural safeguards, such as the requirement of proof beyond a reasonable doubt, protection against selfincrimination and double jeopardy. Other points of critique relate to the vagueness of liability standards leading to unpredictable and excessive awards, the windfall effect of punitive damages, the ineffectiveness of the deterrent function, and the relation to litigation costs.

To conclude, section 4.4 has described the methods that the Americans use to control improper punitive damages awards. In order to put a stop to punitive damages that get out of control, American punitive damages law has been affected by two important developments. First, the law has been subjected to a number of legislative reforms to put an end to excessive and improper awards. Second, punitive damages awards are controlled by judicial review. Judicial review of punitive damages is a topic of much debate, particularly since the tort law reform movement that even attracted the attention of the U.S. Supreme Court. This Court has explored the constitutionality of punitive damages awards, especially under the Excessive Fines Clause and the Due Process Clause, and thereby it developed a framework that teaches lower courts how to prevent excessive and unreasonable awards. As mentioned above, the overview of U.S. Supreme Court decisions on the constitutionality of punitive damages provided in this chapter is not exhaustive. It is however safe to state that the most important decisions have been analysed. The decisions give a good insight into some of the major problems and controversies relating to American punitive damages law. Most important is that the U.S. Supreme Court has constantly emphasised the need for reasonable punitive damages awards, for example in relation to: the deterrent and retributive function of the award, the wrongful behaviour, the harm sustained, the compensatory damages awarded, and the criminal fines or civil penalties available for similar conduct. The Court however also stressed that it is impossible to draw a 'mathematical bright line between the constitutionally acceptable and the constitutionally unacceptable that would fit every case'. ${ }^{293}$ Furthermore, the Court has made clear that there should be proper jury instructions and judicial review. An important lesson that should be drawn from State Farm and Philip Morris USA is that punitive damages cannot be used to punish a defendant for wrongful harm to a third party. In its most recent decision Exxon Shipping Co. v. Baker, the Court addressed the problem of unpredictability of punitive damages. According to the Court, the best solution would be to use a ratio of the punitive damages to the compensatory damages: a 1:1 ratio is considered a fair upper limit. To conclude, note that not everyone is pleased with the Court's work. Zipursky for example refers to the Court's 'failure to come to terms with punitive damages and due

${ }^{293} B M W$, at $\S 582-583$. 
process'. ${ }^{294}$ Others, for example Gottlieb, argue that the legislative and the judicial control mechanisms undermine the functions of punitive damages: ${ }^{295}$

No matter what the facts are, there are still those who insist that lawmakers and the U.S. Supreme Court should interfere with the longstanding authority of the courts and restrict the ability of judges and juries to hand down punitive damages. The results have been devastating to the rights of consumers in specific states and the welfare of society as a whole.

It is probably right to argue that the U.S. Supreme Court has not solved all issues; however it did play an important role in the development of some guiding punitive damages principles that can be used by lower courts in order to prevent disproportionate awards, especially in light of excessiveness and due process. The fact that the punitive damages doctrine has survived several powerful constitutional attacks emphasises the firmness of the doctrine in American law. Twerski has put it as follows: ${ }^{296}$

For all of the trouble associated with the punitive damages doctrine, it will not go away. Although it may be curtailed or refined at times; the doctrine has staying power. If I am right that it serves as a voice of outrage for the body politic, then courts have a duty to assure that only cases that truly fit the profile of outrageousness are awarded punitive damages.

Chapters two, three and four have provided an introduction into American punitive damages law. This introduction addresses the first research question concerning the main characteristics of the civil remedy in American law, such as the functions of and conditions for awarding punitive damages. The next chapter will describe the main findings of this American introduction and concretises a number of aspects of American punitive damages law that are relevant and useful for the European punitive damages debate.

294 Zipursky 2012, p. 1772.

295 Gottlieb 2011, p. 10.

296 Twerski 1994, p. 361. 



\section{CHAPTER FIVE}

\section{THE PUNITIVE DAMAGES REMEDY IN AMERICAN LAW: A MID-TERM REVIEW}

\subsection{Introductory Remarks}

Before exploring the European punitive damages debate in chapters six to nine, it is useful to point out important conclusions from the previous chapters regarding American punitive damages law. In this chapter, some main findings of the introduction into American law will therefore be provided. This mid-term review does not entail a detailed repetition of, for example, the history and purposes of punitive damages or the conditions for awarding punitive damages. Rather, this chapter concretises a number of selected aspects of American punitive damages law and practice that are relevant for the European punitive damages debate, especially in respect of the largely negative idea that many outsiders seem to have of this civil remedy. As mentioned in chapter one, only a correct knowledge of the facts relating to this civil remedy can create the possibility to answer the question whether it has a future in continental Europe in a fair manner. The overview of relevant aspects derived from the American law description that will be presented in this chapter gives a good preparation to move on to the next chapters. This chapter thus also forms a connection between chapters two to four on the American situation and chapters six to nine on the European situation.

The following aspects have been selected and will be described in a concise manner: (a) the American legal system has a civil justice system (section 5.2); (b) criticism of American punitive damages law and practice has led to mechanisms to control improper punitive damages awards (section 5.3); and (c) allegations concerning the excessiveness of punitive damages awards therefore seem to be exaggerated (section 5.4).

\subsection{A Civil Justice System}

The first aspect of American punitive damages law that is relevant for the European debate does not concern the punitive damages doctrine as such. Nonetheless, the punitive damages doctrine is a relevant aspect as it gives us important information about the American context or setting in which punitive damages are available. This context is that of a civil justice system which, as explained in section 2.2.2, facilitates private enforcement. Americans are being raised with the idea that if they are wrongfully hurt by somebody, they can use their fundamental right derived from the Constitution and the Bill of Rights to hold the wrongdoer accountable in a civil court. Civil litigation and the right to sue are essential parts 
of American society. It is for this reason that the United States has become known as a compensation culture, but this terminology does not necessarily have the negative connotation as it seems to have in Europe. In the Netherlands, for instance, a socalled claim culture after the example of the American litigation system is considered undesirable. ${ }^{1}$ Although Europeans are also aware of their rights, it seems generally accepted that the right to sue is given more emphasis in the United States than in Europe. ${ }^{2}$ Empirical research however shows that even though the civil justice system is important in the United States, an excessive or out-of-control litigation system is not condoned nor does it exist there. ${ }^{3}$ As mentioned earlier, the picture that many outsiders have of the American tort system, which is painted mostly by the media and political tort reformers, is not entirely representative of the American system. In fact, tort cases form a relatively small percentage of civil lawsuits and tort damages are relatively modest in amount. Most American personal injury victims never come to litigation, and those that do often settle their tort claims out of court: the majority of tort claims are settled, and these settlements usually do not compensate the plaintiff completely. ${ }^{4}$ However, even though the civil justice system is in practice not as excessive as is often believed, it does play an important role in the United States. This is especially so in comparison to other legal systems: as mentioned above, there is a noticeable difference between the United States and Europe when it comes to civil litigation.

Along with the American civil justice system comes a procedural organisation that is - at least technically, as we need to keep in mind the large number of settlements mentioned above - well equipped for civil litigation and creates a legal climate in which civil litigation is made accessible. In this regard, a connection can also be made to punitive damages awards. For example, a relevant characteristic of the American legal system that is absent in continental European legal systems is adversarial legalism. An important element of adversarial legalism is strong legal penalties: the powerful punitive damages remedy is known as a civil sanction through which high standards of justice can be demanded. ${ }^{5}$ Also the American rule on litigation costs combined with contingency fees - firstly - facilitates access to court for everyone and gives an incentive to initiate civil proceedings, and secondly - influences the amount of the punitive damages award as courts will usually take litigation costs into account when determining this award. Procedural law mechanisms thus set up conditions and thereby indirectly enable the imposition of punitive damages awards.

It appears that the punitive damages remedy is indeed entrenched in the American legal system and that this is also the result of the laid-back role of the state and the importance attributed to the civil justice system. Although the United

1 Hartlief 2005, p. 830, citing Kamerstukken II 1998/99, 26 630, nr. 1, i.e. a letter in which the Dutch government expressed concerns regarding the rise of a claim culture. See also Kamerstukken II 2012/13, 31753 , nr. 62.

Section 2.2.3.

Section 2.2.3.1.

Baker 1998b, p. 212; Koenig 1998, p. 171, 208.

Section 2.2.2.1. 
States is not a purely reactive state, as the federal and state governments have intervened in a number of policy fields, the rather reserved role of the American government affects the objectives of judicial proceedings. The American civil justice system performs functions that in other modern jurisdictions are settled by governmental institutions. In the United States, public policy is privately enforced to a great extent, which means that enforcement of public norms is entrusted to private litigants and their lawyers. Punitive damages awards play a role in this. Apart from a punishing and deterring function, punitive damages have an important instrumental function: the civil remedy serves as an incentive for potential plaintiffs to initiate civil litigation as private attorneys general. ${ }^{6}$ The use of punitive damages may thus be explained by the modest role of the executive and regulatory arms of the American state as well as the position of the civil justice system in American society.

It is indeed difficult to see punitive damages as a remedy that works on its own. Rather, the remedy forms part of a predominantly well-functioning civil justice system that is supported by a set of procedural law mechanisms. The punitive damages remedy is not the only available legal instrument that gives an incentive to private litigants to start a lawsuit. The American legal system offers other mechanisms that may motivate potential plaintiffs, such as contingency fees and class actions. The civil justice system, including powerful civil sanctions such as punitive damages, can only be judged in consideration of the American legal context. The system functions rather well because of the comparatively reserved role for other compensatory and regulatory mechanisms such as public law enforcement, social security and private insurance. In comparison to the civil justice system in the United States, civil litigation and citizens who function as private attorneys general is an unknown phenomenon in Europe. European legal systems are not practically equipped for civil litigation to a similar extent as the American legal system.

Thus, the first important finding of the introduction into American law relates to the context in which punitive damages are available: the civil justice system. The punitive damages remedy forms part of a system wherein the citizen, civil claims and the civil justice system play a vital role in the process of dealing with everyday problems. Moreover, the European debate on problems relating to law enforcement and deterrence of wrongdoers gives us reason to believe that we should deal with these problems and could learn in this respect from the way in which they are addressed in the American legal system. European policymakers, legislators and courts should certainly not be influenced by fears of excessive punitive damages claims and the rise of a compensation culture. Based on the previous introduction into American law, the following two reasons to support this idea will be explained in the next sections: (1) criticism of American punitive damages law and practice has led to control mechanisms, and (2) often heard allegations concerning excessive, extreme and improper American punitive damages awards are exaggerated.

6 Section 2.2.2.2 


\section{3}

\section{Criticism Has Led to Control Mechanisms}

As we have seen in chapters two to four, American punitive damages law is an extensive legal area that cannot be described in a nutshell. As mentioned above, detailed aspects of the law will not be repeated here. Important at this point is that it is generally accepted in the United States that punitive damages are a form of penal remedy in civil law: the theory of punitive damages is neither completely civil nor criminal in nature. Furthermore, it is important to point out that, also in the American legal system, this mixed character seems to be the main reason for the controversy that has always surrounded the punitive damages doctrine. ${ }^{7}$ Criticism of punitive damages is as old as the legal remedy itself, and this book explicitly does not want to ignore this important aspect of American punitive damages law. ${ }^{8}$ This follows already from the attention paid, in chapter four, to legislative and judicial initiatives to control punitive damages awards, for instance in the U.S. Supreme Court decisions regarding the constitutionality of particular punitive damages awards.

The main point of critique in the American debate indeed relates to the so-called public-private divide and the fact that punitive damages have the nature of a civil penalty that is imposed without criminal procedural safeguards, such as the requirement of proof beyond a reasonable doubt, protection against self-incrimination and double jeopardy. Other points of critique relate to the vagueness of liability standards leading to unpredictable and excessive awards, the windfall effect of punitive damages, the ineffectiveness of the deterrent function, and the relation to litigation costs. The different points of critique have led to a number of control mechanisms to prevent excessive, extreme and improper punitive damages awards. Both the criticism and the control mechanisms provide interesting information with regard to the problem statement of this book - i.e. does the punitive damages remedy have a future in continental Europe? - and the related lessons and caveats that should be kept in mind by European punitive damages supporters and policymakers who consider the introduction of punitive damages.

To start with, an important lesson can be drawn from the American method of assessing punitive damages awards. Despite what is often believed, punitive damages are not available in the United States for all sorts of misconduct and can only be awarded if a number of requirements have been met. A first foundational requirement for a punitive damages award is the invasion of a legally protected interest. However, the sole fact that the defendant committed an unlawful act is not a sufficient basis for a punitive damages award: the unlawful behaviour must also involve a certain element of major aggravation. Lastly, the plaintiff must have suffered actual damage in order to obtain punitive damages. The rationale of the latter requirement is that conduct that caused no measurable objective injury should not be punished, which goes hand-in-hand with the principle that private individuals should not be encouraged to start litigation if they have suffered no

Section 2.3.2.

Section 4.3. 
injury. Note that, as explained in section 3.2.4, the majority of jurisdictions take the view that nominal damages are a sufficient basis for punitive damages. Thus, the following three general requirements in American law already determine some limits of awarding punitive damages: (1) the invasion of a legally protected interest by the defendant; (2) an element of major aggravation in the defendant's unlawful conduct; and (3) actual damage suffered by the plaintiff. Furthermore, through the years, a number of legislative and judicial methods have been introduced in the American legal system to put an end to excessive and improper awards.

Examples of legislative measures to control the imposition of punitive damages that could be relevant for Europe are the clarification of vague legal standards relating to measurement, liability and misconduct, the use of caps on punitive damages awards, permitting payment of (part of) the punitive damages award to the state or state agencies instead of to the plaintiff, separating questions of liability and compensatory issues from punitive damages issues, limiting punitive damages awards to one punishment for a single egregious act, and requiring a higher standard of proof for the recovery of punitive damages in comparison to the recovery of compensatory damages.

In respect of judicial review mechanisms, lessons can be drawn from a set of guidelines created by the U.S. Supreme Court to prevent improper awards, especially in light of constitutional safeguards relating to excessiveness and due process. Even though this court has made clear that it is impossible - and also undesirable given the functions of punitive damages - to draw a crystal-clear line between the constitutionally acceptable and the constitutionally unacceptable, the court has constantly emphasised the need for reasonable punitive damages awards. A punitive damages award should specifically be reasonable in relation to the deterrent and retributive function of the award, the wrongful behaviour, the harm sustained, the compensatory damages awarded and the criminal fines or civil penalties available for similar conduct. With regard to the relationship between punitive and compensatory awards, the median ratio of punitive to compensatory awards remains less than 1:1 in the majority of cases. ${ }^{9}$ The U.S. Supreme Court made clear in Exxon Shipping Co. v. Baker that a 1:1 ratio of punitive to compensatory damages is indeed seen as a fair upper limit. ${ }^{10}$ The Court established this ratio in the context of the 'stark unpredictability of punitive awards'. ${ }^{11}$

Note that an important reason for the necessity of these legislative and judicial reform mechanisms in the United States is the unclear situation that exists there because each American state has a different punitive damages regime. European national legislators who wish to incorporate the punitive damages remedy as part of their law of damages can prevent such a lack of clarity in advance by using a set of clear and consistent rules.

Section 4.2.2

Exxon Shipping Co. v. Baker, 554 U.S. 471, 128 S.Ct. 2605 (U.S. 2008), at § 473-474.

Exxon, at $\S 472$. 
A final important lesson that Europe can learn from American punitive damages law relates to the above-mentioned argument that is most often used by punitive damages opponents: the public-private divide or the confusion of tort law with criminal law. Even though this is also an issue of concern in the United States, it does not prevent the awarding of punitive damages by civil courts for the following reasons. First of all, the imposition of punitive damages in the United States is a choice of policy that cannot be impeded by the public-private divide. As will be further explained in section 6.3, the public-private divide traditionally weighs heavier in civil law systems than in common law systems. Common law lawyers also respect the division, but they do not put so much weight on it, which explains why punitive damages can be awarded in the absence of criminal procedural safeguards. ${ }^{12}$ This can be illustrated by the fact that a criminal conviction in principle does not bar the imposition of punitive damages for the same act in a civil lawsuit. The general idea is that the double jeopardy principle or ne bis in idem principle cannot be invoked to prevent the imposition of any additional civil sanction, as this principle only protects against the imposition of multiple criminal punishments for the same offence in successive proceedings. Furthermore, in order to solve the problem of lack of safeguards relating to the requirement of proof beyond a reasonable doubt, most states require clear and convincing evidence for punitive damages to be awarded. As regards protection against self-incrimination, the defendant is entitled to the privilege of protection against self-incrimination and the punitive damages defendant who is also charged with a crime is usually protected from self-incrimination by a suspension of the civil procedure. This obliges the plaintiff to wait until the criminal proceedings are closed. Nevertheless, not in the last place because of the criticism relating to the public-private divide and the lack of criminal procedural safeguards, American legislators and courts have generally taken the position that punitive damages should be awarded with great caution and that largely disproportionate awards should be avoided.

\subsection{Allegations Concerning Excessiveness Exaggerated}

What should also be taken into account by participants in the European punitive damages debate is that often heard allegations concerning excessive, extreme and improper American punitive damages awards are exaggerated. As was seen in chapter three, although punitive damages are in theory only recoverable for tort actions, the civil remedy is in fact available in an extensive number of actions based upon tortious behaviour, provided that the required aggravating circumstances are present and the plaintiff has suffered actual damage. ${ }^{13}$ This does not mean, however, that punitive damages are easily awarded by American courts. Empirical research has shown that American punitive damages awards are uncommon and rarely awarded and that both the incidence and the size of

12 Section 3.3.4 and section 4.3.2.1.

13 Section 3.2.1. 
American punitive damages awards are - in the main - not excessive. ${ }^{14}$ In this respect, the main findings of the introduction into American law will be summarised at this point.

Firstly, six major studies reviewing punitive damages verdicts from 1985 onwards disclose that punitive damages have been awarded in 2 to $9 \%$ of all cases that were won by the plaintiff. With regard to the size of these awards, the median was between $\$ 38,000$ and $\$ 52,000$ per award. ${ }^{15}$ Furthermore, a close correlation between the amount of compensatory and punitive damages has been found, which implies that punitive damages are not as unpredictable as often believed. ${ }^{16}$ The Bureau of Justice Statistics of the U.S. Department of Justice has also contributed - by the publication of three reports in 2005, 2009 and 2011 containing analyses of punitive damages application in the seventy-five most populous counties - to the awareness of application of punitive damages awards. Its report of 2011 for instance reveals that in 2005 punitive damages were sought in $12 \%$ of the approximately 25,000 tort and contract cases that were concluded in state courts. ${ }^{17}$ Punitive damages were awarded in $700(5 \%)$ of the 14,359 cases that were won by the plaintiff. The median award for these 700 cases was $\$ 64,000$, whereas in $13 \%$ of the 700 cases punitive damages of $\$ 1$ million or more were awarded. ${ }^{18}$ The report from 2009 only concerns state court tort trials in 2005. Punitive damages were awarded in 254 (3\%) of the 8,763 tort trials with plaintiff winners; the median punitive damages award in these cases was $\$ 55,000 .^{19}$

Secondly, a very interesting finding of American punitive damages law concerns the types of cases in which punitive damages are mostly awarded. ${ }^{20}$ Contrary to popular belief, punitive damages awards are relatively rare in cases concerning personal injury resulting from negligence, automobile accidents, medical malpractice, and products liability. These categories of cases actually play a minor role in American punitive damages law, at least in comparison to the popular punitive damages categories. Punitive damages verdicts are largely dominated by intentional torts such as battery and assault, defamation cases, and financial torts such as fraud and bad faith insurance. These figures are based on the 2011 report of the Bureau of Justice Statistics. ${ }^{21}$ The 2005 report containing data from 2001 reveals that in that year no more than $356(6 \%)$ of the 6,504 state court civil trials that were won by the plaintiff resulted in punitive damages. ${ }^{22}$ The types of tort cases in which punitive damages were mostly awarded in that year were libel and slander

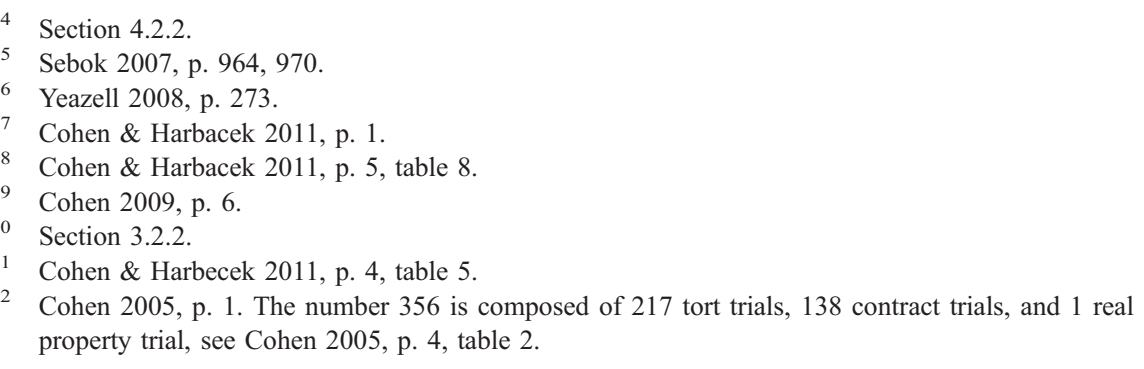


$(58 \%)$, intentional torts (36\%), and false arrest or false imprisonment $(26 \%)$. Of the contract cases, punitive damages were mainly awarded in partnership disputes (22\%), employment discrimination (18\%) and fraud cases (17\%). In half of the 356 trials, plaintiffs obtained a punitive damages award of $\$ 50,000$ or more. In 41 $(12 \%)$ of the trials resulting in punitive damages, damages that equaled or surpassed \$ 1 million were awarded and in $9(3 \%)$ trials punitive damages of $\$ 10$ million or more were awarded. The report estimates the median for punitive damages for the tort cases at $\$ 25,000$ and for the contract cases the median was estimated at $\$ 83,000 .^{23}$ A plausible explanation for these results is the aggravating element that is required for the imposition of punitive damages. This aggravating element is probably more often present when the cause of action falls within one of the three popular punitive damages categories, i.e. intentional tort, defamation or financial tort, than in personal injury cases resulting from negligence, automobile accidents, medical malpractice, and products liability. However, it must be remembered that the relatively low percentage of punitive damages awarded in the latter categories in comparison to the other categories obviously does not mean that punitive damages are never awarded in such personal injury cases.

An important research result in respect of the main focus of this book is that the categories of wrongful behaviour in which punitive damages could especially play a role in continental Europe are known in American law as intentional torts, defamation and financial torts. These three categories cover both intentional and grave wrongdoing, which particularly applies to the intentional torts and calculative wrongdoing, for example defamation and fraud. This seems to be in line with the above-mentioned attention in Europe for powerful civil remedies to improve the enforcement of tort law standards and deal with intentional, calculative and grave misconduct. ${ }^{24}$ This development, which is an important reason for the increased European interest in the punitive damages remedy, will be explained in chapter seven.

Thirdly, as regards the assessment and amount of punitive damages, we have seen that punitive damages issues are normally decided by both trial court and jury. It is generally argued that the size and amount of punitive damages will be smaller if such claims are decided by judges instead of jurors. Jury punitive damages awards are criticised because juries are believed to be more biased, irrational and emotionally in support of the plaintiff than judges. Empirical research into decision-making of judges and jurors shows that this assertion is not necessarily correct. $^{25}$ The already mentioned study of the Bureau of Justice Statistics containing data from 2001 reveals that in 6,504 civil trials plaintiffs received punitive damages in $6 \%$ of jury trials and $4 \%$ of court trials. ${ }^{26}$ Furthermore, the median punitive damages awarded by juries amounted to $\$ 50,000$, whereas courts

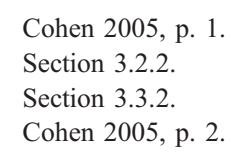


awarded $\$ 46,000$. Of the 260 jury trials in which a plaintiff obtained punitive damages, $14 \%$ resulted in an award of $\$ 1$ million or more. Punitive damages of $\$ 1$ million or more were awarded in $2 \%$ of the 79 court trials with punitive damages. These latter figures do show that juries are slightly more inclined to award large punitive damages awards than judges are. Thus, the skepticism that surrounds jury punitive damages awards has been put into perspective. Europeans should therefore not unquestioningly accept the idea that juries contribute to excessive punitive damages awards in the United States, nor should they be put off by it. This idea seems to be a misconception, just as the many other misconceptions that are often brought forward in the punitive damages debate. Even though this theme is not really relevant for the European debate due to the absence of a jury system in continental European legal systems, it is a valuable and striking research result which should lead to the conclusion that the excessiveness of punitive damages awards by juries should not play a major role in the European punitive damages debate.

Lastly, although Europeans might believe otherwise, in the American legal system, value is attached to the general principle that the punitive damages award should be reasonable and should not go beyond what is necessary to achieve its goals. In assessing the amount of the punitive damages award, the trier of fact can consider the character of the defendant's act, the nature and extent of the harm that the defendant caused or intended to cause, and the wealth of the defendant. The fact that a defendant gained money from his wrongful act can also influence the size of the punitive damages award. Draconian punitive damages awards are generally not allowed. There must be a reasonable relation to the harm done to the plaintiff and to the potential harm. Furthermore, in some jurisdictions the reasonable ratio rule applies, meaning that there must be a reasonable relation to the amount of compensatory damages awarded. However, due to the mainly noncompensatory purpose of punitive damages, a relationship between punitive and compensatory damages is not required by most courts. Note that the U.S. Supreme Court does consider the ratio between the punitive and compensatory award a relevant factor that should be used by trial and appellate courts in evaluating whether a punitive damages award is unconstitutionally excessive. Although the Court has made clear on more than one occasion that it is impossible and undesirable - given the functions of punitive damages - to draw a clear line between the constitutionally acceptable and the constitutionally unacceptable in all circumstances, the Court has given further guidance to lower courts on what is considered a fair ratio between punitive and compensatory awards. As explained in section 4.4.4.3, in Exxon Shipping Co. v. Baker the Court addressed the problem of the unpredictability of punitive damages awards and decided that a $1: 1$ ratio is a fair upper limit. ${ }^{27}$

To conclude, although information with regard to the entirety of American punitive damages verdicts cannot be given as there is no empirical research available to that extent, the existing data does show that the criticism relating to the

27 Exxon Shipping Co. v. Baker, 554 U.S. 471, 128 S.Ct. 2605 (U.S. 2008), at § 472-474. 
frequency and amount of American punitive damages awards is exaggerated and often based on preconceived ideas. Furthermore, as was seen in chapter four, misunderstandings brought forward by media and anti-punitive damages lobbyists largely explain the negative image that is portrayed of American punitive damages awards. The conclusion that both the frequency and amount of punitive damages awards are not 'skyrocketing' nor 'out of control' can be considered a plausible one. This is an important research result in light of the often heard negative perception that outsiders have of American punitive damages law which is allegedly surrounded by excessiveness. As was seen in chapter one, the objective of this book is to increase the understanding of the punitive damages remedy; only a correct knowledge of the facts relating to this civil remedy creates the possibility to answer the question whether it has a future in continental Europe in a fair manner. Participants in this debate should be aware of the fact that American punitive damages awards are generally neither extreme nor common, which is an often suggested misconception.

\subsection{Concluding Remarks}

This chapter has provided three points of special interest with regard to American punitive damages law. Firstly, the American legal system has a civil justice system in which the punitive damages remedy plays a vital role. Secondly, also in the American legal system, the punitive damages remedy is considered a controversial civil remedy, but this critique has led to a set of control mechanisms that help to prevent excessive, extreme and improper punitive damages awards. Thirdly, despite what is often suggested by outsiders, American punitive damages awards are in fact uncommon and rarely awarded. In the American legal system, a lot of attention has been and is being paid to the necessity of reasonable punitive damages awards.

These three findings concerning the acceptance and application of punitive damages in the United States should help to put the largely negative perception that many outsiders seem to have of the civil remedy into perspective. This is especially interesting for those who participate in the European punitive damages debate: understanding of the American savoir faire with regard to punitive damages is helpful when examining the question whether the remedy has a future in continental Europe.

The introduction into American punitive damages law has provided a firm foundation upon which to continue with the remainder of this book: chapters six to nine which relate to the European punitive damages debate. In order to be able to analyse the problem statement adequately, a number of issues will be addressed in these chapters. To start with, chapter six will deal with the underlying reasons for the non-existence of punitive damages in continental Europe. 


\section{CHAPTER SIX}

\section{REASONS FOR THE NON-EXISTENCE OF PUNITIVE DAMAGES IN CONTINENTAL EUROPE}

\subsection{Introductory Remarks}

The previous chapters provided an overview of the core characteristics of American punitive damages law. This formed an answer to the first research question, which was a basic requirement for analysing the problem statement of this book. As explained in chapter one, the other essential research questions relate to (1) the underlying reasons for the non-existence of punitive damages in continental European legal systems; (2) the developments that illustrate the increased European interest in punitive damages as well as the explanations for these developments; (3) the status quo of punitive damages rejection in Europe; and (4) the existence of civil sanctions, especially sanctions that bear a resemblance to the punitive damages remedy, in a number of European legal systems.

Chapters seven, eight and nine will focus on the last three topics mentioned. This chapter will focus on the first topic: the reasons for the non-existence of punitive damages in continental Europe. The fact that there is more and more attention for punitive damages does not mean that the civil remedy is suitable for continental European legal systems. The punitive damages remedy is not an accepted remedy in continental Europe. The only countries in Europe that do accept a restricted form of punitive damages are England and Wales, Ireland and Cyprus. These countries are indeed not situated on the European continent and have a common law or mixed legal system. ${ }^{1}$

In this chapter, the traditional explanations for the non-existence of punitive damages on the European continent will be provided. At least three reasons seem to prevent the existence of punitive damages in civil law systems. ${ }^{2}$ The first reason is that this legal remedy is considered inconsistent with the traditional functions of private law, in particular tort law. The second reason, which relates to the first, is that there is fundamental rejection due to the division between public law and private law. The third reason is that different views on the role of government may explain the absence or presence of punitive damages in a certain legal system. The different views that will be dealt with in this chapter concern the values attached to private enforcement, government regulation, the importance of compensation mechanisms other than tort damages, and the influence of procedural law aspects. Although the views relating to the role of government are seen from a broader 
perspective and focus on the impact they have on civil litigation in general, the differences have implications for the use of punitive damages as well.

These three reasons, which form the main explanation for the rejection of punitive damages in continental European legal systems, will be dealt with in sections 6.2 to 6.4 . Section 6.2 will consider the functions and practice of tort law. The division between public law and private law and several arguments relating to this subject will be discussed in section 6.3 , whereas section 6.4 deals with the different arguments in relation to the view on the role of government. To conclude, section 6.5 explains some other relevant (dogmatic) reasons against punitive damages that are often put forward in the European punitive damages debate.

\subsection{There is the Traditional Function of Tort Law...}

The first reason for the absence of punitive damages in continental Europe relates to the traditional compensatory function of civil damages. As punitive damages are in principle available under American law for aggravated tortious behaviour, the focus will be on tort law and tort damages. ${ }^{3}$ In this section, the universal approach to the functions and practice of tort law will be described. The primary function of tort law is compensation of the injured person for the actual loss he has suffered. ${ }^{4}$ As will be explained in section 6.2.2.1 below, historically tort law had a clear punitive character in addition to its compensatory function in both common law and civil law systems. But unlike in common law systems, punishment has not become a recognised function of modern tort law in European civil law systems. This is the first reasonable argument that can be put forward in answering the question why the punitive damages remedy is not an accepted civil remedy in continental Europe.

\subsubsection{The Starting Point}

Tort law in general, this means universally accepted, concerns the obligation of citizens to respect each other's safety, property and personality and for that reason lays down rules of proper social conduct. ${ }^{5}$ From the perspective of the victim, the ground or foundation of tort law is the protection of the status quo ante. ${ }^{6}$ This principle is often bracketed together with the principle restitutio in integrum, a general principle underlying tort law that can be explained as either restoration in kind or monetary compensation. ${ }^{7}$ Further information on this principle will be provided in section 6.2.2.2 below concerning the compensatory function of tort law. There is both an ex ante and an ex post approach to tort law: improper harm to

3 Although this forms the starting point, as explained in section 3.2.1, American courts award punitive damages in all sorts of situations, including contract cases.

Deakin, Johnston \& Markesinis 2008, p. 52.

Owen 1995, p. 7; Deakin, Johnston \& Markesinis 2008, p. 19.

Hartlief 1997, p. 15; Van Gerven, Lever \& Larouche 2000, p. 33; Lindenbergh 2008c, p. 7-9.

See for instance Owen 1995, p. 21; Van Gerven, Lever \& Larouche 2000, p. 770. 
others should be avoided, and wrongfully caused harm should be compensated. Tort law protects the rights of injured persons and determines under what conditions it is justified to place the injured person in the situation he would have been in but for the tort. Therefore, the important question in tort law is: when is compensation for harm appropriate? It is obviously impossible to have all losses compensated: ${ }^{8}$

There is no plausible moral argument for requiring others to compensate every person for every loss no matter how it occurred, and neither tort law nor law in general makes any attempt to achieve such universal compensation.

Now that we have seen that an important ground of tort law is the protection of the status quo ante, two other long accepted grounds that play a central role in tort law should be pointed out. These principles are related to each other but, as they both lead to a different result, the rules of tort law should find a balance between the two that is in accordance with societal conditions. ${ }^{9}$ The first is the principle casum sentit dominus or res perit suo domino, meaning that the owner bears the damage. The second is the principle alterum non laedere, which means that one should not injure others and that damage of others should be prevented. The first principle, these days also translated as 'the loss lies where it falls', is explained as follows by Zimmermann: ${ }^{10}$

It is the owner who has to bear the risk of accidental loss or destruction and, except by way of insurance, he cannot shift the risk onto somebody else's shoulders.

As long as there is no specific reason to shift the loss, the harmed person has to bear the loss. The above-mentioned balancing of principles then leads to the result that a victim's damage falls within his own risk of life, in Germany known as das allgemeine Lebensrisiko. ${ }^{11}$ According to Holmes: ${ }^{12}$

Sound policy lets losses lie where they fall, except where a special reason can be shown for interference.

Tort law points out the special reasons, in particular when the loss was caused as a result of the tortfeasor's culpa (fault) and dolus (intent), but even if the loss is accidental there may be a good reason for shifting the loss. ${ }^{13}$ Thus, tort law lays down rules to distribute responsibility for losses. ${ }^{14}$ The reasons to shift losses are

Wright 1995, p. 157.

Asser/Hartkamp \& Sieburgh 2011/18; Van Maanen 2012, p. 2, 7. See for an overview of the grounds of tort law also Engelhard \& Van Maanen 2008, p. 1-7.

Zimmermann 1992, p. 154.

11 Asser/Hartkamp \& Sieburgh 2011/20.

12 Hartlief 1997, p. 11, citing O.W. Holmes, Jr., The Common Law, 1923, p. 50. See also Deakin, Johnston \& Markesinis 2008, p. 55.

13 Zimmermann 1992, p. 154.

14 Rogers 2006, p 2. 
subject to change due to varying social and political desires. ${ }^{15}$ Tort law has some common characteristics that can be found in each legal system. Even so, it should be kept in mind that approaches towards tort law may also differ per country. This has to do with the 'high policy impact' of tort law, which results in different views on the most favourable approach. ${ }^{16}$ In this respect, a very good example is the awarding of punitive damages in common law systems, whereas civil law systems oppose this practice. Furthermore, per legal system one will find differences with regard to, for example, the impact of strict liability rules and the liability of public authorities.

On a broader level, in each legal system the function of tort law and the kind of justice that is pursued may differ to a greater or lesser extent. ${ }^{17}$ This is relevant in view of the main focus of this book, because the punitive damages doctrine can be explained by the underlying theories of tort law. From a general tort law perspective, a lot of attention has been paid to the theories of corrective justice and distributive justice - which goes back to Aristotle who already distinguished these forms of justice - in order to explain different contemporary views on tort law. ${ }^{18}$ The theories of corrective and distributive justice are principles of justice that form a justification for tort law. ${ }^{19}$ Corrective justice is about the 'fairness of interactions between individual persons, ${ }^{20}$ and correcting or restoring wrongs that occur in bilateral relationships, which is also denoted by the term 'correlativity'. 21 Honoré explains the corrective justice theory as follows: ${ }^{22}$

On a wide view it requires those who have without justification harmed others by their conduct to put the matter right. This they must do on the basis that harm-doer and harm-sufferer are to be treated as equals, neither more deserving than the other. The one is therefore not entitled to become relatively better off by harming the other. The balance must be restored.

On the contrary, distributive justice is concerned with the needs of society as a whole and a fair distribution of goods, such as the distribution of losses as well as disadvantages of risky activities. ${ }^{23}$ An important aspect of this risk distribution is the balance between the freedom of individuals to take risks and the responsibility of others to limit such risks. ${ }^{24}$ The distributive justice theory is the starting point for economic approaches to tort law, whereas the corrective justice theory is considered a challenge to the economic view. ${ }^{25}$

15 Hartlief 1997, p. 24

16 Van Dam 2013a, p. 144.

Van Dam 2013a, p. 144.

Gordley 1995, p. 132.

Clerk et al. 2006, p. 7

Beever 2008a, p. 476.

Cane 1996, p. 471.

Honoré 1995, p. 78-79.

Van Dam 2013a, p. 145; Keating 2000, p. 194; Honoré 1995, p. 83. See also Sheinman 2003; Coleman 1995.

24 Clerk et al. 2006, p. 9.

25 Coleman 1995, p. 57, footnote 13; Keating 2000, p. 195; Sheinman 2003, p. 22. 
Tort law is traditionally a system of corrective justice. ${ }^{26}$ Corrective justice is considered the dominant theory: the victim's right to compensation and the tortfeasor's duty to compensate is based on this theory. ${ }^{27}$ However, the introduction of strict liability rules and the focus on notions of fairness, justice and reasonableness has placed more weight on the importance of distributive justice. ${ }^{28}$ The issue of corrective or distributive justice in tort law remains complex: ${ }^{29}$

The truth is that tort law is a mosaic in which the principles of corrective justice and distributive justice are interwoven. And in situations of uncertainty and difficulty a choice sometimes has to be made between the two approaches.

By analysing tort law in a given legal system, one can determine whether the main focus is on corrective or distributive justice. This has for example been done in respect of some European countries by Van Dam, according to whom French tort law is predominantly about distributive justice, as it is very much focused on compensating and protecting victims and for that reason has a lot of strict liability rules. $^{30}$ English tort law, on the other hand, is primarily focused on corrective justice and regulating conduct, and it is therefore predisposed to fault liability rather than strict liability. It is thus important to understand underlying theories and to remember that differences between tort systems are in the first place caused by diverging cultures and policy approaches. ${ }^{31}$

As stated above, the underlying reasons of tort law might also explain the different values attached to the role of punishment in private law. According to Beever: ${ }^{32}$

The different attitudes to the role of punishment in private law exhibited by civil and common lawyers is explained, in part, by different understandings of the kind of justice relevant to that law. For the civil lawyer, at least traditionally, private law was concerned with corrective justice and so allowed no room for punishment. For the common lawyer, on the other hand, private law is about a mixture of distributive and retributive justice. Accordingly, the common lawyer tends to find the idea that punishment has a place in private law quite intuitive.

Even though, as pointed out by Van Dam, tort liability is generally about compensation and not about punishment the obligation to pay compensatory damages may also have a corrective function; the preventive and punitive function of tort damages thus, in a way, also forms an application of the corrective justice theory. ${ }^{33}$ There is no complete agreement in American literature on the question whether the punitive damages doctrine forms part of the corrective justice theory,

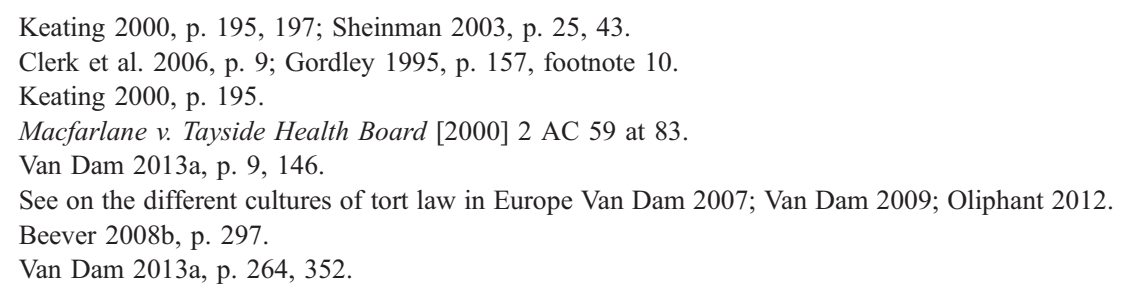


the distributive justice theory or some other justice theory of tort law. Like Beever, most authors seem to exclude punitive damages from the ambit of corrective justice, as such damages are essentially punitive and not reparative. Some have introduced a form of justice that includes punitive damages: retributive justice. ${ }^{34}$ Beever explains quite clearly why retributive justice is the leading theory in the common law tort systems: ${ }^{35}$

It is the retributive justice model that dominates. This is the common law model for understanding tort law. The rights upon which tort law is based are justified by distributive justice and responses to the violation of those rights proceed in accordance with retributive justice. Tort law has the same structure as criminal law. It is no surprise, then, that many common lawyers think that punishment has a legitimate role to play in private law and greet the view that punishment is necessarily out of place in that law with bewilderment.

Clerk et al. also notice that a plaintiff's right to sue a wrongdoer for compensation must be based on some principles of justice. According to them, the justification for tort law can be found in a combination of corrective, distributive and retributive justice theories. ${ }^{36}$ In the retributive theory, a punitive sanction is considered the best remedy for crimes and torts. On the other hand, according to Sheinman and Nezar punitive sanctions do form part of the corrective justice theory which is in line with the just mentioned words of Van Dam. ${ }^{37}$ To conclude, the starting point in tort law is that different justice theories are used to explain the differences between tort systems, also in respect of the punitive damages doctrine. This means that it is important to understand the underlying theories of a certain tort system in order to find out whether the punitive damages remedy can be introduced there.

\subsubsection{The Functions of Tort Law}

The aforementioned ground of tort law, that is protection of the status quo ante, is the main factor which justifies the obligation that may be imposed on the tortfeasor for committing the tort. This means that in the absence of this ground there is no justification. The ground needs to be distinguished from the functions of tort law. The ground as such gives no information about the functions, i.e. the intended purpose of protecting the status quo ante and the question when there is a right to such protection. ${ }^{38}$ This section will therefore explore the functions of tort law, which have been subject to change over time. ${ }^{39}$ To understand such developments, it is important to look briefly into the historical evolution of tort law. Subsequently, the recognised functions of tort law will be discussed one by one.

34 Sheinman 2003, p. 66. See also Markel 2009b, p. 1386: 'punitive damages should be understood and restructured to advance the public's interest in retributive justice'.

35 Beever 2008b, p. 290.

36 Clerk et al. 2006, p. 7.

37 Sheinman 2003, p. 66; Nezar 2011, p. 718.

38 Hartlief 1997, p. 16; Engelhard \& Van Maanen 2008, p. 11.

39 Deakin, Johnston \& Markesinis 2008, p. 50. 


\subsubsection{Some Remarks on the Legal History of Tort Law}

In the Roman period, there was no real division between public law and private law. Instead, a mixed system of criminal law existed. ${ }^{40}$ According to Shelton: ${ }^{41}$

Early legal systems unified the goals of redress, deterrence, and punishment and failed to distinguish between public and private law when an individual committed a wrong; punishment of the perpetrator and justice for the victim usually were merged through victim self-help encouraged or regulated by law.

Ancient Roman law had a system of private criminal law that was used for the majority of delicta privata. Public criminal law, on the contrary, was underdeveloped because state authority was weak and unable to enforce the law, impose criminal sanctions and compensate victims. ${ }^{42}$ High treason or serious sacral offences were examples of crimina publica that could lead to public prosecution. ${ }^{43}$ These offences were considered to affect the community at large in a severe way. In the case of other offences, including theft (furtum), robbery (rapina), destruction (damnum inuria datum) and defamation (inuria), interference of the state was not required and the victim was allowed to take the law into his own hands. ${ }^{44}$ Roman citizens thus played an important role as private attorneys general, just like American citizens nowadays do. Most ancient Roman law enabled an injured person to acquire, by court order, a hold on the body of the wrongdoer which usually resulted in the imprisonment of the wrongdoer. However, the sanction to graver delicta could also be the chastising or even killing of the wrongdoer. ${ }^{45}$ Thus, the victim of a private wrong was in certain situations allowed to kill his wrongdoer. As this was considered a very harsh solution, the state began to exercise some control over such matters. Excessive injuries to the wrongdoer were no longer allowed: according to the newly imposed lex talionis (Retaliation Act) the victim could not inflict more bodily harm on the wrongdoer than was done to himself: 'an eye for an eye and a tooth for a tooth' ${ }^{46}$ This rule can be traced back to the Old Testament, for example the book of Exodus: ${ }^{47}$

$[\ldots]$ if any harm follows, then you shall give life for life, eye for eye, tooth for tooth, hand for hand, foot for foot, burn for burn, wound for wound, stripe for stripe.

Because this 'restricted' form of revenge was still considered to be quite cruel, the law further developed and the wrongdoer could be set free after having paid a civil fine (poena) to the victim, which prevented the victim from pursuing his own justice by taking control over the wrongdoer's life. This monetary sanction, which

40 Asser/Hartkamp \& Sieburgh 2011/3-5.

41 Shelton 2005, p. 23.

Zimmermann 1992, p. 2, 914, 918; Spruit 2001, p. 362

Zimmermann 1992, p. 917; Ahsmann 1995, p. 11.

Spruit \& Feenstra 1989, nr. 25; Spruit 2001, p. 362-364; Hallebeek 2014, p. 17.

Zimmermann 1992, p. 3; Ahsmann 1995, p. 12.

Zimmermann 1992, p. 3.

Exodus, 21. 
was comparable to the modern punitive damages remedy, had the function of punishing the wrongdoer's behaviour and thereby buying off the victim's vengeance. $^{48}$

Punitive and compensatory elements were not only combined in the law of delict in the legal systems in the Roman law tradition, i.e. the civil law systems, they were also combined in tort law in the common law sytems. ${ }^{49}$ Beever explains this as follows: ${ }^{50}$

\footnotetext{
In their beginnings, both the common law of tort and the civil law of delict had 'a strongly criminal flavour'. Both combined punitive and compensatory elements to such a degree that it is impossible clearly to distinguish penal from tort law in those jurisdictions. However, as each developed, the punitive parts of the law of tort gradually separated, giving rise to or completing criminal law. But the extent of the development differs between the traditions. In most civilian jurisdictions, tort law entirely surrendered its punitive elements. [...] On the other hand, common law has retained punishment in the form of exemplary or punitive damages.
}

The functions of tort law, at the time when it was inseparable from criminal law, were primarily punishment, retribution and appeasement. This was even still the case in the nineteenth century. Englard for example explains the following about Von Jhering's attitude towards punitive damages: $:^{51}$

He moved from his earlier fierce opposition to private punishment to strongly support delictual liability's retributive and deterrent functions.

Moreover, Wagner and Von Bar refer to the work of Von Savigny who was of the opinion that the law of delict did not only have a compensatory function but also a retributive function to deter and reform. ${ }^{52}$ Although these are still considered functions of tort law in our time, it is generally agreed that the function of punishment should nowadays be primarily left to criminal law. The best example as regards the current punitive function of tort law is indeed - not surprisingly that of punitive damages awarded in common law systems for outrageous tortious behaviour. On the contrary, civil law systems do not have punitive elements in tort law to a similar extent as common law systems do. Wagner rightly points out that the common law of torts is therefore, ironically enough, more closely related to classical Roman law than continental European tort systems. ${ }^{53}$ In continental European legal systems, punitive elements in tort law do exist but on a limited scale and not without criticism. ${ }^{54}$ According to Englard: ${ }^{55}$

48 Zimmermann 1992, p. 3; Hartlief 1997, p. 17; Spruit 2001, p. 364; Lokin 2003, p. 30-33; Deakin, Johnston \& Markesinis 2008, p. 50; Hallebeek 2014, p. 17, 22.

49 Edelman 2008, p. 228; Jansen 2012, p. 1038

50 Beever 2008b, p. 249

1 Englard 2012, p. 5.

2 Wagner 2012, p. 1403; Von Bar 1998, p. 628.

Wagner 2012, p. 1403

54 For criticism in Dutch literature, see Asser/Hartkamp \& Sieburgh 2011/8; Bloembergen \& Lindenbergh 2001, p. 15; Lindenbergh 2008c, p. 15; Blaauw 1988, p. 10; Stolker 1995, p. 41.

55 Englard 2012, p. 6. See also Koziol 2009, p. 284-287; Coderch 2001, p. 605-606. 
In principle, Continental European legal systems disapprove of punitive damages. Nevertheless, in some systems there are hidden practices of awarding damages in specific circumstances that may have a punitive dimension.

As will be further explained in section 9.4.1.3, an example in Dutch law is article 6:104 BW on disgorgement of profit obtained as a result of tortious conduct. Disgorgement of profit has the aim of preventing the tortfeasor from being unjustly enriched by his tortious behaviour. The focus is in that way not on the compensatory function of tort law, as the harm done to the victim may be less than the profit gained by the tortfeasor. ${ }^{56}$ The question concerning the already existing civil sanctions in continental European legal systems is relevant for analysing the problem statement. Historically, given the combination of punitive and compensatory elements in the Roman law of delict, this question is well explicable: although a punitive function of tort law is theoretically no longer accepted, continental European legal systems might in practice - albeit to a lesser extent - still adhere to the Roman law approach of combining the functions of punishment and compensation. As will be shown in chapter nine, an example that is often mentioned in this respect is that of immaterial damages awards. Hallebeek for instance makes clear that although the present acceptance of liability for immaterial loss is dogmatically seen as an enormous difference compared to the punitive character of the Roman law of delict, from a functional point of view this difference should be put into perspective. He points out that the function of the immaterial damages award, which was introduced when the law of delict lost its punitive function, is comparable to the function of the ancient poena. ${ }^{57}$ In respect of chapter nine, especially civil sanctions that bear a resemblance to the punitive damages remedy may be indicative for participants in the European punitive damages debate, in the sense that their existence renders often heard arguments against punitive damages such as the compensatory function of tort law and the public-private divide unfounded. For that reason, close attention will be paid to this subject in chapter nine where analyses of civil sanctions in the Dutch, German, French, and English legal systems will be given.

Before going into the contemporary functions of tort law in European civil law systems, some final remarks on the historical development of tort law should be made. For that it is appropriate to go back to the poena mentioned above. Initially the sum was negotiable, later a fixed sum was attached to each specific wrong depending on the nature of the delictum privatum. But if the wrongdoer was unable to pay, the victim regained his right of vengeance. The legal right to a poena developed from a buy-off into a form of penalty that was enforced in a civil procedure via the so-called actio poenalis. ${ }^{58}$ For example, in case of theft the poena could be the double amount (actio furti nec manifesti) or the quadruple amount (actio furti manifesti) of the stolen thing, whereas in case of personality

\footnotetext{
Van Gerven, Lever \& Larouche 2000, p. 741.

Hallebeek 2014, p. 23-24. See also Lokin 2003, p. 33-34

Spruit 2001, p. 362; Zimmermann 1992, p. 3, 914-915.
} 
right infringements the judge could impose every reasonable amount (actio iniuriarum). ${ }^{59}$

The poena was not meant as a means to compensate the injury but, as mentioned above, rather it took the form of punitive damages. ${ }^{60}$ Then, slowly but surely, due to the influence of canon law, one started to believe that the delictum privatum itself formed a basis for the obligation to pay a sum of money. The focus shifted from punishment of the wrongdoer to satisfaction of the victim (satisfacere). ${ }^{61}$ In other words: the money paid by the wrongdoer was no longer primarily meant as a penalty but rather as compensation for the injury done to the victim, which is to the present day the general belief in civil law systems. Shelton puts it as follows: ${ }^{62}$

It has been suggested that the law of remedies developed in legal systems to replace private revenge. Roman law came to permit wrongdoers in certain cases to pay compensation in money or in kind. The offer of the appropriate amount excluded the right to take revenge.

Committing a private wrong would from then on create a civil law obligatio ex delicto to pay compensation. ${ }^{63}$ Due to this process of the development of the law that had taken place over centuries, the law of delict had become a separate area of law. Another important reason that contributed to this separation was the development of a stronger public criminal law from the thirteenth century onwards: punishment of wrongful conduct was from then on left to public law mechanisms. $^{64}$

The roots of tort law lie in Roman law, but also the common law has played a vital role in the development of modern tort law. Koenig and Rustad explain how tort law became a separate branch of the law in common law systems, especially preindustrial America and England, in the middle of the nineteenth century. ${ }^{65}$ Early common law torts particularly corrected intentional behaviour that threatened the individual, the family, and the community. The idea of tort law in the time prior to industrialisation was to preserve the social order in the smaller, mostly rural, communities. Then, in the period of developing industries, technology and infrastructure, the negligence principle was created and tort law became an instrument that 'belonged to the corporate defense': most injuries were seen as unavoidable costs of industrialisation, whereas it was quite clear that the promotion of industrial progress was considered most important and that the burden of injuries was generally left to the victim. ${ }^{66}$ An exception is formed by railway

59 Spruit \& Feenstra 1989, nr. 24, nr. 71; Spruit 2001, p. 365.

60 Zwalve 1995, p. 23; Feenstra 1984, p. 163; Bloembergen \& Lindenbergh 2001, p. 12; Kortmann 2009, p. 17.

61 Hallebeek 2014, p. 22; Spruit 2001, p. 363.

62 Shelton 2005 , p. 24.

63 Von Bar 1996, p. 5.

64 Hallebeek 2014, p. 22.

65 Koenig \& Rustad 2001, p. 12. See for a historical overview of American tort law also White 2003.

66 Koenig \& Rustad 2001, p. 12. This does not mean that liability for negligent behaviour was never accepted in the nineteenth century. See for this topic in Dutch literature Van Maanen 1999. 
accidents, which dominated the law of negligence in the late nineteenth century. ${ }^{67}$ After World War II, tort law expanded into a victim-friendly field of law, in which more and more possibilities were created for victims to obtain compensation for accidents. Of course, tort law developed in a comparable manner in industrialised countries other than America and England. Due to the increased reliance on tort law to deal with wrongful situations, tort law nowadays seems to be the driving force behind the aforementioned compensation culture that is noticeable not only in the United States but also, albeit to a lesser degree, in Europe. ${ }^{68}$

The main conclusions that can be drawn from this historical development of tort law are: (1) although in both common law and civil law systems tort law historically had a clear punitive character in addition to its compensatory function, modern civil law systems hardly accept - at least theoretically - punitive elements in tort law whereas common law systems do accept a general punitive function, for example in the form of punitive damages, and (2) tort law nowadays plays a rather important role as a compensation mechanism to deal with the many wrongful and harmful situations that occur in our modern society.

Following this historical description of tort law, the next subsections will describe the separate functions of modern tort law in European civil law systems.

\subsubsection{Compensation as the Traditional Function}

It is generally believed that the primary function of modern tort law is the compensation of the injured person for the actual loss he has suffered. ${ }^{69}$ This function is usually realised by awarding monetary damages, as reparation in kind is often not possible or out of place. ${ }^{70}$ Thus, monetary compensation is the rule whereas reparation in kind is the exception. Apart from monetary damages, injunctive relief and other reasonable remedies may be ordered, depending on the legal system at hand. ${ }^{71}$ However, most tort cases are about monetary compensation: ${ }^{72}$

In the great majority of tort actions coming before the courts the claimant is seeking monetary compensation (damages) for the injury he has suffered, and this fact strongly emphasizes the function of tort in allocating or redistributing loss.

In all legal systems, the nature and extent of compensatory damages in tort is determined by the extent of the (estimated) actual loss; ${ }^{73}$ no more, no less. If an

Koenig \& Rustad 2001, p. 12. See for Dutch law developments in this field Van Maanen \& Van Dam 2010.

68 Deakin, Johnston \& Markesinis 2008, p. 6.

69 Von Bar 1996, p. 1-2; Van Gerven, Lever \& Larouche 2000, p. 19; Deakin, Johnston \& Markesinis 2008, p. 52.

70 Van Gerven, Lever \& Larouche 2000, p. 740.

71 Koenig \& Rustad 2001, p. 11.

72 Rogers 2006, p. 2.

73 Koziol 2009, p. 299 
injured person brings a civil action for damages and the court rules in his favour, the person held liable must restore the injured person to his status prior to the injury. This principle, which has already been referred to in section 6.2.1 above, is known as restitutio in integrum and can be explained as restoration in kind or monetary compensation. Restoration in kind is defined as restoration of the status quo ante, which is the position in which the victim would have been without the tort. However, as stated above, restoration in kind is not always the best possible solution, whereas in most situations an equivalent in money is. The liable person has a duty to repair both the material and the immaterial loss of the injured person, but in continental Europe a compensatory damages award may under no circumstances lead to the unjust enrichment of the plaintiff. $^{74}$

Under the traditional theory, tort law has a number of other functions such as deterrence or prevention, law enforcement, declaration of right, or even retribution and punishment. In civil law systems these are seen as additional functions that cannot exclusively form the basis of a damages award. ${ }^{75}$ Then again, it is incorrect to state that tort law has only one function. ${ }^{76}$ Although the one function may be less apparent than the other, none of the functions that are discussed in this section 'offers a complete justification for the law'. ${ }^{77}$ Tort law has a combination of functions, and it depends on societal and political circumstances and per legal system which functions are predominant. ${ }^{78}$ For example, as will be shown below, over the past decennia the deterrent function of tort law has become increasingly important under the influence of law and economics scholars. Furthermore, the function of tort law as a law enforcement instrument receives more and more attention. ${ }^{79}$ There is for instance attention for tort law as a possible instrument to enforce fundamental human rights, e.g. in the area of anti-discrimination, as well as for the effects of human rights on private law. ${ }^{80}$ According to Van Dam: ${ }^{81}$

It is the State's duty to ensure that human rights are respected, also by corporations, and to provide effective remedies in case these rights are infringed, regardless of whether this was due to governmental, corporate or an individual's conduct. One of the most important ways for a State to discharge its duty to provide for an effective remedy is tort law. Human rights issues have been clear in areas like the protection of privacy, honour and reputation, and the freedom of speech, but they also play a role in cases of death and personal injury. In the end, it is immaterial from the victim's perspective who infringed his human rights: the State, a company or an individual.

74 Nagy 2012, p. 5

75 Hartlief 1997, p. 16 et seq.; Magnus 2001b, p. 185; Engelhard \& Van Maanen 2008, p. 13-20.

6 Rogers 2006, p 2-3.

77 Deakin, Johnston \& Markesinis 2008, p. 49.

78 Hartlief 1997, p. 22; Van Gerven, Lever \& Larouche 2000, p. 18; Giesen 2013, p. 292; Samoy et al. 2014, p. 147.

79 See e.g. Van Boom 2006a; Engelhard et al. 2009

80 Van Maanen \& Lindenbergh 2011; Hartlief 2012c, p. 6; Barkhuysen \& van Emmerik 2006a, p. 45; Lindenbergh 2010, p. 379 (at § 7); Castermans 2008; Van Dam 2011a; Emaus 2013.

81 Van Dam 2011a, p. 243. 
And: ${ }^{82}$

Although tort law does not use human rights terminology, it has been a pivotal protector of human rights since time immemorial. Whereas the State's duty to protect is the most important public route for human rights protection, tort law can be considered to be the most important private law enforcer of human rights and contributor to the privatisation of constitutional law. Tort law and human rights law are complimentary. In fact, they are brothers in arms.

As remarked by Morgan, fundamental human rights law, for a long time, has been the legal field in which so-called judicialisation, i.e. the intervention of judges in policymaking and law enforcement, is 'most readily observable'. ${ }^{83}$ A last example of the widespread functions of tort law is that the compensatory function is sometimes seen as a synonym for victim protection. Victim protection is considered a function of tort law as such, which also follows from specific tort provisions that have been created to protect employees, participants in traffic and other 'weaker' parties. ${ }^{84}$ It has also been said that victim protection is a consequence of the general principle of full compensation of loss rather than a function as such. ${ }^{85}$

It should be made clear at this point that the compensatory function of tort law, and especially its alleged primacy, is not as unambiguous as one would assume at first and therefore needs further explaining. Some say that it is not so much the compensation for losses that is the primary function of tort law; according to critics, to suggest that compensation is the function of tort law would be the same error as to suggest that divorce is the function of divorce law. ${ }^{86}$ Rather, the primary function of tort law is the determination of when compensation is required. ${ }^{87}$ Furthermore, to strive for full compensation of all damage that falls in society would be an undesirable aim that would have a paralysing effect, as one person's right to compensation automatically restricts another person's freedom to act. ${ }^{88}$ Therefore, as explained above, compensatory damages should be allowed only if there are special reasons to do so. In addition to this nuancing, others suggest that the compensatory function should not be overstated for two reasons. ${ }^{89}$ Firstly, tort law is by no means the exclusive source of compensation. In fact, only a small percentage of victims receive compensation through tort law. ${ }^{90}$ Most compensation money in Europe - at least in case of accidents - comes from other sources, in particular the social security system and first-party insurance. ${ }^{91}$ This probably also

82

Van Dam 2011a, p. 254.

Morgan 2005, p. 247

Hartlief 1997, p. 18.

Bloembergen \& Lindenbergh 2001, p. 20

Hartlief 1997, p. 18, citing H. Kötz, Deliktsrecht, Neuwied: Luchterhand, 1996, p. 18.

Keeton et al. 1984, p. 20; Von Bar 1996, p. 1-2; Hartlief 1997, p. 18; Keirse 2009, p. 99; Asser/ Hartkamp \& Sieburgh 2011/18.

Hartlief 1997, p. 23.

Deakin, Johnston \& Markesinis 2008, p. 52.

Kagan 2001, p. 129; Deakin, Johnston \& Markesinis 2008, p. 4; Wright 1995, p. 159. See section 2.2.3.1. Cavaliere 2004, p. 307; Engelhard \& Van Maanen 2008, p. 11; Oliphant 2012, p. 155; Jansen 2012, p. 1038 . 
has to do with the idea that tort law is not the most efficient compensation system; for example, the civil procedure is rather costly and time consuming, notwithstanding the existence of procedural mechanisms such as legal aid and class actions (or in Dutch law: mass damages settlement agreements) that improve access to justice. ${ }^{92}$ The question how the tort compensation mechanism is affected by other institutions such as insurance and social security relates to the institutional context of tort law. ${ }^{93}$ Secondly, by emphasising the compensatory function, other important functions are undervalued. The example given by Deakin et al. relates to the function of restitution. ${ }^{94}$ Restitutionary damages in tort are measured according to the profits made by the tortfeasor. Although such damages are not based on the loss of the plaintiff as is the case with compensatory damages, and they are thus not based on the notion of compensation, restitution is still considered an important function of tort law. Disgorgement of profit obtained as a result of tortious conduct is an accepted function in, for example, the Dutch legal system. Based on the above-mentioned article 6:104 $\mathrm{BW}$, which will be further explained in section 9.4.1.3, certain profits made by the tortfeasor may influence the extent of a damages award. ${ }^{95}$ Another example from Dutch law in which profits made by the tortfeasor can be taken into account in assessing the damages award is when immaterial damages are awarded on the basis of article 6:106 BW, especially if the profits result from a wrongful publication that infringes someone's honour or reputation. ${ }^{96}$ The general idea behind restitution is that the tortfeasor should be prevented from being unjustly enriched by his tortious behaviour. ${ }^{97}$ Moreover, in the latter example it is well defensible that the immaterial damages award also has a punitive objective, because the seriousness of the infringement rather than the nature of the immaterial loss is the main reason for the award. As this example is also clearly relevant in respect of the theme of this book, more attention will be paid to it in chapter nine.

However, despite these critical assertions in respect of the compensatory function, it is generally accepted that tort law is designed around the idea of compensation. According to the American writer White, this was different prior to the twentieth century: ${ }^{98}$

[...] it should be recalled that tort actions, prior to 1900 , had not principally been conceived as devices for compensating injured persons. Compensation had been a consequence of a successful tort action, but the primary function of tort liability had been seen as one of punishing or deterring blameworthy civil conduct.

Engelhard \& Van Maanen 2008, p. 11; Hartlief 2003a, p. 25. See on these mechanisms section 2.2.3. Oliphant 2012, p. 148, 155. See on this topic section 6.4 .2 below.

Deakin, Johnston \& Markesinis 2008, p. 52.

95 Bloembergen \& Lindenbergh 2001, p. 14.

96 Bloembergen \& Lindenbergh 2001, p. 14; Lindenbergh 2008c, p. 15; Asser/Hartkamp \& Sieburgh 2013/106.

97 Van Gerven, Lever \& Larouche 2000, p. 741.

98 White 2003, p. 62 
As all law, tort law reflects its society. ${ }^{99}$ The compensatory function of tort law became more significant due to developments such as industrialisation, urbanisation and increased population. These developments led to more people being injured, and tort law became a source of redress for those injured. ${ }^{100}$ However, we have already seen in the previous section that in the late nineteenth century the compensatory function of tort law was quite restricted as liability was limited by a constrained fault standard. Only the people who had behaved badly were obliged to pay for the losses they had caused to others. It was considered morally wrong to hold those who were not at fault liable. One has to keep in mind that, due to the non-existence of an insurance market in the nineteenth century, the tortfeasor was responsible for coming up with the compensatory damages award. Therefore, some say that the deterrent function of tort law in those days was more apparent than nowadays. ${ }^{101}$ Due to changing societal needs, different views on the social consequences of injuries and the rise of insurance, lower hurdles for establishing liability were created from the twentieth century onwards. ${ }^{102}$ From the midtwentieth century, the state started to pay more attention to the needy parties in society. ${ }^{103}$ Since then, the compensatory function has played the leading role in tort law.

Having looked into the compensatory function of tort law, the next section will explore the deterrent function. This function is especially relevant in respect of the theme of this book. As mentioned in section 2.3.3, deterrence is an important function of the punitive damages remedy, which partly explains the increased European interest in the civil remedy that will be further explained in chapter seven.

\subsubsection{An Important Additional Function: Deterrence}

Another important and more modern function of tort law, especially according to law and economics scholars, is deterrence. The economic analysis of tort law was initiated by American scholars in the 1960s - among the founders of the law and economics movement are Coase, Calabresi and Posner - and has grown into a widely recognised method to value tort law all over the world. ${ }^{104}$ As tort law deals with losses and damages, it has an economic impact. Law and economics scholars apply economic theories to examine the efficiency of tort rules. According to Calabresi, the aim of tort law is to minimise the social costs of a tort, consisting of accident prevention costs of wrongdoer and victim plus the losses that still occur, costs of optimal risk spreading, and administration costs. ${ }^{105}$ If person A carries out

99 Deakin, Johnston \& Markesinis 2008, p. 10.

100 White 2003, p. 61.

${ }^{101}$ Deakin, Johnston \& Markesinis 2008, p. 55-56.

102 Hartlief 1997, p. 24; White 2003, p. 62.

103 Deakin, Johnston \& Markesinis 2008, p. 56.

104 Faure 2009, p. xxi, xxiv; Burrows 2004, p. 20; Cooter \& Ulen 2004, p. 320. See further e.g. Posner 1972a; Posner 1972b; Cooter 1982; Ellis 1982; Coase 1960; Priest 1991; Calabresi 1970; Landes \& Posner 1987; Polinsky 1989; Shavell 1987; Shavell 2004.

105 See Calabresi 1970, p. 24; Visscher 2009, p. 153; Schäfer \& Müller-Langer 2009, p. 3. 
an activity, he creates a certain risk for person $\mathrm{B}$, and perhaps also for $\mathrm{C}$ and $\mathrm{D}$ and so on, to suffer loss as a result of the activity. In economics, activities that may result in loss to others are called negative externalities which, in an optimal situation, should be internalised. Person A may be able to prevent damage to others, if he includes their possible loss in his decision on the level of care to be taken and the frequency of carrying out the activity. ${ }^{106}$ The idea is that the threat of liability and the obligation to pay damages constitutes a behavioural incentive for participants in society not to behave wrongfully: ${ }^{107}$

[...] social welfare is advanced by internalizing costs, including injury costs, to the activities generating them. Cost internalization creates incentives for injurers to change their behavior to prevent injuries or, if the injuries cannot be effectively prevented, to consider injury costs in production decisions to reduce the level of injury-causing activity.

The focus shifts from ex post action taking against objective law infringements by the use of legal remedies, for example damages, to ex ante prevention of such infringements. ${ }^{108}$ A distinction is made between specific deterrence focused on the individual tortfeasor and general deterrence focused on the prevention of tortious conduct in society as a whole. Tort law is in this way seen as an instrument to minimalise the social costs of accidents, and eventually to enhance social welfare. The deterrent effect of tort law is open to doubt in a similar way as criminal law sanctioning is criticised, for example on the basis of empirical research. ${ }^{109}$ However, according to Deakin et al. the deterrent effect of tort damages is generally less than that of criminal law sanctions because the consequences of a successful tort action are usually less severe: ${ }^{110}$

[...] the deterrent or admonitory effect of money compensation is generally less than that of the corporal punishment of criminal law (e.g. imprisonment). The lighter consequence of a successful tort action, therefore, blunts its deterrent value. [...] Further, as already indicated, tort damages do not, in principle, correspond exactly to the gravity of conduct (as they tend to do in criminal law). The amount of damages is generally speaking the same whether the tort was committed negligently or intentionally (though some rules, e.g. those concerning 'remoteness of damage', are different); and the triviality of the fault bears little relation to the possible enormity of its financial consequences.

This is even more so the case if the defendant is insured, although - as already mentioned in section 4.3.2.4 - the insurer might give incentives to its insured via conditions in the policy such as a policy excess (own risk) and a bonus-malus system, increment of the insurance premium or cancellation of insurance coverage. However, as prevention is better than cure there is no doubt that tort rules are in any case rules of conduct that have been created to have a positive effect on human

106 Visscher 2009, p. 153.

107 See Priest 1991, p. 34

108 Hartlief 1997, p. 19.

109 Visscher 2005, p. 288; Jansen 2012, p. 1039.

110 Deakin, Johnston \& Markesinis 2008, p. 50-51. 
behaviour. ${ }^{111}$ The deterrent function of tort law also becomes visible in the area of injunctions, another important tort remedy by which the claimant wants to prevent future harm. ${ }^{112}$

In respect of the theme of this book, the deterrent function of tort law receives a lot of attention in the field of punitive damages law. ${ }^{113}$ Deterrence is even seen as the leading function of punitive damages: in this view, punishment is not a function of punitive damages in itself but rather a means to an end, namely deterrence. As mentioned above, the assumed deterrent effect of punitive damages is one of the reasons why the civil remedy has become of interest in continental Europe. The reasons for the increased European interest in punitive damages will be further explained in chapter seven.

\subsubsection{Loss-Spreading}

The next more modern function of tort law is loss-spreading of the costs of accidents. ${ }^{114}$ The question is not only how to shift losses that fall in society, but also how to distribute them. Combined with social security and first-party insurance, tort law spreads losses over society. ${ }^{115}$ Distributing losses that fall in society can make the burden of such losses more bearable, and the function of lossspreading is obviously based on the theory of distributive justice. ${ }^{116}$ As mentioned above, the fault of the tortfeasor was for a long time the only reason to shift losses. This approach towards what is morally accepted changed in the twentieth century, when liability without fault was introduced. This opened the possibility to hold, for example, manufacturers, car owners and employers strictly liable, which aimed at and resulted in a higher level of victim protection. Furthermore, due to the development of the modern insurance system, those held liable were no longer in danger of becoming bankrupt. The standard belief that 'he who is not at fault does not have to pay', little by little, receded into the background, whereas the important question became 'who is in the best position to spread the loss?' Losses may be spread over, for instance, the government in case of governmental liability, a group of third-party insured or a collective of consumers through pricing. ${ }^{117}$ The question of loss spreading plays a role on the legislative level. To a certain extent also the judiciary plays a role in it, but it is primarily the legislator who decides in what way losses should be shifted to and spread over parties in society. The lossspreading function of tort law becomes especially relevant in respect of the theme of this book where it concerns the insurability of punitive damages. American courts have held that insurance coverage of punitive damages and the resulting

111 Keirse 2009, p. 100; Hartlief 1997, p. 20

112 Rogers 2006, p. 2; Van Gerven, Lever \& Larouche 2000, p. 741. See on this topic also Ogus \& Visscher 2010.

113 Section 2.3.3 and 2.3.4.

114 Deakin, Johnston \& Markesinis 2008, p. 49.

115 Van Gerven, Lever \& Larouche 2000, p. 22.

116 See Cane 1996, p. 472

117 Hartlief 1997, p. 19. 
loss-spreading is inconsistent with the punitive and deterrent function of the award: ${ }^{118}$

Allowing an intentional tortfeasor to avoid liability and spread the loss among the community at large, solely in the name of freedom of contract, defeats the dual purpose of punitive damages to punish the wrongdoer and to deter similar conduct in the future. In such a case, punitive damages would never possess the "sting" our tort system intends them to inflict.

However, as was seen in section 3.4, the majority of American states allow insurance of both directly and vicariously assessed punitive damages.

\subsubsection{Other Functions of Tort Law?}

As stated above, tort law has more than one function. In addition to compensation, loss-spreading and deterrence, the following functions should be mentioned.

Firstly, a function of tort law related to the deterrent function and based on the 'polluter pays' principle is loss allocation. ${ }^{119}$ From that perspective, tort law is used as a system to assign certain costs to the parties in whose sphere of responsibility they fall, in other words passing on costs to the polluter, for example in situations of environmental liability.

Secondly, a function that is more related to the functions of compensation and victim protection is vindication on the part of the victim. ${ }^{120}$ Furthermore, tort remedies may be used by claimants to realise a declaration of rights. This generally recognised function concerns the judicial recognition of a legally protected right or interest of the claimant. In this regard, also the process of establishing the truth, which helps the victim to come to terms with his loss, is seen as a function of tort law. ${ }^{121}$ Thus, liability of the tortfeasor forms an affirmation of the infringed right or interest of the victim. The declaration of rights plays a role in all tort cases, but it can be especially important in cases of immaterial harm where monetary compensation is not always effective or corresponding to the harm done. It is for that reason that the German legal system makes a distinction between compensation for material harm and satisfaction for immaterial harm. ${ }^{122}$

Thirdly, tort actions have an important instrumental function: law enforcement. As mentioned earlier in chapter two, this is especially so in the United States where private litigants act as private attorneys general by filing civil claims. However, also in Europe there is increased attention for the law enforcement function of private law, particularly tort law. ${ }^{123}$ A wide range of legal mechanisms offered by public law, such as the criminal law, the administrative law and governmental regulators, is available to detect and deter wrongful conduct in society. However, the traditional reliance on public law mechanisms does not produce satisfactory

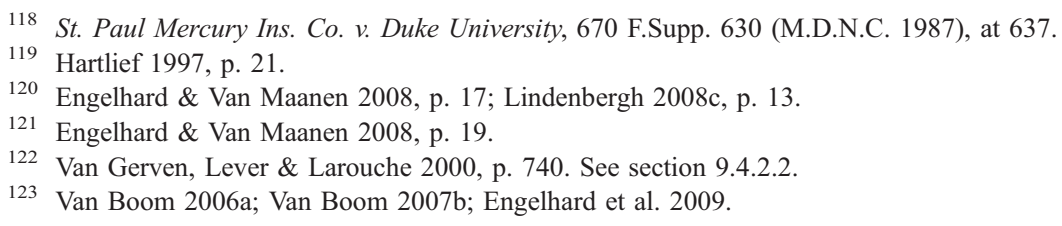


results in all situations of persons suffering damage due to the wrongful conduct of others. Public law does not provide sufficient incentives to deal with each kind of unlawful activity. Law enforcement through public law may not be effective for various reasons, such as the lack of capacity of public authorities, police forces and public prosecutors to respond to each (minor) offence. Moreover, starting criminal proceedings is generally seen as the ultimate resort (ultimum remedium). ${ }^{124} \mathrm{~A}$ noteworthy function that has been assigned to tort law by a Canadian judge and that is related to the law enforcement function is the ombudsman function of dealing with tortious behaviour in society. ${ }^{125}$ The idea is that corporations that are liable for causing great amounts of damage are summoned before a civil court to answer in public for their behaviour. There are also examples of murder cases in which a civil action is initiated in order to stimulate the public prosecutor to take action, such as Halford v. Brookes. ${ }^{126}$ The law enforcement function of tort law will be dealt with in depth in section 7.2 , as it is one of the reasons why there is increased European interest in the punitive damages remedy.

To conclude, in view of the theme of this book it is important to stress once more that, contrary to common law systems, a punitive function of tort law is nowadays theoretically not accepted in civil law systems. ${ }^{127}$ As explained in section 6.2.2.1 above, the Roman law roots of tort law did have an explicit punitive character. ${ }^{128}$ Modern tort law in civil law systems has lost this punitive function. The difference between compensation and punishment for example becomes clear from the fact that in these legal systems tort damages are - as opposed to criminal law sanctions in principle not calculated on the basis of the nature and gravity of the wrongful conduct but rather on the basis of the amount of loss. ${ }^{129}$ This also means that serious wrongdoing may result into only a small amount of compensation due, whereas the slightest fault can lead to enormous loss and resulting tort damages. However, despite the contemporary rejection of a punitive function, some say that punitive elements in tort law are in fact accepted in civil law systems. ${ }^{130}$ Due to the relevance of this argument for this research, particular attention will be paid to it in chapter nine. It is important to emphasise that although a punitive function of tort law is theoretically not accepted in continental Europe, tortfeasors might certainly experience the obligation, imposed by a civil judge, to pay damages to their victim as a form of punishment. ${ }^{131}$ This is another reason why the punitive function that tort law has in practice should not be underestimated.

124 Bolt \& Lensing 1993, p. 80.

125 Rogers 2006, p. 3. Clerk et al. also speak of the ombudsman function of tort law, Clerk et al. 2006, p. 7.

126 Halford v. Brookes [1991] 1 WLR 428. See Rogers 2006, p. 3, 87.

127 Von Bar 1996, p. 604; Wagner 2012, p. 1404.

128 Bloembergen \& Lindenbergh 2001, p. 12.

129 Bloembergen \& Lindenbergh 2001, p. 12; Deakin, Johnston \& Markesinis 2008, p. 50.

130 Von Bar 1998, p. 628; Van Dam 2013a, p. 350

131 Engelhard \& Van Maanen 2008, p. 16; Lindenbergh 2008c, p. 13. 
Now that an overview of the universally recognised functions of tort law has been provided, it is also interesting in respect of the main focus of this book to explore European views on the functions of tort law. Therefore, the next subsection will refer to European harmonising initiatives that have an impact on the tort law debate throughout Europe. In Europe, there have been a number of attempts to find a common core of tort law. For example, in the Principles of European Tort Law (PETL) from 2005, as well as book VI on non-contractual liability arising out of damages caused to another of the Draft Common Frame of Reference (DCFR) from 2009, a rather up-to-date viewpoint on the current functions of tort law according to a group of European scholars is provided. Even with the non-binding status of these projects, it would be unwise not to pay attention to them when examining the functions of tort law. Before going into the relevance of these two initiatives in view of the functions of tort law, their status and meaning will be explained.

\subsubsection{The Functions of Tort Law According to the PETL and the DCFR}

Let us first look briefly into the background of these two harmonising projects. The PETL are an initiative of the European Group on Tort Law, which is composed of a group of tort law scholars and was established in 1992. This group cooperates with the European Centre of Tort and Insurance Law (ECTIL) as well as the Institute for European Tort Law (ETL), which are both situated in Vienna. The mission statement of the group is formulated as follows on its website: ${ }^{132}$

The European Group on Tort Law aims to contribute to the enhancement and harmonization of tort law in Europe through the framework provided by its Principles of European Tort Law (PETL) and its related and ongoing research, and in particular to provide a principled basis for rationalisation and innovation at national and EU level.

The DCFR is a project of the Study Group on a European Civil Code in cooperation with the Research Group on EC Private Law. The Study Group is also a network of European scholars who conduct comparative research in private law. However, contrary to the European Group on Tort Law, which can be seen as a 'private' initiative, the Study Group on a European Civil Code is the result of two resolutions of the European Parliament in which the legal academic community was summoned to create a European Civil Code. ${ }^{133}$ Furthermore, the DCFR was partly funded by the European Union. ${ }^{134}$ Although the Study Group emphasises that it is a non-political body with a purely academic task, the involvement of the European Union and the task to do research into private law in general might give the DCFR a somewhat different status than the PETL. The aim of the Study Group is however rather comparable: ${ }^{135}$

\footnotetext{
132 See www.egtl.org.

133 European Parliament Resolutions OJ C 158 (28.6.1989), resolution of 26 May 1989, and OJ C 205 (25.7.1994), resolution of 6 May 1994. See www.sgecc.net/pages/en/introduction/88.background. htm.

134 Von Bar 2009, p. xi

135 www.sgecc.net/pages/en/introduction/100.aims.htm.
} 
The aim of the Study Group is to produce a set of codified principles for the core areas of European private law (patrimonial law). Although the foundation for our work is detailed comparative law research, the principles which we are fashioning will represent more than a mere restatement of the existing law in the various EU jurisdictions from the standpoint of the predominant trends among the diverse legal regimes. Instead the Study Group seeks to formulate principles which constitute the most suitable private law rules for Europe-wide application.

Even though both projects are seen as soft law they should be considered as guiding and inspiring in the European debate on harmonising tort law. The following paragraphs will address the functions of tort law according to these two initiatives.

To start with, in the PETL, the most relevant article is article 10:101 on the nature and purpose of damages:

Damages are a money payment to compensate the victim, that is to say, to restore him, so far as money can, to the position he would have been in if the wrong complained of had not been committed. Damages also serve the aim of preventing harm.

Thus, we clearly see that compensation of harm based on the principle of restitutio in integrum is an important aim of damages. Furthermore, the aim of damages is to prevent harm. According to the Commentary to the PETL, this means that 'by the prospect of the imposition of damages a potential tortfeasor is forced or at least encouraged to avoid doing harm to others'. ${ }^{136}$ It can hence be established that the PETL has accepted the law and economics theory of tort law. The Commentary continues by stating that a punitive function is implicitly refused by not mentioning it: ${ }^{137}$

The borderline between the aim of prevention and the aim of punishment may be sometimes difficult to draw. But it is clear that the Principles do not allow punitive damages which are apparently out of proportion to the actual loss of the victim and have only the goal to punish the wrongdoer by means of civil damages.

The drafters of the PETL do not go into the often heard suggestion that the purpose of punishment is deterrence, while the preventive function is explicitly mentioned as one of the functions in article 10:101 PETL. ${ }^{138}$ As already mentioned in section 2.3.3, the idea that deterrence is the purpose of punishment is supported by Posner and other law and economics scholars, whose theory will be further explained in section 7.3.1.

The main purpose of tort law according to the Study Group on a European Civil Code is the protection of human and basic rights at the level of private law with the legal remedies that are made mutually available between citizens. ${ }^{139}$ Therefore, the basic rule laid down in article 1:101 of book VI DCFR gives the person who

136 Koziol et al. 2005, p. 150.

137 Koziol et al. 2005, p. 150. See also Koziol 2009, p. 287.

138 Lindenbergh 2008b, p. 222.

139 Von Bar 2009, p. 229. 
suffers legally relevant damage a right to reparation from the liable person, i.e. restitutio in integrum. Another important function of tort law according to the DCFR is prevention, although there is a clear focus on the prevention of impending damage (article 1:102 of book VI DCFR) instead of on prevention in general. This means that a specific threat of damage is explicitly required for preventative protection of legal rights on the basis of article 1:102. ${ }^{140}$ The preventive function should therefore be understood in terms of injunctive relief. ${ }^{141}$ In chapter six of book VI DCFR, both the right to compensation (sections 1 and 2) and the right to prevention (section 3) are further construed. The Commentary to the DCFR also makes clear that the punishment of wrongdoers is not a function of tort law and that punitive damages are for that reason not accepted: ${ }^{142}$

These Principles are based on the fundamental maxim that the aim of the law on liability under private law is not to punish. Punishment belongs to the realm of criminal law whereas the function of the law on liability in private law is compensatory, nothing more and nothing less. For this reason, punitive damages do not form part of these Principles.

There are different views on the issue whether European harmonisation of tort law, or more general private law, is desirable and possible. But one cannot deny that, despite this lack of agreement, the PETL and the DCFR have given food for thought with regard to the accepted functions of tort law in Europe. Consequently, it would be unwise to ignore that both the PETL and the DCFR seem to have rejected a punitive function of tort law. Both harmonising initiatives are indicators displaying the ideas of a number of European scholars about a punitive function of tort law and punitive damages. The conclusion that should be drawn from the above is that, if it was up to the drafters of the PETL and the DCFR, the punitive damages remedy would not be received with open arms, quite the contrary. On the other hand, both documents pay particular attention to the preventive function of tort law and, although it has been made clear that punitive damages are not accepted, the question what is allowed in terms of this function remains largely unanswered. Furthermore, as a common denominator that stays on the safe side, these two harmonising initiatives are arguably outdated and not suitable to signal new developments. In other words, the fact that both initiatives reject punitive damages does not per se mean that there is no (current) support in Europe for punitive damages. Lastly, as stated above, the creators of the PETL and the DCFR emphasise their academic and even their non-political status. Thus, notwithstanding the involvement of the European Union in case of the DCFR, both soft law initiatives might be guiding and inspiring in the European tort law debate, also for policymakers, but they should still primarily be seen as non-binding contributions

140 Von Bar 2009, p. 265; Von Bar \& Clive 2009, p. 3105.

141 Wagner 2012, p. 1406.

142 Von Bar 2009, p. 239. See also Von Bar 2009, p. 909 and Von Bar \& Clive 2009, p. 3724: 'The punishment of wrongdoers is a question for criminal law, not private law. Under these model rules, punitive damages are not available. They are not consistent with the principle of reparation'. 
to the academic debate. This insight makes clear that there is room for different views on a punitive function of tort law and punitive damages in Europe.

To conclude, note that the increased attention for the deterrent function of tort law not only follows from soft law initiatives but also from binding European Union law. This results from a formula that was originally created by the Court of Justice of the European Union (hereafter also: CJEU) stating that national sanctions which may be imposed for breaches of European Union law should be 'effective, proportionate, and dissuasive'. ${ }^{143}$ This formula was first mentioned by the Court in a judgment from 1989, Commission v. Greece, ${ }^{144}$ and has become an important tool in a number of European Directives concerning employment discrimination. ${ }^{145}$ Furthermore, as will be explained in section 7.2.3, it has been further interpreted by the Court in the context of breaches of EU competition law. At this point, it is sufficient to mention that the formula has been connected to the punitive damages remedy. According to Ebert: ${ }^{146}$

However, recently there has been a certain shift in the general European attitude when it comes to punitive damages. Even some of those formerly strictly opposing anything remotely resembling punitive aspects of civil law have started to recognise that there are some areas of tort law where something beyond compensation of the damage done is needed and public law does not and cannot provide a solution. Infringements of personality or intellectual property rights, competition law violations and illegal discrimination are among the most obvious examples. Here, national or European law demands effective preventive sanctions [emphasis added], regardless of any damage in the traditional sense, while most European jurisdictions have no intention (or option) of introducing these in criminal or otherwise public law. Therefore, suddenly, punitive damages even though usually under a different name - seem to be an acceptable alternative.

The punitive damages remedy is thus seen as a possible solution for national legislators to deal with breaches of European Union law in several legal fields, such as intellectual property law, competition law, infringements of personality rights and discrimination.

The above gives an overview of the grounds and functions of tort law. It is generally accepted that the primary function is compensation, but other functions have also been recognised. As explained, unlike in common law systems, punishment is - at least in theory - not a recognised function of modern tort law in civil law systems. This is the first reasonable argument that can be put forward in answering the question why the punitive damages remedy is not a recognised civil remedy in continental Europe.

143 Since the entry into force of the Lisbon Treaty on 1 December 2009, the official name of the judiciary of the European Union is Court of Justice of the European Union, which consists of two courts: the General Court (formerly Court of First Instance or CFI) and the Court of Justice (formerly European Court of Justice or ECJ).

144 CJEU 21 September 1989, case 68/88, ECR 2965 (Commission v. Greece). See section 8.4.

145 E.g. Directives 2000/43/EC; 2000/78/EC; 2002/73/EC.

146 Ebert 2013, p. 95. 
The next section will be about the second reason for the non-existence of punitive damages in European civil law systems, i.e. the division between public law and private law, which is strongly related to the first reason.

\subsection{The Division between Public Law and Private Law}

Criminal law and tort law have a common ground in the sense that they both deal with unlawful conduct. The difference between a crime and a tort is that the first constitutes a public wrong, a wrong to society at large, whereas a tort is a civil wrong, a wrong to the individual victim. ${ }^{147}$ As was seen in section 3.3.4, this difference explains the general rule in American law that a criminal conviction does not bar the imposition of punitive damages for the same act in a civil lawsuit. Both areas of law have their own functions and measures, either sanctions or remedies, although we also find common characteristics in that regard. ${ }^{148}$ In any case, criminal law has a punitive, retributive and deterrent function which cannot principally be said of tort law. ${ }^{149}$ Criminal law sanctions have the intention of causing harm to offenders, so as to punish them for the harm they have done to society. This follows clearly from the fact that criminal law is based on the idea of sanctioning others. ${ }^{150}$ Criminal sanctions may take the form of imprisonment, monetary fines and, in some legal systems, even capital punishment. An important aspect of criminal sanctions in comparison to tort damages - i.e. those used in European civil law systems - is that the primary objective of criminal sanctions is the deliberate infliction of punishment, whereas although the defendant in a civil lawsuit may experience the imposition of tort damages as a punishment this is not its primary objective. As explained above, European civil law systems do not recognise a punitive function of tort law, even though the idea of a sanction could also be relevant for tort law as 'the legal consequences of an act are attached to a violation of a duty and faulty behaviour'. ${ }^{151}$ Some go even further by stating that there is no reason why criminal law and private law should have exclusive functions. ${ }^{152}$ According to Lord Wilberforce: ${ }^{153}$

English law does not work in an analytical fashion; it has simply entrusted the fixing of damages to juries upon the basis of sensible, untheoretical directions by the judge with the residual check of appeals in the case of exorbitant verdicts. That is why the terminology used is empirical and not scientific. And there is more than merely practical justification for this attitude. For particularly over the range of torts for which punitive damages may be given (trespass to person or property, false imprisonment and defamation being the commonest) there is much to be said before one can safely assert that the true or basic principle of the law of damages in tort is compensation, or, if it is, what the compensation is for (if one says that a plaintiff is given compensation because he has been

47 Zimmermann 1992, p. 902; Asser/Hartkamp \& Sieburgh 2011/6-7.

148 Van Gerven, Lever \& Larouche 2000, p. 19.

149 Ashworth 2003, p. 17-18; Reed \& Fitzpatrick 2006, p. 2-4

150 Koziol 2008, p. 751.

151 Koziol 2008, p. 751.

152 See Wilcox 2009, p. 33.

153 Cassell \& Co. Ltd. v. Broome [1972] AC 1027, at § 1114. 
injured, one is really denying the word its true meaning) or, if there is compensation, whether there is not in all cases, or at least in some, of which defamation may be an example, also a delictual element which contemplates some penalty for the defendant.

He continues:

It cannot lightly be taken for granted, even as a matter of theory, that the purpose of the law of tort is compensation, still less that it ought to be, an issue of large social import, or that there is something inappropriate or illogical or anomalous (a question-begging word) in including a punitive element in civil damages, or, conversely, that the criminal law, rather than the civil law, is in these cases the better instrument for conveying social disapproval, or for redressing a wrong to the social fabric, or that damages in any case can be broken down into the two separate elements. As a matter of practice English law has not committed itself to any of these theories: it may have been wiser than it knew.

This statement of Lord Wilberforce affirms the acceptance of a punitive function of tort law in common law systems; in this regard he for instance mentions the tort of defamation. Interesting in respect of the theme of this book is that we have already seen in section 3.2.2 that defamation is one of the three categories for which punitive damages are mostly awarded in the United States, the other categories being intentional torts (e.g. battery, assault) and financial torts (e.g. fraud, bad faith insurance).

Even so, the accepted viewpoint in continental European legal systems is that the primary function of tort law is compensation. Although this is also the main function in common law systems, we see that the line between criminal law and tort law is somewhat more blurred there: ${ }^{154}$

$[\ldots]$ the distinction in purpose between criminal law and tort is not, and has never been, entirely crystal-clear.

The division between public law and private law traditionally weighs heavier in civil law systems than in common law systems. ${ }^{155}$ Common lawyers also respect the division, but they do not put so much weight on it. While the public-private divide is of fundamental importance in civil law systems, common law systems attach less value to the dogmatic belief. This has to do with historical and cultural differences: $:^{156}$

[...] lawyers, judges, and legislators trained in the civil law learn that law is a body of rules and are thereby better equipped to maintain the formal distinction between the two domains in the face of policy arguments for exceptions. By contrast, students of the common law study discrete cases and the facts, reasons, and distinctions courts rely on to resolve them. The history of the common law is one of endless innovation and assimilation of new ideas. General principles are always giving way, and students learn that rule-based arguments routinely lose in the battle between form and substance. The acceptance of punitive damages is an illustration of that general theme.

154 Clerk et al. 2006, p. 6

155 Auby \& Freedland 2006, p. 3; Jurgens \& Van Ommeren 2009, p. 1; Samuel \& Rinkes 1991, p. 50; Samuel 2001, p. 273-274

156 Wells 2010, p. 560. See also Harris 1989, p. 1082. 
Thus, these different perspectives on the public-private divide explain the disagreement that the two legal families have on the issue of punitive damages. ${ }^{157}$ In the United States the punitive function of tort law is traditionally not rejected, which is illustrated by the awarding of punitive damages in the majority of states. The public-private divide cannot impede the imposition of punitive damages in the United States; rather the imposition of punitive damages is a choice of policy: ${ }^{158}$

Although we, too, respect the private-public law distinction, no prudent common lawyer would try to put so much weight upon it, nor would he invoke an abstract proposition like "the principle of mutual justification of legal consequences" as a decisive impediment to punitive damages. Rather, American lawyers and scholars know that they must identify substantive policies favoring limits on punitive damages.

This seems to be in line with the idea that the public-private divide as such, which is an often debated topic, has a significant political character. According to Jurgens and Van Ommeren, who wrote a book on this topic in English law, the question whether a certain topic is regulated via private law or public law is not merely juridical but also political. ${ }^{159}$ Furthermore, they suggest that the public-private divide is especially important for procedural reasons, as the common characteristics of substantive norms sometimes make it difficult to classify them as either public or private. Some authors even find the classification of a certain body of law as public or private 'unlikely to be a matter of importance' and criticise the continental public-private divide for being 'old-fashioned and undesirable'. ${ }^{160}$ Harlow puts it as follows: ${ }^{161}$

I believe myself that the "public/private" classification is part of another, more insular tradition. It is nothing more than an attempt by the judiciary to conceal political issues behind a formalist facade and to shield from public criticism some highly executiveminded decisions.

This English view supports the above-mentioned American idea that in common law systems the imposition of punitive damages is a policy choice that cannot be impeded by the public-private divide. In contrast, one of the difficulties with punitive damages in civil law systems is that the remedy does not fit into a tort system that is designed around the central function of compensation, because punishment of tortfeasors by imposing civil fines is not a legitimate function of tort law. ${ }^{162}$ The idea in civil law systems that tort law has a compensatory rather than a punitive objective is not only based on the theoretical analysis of tort law, as such, but also results from the strict division between public law and private law, which is considered 'an achievement of modern legal culture'. ${ }^{163}$

7 Wells 2010, p. 559, 565.

158 Wells 2010, p. 564-565.

159 Jurgens \& Van Ommeren 2009, p. 107

160 Yeung 2006, p. 162; Harlow 1980, p. 242.

161 Harlow 1980, p. 265.

162 Behr 2003, p. 105; Koziol 2009, p. 299

163 Koziol 2008, p. 755-756. See on the public-private divide also Sebok 2003, p. 3; Merryman \& Pérez-Perdomo 2007, p. 92. 
A final important remark in view of the theme of this book that should be mentioned at this point is that the rather strict public-private divide adhered to in civil law systems becomes more and more blurred and law enforcement theories are shifting from the public to the private level. ${ }^{164}$ This development certainly influences the increased European interest in punitive damages. In 2005, Ginsburg and Kagan wrote the following: ${ }^{165}$

Scholars also now write about the "Americanization" of European law and "The Globalization of American Law" - shorthand for a style of governance, which one of us has dubbed "adversarial legalism," featuring lawyer-dominated litigation and frequent use of courts to challenge governmental and corporate actions.

An important reason given for this shift in Europe, to be more precise in the Member States of the European Union, is the impact of European Union law and the extension of the effectiveness of European norms in the Member States. ${ }^{166}$ Ginsburg and Kagan also address the role of the CJEU in this regard: ${ }^{167}$

[...] the ECJ is confronted with a steady diet of cases concerning the rules of fair competition and elimination of non-tariff barriers, propelling it into the realm of EU-wide policymaking. By formulating the "direct effect" doctrine, it has invited private interests to bring cases based on EU law into member state courts, expanding their role in governance as well.

Another reason provided by these authors is the gradual privatisation of European economic markets (examples mentioned are: privatising government monopolies, contracting out services to private companies and lowering restrictions on competition) which results in more regulation of such markets via civil litigation. ${ }^{168}$ As explained in section 2.2.2.2, this already is common practice in the American legal system. Merryman and Pérez-Perdomo also give several reasons, ten in total, why the public-private divide is 'in crisis' ${ }^{169}$ An important reason is that civil lawyers seem to have learned from common lawyers: ${ }^{170}$

They are aware that other Western, democratic, capitalist societies than their own have been able to reach an advanced state of legal development without making a technical distinction between public law and private law. This need not lead them to conclude that their own legal system should discard the dichotomy, but it does suggest that it is not a necessary part of every developed legal order.

Rijnhout et al. refer to a newly acknowledged phenomenon in civil litigation and private law, the so-called public interest litigation, i.e. civil procedures - initiated

164 See Jurgens \& Van Ommeren 2009, p. 102, 129; Auby \& Freedland 2006, p. 4; Bolt \& Lensing 1993, p. 82; De Haan 1999, p. 8; Klein 1999, p. 679; Redish \& Mathews 2004, p. 3; Samuel \& Rinkes 1991, p. 51; Samuel 2001, p. 274-275; Weyts 2011, p. 202.

165 Ginsburg \& Kagan 2005, p. 4-5.

166 Auby \& Freedland 2006, p. 4; Adriaanse et al. 2008, p. 276-277.

167 Ginsburg \& Kagan 2005, p. 9.

168 Ginsburg \& Kagan 2005, p. 9.

169 Merryman \& Pérez-Perdomo 2007, p. 95-98.

170 Merryman \& Pérez-Perdomo 2007, p. 95. 
by citizens and NGOs - with a public interest that are at the interface of privatisation and globalisation and that deal with problems relating to, for instance, climate change, depletion of natural resources, corruption, and violations of human rights. These authors also call the retreat of government a reason for shifts from public to private law enforcement - with an important role for tort law - in areas such as health care, housing, energy supply, information provision concerning financial and health risks and transport. ${ }^{171}$ The changing view on law enforcement theories can be seen as one of the reasons for the increased interest in punitive damages in continental Europe; more attention will be paid to this subject in chapter seven. Note that the above-mentioned changes in view of the publicprivate divide and private enforcement will have more impact in continental Europe than in the United Kingdom, which is a common law system within Europe that is already attuned to the American approach.

This section will go further into different aspects of the long-established division between public law and private law, which is one of the reasons for the nonexistence of punitive damages in continental Europe.

\subsubsection{Undesirable Consequences for the Prosecution Policy}

Despite the changing views on the public-private divide and law enforcement theories in Europe, a major objection to punitive damages in European civil law systems remains that punishment and retribution are objectives of criminal law, which should be left to state authorities. As stated above, criminal law is a public matter whereas tort law is a private matter. Critics consider it unwise to transfer public powers to private individuals by means of punitive damages, because these individuals are influenced too much by their own private interests and lack the objectivity and accountability that is needed to exercise public power; in their decision-making, individuals are 'free from the ethical, political, and constitutional constraints imposed on public actors'. ${ }^{172}$ Note that the public-private divide is also used as an argument against punitive damages in the United States, even though the Americans have a more liberal approach towards the division and the division does not impede the imposition of punitive damages in the end. ${ }^{173}$

Generally speaking, criminal prosecutions are indeed instituted by the state and tort actions are initiated by individuals. Reed and Fitzpatrick explain in their criminal law handbook when the criminal law gets involved: ${ }^{174}$

$[\ldots]$ the criminal law is not primarily used for resolving private disputes. When a criminal case is brought, it is, in the vast majority of cases, brought on behalf of the state. Criminal law is a public matter (you may see criminal law referred to as a branch of public law) - the criminal law articulates social norms. So, for the criminal law to get involved, the wrongful behaviour would seem to have to be of a level of seriousness to warrant the intervention of the state.

171 Rijnhout et al. 2013, p. 173-174. See also Enneking \& De Jong 2014.

172 Redish \& Mathews 2004, p. 3-4.

173 Bolt \& Lensing 1993, p. 38-39. See section 4.3.1.

174 Reed \& Fitzpatrick 2006, p. 2. 
Some legal systems, for example in the Netherlands, that have a strict division between public law and private law have created a monopoly for the public prosecutor to bring cases before the criminal court. In the Dutch legal system, which has taken a rather classical stance when compared to surrounding countries, neither the citizen nor any other party, for example the police, has the same competences as the public prosecutor. ${ }^{175}$ It should be stressed that the Dutch approach to prosecution is rather strict when compared to other European countries. In this regard, Tak gives a clear overview of prosecution policies in the Netherlands, Austria, England and Wales, Finland, France, Germany, Italy, and Sweden. ${ }^{176}$

The Dutch prosecution monopoly is based on the principle of discretionary powers (opportuniteitsbeginsel), i.e. the freedom of the public prosecutor to select - out of a number of criminal cases - those suitable for prosecution. This policy is possibly frustrated if citizens would have their own private prosecution system. It is questionable whether citizens should be enabled to initiate prosecutions if the public prosecutor has decided earlier to dismiss a case in the public interest. ${ }^{177}$ For that reason, it is perhaps also undesirable that citizen A would be enabled to claim punitive damages, with all its consequences, from citizen B. In other words, victims who claim punitive damages may form an undesirable threat to the prosecution policy and monopoly. According to Bolt and Lensing - who wrote a preliminary advice on the possible introduction of punitive damages in the Dutch legal system importance must be attached to this objection in the sense that punitive damages should not be allowed in all situations and that the situations for which punitive damages are available should be tailored to the prosecution policy of the public prosecutor. ${ }^{178}$ One could in this regard think of situations in which problems of law enforcement are evident; punitive damages are then justified in favour of law enforcement. The fact that this happens at the expense of the criminal law safeguards of the wrongdoer is something that one should be prepared to put up with. In other words, the advantage in respect of law enforcement outweighs the disadvantage in view of high-level protection of the wrongdoer. Furthermore, as explained in section 4.3.2.1, punitive damages supporters argue that criminal law safeguards are not necessary because there is a difference between criminal and civil punishment, i.e. a punitive damages verdict is far less stigmatising than a criminal conviction. Note that a system of less stringent protection already applies to the imposition of punitive damages by American courts and is therefore an accepted strategy in the United States. ${ }^{179}$ Another example is when the defendant is guilty of serious wrongdoing such as murder or grave crimes against the environment.

175 Bolt \& Lensing 1993, p. 60, 82.

176 See Tak 2008.

177 Corstens \& Borgers 2011, p. 35.

178 Bolt \& Lensing 1993, p. 82.

179 Section 4.3.2.1. 
According to Bolt and Lensing, punitive damages are then in particular justified in favour of the public interest as such behaviour is simply not accepted in society. ${ }^{180}$

As already explained in chapter two, objections to citizens claiming punitive damages, and thereby acting as private attorneys general, do not exist to the same extent in common law systems. In the United States, for example, the private prosecution policy is accepted for several reasons; for instance, it contributes to law enforcement and to solving problems relating to lack of capacity of public authorities, police forces and public prosecutors. This links to the above-mentioned problem that private prosecution is at the expense of certain criminal procedural safeguards. This problem will be further explained in the next subsection.

\subsubsection{Compatibility of Punitive Damages with Criminal Procedural Safeguards}

An often heard difficulty in relation to the possible introduction of punitive damages in continental Europe is the compatibility of this civil remedy with criminal procedural safeguards. ${ }^{181}$ In legal systems where there is a strict division between public law and private law, imposing civil fines may easily be considered a violation of fundamental safeguards underlying the constitutional state. These principles are important as they have been created to protect citizens against the far-reaching prosecuting powers of the state, and they form part of every modern legal system. Opponents of punitive damages argue that the civil remedy violates such principles.

In this regard, the following principles are usually brought forward. ${ }^{182}$ The first is the principle of legality, meaning that conduct does not constitute a crime and punishment is forbidden unless laid down in the law (nulle poene sine previa lege). This principle is codified in both international legal instruments, such as article 7(1) ECHR or article 15(1) ICCPR, and national law, for example article 16 of the Dutch Constitution or article 1 of the Dutch Penal Code. The problem with punitive damages in terms of this principle, which is also known as the rule of law, is that through the use of vague norms such as 'malice' or 'gross negligence' it is unclear what kind of conduct may lead to punitive damages. The Law Commission for England and Wales has therefore concluded in its report on, among other remedies, exemplary damages that: ${ }^{183}$

The 'rule of law' principle of legal certainty dictates that the criminalization of conduct is in general properly only the function of the legislator in new cases: it further dictates that there is a moral duty on legislators to ensure that it is clear what conduct will give rise to sanctions and to deprivation of liberty. Broadly-phrased judicial discretions to award exemplary damages ignore such consideration.

Another problem relating to the principle of legality is that - contrary to criminal sanctions - the amount of punitive damages awards is not laid down in the law;

180 Bolt \& Lensing 1993, p. 83.

181 See, extensively on this topic, Nordin 2014, chapter six.

182 Koziol 2009, p. 302.

183 Law Commission Report 1997, p. 99. 
this unpredictability is considered undesirable. The European Court of Human Rights has dealt with the latter problem, albeit partly, in Miloslavsky v. The United Kingdom. ${ }^{184}$ Although this decision does not concern punitive damages, as such, it explores the question whether (excessive) civil damages violate the principle of legality. In this libel case, the Court addressed the compatibility of an immaterial damages award amounting to $£ 1,500,000$ with the principle of legality. The award was 'three times the largest amount previously awarded by an English libel jury' and 'substantially greater than the sum that would be awarded to a plaintiff suffering permanent and extremely severe physical or mental disablement in a personal injury action'. ${ }^{185}$ The Court nevertheless held that the applicant's freedom of expression was not violated because the 'relevant legal rules concerning damages for libel were formulated with sufficient precision' and therefore 'prescribed by law' within the meaning of article 10 ECHR. ${ }^{186}$ This means that the principle of legality also was not violated. ${ }^{187}$ According to the Court, the size of civil damages for injury to reputation depends on the circumstances of each particular case: ${ }^{188}$

The Court accepts that national laws concerning the calculation of damages for injury to reputation must make allowance for an open-ended variety of factual situations. A considerable degree of flexibility may be called for to enable juries to assess damages tailored to the facts of the particular case. [...] It follows that the absence of specific guidelines in the legal rules governing the assessment of damages must be seen as an inherent feature of the law of damages in this area. Accordingly, it cannot be a requirement of the notion of "prescribed by law" in Article 10 (art. 10) of the Convention that the applicant, even with appropriate legal advice, could anticipate with any degree of certainty the quantum of damages that could be awarded in his particular case.

The Court did however make clear that the discretion of the jury in respect of the assessment of damages is not unlimited: ${ }^{189}$

It is further observed that the discretion enjoyed by the jury in the assessment of damages was not unfettered. A jury was bound to take into account such factors as injury to feelings, the anxiety and uncertainty undergone in the litigation, the absence of apology, the reaffirmation of the truth of the matters complained of, vindication of the plaintiff's reputation (see paragraph 23 above). It was for the trial judge to direct the jury on the law. In addition, the Court of Appeal had power to set aside an award, inter alia on the ground of irrationality and to order a new trial. It therefore appears that, although the principle of proportionality as such may not have been recognised under the relevant national law, decisions on awards were subject to a number of limitations and safeguards.

Even though the Court decided that the immaterial damages award was prescribed by law and for that reason did not violate the freedom of expression nor the

184 ECtHR 13 July 1995, Miloslavsky v. The United Kingdom, no. 18139/91. See on this decision Verheij 1997, p. 79-80.

185 Miloslavsky v. The United Kingdom, at $\S 38$.

186 Miloslavsky v. The United Kingdom, at $\S 44$.

187 Verheij 1997, p. 80

188 Miloslavsky v. The United Kingdom, at $\$ 41$.

189 Miloslavsky v. The United Kingdom, at $\S 42$. 
principle of legality, it found a breach of article 10 ECHR on the basis of another argument. According to the Court, due to the lack of effective safeguards, the award was disproportionate to the legitimate aim of protecting personality rights as well as the loss suffered and therefore not 'necessary in a democratic society'. ${ }^{190}$ This decision is interesting for participants in the European punitive damages debate, in the sense that the Court does not per se consider substantially large civil damages problematic in relation to the principle of legality. Note that a solution to these two problems of legality in American punitive damages law is the general reform measure relating to the clarification of vague standards relevant to questions of measurement, liability and misconduct. As explained in section 4.4.1, this is one of the measures that have been taken by legislators and courts to control improper punitive damages awards.

A second principle that is often brought forward in the punitive damages debate is the ne bis in idem principle, in common law systems known as the double jeopardy rule. ${ }^{191}$ The meaning of this principle is that prosecution cannot be initiated twice for the same wrongful behaviour. This principle has, for example, been codified in article 4 of Protocol Seven ${ }^{192}$ to the ECHR, article 14 ICCPR and article 68 of the Dutch Penal Code. The ne bis in idem principle is closely connected to the una via principle, on the basis of which the government is obliged to make a choice for one sanction if different sanctions are available. ${ }^{193}$ Questions that arise with regard to the principles of ne bis in idem and una via are whether a wrongdoer could be obliged to pay punitive damages when he has already been sanctioned via criminal or administrative law and vice versa. The awarding of punitive damages might be problematic in light of these principles. As explained by the Law Commission: ${ }^{194}$

Defendants should not be placed in jeopardy of double punishment in respect of the same conduct, yet this would be the result if a defendant could be liable to pay both a criminal fine following conviction in the criminal courts and an exemplary damages award after an adverse decision in the civil courts.

According to Zippro, who discusses punitive damages in relation to the debate concerning the private enforcement of competition law, both principles cannot be ignored if punitive damages are made available. ${ }^{195}$ In that case, he suggests that concurrence (samenloop) of sanctions be regulated in a similar way as has been done in the Dutch General Administrative Law Act (Algemene Wet Bestuursrecht), especially article 5:44 thereof. According to this provision, the administrative punitive sanction (bestuurlijke boete) cannot be imposed on a wrongdoer who is

190 Miloslavsky v. The United Kingdom, at § 46-51.

191 See section 3.3.4.

192 Protocol Seven to the ECHR has been ratified by 39 member states of the Council of Europe, not including the Netherlands.

193 Zippro 2009, p. 454.

194 Law Commission Report 1997, p. 98.

195 Zippro 2009, p. 459. 
criminally prosecuted for the same act. Interestingly, also in relation to the punitive damages debate, Dutch administrative law has a set of sanctions that can be imposed by the administrative court to enforce the law. ${ }^{196}$ It distinguishes the bestuurlijke boete, which has a punitive function, from two other administrative sanctions that have a restorative and preventive function (bestuursdwang and dwangsom). In contrast to the prohibition of administrative-criminal concurrence, as referred to above, both categories of administrative sanctions can be imposed simultaneously for the same offence due to the different nature of the sanctions. ${ }^{197}$ This means that it is, at least in Dutch administrative law, not always made impossible to impose different sanctions for the same offence: the possibility depends on the nature and purpose of the sanctions. In line with this reasoning, one could argue that if punitive damages were introduced in continental Europe it is vital both to have a clear understanding of the nature and purpose of this civil sanction and to be able to distinguish it from criminal sanctions. Problems relating to the concurrence of criminal sanctions could possibly be solved if deterrence, rather than punishment, is seen as the leading purpose of punitive damages. As we have seen in section 2.3.3, this theory receives support in the United States. Note that the imposition of administrative punitive sanctions is also discussed in light of criminal procedural safeguards. ${ }^{198}$ The European Court of Human Rights for example decided in Öztürk v. Germany ${ }^{199}$ that the protection afforded by article 6 ECHR is also, to a certain extent, applicable to administrative punitive sanctions. The debate concerning the applicability of article 6 ECHR on the imposition of punitive damages will be discussed below.

In addition to the above-mentioned procedural principles, one must also think of evidential safeguards that have been created to protect the wrongdoer. In case of civil punishment, the defendant could easily be deprived of the high standards that apply to evidence in criminal law. ${ }^{200}$ The starting point in a criminal proceeding is the principle that someone is innocent unless and until proven guilty, i.e. the praesumptio innocentiae or presumption of innocence. ${ }^{201}$ The accused can also rely on the principle of nemo tenetur, meaning that no one can be forced to selfincrimination, which includes the right to remain silent. Furthermore, the standard of proof in a criminal proceeding is higher than in a civil case: the burden of proof is on the public prosecutor who needs to collect convincing evidence to show that guilt exists beyond reasonable doubt.

The combination of civil punishment and lack of criminal procedural safeguards also leads to discussion in the American legal system. However, as explained before, the generally accepted rule in American law is that criminal punishment does not bar the imposition of punitive damages for the same act in a civil lawsuit. The idea is that criminal punishment and civil punishment can be imposed

196 See chapter five of the Dutch General Administrative Law Act.

197 Van Buuren, Jurgens \& Michiels 2011, p. 20.

198 See for example Ankaert et al. 2006.

199 ECtHR 21 February 1984, Öztürk v. Germany, no. 8544/79.

200 Law Commission Report 1997, p. 98.

201 Ashworth 2003, p. 84. 
simultaneously, as the first is primarily for the wrong done to society whereas the latter is above all for the wrong done to the individual plaintiff. Furthermore, even though the lack of criminal procedural safeguards does not prevent the awarding of punitive damages by the majority of American courts, also in the United States it is agreed that punitive damages should be awarded with great caution. For example, what is in principle not allowed is that the punitive damages award is disproportionate to the damage caused by the wrongdoer. ${ }^{202}$ Another measure to control punitive damages awards is a heightened burden of proof for the recovery of punitive damages. The ordinary standard of proof required in civil litigation is preponderance of the evidence, but several courts and legislators have raised the standard for punitive damages claims to clear and convincing evidence or even to proof beyond a reasonable doubt, i.e. the above-mentioned criminal law requirement. ${ }^{203}$ To conclude, as was seen in section 4.3.2.1, the defendant is entitled to the privilege of protection against self-incrimination and the defendant who is also charged with a crime is usually protected from self-incrimination by a suspension of the civil procedure, which obliges the claimant to wait until the criminal proceedings are closed.

\subsubsection{Compatibility of Punitive Damages with Article 6 ECHR}

The question whether punitive damages violate criminal law safeguards is a difficult juridical problem which arises out of the value attached to the publicprivate divide. As already mentioned above, an important source of such safeguards is the European Convention on Human Rights (ECHR). Problems especially seem to arise in relation to the consistency of punitive damages with article 6 ECHR on the right to a fair trial. ${ }^{204}$ This is a central European guideline for the determination of an individual's civil rights and obligations or of the justness of a criminal charge against him. Paragraph 1 of this provision - which is applicable to both criminal and civil cases - lays down the right to have 'a fair and public hearing within a reasonable time by an independent and impartial tribunal established by law'. ${ }^{205}$ This includes the right to be admitted to a court and the requirement that the judgment will in principle be passed in public. ${ }^{206}$ Additional minimum requirements are given for proceedings that involve a person charged with a criminal offence, such as the presumption of innocence (paragraph 2) and the right to defence (paragraph 3). Thus, it does make a difference whether a judgment to pay punitive damages is considered a civil obligation or a criminal charge. The terminology civil rights and obligations covers almost all civil and administrative legal rights and obligations that are recognised according to national law. ${ }^{207}$ An example is the obligation to compensate damages under tort law. As the

202 Boot 2008, p. 206, citing United States v. Halper, 490 U.S. 435, 109 S.Ct. 1892 (U.S.N.Y. 1989). See on this decision section 4.3.2.1.

203 See section 4.4.1.

204 See generally on this topic Grozev et al. 2009.

205 Article 6 § 1 ECHR.

206 Zippro 2009, p. 450.

207 Barkhuysen \& Van Emmerik 2006b, p. 130. 
obligation to pay punitive damages imposed by a civil judge will undoubtedly be seen as a civil obligation, the applicability of article 6, paragraph 1, is not problematic. $^{208}$ But if the imposition of punitive damage is similar to a criminal charge, the additional requirements of article 6, paragraph 2 and 3 are applicable. The character of punitive damages - civil or criminal - leads to discussion whenever the legal remedy is available. This is also true for the United States, but as was discussed earlier the public-private divide and the lack of criminal law safeguards in practice does not impede the imposition of punitive damages by the majority of American courts. The topic also leads to discussion in Europe, as follows for example from Dutch and Belgian literature. ${ }^{209}$ For instance, in the Dutch legal system, all forms of fines are imposed under the terms of criminal law safeguards. As referred to above, this is even so if the fine is imposed via administrative law. ${ }^{210}$ If the criminal charge standard applies to punitive damages, criminal law safeguards will also become important in a private law context.

The terms criminal and charge have both been explained extensively in the case law of the European Court of Human Rights. The Court has thereby offered a benchmark that may help to analyse the character of punitive damages. ${ }^{211}$ Although the Court has interpreted both terms separately, as some authors also seem to prefer in the punitive damages debate, in the end the Court seems to work with an autonomous interpretation of the notion criminal charge on the basis of three criteria. In this regard, autonomous means independent of national law: the fact that the national legislator considers punitive damages a civil remedy is not a decisive factor. ${ }^{212}$ The Court has a strategic reason for this autonomous interpretation, namely to make sure that parties to the Convention do no circumvent their obligations under article 6 ECHR by placing certain sanctions outside the ambit of criminal law. ${ }^{213}$ This standpoint has been motivated in the case Öztürk $v$. Germany: ${ }^{214}$

[...] if the Contracting States were able at their discretion, by classifying an offence as "regulatory" instead of criminal, to exclude the operation of the fundamental clauses of Articles 6 and 7 (art. 6, art. 7), the application of these provisions would be subordinated to their sovereign will. A latitude extending thus far might lead to results incompatible with the object and purpose of the Convention.

Before explaining - in view of the punitive damages debate - the three criteria developed by the Court, attention will first be given to the only case decided thus far by the Court on the question whether imposing a civil fine is considered a criminal charge. $^{215}$

208 Zippro 2009, p. 446.

209 Bolt \& Lensing 1993, p. 58; Zippro 2009, p. 445-459. See also Adriaanse et al. 2008; Boot 2008; Nordin 2011

210 Boot 2008, p. 200.

211 Bolt \& Lensing 1993, p. 58.

212 Grozev et al. 2009, p. 2; Zippro 2009, p. 446; Harteveld et al. 2004, p. 79-80.

213 Zippro 2009, p. 449.

214 Öztürk v. Germany, at § 49.

215 See Adriaanse et al. 2008, p. 280. 


\subsection{Blake v. The United Kingdom}

Blake v. The United Kingdom ${ }^{216}$ is an admissibility decision from 2005. Applicant Blake challenged the duty imposed on him to pay restitutionary damages for breach of contract, on the basis that it constituted a criminal charge, but the Court disagreed with him on the following grounds: ${ }^{217}$

$[\ldots]$ as regards the severity of the penalty in this case, the Court recalls that an account of profits is a standard remedy in civil proceedings such as breach of confidence and breach of fiduciary duty (Relevant domestic Law and Practice above). It was limited to preventing the applicant obtaining the remaining royalties due to him following the publication of his book rather than a fine requiring him to disburse monies. There was, in addition, no potential penalty of detention and no possibility of his being imprisoned in default of payment. In such circumstances, the Court does not consider that the present penalty renders criminal the action against the applicant.

The Court found that, in the circumstances of the case, a penalty consisting of payment of restitutionary damages for breach of contract is a civil obligation and not a criminal charge. This is an understandable outcome, given the fact that Blake's obligation to pay was a direct consequence of his breach of contract. ${ }^{218}$ Furthermore, although the decision concerned contractual liability, the private law context was not of overriding importance in deciding whether the obligation to pay was a civil obligation or a criminal charge. ${ }^{219}$ The Court has not (yet) decided on the criminal charge character of civil fines imposed for non-contractual liability, which leaves room for interpretation in that respect. ${ }^{220}$ In other words, this decision does not form an obstacle to interpret the obligation to pay punitive damages in non-contractual situations as a criminal charge. This means that, should the Court decide in this manner in the future, the additional requirements of article 6, paragraph 2 and 3 are applicable to the imposition of punitive damages in non-contractual situations.

To conclude, a general remark with regard to the Court's practice of awarding punitive damages is called for. Although this is a different topic, it is also important in view of the problem statement of this book, i.e. whether the punitive damages remedy has a future in continental Europe. Adriaanse et al. point out that the European Court of Human Rights has thus far never awarded punitive damages on the basis of claims for just satisfaction under article 41 (old article 50) ECHR. ${ }^{221}$ But they also make clear that, according to them, this rejection of the Court is by no means an indication of the Court's opinion about the character - either civil or criminal - of punitive damages. The issue of the Court's practice of awarding punitive damages will be further explained in section 8.2.

216 ECtHR 25 October 2005, Blake v. The United Kingdom, no. 68890/01.

217 Blake v. The United Kingdom, at § 99.

218 Zippro 2009, p. 446.

219 Adriaanse et al. 2008, p. 281; Zippro 2009, p. 446

220 Adriaanse et al. 2008, p. 281.

221 Adriaanse et al. 2008, footnote 48 . 


\subsection{When is an Offence a Criminal Charge under Article 6 ECHR?}

The Court has established three criteria that form the starting point for determining if offences should be considered a criminal charge under article 6 ECHR. These criteria were first introduced in the case of Engel $v$. The Netherlands ${ }^{222}$ and further developed in the cases of Öztürk v. Germany ${ }^{223}$ and Lutz v. Germany. ${ }^{224}$ The first criterion is the classification of the offence according to national law (kwalificatie van de overtreding naar nationaal recht): ${ }^{225}$

[...] it is first necessary to know whether the provision(s) defining the offence charged belong, according to the legal system of the respondent State, to criminal law, disciplinary law or both concurrently. This however provides no more than a starting point. The indications so afforded have only a formal and relative value and must be examined in the light of the common denominator of the respective legislation of the various Contracting States.

Thus, offences that belong to criminal law will normally be considered criminal. However, having regard to the second part of the quote, this does not mean that offences that do not belong to criminal law, for example those resulting in a civil fine, can never be considered criminal. They can still be considered criminal if criteria two or three, which are alternative and not cumulative, ${ }^{226}$ are met. The first criterion is for that reason not decisive. ${ }^{227}$ The second criterion, which is a factor of greater importance according to the Court, concerns the nature of the offence (aard van de overtreding). ${ }^{228}$ To find the nature of the offence, it should be considered whether the legal provision that is breached by the offence is of a general character, i.e. binding on all citizens, and if the purpose of the penalty is deterrent and punitive: ${ }^{229}$

Above all, the general character of the rule and the purpose of the penalty, being both deterrent and punitive, suffice to show that the offence in question was, in terms of Article 6 (art. 6) of the Convention, criminal in nature.

This means that also the nature of the norm (aard van de norm) is an important factor that should be considered. The second criterion, the nature of the offence, is in itself considered in relation to the third criterion concerning the nature of the corresponding penalty. ${ }^{230}$ The Court also looks at the way in which other legal systems judge similar offences. ${ }^{231}$ The last and third criterion is the nature and

222 ECtHR 8 June 1976, Engel and Others v. The Netherlands, no. 5100/71, 5101/71, 5102/71, 5354/ $72,5370 / 72$, at $\$ 82$.

223 Öztürk v. Germany, at $\$ 50$.

224 ECtHR 25 August 1987, Lutz v. Germany, no. 9912/82, at § 54-55.

225 Engel and Others $v$. The Netherlands, at $\$ 82$.

226 Lutz v. Germany, at $\S 55$.

227 Zippro 2009, p. 446.

228 Engel and Others v. The Netherlands, at $\S 82 ;$ Öztürk v. Germany, at $\S 52$.

229 Öztürk v. Germany, at § 53; See also Lutz v. Germany, at § 54; Bolt \& Lensing 1993, p. 58; Adriaanse et al. 2008, p. 281; Boot 2008, p. 204; Zippro 2009, p. 447.

230 Öztürk v. Germany, at $\S 52$.

231 Öztürk v. Germany, at § 53; Boot 2008, p. 204; Zippro 2009, p. 447. 
degree of severity of the penalty that the person concerned risks incurring (aard en zwaarte van de sanctie). ${ }^{232}$ This factor only plays a role if a criminal character cannot be established on the basis of the first two criteria, but the nature and degree of severity of the penalty is in itself so serious that the criminal character is a given. $^{233}$ This could for example apply to the deprivation of liberty: ${ }^{234}$

In a society subscribing to the rule of law, there belong to the "criminal" sphere deprivations of liberty liable to be imposed as a punishment, except those which by their nature, duration or manner of execution cannot be appreciably detrimental.

In the following subsection, the criteria developed by the Court for assessing the criminal charge will be connected to the punitive damages remedy.

\subsection{Applying the Three Criteria to the Imposition of Punitive Damages}

What if the above-mentioned criteria are applied to the imposition of civil fines and more specifically punitive damages? Punitive damages are awarded for serious wrongful behaviour in a private law context. For that reason, the first criterion is not met. But as stated above, the first criterion is not decisive and a civil fine can still be considered a criminal charge on the basis of criterion two or three. Criterion two has more chance of success. As punitive damages are generally imposed to enforce legal provisions that are binding on all citizens - which includes civil law norms - and the deterrent and punitive purpose of punitive damages is commonly accepted, the second criterion will probably be fulfilled. ${ }^{235}$ However, the American legal system could perhaps serve as an example in arguing the contrary. As explained in section 3.3.4, a generally accepted principle in American punitive damages law is that a criminal conviction does not form an obstacle to the imposition of punitive damages for the same act in a civil procedure. The main argument to support this principle is that the criminal sanction is imposed on behalf of the public for the wrong done to society, whereas the civil sanction is imposed for the wrong done to the individual plaintiff. It thus simply depends on the interpretation of the nature and purpose of punitive damages whether the second criterion can be fulfilled: the more punitive damages are seen in a private law context, the more difficult the fulfilment of the second criterion will become. Due to the alternative character of the three criteria, the conclusion that a punitive damages award has a criminal character on the basis of criterion two does not change for the mere reason that criterion three has not been met, for example because of the minimal degree of severity of the fine. ${ }^{236}$ Then again, the nature and degree of severity of the penalty can also by itself lead to the conclusion that there is a criminal charge. ${ }^{237}$ Even small sized penalties can be considered a criminal

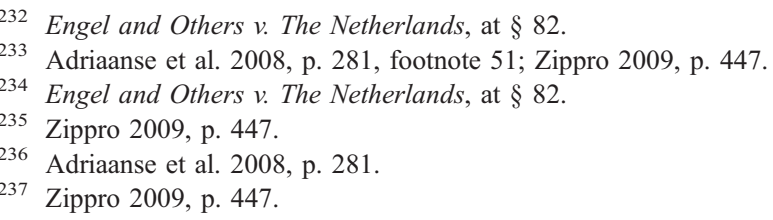


charge, although the Court has decided that if such a small penalty is imposed for violating a legal rule that does not belong to the hard core of criminal law, the safeguards of article 6 ECHR are not fully applicable. ${ }^{238}$ According to the Court: ${ }^{239}$

Notwithstanding the consideration that a certain gravity attaches to criminal proceedings, which are concerned with the allocation of criminal responsibility and the imposition of a punitive and deterrent sanction, it is self-evident that there are criminal cases which do not carry any significant degree of stigma. There are clearly "criminal charges" of differing weight. What is more, the autonomous interpretation adopted by the Convention institutions of the notion of a "criminal charge" by applying the Engel criteria have underpinned a gradual broadening of the criminal head to cases not strictly belonging to the traditional categories of the criminal law [...].

The Court then mentions some examples that do not strictly belong to traditional criminal law, namely administrative penalties, prison disciplinary proceedings, customs law, competition law, penalties imposed by a court with jurisdiction in financial matters, and tax surcharges. As these examples do not form part of the hard core of criminal law, the 'criminal-head guarantees will not necessarily apply with their full stringency'. ${ }^{240}$ However, the Court has thus far not explained what this lower level of protection should precisely look like. ${ }^{241}$ According to Wils, an example of different treatment of cases belonging to the hard core of criminal law and cases outside the hard core of criminal law is that in the latter category the penalty can be imposed - in the first instance - by an administrative or non-judicial body, such as a tax authority, rather than an independent tribunal. ${ }^{242}$ In this respect, the Court in Jussila v. Finland refers to the cases Bendenoun v. France and Janosevic $v$. Sweden, in which it decided that tax authorities should be free to impose sanctions even if they come to large amounts. ${ }^{243}$ As pointed out by Wils, also the CJEU has adopted the view that criminal law safeguards, such as the principle nullum crimen, nulla poena sine lege are not fully applicable to fines imposed for violations of EU competition law. ${ }^{244}$

It has been suggested that a less strict treatment as referred to in Jussila $v$. Finland should also apply in the case of civil sanctions, due to the character of such sanctions. ${ }^{245}$ Civil sanctions are for example imposed by a civil judge, who does not have similar possibilities with regard to investigation as the criminal judge. Furthermore, as explained before, civil sanctions are generally considered less severe

238 ECtHR 23 November 2006, Jussila v. Finland, no. 73053/01. See Adriaanse et al. 2008, p. 281; Zippro 2009, p. 448; Wils 2010, p. 15-17; Nordin 2011, p. 161

239 Jussila v. Finland, at $\S 43$.

240 Jussila v. Finland, at $\S 43$.

241 Adriaanse et al. 2008 , p. 281

242 Wils 2010, p. 16

243 Jussila v. Finland, at $\S 43$, citing ECtHR 24 February 1994, Bendenoun v. France, no. 12547/86 at $\S 46$ and ECtHR 21 May 2003, Janosevic v. Sweden, no. 34619/97 at $\S 81$.

244 Wils 2010, p. 16, citing CJEU 8 July 2008, case T-99/04, ECR II-1501 (AC-Treuhand $A G v$. Commission), at $\S 113$

245 Cauffman 2007, p. 845; Nordin 2011, p. 161. 
and less stigmatising than criminal sanctions, which for example include imprisonment. $^{246}$ The smaller risk of violating the wrongdoer's privacy in civil procedures justifies a smaller degree of protection and therefore the availability of less procedural safeguards.

\subsection{Concluding Remarks with regard to Article 6 ECHR}

Due to the broad definition of civil obligation in the sense of article 6, paragraph 1 ECHR, it is defensible that punitive damages are to be considered as such. This means that this provision is applicable to the imposition of punitive damages, which gives punitive damages defendants the right to have 'a fair and public hearing within a reasonable time by an independent and impartial tribunal established by law'. ${ }^{247}$ In fact, given the background of the punitive damages doctrine in American law, categorising the civil remedy as civil obligation seems logical. The question remains, however, whether the remedy should also be seen as a criminal sanction. Based on the three criteria developed by the Court it is also defensible to label the imposition of punitive damages as a criminal charge. ${ }^{248}$ Although this should not by itself lead to the conclusion that article 6 ECHR is breached, the additional safeguards of paragraph 2 (presumption of innocence) and 3 (right to defence) ECHR are then applicable. ${ }^{249}$ However, as it is - unfortunately - not the Court itself that has reached this conclusion, it is thus far quite unclear what the level of protection for potential punitive damages defendants should be. In line with the Jussila v. Finland decision explained above, there are for example arguments that support a system of less stringent protection, as is current practice in the United States. ${ }^{250}$

A conclusion to the contrary, i.e. the imposition of punitive damages cannot be considered a criminal charge, is evident and justifiable in case none of the three alternative criminal charge criteria can be fulfilled. ${ }^{251}$ Some authors that have interpreted the criminal charge concept separately in the punitive damages debate subscribe to this conclusion. Boot for example argues that an award of punitive damages can never be considered a charge, as the initiative to claim punitive damages is taken by a private party instead of a public prosecutor. ${ }^{252}$ The charge aspect has been explained by the Court in the case Deweer v. Belgium. ${ }^{253}$ According to the Court: ${ }^{254}$

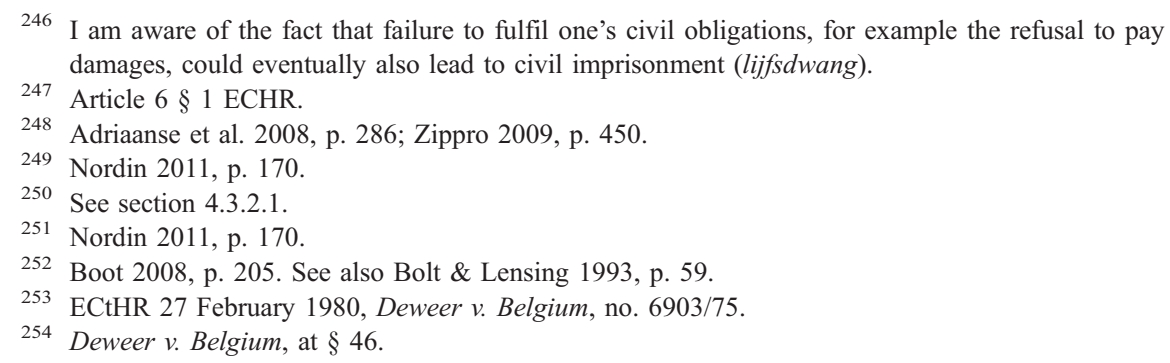


The "charge" could, for the purposes of Article 6 par. 1 (art. 6-1), be defined as the official notification given to an individual by the competent authority of an allegation that he has committed a criminal offence.

This means, in the literal sense, that there has to be an act of public prosecution in order to find a charge. However, the Court has decided in a different case that the fact that a procedure has been initiated by a private party does not by itself take away the criminal nature of the proceedings. ${ }^{255}$ Furthermore, as explained in section 6.3.2.1 above, the Court has made clear that it is in favour of a strategic interpretation of the criminal charge concept, most likely for protective reasons and to make sure that parties to the Convention do no circumvent their obligations under article 6 ECHR by placing certain sanctions outside the ambit of criminal law. This preference also follows from the consideration put forward by the Court in the Deweer case to give the charge concept a substantive rather than a formal meaning because of the important position that the right to a fair trial has in a democratic society. ${ }^{256}$

The Court is compelled to look behind the appearances and investigate the realities of the procedure in question.

The Court continued that a charge can also be identified if: ${ }^{257}$

[...] the situation of the [suspect] has been substantially affected.

The Court concluded that Mr. Deweer had been charged in the sense of article 6 , paragraph 1 ECHR, despite the fact that no criminal investigation had been instigated against Mr. Deweer, that he had not been arrested, and that no official notification of impending prosecution had been given to him. ${ }^{258}$ The main reasons for the Court were that Mr. Deweer was threatened with the use of terms such as 'offender' and 'offence', 'heavy penalties' and that, by paying a fine that was meant as 'a kind of compensation to the community for his reprehensible conduct', he had admitted his 'guilt'. 259

The question remains whether a charge can exist in a private law context, as the Court has also not yet clarified this particular subject. Thus far, there has not been a straightforward answer to the question whether the imposition of punitive damages is similar to a charge. An argument in support of a positive answer is that it is not merely private parties but definitely also government authorities, i.e. the legislator and courts, that create the possibility of awarding punitive damages. ${ }^{260}$

255 ECtHR 25 March 1983, Minelliv. Switzerland, no. 8660/79. Cf. article 12 Sv-procedures in Dutch law, giving the person concerned the possibility to make a complaint about the public prosecutor's decision not to bring a case before the criminal court.

256 Deweer v. Belgium, at $\S 44$; Adriaanse et al. 2008, p. 282.

257 Deweer v. Belgium, at $\S 46$.

258 Deweer v. Belgium, at $\S 43$.

259 Deweer v. Belgium, at $\S 45$.

260 Adriaanse et al. 2008, p. 282 
Opinions on the applicability of the safeguards provided in article 6 , paragraph 2 and 3 ECHR in case of the imposition of punitive damages differ. Both arguments in favour and arguments against applicability are defensible. What is important is that the discussion remains rather vague and abstract, which also results from the fact that the Court itself has not given clear guidance on this particular matter. The argument that the imposition of punitive damages violates criminal procedural safeguards is often brought forward by punitive damages opponents in the European debate. In contrast, although the lack of such safeguards in civil procedures where penalties are imposed also causes discussion in the American legal system, nota bene a system in which due process is really highly valued, ${ }^{261}$ the current practice concerning punitive damages there can be brought forward by supporters to illustrate that the system has worked as it does for many years now. Nevertheless, in the hypothetical situation that the imposition of punitive damages is considered a criminal charge, the defendant in the civil procedure can rely on the additional safeguards of article 6, paragraph 2 and 3 ECHR, most importantly the presumption of innocence, the nemo tenetur principle which includes the right to remain silent, and the right to defence. Furthermore, the principles of full jurisdiction and proportionality apply: at least one judicial body should have full jurisdiction to establish the facts, apply the relevant legal norms, and examine if a sanction is proportionate. ${ }^{262}$ The application of these safeguards in case of the imposition of punitive damages for tortious behaviour will not always be easy. According to Cauffman, one of the safeguards with problematic practical value in a civil procedure is the presumption of innocence. It is for example difficult to reconcile this principle with liability presumptions in tort law and the possibility to hold someone strictly liable. ${ }^{263}$ Application of other safeguards, such as the right to remain silent, will also influence existing civil procedural law. On the other hand, the principle of proportionality could for instance rather easily be incorporated into existing legislation concerning damages. ${ }^{264}$

As most of the additional safeguards are not traditionally developed for a private law context, the system of protection in relation to the imposition of punitive damages certainly has to crystallise and be adapted to the situation. This should preferably be initiated by the Court and in at a later stage it can be further developed by the (European or national) legislator. The Court could in this respect for example start by making clear what a less strict treatment, as referred to in Jussila v. Finland, should precisely look like and whether this treatment could also apply to civil sanctions. As mentioned in the previous section, the Court decided in this case that in criminal cases that do not carry any significant degree of stigma, for example if a penalty is imposed for violating a legal rule that does not belong to

261 For example: the Constitution of the United States, Fifth and Fourteenth Amendment, contains Due Process clauses. See section 4.4 .4 for the U.S. Supreme Court's opinion on punitive damages in light of the Excessive Fines Clause and the Due Process Clause.

262 Zippro 2009, p. 452.

263 Cauffman 2007, p. 850.

264 Zippro 2009, p. 453. 
the hard core of criminal law, the safeguards of article 6 ECHR are not fully applicable. ${ }^{265}$ To conclude, questions remain in the European discussion concerning punitive damages and criminal law safeguards. Although this is understandable as the punitive damages remedy is not an accepted civil remedy in continental Europe, it also forms a problem in respect of the main focus of this book. Should punitive damages one day be introduced in continental Europe, a nuanced approach to this problem similar to that in the American legal system is worth considering; as explained in section 4.3.2.1, a system of less stringent protection applies to the imposition of punitive damages by American courts.

The second reason for the non-existence of punitive damages in European civil law systems is the value that is attached to the public-private divide. This divide traditionally weighs heavier in civil law systems than in common law systems, although changes are nowadays visible in Europe due to shifting views on law enforcement theories and increased attention for private enforcement. Punitive damages cannot be introduced in European civil law systems without giving fair consideration to certain problems relating to the public-private divide, most importantly the compatibleness with criminal procedural safeguards. This topic will therefore play a role in the concluding chapter ten. The solutions that are offered by American punitive damages law thereby serve as an example.

\subsection{The Role of Government}

This section is about governmental interference and the way in which governmental policy choices influence the view on punitive damages in continental Europe. After the introduction of American punitive damages law in chapters two to five, in this section a comparison in view of certain policy choices will be made between Europe and the United States. There is a difference between the two when it comes to governmental influence over the well-being of citizens. ${ }^{266}$ In Europe, the public sector is to a reasonable extent responsible for social welfare policy. According to Ginsburg and Kagan: ${ }^{267}$

In strong welfare states, compensation for injuries is handled primarily through social insurance systems, and judge-made tort law is not a salient factor.

In contrast, Americans have learned to protect their own interests by using legal remedies. This contrast between Europe and the United States also results in a different perception of the possible use of civil litigation and, as the Americans call it, the civil justice system. As stated in chapter one, according to Magnus, the American attitude with regard to civil litigation corresponds to the idea of Von Jhering to fight for one's violated rights by means of the 'justice machinery' (der

265 ECtHR 23 November 2006, Jussila v. Finland, no. 73053/01, at § 43.

266 See Kagan 2007, p. 41-70.

267 Ginsburg \& Kagan 2005, p. 5. 
Kampf ums Recht). ${ }^{268}$ Magnus makes clear that the American civil litigation culture is entirely different from that in European civil law systems. He gives four reasons for this apparent distinction. First of all, there is the strong American feeling to protect tort victims in order to compensate for the shortcomings of social security. Due to the retreat of the Welfare State, this feeling slowly but surely becomes more visible in Europe. ${ }^{269}$ The second reason is the interest that the American legal profession has in civil litigation, as contingency fee arrangements and class actions are fairly beneficial for them. As explained in section 2.2.3, this interest can also become more important in Europe. Think for instance of the Dutch developments relating to the 'no cure, no pay' experiment as well as the Act on Collective Settlements Mass Damages (WCAM). Third, American individuals are motivated to enforce their own rights. In so doing, they contribute to general safety in society and discharge the state from tasks relating to law enforcement, which is considered to be in the common interest: ${ }^{270}$

To a far greater extent than in the European civil law countries, tort victims in the US are accorded the task of restoring the public order which the tort has violated.

The idea of private individuals pursuing the common interest by filing civil claims is less lively in Europe: ${ }^{271}$

The optimistic and liberal idea of giving individuals such a great (economic) incentive that they also act in the common interest finds fewer defenders in Europe. Here, the more pessimistic and paternalistic view still prevails that individuals will generally act only in their own interest and that the state has the task of pursuing the common good.

The last reason is the comparative lack of regulatory mechanisms in the American legal system. Americans believe that the lack of government regulation can be neutralised by civil litigation. When looking at these four reasons, one indeed realises that, despite the European developments mentioned, they do not really apply to the situation in continental Europe yet. In Europe, the government plays a greater role in the regulation of, for example, health and safety. Furthermore, the incentive to litigate for both tort victims and their lawyers is not as high as in the United States.

It is plausible that the general view on the role of government also plays a part in the non-existence of punitive damages in continental Europe. This section will focus on an important aspect of the American legal system that already received considerable attention in chapter two and is almost completely absent in European legal cultures, i.e. private enforcement or citizens who function as private attorneys general. In addition, reference will be made to European policy choices in respect

268 Magnus 2010, p. 109, referring to 'Der Kampf ums Recht', a lecture held by Rudolf Von Jhering in 1872.

269 See section 6.4.2.2

270 Magnus 2010, p. 121.

271 Magnus 2010, p. 123. 
of public compensation schemes, private insurance, government regulation, and a number of procedural law aspects.

\subsubsection{The Citizen as a Private Attorney General?}

A first characteristic relating to the role of government is that Americans are used to a relatively inactive government that holds on to the theory of laissez-faire. In relation to civil litigation, this for instance means that in the United States great value is attached to private enforcement and that citizens are seen as so-called private attorneys general. By the efforts of American citizens, legal rules are enforced and courts are confronted with situations for which new rules need to be created. In contrast, Europeans are used to more active governments and do not put so much weight on private enforcement.

There is a difference between the United States and Europe when it comes to law enforcement. The role of the American citizen as a private attorney general has been extensively explained in section 2.2.2.2. In Europe, citizens do not really seem to have an incentive or possibility to act as private attorneys general - at least not to a similar extent as in the United States - since there the state dominates law enforcement. The role of the state in respect of law enforcement affects the objectives of judicial proceedings. ${ }^{272}$ The American civil justice system is said to perform functions that in other modern jurisdictions are performed by governmental institutions. ${ }^{273}$ Public policy issues are privately implemented, meaning that the enforcement of public norms is entrusted to individuals who bring cases of social, political and economic importance before the courts. This transfer of public policy powers from the government to civil litigation is seen as an aspect of adversarial legalism, which characterises the American legal system and the civil justice system in particular. Note that also in the United States the level of interference of the government fluctuates and is dependent on the party that is in charge: Democrats or Republicans. The Democrats generally believe in more government interference and focus mainly on the public interest above the individual person, whereas the Republicans desire less government interference and focus primarily on the individual person. Nevertheless, although the level of interference of the American government can have relatively high and deep points, it is evident that the American government has a rather modest role whereas the American citizen has a rather important role in comparison to the situation in European countries.

This modest role of the American government and the value attached to the civil justice system also paves the way for the use of punitive damages in the United States. Punitive damages awards work as a procedural mechanism which ought to contribute to the enforcement of public norms and the deterrence of wrongful behaviour. The idea is that this civil remedy motivates potential plaintiffs to bring lawsuits and thereby functions as a "vehicle by which private individuals enforce

272 Verkerk 2010, p. 304.

273 Von Mehren \& Murray 2007, p. 163. 
public values'. ${ }^{274}$ European countries hardly know the concept of the citizen acting as private attorney, for the reason that law enforcement is an issue that is primarily dealt with by governmental authorities. ${ }^{275}$ But what we need to keep in mind is that, as explained in the introduction to section 6.3 above, there seems to be a shift taking place in Europe from public to private law enforcement. Think for instance of the current attention for public interest litigation. ${ }^{276}$ This shift is one of the reasons for the increased European interest in punitive damages, which will be further explained in chapter seven.

\subsubsection{The Influence of Other Compensation Mechanisms on Civil Litigation}

When it comes to victim protection and victim compensation, tort law is not the only possible compensation mechanism. In addition, there are two other important systems namely first-party insurance on the one hand and social security and social insurance on the other hand. ${ }^{277}$ Another type of insurance is third-party insurance. Third-party insurance, which may be concluded for possible damage of a third party, is considered an integral part of the tort compensation mechanism and is therefore not included in this paragraph concerning other compensation mechanisms. Examples of third-party insurance are the insurances for drivers, doctors, lawyers, employers, and so on.

In contrast to the American legal system, compensation via tort law is considered a rather marginal phenomenon in Europe, as the greater part of losses that fall in society are compensated via private insurance and social security. ${ }^{278}$ In other words, contrary to the United States, in Europe other compensation systems seem to be more important than tort damages. ${ }^{279}$ According to Rogers: ${ }^{280}$

If there is no defendant whose liability can be established according to the principles of the law, then the claimant is left without redress so far as private law is concerned. He may, of course, look to the Welfare State or to a private loss insurance contract he may have made.

The availability of social security is first and foremost a policy choice made by the government, whereas the insurance industry has decisive influence as regards first(and third-) party insurance. It is very well arguable that policy choices made by the government and insurers influence the extent of civil litigation, including the use of punitive damages.

Next the two other compensation mechanisms will be addressed.

274 Redish \& Mathews 2004, p. 38.

275 Kagan 2007, p. 57.

276 Rijnhout et al. 2013; Enneking \& De Jong 2014

277 Hartlief 2003a, p. 15.

278 Hartlief 1997, p. 29; Faure \& Hartlief 1999, p. 2015.

279 However, section 2.2.3.1 explains that also in the United States the tort system is not excessive, that most personal injury victims never come into action and that the majority of tort cases is settled in case they do.

280 Rogers 2006, p. 4 


\subsubsection{First-Party Insurance}

First-party insurance is a system whereby a person buys, by means of paying a premium, a type of insurance coverage such as private health insurance (as opposed to social security, which is a system of public health insurance), disability insurance, accident insurance and travel insurance. ${ }^{281}$ The first-party insurance policy is concluded for possible future harm and corresponding damage. ${ }^{282}$ If damage occurs and the damage is covered by the insurance policy, the insurer directly pays compensation to the insured. Compensation via first-party insurance is different from compensation via tort law, as payment by the insurer occurs irrespective of whether there is liability or what the cause of the damage is. Furthermore, in case of first-party insurance the insured is usually entitled to a fixed amount of compensation instead of full compensation of the damage.

Although first-party insurance is an established compensation mechanism in both Europe and the United States, the mechanism seems to be more extensively used in Europe as an alternative to tort litigation. As will be shown in the next section, this does not mean that this compensation mechanism is not also well developed in the United States.

Another important compensation mechanism that is more closely related to private insurance than to compensation via tort law is social security, which is in fact a form of public first-party insurance. ${ }^{283}$ With regard to social security, there is a difference between the United States and Europe.

\subsubsection{Social Security and Social Insurance}

The victim of an accident with consequential loss could perhaps also rely on social security and social insurance laws, which is a system of public compensation. Social security is normally funded via taxpayers and via premiums of insureds and their employers. ${ }^{284}$ In this way costs relating to, for instance, medical expenses (health insurance) or disabled employees (workers compensation) are covered. Europe - or in any case the wealthier European countries - has an extensive apparatus of social security, which is a reflection of the Welfare State in which the state is responsible for social welfare: ${ }^{285}$

[I]n Europe generally a large percentage of the population is either voluntarily or mandatory insured under social security schemes.

In contrast, the reliance on social security in the Unites States is by far not as high as in Europe: ${ }^{286}$

Rather than adopt social insurance programs [...], Americans remain obsessed with litigation.

281 Hartlief 1997, p. 28.

282 Bruggeman 2010, p. 83.

283 Hartlief 2003a, p. 15.

284 Bruggeman 2010, p. 352.

285 Magnus 2010, p. 118.

286 Centner 2008, p. 11; See also Magnus 2010, p. 118. 
Similarly, according to Howells: ${ }^{287}$

Litigation in the U.S. is widely recognized as a surrogate for the European welfare state.

The American approach can be illustrated by the status of health insurance prior to the health care measures that have been taken by president Obama. In the United States, in principle, only the old, disabled and poor people were covered by government health insurance in case of health risks. ${ }^{288}$ Government health insurance was thus available only to specific groups of people who cannot afford private health insurance; existing programs are Medicare and Medicaid. The latter program includes the Children's Health Insurance Program. ${ }^{289}$ The alternative for those who did not have access to these programs was private health insurance; yet in the previous years approximately $15 \%$ of the American population did not have any health insurance $(15.3 \%$ in $2007,16.3 \%$ in 2010 and $15.7 \%$ in 2011$) .{ }^{290}$ In numbers, this for example means that, in 2010, 49.9 million out of the approximately 310 million American citizens did not have health insurance. ${ }^{291}$ In 2008, $84.6 \%$ of the American population was covered by private or government health insurance, of which $66.7 \%$ had private health insurance. These percentages had hardly changed in 2009: $83.3 \%$ had health insurance, of which $63.9 \%$ was privately insured. ${ }^{292}$ From these figures, the conclusion can be drawn that public health insurance plays a relatively small role in the United States.

The signing into law of the Patient Protection and Affordable Care Act, also known as Obamacare, in March 2010 has created a more optimistic outlook on American health insurance. ${ }^{293}$ The key objectives of the Act are: stronger consumer rights and protections, more affordable coverage, better access to care, and stronger medicare. ${ }^{294}$ The Act should improve access to affordable health coverage for all Americans and, together with the Health Care and Education Reconciliation Act, it forms the American health care reform plan. Obamacare helps those who do not have access to affordable health insurance to buy private health insurance, by providing discounts on state or federal run insurances; this means that although the health care reform plan serves a public goal by providing access to private health insurance for everyone, it is not similar to government health care and 'will not lead to a government takeover of healthcare'. ${ }^{295}$ From 2014, most Americans will be obliged to buy health care insurance; refusal to do so

287 Howells 2000, p. 307.

288 Magnus 2010, p. 119.

289 See www.medicare.gov and www.medicaid.gov.

290 Report U.S. Census Bureau 2008, p. 19; Report U.S. Census Bureau 2011, p. 23; Report U.S. Census Bureau 2012, p. 21.

291 Report U.S. Census Bureau 2011, p. 23.

292 Report U.S. Census Bureau: Statistical Abstract of the United States 2012, p. 111, table 155.

293 See www.whitehouse.gov/healthreform.

294 See www.whitehouse.gov/healthreform/healthcare-overview\#healthcare-menu and obamacarefacts. com/index.php.

295 See www.whitehouse.gov/healthreform/myths-and-facts\#healthcare-menu and obamacarefacts. com/whatis-obamacare.php. 
will lead to a fine. Employers will also be more often obliged to provide health care insurance to their employees. Small businesses are entitled to a tax advantage in this regard. For individuals who lack the money, health insurance will be made more affordable. Since Obamacare passed in 2010, it has received a lot of attention and criticism. In 2012, the U.S. Supreme Court upheld the majority of the Act, which was good news for the health care reform plan. ${ }^{296}$ The United States House of Representatives passed a bill to repeal Obamacare on July 11 th $2012,{ }^{297}$ but just like earlier initiatives the House will probably not be successful in its effort to stop the health care reform as the Democrats who currently control the Senate will almost certainly not allow this.

However, despite this optimistic initiative to reform American health care, differences between the American and European approach to social security, i.e. public health insurance, will likely continue to exist for a while. Since World War II, the United States has spent considerably less on social benefits than Western European Countries. In 1995, public social welfare expenditures in the United States equaled $17.1 \%$ of GDP as compared to $35-37 \%$ in Scandinavian countries and $25-30 \%$ in Germany, the Netherlands, Italy, and the UK. ${ }^{298}$ According to Kagan: ${ }^{299}$

Despite the pressure of global economic competition, there are few signs that Western European governments have moved or will move substantially towards the less generous, more privatized, more voluntary model of social provision and employee protection.

Public health insurance thus plays a greater role in European countries than in the United States. The remainder of this section will therefore focus on Europe. The European system of social security was initially created to protect poorer people with an insufficient income. The first social security laws were meant for workers. Later on, after World War II, one started to believe that social security should be available to all categories of the population. Nowadays, the most important function of social security is to provide access to health care and income security to those who are unable to earn their own money, for example because of their sickness, disability, age, or forced unemployment. ${ }^{300}$ Furthermore, social security supplements incomes if the income is below the social minimum and provides for partial support in the costs of medical care, housing and raising children. Social security in the European Union is regulated in European Union legislation, for example in a Regulation on the coordination of social security systems and a Regulation on the application of social security schemes to employed persons, self-employed persons and members of their

296 National Federation of Independent Business v. Sebelius, 132 S.Ct. 2566 (U.S. 2012).

297 See www.metro.us/newyork/national/article/1147425-house-of-representative-votes-to-repealobamacare-for-33rd-time.

298 Kagan 2007, p. 44.

299 Kagan 2007, p. 59.

300 Pennings 2006, p. 653-655. 
families moving within the Community. ${ }^{301}$ Furthermore, each Member State has its own national social security system. For example, the following social security laws can be found in Dutch law. In case of illness, employees may rely on the Sickness Act (Ziektewet) and the Work and Income Capacity for Work Act (Wet Werk en Inkomen naar Arbeidsvermogen). Furthermore, based on article 7:629 BW, the employer is obliged to pay the salary of an employee who is absent due to sickness for a maximum period of two years. If an employee becomes disabled, the Invalidity Insurance Act (Wet op de Arbeidsongeschiktheidsverzekering) applies, while the Unemployment Insurance Act (Werkloosheidswet) is applicable in case of joblessness. These are all forms of employee insurance, which is distinguished from national insurance. Available national insurance laws in Dutch law are the Healthcare Insurance Act together with the Exceptional Medical Expenses Act (Zorgverzekeringswet and Algemene Wet Bijzondere Ziektekosten), the General Old Age Pensions Act (Algemene ouderdomswet), the General Child Benefit Act (Algemene Kinderbijslagwet) and the Surviving Dependants Act (Algemene Nabestaandenwet). ${ }^{302}$ As mentioned earlier, although these insurances are laid down in social security laws, it mostly concerns public first-party insurance as the greater part of the insurances are paid via premiums of the insureds and their employers.

Social security is an accessible system for compensation. The insured has a right to receive a social security benefit no matter what the cause of the situation leading to his damage is. Moreover, social security benefits are fixed amounts that are often only temporarily rewarded. Victims will for that reason keep looking for other compensation systems, i.e. compensation via tort law and private insurance. In contrast to social security, which has certain limits on compensation like private insurance, due to the principle of full compensation tort law is especially interesting for victims who have suffered personal injury to receive compensation for the so-called top of the income (top van het inkomen) and for immaterial damage. $^{303}$

It follows from the above that in addition to the tort system there are other important compensation systems for victims who have suffered personal injury, which all influence each other. The compensation mechanisms of private insurance and social security have been developed to a wider extent in Europe than in the United States as alternatives to tort litigation. In Europe, situations involving personal injury are often dealt with by social security or private insurance. ${ }^{304}$ As mentioned above, compensation via tort law has therefore become a rather marginal phenomenon. ${ }^{305}$ This provides a plausible explanation for the underdevelopment of civil litigation in Europe when compared to the United States.

301 Regulation 883/2004/EC and Regulation 1408/71/EC. See for an overview of social security rights per EU Member State ec.europa.eu/social/main.jsp?catId=849\&langId=en.

302 Bruggeman 2010, p. 352.

303 Hartlief 1997, p. 29.

304 Magnus 2010, p. 118. See also Magnus 2003.

305 The right of recovery withheld: those who invoke their right of recourse against the wrongdoer, such as insurers and employers, often use the tort system. On balance, a lot of money paid in tort litigation goes to those who take recourse against the tortfeasor rather than directly to the victim. 
However, one must keep in mind that there is a 'retreat of the European Welfare State' development going on, which was already signaled by Howells and Mildred fifteen years ago. ${ }^{306}$ Also due to the financial and economic crises that have captivated the world in the past years, a policy of retrenchment still predominates, which means that social security benefits have been further reduced. This makes compensation via tort law a more appealing compensation mechanism for Europeans. ${ }^{307}$ Note however that it is likely that the existence of a well-developed social security system in Europe is a factor that will reduce the chances of the development of a compensation culture similar to that in the United States.

\subsubsection{The Influence of Government Regulation on Civil Litigation}

As stated above, the level of interference of the government in regulating different areas, such as health and safety, may also influence the development of civil litigation. It is interesting to see the difference in this respect between the United States and Europe. In light of the private enforcement theme discussed earlier, American civil litigation and punitive damages awards in particular serve a regulatory function as a surrogate for the government. ${ }^{308}$ In Europe, the regulatory function is primarily fulfilled by governmental authorities and not by civil litigation. ${ }^{309}$ This difference between Europe and the United States will be illustrated further at this point, firstly by giving an example from products liability law, secondly by paying attention to research that has been done into the question how values are influenced by culture and lastly by exploring different views on own responsibility.

\subsubsection{An Example from Products Liability Law}

Products liability law regulates the legal responsibility of, among others, producers for damage caused by a product. The victim of a product-related accident should be able to obtain compensation for damage suffered. American courts were the first to recognise this and thereby anticipated the consequences of the industrial revolution. In 1944, the California Supreme Court acknowledged that consumers need to be protected against business and that business should bear the costs of harm inflicted on consumers. ${ }^{310}$ In 1963, the same court imposed strict liability, also known as liability without fault, on the manufacturer of a defective product. ${ }^{311}$ For this reason, the United States is known as the birthplace of products liability law. Nowadays, American products liability law is a highly developed legal field. In the United States, it is more common for victims of product related accidents than in Europe to start civil proceedings and to obtain compensation -

306 Howells \& Mildred 1998, p. 988.

307 Faure \& Hartlief 1999, p. 2013; Magnus 2010, p. 118.

308 See e.g. Howells \& Wilhelmsson 1997, p. 209 et seq.

309 Magnus 2010, p. 123.

310 Escola v. Coca Cola Bottling Co. of Fresno, 24 Cal.2d 453, 150 P.2d 436 (CA. 1944).

311 Greenman v. Yuba Power Products, Inc., 59 Cal.2d 57, 377 P.2d 897, 27 Cal.Rptr. 697 (CAL. 1963). 
often by joining a class action - for damage suffered. As regards the awarding of punitive damages in products liability cases, some necessary differentiations have to be made. American courts do award punitive damages in these cases, but this does not happen as often and is not as extreme as many laymen believe. As explained in section 3.2.2, punitive damages are far more often awarded in cases concerning intentional torts, defamation and financial torts than in cases concerning personal injury resulting from products liability, medical malpractice, automobile accidents, and negligence. Nevertheless, no other country in the world has or probably ever will have a similar method of products liability legislation and practice, which also includes the awarding of punitive damages. ${ }^{312}$ An important reason for the attractiveness of products liability law is the underdevelopment of other compensation schemes as referred to in the previous section. ${ }^{313}$ In the United States, products liability litigation is originally perceived as a surrogate for other compensation mechanisms. As a result, claimants in the United States have more actual interest in a claim than claimants in Europe. Furthermore, as will be explained below, contrary to Europe, products liability litigation is used as a regulatory tool in the United States. The products liability system is more extensively used in the United States, at least when compared to the European Union where products liability law was a 'minority area of practice' in $2000 .{ }^{314}$ In the past years, this image has not changed drastically.

In 1985, the legislator of the European Union issued a Products Liability Directive $^{315}$ in which 'the model of extended liability was borrowed largely from the law of the United States'. ${ }^{316}$ From the 1960s onward, consumers were increasingly injured by unsafe products. Europe was however confronted with 'the inadequacy of traditional legal principles to deal with the modern phenomenon of products liability'. ${ }^{317}$ The real catalyst for the development of European products liability legislation was the Thalidomide disaster. In the 1950s and 1960s, thousands of pregnant women around the world used the pharmaceutical drug Thalidomide to prevent morning sickness. As a result of using the medicine, they gave birth to severely deformed children. Another well-known example is the DES-case, which was already mentioned in the context of class actions in section 2.2.3.6. DES (diethylstilbestrol) was prescribed to pregnant women to prevent miscarriage. Today, the devastating effects of exposure to the drug are still noticeable: so-called 'DES daughters' suffer from various forms of rare cancer. Society has learned a hard lesson from these awful experiences: a high level of consumer protection is needed in order to prevent consumers from suffering damage relating to defective products. Most consumers will have certain expectations with regard to the products they use. An important aspect of their expectations is that the products are safe and that the safety

312 Products liability occupies a central role in American law: thousands of products liability suits are filed each year. See Owen 2005, p. 24

313 Howells \& Wilhelmsson 1997, p. 211

314 Howells 2000, p. 306.

315 Council Directive 85/374/EEC of 25 July 1985.

316 Deakin, Johnston \& Markesinis 2008, p. 703.

317 Howells \& Mildred 1998, p. 990. 
of products is ensured in the best possible way. Consumer protection can be achieved in two ways. First, product safety regulation can contribute to the prevention of damage resulting from unsafe and defective products. Product safety regulation likely encourages producers to create safe products. Second, consumers should be compensated if damage occurs despite the existence of preventative measures. Products liability law is the instrument by which injured persons can obtain compensation.

It seems as if Europeans deal with the safety of products in a different way than Americans do. This can be illustrated by the different approach to products liability law. The mentioned Products Liability Directive has little practical value in the Europen Union, where the idea of maintaining public safety is not the primary incentive of products liability claims. In the European Union, the safety of products is primarily left to public regulation. ${ }^{318}$ Numerous EC product safety laws together form a strong regulatory regime. ${ }^{319}$ Products that do not meet the safety requirements are quite easily 'recalled'. Products liability litigation serves a supplementary preventive role, but primarily it has a compensatory function in the (rare) situations where a defective product did cause damage. The European system works well as it does, but in a different manner than in the United States, where products liability law is the main regulatory tool to monitor, or even enhance, product safety. This is also reflected by the imposition of punitive damages in this legal field. Howells clearly explains the difference in approach: ${ }^{320}$

Products liability has, however, two (often conflicting) functions - compensating injured persons and acting as a gate-keeper and deterrent to ensure producers only market safe products. The role of punitive damages in the U.S. suggests that the regulatory function of litigation is important. Moreover, the threat of wide scale products liability litigation can be seen as an incentive for producers to improve the quality of their products, often with fiscal incentives from insurers. Although civil liability rules have a regulatory dimension in Europe, my impression is that products liability is more responsive to the compensatory needs of accident victims than to the regulatory aspects. Many Americans consider Europe to have a weak products liability litigation culture, but I gain the impression that there is sometimes a failure to appreciate the depth of the product safety regulatory regimes, which may explain why there is less need for products liability litigation as a means of regulatory control.

The difference between American and European product safety regulation is clearly demonstrated by the example of defective cars. In the United States, products liability law has a specific area of automotive litigation. In the European Union, the safety of cars is mainly regulated through product safety law. ${ }^{321}$ To conclude, the United States developed a litigation strategy whereas the European Union developed a regulation strategy toward the protection of health and safety in society. This is in fact not exclusively applicable to products liability law, but it can

318 Reimann 2003, p. 251; Howells \& Wilhelmsson 1997, p. 265.

319 Fairgrieve \& Howells 2006, p. 59.

${ }^{320}$ Howells 2000, p. 307-308.

321 For example Directive 96/79/EC and Directive 96/27/EC. See on general product safety Directive 2001/95 EC. 
be seen as an important characteristic of the American and European legal cultures as such.

\title{
6.4.3.2 Values Are Influenced by Culture
}

In considering how values are influenced by culture, it is interesting to mention the research of Hofstede. ${ }^{322}$ Hofstede does empirical research into the question how values are influenced by culture in many different countries. This research has been linked to the different cultures of tort law in Europe by Van Dam. ${ }^{323}$ Hofstede distinguishes between six dimensions of culture, such as IDV (individualism versus collectivism) and MAS (masculinity versus femininity). A dimension that seems to be especially interesting in respect of the theme government regulation is UAI (uncertainty avoidance). This dimension is explained as follows: ${ }^{324}$

The uncertainty avoidance dimension expresses the degree to which the members of a society feel
uncomfortable with uncertainty and ambiguity. The fundamental issue here is how a society deals
with the fact that the future can never be known: should we try to control the future or just let it
happen? Countries exhibiting strong UAI maintain rigid codes of belief and behaviour and are
intolerant of unorthodox behaviour and ideas. Weak UAI societies maintain a more relaxed attitude
in which practice counts more than principles.

Not surprisingly, on the issues of uncertainty avoidance, the United States scores lower (46) than a number of Western European countries: France (86), Germany (65), and the Netherlands (53). According to Hofstede, the relatively low score of the United States can be explained as follows: ${ }^{325}$

\begin{abstract}
The US scores 46 on this dimension and therefore, American society is what one would describe as "uncertainty accepting." Consequently, there is a larger degree of acceptance for new ideas, innovative products and a willingness to try something new or different, whether it pertains to technology, business practices, or foodstuffs. Americans tend to be more tolerant of ideas or opinions from anyone and allow the freedom of expression. At the same time, Americans do not require a lot of rules and are less emotionally expressive than higher-scoring cultures.
\end{abstract}

This can be contrasted with the relatively high score of France: ${ }^{326}$

At 86 France has one [of] the highest scores on the UAI Index. Certainty is often reached through academic work and concepts that can respond for the need of detail, context, and background. Teachings and trainings are more deductive. In management structure, rules and security are welcome and if lacking, it creates stress. Therefore planning is favored, some level of expertise welcome, when change policies on the other hand are considered stressful.

The high level of uncertainty acceptance in the United States might also be explained by the often heard idea that Americans are raised with the right to sue

322 Hofstede, Hofstede \& Minkov 2010; Hofstede 2001; Hofstede 1998. The figures used in this section were sourced via the website of Geert Hofstede: geert-hofstede.com.

323 Van Dam 2007; Van Dam 2009. See also section 6.2.1.

324 See geert-hofstede.com/dimensions.html.

325 See geert-hofstede.com/united-states.html.

326 See geert-hofstede.com/france.html. 
and holding others responsible for their own bad luck, whereas Europeans seem to focus more on own responsibility. ${ }^{327}$ This idea will be further explained in the next section.

Another relevant dimension in view of government regulation could be LTO (long-term versus short-term orientation). Although the differences are clearly smaller, the United States scores lowest (29) on this dimension in comparison to France (39), Germany (31) and the Netherlands (44), which means that of these countries the United States is the most short-term oriented culture according to Hofstede. Lastly, it is not a surprise that the United States is the most individualistic country of the four: the United States (91), France (71), Germany (67), and the Netherlands (80). Of course, these figures only give an idea of the differences in culture between the United States on the one hand and three continental European countries on the other hand. Hofstede's research nevertheless gives a valuable insight into the influence that different cultures have on values in society.

As follows from the next subsection, research has also been done into the impact of cultural differences on civil litigation. The American author Centner, among others, refers to a difference in culture with reference to the view on own responsibility. He suggests that different views on own responsibility have an impact on the use of litigation.

\subsubsection{The View on Own Responsibility}

Europeans may not rely on civil litigation to the same extent as Americans do because Europeans seem to take more responsibility for their own actions, whereas Americans focus more on mistakes of others and feel that others have responsibilities in respect of their safety. ${ }^{328}$ At risk of overgeneralising things, there probably is a truth in this statement. Note however that as explained in section 1.1, in the past years, also in Europe citizens seem to have developed an enhanced consciousness of rights and a stronger motivation to fight for their rights. Nonetheless, the following parts from Centner's book called 'America's blame culture' strikingly point out the difference between the United States and Europe with regard to responsibility: ${ }^{329}$

As I taught and traveled in numerous foreign countries, I observed my surroundings with respect to features relating to personal safety. I was often surprised by what I saw. In many western democracies, I observed features and situations that do not exist in the United States due to our legal climate. For example, in a public park in Western Australia, visitors are able to climb a metalrung ladder 167 feet up the side of a tree without supervision. Would you expect a government to develop a similar feature in a giant California Redwood? Obviously not; it's too dangerous. Someone would be injured and sue the landowner.

327 Section 2.2.3.

328 See also Keirse 2007, p. 2424.

329 Centner 2008, p. 6-7. 
The author, who has lived with his family in Germany for a while, continues:

During my travels, I often wondered why numerous unsafe conditions were permitted to continue? Yet I did not see injuries from the unsafe conditions. It wasn't until I took my eight- and ten-year-old children to live in Germany that I became aware of the answer. Some unsafe conditions do not lead to injuries if people take charge of their own safety. Europeans accept more responsibilities than Americans and employ care to avoid being injured. [...]. When people assume responsibility for their own safety, they sustain few injuries despite the dangers presented by their physical surroundings. By accepting responsibility for their actions, Europeans do not attempt to blame someone else in a lawsuit.

Finally, the author gives a suggestion to the Americans:

How simple to fix the American litigation system: require people to pay attention to take charge of their lives. If you keep yourself safe, you don't need a lawyer to sue for your injuries. My experiences keeping my young kids safe in Europe allowed me to discover that one culprit of some of our litigation woes is responsibility. Americans decline to act responsibly when they fail to use care to avoid accidents. As a result, they are more likely to be injured. Furthermore, rather than accepting responsibility for their mistakes, they commence lawsuits. Europeans forgo blaming others because they approach responsibility differently.

To conclude, due to different perspectives on own responsibility, Europeans may not rely on civil litigation to the same extent as Americans do. Keeping in mind the functions of punitive damages, this might also indirectly explain the different views on the use of punitive damages. In this respect, it is however essential to remember that American punitive damages awards are not predominated by cases in which the protection of health and safety plays the most important role, i.e. cases concerning personal injury resulting from products liability, medical malpractice, automobile accidents, and negligence. Rather, punitive damages are far more often awarded in cases concerning intentional torts, defamation and financial torts. ${ }^{330}$

The above explains how different perspectives on private enforcement, other compensation mechanisms and government regulation may influence views on civil litigation in Europe and the United States. A last characteristic that can be mentioned in this regard is the availability of certain procedural law mechanisms, i.e. the subject of the next section.

\subsubsection{The Influence of Procedural Law Aspects on Civil Litigation}

In section 2.2.3, attention was already paid to certain procedural law mechanisms available in American law that create a legal climate in which civil litigation is made accessible. Most of these mechanisms are not or only partially known in European countries and this causes a difference between the United States and Europe as regards the prevalence of civil litigation. The main procedural law aspects will be briefly mentioned here.

${ }^{330}$ See section 3.2.2. 
Firstly, most European legal systems are not so much influenced by adversarial legalism, which is a fundamental characteristic of the American legal system. ${ }^{331}$ Kagan points out that the United States has a distinctive legal style when compared to Western European governments, including the United Kingdom. ${ }^{332}$ The outcome of a legal procedure is to a large extent influenced by the parties' lawyers who have to reveal the truth to the passive decision maker. Although party autonomy also plays an important role in continental European legal systems, such as the Netherlands, especially when it comes to the law of evidence, the European judge seems to have a more inquisitorial role to actively reveal the truth than the American judge. As mentioned in section 2.2.2.2, the transfer of public policy powers from the government to civil litigation, i.e. the use of private attorneys general, is an important aspect of adversarial legalism. ${ }^{333}$ The same is true for powerful civil sanctions and for decision-making by juries, which forms the next procedural aspect that is unknown to continental European legal systems.

Secondly, a characteristic of the American legal system that is largely unknown to continental Europe - with some exceptions, for instance Belgium - is the use of juries. As a passive decision maker, the jury fits well in an adversarial system. ${ }^{334}$ The jury has substantial influence in civil litigation as it may decide on issues of fact and is able to influence the amount of (punitive) damages awards without having to motivate its decisions.

Thirdly, the decision for a victim to start expensive proceedings may become easier due to the American rule on litigation costs and the system of contingency fees or remuneration of lawyers on the basis of 'no cure, no pay'. The American rule implies that the parties in a civil lawsuit have to pay for their own legal representation costs, regardless of the outcome of the lawsuit. ${ }^{335}$ The effect of the American rule is that it most likely influences the amount of punitive damages awards, as juries usually take litigation costs into account when calculating these awards. $^{336}$ In contrast, continental European legal systems apply the European rule, which means that the losing party also has to pay - in line with a fixed list of amounts - for the litigation costs of the winning party. This will prevent most claimants from bringing doubtful or risky cases before the court. ${ }^{337}$ Claimants are not able to exclude the risks of having to pay litigation costs in the same way as Americans can, as contingency fee arrangements are illegal in most European countries where lawyers should stick to fixed hourly rates in order to uphold their independence, incorruptibility and integrity. ${ }^{338}$

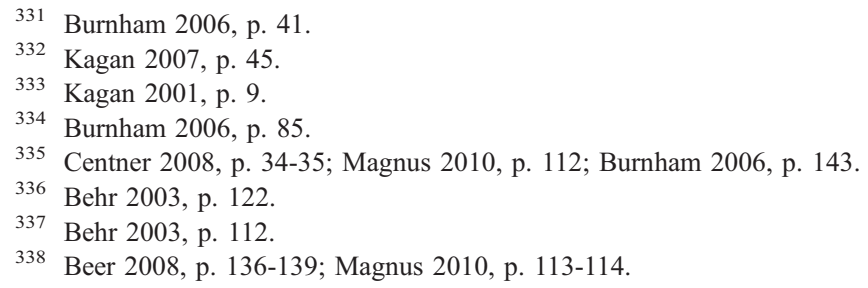


Fourthly, a characteristic of the American legal system is the near absence of legal aid from public funds. ${ }^{339}$ Legal aid is considered unnecessary due to the American rule on litigation costs, which enables even the poorer people to start a civil procedure. In contrast, the European rule has made legal aid from public funds necessary in European legal systems. In Europe, a person is usually only entitled to financial support if certain requirements are fulfilled, such as reasonable prospects of success of the claim. ${ }^{340}$ Thus, legal aid is an important mechanism in Europe to filter out claims of little value or importance. ${ }^{341}$

Fifthly, the final characteristic of American law that most likely facilitates civil litigation is the class action or collective civil litigation. Most European civil law systems do not have a mechanism that is similar to the American class action, although, as explained in section 2.2.3.6, in recent years the European interest in class actions has increased. For example, the Act on Collective Settlements Mass Damages (Wet Collectieve Afhandeling Massaschade) ${ }^{342}$ from 2005 is an important reason for this increase in the Netherlands. Also in the United Kingdom there is more and more attention for class actions as the government recently announced plans to introduce opt-out class actions in competition law cases. ${ }^{343}$ Furthermore, two recent documents of the European Commission concerning collective redress should be mentioned: the Member States are therein advised to create national collective redress systems to enable private enforcement of rights granted by European Union law in areas such as competition, consumer protection, financial services, investor protection, non-discrimination, environmental protection, and protection of personal data. ${ }^{344}$ However, at present, tort law class actions still seem to play a rather small role in Europe.

To conclude, in view of the value that is attached to private enforcement and the civil justice system in the United States, these procedural law mechanisms are most likely created in American law to make access to courts for private citizens easier. Thus, the different perspectives in the United States and Europe on private enforcement and civil litigation probably also explain why such procedural mechanisms are largely absent in continental European legal systems.

\subsection{Other Reasons for the Non-Existence of Punitive Damages}

Three traditional reasons for the non-existence of punitive damages in continental Europe have been described above. Essential are the view on the functions of tort law, the division between public law and private law and the role of government. However, that does not mean that these are the only available reasons. This section will explain some other, primarily dogmatic, reasons against punitive damages that

339 Centner 2008, p. 22.

340 See e.g. in Dutch law article 12 Wet op de Rechtsbijstand.

341 Magnus 2010, p. 114.

342 Incorporated into the Dutch civil code (articles 7:907 to 7:910 BW) and in the Dutch code of civil procedure (articles 1013 to $1018 \mathrm{Rv}$ ).

343 See Higgins \& Zuckerman 2013.

$344 \operatorname{COM}(2013) 401 / 2$, at $\S 3.1 ; \mathrm{C}(2013) 3539 / 3$, at $\S 31$. 
pop up in the European punitive damages debate and are also put forward by opponents of the civil remedy in common law systems such as the United States.

\subsubsection{Some Common Additional Reasons against Punitive Damages}

The traditional and most common reasons against punitive damages relate to the public-private divide. ${ }^{345}$ As mentioned above, examples are the criminal law character of a punitive damages award, the lack of criminal procedural safeguards in a civil procedure and the undesirable consequences for prosecution policies. However, reasons against punitive damages outside the public-private sphere also exist. Section 4.3 has already provided an extensive overview of general points of critique on the punitive damages remedy. It is useful to briefly repeat such reasons at this point as they are also referred to by opponents of punitive damages in continental Europe.

One common reason relates to the assumed deterrent function of punitive damages. Critics doubt the deterrent - both general and special - effect of punitive damages, especially when punitive damages insurance is allowed. A similar debate is centered on criminal law sanctions, as the deterrent effects of such sanctions can also not be established with complete certainty. ${ }^{346}$ Likewise, there are doubts about the effect that this remedy could have in respect of law enforcement. As will be further explained in chapter seven, there is a discussion going on in Europe about the (lack of) the enforcement of legal standards. Recent Dutch legal research for example shows that already in the early nineties, various policy documents referred to problems relating to law enforcement. ${ }^{347}$ The idea is that the traditional reliance on public law mechanisms - i.e. criminal law, administrative law and governmental supervisors - does not produce satisfactory results in all situations of criminal or wrongful conduct. A supposed reason for this undesired result is the lack of capacity of public authorities, police forces, public prosecutors, and so on. Civil punishment in the form of punitive damages could help to resolve problems in the area of law enforcement. In line with the American strategy, the civil remedy could work as a supplement to criminal sanctions. ${ }^{348}$ However, critics suggest that it is open to discussion whether this is indeed the best solution; the same or even better results could perhaps be reached by improving the existing public law mechanisms. ${ }^{349}$

A reason that is also often used against punitive damages concerns the unjustified benefit that a punitive damages award gives to the victim, i.e. the earlier explained windfall-effect. This effect is considered incompatible with the principles of restitutio in integrum and full compensation of loss that are upheld in continental Europe: ${ }^{350}$

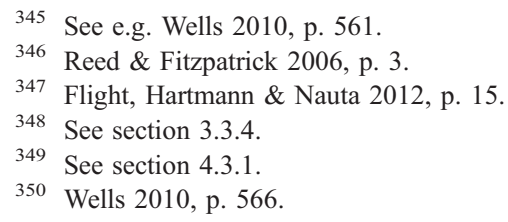


The aim of tort law is to make the victim whole, and punitive damages are often at odds with that aim.

Opponents argue that, as punitive damages are also awarded in the public interest rather than to vindicate the interests of the victim, the financial benefit should go to the state rather than to the victim.

To conclude, a topic that also receives attention from critics concerns the alleged unpredictability and uncertainty of punitive damages awards. Due to the vagueness of liability standards often seen in American punitive damages law, opponents in Europe fear that the civil remedy will be surrounded by ambiguity and will be threatening for legal certainty because of its excessive and unpredictable character. $^{351}$

These are the most important additional reasons against punitive damages which, as idle as they may seem, all play a role in respect of the rather negative view on punitive damages in continental Europe.

\subsection{Concluding Remarks}

In this chapter, three traditional reasons that explain the non-existence of punitive damages in continental Europe have been analysed, as well as some other reasons against punitive damages.

The first reason relates to the compensatory function of tort law. Historically, both in the common law and in the civil law tradition, tort law was inseparable from criminal law and punitive and compensatory elements were combined in a single body of law. Nowadays, in both legal systems the main function of tort law is compensation. But as regards the punitive function, the systems developed in a different direction. While in most civil law systems punitive elements in tort law have been abolished, common law systems have preserved a general punitive function of tort law. However, it has been argued that punitive elements in tort law are de facto recognised in modern civil law systems and that reconciliation between the common law and civil law tradition is again taking place. ${ }^{352}$ According to some, a punitive function of tort law occurs beneath the surface, for instance under the heading of immaterial damages for physical injury or personality right infringements. ${ }^{353}$ Note that, due to the relevance of this argument for analysing the problem statement, (hidden) civil sanctions will be the central theme of chapter nine. Nonetheless, it is generally accepted that punishment has not become a recognised function of modern tort law in European civil law systems. This is the first reasonable argument that can be put forward in answering the question why the punitive damages remedy is not a recognised civil remedy in continental European tort systems. Punishment of wrongful behaviour should, in the public opinion, be left to public law mechanisms and is not a goal that should

351 Wells 2010, p. 566.

352 Beever 2008b, p. 292; Nagy 2012, p. 5.

353 Von Bar 1998, p. 629. 
be pursued by private law. In Europe, the main focus is on a wide range of legal mechanisms offered by public law, such as criminal law, administrative law and governmental supervisors. These are the traditional mechanisms that are available to deter, detect and punish wrongful conduct in society. At this point it should again be made clear that the reason for the European interest in punitive damages is the changing perspective on law enforcement and powerful civil sanctions to deal with situations of serious wrongdoing. The American idea that punitive damages could play a supplementary function to solve societal problems relating to inadequate protection by, for instance, criminal law mechanisms has become part of the European debate. A more detailed analysis of the increased European attention for punitive damages will be given in chapter seven.

As regards the compensatory function of tort law, what needs to be remembered is that compensation via tort law is nowadays seen as one of the three mechanisms to deal with wrongful losses that fall in society. Whereas it is generally accepted that compensation is the primary function of tort law, it is not the sole function. Tort law has a combination of functions, and it depends on social and political circumstances and per legal system which function is predominant. In the past decennia, the deterrent function has for example received increased attention in addition to the compensatory function. Other relevant functions of tort law are law enforcement, loss-spreading, loss-allocation, vindication for the victim, and declaration of rights.

The second reason, which is strongly related to the first reason, concerns the public-private divide. The division between public law and private law is traditionally considered more important in civil law systems than in common law systems. Common lawyers also respect this division but they do not attach so much value to it as civil lawyers do. This explains - to a large extent - why the two legal systems disagree on the issue of punitive damages. The public-private divide cannot impede the imposition of punitive damages in the United States, where this is considered a choice of policy. In contrast, the idea in civil law systems that tort law has a compensatory rather than a punitive objective is not only based on the theoretical analysis of tort law as such, but it also results from the strict division between public law and private law. We do see, however, that in civil law systems the public-private divide becomes increasingly blurred and theories on law enforcement are shifting from the public to the private level. This shift can be seen as one of the reasons for the increased European interest in punitive damages. There is one aspect to the public-private divide that is especially put forward as an argument against punitive damages, i.e. incompatibilty with criminal law safeguards, for example in the context of article 6 ECHR. As the punitive damages remedy can obviously not be introduced in continental Europe without giving fair consideration to this problem, it will also be addressed in the concluding chapter ten.

The third reason relates to the role of government. It is plausible that the general view on the role of government, which covers several aspects, also plays part in the non-existence of punitive damages in continental Europe. Certain governmental 
policy choices influence the view on punitive damages. This argument is drawn from the noticeable difference between the United States and Europe in respect of civil litigation. An important aspect of the American legal system that is virtually absent in Europe is private enforcement or citizens who function as private attorneys general. However, as mentioned above, there are indications that point towards increased attention for private enforcement in Europe. Other aspects of the role of government that may have an impact on civil litigation in general and the awarding of punitive damages in particular concern views on other compensation mechanisms and government regulation. Lastly, the unfamiliarity with certain procedural law mechanisms, such as class actions and contingency fees, does not facilitate civil litigation in Europe. At least, what can be said is that, in comparison to the United States, European legal systems do not have a similar array of procedural mechanisms that facilitate civil litigation.

This chapter has explained the traditional reasons for the non-existence of punitive damages in continental Europe. The information provided gives a sufficient basis to explore the next research question: the developments that illustrate the increased European interest in punitive damages as well as the explanations for these developments. The next chapter will analyse this problem and will eventually help to answer the question whether the punitive damages remedy has a future in continental Europe. 


\section{CHAPTER SEVEN}

\section{PRIVATE ENFORCEMENT AND POWERFUL CIVIL SANCTIONS: CAUSES OF THE INCREASED EUROPEAN INTEREST IN PUNITIVE DAMAGES}

\subsection{Introductory Remarks}

The previous chapters give an overview of punitive damages law in the United States, the legal system known for its most widespread use of the civil remedy (chapters two to five) and - in contrast - the non-existence of punitive damages in continental Europe (chapter six).

As explained in chapter six, at least three reasons prevent the acceptance of the punitive damages remedy in civil law systems. These reasons relate to: (a) the traditional compensatory function of tort law, (b) the fundamental rejection in relation to the public-private divide, and (c) the view on the role of government.

Despite the objections to punitive damages in continental Europe following from certain obstacles that are intrinsic to the civil law tradition, there appears to be growing European attention for the civil remedy. This tendency is visible enough to form the reason for this research. In this chapter answers will be provided to two questions which, as explained in chapter one, together form research question three. Firstly, which developments have led to the idea that punitive damages may form a useful addition to the already existing tort remedies in continental Europe and, secondly, how can these developments and the increased European interest be explained? Answering these questions will eventually help to analyse the problem statement, i.e. does the punitive damages remedy have a future in continental Europe?

An important cause for the growing European interest in punitive damages is the already mentioned concept of private enforcement, a rather contemporary - at least for continental Europe - concept that finds its origins in the field of competition law (in the United States known as antitrust law). Another important cause, which is closely connected to the first cause, may be found in perspectives on the functions of tort law that are increasingly subject to change. This leads to calls for powerful civil sanctions. As regards the first cause, private law has been discovered as an instrument to enforce various legal standards at both the European Union and national levels, for example in the field of environmental law, consumer law, human rights law, competition law, intellectual property law, anti-discrimination law, and personality rights. ${ }^{1}$ The CJEU, for example, has created a formula stating that national sanctions which may be imposed for breaches of European Union law should be 'effective, proportionate and dissuasive', a development that has already been connected to the punitive damages remedy, even though the

1 Cauffman \& Weyts 2009, p. 4; Adriaanse et al. 2008, p. 276; Kilpatrick 2000, p. 2. 
formula was probably not created for this purpose. ${ }^{2}$ Law enforcement through private law mechanisms such as tort damages is known as private enforcement, a concept that will be explained in detail below. With regard to the second cause, there is growing attention for the need to introduce powerful civil sanctions to improve the enforcement of tort law standards and deal with intentional, calculative and grave misconduct of tortfeasors. In this respect, an often heard example is the infringement of personality rights due to wrongful publications by tabloids. In most instances, the victim avoids the trouble of bringing a civil action for damages, even if he has the right to do so. If the victim does decide to file a claim, tabloids usually seem quite willing to rectify and pay damages. However, the damages awarded are as a rule not in proportion to the profits made by the tabloid, which enables tabloids to infringe personality rights without having to suffer substantial consequences. This has been illustrated by a German case concerning Caroline von Hannover, also known as Caroline I. ${ }^{3}$ The German Supreme Court decided that the gains incurred at the expense of Caroline's rights - a tabloid unlawfully published pictures and a false interview with incorrect details about her personal life - were to be returned. According to the Court, profit made because of the infringement of a personality right is a factor that can be taken into account in assessing the damages award. The reasoning that mere compensation is not an effective method to deal with personality right infringements is quite interesting. According to the Court, using the method of compensation would not lead to the effective prevention of such infringements, as the compensation awarded is usually far below the profit resulting from the infringement. ${ }^{4}$ Wagner and Koziol explain that the immaterial damages award that was granted to Caroline for the infringement of her personality right obviously serves the function of deterrence. ${ }^{5}$ Although the immaterial damages award was originally fixed at DM 30,000, Caroline's case was referred to the Hamburg Court of Appeal and a total sum of DM 180,000 was awarded. ${ }^{6}$ This sum, which also covers two later wrongful publications, is one of the - if not the - highest immaterial damages awards for personality right infringements ever awarded in Germany. ${ }^{7}$ Caroline also took her case to the European Court of Human Rights, which decided in 2004 that the German government was in breach of article 8 ECHR. ${ }^{8}$ An award of just satisfaction was not granted in this case. ${ }^{9}$ In a second, more recent case that had been brought before the Court by Caroline and her husband, the Court decided that

\section{See section 7.3.1 and section 8.4.}

BGH 15 November 1994, BGHZ 128, 1 = NJW 1995, 861 (Caroline I). Shortly after Caroline I, three other cases concerning the infringement of Caroline's personality right were decided: BGH, NJW 1996, 984 (Caroline II); BGH, NJW 1996, 1128; BGHZ 131, 332 (Caroline III); BGH, NJW 1996, 985 (Caroline's son).

Koziol 2009, p. 286.

Wagner 2006b, p. 384-386; Koziol 2012, p. 70.

OLG Hamburg 25 July 1996, NJW 1996, 2870.

Amelung 1999, p. 22.

ECtHR 24 June 2004, Von Hannover v. Germany, no. 59320/00, at § 76-81.

Von Hannover v. Germany, at $\S 85$. 
there was no violation of article $8 \mathrm{ECHR}^{10}$ In this respect, one of the main arguments of the Court was that the national courts had carefully balanced the right of the publishing companies to freedom of expression against the right of the applicants to respect for their private life and that this balancing of rights was done in accordance with German case law as well as relevant case law of the European Court of Human Rights, including the first Caroline decision from 2004. Despite the 2012 decision in which no violation of the ECHR was found, Caroline has become known as the champion of the protection of privacy rights. ${ }^{11}$

Note that the above-mentioned immaterial damages award of DM 180,000 granted to Caroline, as well as other German immaterial damages awards, should also be seen in the context of the value attached in the German legal system to the general personality right (das allgemeine Persönlichkeitsrecht), which is a judgemade right to compensation of immaterial loss in case of serious personality right infringements created by the German Supreme Court in $1954 .^{12}$ This general personality right will be further explained in section 9.4.2.2. Furthermore, German immaterial damages awards are generally rather substantial, especially when compared to surrounding countries. ${ }^{13}$ For example, in 2006 the highest German immaterial damages award was a sum of $€ 500,000$ plus $€ 500$ per month to (the parents of) a severely handicapped three-year-old child in a case from $2003 .{ }^{14} \mathrm{In}$ respect of the deterrent and law enforcement function of damages awards in the case of personality right infringements, reference should not only be had to German cases. Another good example can for instance be found in the case Krone Verlag GMBH v. Austria, decided by the European Court of Human Rights in $2012 .^{15}$ In this case, the Court upheld a compensatory damages award of $€ 130,000$ for the infringement of privacy rights under the Austrian Media Act. In addition to the tabloid example, one could think of other situations in which powerful civil sanctions might be necessary. Examples of such situations will be provided in section 7.3 below.

To start with, the increased European attention for private enforcement will be further explained in section 7.2.

\subsection{Private Enforcement}

Every legal system has to deal with the (lack of) enforcement of legal norms, i.e. norms to protect public and private interests. As explained in section 6.2.2.5, a wide range of public law mechanisms has been created to detect and deter

10

ECtHR 7 February 2012, Von Hannover v. Germany (no. 2), nos. 40660/08 and 60641/08, at $§ 124-$ 126.

11 See generally on this topic Barnes 2010.

2 BGH 25 May 1954, BGHZ 13, 334 (Schacht).

Von Bar 2000, p. 184-185.

Lindenbergh 2008a, p. 77, citing LG Kiel 11 July 2003, AZ O 13/03. See further section 9.4.2.2.

ECtHR 19 June 2012, Krone Verlag GMBH v. Austria, no. 27306/07. See on this case section 8.2. 
wrongful conduct in society. However, the traditional reliance on such mechanisms does not produce satisfactory results in all situations of wrongdoing.

In recent years, private enforcement has for that reason become a re-emerging term in the European juridical debate. At this point, it is important to first explain the origin and meaning of the term law enforcement. Law enforcement, which means both ex ante prevention of objective law infringements and ex post action taking against such infringements by the use of legal sanctions or remedies, is usually divided into public enforcement and private enforcement. ${ }^{16}$ Public enforcement refers to the use of governmental authorities (such as governmental supervisors and regulators, police forces, public prosecutors) to detect and to sanction violators of public law norms. In that sense, law enforcement is seen as a traditional task of the government. Public enforcement action taking is authorised by criminal law, administrative law, tax law, constitutional law, and other parts of the law that deal with the organisation of the State and aspects of it that are of direct concern to the State. ${ }^{17}$ Private enforcement refers to a private person (for example a consumer, an entrepreneur or a governmental entity acting as a private person) using a private law mechanism in order to obtain justice. The private person may, for example, file a civil suit, which could result in a damages award or an injunction. Law enforcement has then become a matter of private initiative and not a matter of the government. ${ }^{18}$ Where does the concept of private enforcement actually come from? The next section will briefly address its origin.

\subsubsection{Origin of the Concept}

Whereas private enforcement is a rather unknown concept in Europe, quite the opposite is true for the United States, where private enforcement is the primary method of enforcing numerous laws, such as securities laws, consumer protection laws, civil rights laws, antitrust laws and environmental laws. ${ }^{19}$ For example, more than $90 \%$ of antitrust laws ${ }^{20}$ are privately enforced in the United States. $^{21}$ Research shows that between 1941 and 1985 a total of 29,588 antitrust claims were filed in United States courts. Since 1985, 600 to 1,000 antitrust claims per year are being filed. ${ }^{22}$

As explained in chapter two, American public policy is privately implemented to a great extent in the sense that the enforcement of public norms is entrusted to private litigants. According to Carrington, private enforcement is surrounded by a certain 'mistrust of the political institutions and government officials upon whom American citizens would have to depend if private law enforcement were not

\footnotetext{
Van Boom 2006a, p. 27. See also on this topic Van Boom 2007a; Holmes 2004.

Polinsky \& Shavell 2005, p. 3.

Zippro 2009, p. 2-3; Polinsky \& Shavell 2005, p. 4.

Landes \& Posner 1975, p. 2; Carrington 2004, p. 1413-1414.

For an overview of federal antitrust laws see Cavanagh 1987, p. 779, footnote 5.

Nebbia 2008, p. 25; Zippro 2009, p. 15; Adriaanse 2007, p. 314.

Zippro 2009, p. 165, citing Jones 1999, p. 79 and the Annual Report of the Director for the years 1941-1985 of the Administrative Office of the United States Court.
} 
available'. ${ }^{23}$ This mistrust, Carrington continues, is supposedly reflected in the state and federal constitutions that emphasise the weakness and ineptitude of governmental institutions other than courts, and also in the American tradition of going to court whenever an important issue is at stake. ${ }^{24}$ Americans started to rely on private regulation, especially the regulation of business, during the period of industrialisation in the nineteenth century. ${ }^{25}$ A good example stemming from this time is the federal antitrust law. The Sherman Antitrust Act of $1890,{ }^{26}$ the first federal law to prohibit trusts and monopolies, was created to protect smaller businesses from anticompetitive behaviour and still forms an important basis for antitrust litigation. Congress designed the act with the idea that private enforcement would be the best method to enforce it, as the big commercial trusts were 'politically powerful institutions' that were 'able to intimidate and subvert public enforcement' by the inexperienced United States Department of Justice, in those days already responsible for law enforcement. ${ }^{27}$ Under the original version of the Sherman Act, private claimants were able to recover double damages for any harm resulting from infringements of antitrust law. This was later increased to treble damages, plus the award of attorney's fees to prevailing claimants. ${ }^{28}$ Such damages were then made applicable to all actions in which private parties sought recovery under the antitrust laws: ${ }^{29}$

... [A]ny person who shall be injured in his business or property by reason of anything forbidden in the antitrust laws may sue therefor in any district court of the United States in the district in which the defendant resides or is found or has an agent, without respect to the amount in controversy, and shall recover threefold the damages by him sustained, and the cost of suit, including a reasonable attorney's fee.

Apart from the award of treble damages including attorney's fees, the federal legislator has incorporated some other powerful incentives into the antitrust laws to encourage private enforcement that are worth mentioning. ${ }^{30}$ Notably, when the civil action follows a successful civil or criminal proceeding brought by the government, the claimant can rely on the factual findings of these proceedings, which are in that way considered as prima facie evidence. ${ }^{31}$ Furthermore, in the 1970 s also (the attorneys general of) states were empowered to bring a civil action

24 Carrington 2004, p. 1413. The French political scientist Alexis de Tocqueville noticed the American habit of litigating and wrote about it in his famous work 'de la Démocratie en Amérique' of 1835. See Centner 2008.

25 Carrington 2004, p. 1414

26 Act of July 2, 1890, 26 Stat. 209, codified at 15 USC $\S \S 1-7$.

27 Carrington 2004, p. 1414.

28 The treble damages provision was originally embodied in Section 7 of the Sherman Act and later incorporated into Section 4 of the Clayton Act (Act of Oct. 15, 1914, 38 Stat. 730, 731, codified at 15 USC $\S \S 12-27)$

2915 USC $\S 15(a)$.

30 Cavanagh 2005, p. 153.

3115 USC § 16; Cavanagh 2005, p. 153. 
in the name of the state, as parens patriae on behalf of its citizens. ${ }^{32}$ Although this is not private enforcement in the traditional meaning, i.e. the enforcement of law through private litigants, it does say something about the value that is attached to the concept. Lastly, the claimant can ask for injunctive relief if this fits the situation. $^{33}$

Direct compensation of private parties has always been an important goal of private enforcement. But private enforcement also plays a role in the 'self-policing capacity of business', and so in pursuing public enforcement goals. ${ }^{34}$ The federal legislator allegedly created private enforcement rights to complement the public enforcement of antitrust laws (which is nowadays in the hands of the Department of Justice Antitrust Division and The Federal Trade Commission), ${ }^{35}$ for fear that 'the government would not have the necessary resources to uncover, investigate and prosecute all violations of the antitrust laws'. ${ }^{36}$ However, the 'core' rationale for private enforcement is deterrence. ${ }^{37}$ The possibility that private parties and their lawyers will be rewarded for their bounty hunting works not only as an incentive for claimants but it also has deterrent effect on defendants. Buxbaum points out the relevance of the law and economics theory to explain the goal of antitrust damages and antitrust law: the goal of antitrust damages is to achieve optimal deterrence, whereas the goal of antitrust law is to enhance economic efficiency. ${ }^{38}$ She explains that although courts and policymakers consider compensation an important goal of private antitrust actions, the debate concerning private enforcement of antitrust law mostly relates to the question whether private actions in this field lead to an optimal level of deterrence. ${ }^{39}$ Also in the European debate on private enforcement of competition law, which will be explained in the next sections, both compensation and deterrence are considered the most important aims and advantages of private enforcement. ${ }^{40}$

American business is not the only area that is largely regulated through private enforcement. Also standards of professional conduct (think of standards for lawyers, doctors and accountants) are often privately enforced; doctors, for example, regularly face damages actions. ${ }^{41}$ Note that this practice is of course not exclusive for the United States: also in other legal systems private enforcement plays a role in controlling professional conduct. In other words, doctors are also

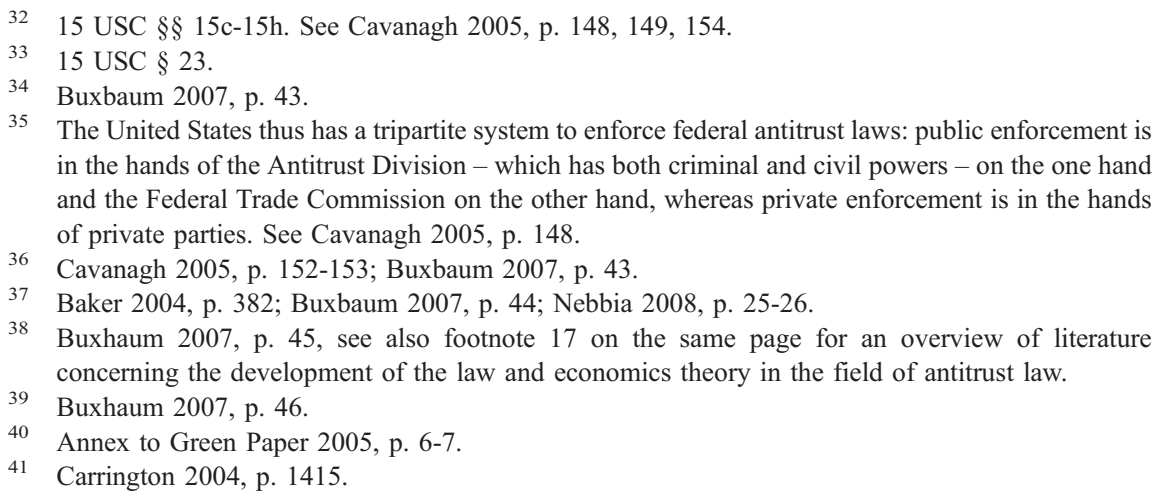

The United States thus has a tripartite system to enforce federal antitrust laws: public enforcement is in the hands of the Antitrust Division - which has both criminal and civil powers - on the one hand and the Federal Trade Commission on the other hand, whereas private enforcement is in the hands of private parties. See Cavanagh 2005, p. 148.

36 Cavanagh 2005, p. 152-153; Buxbaum 2007, p. 43

37 Baker 2004, p. 382; Buxbaum 2007, p. 44; Nebbia 2008, p. 25-26.

38 Buxhaum 2007, p. 45, see also footnote 17 on the same page for an overview of literature concerning the development of the law and economics theory in the field of antitrust law.

39 Buxhaum 2007, p. 46.

40 Annex to Green Paper 2005, p. 6-7.

41 Carrington 2004, p. 1415. 
being sued in, for instance, the Netherlands, Germany, France and England. There is however a noticeable difference in the extent to which private enforcement is used in the United States on the one hand and European legal systems on the other hand.

The fact that there is extensive use of private enforcement in the United States, whereas private enforcement is still a rather underdeveloped concept in Europe, may be explained by a different approach towards the public-private divide in the two areas, as will be described in the next subsection.

\subsubsection{Increased Attention for Private Enforcement in Europe}

Thus, there is a traditionally extensive use of private enforcement in the United States, whereas there is limited use of the mechanism in Europe. This may be explained by different approaches towards the public-private divide. Many of the privately enforced American laws mentioned above would be denoted as public law in a civil law country, while according to Carrington the division between public law and private law is hardly ever noticed in American law. ${ }^{42}$ At least, as explained in section 6.3, Americans seem to put less weight on the public-private divide than civil lawyers do.

In contrast, we have seen that civil law countries differentiate public law norms from private law norms. The public-private divide goes back to Roman law and civil law countries have stuck with it until now. Roman law made a distinction between ius publicum and ius privatum; the first regards the organisation of the Roman state, whereas the latter regards the welfare of individuals. ${ }^{43}$ Private law norms still regulate legal relationships between individuals and therefore focus on the individual. ${ }^{44}$ Because private law rules are of no direct concern to the state, they are as a rule privately enforced. Conversely, public law norms are in principle still designed to protect public interest goals and are therefore controlled by governmental organs through public enforcement. This is reflected in the monopoly position of the government to prosecute and punish citizens and to regulate different areas such as health and safety. ${ }^{45}$ The monopoly position excludes private persons, even if they are prejudiced or interested parties themselves, to take part in public law enforcement, prosecution and punishment. ${ }^{46}$

42 Carrington 2004, p. 1413.

43 Ulp. D. 1,1,1,2 = Inst. 1,1,4. Huius studii duae sunt positiones, publicum et privatum. Publicum ius est quod ad statum rei Romanae spectat, privatum quod ad singulorum utilitatem: sunt enim quaedam publice utilia, quaedam privatim. See Spruit 2001, p. 22; Dubber 2009, p. 3.

44 Kortmann \& Sieburgh 2009, p. 255, citing Opzoomer (Het Burgerlijk Wetboek verklaard door C.W. Opzoomer, deel 1, $3^{\text {e }}$ druk, a.w., p. 7).

45 Kortmann \& Sieburgh 2009, p. 255, citing the framer of the new Dutch civil code Meijers (Ontwerp voor een Nieuw Burgerlijk Wetboek, Toelichting, Eerste gedeelte (Boek 1-4), Den Haag 1954, p. 12-13).

46 Kortmann \& Sieburgh, p. 255, citing 'Parlementaire geschiedenis bij het Wetboek van Strafvordering', Bijl. Hand. II 1917/1918, 77 stuk I, p. 44-45, Stb. 1921, 14. 
It should be made clear again, as has been done in chapter six, that the publicprivate divide in civil law countries is not as strict anymore as it used to be. ${ }^{47}$ There is more and more overlap between the two, which runs parallel to changing policy views. European policymakers have shown interest in the concept of private enforcement to achieve public interest goals. This has even been noticed in the United States. According to Baker, private enforcement of competition law has 'suddenly arrived as a policy goal in the U.K., the European Union, and elsewhere'. ${ }^{48}$ Likewise, Jones concludes the following: ${ }^{49}$

The export of antitrust from the United States is gradually being followed by the increasing export of private enforcement actions to the foreign courtrooms of the world. As more countries seek to expand the implementation and enforcement of antitrust rules, they increasingly realize that supplemental private enforcement is needed to provide effective levels of enforcement and in particular to compensate victims as well as deter violators. While the United States is still superior as a venue for private damage actions, the courtrooms of the world are improving, and I think it is mostly a matter of time (and perhaps some legislation) before private litigation becomes effective abroad.

As stated above, private enforcement is a rather broad term. It covers the enforcement of public law norms by means of private law mechanisms, which may include tort law, contract law, property law, family law, and other legal fields that regulate legal relationships between individuals. Contract law may for example be used for the private enforcement of anti-discrimination law or competition law, respectively. Firstly, in case a landlord relies on a term from the tenancy agreement to dissolve the agreement for discriminatory reasons, such as disliking the tenant's religion, the tenant can fight the unjustified dissolution in court on the basis of contractual principles such as pacta sunt servanda. ${ }^{50}$ Secondly, the consumer who suffers damage due to anticompetitive behaviour may request the court to declare agreements that are in breach of competition law void. In the context of this chapter concerning the growing European interest in punitive damages, private enforcement is seen from a narrow perspective, namely private enforcement via tort law and especially damages actions in tort. This section explains why private enforcement in general and punitive damages in particular have become part of the European agenda, by which the agenda of the European Union is primarily meant.

\subsubsection{The Court of Justice of the European Union Takes the Lead...}

As in the United States, the debate on private enforcement in Europe started in the field of competition law. ${ }^{51}$ In 2000 , the European Union openly declared that it

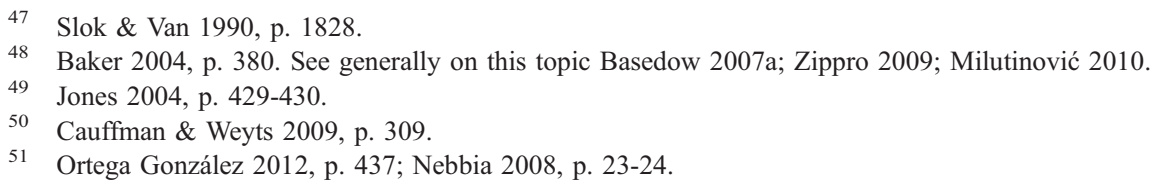


wants to become 'the most competitive and dynamic knowledge-based economy in the world'. ${ }^{52}$ The special action plan that has been developed to this end is known as the Lisbon strategy. Part of this strategy is an optimally functioning competition law, seeing that anticompetitive behaviour is harmful to the economy as a whole. ${ }^{53}$ The core of EU competition law is found in articles 101 and 102 TFEU (old articles 81 and 82 EC Treaty) regarding the prohibition of anticompetitive agreements, decisions or concerted practices, as well as the prohibition of abuse of a dominant position, respectively. These provisions have been formally worked out in Regulation 1/2003. ${ }^{54}$ According to articles 4 to 6 of this Regulation, the Commission, national competition authorities (NCAs) and national courts are empowered to apply articles 101 and 102 TFEU. This means that the Regulation already leaves room for private enforcement - namely via the national judge. ${ }^{55}$ Private enforcement does not necessarily have to substitute public enforcement of EU competition law, but it should act as a complement to it. ${ }^{56}$ As stated in the Green Paper on damages actions for breach of EC antitrust rules from 2005, which will be further explained in section 7.2.4.2 below: $^{57}$

Under Regulation 1/2003, the Commission and NCAs constitute a network of competition authorities responsible for public enforcement of the applicable Community antitrust rules. As part of their enforcement activities, these authorities adopt, among other things, decisions finding that an undertaking has infringed antitrust law as well as decisions imposing fines. Public enforcement is indispensable for effective protection of the rights conferred and effective enforcement of the obligations imposed by the Treaty.

The CJEU has played a central role in respect of the increased interest in punitive damages at the European Union level. The Court's decision-making with regard to the effectiveness of national sanctions that may be imposed for breaches of European Union law, especially the formula designed by the Court that all sanctions should be 'effective, proportionate and dissuasive' is, according to some, proof of the European Union's ambivalent and self-contradictory position on punitive damages, even though the Court probably did not have punitive damages in mind when creating this formula. ${ }^{58}$ The relevant decisions of the Court which concern private enforcement of, in particular, EU competition law will be discussed here. ${ }^{59}$ $100 / 00$, at $\S 5$.

53 Basedow 2007b, p. 1; see also Boot 2008, p. 200 et seq.

54 Regulation 1/2003/EC.

55 Cf. Boot 2008, p. 201

Paulis 2007, p. 9; Green Paper 2005, § 1.1; Annex to Green paper 2005, § 13.

Green Paper 2005, § 1.1.

See section 7.3.1 and section 8.4.

Wagner 2006a, p. A 71. See further section 8.4. 
The complementary nature of private enforcement of rights deriving from European Union law was already recognised by the CJEU in the case Van Gend en Loos of 1963: ${ }^{60}$

The vigilance of individuals concerned to protect their rights amounts to an effective supervision in addition to the supervision entrusted by Articles 169 [now article 258 TFEU] and 170 [now article 259 TFEU] to the diligence of the Commission and of the Member States.

As pointed out by Craig and De Búrca, the mechanism for public enforcement in article 258 TFEU - which allows the Commission to bring a Member State that has breached EU law before the CJEU - was weak and could not be used against private individuals; this explains why the CJEU has legitimised private enforcement. ${ }^{61}$ Private enforcement was also the central theme in a ruling of the Court in 1984, namely Von Colson and Kamann v. Land Nordrhein-Westfalen. ${ }^{62}$ In that case, which is outside the ambit of competition law, the Court had to rule on the compatibility of national sanctions for breaching the Equal Treatment Directive. ${ }^{63}$ Without giving solid reasons, an employer had rejected a female applicant for a job. Although this was held to be discriminatory according to the German court deciding the case, only the travel expenses incurred by the claimant were compensated (on the basis of $\S 611 \mathrm{a}(2) \mathrm{BGB}$ ), whereas other claims were dismissed. ${ }^{64}$ This was, according to the CJEU, unacceptable: ${ }^{65}$

Although, as has been stated in the reply to question 1, full implementation of the Directive does not require any specific form of sanction for unlawful discrimination, it does entail that that sanction be such as to guarantee real and effective judicial protection. Moreover it must also have a real deterrent effect on the employer. It follows that where a Member State chooses to penalize the breach of the prohibition of discrimination by the award of compensation, that compensation must in any event be adequate in relation to the damage sustained.

The Court ruled similarly in the case Harz v. Deutsche Tradax GmbH - decided on the same date as Von Colson - which is also about effective sanctions for breaching the Equal Treatment Directive: ${ }^{66}$

Although Directive No 76/207/EEC, for the purpose of imposing a sanction for the breach of the prohibition of discrimination, leaves the Member States free to choose between the different solutions suitable for achieving its objective, it nevertheless requires that if a Member State chooses

60 CJEU 5 February 1963, case 26/62, ECR 1 (Van Gend en Loos NV Algemene Transport- en Expeditie Onderneming v. Nederlandse Administratie der Belastingen), at § II B. See Craig \& De Búrca 2011, p. 183-186.

61 Craig \& De Búrca 2011, p. 181.

62 CJEU 10 April 1984, case 14/83, ECR 1891 (Von Colson and Kamann v. Land NordrheinWestfalen).

63 Directive 76/207/EEC.

64 Von Colson, at $\S 5$.

65 Von Colson, at $\S 23$.

66 CJEU 10 April 1984, case 79/83, ECR 1921 (Harz v. Deutsche Tradax GmbH), at $\S 28$. See on the Von Colson and Harz decisions: Curtin 1985. 
to penalize breaches of that prohibition by the award of compensation, then in order to ensure that it is effective and that it has a deterrent effect, that compensation must in any event be adequate in relation to the damage sustained and must therefore amount to more than purely nominal compensation such as, for example, the reimbursement only of the expenses incurred in connection with the application. It is for the national court to interpret and apply the legislation adopted for the implementation of the directive in conformity with the requirements of Community law, in so far as it is given discretion to do so under national law.

The requirement of 'effective, proportionate and dissuasive' sanctions is nowadays an important tool in European legislation concerning anti-discrimination in employment matters. We have already seen that, as will be further explained below, a connection between this development and punitive damages is being made.

Despite these early observations by the CJEU, enforcement in the field of competition law is still mainly controlled by the Commission in conjunction with NCAs of the Member States. The enforcement of competition law has been a matter of public enforcement for half a decade - fines that have been imposed by the Commission and the NCAs are deposited with the European and national treasuries $^{67}$ - whereas the situation of individual victims has not really been cared about for quite some time. ${ }^{68}$ A turning point came in 2001 when the CJEU acknowledged in Courage Ltd. v. Crehan ${ }^{69}$ the right of any individual, which includes contracting parties, ${ }^{70}$ to claim damages before national courts for loss caused by anticompetitive behaviour (the case concerned old article 81 EC). Individuals are hence entitled to compensation, a development that 'can make a significant contribution to the maintenance of effective competition in the Community'. ${ }^{71}$ In Courage Ltd. v. Crehan, another important ruling was given by the Court: $^{72}$

... In the absence of Community rules governing the matter, it is for the domestic legal system of each Member State to designate the courts and tribunals having jurisdiction and to lay down the detailed procedural rules governing actions for safeguarding rights which individuals derive directly from Community law, provided that such rules are not less favorable than those governing similar domestic actions (principle of equivalence) and that they do not render practically impossible or excessively difficult the exercise of rights conferred by Community law (principle of effectiveness).

Therefore, if effective European procedural rules are lacking, every Member State needs to create an operative procedure for individuals enabling them to enforce competition law privately. ${ }^{73}$ Courage Ltd. v. Crehan was later confirmed and

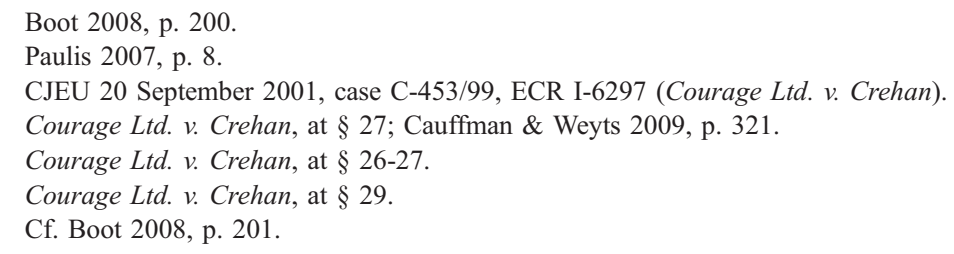


elaborated on by the CJEU in the Manfredi case. ${ }^{74}$ The Court decided in Manfredi that it is for the national courts to set the criteria for determining an appropriate award of damages for harm caused by anticompetitive behaviour, provided that the principles of equivalence and effectiveness are observed. ${ }^{75}$ Thus, national courts play an essential role in applying European Union law. ${ }^{76}$ The Court pointedly mentioned the possibility of awarding punitive damages for claims founded on EU competition law if such damages may be awarded pursuant to similar actions based on national law. ${ }^{77}$ As pointed out in one of the working documents that accompany the Commission White Paper on damages actions for breach of the EC antitrust rules, this acceptance of punitive damages shows that the Court is not concerned about unjust enrichment or a windfall for the plaintiff in case such damages are awarded, although it does allow the Member States to take steps to prevent unjust enrichment: ${ }^{78}$

The fact that the Court accepts the existence of punitive damages, which by definition implies a transfer of assets to the claimant beyond the damage actually suffered, shows that there is no absolute principle of Community law that prevents victims of a competition law infringement from being economically better off after a successful damages claim than the situation they would be in 'but for' the infringement. It can thus be assumed that an enrichment would no longer be unjust if it results directly from the application of the relevant substantive and procedural rules, meaning that it would be 'justified' by law. In the absence of such rules, the Court seems to accept domestic rules that aim at prohibiting enrichment without a just cause.

Furthermore, the Court decided in Manfredi that 'injured persons must be able to seek compensation not only for actual loss (damnum emergens) but also for loss of profits (lucrum cessans) plus interest'; according to the Court, this follows from the principle of effectiveness and from the right to be compensated for losses caused by competition law infringements. ${ }^{79}$ Lastly, as has been mentioned in the White Paper working document, the Court did not consider punitive damages to be contrary to the European public order: ${ }^{80}$

74 CJEU 13 July 2006, joined cases C-295/04 to C-298/04, ECR I-6619 (Manfredi and Others). As pointed out by Nordin, also in decisions from 2011 and 2013, the CJEU repeated that damages imposed by national courts play an important role in the enforcement of competition law in the European Union. See Nordin 2014, p. 110, citing CJEU 14 June 2011, case C-360/09, ECR I-05161 (Pfleiderer AG v. Bundeskartellamt); CJEU 6 June 2013, case C-536/11, not yet published (Bundeswettbewerbsbehörde v. Donau Chemie AG and Others).

75 Manfredi, at § 92, 98.

76 Cf. Regulation 1/2003, paragraph 7.

77 Manfredi, at § 93: 'In that respect, first, in accordance with the principle of equivalence, it must be possible to award particular damages, such as exemplary or punitive damages, pursuant to actions founded on the Community competition rules, if such damages may be awarded pursuant to similar actions founded on domestic law [...]'.

78 Annex to White Paper 2008, at $\S 201$. See on the White Paper 2008 and its working documents section 7.2.4.3 below. See also Manfredi, at $\S 95$.

79 Manfredi, at $\S 95$.

80 Annex to White Paper 2008, at $\S 199$. 
Provided that they are awarded in accordance with the general principles of Community law, amongst which the fundamental rights, punitive damages founded on an infringement of EC competition rules are thus not excluded. They are available if and under not less favourable conditions than punitive damages founded on similar national law infringements are.

Note that in this respect an apt comparison has been made to Rome $\mathrm{II}^{81}$ i.e. the Regulation on the law applicable to non-contractual obligations, which will be further explained in section 8.3. ${ }^{82}$ Contrary to the CJEU in Manfredi and the Commission in the White Paper working document, the legislator of the European Union did declare punitive damages as being contrary to public policy in recital 32 of the Preamble of Rome II. This is a clear example of the uncertain and selfcontradictory position of the European Union with regard to punitive damages. ${ }^{83}$

Nowadays, the right to damages for breaches of European Union law is an established right which goes hand-in-hand with the principle that national remedies must secure the effectiveness of European Union law. The principle of effectiveness (effet utile) of European Union law has been developed by the CJEU from the 1990 s onwards as a requirement for national courts to give adequate effect to directly applicable Community rights in cases arising before them. ${ }^{84}$ Equally important for the correct observance of European Union law by the Member States are the established principles of practical possibility (national law and procedures should not make the exercise of EU rights impossible in practice), equivalence (the remedies and forms of action available to ensure the observance of national law must be made available in the same way to ensure the observance of EU law), as well as the requirement of proportionality of penalties. ${ }^{85}$ Furthermore, as was established by the CJEU in the Francovich case ${ }^{86}$ and further developed in the joined cases Brasserie du pêcheur and Factortame III, ${ }^{87}$ a Member State may be held liable for damages under the principle of (Member State) liability for breach

81 Regulation 864/2007/EC.

82 Annex to White Paper 2008, at footnote 96.

83 See sections 8.3 and 8.4 .

84 E.g. CJEU 10 April 1984, case 14/83, ECR 1891 (Von Colson and Kamann v. Land NordrheinWestfalen); CJEU 19 June 1990, case C-213/89, ECR I-2433 (R. v. Secretary of State for Transport, ex parte: Factortame Ltd. and Others) (Factortame I); CJEU 8 November 1990, case C-177/88, ECR I-3941 (Dekker v. Stichting Vormingscentrum voor Jong Volwassenen); CJEU 13 March 1991, case C-377/89, ECR I-1155 (Cotter and McDermott v. Minister for Social Welfare and Attorney General); CJEU 25 July 1991, case C-208/90, ECR I-4269 (Emmott v. Minister for Social Welfare and the Attorney General); CJEU 2 August 1993, case C-271/91, ECR I-4367 (Marshall v. Southampton and South West Hampshire Area Health Authority); CJEU 8 March 2001, joined cases C-397/98 and C-410/98, ECR I-1727 (Metallgesellschaft and Hoechst v. Commissioners of Inland Revenue); CJEU 20 September 2001, case C-453/99, ECR I-6297 (Courage Ltd. v. Crehan). See on the principle of effectiveness also Craig and De Búrca 2011, p. 231-237; Annex to Green Paper 2005 , at $\S 19-22$.

85 Craig \& De Búrca 2011, p. 218-219.

86 CJEU 19 November 1991, joined cases C-6/90 and C-9/90, ECR I-5357 (Francovich and Bonifaci v. Italy).

87 CJEU 5 March 1996, joined cases C-46/93 and C-48/93, ECR I-1029 (Brasserie du pêcheur SA v. Germany and R. v. Secretary of State for Transport, ex parte: Factortame Ltd. and Others (Factortame III)). 
of European Union law. ${ }^{88}$ In the latter case, the Court especially referred to damages with a punitive function: ${ }^{89}$

As regards in particular the award of exemplary damages, such damages are based under domestic law, as the Divisional Court explains, on the finding that the public authorities concerned acted oppressively, arbitrarily or unconstitutionally. In so far as such conduct may constitute or aggravate a breach of Community law, an award of exemplary damages pursuant to a claim or an action founded on Community law cannot be ruled out if such damages could be awarded pursuant to a similar claim or action founded on domestic law.

\section{The Court continued: ${ }^{90}$}

Accordingly, the reply to the national courts must be that reparation by Member States of loss or damage which they have caused to individuals as a result of breaches of Community law must be commensurate with the loss or damage sustained. In the absence of relevant Community provisions, it is for the domestic legal system of each Member State to set the criteria for determining the extent of reparation. However, those criteria must not be less favourable than those applying to similar claims or actions based on domestic law and must not be such as in practice to make it impossible or excessively difficult to obtain reparation. National legislation which generally limits the damage for which reparation may be granted to damage done to certain, specifically protected individual interests not including loss of profit by individuals is not compatible with Community law. Moreover, it must be possible to award specific damages, such as the exemplary damages provided for by English law, pursuant to claims or actions founded on Community law, if such damages may be awarded pursuant to similar claims or actions founded on domestic law.

As pointed out by Oliphant, the principle of equivalence should in this respect be interpreted as requiring the award of punitive damages if such damages could in similar circumstances be awarded according to national law. ${ }^{91}$ And, on the basis of the Manfredi case, this requirement does not only apply to Member State liability but also to actions by private parties for breach of EU competition rules. ${ }^{92}$

\subsection{4 ...And the European Commission Carries the Work Forward}

In particular the elaboration of the principle of effectiveness by the CJEU has given momentum to the European debate on private enforcement. ${ }^{93}$ As stated above, according to Courage Ltd. v. Crehan and Manfredi, national law must provide, in principle, for an appropriate action for damages in case of breach of EU competition law. After Courage Ltd. v. Crehan, the Commission conceived the idea to stimulate natural and legal persons - this may be consumers or competitors - who are harmed as a result of anticompetitive behaviour to obtain justice by asking for compliance of EU competition law in civil disputes before national courts.

88 Craig \& De Búrca 2011, p. 241-253.

89 Joined cases Brasserie du pêcheur and Factortame III, at $\S 89$.

Joined cases Brasserie du pêcheur and Factortame III, at $\$ 90$.

91 Oliphant 2008, p. 244. See also Annex to Green Paper 2005, p. 36

92 Manfredi, at $\S 93$.

93 Craig \& De Búrca 2011, p. 181-183. Cf. Kortmann \& Sieburgh 2009, p. 249. 
Private enforcement of EU competition law can take different forms: private persons can for example claim the nullity of an unlawful agreement, file an action for injunctive relief in order to stop the anticompetitive behaviour or file an action for enforcement of a contract. ${ }^{94}$ Most importantly however - also in the context of this book - a private person may claim compensation for damages suffered. ${ }^{95}$ The sanction of nullity is explicitly provided for by article 101(2) TFEU itself. ${ }^{96}$ Damages actions and actions for injunctive relief may either be based on article 10 EC Treaty or national conditions and procedures (following the CJEU case law on the effectiveness of directly applicable Community law mentioned above). ${ }^{97}$ Furthermore, one must keep in mind that damages claims for anticompetitive behaviour cannot only be based on EU competition law but also on national competition law regimes. The following sections concern the Commission's actions in light of the enforcement of EU competition law.

\subsubsection{The Ashurst Report}

In most Member States, claims for damages resulting from competition law infringements will be based on tort law. For example, the legal basis for bringing an action for damages in the Netherlands is the general tort provision, article 6:162 BW. Tort law has not (yet) been harmonised at the European level. ${ }^{98}$ This means that there are to date 28 different legal systems for the private enforcement of EU competition law. $^{99}$ In 2004, prior to the Manfredi judgment, the Commission initiated a study to identify the obstacles to private enforcement in the then 25 Member States. ${ }^{100}$ The outcome was, as expected, not very optimistic about the current system: ${ }^{101}$

The picture that emerges from the present study on damages actions for breach of competition law in the enlarged EU is one of astonishing diversity and total underdevelopment.

With regard to the point of diversity, it appears from the report that only three Member States ${ }^{102}$ have a specific legal basis for bringing damages actions based on EU competition law, whereas twelve Member States ${ }^{103}$ have such a legal basis for claims based on national competition law. In the absence of a specific legal basis, thirteen Member States refer to general provisions for the conditions of liability (in fact, also the specific legal bases usually refer to these general provisions). According to the reporters, the absence of a specific legal basis in

94 Annex to Green Paper 2005, at $\S 16$

95 Cauffman \& Weyts 2009, p. 303.

96 Article 101(2) TFEU (old article 81(2) EC Treaty): 'Any agreements or decisions prohibited pursuant to this Article shall be automatically void'.

97 Annex to Green Paper 2005, at $\S 17$.

98 See section 6.2.2.6 on two European tort law harmonizing initiatives with a non-binding status.

99 Boot 2008, p. 201.

100 Ashurst report 2004.

101 Ashurst report 2004, p. 1

102 Finland, Lithuania, Sweden.

103 Cyprus, Estonia, Finland, Germany, Ireland, Italy, Latvia, Lithuania, Slovenia, Spain, Sweden, UK. 
most Member States does not in itself create obstacles, although the existence of a legal basis may 'raise the profile' and thereby encourage private persons to initiate proceedings. ${ }^{104}$

As regards the point of underdevelopment of private enforcement of competition claims, the study mentions the following: ${ }^{105}$

[...] the study has revealed only around 60 judged cases for damages actions (12 on the basis of EC law, around 32 on the basis of national law and 6 on both). Of these judgments 28 have so far resulted in an award being made ( 8 on the basis of EC competition law, 16 on national law and 4 on both).

Thus, according to this study, throughout the European Union a total of 60 antitrust claims were reported by 2004, of which only 28 have resulted in a damages award. Although the study does not give any official statistics, the fact that national reporters are able to bring up only a small amount of cases is an indication in itself. According to different research carried out in the Netherlands, between 1975 and 1998 no more than about 10 competition claims per year were brought before the Dutch civil courts. Since 1998, when the Dutch Competition Act (Mededingingswet) entered into force, there has been an average of 40 claims per year. ${ }^{106}$ On top of that, among this small number of cases, there are hardly any damages claims: the majority of claims concern the question whether agreements that are in breach of competition law rules should be complied with. ${ }^{107}$

In contrast, as mentioned in section 7.2.1 above, every year 600 to 1,000 antitrust claims are filed in the United States. The ratio between private enforcement and public enforcement of American antitrust claims varies from 10:1 to $20: 1$, which in practice means that 90 to $95 \%$ of all claims are privately enforced. ${ }^{108}$ Compared to the European figures mentioned above, the difference is enormous: it becomes quite clear from these figures that privately enforced antitrust claims are a normality in the United States and an exception in the European Union.

Haak and VerLoren van Themaat give three explanations for the lack of private enforcement of competition law, most importantly damages claims, in the Netherlands as well as in the rest of Europe: (1) the financial and other risks are outweighed by the expected benefits of the procedure; (2) it is very difficult for an injured party to produce proof of a competition law infringement; and (3) it is also difficult to produce proof as regards the injured party's loss, whereas it is quite easy for the infringer to put up defences in this regard. ${ }^{109}$ The authors also refer to the recommendations given in the Ashurst report to remove the obstacles in respect

104 Ashurst report 2004, p. 1.

105 Ashurst report 2004, p. 1.

106 Zippro 2009, p. 164, citing Haak \& VerLoren van Themaat 2005, p. 2.

107 Zippro 2009, p. 164.

108 Zippro 2009, p. 165.

109 Haak \& VerLoren van Themaat 2005, p. 2. See as regards obstacles from different perspectives also Ashurst report 2004, p. 1-9. 
of private enforcement: (a) improving access to courts; (b) reducing risks in terms of uncertainty of the outcome of the litigation; (c) facilitating proof; (d) reducing the costs involved in litigation; (e) introducing other incentives, such as punitive or multiple damages and using the defendant's profit to measure damages; and (f) improving transparency and publicity. ${ }^{110}$

The report thus also pays attention to punitive damages as a possible private enforcement mechanism in competition law cases. As pointed out by Nordin, this idea to introduce punitive damages in EU competition law was not new, but already formed part of the debate in 2001, i.e. the year that Courage Ltd. v. Crehan was decided by the CJEU. ${ }^{111}$ Only Cyprus, Ireland, England and Wales currently recognise a form of punitive damages in relation to competition law claims, although even in these countries such damages are rarely awarded. ${ }^{112}$ In the other Member States, damages actions are mainly seen as compensatory and restitutionary in nature; this is in line with the traditional compensatory function of tort damages in civil law countries. Some countries provide for other elements that go beyond financial compensation of the victim. For example, in France, Italy, the Netherlands, and Poland a court decision or a confession from the violator may on request of the claimant with the consent of the court - be published in the press. ${ }^{113}$ The reporters think that such publications may encourage the private enforcement of competition law. ${ }^{114}$

The report concludes by giving recommendations to facilitate private enforcement of old articles 81 and 82 EC. ${ }^{115}$ One important research result is that the level of damages in competition law cases is too low and constitutes a disincentive to claimants. The level of damages could, as suggested by the national reporters, possibly be increased in the following ways: (a) calculate the damages award on the basis of the profits made by the violator; (b) award a substantive part of the profits to the victim, which also entails an obligation for the violator to reveal any relevant financial information; (c) introduce a form of punitive damages; (d) award more generous interest rates for longer periods; and (e) fix the moment of injury as the starting date to claim interest (this is the current position in 12 of the Member States, including the Netherlands), increase interest rates generally and allow for victims to claim compound interest. ${ }^{116}$ The last option may result in damages awards that are in fact higher than double or treble damages awards. With regard to option $c$, the report emphasises that 'the availability of punitive, exemplary or treble damages would clearly increase a potential claimant's possible award and constitute an incentive to bring an action in the first place'.

110 Ashurst report 2004, p. 9-13.

111 Nordin 2014, at $\S 381$, citing Van Gerven 2001, p. 83.

112 Ashurst report 2004, p. 84.

113 Ashurst report 2004, p. 49.

114 Ashurst report 2004, p. 105.

115 Ashurst report 2004, p. 118 et seq.

116 Ashurst report 2004, p. 130. 


\title{
7.2.4.2 The Commission Green Paper
}

In 2006, the former European Commissioner for Competition, Neelie Kroes, stated that "we have learnt some lessons from the US system". ${ }^{117}$ Clearly inspired by the American experience with private enforcement of antitrust law, the Commission suggested the use of damages actions, including punitive damages. ${ }^{118}$ The Commission issued a Green Paper in 2005 and a White Paper in 2008 on damages actions for breach of EC antitrust rules. ${ }^{119}$ The Green Paper in fact reacts to Courage Ltd. v. Crehan. ${ }^{120}$ It appears from this paper that the Commission is truly concerned about the relatively small number of victims - usually European consumers and small and medium sized businesses - that institute proceedings in order to claim damages for competition law infringements. The Commission seeks a more effective system of law enforcement - the national competition authorities and the Commission simply lack capacity to deal with all infringements - which she believes can be achieved by means of civil actions for damages brought by private persons. ${ }^{121}$ As mentioned at the end of section 7.2.1 above, according to the Commission the most important aims and advantages of a more developed privately enforced competition law are twofold. Firstly, victims of competition law infringements should be compensated: ${ }^{122}$

\begin{abstract}
It is fundamental to the idea of private damages actions that the victim of a violation of the law is entitled to compensation for the loss suffered as a result of the violation in question. If competition law is to better reach consumers and undertakings and enhance their access to forms of legal action to protect their rights, it is desirable that victims of competition law violations are able to recover damages for loss suffered. Damages can be claimed both in actions between co-contractors, as well as in actions brought by third parties against infringers of the law.
\end{abstract}

\section{Secondly, private enforcement has an important deterrent function: ${ }^{123}$}

Enhanced private enforcement will maximise the amount of enforcement as a means of enforcement additional to public enforcement. Increased levels of enforcement of the law will increase the incentives of companies to comply with the law, thus helping to ensure that markets remain open and competitive. Increased private enforcement will enlarge the range of infringements for which competition law will be enforced as well as the level of enforcement generally. This will arise in particular from litigation which is not brought on the back of decisions adopted by public authorities ("follow-on" actions). In relation to follow-on actions, facilitating private enforcement will add more frequently than before to the fines imposed by public competition authorities the possibility for the victim of the anticompetitive behaviour to recover his losses. Both damages awards and the imposition of fines contribute the maintenance of effective competition and deter anticompetitive behaviour.

117 Kroes 2006

118 Green paper 2005, option 16.

119 Green Paper 2005; Annex to Green Paper 2005; White Paper 2008; Annex to White Paper 2008; Annex to White Paper 2008: Impact Assessment.

120 Basedow 2007b, p. 3.

121 Green Paper 2005, p. 1.

122 Annex to Green Paper 2005, p. 6.

123 Annex to Green Paper 2005, p. 6-7. 
Other aims and advantages of private enforcement are also mentioned, such as the possibility for private parties to combine a claim before a national court with other claims as well as the more general improvement of 'Europe's competitiveness' by contributing to 'ensuring open and competitive markets in the EU's internal market'. ${ }^{124}$ A last reason of the Commission to opt for a more developed private enforcement system is giving the citizen a more active role in the enforcement of competition law: ${ }^{125}$

Bringing Community competition law closer to the citizen will encourage greater involvement in the enforcement of that law and thus a greater awareness of and engagement in competition law on the part of European citizens. It will help bring European citizens and undertakings into closer and more direct contact with laws and policies made at European Union level.

In the eyes of the Commission, the prospect of damages awards constitutes an incentive for persons affected by unlawful anticompetitive conduct to file claims and obtain compensation for their loss. Moreover, sufficient financial pressure would encourage cartel members to cease their wrongdoing. For that reason, the potential use of punitive damages in the form of double damages is also under discussion. The Green Paper discusses several ways to define damages. According to the Commission, one option would be double damages for horizontal cartels, which could be 'automatic, conditional or at the discretion of the court'. ${ }^{126}$ This is explained as follows in the Annex to the Green Paper: ${ }^{127}$

In order to create a clear incentive for claimants to bring antitrust damages cases, it could be envisaged to award double damages in case of the most serious antitrust infringements, i.e. horizontal cartels.

And: ${ }^{128}$

It should be borne in mind that most Member States exclude exemplary or punitive damages as contrary to their public policy. For that very reason, those Member States may refuse to recognize and to enforce decisions providing for such damages. Despite this situation, one has to consider whether it would be appropriate to allow the national court to award more than single damages in case of the most serious antitrust infringements. In doing so, one would create a clear incentive for claimants to file a damages claim. Such an incentive would be most apparent were the national court to automatically award more than single damages in case of the most serious antitrust infringements. One could, however, also make the award dependent on the existence or the absence of predefined conditions or, alternatively, leave it completely to the discretion of the national court.

The Commission's interest in punitive damages may become clearer from the reaction of Neelie Kroes to Microsoft's refusal to comply fully with a decision of

124 Annex to Green Paper 2005, p. 7

125 Annex to Green Paper 2005, p. 7.

126 Green Paper 2005, option 16.

127 Annex to Green Paper 2005, p. 43.

128 Annex to Green Paper 2005, p. 36. 
the Commission. In March 2004, Microsoft was fined $€ 497$ million $^{129}$ and was furthermore ordered to release documents and to share software data with rivals so as to enable fair competition. ${ }^{130}$ Although Microsoft appealed the decision, ${ }^{131}$ the fine - one of the largest ${ }^{132}$ competition fines ever imposed by the Commission was paid in July 2004. ${ }^{133}$ Microsoft however refused to comply with the second part of the decision and for that reason was fined another $€ 899$ million in February 2008. ${ }^{134}$ After Microsoft's refusal had become clear, Kroes reportedly declared: "we have never, ever before encountered a company that has refused to comply with commission decisions" and "we learned we may have to look for a more effective remedy."135 The second fine that was imposed upon Microsoft's refusal to comply completely with the Commission's decision was substantially higher than the first fine, probably because a higher fine is considered more effective. In this respect, keeping in mind the need for effective remedies and the strategy in American antitrust law explained in section 7.2.1, it is not so strange that the Commission mentions the possible use of punitive or double damages as a private enforcement instrument in the case of competition law infringements.

\subsubsection{The Commission White Paper}

The above makes clear that private enforcement is high on the European agenda. Inspired by American antitrust law, the debate started in the field of EU competition law. With Courage Ltd. v. Crehan and Manfredi, the CJEU sends a firm message towards the Member States. On the basis of these two cases, individuals now have a right to claim damages before national courts for harm resulting from anticompetitive behaviour done by any other party. As explained in section 7.2.3 above, the national courts must set the criteria for determining an appropriate award of damages, which may include punitive damages if such

129 Decision C(2004) 900 final, article 3.

130 Decision C(2004) 900 final, articles 5 and 6.

131 CJEU 17 September 2007, case T-201/04, ECR II-3601 (Microsoft Corp. v. Commission). Microsoft's applications were rejected and the Court confirmed the Decision of the Commission. The Court annulled only a minor aspect of the decision, relating to the imposition of a monitoring trustee with investigation powers with respect to Microsoft (article 7 of the Decision). According to the Court, the Commission is in that way delegating excessive powers of investigation to the monitoring trustee, whereas pursuant to Community law the Commission alone can exercise such powers. Both parties were able to appeal to the Court of Justice of the European Union but decided to let it rest.

132 The largest fine to date, $€ 1.06$ billion, was imposed on the microchip maker Intel in May 2009: Decision D(2009) 3726 final, article 2.

133 Matt Hines, 'Microsoft pays EU in full', retrieved via: news.cnet.com/2100-1014_3-5255715.html.

134 Decision C(2008) 764 final, at $\S 23$. This decision fixed the definitive amount of the periodic penalty payment pursuant to article 24(1) of Regulation 1/2003/EC that had already been imposed on Microsoft Corporation by Decision C(2005) 4420 final. Microsoft appealed the decision but the Court recently upheld the decision of the Commission, although it reduced the award from $€ 899$ million to $€ 860$ million: CJEU 27 June 2012, case T-167/08, not yet published (Microsoft Corp. $v$. Commission II).

135 James Rowley, 'Microsoft dispute a lesson, EU says', retrieved via: seattletimes.nwsource.com/ html/businesstechnology/2003675344_microsofteu21.html. 
damages may be awarded in competition law claims based on national law. The CJEU thereby paved the way for the private enforcement of EU competition law, which could possibly be executed with the strong incentive of punitive damages. However, concrete legislative action on the subject of punitive damages has not been taken yet. In the White Paper of 2008, which followed the Green Paper, deliberations on punitive damages have not been continued and the Commission has taken a more reserved position. ${ }^{136}$ In the Annex to the White Paper, attention is paid to the CJEU's ruling in the Manfredi judgment that it should be possible to award punitive damages founded on EU competition law if such damages may be awarded pursuant to similar actions based on national law: ${ }^{137}$

Victims of an EC competition law infringement are entitled to particular damages, such as exemplary or punitive damages, if and to the extent such damages may be awarded pursuant to actions founded on the infringement of national competition law.

In a second working document that accompanies the White Paper, known as the Impact Assessment, the option of punitive damages is also repeated so as to review 'the full spectrum of possible solutions', but the Commission points at legal objections to punitive damages in some Member States and makes clear that the Manfredi ruling does not imply that punitive damages should be introduced in every Member State. ${ }^{138}$

In the White Paper, the Commission indeed does not repeat its point of view with regard to double damages and the possible deterrent effect such damages may have. Instead, the focus of the White Paper is on full compensation of victims of anticompetitive behaviour. As stated in the Annex to the White Paper, the Commission thereby seeks for a balanced system of European competition law that should be created by measures which are 'embedded in, and build on, the European legal cultures and traditions of the 28 Member States'; the measures should be effective, but should not encourage or facilitate unmeritorious litigation. ${ }^{139}$ From this, one could derive that the Commission no longer considers punitive damages or multiple damages an appropriate measure, although this has not been stated as such. ${ }^{140}$

The Commission makes clear that the damages to be awarded should not influence either the level of fines (public enforcement) or the result of any private actions taken (private enforcement). In other words: public enforcement should not be replaced by private actions, and private actions to compensate the victim cannot be replaced by public enforcement: ${ }^{141}$

136 White Paper 2008.

137 Annex to White Paper 2008, at $\S$ 199. See on the Manfredi judgment section 7.2.3 above.

138 Annex to White Paper 2008: Impact Assessment, p. 27-28.

139 Annex to White Paper 2008, at $\S 16$; White Paper 2008, p. 3.

140 Adriaanse et al. 2008, p. 278; Zippro 2009, p. 438.

141 Annex to White Paper 2008: Impact Assessment, at $\S 69$ 
Since the primary objective pursued is full compensation of victims, the damages to be awarded should not influence the level of fines imposed by competition authorities in their public enforcement activities, nor under any future framework of enhanced private actions. Public fines and purely compensatory damages serve two distinct objectives that are complementary: the main objective of public fines (and of potential criminal sanctions) is to deter not only the undertakings concerned (specific deterrence) but also other undertakings (general deterrence) from engaging or persisting in behaviour contrary to Articles 81 and 82. The main objective of private damages is to foster corrective justice by repairing harm caused to individuals or businesses. Of course, as mentioned earlier, this by no means precludes that effective systems for provision of damages also have positive side-effects on deterrence.

It is important to keep in mind that the suggestions given by the Commission in the White Paper should not be seen as imposing limits on the Member States but rather as the 'minimum necessary' to achieve the objective of effective enforcement of competition law to ensure full compensation of victims. ${ }^{142}$ With regard to damages actions, this means that 'the acquis communautaire on the definition of damages should be codified as a minimum standard'. ${ }^{143}$ Similar to the CJEU, the Commission seems to avoid the choice for the introduction of a form of punitive damages in order to ensure this objective to the Member States. ${ }^{144}$ Nonetheless, the Commission has pointed out already that the appropriateness of the current definition of damages must possibly be reconsidered, in particular if the current situation in Europe does not change in the (near) future. It should then be considered what further incentives can be developed in order to ensure that victims of anticompetitive behaviour file their antitrust damages claim: ${ }^{145}$

The acquis communautaire on the definition of damages should be codified as a minimum standard. That being said, one also has to take into account the fact that the risk/reward balance in antitrust damages litigation is skewed against bringing actions. The Commission considers it necessary to address this negative balance by ensuring that there are sufficient incentives for victims of competition law infringements to bring meritorious claims. One way of doing so would be to assure the claimant a priori that if he wins the case, he will be awarded damages that are higher than the loss actually suffered. However, as mentioned in paragraph 194, such a general approach would not appear necessary today. If it were to emerge, though, that the current situation in Europe of very limited repair of the harm caused by infringements of the competition rules does not structurally change over the coming years, it should be considered what further incentives are required to ensure that victims of competition law infringements actually bring their antitrust damages action. In that context the appropriateness of the current definition of damages might have to be reconsidered.

Thus, although the option of double damages has not been repeated by the Commission in the White Paper, it has also not fallen into the background. The current status seems to be that the possible introduction of punitive damages for competition law infringements is still alive in the academic debate, whereas the European Commission continues to emphasise the compensatory principle. ${ }^{146}$ The

142 Annex to White Paper 2008, at $\S 325$; Annex to White Paper 2008: Impact Assessment, at $\S 197$.

143 Annex to White Paper 2008, at $\S 203,320$.

144 Zippro 2009, p. 438.

145 Annex to White Paper 2008, at § 203-204.

146 Zippro 2009, p. 439. See also Danov 2008; Nebbia 2008; Hazelhorst 2010; Cavanagh 2010. 
latter follows for example from a speech on public and private enforcement of competition law delivered by the Directorate General for Competition at the International Competition Conference held in $2012,{ }^{147}$ but it also follows from the Commission's proposal for a Directive on damages actions for EU competition law infringements and the communication on quantifying harm in such damages actions. ${ }^{148}$ The Commission does however make clear in the latter document that, in line with the cases Courage Ltd. v. Crehan and Manfredi, damages actions also serve a deterrent function: ${ }^{149}$

While the objective of the fines is deterrence, the point of damages claims is to repair the harm suffered [italics mine] because of an infringement. More effective remedies for consumers and undertakings to obtain damages would, inherently, also produce beneficial effects in terms of deterring future infringements and ensuring greater compliance with those rules.

To conclude, numerous comments were given on the White Paper by ministries, governments, NCAs, law firms etc. These comments give a glimpse of the public opinion on the matter. The Dutch government, for instance, seems to be relieved to some extent: ${ }^{150}$

The Netherlands is pleased that the Commission is no longer advocating European measures, as part of which punitive elements are factors in determining the level of damages awarded.

In contrast, the Law Society of England and Wales stated: ${ }^{151}$

However, we believe it should be for Member States' legal systems, and possibly the ECJ, to determine the availability of exemplary or punitive damages in accordance with their domestic rules.

While the Dutch government is rather reserved with punitive damages, the English government shows a more liberal approach. This is not so strange, given the fact that punitive damages are an accepted remedy in England, albeit in a more restricted form than in the United States. ${ }^{152}$

147 Italianer, A., 'Public and Private Enforcement of Competition Law', 5th International Competition Conference, 17 February 2012, Brussels, retrieved via: ec.europa.eu/competition/speeches/text/ sp2012_02_en.pdf.

$148 \operatorname{COM}(2013) 404$ final, article 2 and $\S 4.1$ of the explanatory memorandum; C(2013) 3440, at $\S 1.2$. See on this development section 7.2.4.4.

$149 \mathrm{C}(2013) 3440$, at $\S 1.2$.

150 The Netherlands' response to the White Paper on damages actions for breach of the EC antitrust rules, at $\S 1.3$, retrieved via: ec.europa.eu/competition/antitrust/actionsdamages/white_paper_comments.html\#N.

151 Reponse of the Law Society of England and Wales, at $\S 44$, retrieved via: ec.europa.eu/competition/ antitrust/actionsdamages/white paper_comments.html\#N.

152 See section 9.4.4.3. 


\subsubsection{Private Enforcement of Competition Law: Current State of Affairs}

The above shows that the legislator of the European Union has elaborately and openly discussed the possible introduction of punitive damages as a private enforcement instrument to fight breaches of EU competition law. ${ }^{153}$ Although an affirmative decision as regards its introduction has not been made, the legislator has thereby contributed to the increased attention for punitive damages throughout Europe. Note that private enforcement of competition law in the European context as such is still premature. Van Gerven points out that this area requires specific legislative action: ${ }^{154}$

[...] if private enforcement is to be taken seriously, it should be left to the Community legislator to lay down comprehensive legislation, rather than left to the Community and national courts to develop solutions at the occasion of cases eventually brought before it in the years to come.

Also Van den Bergh and Keske refer to the legislator in this respect: ${ }^{155}$

To facilitate private damages claims and increase the deterrent effect of private enforcement, national legal systems may need reforms of their procedural laws. Forms of group litigation are already available in several Member States. Their scope could be extended to facilitate and increase the use of such legal actions. In designing the optimal form of group litigation, one should be cautious to avoid the pitfalls of the US class action. With respect to multiple damages, commentators stress the difficulties of introducing multiple damages into the legal systems of civil law Member States. Apart from the legal problems, the efficiency of multiple damages is also still debated.

As mentioned in the previous section, the European Commission took an important step by adopting a legislative proposal for a Directive on damages actions for EU competition law infringements as well as a communication on quantifying harm in such damages actions in June 2013. ${ }^{156}$ These documents complement the documents of the Commission concerning collective redress. ${ }^{157}$ The Directive proposal, containing a number of measures to facilitate damages actions, has been approved by the European Parliament in April 2014, which then sent the proposal to the EU Council of Ministers for final approval and completion of the legislative process. $^{158}$

Before going into the second cause of the increased European interest in punitive damages in section 7.3, relating to the changing functions of tort law and calls for powerful civil sanctions, the following section will briefly explain some other

153 See on private enforcement of competition law and punitive damages in the European context Hazelhorst 2010.

154 Van Gerven 2007, p. 30.

155 Van den Bergh \& Keske 2007, p. 486.

$156 \operatorname{COM}(2013) 404$ final; C(2013) 3440. The proposal for the Directive is accompanied by an impact assessment report: $\operatorname{SWD(2013)} 203$ final, whereas the communication on quantifying harm is accompanied by a practical guide: SWD(2013) 205 .

157 See section 2.2.3.6 and section 8.3.

158 See: europa.eu/rapid/press-release_IP-14-455_en.htm. 
examples by which the legislator of the European Union seems to demonstrate a more liberal approach towards non-compensatory or even punitive damages.

\subsubsection{European Attention for Private Enforcement outside the Field of Competition Law}

Now that the debate on private enforcement of competition law has been brought forward as an important reason for the increased European interest in punitive damages, it is time to see whether there are other examples in European Union legislation and legislative proposals showing a liberal approach to punitive damages. As will be further explained in section 8.3, the legislator of the European Union has a largely negative approach to punitive damages, which will be illustrated by legislative examples of the rejection of punitive damages. This negative approach has been underlined in legal doctrine. For example, according to Koch: ${ }^{159}$

Despite constant rumours to the contrary, punitive damages do not seem to be of any significance in EU law yet.

Or, in the words of Wagner: ${ }^{160}$

There is no EU legislation specifically authorizing courts to award punitive damages.

Although these authors might be right in the sense that punitive damages do not play a significant role or are specifically mentioned in European legislation, there are some examples of the European legislator's inclination - albeit careful towards punitive damages outside the field of competition law. Koziol for example mentions the Directives concerning employment discrimination, which incorporate the earlier mentioned formula by the CJEU that national sanctions which may be imposed for breaches of European Union law should be 'effective, proportionate and dissuasive'. ${ }^{161}$ This formula can for instance be found in article 15 of the Directive on equal treatment between persons irrespective of racial or ethnic origin $^{162}$ and article $8 \mathrm{~d}$ of the Directive concerning equal treatment of men and women in an employment situation. ${ }^{163}$ As pointed out by Wagner, these Directives are not only relevant in respect of anti-discrimination in employment law but also in general private law. ${ }^{164}$ As follows from the above-mentioned Von Colson and Kamann case, a sanction should 'guarantee real and effective judicial protection' against unlawful discrimination, which must have 'a real deterrent effect on the

159 Koch 2009, p. 208.

160 Wagner 2012, p. 1405.

161 Koziol 2008, p. 749, citing Directives 75/117/EEC; 76/207/EEC; 86/378/EEC; 97/80/EC; 2000/43/ EC; 2000/78/EC; 2002/73/EC. See also Shelton 2005, p. 364.

162 Directive 2000/43/EC.

163 Directive 2002/73/EC.

164 Wagner 2006b, p. 400. 
employer'. ${ }^{165}$ Thus, deterring sanctions - as a general notion, thus not per se meaning punitive damages - for breaches of European Union law have been explicitly recognised, which means that there is a departure from the traditional compensatory function of civil damages taking place at European Union level. ${ }^{166}$ Because it is difficult to draw a clear line between a deterring and a punitive function of non-compensatory damages, it is not so strange that punitive damages pop up in the discussion. Do we not find it hypocrite to accept a form of noncompensatory damages under the name of preventive damages, as Wagner suggests calling them, ${ }^{167}$ whereas the punitive aspect is completely rejected simply because in continental European legal traditions a punitive function of civil damages is not accepted? Does effective deterrence in practice not also entail an element of punishment? And does the European Union itself not contribute to this idea by using the term 'sanction' or even 'penalty'? According to Behr, by ruling in Von Colson and Kamann that the sanction must cause a deterrent effect, the Court indeed expressly connects a punitive function to the sanction: ${ }^{168}$

What the European Court asked for by this requirement was not just the deteriorating effect inherent to every obligation to restitute damages, but additional deterrence instead. Hence, the European Court demanded implementation of tortfeasor-oriented, future-oriented elements into the domestic law of damages. The ruling stated that whatever solution a member state chose in order to appropriately transform the Directive, the solution had to be appropriate to penalize infringement of the prohibition of discrimination.

Behr makes clear that the Court has repeated the idea that damages must penalise discrimination in two decisions. ${ }^{169}$ Note that, as explained in section 3.2.2, employment discrimination is an area in American law with a relatively high occurrence of punitive damages awards. In respect of the main focus of this book, especially the question whether the punitive damages remedy has a future in continental Europe, this is a very interesting point. At the European level, punitive sanctions apparently already receive considerable attention in the field of antidiscrimination. ${ }^{170}$ Given the relatively high occurrence of punitive damages in American employment discrimination cases, punitive sanctions are seen as an important method of dealing with the problem of discrimination in the American legal system. It could be a good idea, at least in the field of anti-discrimination, to let the American approach serve as an example for Europe. In the United States, punitive damages have even been added 'as a weapon for fighting employment

165 CJEU 10 April 1984, case 14/83, ECR 1891 (Von Colson and Kamann v. Land NordrheinWestfalen), at $\S 23$.

166 Wagner 2012, p. 1405.

167 Wagner 2012, p. 1405.

168 Behr 2003, p. 142.

169 Behr 2003, p. 142, citing CJEU 8 November 1990, case C-177/88, ECR I-3941 (Dekker v. Stichting Vormingscentrum voor Jong Volwassenen); CJEU 22 April 1997, case C-180/95, ECR I-2195 (Nils Draehmpaehl v. Urania Immobilienservice $O H G$ ).

170 Wagner 2006b, p. 401 
discrimination' in the Civil Rights Act of $1991 .{ }^{171}$ During the legislative process, Congress made clear that punitive damages were especially necessary to deter unlawful employment discrimination. Seiner cites some of the testimony before Congress: ${ }^{172}$

Compensatory and punitive damages will not give back to a plaintiff, in many cases, the career that they lost or the ability to rise further in that career. Congress doesn't have the ability to do that. It's a lasting permanent damage. I think what the increased remedies under the bill will do, however, is primarily act as a deterrent .... It is the deterrent value that is so important.

It is interesting to see that in respect of employment discrimination, the Americans put special emphasis on the deterrent function of punitive damages. It therefore seems that the American and European approaches do not differ that much, but the Americans are more pragmatic and accept that imposing non-compensatory damages may have both a deterring and a punitive effect. Remember in this regard the theory in American law that deterrence should be seen as the leading purpose of punitive damages. ${ }^{173}$ This theory will be further explained in section 7.3 below.

The position of the legislator of the European Union as regards punitive damages will be addressed here. Koziol not only mentions the anti-discrimination Directives, but he also refers to the Commission's proposal concerning a Consumer Credit Directive. ${ }^{174}$ Proposed article 31 of the Directive reads as follows:

Member States shall lay down penalties for infringements of national provisions adopted in application of this directive, and shall take all necessary measures to ensure that these are enforced. These penalties must be effective, proportionate and constitute a deterrent. [...]

Kelliher also mentions the punitive function of this proposal. ${ }^{175} \mathrm{~A}$ similar provision has been placed in the Preamble, i.e. recital 47 thereof, of the Consumer Credit Directive adopted in 2008. ${ }^{176}$ Furthermore, Koch and Vanleenhove refer to a Regulation from 1995, albeit one with a rather restrictive scope, in particular article 18 thereof. ${ }^{177}$ The Regulation implements rules on the agricultural exemption provided for in article 14(3) of another Regulation on Community plant variety rights. ${ }^{178}$ Article 18 concerns special civil law claims:

1. A person referred to in Article 17 may be sued by the holder to fulfill his obligations pursuant to Article 14 (3) of the basic Regulation as specified in this Regulation.

2. If such person has repeatedly and intentionally not complied with his obligation pursuant to Article 14 (3) 4th indent of the basic Regulation, in respect of one or more varieties of the same holder, the liability to compensate the holder for any further damage pursuant to Article 94(2) of the

171 Seiner 2008, p. 749. The relevant provision is 42 USC $\S 1981$ a. See also Seiner 2012.

172 Seiner 2008, p. 750, footnote 78.

173 Dobbs 1989, p. 858. See section 2.3.3.

174 COM (2002) 443 final.

175 Kelliher 2008, p. 11.

176 Directive 2008/48/EC.

177 Koch 2009, p. 208 and Vanleenhove 2012, p. 340, citing Regulation 1768/95/EC.

178 Regulation 2100/94/EC. 
basic Regulation shall cover at least a lump sum calculated on the basis of the quadruple average amount charged for the licensed production [emphasis added] of a corresponding quantity of propagating material of protected varieties of the plant species concerned in the same area, without prejudice to the compensation of any higher damage.

According to Koch, the multiple damages award provided for in paragraph two of this provision overcompensates the victim and therefore only serves punitive, by which he probably also means deterring, goals. ${ }^{179}$

In conclusion, apart from the debate concerning private enforcement of competition law, there is not much proof of the European Union's inclination towards punitive damages. Some examples can however be pointed out. The idea that punitive damages are fundamentally rejected at the European Union level is for that reason not completely accurate.

\title{
7.2.6 Final Remark
}

The European interest in private enforcement and punitive damages becomes especially clear in the field of competition law. But as competition law forms only a part of European Union law - albeit a fundamental part that concerns the European economy as a whole - the question is whether the implications of the above-mentioned cases, Courage Ltd. v. Crehan and Manfredi, extend to breaches of other directly effective European Union law. The CJEU already made reference to the development of a broader principle for the future in the joined cases Brasserie du pêcheur and Factortame III. ${ }^{180}$ And not only the CJEU, but also the Commission has already referred to the development of a broader principle: ${ }^{181}$

\begin{abstract}
The Commission acknowledges that some of the problems identified in the Green Paper also occur in other areas of civil/tort litigation and that some of the suggestions of the White Paper might thus also be appropriate beyond the boundaries of antitrust damages actions. Where there is a need, a technical feasibility and a clear political will to adopt measures with a more horizontal scope, that route should therefore seriously be considered. However, the similarities between redress for victims of an antitrust infringement and other civil/tort litigation cannot in themselves constitute a sufficient reason to abstain from considering or even taking measures aimed specifically at ensuring the effective exercise of rights which victims of competition law infringements derive directly from Community law. Moreover, civil litigation in the field of competition touches upon a particular public interest and offers a number of specific aspects which - taken together - mean that the bringing of an action is unusually difficult.
\end{abstract}

Indeed, the debate on private enforcement is no longer merely concentrated in the field of competition law. As mentioned in the introduction to this chapter, on both European and national level one speaks already of private enforcement of intellectual property law, environmental law, human rights law, personality rights and consumer law. Van Boom refers to private enforcement as an instrument to

179 Koch 2009, p. 209.

180 Craig \& De Búrca 2011, p. 244, citing joined cases Brasserie du pêcheur and Factortame III, at $\S 22$

181 Annex to White Paper 2008, at $\S 321$. 
strengthen, in general, public policy goals. ${ }^{182}$ Furthermore, as referred to in the previous section, anti-discrimination law is also a theme that is high on the agenda. The legislator of the European Union as well as the CJEU have made clear that violations of European Union law will not be tolerated and that violators deserve to be sanctioned: sanctions with sufficient preventive effect are for that reason considered necessary. In this respect, private enforcement is seen as a complement to public enforcement tools, and also the combined use of public and private law enforcement as supported by law and economics scholars receives attention. ${ }^{183}$

But there seem to be no definite answers yet as to what role punitive (or: multiple, double, treble) damages should play in this. The uncertainty is related to the fact that the punitive damages remedy is alien to continental Europe (systeemvreemdheid) and the resulting difficulties surrounding the introduction of this civil remedy there. ${ }^{184}$ Still, an important conclusion that should be drawn from this section is that punitive damages are a point of debate at European Union level. The second conclusion is that the increased European interest in punitive damages can indeed be explained by the attention paid to deterring sanctions for breaches of European Union law and private enforcement of legal fields such as competition law and anti-discrimination law. The next section will go into the second cause of the increased European interest in punitive damages.

\subsection{Calls for Powerful Civil Sanctions}

\subsubsection{Introduction}

The discussion on private enforcement of competition law has raised dust throughout Europe. More importantly, at least in the context of this book, it has stirred up the interest in punitive damages. Consequently, this debate is seen as an important cause of the current attention for punitive damages. Private enforcement of public law norms is generally thought of as a complement to public enforcement although, as explained in section 2.3.4, law and economics scholars speak of an ideal situation in which there is a balanced mix between public and private enforcement. Hence, private enforcement is a complementary form of law enforcement which, according to contemporary ideas, perhaps even works better if one has access to powerful civil remedies such as punitive damages.

There is another assignable cause of the increased European interest in punitive damages which is closely related to the first cause, as both entail an instrumental view on tort law. As mentioned in the introduction above, there is growing attention for the need to strengthen tort remedies so as to improve the enforcement of tort law standards. Van Nispen observes that the availability of no other form of damages than material and immaterial damages to react to breaches of private law

\footnotetext{
182 Van Boom 2006a, p. 27.

183 Van Boom 2006a, p. 28.

184 Hartlief 2009a, p. 67.
} 
duties creates an enforcement deficiency. ${ }^{185}$ From this perspective, tort law and the way in which tort law could be improved are considered as such. This means that the focus is not only on damages actions to fulfil a certain higher goal, i.e. private enforcement of public law norms in general. Rather, the focus is on law enforcement in tort law. ${ }^{186}$ Private law has its traditional remedies such as the action for damages, annulment, and termination of contract. As was seen in chapter six, the predominant remedy available in tort law is the action for damages to compensate claimants for harm suffered. Consequently, damages actions play a central role in the enforcement of tort law. However, as pointed out by Van Nispen, one could doubt for a number of reasons whether it is desirable from the viewpoint of functional and efficient law enforcement that the reaction to breaches of private law duties is dominated by the notion of compensation. ${ }^{187}$ An important reason for this doubt is under-compensation of the victim. Another important reason is that the preventive effect of mere compensation is open to discussion.

The idea is that if the functions of tort law evolve, the available tort remedies should evolve accordingly: this explains the attention for stronger remedies with a deterrent or even punitive function. This also explains why punitive damages pop up again in both European debates - particularly efforts to harmonise tort law and national debates. In 2008, the Institute for European Tort Law (ETL) declared the following: ${ }^{188}$

With the growing discourse on the subject on the Continent, it seems worthwhile and even an urgency to discuss, thoroughly and on a comparative basis, the nature, role and suitability of punitive damages in tort law and private law in general.

As was seen in chapter two, the punitive damages remedy plays an important role in the American civil justice system and mainly fulfils the functions of punishment, deterrence and law enforcement. In respect of these functions of punitive damages, it should be emphasised that, in the European search for stronger tort remedies, the goals of deterrence and law enforcement seem to prevail whereas punishment is not a goal in itself. The need to strengthen tort remedies becomes evident in specific situations in which available remedies do not exert sufficient pressure on tortfeasors. One could thereby in particular think of intentional, calculative and grave misconduct. In this regard, reference should be had to Wagner who supports the law and economics theory of punitive damages and is in favour of introducing punitive damages in German law as long as they fulfil a preventive rather than a punitive function. ${ }^{189}$ He makes clear that while the functions of prevention and influencing behaviour (Verhaltenssteuerung) are accepted in German private law, a

185 Van Nispen 2003, p. 6, 12-13

186 See in Dutch literature e.g. Van Boom 2006a; Van Boom 2007b; Van Boom 2008; Engelhard et al. 2009; Hartlief 2012b.

187 Van Nispen 2003, p. 12.

188 ETL Conference on Punitive Damages held in Vienna on 17 November 2008. See Koziol \& Wilcox 2009, Preface.

189 Wagner 2006b, p. 473-474. See also Koziol 2009, p. 289. 
punitive function is not recognised in Germany or even Europe in general. He then relates this idea to punitive damages in the following manner: ${ }^{190}$

Soweit über Verhaltenssteuerung im eben beschriebenen Sinne hinaus im engeren Sinn pönale Zweckewahrgenommen werden, bleibt es dabei, daß auf punitive damages lautende Urteile amerikanischer Gerichte nicht anerkennungsfähig sind, weil die Verfolgung pönaler Zwecke mit privatrechtlichen Mitteln wesentlichen Grundsätzen des deutschen Rechts widerspricht. Für die Auseinandersetzung mit der Steuerungsfunktion im deutschen Privatrecht sollte deshalb das Motto gelten: Keine Angst vor punitive damages!

According to Wagner, preventive damages could especially be awarded in situations of calculative wrongdoing, i.e. when the defendant committed the wrongful act with the intent of making a profit, and in the case of insufficient enforcement (Mangelnde Rechtsdurchsetzung) of damages claims. ${ }^{191}$ Interestingly, Wagner cites an idea brought forward by Posner in the case Kemezy v. Peters, ${ }^{192}$ a case that was already mentioned in chapter two, about the twofold function - i.e. deterrence and punishment - of punitive damages. ${ }^{193}$ In line with other law and economics scholars, Posner makes clear that deterrence should be seen as a purpose of punishment: ${ }^{194}$

The standard judicial formulation of the purpose of punitive damages is that it is to punish the defendant for reprehensible conduct and to deter him and others from engaging in similar conduct.

Posner continues: ${ }^{195}$

This formulation is cryptic, since deterrence is a purpose of punishment, rather than, as the formulation implies, a parallel purpose, along with punishment itself, for imposing the specific form of punishment that is punitive damages.

Van Boom also seems to be in favour of a form of punitive damages, which he calls post-facto incentive damages, that aim at specific deterrence: ${ }^{196}$

However, if we redefine punitive damages as some form of post-facto incentive damages exceeding the actual loss and aimed at specific deterrence, then the moderated idea of post-facto incentive damages could perhaps fit better into European legal culture. This concept seems worth further consideration.

190 Wagner 2006b, p. 476.

191 Wagner 2006b, p. 463. Cf. Koziol who is critical about Wagner's idea: Koziol 2009, p. 289; Koziol 2012, p. 56-57.

192 Kemezy v. Peters, 79 F.3d 33 (C.A.7 (Ind.) 1996).

193 Wagner 2006b, p. 474-475.

194 Kemezy v. Peters, at $\S 34$.

195 Kemezy v. Peters, at § 34.

196 Van Boom 2006a, p. 35. 
According to Van Boom, such damages are especially interesting in situations where other remedies fail and should only be used in areas in which public enforcement is 'below an optimal level'. ${ }^{197}$

This is an important finding in respect of the theme of this book. There is a discussion going on throughout Europe about the need for stronger civil remedies, in particular to improve law enforcement and to fulfil a deterrent function. One could for example think of the above-mentioned formula created by the CJEU that national sanctions which may be imposed for breaches of European Union law, such as anti-discrimination law, should be 'effective, proportionate and dissuasive'. Although the Court probably did not have punitive damages in mind when creating this formula in 1989, against the background of the current punitive damages debate it can serve as a point of departure. ${ }^{198}$ Opponents of punitive damages however reject the introduction of the civil remedy to fulfil these functions in continental Europe, primarily because of its punitive function that is inconsistent with continental European legal traditions. Similar to Posner, one could however also consider deterrence as the function of punishment. As a result, punishment is not a goal of punitive damages in itself but rather a means to an end, which is deterrence. This may be a good theoretical starting point, but in practice it is difficult to ignore the punitive aspect of punitive damages awards, as whichever way you look at it, plaintiffs will probably in the first place experience the obligation to pay punitive damages as a punishment.

This section will explain the second cause of the increased European interest in punitive damages by looking into changing perspectives, primarily in legal doctrine, on the functions of tort law in present day society. To start with, some tortious situations for which punitive damages could be especially appropriate will be described.

\subsubsection{Punitive Damages in Specific Tort Situations: Intentional, Calculative and Grave Misconduct}

While at European level the debate seems to be concentrated on private enforcement of public law standards, at the national level punitive damages are considered to be a potential mechanism for the enforcement of tort law standards. The debate concentrates on certain specific torts, such as the infringement of personality rights. As mentioned before, keywords to identify this type of wrongdoing are intentional, calculative and grave misconduct. Note that this is - not surprisingly the type of misconduct for which punitive damages are mostly awarded in the American legal system. As explained in section 3.2.2, the popular punitive damages categories in American law are intentional torts, defamation and financial torts. These three categories cover both intentional and grave wrongdoing, which particularly applies to the intentional torts, and calculative wrongdoing, for example defamation and fraud.

197 Van Boom 2006a, p. 35, 37.

198 CJEU 21 September 1989, case 68/88, ECR 2965 (Commission v. Greece). See section 8.4. 
An example of calculative misconduct that is often heard in the European punitive damages debate is that of illicit publications by tabloids as referred to in the introduction of this chapter. The risk of substantial damages awards being imposed might urge tabloids to reconsider the contents of their publications. The tabloid example has often been discussed in Dutch literature. ${ }^{199}$ An example of a decision in which a Dutch court awarded a substantial damages award concerned a local government official who received $f 125,000$ in immaterial damages because of an unlawful press publication that influenced his future career. ${ }^{200}$ The idea that personality rights and privacy deserve a high level of protection also exists in other European countries ${ }^{201}$ and has been further developed under article 8 ECHR, as follows for example from the earlier mentioned case Krone Verlag GMBH $v$. Austria, decided by the European Court of Human Rights in 2012. ${ }^{202}$

In the Netherlands, the debate on punitive damages is quite alive. There is an ongoing discussion whether the incorporation of the remedy into Dutch tort law is possible and desirable. In 1993, the Netherlands Comparative Law Association issued a consultative report on punitive damages. ${ }^{203}$ The report has an optimistic outcome regarding the introduction of punitive damages. ${ }^{204}$ The government however expressed doubts on punitive damages, due to a fear of the rise of a compensation culture. ${ }^{205}$ Nonetheless, in political as well as academic circles one is increasingly inclined to believe in the instrumental use of tort law. ${ }^{206}$ In his dissertation from 1996, Schirmeister, for example, recommended the introduction of 'a civil law penalty to sanction and deter deliberate damage or damage caused by conscious negligence' ${ }^{207}$ Giesen recently pointed out that he is in favour of an open and positive attitude towards the introduction of punitive damages in Dutch law because the prohibition to do so hinders the development of private law which is variable by nature and dependent on common desires in a certain period. ${ }^{208}$ Although punitive damages may, in the opinion of some authors, be useful, more research into the subject is considered necessary. ${ }^{209}$ Bloembergen and Lindenbergh for instance point out that the desirability of incorporating punitive damages

199 E.g. Van Schaik 1999; Van Harinxma thoe Slooten 2003; Hartlief 2005; Boukema 2008; Hartlief 2008a, p. 776; Hartlief 2009a, p. 65; Giesen 2009, p. 310.

200 Hof Amsterdam 13 september 1990, NJ 1991/334.

201 Van Gerven, Lever \& Larouche 2000, p. 141-168; Van Dam 2013a, p. 184-193; Deakin, Johnston \& Markesinis 2008, p. 753-888. See also e.g. Amelung 1999; Lemmens 2003.

202 ECtHR Krone Verlag GMBH v. Austria, 19 June 2012, no. 27306/07. See on this case section 8.2.

203 Bolt \& Lensing 1993.

204 Bolt \& Lensing 1993, p. 84.

205 Kamerstukken II 1998/99, 26 630, nr. 1.

206 Not everyone agrees, see for example Kortmann 2009, p. 19 et seq.

207 Schirmeister 1996, p. 579. In a later publication, Schirmeister writes that the introduction of punitive damages is worth considering: Schirmeister 2003, p. 159.

208 Giesen 2013, p. 292.

209 E.g. Bolt \& Lensing 1993; Stolker 1995, p. 33; Hartlief 2003b, p. 124-125; Hartlief 2013, p. 619; Hartlief 2014, p. 137; Hondius 2003, p. 2019-2020; Van Boom 2006a, p. 35; Barendrecht 2002, p. 607-608; Schirmeister 2003, p. 159; Samoy et al. 2014, p. 157. 
in Dutch law depends on the extent of the problems relating to law enforcement, as well as the expected effects of the remedy. ${ }^{210}$

In addition to the tabloid example, other situations in which the tortfeasor is accused of calculative misconduct to make profits in excess of compensation payable to the claimant are imaginable. ${ }^{211}$ Most situations concern the unlawful gaining of profit by misusing a person's name, a brand or a product. ${ }^{212}$ The idea is that a tortfeasor weighs the pros and cons of committing the wrongful act and deliberately proceeds with it, because he knows that the profits will outweigh any damages award imposed on him. ${ }^{213}$ In England, such calculative conduct is a form of conduct that may give rise to punitive damages. ${ }^{214}$

Equally problematic are situations in which there is only a small chance that the tortfeasor will be sued. A small chance of being sued exists, for instance, in the case of scattered damages: the damage caused by a single tortfeasor is vast and widespread, whereas the harm to each individual victim is (very) small (strooischade). ${ }^{215}$ None of the victims is likely to bring an individual action for damages because of apathy or lack of interest. This problem can however be solved through a collective action. Although the collective action itself may already have a deterring function, the risk of punitive damages being imposed could serve as an extra deterrent for potential tortfeasors.

One might also think of other situations in which a stronger tort remedy such as punitive damages might be appropriate and necessary. For example, what should be done with insurers who fail to give their clients what they are entitled to, the socalled bad faith insurance practices that already entitle plaintiffs to punitive damages in American law? ${ }^{216}$ In this situation, questions relating to law enforcement and punitive damages arise. Furthermore, as explained in chapter three, in American tort law punitive damages are not available for each tort. On the contrary, a certain conduct and state of mind of the defendant is needed, such as outrageous conduct, evil motive, reckless indifference of the rights of others etc. It may be justified, both for deterrence reasons and to take account of the victim's needs, to award punitive damages if the nature of the infringement (aard van de normschending) is clearly inadmissible, i.e. when the legal norm has been breached in an intentional, calculative or grave manner. An example is the Dutch case of a father who claimed damages for the nervous shock that he suffered as a

210 Bloembergen \& Lindenbergh 2001, p. 15.

211 Van der Heijden 2001, p. 1749; Cauffman 2007, p. 785; Weyts 2006, p. 1650; Vansweevelt \& Weyts 2009, p. 10, 264, 688 .

212 Weyts 2006, p. 1642.

213 Vansweevelt \& Weyts 2009, p. 264.

214 Rookes v. Barnard and Others [1964] AC 1129, at § 1227. The House of Lords has identified three categories in which punitive damages can be awarded: (1) oppressive, arbitrary or unconstitutional action by government servants, (2) conduct calculated by the defendant to make a profit in excess of compensation payable to the plaintiff; and (3) express statutory authorisation. See section 9.4.4.3.1.

215 Barendrecht 2002, p. 607. See also Kerkmeester 1998; Tzankova 2005; Cupa 2012.

216 Van Tiggele-Van der Velde 2009, p. 46; Smeehuijzen 2008; Smeehuijzen 2012. 
result of the horrifying murder of his daughter by her husband. ${ }^{217}$ Other examples that can be mentioned are the parents who lost their children as a result of grave criminal offences leading to a fatal car accident ${ }^{218}$ or the mother who is confronted with the murder of her seven year old son because her husband had the intention of wounding her. ${ }^{219}$ It has been suggested that private law should respond firmly to such grave infringements. ${ }^{220}$ A firm reaction is not only justified for deterrence reasons, but it also has a punitive function as taking into account the nature of the infringement and the level of blameworthiness gives a damages award a clear punitive character. A recent Dutch example in which punitive damages could also be appropriate is that of a woman whose healthy leg was amputated due to grave mistakes by the doctor in attendance as well as the hospital. ${ }^{221}$ The woman, who emphasises that she wants to prevent hospitals from making similar mistakes again, claims civil damages of $€ 1.5$ million, of which $€ 1$ million is in immaterial damages. She is however confronted with the limits of the Dutch tort system in respect of immaterial damages awards based on article 6:106 $\mathrm{BW}$, which will be further explained in section 9.4.1.2. As pointed out by Lindenbergh, the maximum immaterial damages sum ever awarded in the Netherlands is $€ 150,000$ and it was awarded to a man who had become gravely handicapped due to attempted murder. $^{222}$ Immaterial damages awards generally do not exceed $€ 10,000$ to $€ 15,000$, whereas sums above $€ 50,000$ are rarely awarded. The Dutch judge has a rather restrained approach when it comes to awarding immaterial damages, also - and this is interesting - when compared to surrounding European countries. In Germany for instance, substantial immaterial damages awards have been granted to civil claimants. For example, as mentioned in the introduction to this chapter, in 2003 the Landgericht Kiel awarded $€ 500,000$ and an additional $€ 500$ per month to (the parents of) a three-year-old child who had become gravely handicapped due to a traffic accident. ${ }^{223}$ Also Von Bar has done extensive comparative research into the size of immaterial damages awards. ${ }^{224}$

To conclude, several tortious situations in which powerful civil sanctions could be necessary for the purpose of deterrence and law enforcement are imaginable. It concerns specific situations in which the already available civil remedies do not exert sufficient pressure, to be precise situations involving intentional, calculative

217 Rb. Arnhem 29 maart 2006, NJF 2006/252 and subsequent cases Rb. Arnhem 16 mei 2007, NJF 2007/367; Hof Arnhem 26 mei 2009, NJF 2009/311.

218 HR 9 oktober 2009, NJ 2010/387, m.nt. J.B.M. Vranken (Vilt).

219 HR 26 oktober 2001, NJ 2002/216, m.nt. J.B.M. Vranken (Oogmerk).

220 Hartlief 2009c, p. 2253; Nieuwenhuis 2009, p. 235; Verheij 2013a, p. 3-4; Annotation by J.B.M. Vranken on HR 9 oktober 2009, NJ 2010/387, m.nt. J.B.M. Vranken (Vilt). See on this decision section 9.4.1.2.

221 Tonia Wolters told her story in the Dutch current affairs programma Knevel \& Van den Brink on Friday 3 June 2011.

222 Lindenbergh 2008, p. 75, citing Rb. 's-Hertogenbosch 11 April 2007, JA 2007/99.

223 Lindenbergh 2008, p. 77, citing LG Kiel 11 July 2003, AZ O 13/03.

224 Von Bar 1999, p. 175-189. 
and grave misconduct. However, the next subsections explain why punitive damages are not (yet) an option in this regard.

\subsubsection{The (Changing) Functions of Tort Law: Compensation is Still the Primary Function}

Section 6.2 has extensively dealt with the functions of modern tort law. These will not be repeated here in detail. What is most important is that the primary function of tort law in European civil law systems is to compensate the injured person for the actual loss he has suffered and especially to point out in which situations there exists a right to such compensation. ${ }^{225}$ If the injured person brings an action for damages and the court rules in his favour, the person held liable must restore the plaintiff to the position in which he would have been without the tort (restitutio in integrum). The liable person has a duty to repair both the material loss and the immaterial loss of the injured person, whereas the extent of the injured person's claim is determined by the extent of the (estimated) actual loss, ${ }^{226}$ no more and no less. As mentioned before, restitutio in integrum is a general principle underlying tort law, although there are exceptions to this principle. For example, international conventions (such as the Warsaw Convention) and national (strict liability) rules sometimes impose caps on damages awards. ${ }^{227}$ More important in respect of the theme of this book, however, is that in some European legal systems there are (hidden) practices of awarding damages that include a deterrent or even punitive element. ${ }^{228}$ As civil sanctions in four European legal systems will be the theme of chapter nine, at this point an example will do. In Austria, for instance, the degree of fault plays an important role in assessing the extent of damages (§ 1324 ABGB). ${ }^{229}$ As pointed out by Koziol, one could indeed argue that taking into account the degree of fault introduces a penal notion in the law of damages. ${ }^{230}$ According to Wagner: ${ }^{231}$

Among continental European jurisdictions the Austrian and Swiss legal system approach the deterrence and penal functions of the law of delict with relative ease.

This probably results from the German influence and the so-called 'system of gradation' that dominated 'German common law' until the nineteenth century. As explained by Wagner: ${ }^{232}$

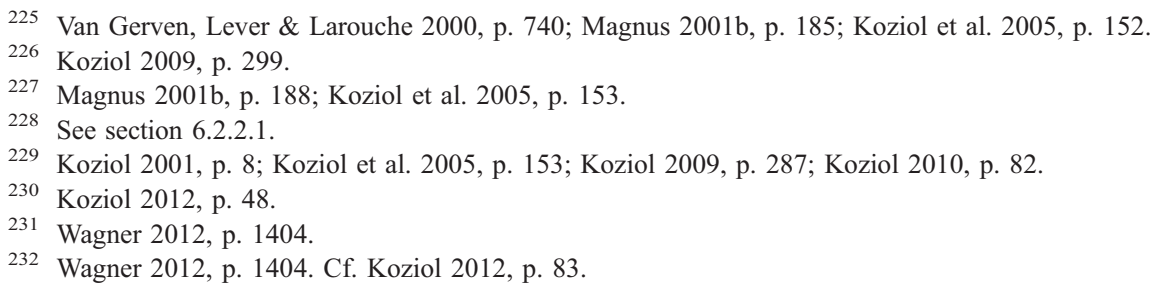


Gradation means that the amount of damages is not only contingent upon the extent of the loss but also on the degree of fault. Under this approach the more reprehensible the conduct of the wrongdoer is, the higher the award of damages has to be. The assessment of damages with an eye to the degree of fault allowed the introduction of moral and pragmatic reasoning into the law of damages.

Although the drafters of the German civil code have explicitly rejected the system of gradation, according to Wagner because they wanted to avoid this introduction of moral and pragmatic reasoning into damages law, non-compensatory elements still seem to be recognised in German law, especially in respect of immaterial loss and personality right infringements. ${ }^{233}$ Von Bar points out that German courts indeed take the degree of fault of the injurer into account when assessing immaterial damages awards and, according to him, this is true for more European legal systems, such as Spain and France. ${ }^{234}$

Under the classical theory, tort law has certain positive side effects such as loss spreading and loss allocation, restitution, satisfaction, declaration of right, deterrence or prevention, law enforcement, retribution, and even punishment. Although these are additional side effects that cannot exclusively form the basis of a compensatory damages award, it seems unwise to neglect such contributory functions and to focus merely on the compensatory function. ${ }^{235}$ An important reason for this is that victims may have needs that go beyond mere compensation. Research shows that satisfaction and retribution play an important role for victims of a tort to come to terms with a bad experience. ${ }^{236}$ Furthermore, changing ideas in society with regard to deterrence and punishment of wrongdoers also plays an important role. Moreover, one has to keep in mind that there is increased attention for private enforcement to complement public enforcement mechanisms and that the tort system interacts and competes with other public law and private law compensation instruments (social security and social insurance as well as private insurance). There are doubts as to whether tort law is a useful compensation mechanism; social security law or private insurance may be better tools to achieve the same goal and tort law is only a small element in this complex compensation system. $^{237}$ On the other hand, the mere reliance on social security or private insurance to obtain compensation could also lead to undesirable situations and perhaps even to abuse of the system, as the occurrence of damage would then be the only decisive factor for compensation, regardless of who caused the damage and under what circumstances. ${ }^{238}$ Most modern legal systems therefore offer protection to victims of accidents on the basis of social security combined with tort law - if there has been involvement of a liable tortfeasor - and private insurance. The role of tort law in this respect should certainly not be underestimated and

233 See section 9.4.2.2.

234 Von Bar 2000, p. 159-160.

235 Hartlief 1997, p. 16 et seq.; Hartlief 2009a, p. 116-117.

236 See, for the Netherlands, e.g. Chao-Duivis 1990; Huver et al. 2007; Akkermans et al. 2008; Mulder 2009; Mulder 2010; Mulder 2013.

237 Nilsen 2012, p. 1038.

238 Magnus 2006, p. 722, citing Faure \& Hartlief 2003. 
should probably even be strengthened, keeping in mind the retreat of the Welfare State due to financial and economic crises and overspending of governments. ${ }^{239}$ But tort law's utility goes further; value must also be attached to the deterrent function of tort law. ${ }^{240}$ The next subsection once more points out the relevance of the deterrent function of tort law for the theme of this book.

\subsubsection{But... the Deterrent Function of Tort Law Steps In}

Under the influence of law and economics scholars, especially the deterrent or preventive function of tort law has become increasingly important for both legal theory and legal practice over the past decennia. The attention paid by law and economics scholars for the deterrent function of tort law in general and punitive damages in particular has already been described in section 6.2.2.3 and section 2.3.4 respectively. However, due to the importance of this argument in light of the increased European interest in punitive damages, it also forms part of this chapter.

Because of the economic implications of tort damages, (micro)economic models can be applied to tort law to explain tort rules in terms of economic efficiency. ${ }^{241}$ Economic analyses of tort law were developed more than half a century ago in the United States. That is obviously no accident, as already then damages in tort played a central role in American society.

As explained in section 6.2.2.3, according to law and economics scholars the central objective of tort law is the minimisation of the social costs of a tort, i.e. administration costs, costs of optimal risk spreading by way of insurance and accident prevention costs of tortfeasor and victim plus the losses that still occur. The idea behind the traditional law and economics approach to tort law is to strive for maximum utility, with the intention of achieving social welfare (welfare economics). Later, the influence of behavioural economics became apparent. It is nowadays believed that tort law may influence the conduct of rational and reasonable individuals like tortfeasors and victims; this is also known as the neoclassical model of tort law. ${ }^{242}$ By giving economic incentives to potential tortfeasors to avoid damage, tort law has an economic function in contributing to public welfare. According to Magnus, 'in the interest of preventing damage, it should not be cheaper to cause damage than to avoid it'. ${ }^{243}$

Although the economic analysis of tort law is often criticised by lawyers, it has been argued that relating theories were created by them. ${ }^{244}$ As already mentioned in section 2.3.4, the Learned Hand formula, created by the American judge Hand in 1947 to determine the optimal standard of care in the tort of negligence, has played an important role in the development of the economic analysis of tort law.

239 Magnus, 2006, p. 722.

240 E.g. Koziol 2012, p. 78-82.

241 Faure 2009, p. 3.

242 Faure 2009, p. xxv; Magnus 2006, p. 721

243 Magnus 2001b, p. 186.

244 Schäfer \& Müller-Langer 2009, p. 6. 
A comparison can be made between the Learned Hand formula and the formula that was developed by the Dutch Supreme Court in the Kelderluik case of $1965 .^{245}$ In this case the Court developed factors, i.e. relevant viewpoints to determine if an individual has created an 'endangering situation' (gevaarzettende situatie) for which adequate precautionary measures are required. ${ }^{246}$ These factors involve: the degree of probability that the required attention and care could be disregarded, the degree of likelihood that this might lead to accidents, the gravity of the consequences of such accidents, and the burden of adequate precautionary measures. $^{247}$ Similar factors to determine the standard of care in situations of increased risk have been created in England, France and Germany. Even the 'European standard of care' recommended in the Principles of European Tort Law is composed in a similar way. ${ }^{248}$ Article 4:102 PETL reads as follows:

The required standard of conduct is that of the reasonable person in the circumstances, and depends, in particular, on the nature and value of the protected interest involved, the dangerousness of the activity, the expertise to be expected of a person carrying it on, the foreseeability of the damage, the relationship of proximity or special reliance between those involved, as well as the availability and the costs of precautionary or alternative methods.

This shows that not only in the American legal system, but also within tort law systems in Europe, instruments to assess the sufficiency of preventive measures have been developed. At the very least, not only for economists but also for jurists, deterrence thus plays an important role as a function of tort law.

\subsubsection{Prevention in 'European' Tort Law}

Most European countries accept prevention as a desirable side effect of tort law. ${ }^{249}$ Liability to pay damages may lead to special deterrence of a particular tortfeasor and to general deterrence of the public at large. ${ }^{250}$ The deterrent function of damages in tort is - at least to some extent - explicitly recognised in, for example, Austrian, French, English, Belgian, German, and Dutch legal doctrine. ${ }^{251}$ However, in none of the European countries, damages may be awarded for a preventive purpose only. ${ }^{252}$ In other words, the damages award should in any case have a compensatory objective.

It follows also from the existence of the injunctive relief remedy that 'preventive legal protection' is an established element of tort law. ${ }^{253}$ The idea behind

245 HR 5 November 1965, NJ 1966/136, m.nt. G.J. Scholten (Kelderluik). Van Maanen et al. have made such a comparison: Van Maanen, Townend \& Teffera 2008, p. 871-888.

246 Van Maanen, Townend \& Teffera 2008, p. 872.

247 Van Maanen, Townend \& Teffera 2008, p. 873

248 Van Maanen, Townend \& Teffera 2008, p. 888

249 Koziol et al. 2005, p. 153; Koziol 2012, p. 79; Kelliher 2008, p. 10.

250 Magnus 2006, p. 720; Koziol 2001, p. 7.

251 Koziol 2001, p. 5; Galand-Carval 2001, p. 78; Rogers 2001, p. 53; Cousy \& Vanderspikken 2001, p. 27; Wissink \& Van Boom 2001, p. 144; Magnus 2001a, p. 89; Weyts 2011, p. 176-177.

252 Magnus 2001b, p. 186.

253 Von Bar 1998, p. 2, footnote 3; Von Bar 2000, p. 141 et seq. 
injunctions is that it is better to prevent damage than to compensate it. Injunctions are available in European countries for different interests protected by tort law, but they are most often used to protect land, business interests and personality rights. Especially in the latter situation, in relation to defamation and infringements of the private sphere, where compensatory damages cannot always do justice to a victim, injunctive relief may be an effective remedy. ${ }^{254}$ As was seen in section 3.2.2, in the American legal system this problem of under-compensation of victims in defamation cases is relatively often solved by awarding punitive damages.

As explained in section 6.2.2.6, the preventive goal of tort damages has not remained unnoticed in European harmonising efforts. Article 10:101 of the Principles of European Tort Law emphasises that damages aim at compensation as well as prevention of harm. ${ }^{255}$ According to the principles commentary, preventing harm means that 'by the prospect of the imposition of damages a potential tortfeasor is forced or at least encouraged to avoid harm to others'. ${ }^{256}$ Not only does the liability of tortfeasors to pay damages result in compensation of the victim for his loss, it also serves - or in any case should serve - as a deterrent. ${ }^{257}$ The principles prepared by the Study Group on a European Civil Code (DCFR) also pay attention to the preventive function of tort law, but they focus more on prevention of impending damage and the preventive function should therefore be understood in terms of injunctive relief. ${ }^{258}$

To conclude, the increased European interest in the deterrent function of tort law also explains the increased interest in powerful civil sanctions such as punitive damages. As was seen before, deterrence is one of the - if not the - main functions of this civil remedy. There is particular interest in punitive damages to improve the enforcement of tort law standards and deal with certain specific situations such as intentional, calculative and grave misconduct. In this view, the punitive damages remedy could complement the traditional compensatory damages award in situations where the latter remedy does not exert sufficient pressure on wrongdoers.

\subsection{Concluding Remarks}

This chapter concerns the increased European interest in punitive damages. It is undeniable that punitive damages are a point of debate in Europe, both at the European Union level and the national level. Two developments have been pointed out to explain this increased interest.

First, the European interest in punitive damages can partly be explained by the attention paid to private enforcement of competition law. The word 'partly' is

\footnotetext{
254 Von Bar 2000, p. 143-144.

255 Article 10:101 PETL.

256 Koziol et al. 2005, p. 150.

257 As explained in section 6.2.2.3, law and economics theories do not refer to deterrence as a side effect of tort law: the economic analysis of tort law pays considerable attention to deterrence as most important function.

258 Articles 1:101, 1:102, 1:103, 2:101, 6:101, 6:301 of book VI DCFR. See Von Bar 2009; Von Bar \& Clive 2009.
} 
deliberately used, as the discussion no longer merely concerns EU competition law. On both the European and national level, there is a shift from public to private enforcement going on in different legal fields, for instance anti-discrimination law. Other examples are environmental law, consumer law, human rights law, competition law, intellectual property law, and personality rights.

Second, the question whether it is desirable - from the viewpoint of law enforcement and deterrence - that the reaction to private law infringements is dominated by the notion of compensation also is an important reason for the punitive damages debate in Europe. The status quo in continental European legal systems is that compensation is indeed the main function of tort law. Moreover, deterrence is already considered an accepted function of tort law. Nonetheless, the need to strengthen tort remedies and react firmly to certain specific situations in which the available remedies do not exert sufficient pressure on tortfeasors is increasingly discussed. One should in this regard especially think of intentional, calculative and grave misconduct of tortfeasors. The punitive damages remedy could be used to deal with such misconduct, which is common practice in the United States as was seen in section 3.2.2.

While a deterrent function of tort law has already been accepted in European legal systems, a punitive purpose of tort law is refused in most European countries. $^{259}$ Punitive damages that are disproportionate to the actual loss and only aim at the punishment of the tortfeasor are for instance clearly not allowed by the PETL. The Commentary to article 10:101 PETL concludes however that it may be difficult to draw a borderline between the aim of prevention and the aim of punishment. ${ }^{260}$ As the preventive effect of compensatory damages is open to discussion, there is attention for powerful civil sanctions with a deterrent or even a punitive function. In this respect, the position of the Court of Justice of the European Union on sanctions for breaches of European Union law, as referred to in section 7.2.3 above, provides an important example.

In line with the idea of Wagner explained in section 7.3.1, punitive damages may be interesting to exert pressure on tortfeasors in certain specific situations and could then serve as a complement to the traditional compensatory damages award. As regards the functions of punitive damages and the role that punitive damages could fulfil in Europe, it should be made clear that punishment does not seem to be a goal in itself in the European search for stronger remedies. In contrast, the main focus seems to be on deterrence and law enforcement. At this point, an interesting idea of Posner, also mentioned in section 7.3.1, should be reiterated. In respect of the twofold function of punitive damages, i.e. deterrence and punishment, Posner has made clear that deterrence should be seen as a purpose of punishment. In other words, the punitive function of punitive damages is not the goal in itself but rather a means to an end, which is deterrence. European opponents of punitive damages mainly reject the introduction of the civil remedy because of its punitive function that is inconsistent with continental European legal traditions. However, in line

259 Koziol et al. 2005, p. 150; Vansweevelt \& Weyts 2009, p. 7.

260 Koziol et al. 2005, p. 150. 
with Posner and in respect of the European search for powerful civil sanctions, a natural conclusion for the European punitive damages debate could be that the advantages of the punitive damages remedy, i.e. deterrence, outweigh its disadvantages, i.e. punishment. As explained in section 7.3.1, although this may be a good theoretical starting point, it is difficult to ignore the punitive aspect of punitive damages awards in practice, as plaintiffs will probably in the first place experience the obligation to pay punitive damages as a form of punishment.

Therefore, it is essential to make clear at this point already that punitive damages should only be awarded with great caution. This advice has already been presented - in section 4.3.2.1 - as one of the current viewpoints in American punitive damages law. In this respect, Englard has made the following remark about introducing punitive damages in Europe: ${ }^{261}$

In conclusion, the joining of ideas of retribution and deterrence into the compensatory process by means of punitive damages should be practised only in exceptional circumstances and to a very limited extent. It should be done in a complementary manner, so that the central aim of compensating the victim of tortious behaviour is maintained without being outweighed by an exorbitant sum of punitive damages.

By analysing causes of the increased European interest in punitive damages, this chapter has answered research question three. It was seen that two developments can be pointed out to explain this interest: (1) increased attention for private enforcement, i.e. law enforcement through private law mechanisms such as tort damages, to complement public enforcement - on both the European Union and national level - of various legal standards, for example in the area of competition law, environmental law, consumer law, human rights law, intellectual property law, anti-discrimination law, and personality rights, and (2) calls for powerful civil sanctions to improve the enforcement of tort law standards and to deal with situations of serious wrongdoing, in particular intentional, calculative and grave misconduct of tortfeasors.

As explained in chapter one, two more questions need to be answered in order to find out if the punitive damages remedy has a future in continental Europe. The first research question concerns the status quo of punitive damages rejection in Europe. Are there signs of a more tolerant approach to the civil remedy? This question will be addressed in the next chapter. The second research question concerns the already existing civil sanctions in four European legal systems. The existence of such sanctions, especially sanctions that bear a resemblance to the punitive damages remedy, could be indicative for policymakers and legislators, in the sense that there are perhaps fewer theoretical and practical obstacles to the introduction of punitive damages than is often believed. Civil sanctions will for that reason be the theme of chapter nine. 


\section{CHAPTER EIGHT}

\section{THE STATUS QUO OF PUNITIVE DAMAGES REJECTION IN EUROPE: TOWARDS MORE LIBERALNESS?}

\subsection{Introductory Remarks}

The previous chapters have explained the reasons for the non-existence of punitive damages in continental Europe, as well as the causes of the increased European interest in the civil remedy, and have thereby answered research questions two and three. This short chapter will focus on research question four concerning the status quo of punitive damages rejection in Europe. ${ }^{1}$ Are there signs of a more liberal approach to the civil remedy? Both a positive and a negative answer to this question will be valuable information for the European punitive damages debate. Also with regard to this book's problem statement, i.e. whether the punitive damages remedy has a future in continental Europe, it is essential to find out if European liberalness can be pointed to. Four concrete examples of the contemporary approach to punitive damages in Europe will be provided. These examples explore punitive damages rejection from a broader European perspective; it was already seen that the general idea throughout Europe is that the civil remedy is considered irreconcilable with continental European legal traditions.

To start with, section 8.2 analyses the position of the European Court of Human Rights in respect of the punitive damages remedy. As mentioned before in chapter six, the Court has - thus far - never awarded punitive damages, at least not in the technical sense. In section 8.3, the uncertain and inconsistent position of the EU legislator with regard to punitive damages, a topic that has already been addressed in the previous chapter, will be further explained. Section 8.4 concerns the position of another important European court with regard to the awarding of punitive damages: the Court of Justice of the European Union. By requiring 'effective, proportionate and dissuasive' sanctions for breaches of European Union law, this Court has, in a way, contributed to the increased European attention for private enforcement and powerful civil sanctions. Although, as mentioned in section 7.3.1, the Court probably did not have punitive damages in mind when creating this formula in 1989, against the background of the current punitive damages debate it can serve as a point of departure. The last section of this chapter explains how foreign punitive damages awards are dealt with in continental Europe from a private international law perspective. In principle, most European courts are hostile to punitive damages awards and have refused to recognise and enforce such awards

1 Chapters six, seven and eight have been put in this order because, before exploring the status quo of punitive damages rejection in continental Europe, a reasonable foundation with regard to the nonexistence of and the increased interest in punitive damages must have been made available. 
for being contrary to public policy (also known as public order or ordre public). However, an interesting development is that some legal systems have shown less opposition by supporting the recognition of punitive damages awards.

These four examples should be distinguished from the traditional reasons for the non-existence of punitive damages in continental Europe that have been explained in chapter six. The developments taking place in the area of private international law form an important illustration of the European view on punitive damages awards. Likewise, the positions of the European Court of Human Rights, the legislator of the European Union and the Court of Justice of the European Union illustrate the non-existence of punitive damages, but they do not form an underlying reason or explanation for this non-existence.

\subsection{Punitive Damages Are Not Awarded by the European Court of Human Rights}

Section 6.3.2.1, has dealt with the compatibility of punitive damages with article 6 ECHR. A different but equally important question in respect of the ECHR is whether the European Court of Human Rights (ECtHR), which rules on individual or state applications alleging violations of the Convention, has ever awarded punitive damages. All Member States of the European Union participate in the Council of Europe and are therefore part of the forty-seven states that have ratified the ECHR. Thus, in view of the theme of this chapter, i.e. the status quo of punitive damages rejection in Europe, it is also interesting to look at the practice of the ECtHR. What is meant by the 'practice' of the Court is whether the Court relies on non-compensatory damages to deal with human rights infringements. What the Court actually does after a complaint has been filed by an individual or a state is deciding whether one of the rights or guarantees laid down in the ECHR has been breached. If so, the Court delivers a judgment finding a violation and this judgment is binding, which means that the relevant state is obliged to comply with it. Furthermore, under article 41 (old article 50) ECHR a compensatory damages award may be awarded as just satisfaction (billijke genoegdoening). The principle of restitutio in integrum or full compensation of loss applies to such awards. ${ }^{2}$ As follows from the Practice Direction on Just Satisfaction Claims, issued by the President of the Court in 2007, an award of just satisfaction is not an automatic consequence of a finding by the Court that there has been a violation of the ECHR. ${ }^{3}$ Just satisfaction may be awarded for pecuniary damage, non-pecuniary damage and costs and expenses, but an award is only possible if domestic law does not allow full compensation and, even in that case, only if the award is necessary. ${ }^{4}$ Article 41 ECHR reads as follows: 
If the Court finds that there has been a violation of the Convention or the Protocols thereto, and if the internal law of the High Contracting Party concerned allows only partial reparation to be made, the Court shall, if necessary, afford just satisfaction to the injured party.

The interesting question is thus if the award of just satisfaction may also have a non-compensatory or punitive function. According to Wilcox, the negative position of the Court in respect of punitive damages is 'clear and unequivocal'.5 Shelton likewise makes clear that punitive damages are not awarded by the Court. ${ }^{6}$ As will be explained below, this follows from case law and from the already mentioned Practice Direction.

The Court was first confronted with a punitive damages claim in the case Silver v. $U K{ }^{7}$ This case is about prison authorities that had stopped a number of letters written by or addressed to Mr. Silver and the other six applicants, which according to the Court constituted a violation of their right to respect for correspondence and of their freedom of expression, guaranteed by articles 8 and 10 of the Convention. They also claimed that their right to an effective remedy in article 13 of the Convention had been breached. Furthermore, the refusal of two petitions by Mr. Silver for permission to seek legal advice allegedly constituted a breach of article 6 $\S 1$ ECHR. ${ }^{8}$ The applicants therefore claimed, as just satisfaction under article 41 ECHR, general damages for a violation of their rights and reimbursement of specified costs and expenses. In addition to that, Mr. Silver and two of the other applicants claimed special damages, i.e. a form of non-compensatory damages. These claims have been rejected by the Court without any further motivation. ${ }^{9}$ The Court's position regarding punitive damages has ever since remained clear: punitive damages are not awardable under the European Convention on Human Rights. ${ }^{10}$ This follows for example from the case Menteş and Others v. Turkey decided in 1998. ${ }^{11}$ In this decision, the Court made clear that by estimating the award for non-pecuniary damage, the seriousness of the violations (of articles 8 and 13 ECHR) had to be taken into account. ${ }^{12}$ As the graveness of the wrongdoing thus plays a role in estimating the award of just satisfaction, one could doubt its sole compensatory function. However, claims for punitive and aggravated damages

Wilcox 2012, p. 500.

6 Shelton 2005, p. 360. Shelton points out that, in addition to the ECtHR, the Inter-American Court of Human Rights in Costa Rica also has no practice of awarding punitive damages. The latter Court does, however, like the ECtHR, award compensation for non-pecuniary damage when grave or aggravated circumstances of extreme violence have resulted in intense suffering of the victim. In this regard, full reparation of the damage involves both compensation and punishment. See Shelton 2005, p. 360-364, citing Myrna Mack-Chang v. Guatemala (2003) 101 Inter-Am.Ct.H.R (ser. C).

7 ECtHR 24 October 1983, Silver and Others v. The United Kingdom, no. 5947/72, 6205/73, 7052/ $75 ; 7061 / 75 ; 7107 / 75 ; 7113 / 75 ; 7136 / 75$.

Silver v. The United Kingdom, at $\S 9$.

Silver v. The United Kingdom, at § 120-122.

Wilcox 2009, p. 24; Wilcox 2012, p. 500.

ECtHR 24 July 1998, Menteş and Others v. Turkey, no. 23186/94.

12 Menteş and Others v. Turkey, at $\S 20$. 
were subsequently rejected by the Court. ${ }^{13}$ This standpoint of the Court has also been laid down in $\S 9$ of the Practice Direction: ${ }^{14}$

The purpose of the Court's award in respect of damage is to compensate the applicant for the actual harmful consequences of a violation. It is not intended to punish the Contracting State responsible. The Court has therefore, until now, considered it inappropriate to accept claims for damages with labels such as "punitive", "aggravated" or "exemplary".

Furthermore, several authorities ${ }^{15}$ can be mentioned in which the Court decided in the same direction, such as the case Aydin v. Turkey. ${ }^{16}$ This case concerned a violation of article 3 ECHR. The victim was a 17-year-old girl who had been raped, ill-treated and subjected to other forms of physical and mental suffering by police officers while she was held in custody. She claimed $£ 30,000$ in punitive damages for just satisfaction, but despite the gravity of the wrongful behaviour the Court unanimously dismissed the claim without further motivation. Compensatory damages for immaterial loss of $£ 25,000$ were awarded to the girl. ${ }^{17}$ In 2006 , the Court restated that it "does not, as a matter of practice, make aggravated or exemplary damages awards". ${ }^{18}$ Likewise, in $2009:{ }^{19}$

In so far as the applicants suggested that daily fines be imposed on the Government until they finally comply with the Court's judgments, the Court has consistently rejected claims for punitive damages. It considers there to be little, if any, scope under the Convention for directing Governments to pay penalties to applicants which are unconnected with damage shown to be actually incurred in respect of past violations of the Convention; in so far as such sums would purport to compensate for future suffering of the applicants, this would be speculative in the extreme.

And in a recent decision from 2012, the Court again affirmed its negative position on punitive damages. ${ }^{20}$ The rejection of punitive damages in case of just satisfaction claims as well as in the Practice Direction can be explained in light of the Court's practice to take guidance from domestic standards. ${ }^{21}$ As already

13 Menteş and Others v. Turkey, at $\S 21$.

14 Practice Direction on Just Satisfaction Claims 2007, p. 2.

15 See, among others, ECtHR 16 September 1996, Gaygusuz v. Austria, no. 17371/90, at partially dissenting opinion; ECtHR 1 April 1998, Akdivar and Others v. Turkey, no. 21893/93, at § 35-38; ECtHR 24 April 1998, Selçuk and Asker v. Turkey, nos. 23184/94 and 23185/94, at $\S 116-119$; ECtHR 18 February 1999, Hood v. The United Kingdom, no. 27267/95, at § 88-89; ECtHR 10 February 2004, B.B. v. The United Kingdom, no. 53760/00, at § 36; ECtHR 27 July 2004, Ikincisoy v. Turkey, no. 26144/95, at $\S 149$; ECtHR 23 November 2010, Greens and M.T. v. the United Kingdom, nos. 60041/08 and 60054/08, at § 97; ECtHR 3 June 2014, López Guió v. Slovakia, no. $10280 / 12$, at $\S 120$.

16 ECtHR 25 September 1997, Aydin v. Turkey, no. 23178/94.

17 Aydin v. Turkey, at $\$ 131$.

18 ECtHR 26 September 2006, Wainwright v. the United Kingdom, no. 12350/04, at $\S 60$

19 ECtHR 18 September 2009, Varnava and Others v. Turkey, nos. 16064/90, 16065/90, 16066/90, $16068 / 90,16069 / 90,16070 / 90,16071 / 90,16072 / 90$ and 16073/90, at $\S 223$.

20 ECtHR 23 October 2012, Hadzhiev v. Bulgaria, no. 22373/04, at § 65.

21 Wilcox 2012, p. 500, citing Practice Direction on Just Satisfaction Claims 2007, § 3 . 
mentioned, the majority of the Member States of the European Union do not allow punitive damages.

Also in view of the earlier noted European interest in private enforcement to enforce fundamental human rights, it is interesting to keep an eye on the Court's position in respect of punitive damages and on the Court's practice concerning damages in general. Does the Court for example recognise only a compensatory function of damages awards, as it emphasised in the Practice Direction? Are substantial immaterial damages awards for grave violations allowed by the Court? This section focuses on the Court's practice concerning punitive damages, as that forms an illustration of the rejection of punitive damages by an important European court. But two recent decisions, in which the Court upholds a compensatory damages award that might include other elements than mere compensation, think of deterrence and punishment, should be mentioned at this point.

In the first case, Krone Verlag GMBH v. Austria, the Court upheld a compensatory damages award of $€ 130,000$ for the infringement of privacy rights under the Austrian Media Act. ${ }^{22}$ Newspaper Kronen Zeitung published thirteen articles accompanied by photographs about a dispute between parents over the custody of their child Christian. Christian brought proceedings in his home country Austria because the articles had disclosed his identity and details of his family life, his health and his emotional state. ${ }^{23}$ The applicant, publisher Krone Verlag GmbH, claimed before the Court that the judgments under the Media Act ordering them to pay $€ 130,000$ in damages had infringed their right to freedom of expression under article 10 of the Convention. The Court found no violation and determined that, given the particular circumstances of the case, the damages awarded were indeed exceptionally high but not disproportionate. According to the Court, an important reason the award should be considered proportionate is that the repeated articles, as well as the wide circulation of the respective newspaper, created 'a climate of continual harassment inducing in the person concerned a very strong sense of intrusion into their private life or even of persecution'. ${ }^{24}$ Furthermore, the Court established that Austrian law included 'adequate and effective domestic safeguards against disproportionate awards'. ${ }^{25}$ The Media Act for example contains guidelines for determining the amount of damages and provides that the award must not 'endanger the economic existence of the media owner'. ${ }^{26}$ The Court concluded that in the particular circumstances of Christian's case, the damages award was not disproportionate. The second decision in which the ECtHR awarded a rather substantial just satisfaction sum is Trévalec v. Belgium. ${ }^{27}$ In this case, the French reporter Trévalec obtained $€ 50,000$ for being shot by two police officers while making a coverage of their police unit. Although the police had authorised the

ECtHR 19 June 2012, Krone Verlag GMBH v. Austria, no. 27306/07.

Krone Verlag GMBH v. Austria, at $\S 50$.

Krone Verlag $G M B V$ v. Austria, at $\$ 59$.

Krone Verlag GMBV v. Austria, at $\S 61$.

Krone Verlag GMBV v. Austria, at $\S 61$.

ECtHR 25 June 2013, Trévalec v. Belgium, no. 30812/07. 
filming, the officers were not informed of Trévalec's presence. In addition to the damages award, the Court confirmed an infringement of article 2 of the Convention (the right to life). Nordin subscribes to the idea that the damages award in this case deviates from the compensatory principle, and makes clear that both the dissenting and the concurring opinion assign a punitive function to the award. ${ }^{28}$ The concurring opinion even stipulates that punitive damages already form part of the Court's practice, as some awards for just satisfaction in reality serve as a punishment. ${ }^{29}$

To conclude, Shelton has compared the ECtHR's view on punitive damages to that of the Inter-American Court of Human Rights. As mentioned above, this latter court also has no practice of awarding punitive damages but, like the ECtHR, does award compensation for non-pecuniary damage when grave or aggravated circumstances of extreme violence have resulted in intense suffering of the victim. ${ }^{30}$ However, according to Shelton, the term 'satisfaction' used in article 41 of the ECHR might give an opening for the ECtHR to start awarding punitive damages: ${ }^{31}$

The European Court has a stronger textual basis to award punitive damages, as there is clear precedent for punitive damages in the arbitral decisions on state responsibility for injury to aliens. The term 'satisfaction' has a broader meaning than is reflected in the judgments of the European Court.

Shelton discusses the meaning of the term satisfaction in the context of (international) human rights law. Her explanation could however also contribute to the general punitive damages debate. She points out that satisfaction generally applies to every form of redress repairing immaterial harm: ${ }^{32}$

Satisfaction may be any measure that the author of a breach is bound to take including: (a) apologies or other acknowledgment of wrongdoing; (b) prosecution and punishment of the individuals concerned; (c) taking measures to prevent a recurrence of the harm; and (d) performing symbolic acts of atonement. [...] The most common types of satisfaction are apologies, punishment of the guilty, assurances as to the future, and pecuniary satisfaction.

Opinions on the functions of satisfaction measures differ: accepted functions are compensation and deterrence, but there is less agreement on a punitive function of such measures. Shelton shows the views of both proponents and opponents and summarises as follows: ${ }^{33}$

[...] The retributive interest in some form of punitive measure remains and suggests the possibility of an award of punitive or exemplary damages in appropriate cases.

\footnotetext{
Nordin 2014, at $\S 302$.

Trévalec v. Belgium, concurring opinion, footnote 2.

See footnote 6 of this chapter.

Shelton 2005, p. 364.

Shelton 2005, p. 78.

Shelton 2005, p. 79.
} 
And: ${ }^{34}$

Even if the accepted rationale for measures of satisfaction is compensatory, to repair moral injury, the measure of the damages most likely will involve an element of condemnation that will vary according to the nature of the wrong. The greater the wrong, the greater the moral outrage and the greater the indemnity awarded to express disapproval of the act.

Against the background of these ideas, she states that one might give a broader meaning to the term 'just satisfaction' in article 41 ECHR: ${ }^{35}$

[...] The wide range of measures of satisfaction that generally have been granted lend meaning to the term 'satisfaction' in the European Convention of Human Rights and suggests that the European Court of Human Rights has broader powers than it has used so far to ensure respect for the Convention. Recent shifts in practice support this notion.

It is for that reason not unwise to keep an eye on the Court's future interpretation of article 41 ECHR. Shelton's personal view on sanctions for human rights violations seems to be that the more grave violations should be sanctioned more severely in order to have credible and effective legal protection. She makes clear that punitive damages could be an option in this respect, and that awarding such damages does not necessarily have to result in a windfall for the applicant. One could for example follow the current practice of the Inter-American Court of Human Rights to establish a trust fund for victims; such a fund might even be useful for those who are not involved in the original procedure but that suffer from similar violations. ${ }^{36}$ According to Laplante, it is imaginable that punitive damages one day will become part of the remedies of the Inter-American Court of Human Rights in order to increase the enforcement of human rights. ${ }^{37}$

Note, as a final remark, that considerable punitive damages have been awarded in American human rights cases. ${ }^{38}$ An example is the case Filartiga v. Pena-Irala, in which citizens of the Republic of Paraguay filed a civil claim against the defendant, also a citizen of Paraguay who was in the United States on visitor's visa, alleging that he had wrongfully caused the death of their brother and son. ${ }^{39}$ The district court of New York, which had jurisdiction under the Alien Tort Statute, decided as follows: ${ }^{40}$

This court concludes that it is essential and proper to grant the remedy of punitive damages in order to give effect to the manifest objectives of the international prohibition against torture.

34 Shelton 2005 , p. 80.

Shelton 2005, p. 103

Shelton 2005, p. 366-367.

Laplante 2004, p. 380.

8 E.g. Filartiga v. Pena-Irala, 577 F.Supp. 860 (D.C.N.Y. 1984); Xuncax v. Gramajo, 886 F.Supp.

162 (D.Mass. 1995). See generally Lillich 1993.

39 Filartiga v. Pena-Irala, at 860.

40 Filartiga v. Pena-Irala, at 865 
The court continued that a variety of factors had to be considered in determining the amount of punitive damages: ${ }^{41}$

Chief among the considerations the court must weigh is the fact that this case concerns not a local tort but a wrong as to which the world has seen fit to speak. Punitive damages are designed not merely to teach a defendant not to repeat his conduct but to deter others from following his example. To accomplish that purpose this court must make clear the depth of the international revulsion against torture and measure the award in accordance with the enormity of the offense. Thereby the judgment may perhaps have some deterrent effect.

And: ${ }^{42}$

The record in this case shows that torture and death are bound to recur unless deterred. This court concludes that an award of punitive damages of no less than $\$ 5,000,000$ to each plaintiff is appropriate to reflect adherence to the world community's proscription of torture and to attempt to deter its practice.

Lillich gives a clear overview of punitive damages awarded in a number of American human rights cases, for example cases that arose under the Alien Tort Statute. ${ }^{43}$ Americans are thus - not surprisingly - familiar with the concept of severe sanctions for human rights infringements.

\subsection{The Uncertain and Inconsistent Position of the EU Legislator}

As referred to earlier by Koch, ${ }^{44}$ Koziol, ${ }^{45}$ Sein, ${ }^{46}$ and Vanleenhove, ${ }^{47}$ Wagner describes - in a publication from 2006 - the position of the European Union with regard to punitive damages as not only ambivalent but also evidently self-contradictory. ${ }^{48}$ By this he probably means that although the position of the legislator of the European Union on punitive damages is largely negative, supporters of punitive damages have found signs that the European Union law does not totally reject punitive damages. Koziol has for example noted an inclination towards punitive damages by the legislator of the European Union and the Court of Justice of the European Union: ${ }^{49}$

On the other hand, an inclination towards punitive damages exists in some directives; for example, on consumer credit and in the area of anti-discrimination in the workplace, particularly with regard

41 Filartiga v. Pena-Irala, at 866.

42 Filartiga v. Pena-Irala, at 866.

43 Lillich 1993, appendix p. 217-229.

44 Koch 2009, p. 197.

45 Koziol 2009, p. 288

Sein 2007, p. 48.

47 Vanleenhove 2012, p. 338.

48 Wagner 2006a, p. A 71. See on the European approach to punitive damages also Koziol 2008; Coderch 2001; Rouhette 2007; Wagner 2012; Gotanda 2007; Georgiades 2005; Cauffman 2007; Wells 2010.

49 Koziol 2008, p. 749. 
to discrimination between men and women. Furthermore, the European Court of Justice demands the effectiveness of sanctions imposed by national laws for the violation of obligations arising from Community law.

The signs of liberalness meant by Koziol have already been explained in chapter seven as they - above all - form part of a bigger picture: increased European interest in private enforcement and powerful civil sanctions. Koziol refers to the requirement of 'effective, proportionate and dissuasive' sanctions for breaches of European Union law, a formula once developed by the CJEU which is nowadays an important tool in European legislation concerning anti-discrimination in employment matters. ${ }^{50}$ This section will primarily focus on current examples of the negative position of the EU legislator with regard to punitive damages.

Furthermore, the focus in this section will be on the legislator of the European Union, i.e. European law in its original meaning, rather than national legislators. It is interesting to see that the European legislator has at times explicitly excluded punitive damages, whereas the position of national legislators primarily follows from the interpretation - by courts and legal scholars - of continental European legal traditions such as the compensatory function of civil damages and the strict public-private divide. In other words, on the face of it, national legislators have not openly excluded punitive damages but the rejection is a more implicit result of codifying, for example, only a compensatory function of tort law. The principle of full compensation is also, as a general rule, strictly observed by national courts. ${ }^{51}$ Nevertheless, Koziol emphasises that although continental European legal systems in principle fundamentally reject punitive damages, the subject slowly but surely grabs the attention of national legislators. ${ }^{52}$ An example can be found in France, where draft legislative proposals depart from the traditional rejection of punitive damages. This development will be further explained in chapter nine.

So, which position does the legislator of the European Union take in respect of punitive damages? First of all, Oliphant makes clear that punitive damages are 'not of general application in EC tort law'. ${ }^{53}$ And if we look at EC tort law in its narrow meaning of the law dealing with compensation claims against Community institutions, punitive damages are 'probably not available at all' ${ }^{54}$ This follows implicitly - from article 340 TFEU (old article 288 EC Treaty), paragraph two, which sticks to the compensatory approach:

In the case of non-contractual liability, the Community shall, in accordance with the general principles common to the laws of the Member States, make good any damage caused by its institutions or by its servants in the performance of their duties.

Koziol and Schulze have also emphasised that the accepted aims of EC tort law are compensation, prevention and allocation of loss; punishment is not an accepted

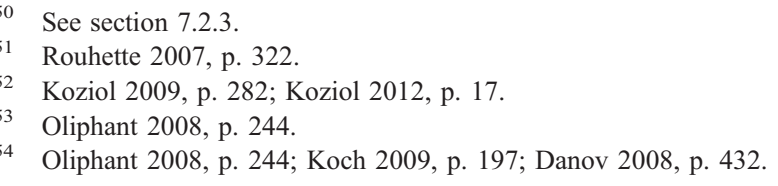


function. $^{55}$ Furthermore, as mentioned earlier in chapter seven, the European Commission has explicitly disapproved of punitive damages on other occasions. At least one Regulation and one Directive can be mentioned. An often cited example of the European legislator's rejection of punitive damages is the Regulation on the law applicable to non-contractual obligations, better known as Rome II. ${ }^{56}$ Recital 32 of the Preamble thereof declares punitive damages as being contrary to public policy: ${ }^{.7}$

Considerations of public interest justify giving the courts of the Member States the possibility, in exceptional circumstances, of applying exceptions based on public policy and overriding mandatory provisions. In particular, the application of a provision of the law designated by this Regulation which would have the effect of causing noncompensatory exemplary or punitive damages of an excessive nature to be awarded may, depending on the circumstances of the case and the legal order of the Member State of the court seised, be regarded as being contrary to the public policy (ordre public) of the forum.

The public policy argument against punitive damages was initially placed in the main text of Rome II but was transferred to the Preamble in the drafting process. ${ }^{58}$ According to Koch, this does not really make a difference because a national court can still regard punitive damages as being contrary to its public policy. ${ }^{59}$ As pointed out by Nagy and Wagner, recital 32 should be interpreted as if only punitive damages of an excessive nature may be regarded contrary to public policy. ${ }^{60}$ Indeed, a careful reading of this paragraph could lead to the conclusion that the refusal to apply foreign law does not automatically apply to all punitive damages cases. In other words, it is likely that the rejection of punitive damages in this Regulation is not absolute. If punitive damages are not per se considered excessive, sanctioning the wrongdoer becomes an aim of EC tort law. ${ }^{61}$

Koch mentions another example of European Union legislation excluding punitive damages, namely the Directive on the enforcement of intellectual property rights. ${ }^{62}$ According to recital 26 of the Preamble:

With a view to compensating for the prejudice suffered as a result of an infringement committed by an infringer who engaged in an activity in the knowledge, or with reasonable grounds for knowing, that it would give rise to such an infringement, the amount of damages awarded to the rightholder should take account of all appropriate aspects, such as loss of earnings incurred by the rightholder, or unfair profits made by the infringer and, where appropriate, any moral prejudice caused to the rightholder. As an alternative, for example where it would be difficult to determine the amount of the actual prejudice suffered, the amount of the damages might be derived from elements such as the

57 Regulation $864 / 2007 / \mathrm{EC}$, at $\S 32$.

58 See on the drafting history of Rome II: $\operatorname{COM}(2006) 83$ final; Koch 2009, p. 198-199; Vanleenhove 2012, p. 338-340; Wagner 2006a, p. A 71.

59 Koch 2009, p. 199.

60 Nagy 2012, p. 10; Wagner 2006a, p. A 71.

61 Koziol \& Schulze 2008, p. 596.

62 Koch 2009, p. 200, citing Directive 2004/48/EC. 
royalties or fees which would have been due if the infringer had requested authorisation to use the intellectual property right in question. The aim is not to introduce an obligation to provide for punitive damages but to allow for compensation based on an objective criterion while taking account of the expenses incurred by the rightholder, such as the costs of identification and research.

Note that - as pointed out in section 2.3.4 - national legislators throughout Europe do seem to accept punitive sanctions for intellectual property right infringements. This follows for example from French legislation implementing the just mentioned Directive, which according to Borghetti comes 'quite close to' recognising punitive damages, ${ }^{63}$ or from the German case law concerning GEMA; these mechanisms will be further explained in chapter nine. Another example is a recent judgment of the Polish Supreme Court, in which the Court decided that article 79(1) of the Polish Copyright Act requiring double or treble damages awards for intellectual property right infringements has a clear punitive nature. ${ }^{64}$ According to the Court, there is no reason to deny this remedy to victims of copyright infringements. ${ }^{65}$

Other examples of European Union legislation excluding punitive damages can be mentioned. Punitive damages are for example not allowed under the Montreal Convention concerning international carriage by air. ${ }^{66}$ The carrier is liable for damage resulting from a delay of passengers, baggage or cargo on the basis of article 19 thereof. Article 29 then reads as follows:

In the carriage of passengers, baggage and cargo, any action for damages, however founded, whether under this Convention or in contract or in tort or otherwise, can only be brought subject to the conditions and such limits of liability as are set out in this Convention without prejudice to the question as to who are the persons who have the right to bring suit and what are their respective rights. In any such action, punitive, exemplary or any other non-compensatory damages shall not be recoverable.

The Montreal Convention is an international convention but, as the European Community has signed it and approved of it in $2001,{ }^{67}$ its provisions are applicable within the European Union. Note that in case of a sustained delay passengers may also file a claim for compensation under Regulation 261/1004 on the compensation and assistance to passengers in the event of denied boarding and of cancellation or long delay of flights, as has been confirmed by the Court of Justice of the European Union and the Dutch Supreme Court. ${ }^{68}$ Articles 6 and 7 of

63 Borghetti 2009, p. 58.

64 Supreme Court Poland, 8 March 2012, V CSK 102/11.

65 See on the Polish decision Kolczynski \& Antas 2013.

66 Convention for the Unification of Certain Rules for International Carriage by Air (Montreal, 28 May 1999).

67 Decision 2001/539/EC

68 Regulation 261/2004/EC. See in respect of compensation for delay also CJEU 10 January 2006, case C-344/04, ECR I-0403 (IATA and ELFAA); CJEU 19 November 2009, joined cases C-402/07 and C-432/07, ECR I-10923 (Sturgeon and Others); CJEU 23 October 2012, joined cases C-581/10 and C-629/10, not yet published (Nelson and Others v. Deutsche Lufthansa AG and TUI Travel and Others v. Civil Aviation Authority); HR 15 juni 2012, NJ 2012/394. See further e.g. Balfour 2012; Lawson \& Marland 2011; Van Dam 2011b. 
this Regulation determine when passengers have a right to compensation and give certain fixed amounts.

In terms of the European Union legislative process, punitive damages are excluded from a Commission proposal - published in 2000 - for a Council Regulation on the Community patent, which should give designers the possibility to obtain one single patent that is legally valid throughout the European Union. ${ }^{69}$ The refusal of punitive damages came up in versions of the proposal dating from 2004 and $2009,^{70}$ but it is not certain at present whether this proposal will ever become law. ${ }^{71}$ Furthermore, according to a press release from 1989 concerning the Commission proposal for a Council Directive on civil liability for damage caused by waste, ${ }^{72}$ the imposition of punitive damages is not provided for under the Directive as it should concentrate merely on the restoration of the status quo ante. $^{73}$

As pointed out by Oliphant, another document in which the Commission has shown its opinion as regards punitive damages is the Green Paper on liability for defective products from $1999 .^{74}$ The Commission makes clear in this paper that European products liability law is better off without punitive damages. ${ }^{75}$ This is in conformity with the Directive on liability for defective products that stems from 1985 and is focused on compensation without even mentioning punitive damages. ${ }^{76}$ Note that, as pointed out by Koziol and Schulze, one could argue that the products liability Directive moves away from the compensatory principle by requiring a mandatory threshold of $500 \mathrm{ECU}$ damage to the victim and an optional cap on damages of 70 million ECU, in order to avoid excessive litigation of small claims and advance foreseeability and insurability of large damages awards. ${ }^{77}$ The Green Paper on consumer collective redress published in 2008 also makes clear that the punitive damages remedy is a remedy that might 'burden business' or 'encourage a litigation culture' and should therefore be avoided. ${ }^{78}$ These are often heard arguments against the introduction of punitive damages which seem to be based on fear of excessiveness, whereas the analysis of American punitive damages law in chapters two to five supports the idea that this is an unfounded attitude. However, the European Commission has again rejected the use of punitive damages in this context in a recent communication of 11 June 2013 concerning the future of a European Horizontal Framework for Collective Redress: ${ }^{79}$

See register.consilium.europa.eu/pdf/en/04/st07/st07119.en04.pdf and register.consilium.europa.eu/ pdf/en/09/st08/st08588.en09.pdf.

1 Oliphant 2008, p. 244; Koch 2009, p. 200

$72 \operatorname{COM}(89) 282$ final, SYN 217.

73 See page 3 of the press release, retrieved via: europa.eu/rapid/pressReleasesAction.do?reference=P/ $89 / 47 \&$ format $=$ HTML\&aged $=1 \&$ language $=E N \&$ guiLanguage $=$ en.

74 Oliphant 2008, p. 244.

$75 \operatorname{COM}(1999) 396$ final, p. 13

76 Directive 85/374/EEC

77 Koziol \& Schulze 2008, p. 597, citing articles 9(b) and 16(1) of Directive 85/374/EEC.

$78 \operatorname{COM}(2008) 794$ final, at $\S 18,48$.

$79 \operatorname{COM}(2013) 401 / 2$, at $\S 3.1$. 
Collective damages actions should aim to secure compensation of damage that is found to be caused by an infringement. The punishment and deterrence functions should be exercised by public enforcement. There is no need for EU initiatives on collective redress to go beyond the goal of compensation: Punitive damages should not be part of a European collective redress system.

The Commission concludes in a similar manner in the recommendation on collective redress mechanisms that was published on the same date: ${ }^{80}$

The compensation awarded to natural or legal persons harmed in a mass harm situation should not exceed the compensation that would have been awarded, if the claim had been pursued by means of individual actions. In particular, punitive damages, leading to overcompensation in favour of the claimant party of the damage suffered, should be prohibited.

This is line with the wishes that were pronounced earlier in this context by the European Parliament, i.e. the prohibition of punitive damages and frivolous litigation. $^{8}$

As explained in section 2.2.3.6, these collective redress documents are not only relevant for competition law and consumer protection law but also in areas such as environmental protection, financial services, investor protection, non-discrimination, and protection of personal data; these are good examples of areas for which 'supplementary private enforcement of rights granted under Union law in the form of collective redress is of value'. ${ }^{82}$ Furthermore, attention should be paid to a number of soft law instruments. This explanation of the European legislator's position on punitive damages could not be finished without paying attention to these instruments, even though they have been created by groups of European scholars and do not have the status of law. As follows from section 6.2.2.6, both the Principles of European Tort Law and the Draft Common Frame of Reference do not allow punitive damages. ${ }^{83}$ The exclusion of punitive damages is not explicitly mentioned in the main text of these two projects, but it follows from the Commentaries to them.

Lastly, the argument that there is no European Union legislation that specifically authorises courts to award punitive damages, as has been pointed out by Wagner, ${ }^{84}$ can also be brought up to defend an alleged negative approach to punitive damages by the European Union. However, according to Vanleenhove this is not necessarily correct as punitive damages supporters have pointed out that positive approaches to punitive damages do exist in European Union documents. ${ }^{85}$ An important example can be found in the debate concerning EU competition law and private enforcement. And, according to Koziol, the availability of punitive damages in the European common law systems of Cyprus, Ireland and (part of) the

$80 \mathrm{C}(2013) 3539 / 3$, at $\S 31$.

81 European Parliament Resolution 2011/2089 (INI) of 2 February 2012, See Tzankova, Plomp \& Raats 2013, p. 180.

$82 \operatorname{COM}(2013) 401 / 2$, at $\S 1.3 ; \mathrm{C}(2013) 3539 / 3$, recital 7 of the Preamble.

83 Koziol 2009, p. 287.

84 Wagner 2012, p. 1405.

85 Vanleenhove 2012, p. 340. See section 7.2.5. 
United Kingdom - which are all Member States of the European Union - might also positively influence European Union law. ${ }^{86}$

\subsection{The Court of Justice of the EU Demands 'Effective, Proportionate and Dissuasive' Sanctions}

In view of the status quo of punitive damages rejection in European Union law, it is of course also interesting to look at the position of the CJEU. Although this Court has underlined the absence of EC rules governing punitive damages, ${ }^{87}$ the rather ambiguous position of the Court with regard to sanctions for breaches of European Union law has been brought forward by supporters of punitive damages as proof of the European Union's uncertain and inconsistent position. As mentioned before, the Court has created a formula that national sanctions which may be imposed for breaches of European Union law should be 'effective, proportionate and dissuasive'. This requirement of effective preventive sanctions, as Ebert calls them, has already been connected to the punitive damages remedy, even though, as mentioned before, the formula was probably not originally created for this purpose. ${ }^{88}$ Wagner contrasts the position of the Court with the negative approach to punitive damages by the European Commission, for example in respect of the Rome II Regulation described above: ${ }^{89}$

Auf der anderen Seite wird der EuGH nicht müde zu betonen, die Mitgliedstaaten seien verpflichtet, Verstöße gegen Gemeinschaftsrecht mit Sanktionen zu ahnden, die "wirksam, verhältnismäßig und abschreckend" sein müssten, und diese Formel hat auch schon Eingang in Richtlinien und Verordnungen gefunden.

And:

In einer Entscheidung zur Staatshaftung wegen Verstoßes gegen Gemeinschaftsrecht hat der EuGH unter dem Gesichtspunkt des Äquivalenzprinzips die englischen Gerichte sogar ausdrücklich für verpflichtet gehalten, exemplary damages zuzusprechen, wenn sie dies in einem vergleichbaren nationalen Fall tun würden!

Reference is in this respect made to the joined cases Brasserie du pêcheur and Factortame $I I I^{90}$ decided by the Court concerning the effectiveness of national sanctions which may be imposed for breaches of European Union law, for example the anti-discrimination Directives. ${ }^{91}$ These joined cases have been analysed in

86 Koziol 2008, p. 748.

87 CJEU 13 July 2006, joined cases C-295/04 to C-298/04, ECR I-6619 (Manfredi and Others), at $\S 92$.

88 Ebert 2013, p. 95

89 Wagner 2006a, p. A 71.

90 CJEU 5 March 1996, joined cases C-46/93 and C-48/93, ECR I-1029 (Brasserie du pêcheur SA v. Germany and R. v. Secretary of State for Transport, ex parte: Factortame Ltd. and Others (Factortame III)).

91 E.g. Directive 2000/43/EC. 
section 7.2.3. Wagner also points out that, given these developments made by the CJEU, the European Commission has done a good job in the drafting process of Rome II by removing the rejection of punitive damages from the main text and placing a restricted formulation of this rejection ('punitive damages of an excessive nature') in recital 32 of the Preamble:

Die EU-Kommission hat deshalb gut daran getan, in ihrem revidierten Vorschlag zur Rom-IIVerordnung auf jede Diskriminierung des Abschreckungsgedankens zu verzichten und den ordrepublic-Vorbehalt auf Strafschadensersatz in unverhältnismäßiger Höhe zu beschränken.

In other words, as stated in recital 32, not all non-compensatory damages awards with preventive effect should be discriminated by holding them contrary to public policy.

The rule that all sanctions should be 'effective, proportionate and dissuasive', according to Koch a magic formula that reoccurs in legislation and court decisions, ${ }^{92}$ was mentioned by the Court as early as 1989 and recently repeated in comparable language in 2009 and in $2014 .{ }^{93}$ In Commission v. Greece, the Court ruled as follows: ${ }^{94}$

It should be observed that where Community legislation does not specifically provide any penalty for an infringement or refers for that purpose to national laws, regulations and administrative provisions, Article 5 of the Treaty requires the Member States to take all measures necessary to guarantee the application and effectiveness of Community law.

For that purpose, whilst the choice of penalties remains within their discretion, they must ensure in particular that infringements of Community law are penalized under conditions, both procedural and substantive, which are analogous to those applicable to infringements of national law of a similar nature and importance and which, in any event, make the penalty effective, proportionate and dissuasive [emphasis added].

Although in this decision as well as in later European Union legislation the formula is used in combination with the term 'penalty', which may refer to several sanctions such as administrative sanctions, it has also been connected specifically to civil remedies or compensation. ${ }^{95}$ In this respect, Koch mentions the examples of three Directives concerning Equal Treatment. ${ }^{96}$ Another Directive even refers to civil remedies as penalties. ${ }^{97}$ This explains why punitive damages pop up. The relevant decisions of the CJEU particularly relate to European Union legislation concerning equal treatment and competition law. As explained in chapter seven,

Koch 2009, p. 200. See also Kelliher 2008, p. 9-10.

3 CJEU 21 September 1989, case 68/88, ECR 2965 (Commission v. Greece); CJEU 23 April 2009, joined cases C-378/07 to C-380/07, ECR I-3071 (Kiriaki Angelidaki and Others); CJEU 11 September 2014, case C-565/12, not yet published (LCL Le Crédit Lyonnais SA v. Fesih Kalhan).

Commission v. Greece, at $\S 23-24$.

95 For an overview of relevant European Union legislation see Koch 2009, p. 200-202.

96 Koch 2009, p. 202, citing article 15 of Directive 2000/43/EC, article 17 of Directive 2000/78/EC, articles 6(2) and 8d of Directive 2002/73/EC

97 Directive 2004/109/EC, article 28(1). 
punitive damages supporters see these decisions of the Court as proof of a positive approach to and increased interest in the civil remedy.

Now that we have seen three examples of the status quo of punitive damages rejection in Europe, i.e. the position of the European Court of Human Rights, the legislator of the European Union and the Court of Justice of the European Union, the next section explores the fourth and last example: the European view on punitive damages awards from a private international law perspective. An evaluation of these examples will be given in the conclusion of this chapter.

\subsection{Punitive Damages from a Private International Law Perspective: Signs of Liberalness}

In respect of the European approach to punitive damages, it is also important and interesting to find out how punitive damages awards are dealt with in continental Europe from a private international law (PIL) perspective. In this legal area, signs of a liberal approach to the civil remedy can be pointed out. This topic receives more and more attention throughout Europe. ${ }^{98}$ The focus in this section will logically - be on American punitive damages awards, as PIL decisions in Europe usually deal with American awards.

To start with, most European courts are hostile to American punitive damages judgments and refuse to recognise and enforce them because these judgments are considered contrary to public policy. ${ }^{99}$ American courts are also aware of this: ${ }^{100}$

Some legal systems not only decline to recognize punitive damages themselves but refuse to enforce foreign punitive judgments as contrary to public policy.

There are in fact three situations in which punitive damages are considered from a PIL perspective. ${ }^{101}$ The first is when a punitive damages claim is filed in country A by a claimant from country B and a court in country A is asked to cooperate with the proceedings against the defendant from their country. The second is when a judgment to pay punitive damages is issued in one country and the court in another country is asked to recognise and enforce the decision. The third is about conflict rules, i.e. when a punitive damages claim is filed and the court has to make a decision as regards the applicable law. This section will not go into all three situations, as that would entail in-depth private international law research. Moreover, requests to cooperate in a foreign lawsuit or questions of applicable law are even rarer than questions relating to the recognition and enforcement (hereafter:

98 See e.g. Hay 1992; Braslow 1999; Nater-Bass 2003; Behr 2005; Brand 2005; Jablonski 2005; Cavalier \& Quéguiner 2007; Quarta 2008; Duintjer Tebbens 2009; Requejo Isidro 2009; Berch 2010; Licari 2011; Janke \& Licari 2012; Nagy 2012; Requejo Isidro 2012; Parker 2013.

99 Requejo Isidro 2009, p. 243; Gotanda 2007, p. 508; Berch 2010, p. 85; Rouhette 2007, p. 328.

100 Exxon Shipping Co. v. Baker, 554 U.S. 471, 128 S.Ct. 2605 (U.S. 2008), at $§ 2623$. See also Berch 2010, p. 77

101 Requejo Isidro 2009, p. 238; Requejo Isidro 2012, p. 311. 
recognition) of foreign punitive damages awards. ${ }^{102}$ Therefore, the focus will be on the second situation concerning recognition.

Most European cases relating to the recognition of punitive damages are German decisions dealing with American requests, but examples from other European countries also exist. ${ }^{103}$ A clear explanation for the relative high incidence of German cases cannot be pointed out; it might logically follow from the fact that punitive elements in private law and punitive damages are topics that receive considerable attention in German law, but this explanation is rather speculative. Furthermore, all recognition decisions - whether negative or positive - have been made with reference to the public policy exception. This exception can be explained in several ways, for example that punitive damages are considered intolerable due to their criminal law function or because the amount of the award is considered excessive or disproportionate. ${ }^{104}$ Nagy mentions three reasons why punitive damages are contrary to public policy: firstly, the prohibition of unjust enrichment which follows from non-compensatory damages awards; secondly, the lack of criminal procedural safeguards; and thirdly, the intrusion on the penal monopoly of the state. ${ }^{105}$ These explanations logically fit with the reasons for the non-existence of punitive damages in continental Europe explained in chapter six. As European courts occasionally do recognise foreign punitive damages awards, reasons why punitive damages are not contrary to public policy must also exist. Nagy mentions two reasons: (1) punitive damages awards are not completely punitive, for example because the attorney's fees of the plaintiff are included or in line with Posner's theory explained in section 7.3.1 - because deterrence is the leading function of the award, and (2) civil law systems also acknowledge punitive elements in private law. ${ }^{106}$ This latter reason forms the subject of chapter nine and will be extensively described there. However, Nagy makes clear that excessive punitive damages awards are probably contrary to public policy in continental

102 Requejo Isidro 2009 , p. 245, 252. With regard to the question of applicable law, it is good to mention the Regulation on the law applicable to non-contractual obligations ("Rome II") and its evolution. As mentioned in section 8.3, recital 32 of the Preamble of Rome II declares punitive damages of an excessive nature as being contrary to public policy. This public policy argument against punitive damages was initially placed in the main text of Rome II but was transferred to the Preamble in the drafting process, cf. footnote 58 of this chapter. An example of a Dutch decision concerning the applicability of American law in which the court decided that punitive damages are contrary to public policy is Rb. Utrecht 8 februari 2012, ECLI:NL:RBUTR:2012:BW1631. An example of a Spanish decision in this respect is Sentencia $\mathrm{n}^{\circ}$ 230/2012 de AP (Audiencia Provincial) Barcelona, Sección 17 7 , 7 de Mayo de 2012. In this case American law was also applicable. The court decided not to award punitive damages; the court's reasoning leading to this conclusion did not relate to public policy but to the understanding of American law that punitive damages are only to be awarded in case of "intencionalidad malévola" (malicious intention) on the part of the defendant, which was not present in the case at hand.

103 Requejo Isidro 2009, p. 245. See also Hay 1992; Behr 2005; Nagy 2012.

104 Requejo Isidro 2009, p. 245-246; Requejo Isidro 2012, p. 325-326.

105 Nagy 2012, p. 5.

106 Nagy 2012, p. 5. 
Europe, whereas this is not necessarily true for awards with 'a little punitive flavor'. 107

The legal instrument to be used by a European court when dealing with recognition issues is conditional upon the question whether the decision comes from a Member State or not. ${ }^{108}$ In case of non-community decisions such as American judgments, the autonomous system of the country where recognition is requested applies. Requejo Isidro and Nagy make clear that in the future a recently created Hague Convention, which is not in force yet but signed by both the European Union and the United States, might also apply. ${ }^{109}$ Although the Convention is only applicable when the parties have agreed on the jurisdiction of the foreign court, Nagy remarks that it will probably 'profoundly influence the recognition of punitive awards in general'. ${ }^{110}$ The relevant provision as regards punitive damages is article 11, providing that if a foreign award consists of a compensatory and a punitive part, only the punitive part may be refused. If the punitive damages decision is made by a Member State, the Brussels I Regulation, as well as the EC Regulation creating a European enforcement order for uncontested claims, applies. ${ }^{111}$ The Court of Justice of the European Union recently affirmed that Brussels I 'applies to the recognition and enforcement of a decision of a court or tribunal that contains an order to pay a fine in order to ensure compliance with a judgment given in a civil and commercial matter'. ${ }^{112}$ The public policy exception forms a barrier to the recognition of foreign punitive damages judgments in all of the mentioned legal instruments. Thus far, there have been no requests for the recognition of punitive damages where two Member States are involved. ${ }^{113}$ This section will therefore concentrate on the first category, i.e. recognition requests for non-community (in practice: American) punitive damages decisions.

Although the attitude - from a PIL perspective - towards punitive damages differs per Member State, thus far most national courts have rejected recognition. ${ }^{114}$ Examples of PIL decisions by German, Dutch, Spanish, French, Greek, Italian, and Swiss courts have been described in literature. ${ }^{115}$ Nagy distinguishes three approaches as regards recognition of American punitive damages awards by European courts and gives examples for each category: (1) complete rejection of awards containing a punitive element; (2) partial recognition, i.e. rejection of the punitive part of the award but recognition of the compensatory part, which is also

107 Nagy 2012, p. 4, 7.

108 Requejo Isidro 2009, p. 245.

109 Requejo Isidro 2012, p. 323 and Nagy 2012, p. 10, citing Convention of 30 June 2005 on Choice of Court Agreements, retrieved via: www.hcch.net/index en.php?act=conventions.text\&cid=98.

110 Nagy 2012, p. 10.

111 Regulation 44/2001/EC; Regulation 805/2004/EC.

112 CJEU 18 October 2011, case C-406/09, ECR I-09773 (Realchemie Nederland BV v. Bayer CropScience $A G)$ at $\S 51$.

113 Requejo Isidro 2012, p. 324.

114 Nagy 2012, p. 7.

115 Nagy 2012, p. 7-10; Requejo Isidro 2009, p. 245-249; Requejo Isidro 2012, p. 325-329. 
the approach followed by the above-mentioned Convention; (3) recognition, in fact or in principle, of the punitive damages award. ${ }^{116} \mathrm{~A}$ recent decision known as Fountaine Pajot of the French Supreme Court belongs to the latter category, which held that punitive damages are in principle recognisable except for excessive or disproportionate awards. ${ }^{117}$ This decision will be explained below.

It is appropriate to begin with categories one and two. As the recognition of punitive damages is denied in both situations, the cases that fall into these categories will be described together. The strictest denial of recognition by a European court is that of the Italian Supreme Court in the Fimez case decided in 2007. ${ }^{118}$ This Supreme Court refused to recognise an American judgment and thereby affirmed an earlier decision of the court of appeal of Venice. It concerned a products liability decision ordering an Italian manufacturer to pay a damages award of \$ 1 million for producing a defective motorcycle helmet, which allegedly had caused the death of the plaintiff's son in a traffic accident. ${ }^{119}$ The American judgment had not specified the damages award as either compensatory or punitive, but the court of appeal assumed the punitive nature of the award and primarily based this assumption on its excessiveness. As punitive damages are in principle unknown in the Italian legal system, there was sufficient reason for the court of appeal to declare the award contrary to domestic public policy. ${ }^{120}$ The plaintiff appealed to the Supreme Court and tried to show that penalty clauses and immaterial damages also pursue a punitive aim within the Italian legal system. The Supreme Court determined that the damages award could not be recognised as this would be against public policy. Furthermore, the Court disagreed with the plaintiff as regards the aim of civil damages and made explicit that punitive civil damages are alien to the Italian legal system: ${ }^{121}$

In the current legal system, the idea of punishment is alien to any award of civil damages. The wrongdoer's conduct is also considered irrelevant. The task of civil damages is to make the injured party whole by means of an award of a sum of money, which tends to eliminate the consequences of the harm done. The same holds true for any category of damages, moral and non-economic damages included, whose award not only is unresponsive to both the injured parties' conditions and defendants' wealth, but it also requires that plaintiffs prove the existence of a loss stemming from the offense, resorting to concrete, factual evidence, on the assumption that such evidence cannot be considered in re ipsa.

The Italian Supreme Court thereby declined to recognise the entire American judgment, and in so doing left the injured party with no remedy at all. Nagy rightly

116 Nagy 2012, p. 7-10.

117 Cour de cassation, Première chambre civile, 1 décembre 2010, 09/13303 (Fountaine Pajot). See on this decision Licari 2011; Janke \& Licari 2012; Wester-Ouisse \& Thiede 2012; Parker 2013; Sibon 2013.

118 Corte di Cassazione, 19 gennaio 2007, 1183, affirming Corte di Appello di Venezia, 15 ottobre 2001, 1359, Giur. It., II, 2002, 1021. See on this decision Quarta 2008 (including a translation of the Italian decision); Ostoni 2005; Barzaghi 2005; Scarso 2009, p. 106.

119 Quarta 2008, p. 753.

120 Quarta 2008, p. 756-757.

121 Quarta 2008, p. 782. 
points out that the Court seemed to forget that leaving an injured party with no compensation is also alien to civil law systems. ${ }^{122}$ Note that this Italian refusal is at odds with two earlier domestic decisions in which danni punitive, the Italian translation of punitive damages, have explicitly been awarded. ${ }^{123}$ Thus, despite the already mentioned principal rejection of a punitive function of civil damages in Italian law, such a function has been recognised by lower national courts. Furthermore, Italian courts also explicitly recognise and pay particular attention to the deterrent function of tort law. ${ }^{124}$ Recognition of a foreign punitive damages award was nevertheless considered contrary to public policy by the highest Italian court. Also in the Netherlands, a recognition request with regard to an American damages award of \$ 520,000 in compensatory damages and \$ 1 million in punitive damages has been denied: a further explanation on the amount of the damages award was deemed necessary by the court as particularly the punitive damages award, which clearly deviates from the compensatory principle and the actual loss suffered by the plaintiff, cannot be recognised by a Dutch court without any review with respect to the content of the award. ${ }^{125}$

Another Member State in which the recognition question has been raised and answered negatively in respect of the punitive aspect of a judgment is Germany. In 1992, the German Supreme Court denied recognition of an American punitive damages award. ${ }^{126}$ The plaintiff was an American citizen, whereas the defendant had both German and American citizenship. The plaintiff, alleging that he had been sexually abused by the defendant, filed a civil claim in California. The wrongdoer was also convicted under criminal law. The California Supreme Court ordered the defendant, who had fled to Germany after serving his prison sentence, to pay approximately $\$ 350,000$ in compensatory damages and $\$ 400,000$ in punitive damages to the plaintiff. When recognition of the judgment in Germany was sought, the German Supreme Court recognised only the compensatory damages award. The punitive part was refused completely and considered contrary to German public policy because of its criminal and disproportionate nature. ${ }^{127}$ Requejo Isidro remarks that, according to current German legal doctrine, a proportionate punitive damages award could perhaps be recognised in Germany because national civil law also recognises instruments that are not merely compensatory, such as substantial immaterial damages awards in case of personality right infringements. ${ }^{128}$ Furthermore, in a case from 2000 the Supreme Court

122 Nagy 2012, p. 7

123 Requejo Isidro 2009, p. 248, citing Tribunale di Torre Annunziata, Sezione Stralcio, 24 febbraio 2000; Tribunale di Torre Annunziata, Sezione Stralcio, 14 marzo 2000.

124 Scarso 2009, p. 113.

125 Rb. Rotterdam 17 februari 1995, NIPR 1996, 134, upheld by Hof 's-Gravenhage 29 oktober 1996, NIPR 1997, 244

126 BGH 4 June 1992, BGHZ 118, 312

127 Nagy 2012, p. 8; Requejo Isidro 2009, p. 246.

128 Requejo Isidro 2009, p. 246. See section 9.4.2. 
explicitly left open, i.e. did not answer negatively, the question whether foreign punitive damages awards should be recognised by German courts: ${ }^{129}$

Punitive damages sind daher, wenn auch nicht pönale Elemente des deutschen Privatrechts, so doch mögliche pönale Elemente des in Deutschland anzuwendenden Privatrechts.

Nonetheless, thus far no German court has explicitly accepted the recognition of a foreign punitive damages award.

As explained in the introduction to this chapter, some legal systems reveal less opposition and seem to attach less value to the public order exception by supporting the recognition of American punitive damages awards. This important development shows that the largely negative approach to punitive damages in continental Europe is currently subject to change or, to put it differently, that objections to punitive damages are slowly fading. This might have to do with the earlier mentioned changing ideas in Europe on the public-private divide and private enforcement. ${ }^{130}$ The development of less opposition will be illustrated at this point by giving a short overview of the court decisions that fall into the third category, i.e. European national courts that have recognised foreign punitive damages awards. First of all, the French legal system increasingly shows less opposition towards such awards. When a French law professor was asked one day in March 2004 if French law allows punitive damages, he seems to have answered: ${ }^{131}$

"No, no, and No!; three times No! But..."

The authors of an article on punitive damages and French public policy used his words in their opening sentence. At the end of the article, they conclude: ${ }^{132}$

As to whether punitive damages are admitted by French international public policy, and three years after Professor Durry's reply, we conclude that: "punitive damages may not be here yet, but they are on their way..."

The authors might be proven right, as in the above-mentioned judgment Fountaine Pajot the French Supreme Court overruled the decision ${ }^{133}$ of a lower court by holding that it depends on the circumstances of the case whether punitive damages are incompatible with French public policy: ${ }^{134}$

129 Ebert 2004, p. 531, citing BGH 8 May 2000, NJW-RR 2000, S. 1372f., 1372.

130 See section 6.3.

131 Cavalier \& Quéguiner 2007, p. 2, citing Georges Durry at a conference about punitive damages in the French Cour de cassation on 25 March 2004.

132 Cavalier \& Quéguiner 2007, p. 9.

133 Cour d'Appel de Poitiers, Premiére chambre civile, 26 février 2009, 07/02404.

134 Fountaine Pajot, final paragraph. 
Mais attendu que si le principe d'une condamnation à des dommages intérêts punitifs, n'est pas, en soi, contraire à l'ordre public, il en est autrement lorsque le montant alloué est disproportionné au regard du préjudice subi et des manquements aux obligations contractuelles du débiteur.

This means that 'the principles underlying an award of punitive damages are not in themselves contrary to public policy' but that 'incompatibility may result from the awarded sum if it is disproportionate in relation with the injury suffered and the breach of the contractual obligations of the debtor'. ${ }^{135}$ Thus, foreign punitive damages awards can in principle be recognised in France except if they are disproportionate to the harm sustained and the contractual breach. In other words, an award will be considered excessive and therefore contrary to public policy if it is not proportionate to the actual damages award and to the wrongdoer's fault. ${ }^{136}$ This case was about an American couple that had bought a boat from a French company. As the boat had serious defects, the couple brought a civil lawsuit in California. The judgment for which recognition in France was asked is the American judgment in which approximately $\$ 1.39$ million in compensatory damages, \$ 402,000 for attorney's fees and \$ 1.46 million in punitive damages had been awarded to the couple. The French Supreme Court decided that this particular award was clearly disproportionate but that punitive damages awards are not contrary to public policy per se.

Another decision that belongs to the third category, i.e. that of recognised foreign punitive damages awards by European national courts, is a Swiss case decided in 1989. ${ }^{137}$ The fact that Switzerland is not a Member State of the European Union does not make this PIL decision concerning punitive damages less relevant for the European discussion. The Swiss case concerned an American judgment ordering a Swiss company to pay $\$ 120,060$ in compensatory damages and $\$ 50,000$ in punitive damages to a Californian company for fraudulent misappropriation of cargo containers. A Swiss district court determined that the American decision, which had been based on English law, was not contrary to the notion of public policy in article 27 of the Federal Statute on Private International Law, and therefore recognisable in Switzerland. The main reasoning of the court was that the punitive damages award primarily aimed at restitution of the unlawful profit made by the defendant, even though the award exceeded the exact amount of the profit. Furthermore, the court held that the award clearly had a civil nature and that punishment was no more than a secondary aim. ${ }^{138}$ The court made clear that enforcement of a foreign decision is impossible when this is evidently contrary to (offensichtlich unvereinbar mit) public policy, which is the case when there is an intolerable contradiction with (unerträglichem Widerspruch zur) Swiss legal

135 Translation Requejo Isidro 2012, p. 327.

136 Nagy 2012, p. 9.

137 Nater-Bass 2003, p. 155, citing Zivilgericht Basel-Stadt, 1 February 1989, BJM 1991, 31 (S.F. Inc. v. T.C.S. $A G$ ). See also Nagy 2012 , p. 8.

138 S.F. Inc. v. T.C.S. $A G$, at p. 35 . 
tradition. However, according to the court, the notion of public policy should be interpreted in a very narrow way: ${ }^{139}$

In Vollstreckungsverfahren ist die ordre public-Klausel, nach dem ausdrücklichen Gesetzeswortlaut (vgl. Art. 27 Abs. 1 mit Art. 17 IPR-Gesetz), besonders restriktiv anzuwenden, da man es hier mit Rechtsverhältnissen zu tun hat, über die im Ausland bereits rechtskräftig bzw. endgültig entschieden worden ist und die Schaffung einer hinkenden Rechtslage, die durch die Anwendung der ordre public-Klausel in diesem fall entstünde, wenn immer möglich, vermeiden möchte.

The decision was affirmed by the appellate court of Basel, whereas appeal to the Federal Supreme Court was rejected on procedural grounds. The latter court did however make clear that it also considered the American judgment a civil decision but for a different reason: the punitive damages were awarded to an individual and not to the state. ${ }^{140}$ Note that Bernet and Ulmer refer to another Swiss case from 1982, in which a first instance court did reject the recognition of an American punitive damages award on the basis of public policy. ${ }^{141}$ The Swiss position with regard to the recognition of foreign punitive damages awards is therefore not entirely clear.

The recognition of punitive damages has also been allowed in a Spanish decision from 2001. ${ }^{142}$ The Spanish Supreme Court recognised an American treble damages award imposed on the Spanish company Alabastres Alfredo, S.A. for the unauthorised use of intellectual property, violation of a registered trademark and unfair competition. ${ }^{143}$ According to Alabastres Alfredo, recognition of the damages award should be refused because it was penal in nature and therefore contrary to Spanish public policy. The company also had several procedural arguments against recognition, which were rejected. Although the Court acknowledged that punitive damages are not recognised in the Spanish legal system, the public policy argument was not accepted. The Court made clear that compensation is the general rule in Spain but that it is not always easy to make a distinction between concepts of compensation, in particular the 'sum of the coercive sanction and the sum which corresponds to reparation for moral damages'. Furthermore, the Court stated that Spanish law does not strictly separate civil law and criminal law and some overlap between the two is known. Punitive damages, as an aspect of civil liability and therefore part of private law, can complement criminal law which is in accordance with the criminal law doctrine of minimum intervention. As was seen in section 3.3.4, the theory that the punitive damages remedy is originally meant to supplement criminal law sanctions receives support in the American legal system. According to the Spanish Court, the punitive and preventive character of the award followed from a legal norm and was proportionate given the grave

139 S.F. Inc. v. T.C.S. $A G$, at p. 34.

140 Nater-Bass 2003, p. 155.

141 Bernet \& Ulmer 1994, p. 273.

142 Tribunal Supremo, 13 noviembre 2001, Exequátur No. 2039/1999 (Miller Import Corp. v. Alabastres Alfredo, S.L.). See on this decision Jablonski 2005 (including a translation of the Spanish decision); Gotanda 2007, p. 521; Requejo Isidro 2009, p. 247; Nagy 2012, p. 9.

143 Gotanda 2007, p. 521. 
violation of intellectual property rights by the defendant. Lastly, the Court referred to the international character of the case and its relationship with Spain, and it emphasised that the interest pursued by the damages award is the protection of intellectual property rights which is a universally accepted desire. ${ }^{144}$ As explained in chapter seven, the interest in punitive and deterring sanctions in the area of intellectual property law is not coincidental: private law has been discovered as an instrument to enforce various legal standards on both the EU and national level, for example in the area of intellectual property law. ${ }^{145}$

The last example of PIL cases that belong to the third category of recognised punitive damages awards in Europe, according to Nagy, is a decision from a Greek court made in 1996. ${ }^{146}$ The judgment for which recognition was asked was again an American judgment to pay approximately $\$ 1.36$ million, of which $\$ 650,000$ was for punitive damages. The Court of Appeal of Larissa recognised the award and rejected the public policy exception out of respect for the foreign judgment, but the Greek Supreme Court revoked this decision as it found the punitive award was disproportionate to the compensatory award. The refusal to recognise the award was thus not based on the punitive nature of the award. Despite the negative outcome in this particular case, it is still an interesting decision as - similar to the French Supreme Court in Fountaine Pajot - the Greek court made clear that punitive damages are not per se contrary to public policy and therefore in principle recognisable. ${ }^{147}$

The above gives a brief, nonexclusive overview of important developments in the area of private international law and foreign punitive damages judgments. Recognition requests before European courts mostly concern American punitive damages awards. In case of such non-community decisions the autonomous system of the country where recognition is requested currently applies. National courts from different countries have therefore reached different conclusions, particularly as regards the level of importance that is attached to the public policy exception.

Although France, Switzerland, Spain, and Greece seem to have taken a rather liberal approach to the recognition of foreign punitive damages awards, these are only a few examples throughout the whole of Europe. Based on public policy considerations, the approach in respect of recognition of punitive damages has been largely negative. ${ }^{148}$ However, Nagy refers to a mainstream approach in legal doctrine that the 'current hostility towards punitive damages is misplaced'. ${ }^{149}$ Parker uses the Fountaine Pajot decision and other indications to show that, while

144 Jablonski 2005, translation of the Spanish decision, at $\S 9$. See also Requejo Isidro 2009, p. 247 248.

145 Cauffman \& Weyts 2009, p. 4; Adriaanse et al. 2008, p. 276; Kilpatrick 2000, p. 2.

146 Nagy 2012, p. 9. See also Requejo Isidro 2009, p. 247. For an overview of the Greek decision, see Triadafillidis 2002 .

147 Cf. Koziol \& Schulze 2008, p. 596; Koziol 2009, p. 284. The authors cite a decision of the Greek highest court in which punitive damages have been considered against public policy: Greek Areios Pagos (Full Bench) 17/1999, NoB 2000, p. 461-464.

148 Requejo Isidro 2009, p. 255.

149 Nagy 2012, p. 10. 
the punitive damages remedy has received substantial critique in continental Europe, the tides may be changing. ${ }^{150}$ Furthermore, Requejo Isidro concludes that the tolerant approach of the liberal courts should form an example to others. ${ }^{151}$ Thus, it is perhaps time to change the broad conservative position on the public policy exception, which seems to be a high hurdle when it comes to the recognition of punitive damages in continental Europe. Note that the public policy concept is perfectly suitable for adaptation if this is required by changing social and political desires.

To conclude, as mentioned in the introduction to this chapter, the rejection of foreign punitive damages awards on PIL grounds is an illustration of rather than a reason for the non-existence of punitive damages in continental Europe. Similarly, the recognition of foreign punitive damages awards is an illustration of the changing views on this controversial remedy, but it does not in itself explain this interest.

\subsection{Concluding Remarks}

In this chapter, which builds on the previous chapters concerning the traditional reasons for the non-existence of punitive damages in continental Europe and causes of the increased European interest in the civil remedy, some concrete examples of the status quo of punitive damages rejection in this area have been described.

To start with, the European Court of Human Rights seems relatively clear as regards its position on punitive damages: punitive damages are simply not awarded by the court. The reason for the Court's rejection of punitive damages awards is that the function of an award of just satisfaction based on article 41 ECHR is to compensate the applicant for the actual harmful consequences of a violation. This follows not only from a number of cases decided by the Court but also from the Court's Practice Direction on Just Satisfaction Claims from 2007. However, as explained above there might be room for broader interpretation of the term 'satisfaction' in article 41 ECHR. At least two recent decisions can be pointed out in which the Court allegedly deviates from the compensatory principle by using the award for just satisfaction as a deterrent or even a punishment. ${ }^{152}$ It is therefore wise to keep an eye on the Court's future interpretation of this term. In this respect it was also seen that considerable punitive damages have been awarded in American human rights cases.

The position of the legislator of the European Union in respect of punitive damages has been described in legal doctrine as ambivalent and evidently selfcontradictory. We have seen a number of examples showing the largely negative approach of the EU legislator to punitive damages. A first example is the Rome II

150 Parker 2013, p. 431.

151 Requejo Isidro 2012, p. 329.

152 ECtHR 19 June 2012, Krone Verlag GMBH v. Austria, no. 27306/07; ECtHR 25 June 2013, Trévalec v. Belgium, no. 30812/07. 
Regulation which considers punitive damages contrary to public policy. Nevertheless, as was seen in section 8.3, it is likely that the rejection of punitive damages in this Regulation is not absolute because only punitive damages of an excessive nature may be regarded contrary to public policy. Other examples can be found in the enforcement of intellectual property rights Directive, the Montreal Convention on international carriage by air which is applicable within the European Union, the documents of the European Commission in the context of collective redress from 2013 and some European Union legislative proposals. However, and this causes the uncertainty, the European legislator has also shown positivity to punitive damages, for example in the Green Paper on damages actions for breach of EC antitrust rules. The private enforcement debate has been explained in chapter seven as it forms an important reason for the increased European interest in punitive damages. Another example that contributes to the European Union's uncertain position is the requirement of effective preventive sanctions for breaches of European Union law, which - as explained in section 7.2.5 of the previous chapter has been laid down in European legislation concerning anti-discrimination in employment matters.

Similar to the EU legislator, the Court of Justice of the European Union also does not really have a clear approach with regard to punitive damages. What can be said is that, on the one hand, the Court has underlined the absence of European Union law on punitive damages. One the other hand, according to some - punitive damages supporters in particular - the Court contributes to the ambivalent and selfcontradictory position of the European Union in respect of punitive damages. This allegation results from a formula developed by the Court that sanctions which may be imposed for breaches of European Union law should be 'effective, proportionate and dissuasive', i.e. the above-mentioned effective preventive sanctions. This formula, which has been connected to the punitive damages remedy, has been further interpreted by the Court in the context of employment discrimination and breaches of competition law. The relevant cases have already been discussed in chapter seven in light of the private enforcement debate.

Lastly, the European view on punitive damages has been described from a private international law perspective. Although foreign punitive damages judgments are generally viewed with hostility and recognition of such judgments is difficult, as this will usually be considered contrary to a country's public policy, at least four national courts in different European countries have shown a more liberal and positive attitude in respect of the recognition of American punitive damages awards. This positivity has not only been signaled but has also been supported in legal doctrine: the fact that the negative European approach to punitive damages from a private international law perspective is subject to change is, as explained in the previous section, considered a good development by several authors. ${ }^{153}$

This chapter has provided four concrete examples of the status quo of punitive damages rejection in Europe and has thereby answered research question four.

153 Nagy 2012, p. 10; Parker 2013, p. 431; Requejo Isidro 2012, p. 329. 
Signs of liberalness can especially be pointed out in the area of private international law. Furthermore, at the level of the EU legislator and the Court of Justice of the European Union, there is increased attention and need for effective preventive sanctions, which could possibly include punitive damages. Only the European Court of Human Rights technically rejects awarding punitive damages, but the Convention might provide an opening for the Court to start awarding punitive damages by a different interpretation of the term 'satisfaction' used in article 41 of the ECHR. The two recent decisions mentioned above, Krone Verlag GMBH v. Austria and Trévalec v. Belgium, already point into that direction. It has indeed been suggested that serious human rights violations should perhaps be sanctioned more severely in order to have credible and effective legal protection. The American legal system could thereby serve as an example, as human rights infringements have led to considerable punitive damages awards there. This brings us to the fifth and final research question that should be answered in order to analyse the problem statement adequately, namely: which existing civil sanctions, especially sanctions that bear a resemblance to the punitive damages remedy, can be distinguished in four European legal systems, i.e. the Netherlands, Germany, France, and England? This research question will be dealt with in the following chapter nine. 



\section{CHAPTER NINE \\ EXISTING CIVIL SANCTIONS IN FOUR EUROPEAN LEGAL SYSTEMS}

\section{$9.1 \quad$ Introductory Remarks}

In chapter eight, the status quo of punitive damages rejection in Europe was explained from the perspective of: (1) the European Court of Human Rights, (2) the legislator of the European Union, (3) the Court of Justice of the European Union, and (4) private international law. Although it has become clear that the contemporary European position on punitive damages is largely negative from all four perspectives, signs of a more positive and liberal view have also been pointed out. The previous chapters, which have provided answers to research questions two to four, do not yet give a firm foundation for an adequate analysis of the problem statement in the following - concluding - chapter ten. Because the punitive damages remedy is assumed to be alien to continental Europe (systeemvreemdheid), which has already been referred to in section 7.2.6, there seem to be no definite answers at this point as to what role the civil remedy could play in continental Europe. This chapter will focus on this notion, which plays a central role in the European punitive damages debate. Information about the extent to which punitive damages are alien to the European system is needed to find out if the remedy has a future in continental Europe. This chapter therefore tries to find an answer to the fifth and last research question: which already existing civil sanctions can be distinguished in private law systems within Europe? To be more precise, it provides a structured overview of a number of civil sanctions in Dutch, German, French, and English law. As mentioned before, the existence of civil sanctions that bear a resemblance to the punitive damages remedy could be indicative for participants in the European punitive damages debate, in the sense that there are then fewer theoretical and practical obstacles to the introduction of punitive damages than is often believed.

The focus area in this chapter will be tort law, given the fact that in the American legal system punitive damages are in principle recoverable for tort actions and are part of private law for that purpose. As explained in section 3.2.1, American courts in fact impose punitive damages in all sorts of situations - for instance where a breach of contract and an intentional tort are constituted by the same act - provided that certain requirements are met. It was seen that the following three general requirements in American law determine the limits of awarding punitive damages: (1) the invasion of a legally protected interest by the defendant; (2) an element of major aggravation in the defendant's unlawful conduct; and (3) actual damage suffered by the plaintiff. 
Another reason for the focus on tort law is that it is a legal area in which the question of importance of the public-private divide, which is one of the main arguments that is brought forward by punitive damages opponents, inevitably and expressly presents itself: often, certain wrongful behaviour is forbidden by both tort law and criminal law. ${ }^{1}$ Due to the role of tort law in regulating and preventing wrongful behaviour, this legal field has started to play an important part in the European debate on private enforcement and the related interest in punitive damages.

This chapter will therefore not provide an extensive overview of all possible sanctions in the private law systems of the European countries. However, some sanctions outside the domain of tort law do form part of the discussion. An example is the contractual penalty clause, but also mechanisms in insurance law or intellectual property law provide good examples. The approach to civil sanctions in three continental European legal systems, i.e. the Netherlands, Germany and France, will eventually be compared to the American approach. Moreover, one additional European legal system, namely England, will be included in the comparison. As England is a common law system within Europe that allows punitive damages, albeit in a more restricted form, it is worthwhile to describe the English approach.

The reasons for choosing the four legal systems have also been explained in chapter one. Contrary to the previous three chapters, which focus mainly on the general European view on punitive damages, this chapter is about the approach of national legislators and courts to civil sanctions. Although it would of course be desirable and useful in this respect to publish results from all or at least a large number of legal systems in Europe, this is practically impossible and falls outside the scope of this chapter. As mentioned in chapter one, research with regard to punitive elements in private law in a number of other European countries, such as Hungary, Italy, Norway, Sweden, Denmark, Spain, Estonia, and Switzerland, has been published elsewhere. ${ }^{2}$ In this chapter, four legal systems within Europe will be dealt with: the Netherlands, Germany, France, and England. A number of influential European authors who have compared European liability systems earlier have denoted the German, French and English legal systems as the most important systems within Europe. ${ }^{3}$ In line with these authors, this chapter will deal with these three systems. The Netherlands has been added since I am Dutch and most familiar with this legal system, which is highly influenced by the French legal tradition. All four legal systems recognise - to a certain extent - civil sanctions and a noncompensatory function of private law. Furthermore, the punitive damages debate is quite alive in the Netherlands, starting with a preliminary advice on the possible incorporation of punitive damages in the Dutch legal system and the topic of powerful civil sanctions to deal with serious wrongdoing receives increased

\footnotetext{
Ebert 2004, p. 409.
}

E.g. Koziol \& Wilcox 2009; Meurkens \& Nordin 2012. See also Shelton 2005, p. 42; Lemmens 2003, p. 403; Georgiades 2005, p. 156; Lahe 2011.

3 Van Gerven et al. 1998; Van Gerven, Lever \& Larouche 2000, p. 2; Van Dam 2013a, p. 9. 
attention here. ${ }^{4}$ Also in Germany and France, punitive elements in private law and punitive damages are topics on the legal agenda, which follows for example from publications of Ebert, Koziol, Carval, and Jault. ${ }^{5}$ As already mentioned, England is interesting as it is one of the few countries in Europe that recognises a restricted form of punitive damages.

As explained in chapter six, one of the reasons for the non-existence of punitive damages in continental Europe is that it is against legal tradition to attach a punitive function to private law: the civil remedy is inconsistent with the traditional compensatory function of tort law, and there is a fundamental rejection in relation to the public-private divide. But there is something strange about holding on to this argument at all costs when private law does accept other sanctions with a non-compensatory function. As already mentioned in section 6.2, it is argued by some that punitive elements in tort law are de facto recognised in modern civil law systems. ${ }^{6}$ This would mean that reconciliation between the common law and civil law traditions is again taking place. ${ }^{7}$ In ancient times both systems combined punitive and compensatory elements in tort law, whereas nowadays only the common law systems have generally accepted a punitive function of tort law. But punitive elements in tort law can also be pointed out in civil law systems. Such elements for instance seem to occur beneath the surface under the heading of immaterial damages for physical injury or personality right infringements. ${ }^{8}$ To illustrate this interesting observation, reference should be made to Nagy and Beever.

Nagy has recently drawn attention to a number of examples that point towards the recognition of punitive elements in private law: (a) the possibility to disgorge profit, for instance in case of violations of personality rights or intellectual property rights; (b) the possibility to award a 'summary compensation', i.e. not the precise amount of actual damage suffered but an estimated amount to compensate material and immaterial losses; (c) the possibility to award damages that serve the purpose of deterrence, for example in case of personality right infringements; (d) the recognition of a so-called 'punitive interest rate' which should be paid by the debtor in order to increase his willingness to pay or perform his obligations; (e) the proposal made by the European Commission to introduce double damages to enable the private enforcement of competition law which has been extensively dealt with in chapter seven, and (f) the possibility under Hungarian law to impose a fine on the wrongdoer, which is to be used for public interest purposes, if the

4 Bolt \& Lensing 1993. See on the topic of private enforcement in Dutch literature e.g. Engelhard et al. 2009; Adriaanse 2007; Adriaanse et al. 2008; Van Boom 2006a; Van Boom 2007b; Van Boom 2008.

5 Ebert 2004, see for an extensive overview of punitive elements in German private law especially part C thereof; Koziol 2012, p. 50-57; Jault 2005; Carval 1995.

Beever 2008b, p. 292; Behr 2003, p. 130; Magnus 2001b, p. 186-187; Nagy 2012, p. 5.

7 Beever 2008b, p. 250, citing Behr 2003, p. 125-150; Magnus 2001b, p. 186; Nagy 2012, p. 6. See in this respect section 6.2.2.1.

8 Koziol 2009, p. 284-287. 
compensatory damages award for a personality right infringement is disproportionate to the wrong done. ${ }^{9}$

According to Beever, the finding that civil law systems (covertly) recognise punitive elements in private law results from the decline in adherence to the corrective justice theory which takes place in continental Europe. ${ }^{10}$ As explained in section 6.2.1 in civil law systems private law is traditionally concerned with corrective justice, whereas in common law systems private law is about a mixture of distributive and retributive justice. Beever mentions some often heard reasons why civil law systems are said to recognise punitive damages: ${ }^{11}$

[T] he law allows for the recovery of non-pecuniary loss; an award of damages is viewed as a sanction and hence as punitive; the law sometimes calculates awards, in part, by looking to the degree of fault exhibited by the defendant; and the law allows profit stripping or disgorgement. None of these, so it is claimed, can be compensatory and so must be punitive.

Without going into the correctness of these examples at this point - it is for instance debatable whether Beever's statement that a sanction that is not compensatory must be punitive is correct - they show that there is attention in legal doctrine, in respect of the European punitive damages debate, for existing punitive elements in private law.

In conclusion, this chapter gives an overview of relevant civil sanctions especially sanctions in tort law - in four European legal systems. To begin with, section 9.2 will analyse the importance of this topic in view of the theme of this book. Furthermore, the concept civil sanction will be defined and narrowed down, after which section 9.3 will explore the sanction that is most important for us, i.e. monetary damages. Then, in section 9.4, the civil sanctions per legal system will be explained. Section 9.5 will deal with the question whether each legal system prefers a compensatory or perhaps (also) a punitive approach to sanctions. The idea is to provide a comparison scale of all legal systems, to see the extent to which civil sanctions that are relevant for the theme of this book are recognised. The four European legal systems will eventually be compared to the American legal system, which is obviously on the most punitive side of the scale.

\subsection{Defining the Topic}

Before going into a more in-depth analysis per legal system, it is important to make clear why it is interesting, in view of the theme of this book, to explore existing civil sanctions. This will be done in section 9.2 .1 by connecting this particular topic to the problem statement. After that, in section 9.2.2, the concept civil sanction will be further defined and narrowed down in order to clarify the scope of this chapter.

\footnotetext{
Nagy 2012, p. 6, citing Berch 2010 who gives more examples on p. 81-83.

10 Beever 2008b, p. 292.

11 Beever 2008b, p. 293.
} 


\subsubsection{Relevance in View of the Problem Statement}

As stated in chapter one, the problem statement of this book is formulated as follows: does the punitive damages remedy have a future in continental Europe? An important research question that needs to be answered in order to analyse this problem statement adequately is which civil sanctions, especially sanctions that bear a resemblance to the punitive damages remedy, can be distinguished in the four European legal systems mentioned above. This will be done by 'checking' the already existing sanctions, which implies a systematic and goal-oriented search rather than an at-random investigation. To find out what exactly should be looked for, it is good to recall the reasons behind the problem statement.

As explained in chapter seven, the main cause for the increased European interest in the punitive damages remedy is twofold. Firstly, there is the attention for private enforcement, i.e. the use of private law mechanisms to enforce several legal rules. Secondly, there are calls for powerful civil sanctions to deal with serious wrongdoing and to protect private law interests. These two causes are closely related to each other: a similarity lies in the instrumental view on tort law. ${ }^{12}$ In both situations, punitive damages are seen as a potential instrument to (a) enforce the law and (b) react firmly to intentional, calculative and grave misconduct.

The interest in punitive damages goes hand-in-hand with the question whether this powerful civil remedy is consistent with continental European legal traditions. It is generally accepted that this is currently not the case. However, two arguments can be brought forward to put this rejection into perspective. Firstly, as mentioned before in section 6.2.2.1, the approach to punitive elements in tort law used to be different in ancient times. Tort law in common law and civil law systems share the same roots and used to include both compensatory and punitive elements. Thus even though punitive damages are rejected according to the contemporary view, history tells us that punishment once did form an essential part of tort law in civil law systems. Secondly, even today punitive elements in tort law can be pointed out in civil law systems. This chapter concerns the second argument.

\subsubsection{Civil Sanctions}

It is important to explain not only the relevance of this chapter but also its scope. First of all, private law is not a very specific term. On the contrary, it is a broad legal area dealing with interests of and relationships between private individuals that are of no direct concern to the state (in contrast to public law), encompassing different fields such as property law, family law and the law of obligations. ${ }^{13}$ This makes the term private law a somewhat difficult term to work with, especially in a comparative law perspective. Therefore, a clear focus is needed. As stated above in the introduction to this chapter, the main focus will be on sanctions in a particular part of private law, namely tort law. However, it should be clarified at this point

12 Meurkens 2012a, p. 41.

13 Martin 2003, p. 382. 
that although the primary objective is to look into private law infringements, civil remedies may be relevant for other legal fields as well. A good example is human rights law. A number of measures can be taken to react to an actual or threatened violation of human rights. ${ }^{14}$ Access to effective remedies - in practice this will often be monetary compensation but also declaratory relief, injunctions or orders has therefore been laid down in substantive public law rules, such as article 13 of the European Convention on Human Rights:

Everyone whose rights and freedoms as set forth in this Convention are violated shall have an effective remedy before a national authority notwithstanding that the violation has been committed by persons acting in an official capacity.

Other examples can be found in European Union law, for instance competition law (Regulation 1/2003), intellectual property law (Directive 2004/48) and antidiscrimination law (Directive 2002/73). ${ }^{15}$ Thus, although one can differentiate between the objectives of civil remedies, meaning that they may be used in both private law cases (wrongs committed against the private individual) and public law cases (wrongs committed against the social order), ${ }^{16}$ both objectives are relevant for this chapter. This is in line with the above-mentioned causes for the increased European interest in punitive damages: facilitate private enforcement on the one hand and deal with intentional, calculative and grave misconduct in civil cases on the other hand.

One may also look a bit further into the concept civil sanction. In this context, sanction should be defined as a legal remedy either to prevent or to punish breach of private law duties. ${ }^{17}$ Van Nispen clearly describes the possible functions of civil sanctions: prevention of impending injustice, compensation of losses suffered, satisfaction of the injured party, punishment of the wrongdoer, annulment of unlawful enrichment of the wrongdoer, and enforcement of private law norms. ${ }^{18}$ Vanlerberghe also makes a distinction between punitive, reparative and preventive sanctions while pointing out that the distinction is not always crystal-clear. ${ }^{19}$ Legal rules, for example liability rules, are only effective if the law provides remedies and sanctions to enforce these rules. ${ }^{20}$ This adage is also supported in international treaties, such as the aforementioned article 13 ECHR. Van Gerven defines the legal remedy as follows: ${ }^{21}$

21 Van Gerven, Lever \& Larouche 2000, p. 739. 
No branch of the law can live without remedies, i.e. legal actions which can be brought before a court of law to enforce the rights which individuals or collectives derive, or believe that they can derive, from the rules of that branch of the law.

This assistance that a person can ask from a court to respond to a (threatened) infringement of his legal rights is also known under the concept of judicial remedies. $^{22}$ These are distinguishable from the so-called self-help remedies, for example termination of contract, which are available without coming to court and fall outside the scope of this chapter. ${ }^{23}$ The judicial remedy can be divided into coercive and non-coercive remedies: the former is a court order to do or not to do something (pay monetary damages, comply with injunction or specific performance), whereas the latter is an affirmation by the court specifying rights or duties (declaratory judgment). ${ }^{24}$ Although the distinction between judicial and self-help remedies is taken from the English legal system, and other legal systems may make a different distinction, it is a good way to categorise legal remedies in general. ${ }^{25}$ This chapter is concerned with the coercive judicial remedies, in particular monetary damages. Thus, examples of civil remedies that fall outside the scope of this chapter are all non-monetary remedies including specific performance (this is typically a civil law remedy; in common law systems, the main remedy for breach of contract is damages whereas the remedy of specific performance is used only in a limited number of cases), ${ }^{26}$ rescission of contract, annulment of contracts or other legal acts, declarations of law, and mandatory or prohibitory injunctions. It can therefore be said that this chapter is particularly concerned with the legal remedies that are placed within the law of damages and - obviously - especially those having a non-compensatory (i.e. deterrent or punitive) element. This chapter is not concerned with the question whether liability of the defendant - on the basis of a tort or breach of contract - to pay monetary damages exists. Furthermore, it will deal with the substantive law concerning monetary damages and not the procedural law aspects of enforcing monetary damages judgments.

In conclusion, the scope of this chapter is to give an overview of sanctions in Dutch, German, French, and English private law. In practice, this will result in an overview of monetary damages with a non-compensatory element. As the punitive damages remedy is typically linked to tortious situations, this chapter will mainly focus on tort damages.

\subsection{A General Perspective of Monetary Damages: Compensatory or Non- Compensatory}

Before giving an overview of civil sanctions in the four legal systems, this section will first explain the legal remedy that is most relevant in this respect, i.e. monetary

Burrows 2004, p. 1; Van Gerven, Lever \& Larouche 2000, p. 847.

Burrows 2004, p. 1; Samuel 2001, p. 136.

Burrows 2004, p. 2.

Van Gerven, Lever \& Larouche 2000, p. 868.

Van Hooijdonk \& Eijsvoogel 2009, p. 48; Hondius 2009, p. 56. 
damages. Monetary damages are an important - if not the - main legal remedy that an injured person can seek from a civil judge for a tort or a breach of contract. This is acknowledged in both common law and civil law systems. For the rest, there are some vital differences between the two systems as regards categories of monetary damages used in civil lawsuits. The rules on damages may also differ depending on the basis of the claim, i.e. a tort or a breach of contract. It is unfeasible and also unnecessary for the purpose of this book to point out all these differences. Rather, this section will briefly describe the main forms of damages that exist in both or one of the two systems. Thus, the idea is not to give a complete overview but to describe the overlap and main differences.

Two general observations will be provided to start with. Although this chapter will not deal with the question whether liability of the defendant to pay monetary damages exists, it is important to indicate at this point that monetary damages cannot be awarded in the absence of a wrong, even though the claimant suffered loss (damnum sine injuria). ${ }^{27}$ As will be explained below, common law systems have a form of damages that can be obtained in case there has been a wrong but no resulting loss (injuria sine damno). Thus, the question whether monetary damages are available arises only if the initial question whether a wrong has been done to the claimant is answered positively. As common lawyers put it, a cause of action is needed, i.e. 'a factual situation the existence of which entitles one person to obtain from the court a remedy against another person'. ${ }^{28}$ The second observation worth mentioning concerns the functions of monetary damages. As will be shown below, these functions are represented in the different available forms of damages. The main functions are compensation and reparation. Other often heard functions are restitution, declaring rights, recognition and vindication, satisfaction, deterrence or prevention, and punishment.

This introduction will make a distinction between compensatory damages and non-compensatory damages, i.e. damages that are not (entirely) based on compensation of the loss suffered by the plaintiff. ${ }^{29}$ Further explanations, relevant examples and illustrations can be found in the subsequent reports of the four legal systems in section 9.4 .

\subsubsection{Compensatory Damages}

Compensatory damages primarily aim at restoring the plaintiff to the position in which he would have been without the tort or full compensation of loss, resulting from either tortious conduct or breach of contract. ${ }^{30}$ In both situations, this principle that is also known as restitutio in integrum is 'an adequate and fairly easy guide to the estimation of damage'. ${ }^{31}$ Full compensation is the guiding

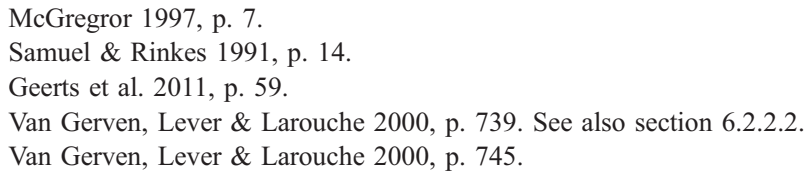


principle in all legal systems that are described in this chapter. The difference between torts and contracts in this respect is that in case of a breach of contract the damages award should place the party that has suffered loss in the situation as if the contract had been performed, whereas in case of a tort the award should place the victim in the position he would be in without the tort. ${ }^{32}$

Full reparation can be reached in two ways: restitution in kind, for example by replacing a car, or compensation by giving a monetary equivalent for the harm suffered. ${ }^{33}$ The latter form, which is mostly used, encompasses the award of a sum of money that (more or less) corresponds to the damage or injury of the claimant. ${ }^{34}$ A compensatory damages award is therefore based on loss of the claimant, contrary to a restitutionary damages award which, as will be explained below, is based on gain of the defendant.

Two categories of damage recoverable by compensatory damages are usually distinguished: pecuniary and non-pecuniary loss. ${ }^{35}$ Furthermore, legal doctrine makes a threefold distinction between personal damage, property damage and pure economic loss, the latter being loss that does not result from personal or property damage. ${ }^{36}$ Pecuniary loss, also known as material loss, encompasses financial loss, i.e. loss of wealth resulting for example from the inability to work or medical expenses but also future losses. ${ }^{37}$ For this type of loss, the assessment of the compensatory damages award is either precise or rather exactly estimated. This makes the material damages award less interesting for this book, as it is an amount of money that is accurately estimated on the basis of the claimant's loss and therefore it can hardly be believed - except for certain specific situations in which the judge may abstract from (some of) the concrete circumstances and focus on objective standards instead - that there is a punitive element in the material damages award, even though tortfeasors might experience the obligation to pay damages as a form of punishment. ${ }^{38}$ More interesting in terms of this book is compensation for non-pecuniary or immaterial loss, which does not involve a detriment in someone's financial wealth. Rather, immaterial loss may consist of pain and suffering, loss of amenities, loss of reputation, injury to feelings, mental distress, etc. ${ }^{39}$ As for this kind of loss it is difficult to measure the exact amount of immaterial damages, the award will be an abstract estimation by the court instead of an exact equivalent to the concrete loss.

Burrows 2004, p. 29; McGregor 1997, p. 8

McGregor 1997, p. 8.

Hartlief 2012a, p. 249

7 Burrows 2004, p. 29; Van Gerven, Lever \& Larouche 2000, p. 8; Deakin, Johnston \& Markesinis 2008, p. 978.

38 See sections 6.2.2.5 and 9.4.1.1. Some say that another exception is formed by the possibility to include in the material damages award the profit made by the wrongdoer, for example on the basis of article 6:104 BW, as will be discussed below.

39 Burrows 2004, p. 29; McGregor 1997, p. 8. 
The primary function of both material and immaterial damages in civil law systems is compensation of the claimant; additional functions are deterrence or prevention, loss-spreading, loss-allocation, vindication, satisfaction, and law enforcement. ${ }^{40}$ The idea that compensation is the main function is also illustrated by the fact that the additional functions cannot exclusively form the basis of a damages award. However, there is room for other, dissenting, ideas. Especially for the category of immaterial damages, where the loss is intangible, the function of satisfaction and even punishment is considered an important side effect. ${ }^{41}$ Von Bar for example connects a punitive function to immaterial damages: ${ }^{42}$

Thus civil and criminal functions merge wherever the compensation of immaterial losses is intended to give the plaintiff moral satisfaction for the wrong he has suffered.

Furthermore, as explained in section 6.2.2.1, Hallebeek points out that from a historical perspective the present acceptance of liability for immaterial loss can be compared to the punitive character of the Roman law of delict. ${ }^{43}$ According to Van Nispen, immaterial damages awards partly solve the law enforcement deficiency that arises in Dutch law now that the reaction to breaches of private law duties is mainly dominated by the notion of compensation; he also mentions the introduction of punitive damages in Dutch private law to completely solve this problem. ${ }^{44}$ Thus, immaterial damages may fulfil similar functions in civil law systems as punitive damages do in common law systems. Although this is not theoretically acknowledged as such, apart from academic opinions in legal doctrine, it is of course an interesting notion in view of the theme of this book.

A special form of monetary compensation for immaterial loss available in some common law systems in case the wrong has been committed in a very reprehensible or inexcusable manner is aggravated damages. ${ }^{45}$ Civil lawyers are not familiar with this terminology, although forms of compensation with a comparable function do exist in civil law systems. ${ }^{46}$ Also between the common law countries distinctions are made with regard to what is covered by an award of aggravated damages. English law distinguishes aggravated damages from punitive or, in the English terminology, exemplary damages, whereas in American law such a distinction does not exist and the terms aggravated, punitive and exemplary damages can be used interchangeably. ${ }^{47}$ In English law, aggravated damages may be awarded for the claimant's wounded feelings apart from damages for pain and suffering, whereas punitive damages focus on punishment and deterrence of the defendant's wrongful conduct. If the motives and conduct of a tortfeasor

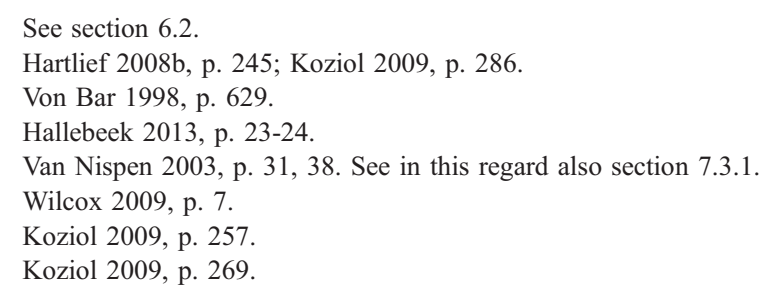


aggravate, or worsen, the claimant's damage by injuring his feelings of dignity, pride and self-respect, it is considered justifiable to award aggravated damages.

To conclude, note that the principle of restitutio in integrum is not absolute. In some situations, this would be unfair to the defendant. ${ }^{48}$ National legislators have incorporated in their laws of damages several ways to limit compensatory damages awards, for example reduction of damages due to contributory negligence, questions of causation and mitigation of damage. ${ }^{49}$ In contrast, damages awards that are not totally in conformity with the principle of full compensation, because the judge has taken the fault of the wrongdoer into account when assessing an immaterial damages award, are also imaginable. As will be further explained in section 9.4, immaterial damages awards then also serve a non-compensatory function. Thus, the notion that the principle of full compensation is not absolute has two sides: compensatory damages awards may be limited on the one hand and include non-compensatory elements on the other hand. Keeping in mind the theme of this chapter, before the relevant civil sanctions per legal system will be explored in section 9.4, the next subsection will first explain categories of damages awards that are not exclusively based on the principle of full compensation.

\subsubsection{Damages That Are Not Exclusively Based on Compensation}

A first category of non-compensatory damages is restitutionary damages. Like aggravated damages, restitutionary damages were originally a common law remedy. Restitutionary damages differ from compensatory damages in the sense that the former are used to restitute a profit gained by the defendant, whereas the latter should make good a loss suffered by the claimant. Although the term restitution is sometimes used as a synonym for compensation, i.e. to restore the value of what the claimant has lost, in its original meaning restitutionary damages aim at recovery for unjust enrichment. ${ }^{50}$ Unquestionably, civil law systems are also familiar with unjustified enrichment and restitution. For that reason, restitutionary damages are not exclusively a common law phenomenon. Restitution can be based on a wrong leaving the defendant unjustly enriched but also in the absence of a wrong due to for example the claimant's payment by mistake. ${ }^{51}$ For the purpose of this book, the latter category of restitution for 'mere' unjust enrichment will be left aside and the focus is on restitution for wrongs. In particular one type of restitutionary damages for wrongs - also known as disgorgement damages - aiming at 'the stripping away of profits made by the defendant committing a wrong to the claimant' is an interesting remedy that will be discussed as part of section 9.4..$^{52}$

\footnotetext{
McGregor 1997, p. 65.

McGregor 1997, p. 78, 82, 185.

Schoenbrod et al. 1996, p. 661-662; Samuel \& Rinkes 1991, p. 23.

Burrows 2004, p. 371.

2 Burrows 2004, p. 374.
} 
A second category of non-compensatory damages is, obviously, punitive damages. The primary objective of such damages is not to compensate the claimant but to punish the defendant and thereby deter him and others from similar behaviour in the future. ${ }^{53}$ As this civil remedy has been extensively explained in chapters two to five, it suffices to indicate at this point that it is a typical common law remedy that is not available in civil law systems. Thus, there is a restricted form of punitive damages in English law, whereas punitive damages as such do not - currently - exist in Dutch, German and French law. Interesting (legislative) developments in this respect, for example in France, will of course be explained below.

A third category of damages with a different purpose than compensation is nominal damages. Common law lawyers are familiar with nominal damages, which can be awarded by a civil judge in case a wrong has been done but no actual loss has resulted from this. In English law, nominal damages may be awarded if there has been a breach of contract or a tort actionable per se (without actual loss), such as libel and slander. The nominal damages award is of no real value, but it is meant to affirm that there has been an infringement of a legal right and thereby serves the functions of declaring rights and vindication. ${ }^{54}$ The Dutch, German and French tort systems do not allow compensation for wrongs in the absence of damage: there, damage is one of the prerequisites to hold someone liable. Civil law systems however do have a remedy with similar objectives as nominal damages, i.e. the declaratory judgment. In a handbook on remedies in American law, the definition of nominal damages is as follows: ${ }^{55}$

Nominal damages are a nominal or trivial sum of money (frequently one dollar) awarded to plaintiffs who have established a cause of action, but have not shown an injury for which compensatory damages can be awarded.

As explained in section 3.2.4, in American law nominal damages are relevant in relation to punitive damages awards. For punitive damages to be awarded, most American courts require that the plaintiff is entitled to at least nominal damages. ${ }^{56}$

A fourth and final category of non-compensatory damages is the contractual penalty clause. Both common and civil law systems are familiar with this remedy that is used in cases concerning breach of contract. The common law terminology is the award of an agreed sum or liquidated damages clause. ${ }^{57}$ In civil law systems, the terminology is more connected to the punitive element in such contractual clauses: the clause pénale in articles 1152 and 1226-1233 Cc, the boetebeding in article 6:91 BW and the Vertragsstrafe in $\S 339$ et seq. BGB. In principle, this is a self-help remedy as opposed to the above-mentioned judicial remedies. But in practice a court procedure can be necessary, for example when parties disagree on

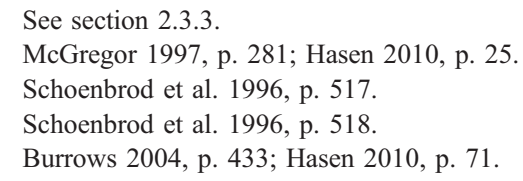


whether the contract was breached and ask the court to decide on the issue and enforce the contractual penalty clause. The contractual penalty clause is thus, firstly, an instrument from contract law and, secondly, a self-help remedy. The reason why this hybrid remedy is interesting for this chapter is that it is a civil remedy with a punitive character, similar to punitive damages. Furthermore, as mentioned before, another parallel between the two remedies is that punitive damages may also be awarded if there has been a breach of contract. Some attention will therefore be paid to the contractual penalty clause. Not a negligible difference between the two remedies, however, is that in contrast to the obligation to pay punitive damages imposed on a defendant by the court, parties to a contract deliberately choose for a contractual penalty clause in their contract. Parties to a contract can agree that an amount of money - usually higher than legal damages has to be paid if the contract is breached by either or one of the parties. ${ }^{58}$ This agreement forms part of the contract and generally has two functions, although this might differ per legal system as will be explained below. ${ }^{59}$ On the one hand, it is used to fix, in advance, the damages to be awarded in case of a breach of contract. A juridical assessment of the damage afterwards has thereby become unnecessary, which supposedly is good for legal certainty as the parties to the contract know which financial consequences a breach of the contract will have. On the other hand, the contractual clause has a deterrent and punitive element in it in the sense that it compels observance of a contractual obligation. This also contributes to legal certainty, as performance becomes more likely due to the financial incentive. ${ }^{60}$ According to Schoenbrod et al.: ${ }^{61}$

Without an enforceable clause purporting to liquidate damages, the nonperforming party may fear that the performing party will have insufficient incentive to perform if the latter realizes that damages he has caused are not sufficiently provable to be collected. Such a clause is a penalty in that its principal function is to coerce performance.

The punitive element in liquidated damages follows for example from its Dutch equivalent, the boetebeding in article 6:91 BW, which will be explained below.

The above gives an insight into the possible forms of monetary damages in private law. After this abstract overview, the next section will become more concrete. Not all civil remedies are equally interesting for this research. The next section will pay attention in particular to the non-compensatory function of abstract estimation of damages, for instance in case of immaterial damages awards and disgorgement of profit. Furthermore, some remarks will be made about contractual penalty clauses. With regard to the latter sanction, the above-mentioned difference, i.e. parties to a contract may deliberately choose for a contractual penalty clause, should however be kept in mind.

\footnotetext{
Schelhaas 2004, p. 5; McGregor 1997, p. 314.

9 Schelhaas 2004, p. 5; Burrows 2004, p. 433.

Schelhaas 2004, p. 5 .

61 Schoenbrod et al. 1996, p. 635.
} 


\subsection{Civil Sanctions: an Overview per Legal System}

As explained in the introduction above, this section will analyse civil sanctions in four European legal systems, i.e. the Netherlands, Germany, France and England. Furthermore, in section 9.5 a comparison scale of all four legal systems will be provided to see the extent to which civil sanctions are recognised in these legal systems in comparison to the American legal system. It will follow from section 9.5 that the Netherlands and Germany take an intermediate position on the scale: civil sanctions that closely resemble the punitive damages remedy are not recognised there, but monetary damages awards with a deterrent and perhaps even a punitive function can nonetheless be pointed out. For that reason, this section will start with the Dutch and German legal system. What follows is an overview of relevant civil sanctions in the French legal system. Compared to the Netherlands and Germany, France currently seems to have the most liberal view on civil sanctions, which also follows from three legislative proposals that all contain a provision concerning punitive damages to sanction wrongful behaviour, to be precise lucrative faults and intentional personality right infringements. Lastly, relevant information on the use of civil sanctions in England will be provided. Of the four European countries that have been studied, the English legal system is on top of the scale as the punitive damages remedy is explicitly recognised there, albeit in a more restricted form than in the United States.

\subsubsection{The Netherlands}

\subsubsection{Basic Principles of the Law of Damages}

The relevant provisions in Dutch law concerning the obligation to pay damages on the basis of a statutory duty, such as a tort (article 6:162 BW) or breach of contract (article 6:74 BW), have been laid down in articles 6:95 to 6:110 BW. Also in Dutch law, the guiding principle in both contractual and non-contractual situations is full compensation of loss. ${ }^{62}$

Taking into consideration the previous section, Dutch law has the following forms of damages: material damages, including disgorgement of profit, immaterial damages, and contractual penalties. Nominal damages and punitive damages are

62 Bloembergen \& Lindenbergh 2001, p. 8, 17; Hartlief 2012a, p. 239. Note that also in Dutch law the principle of full compensation is not absolute and a number of exceptions apply: (1) causality plays an important role in determining whether the damage suffered is sufficiently connected to the wrongful event (article 6:98 BW); (2) in case the wrongful event has brought the claimant any benefits, these benefits should be balanced with the damage in calculating the damages award (article 6:100 BW); (3) the damages award can be diminished if the claimant contributed to the damage, meaning that he was at fault himself (article 6:101 BW); (4) in case of certain special circumstances, the judge has the possibility to mitigate or reduce the damages award (article 6:109 BW); (5) if there can be no reasonable insurance coverage, in particular situations limits on damages awards may be agreed upon by the legislator (article 6:110 BW). 
not recognised forms of monetary damages in Dutch law. Damage is defined as depreciation in an object, which can be both financially and non-financially. ${ }^{63}$ Article 6:95 BW determines which damage is compensable: financial damage (material loss), on the one hand, and other injury (immaterial loss), but only as far as the law entitles the reparation of such loss, on the other hand. According to article 6:96 BW, paragraph 1, financial damage can be either actual suffered loss (damnum emergens) or loss of profit (lucrum cessans). Paragraph 2 of this article gives some other costs that qualify for compensation: reasonable costs to prevent or minimise damage, reasonable costs to assess damage and liability, reasonable costs to obtain compensation outside the law, such as costs of collection or serving notice upon the debtor. Immaterial loss is compensable only as far as this is determined by law. The relevant provision is article 6:106 $\mathrm{BW}$, which will be discussed more in detail below.

The judge needs to assess the damage in accordance with its nature and, in case the damage cannot be precisely assessed, it will be estimated (article 6:97 BW). In principle, the starting point is a concrete estimation of damage (concrete schadebegroting), meaning that in assessing a damages award the judge will take into account all relevant circumstances relating to the concrete situation of the victim. This method goes best with the purpose of Dutch tort law, i.e. full compensation of the victim to bring him back to the position he would be in without the wrongdoing. ${ }^{64}$ The Dutch Supreme Court confirmed in 2008 that the general rule, also in case of bodily injury, is a concrete estimation of damage. ${ }^{65}$ However, in some specific situations the judge may - for reasons of practicality or reasonableness abstract from (some of) the concrete circumstances (abstracte schadebegroting) and focus on objective standards instead, thereby forming an exception to the general rule. ${ }^{66}$ In the case at hand, the Court decided that the liable person should compensate the costs of household help that the victim receives because he is no longer capable of doing the work himself. The damages award may then be estimated on the basis of the costs of professional help, even though in the concrete situation the help is given by someone who is not reimbursed for the costs (in casu the victim's partner). ${ }^{67}$ Another example of a situation in which the abstract form of estimation is used is when the plaintiff has suffered property damage. Suppose a car is damaged in an accident for which someone else is liable, even though the owner, who has a service station, bought his car from a friend for a minimum price and has fixed it in his own company, the liable person still needs to compensate the objectively valued reparation costs. ${ }^{68}$ An abstract estimation of damage on the basis of article 6:97 BW may also result in compensation of more than the actual loss; the accepted function of such an award is law enforcement. ${ }^{69}$ Another form of

HR 5 december 2008, NJ 2009/387, m.nt. J.B.M. Vranken, r.o. 3.3.

HR 5 december 2008, NJ 2009/387, m.nt. J.B.M. Vranken, r.o. 3.4.

7 HR 5 december 2008, NJ 2009/387, m.nt. J.B.M. Vranken, r.o. 3.5.1.

Hartlief $2012 \mathrm{a}$, p. 257.

9 Geerts et al. 2011, p. 61, citing Engelhard et al. 2009; Kortmann \& Sieburgh 2009; De Groot 1980. 
abstract calculation of damage with a non-compensatory function is article 6:104 BW concerning the disgorgement of profit. ${ }^{70}$ This provision will be discussed in more detail below.

These basic principles give a general understanding of the Dutch law of damages. As full compensation of loss is the general principle, compensation is in theory based on the loss of the victim and not on the behaviour of the wrongdoer. However, in practice the judge has some power - within the framework of article 6:98 BW concerning causation, article 6:101 BW on the wrongdoer's own fault and article 6:106(1)(a) BW on immaterial loss - to take factors such as the degree of blameworthiness of the tortfeasor into account. ${ }^{71}$ As already mentioned in chapter two, taking into account the degree of blameworthiness gives a punitive character to civil damages awards. The higher the degree of fault, the more room a judge has to award larger damages and thus for deviating from the principle of full compensation. ${ }^{72}$ As will be explained below, this also applies to the assessment of immaterial damages. Another category of damages recognised in Dutch private law that allows deviation from the principle of full compensation is the contractual penalty clause. ${ }^{73}$

Other European legal systems in which the judge may take the fault of the wrongdoer into account when assessing an immaterial damages award are for example Austria, France, Germany, Greece, Italy, Norway, Portugal, and Switzerland. ${ }^{74}$ Some say that by taking the wrongdoer's fault into account justice is done to the compensatory function of tort law and that this does not have a punitive purpose. ${ }^{75}$ On the other hand, authors who plead for graver sanctions in tort law often connect this to the degree of blameworthiness, as is for example done by Hartlief and Verheij. ${ }^{76}$ Shelton mentions the following in this respect: ${ }^{.7}$

States that take fault into account in assessing moral damages can be said to inject a punitive element into the civil remedy.

Although non-compensatory elements are the exception rather than the rule in the Dutch law of damages, the remedies that will be discussed below are not merely compensatory. $^{78}$

\subsubsection{Immaterial Damages}

According to article 6:95 BW not only financial loss but also other loss is compensable, but they are compensable only as far as this is determined by law

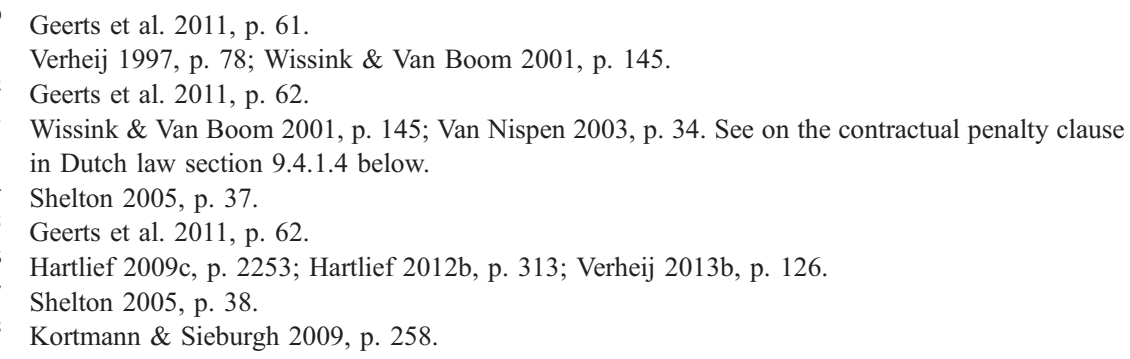


and in a limited number of situations. ${ }^{79}$ This means that immaterial damages can only be awarded if this is explicitly authorised by law. The term 'other loss' is further defined in article 6:106 $\mathrm{BW} .{ }^{80}$ According to the first paragraph of this provision, a claimant has a right to compensation of immaterial loss in three situations: (a) the liable person intended to cause the loss; (b) the injured person is physically injured, his honour or reputation is infringed, or his person is injured in another way; (c) the loss consists of the violation - inflicted upon the spouse (the spouses were not separated in bed and board), registered partner or blood relative to the second degree - of the memory of a deceased person, provided that the injury occurred in a manner which would have given the deceased, had he still been alive, the right to damages for injury to his honour or reputation.

The main category is formed by category $b$, whereas categories $a$ and $c$ have fairly little practical value. ${ }^{81}$ The focus in this section will therefore be on category $b$, which distinguishes between: (1) physical injury; (2) infringement of someone's honour or reputation; and (3) injury of a person in another way. Lindenbergh makes clear that by far the biggest part of immaterial damages is awarded for physical injury and that these are not the most problematic cases in Dutch law. ${ }^{82}$ This is different for cases concerning the infringement of someone's honour or reputation and injury of a person in another way. According to the Dutch Supreme Court, immaterial damages for injury to the person other than physical injury can only be awarded in case of serious wrongdoing, such as the grave infringement of someone's private life. ${ }^{83}$ Immaterial damages for the infringement of someone's honour or reputation have for example been awarded to person $\mathrm{K}$. because policemen had told K.'s future in-laws about his criminal past, as a result of which his lover had broken off the relationship. According to the Court, the policemen's action constituted a serious infringement of K.'s private life. ${ }^{84}$ The publication without permission of a nude picture in a naturist magazine is also seen as a serious infringement of one's private life and a shocking experience for which immaterial damages can be awarded. ${ }^{85}$ Other comparable examples are the case of a teacher whose nude pictures that were taken while posing for amateur painters were published on the internet without his permission and turned up at his school, ${ }^{86}$ and the case of a local politician who had been wrongly accused of rape and received immaterial damages from another politician who had reported on

80 Dutch law has some other bases for compensation of immaterial loss, such as article 7:510 BW concerning the travel agreement.

81 Lindenbergh 2008a, p. 25-26.

82 Lindenbergh 2008a, p. 26. Lindenbergh points out that problems do arise in physical injury cases concerning comatose victims and wrongful life claims. Furthermore, the calculation of the immaterial damages award as such may lead to difficulties.

83 Asser/Hartkamp \& Sieburgh 2013/140.

84 HR 1 november 1991, NJ 1992/58 (K/Staat), r.o. 3.5.

85 HR 30 oktober 1987, NJ 1988/277, m.nt. L. Wichers Hoeth, r.o. 3.5.

86 Rb. 's-Gravenhage 26 oktober 2005, NJF 2006/33. 
the rape in a radio interview. ${ }^{87}$ Immaterial damages awards for infringements of honour or reputation can be rather substantial, especially when compared to awards for physical injury, although the majority of awards are modest in amount. ${ }^{88}$ Note that the judge may also choose to oblige a tortfeasor who infringed someone's honour or reputation to a rectification based on article 6:167 $\mathrm{BW}$; when the rectification does not give sufficient justification to the victim, additional immaterial damages may be awarded. ${ }^{89}$ The last category mentioned in paragraph $b$, injury of a person in another way, usually concerns mental injury or infringement of a personality right other than honour or reputation. This includes most importantly the right to self-determination, which encompasses, for example, the right to make an informed decision about abortion. The position of the judge with regard to this category is rather reserved in comparison to situations where there is physical injury or injury to someone's honour or reputation. ${ }^{90}$ The Supreme Court confirmed in a recent decision that the general requirement to award immaterial damages on the basis of this category is that the victim has suffered psychological damage. ${ }^{91}$ However, the Court also acknowledged that the extreme gravity of the infringement and the consequences thereof for the victim (bijzondere ernst van de normschending en de gevolgen daarvan voor het slachtoffer) may justify an exception to this general requirement. ${ }^{92}$

This section will take a closer look at the functions of immaterial damages awards in Dutch law. Four functions have been distinguished in legal doctrine, of which compensation and satisfaction are considered most important. ${ }^{93}$ The first function is compensation for pain and suffering in the case of physical injury, which is - as was seen above - the main category in which immaterial damages are awarded. This however does not mean that in case of physical injury compensation is the only function of immaterial damages: other functions are satisfaction, recognition and prevention. ${ }^{94}$ The compensatory function of immaterial damages is generally acknowledged and fits well into the classical theory of the law of damages, i.e. full compensation of loss, although in case of immaterial loss the damage cannot be exactly determined. The Dutch Supreme Court decided that in estimating the immaterial damages award in case of physical injury, 'the nature,

87 Rb. Groningen 5 december 2007, NJF 2008/62.

88 Lindenbergh 2008a, p. 30. Cf. Van Harinxma thoe Slooten 2003, p. 1994, according to whom the average immaterial damages award on the basis of article $6: 106(1)(\mathrm{b}) \mathrm{BW}$ is between $€ 450$ and $€ 9,000$ with a few peaks between $€ 10,000$ and $€ 60,000$.

89 E.g. Rb. Utrecht 17 januari 2006, NJF 2006/131; Hof Amsterdam 31 mei 2007, NJF 2007/348; Rb. Amsterdam 28 juni 2000, NJ 2000/621; Rb. 's-Hertogenbosch 7 november 2003, NJF 2004/34.

90 Lindenbergh 2008a, p. 33-34; Hartlief 2012a, p. 305.

91 HR 29 juni 2012, NJ 2012/410 (Blauw oog).

92 HR 29 juni 2012, NJ 2012/410 (Blauw oog), r.o. 3.5

93 Lindenbergh 2008a, p. 6. See also Bolt \& Lensing 1993, p. 63; Stolker 2003, p. 308; Hartlief 2012a, p. 304.

94 Lindenbergh 2008a, p. 8. 
duration and intensity of the pain, the grief and deprivation of joy in life' should be taken into account. ${ }^{95}$

A second important function is satisfaction of the shaken sense of justice of the victim. Much value is attached to the idea that the victim must be satisfied in order to compensate his strong feelings of injustice. Satisfaction of the victim becomes a decisive factor in determining the size of the award and is always important in cases concerning personal injury resulting from acts of violence. A particular example in which an immaterial damages award may have a satisfactory function is that of sexual abuse. This form of misconduct not only constitutes a grave injury of the victim's personal integrity, but it is also highly reprehensible and often deliberately done by the defendant. For that reason, the immaterial damages award fulfils a different function in cases of sexual abuse than in cases of physical injury. The award not only gives satisfaction to the victim, but it also shows disapproval of the wrongdoer's behaviour and compensates harmful consequences of the wrongdoing. In this role, immaterial damages also seem to have a punitive meaning. Some authors indeed relate immaterial damages to punitive damages, as the borderline between satisfaction and punishment is vague. ${ }^{96}$ Others are more reluctant in this regard, considering that the legislator did not intend a real punitive purpose. $^{97}$ There are however some starting points to attribute a punitive function to article $6: 106 \mathrm{BW} .^{98}$ First, in article 6:106(1)(a) BW, the focus shifts from the victim to the defendant whose intentional behaviour is taken into account. As explained above, immaterial damages are recoverable under category $a$ if the liable person intended to cause the loss. An example is that of the wrongdoer who destroys another person's property that has a high emotional value, such as pictures or a family heirloom. ${ }^{99}$ Another shocking example that actually happened is the following case about a couple that had started divorce proceedings. The husband killed their child with the intention of wounding his wife. The court decided that in such a situation of deliberately or intentionally hurting a (surviving) relative, compensation of immaterial loss should be made possible on the basis of article 6:106(1)(a) BW. ${ }^{100}$ This judgment forms an exception to the fairly little practical value that this part of article $6: 106 \mathrm{BW}$ has, as it is difficult to prove that someone intended to cause immaterial loss. ${ }^{101}$ Then again, given the wide-ranging potential uses of article 6:106(1)(a) BW, in case there has been an intentional breach of a

95 Lindenbergh 2008a, p. 7, citing HR 8 juli 1992, NJ 1992/714 (HIV-besmetting); HR 20 september 2002, NJ 2004/112, m.nt. J.B.M. Vranken (Coma).

96 Nispen 2003, p. 38; Lindenbergh 2003, p. 19; Lindenbergh 2008a, p. 8, 14; Slok \& Van 1990, p. 1828; Chao-Duivis 1990, p. 518; Hartlief 2008b, p. 245-246; Betlem, Rodrigues \& Zijlstra 1999, p. 92; Verheij 2013b, p. 126.

97 Lindenbergh 1995, p. 126; Kortmann \& Sieburgh 2009, p. 260.

98 Van Nispen 2003, p. 37.

99 Asser/Hartkamp \& Sieburgh 2013/145.

100 HR 26 oktober 2001, NJ 2002/216, m.nt. J.B.M. Vranken (Oogmerk).

101 Lindenbergh 2008a, p. 25. 
contractual or non-contractual duty, this provision has been mentioned in Dutch literature as a potential basis for punitive damages. ${ }^{102}$

The third function relates to the recognition of immaterial harm caused by nervous shock injury that results from being confronted with a dangerous situation or the consequences thereof. Nervous shock injury may for example arise from the confrontation with an accident leading to injury or death of a close relative, but also of an unknown passenger. The following two Supreme Court decisions are examples of situations in which a right to immaterial damages for nervous shock injury has been acknowledged. The first case, in which the award was based on article 6:106(1)(a) BW, is the above-mentioned case of the father who murdered his child with the intention of wounding his wife. In the second case, the Court decided that the immaterial loss of a mother who was confronted with the shocking accident resulting in the death of her daughter was compensable on the basis of article $6: 106(1)(b)$ BW. ${ }^{103}$ The Court decided in the latter case that immaterial damages for nervous shock injury are not compensable in all circumstances. Firstly, the wrongful act must not only be directed towards the direct victim but also to the shocked person, and, secondly, the immaterial loss of the shocked person must consist of psychological injury that is open to objectification, usually an illness that is recognised in psychiatry, meaning that mere grief is not sufficient. ${ }^{104}$ It appears from a later decision concerning parents who had lost their children as a result of grave criminal offences leading to a fatal car accident that the Court is not willing to relax these strict requirements. ${ }^{105}$ In this decision, the Court refused to award immaterial damages to the parents despite the nature and gravity of the wrongdoing, i.e. the intentional cause of the car accident that resulted in the death of their children. ${ }^{106}$ As mentioned in section 7.3.2, this is an example of a case that has provoked discussion in the Netherlands regarding the need for stronger tort remedies to deal with intentional, calculative and grave misconduct. Note that immaterial harm - not consisting of nervous shock injury in case of injury or death of a loved one is not compensable under Dutch law. ${ }^{107} \mathrm{~A}$ legislative proposal ${ }^{108}$ relating to this subject was rejected by the Senate in 2010. Common arguments against compensation of loss resulting from the death or injury of a loved one is a fear of commercialisation of grief, distasteful proceedings and the rise of a compensation culture. ${ }^{109}$ According to articles 6:107 and 6:108 $\mathrm{BW}$, a limited circle of relatives does have a right to compensation of certain losses in case of injury or death of a loved one, but these losses do not include immaterial loss.

102 Van Nispen 2003, p. 37; Verheij 1997, p. 77; Slok \& Van 1990, p. 1827.

103 HR 22 februari 2002, NJ 2002/240, m.nt. J.B.M. Vranken (Taxibus).

104 Asser/Hartkamp \& Sieburgh 2013/144; Lindenbergh 2008a, p. 47; Hartlief 2009c, p. 2253.

105 HR 9 oktober 2009, NJ 2010/387, m.nt. J.B.M. Vranken (Vilt); Hartlief 2012b, p. 313; Asser/ Hartkamp \& Sieburgh 2013/144

106 HR 9 oktober 2009, NJ 2010/387, m.nt. J.B.M. Vranken (Vilt), r.o. 3.5

107 Lindenbergh 2008a, p. 11.

108 Wetsvoorstel Affectieschade, Kamerstukken I 2004/05, 28 781, A.

109 Hartlief 2012a, p. 309. 
The fourth and final function is enforcement of the right to privacy in case of personality right infringements. The immaterial damages award then functions as an enforcement mechanism or even as a sanction. ${ }^{110}$ Note that the infringement of a personality right is in itself a sufficient basis for immaterial damages. Personality rights, including the right to physical integrity, freedom, honour, and reputation, are fundamental human rights of which the value is not measurable in terms of money. ${ }^{111}$ Yet, even in the absence of measurable loss and physical injury, a personality right infringement can form the basis of an immaterial damages award as long as the infringement is sufficiently serious. ${ }^{112}$ In this respect, also violations of European human rights law, such as the reasonable time requirement of article 6 (paragraph 1) ECHR, can form the basis of an immaterial damages award. ${ }^{113}$ The deliberate violation of someone else's privacy may trigger damages awards that are not solely based on the principle of full compensation but also have a deterrent and punitive objective. ${ }^{114}$ Immaterial damages awards for personality right infringements also serve the function of law enforcement, as private law should be able to react to such infringements. ${ }^{115}$ However, the punitive function of these particular immaterial damages awards is not officially recognised in Dutch court decisions. ${ }^{116}$ Legal doctrine has therefore paid a lot of attention to dealing with personality right infringements, other than by imposing immaterial damages, and has pleaded for stronger tort remedies in this regard. ${ }^{117}$ For these kinds of infringements, the punitive damages remedy is considered a potential alternative, but one also speaks of increasing immaterial damages awards. ${ }^{118}$

What about the size and calculation of Dutch immaterial damages awards? The judge can use his discretionary power and assess the award in fairness (naar billijkheid). He therefore has a lot of freedom in determining the size of the award; he may even decide to refrain from awarding immaterial damages. ${ }^{119}$ The judge should take notice of awards that have been granted by Dutch courts in comparable situations and may even look at foreign developments, although the latter cannot be decisive. ${ }^{120}$ He can take all circumstances into account, such as the nature of the liability, the seriousness of the injury as well as the nature, gravity, length and intensity of the pain and suffering. ${ }^{121}$ These factors are especially geared to immaterial harm resulting from personal injury. As mentioned above in section 7.3.2, compared

110 Cf. Kortmann \& Sieburgh 2009, p. 260.

111 Asser/Hartkamp \& Sieburgh 2013/140.

112 E.g. HR 9 juli 2004, NJ 2005/391, m.nt. J.B.M. Vranken (Groninger Oudejaarsrellen).

113 Rijnhout et al. 2013, p. 181, citing Hof 's-Gravenhage 24 februari 2009, NJ 2010/55, m.nt. E.A. Alkema; Hof 's-Gravenhage 30 augustus 2011, ECLI:NL:GHSGR:2011:BS8801.

114 Van Nispen 2003, p. 36; Geerts et al. 2011, p. 61.

115 Van Nispen 2003, p. 36, citing Verheij 2002, p. 455.

116 Verheij 2002, p. 470; Geerts et al. 2011, p. 61; Spier 2012, p. 8

117 See Boukema 2008; Van Schaik 1999; Van der Heijden 2001; Schuijt 2003

118 Van Harinxma thoe Slooten 2003, p. 2000-2001; Kortmann \& Sieburgh 2009, p. 260.

119 HR 27 april 2001, NJ 2002/91, m.nt. C.J.H. Brunner.

120 Hartlief 2012a, p. 307, citing HR 8 juli 1992, NJ 1992/714 (HIV-besmetting); HR 17 november 2000, NJ 2001/215, m.nt. ARB (Druijff/B.C.E. Bouw).

121 Hartlief 2012a, p. 307; HR 8 juli 1992, NJ 1992/714 (HIV-besmetting). 
to other countries, the Dutch judge is rather reserved when it comes to awarding immaterial damages. ${ }^{122}$ Such awards are relatively small in the Netherlands: the highest immaterial damages sum ever awarded by a Dutch court is $€ 150,000$, but awards of this size are only rarely awarded. The amount mentioned was awarded to a man who became severally handicapped due to attempted murder. ${ }^{123}$ Furthermore, in 1992 a sum of $f 300,000( \pm € 136,000)$ was awarded, also in a personal injury case, to a patient who was infected with HIV due to medical malpractice. ${ }^{124}$ A sum of $€ 136,000$ was also awarded, in 1999, to a man who became severy handicapped due to a car accident. ${ }^{125}$ Most Dutch immaterial damages awards do not exceed $€ 15,000$, and awards exceeding $€ 50,000$ are rare. ${ }^{126}$

To conclude, it is fair to say that in the Dutch legal system most immaterial damages awards are based on paragraph $b$ of article 6:106 BW and especially the first two categories thereof, namely physical injury and infringements of honour and reputation. Furthermore, non-compensatory elements can certainly be found in awarding immaterial damages by Dutch courts. This does not only follow from the nature of the loss, which can hardly be precisely defined, but also from the objective of the award. One of the functions of immaterial damages that comes closest to punishment is the satisfaction of the shaken sense of justice of the victim. Furthermore, it is very well defensible that the discretionary power of the judge to take the nature and gravity of the wrongdoing into account and award substantial immaterial damages in case of serious wrongdoing also has a punitive function. Indeed, even though the size of the awards is relatively small in comparison to some other European countries, ${ }^{127}$ Dutch lower courts have shown willingness to award a substantial sum of immaterial damages in case of grave wrongdoing. There is also a discussion going on in Dutch legal doctrine whether or not to introduce powerful civil sanctions to react to intentional, calculative and grave misconduct. For example, for some areas of tort law, such as personality right infringements, doubts have been expressed about the efficiency of immaterial damages awards which leads to the question whether or not to introduce punitive damages. Furthermore, Verheij has recently suggested that immaterial damages awards be increased in case of grave infringements in the following manner: (1) double immaterial damages in case of gross negligence (grove schuld), for example drunken driving; (2) treble immaterial damages in case of intention (opzet); and (3) quadruple immaterial damages in case of evil intent (opzet op gevolg). In this manner, the degree of blameworthiness of the wrongdoer indeed

122 Lindenbergh 2008a, p. 75-76.

123 Lindenbergh 2008a, p. 75, citing Rb. 's-Hertogenbosch 11 april 2007, JA 2007/99.

124 HR 8 juli 1992, NJ 1992/714 (HIV-besmetting). Cf. French HIV-cases concerning contaminated blood transfusions due to medical malpractice, see Shelton 2005, p. 37-38; Van Gerven, Lever \& Larouche 2000, p. 629-634; Van Dam 2013a, p. 67.

125 Lindenbergh 2008a, p. 77, citing Hof Arnhem 7 december 1999, VR 2000/90.

126 Hartlief 2012a, p. 308; Lindenbergh 2008a, p. 75.

127 Lindenbergh 2008a, p. 77. 
becomes a decisive factor in assessing the immaterial damages award, which gives the award a clear punitive character. ${ }^{128}$

\subsubsection{Disgorgement of Profit}

A special form of abstract estimation of damage, as referred to in section 9.4.1.1 above, can be found in article 6:104 BW on disgorgement of profit. If someone commits a tort, for instance by infringing a personality right, or breaches a contract and gains profit from this, the other party may ask the judge to estimate the damage to the amount of the profit or a part of it. The judge is not obliged to do so. The reason the legislator has designed this provision is twofold: (1) as it is difficult for the victim to point out his exact loss whereas it is clear that the tortfeasor profited from his misconduct, it solves problems relating to evidence; and (2) it gives support to the idea that a wrongdoer should not profit from his behaviour. ${ }^{129}$ These reasons give rise to the question whether this provision has purposes other than compensation, and perhaps it even has a punitive element in it. According to Van Nispen, the general obligation laid down in Dutch law to compensate damage resulting from wrongful conduct has shortcomings if the profit gained by the wrongful conduct exceeds the damage to the victim. ${ }^{130}$ Article 6:104 BW therefore also serves the function of law enforcement. ${ }^{131}$ In respect of a possible punitive function, an important question is whether disgorgement of profit is also possible if the victim himself has not suffered damage. The Dutch Supreme Court has answered this question negatively: article 6:104 BW is not applicable in case there is no damage. Although it is often difficult for the victim to estimate the exact loss, he must at least have suffered some damage. ${ }^{132}$ Thus, this provision cannot form an independent or separate basis for a disgorgement of profit claim. ${ }^{133}$ As in Germany and France, the possibility to disgorge profit also exists in Dutch intellectual property law. Provisions that are comparable to article 6:104 BW can be found in the Copyright Act (article 27a Auteurswet) and the State Patent Act (article 70 lid 5 Rijksoctrooiwet). ${ }^{134}$ The latter article partly implements the Directive on the enforcement of intellectual property rights; this Directive is also implemented in other Dutch legislation, most importantly in the Code of Civil Procedure (articles 1019 to $1019 \mathrm{i} \mathrm{Rv}){ }^{135}$

More recently, the Dutch Supreme Court made two decisions concerning, amongst others, the character of article 6:104 BW. It was explicitly decided that

128 Verheij 2013b, p. 126. See also section 2.3.3 and 2.3.4.

129 Hartlief 2012a, p. 260-261.

130 Van Nispen 2003, p. 40.

131 Kortmann \& Sieburgh 2009, p. 260.

132 HR 24 december 1993, NJ 1995/421, m.nt. C.J.H. Brunner; HR 16 juni 2006, NJ 2006/585, m.nt. J.H. Spoor; HR 18 juni 2010, RvdW 2010/771 (Doerga/Ymere); HR 18 juni 2010, RvdW 2010/772 (Setel/AVR).

133 Asser/Hartkamp \& Sieburgh 2013/105; Hartlief 2012a, p. 261.

134 Hartlief 2012a, p. 262; Kortmann \& Sieburgh 2009, p. 270.

135 Directive 2004/48/EC. 
this provision does not, not even partly, have a punitive character. ${ }^{136}$ Instead, courts should exercise restraint in applying this provision and take a reserved position in establishing the amount of damages: if the profit made by the defendant considerably exceeds the probable loss of the claimant, the court should in principle estimate the damages at a portion of the profit. The Supreme Court refuses to see a punitive element in this provision despite an earlier decision ${ }^{137}$ made by the Benelux Court of Justice, in which the punitive character of a comparable provision concerning disgorgement of profit in the case of intellectual property law infringements, i.e. (current) article 2.21 Benelux Convention on Intellectual Property, was - albeit carefully - recognised. ${ }^{138}$ The punitive character of article 2.21 should be seen in relation to its recognised law enforcement function; as pointed out by Kortmann and Sieburgh, the possibility to disgorge profit on the basis of this article should prevent malicious infringements of intellectual property rights. ${ }^{139}$ The disgorgement of profit takes away the economic incentive of wrongdoers to infringe intellectual property law.

Although the Supreme Court refuses to see a punitive element in article 6:104 BW, it does, however, allow courts to take into account the conduct of the defendant and the degree of blameworthiness. It thereby acknowledges that compensation of the claimant is not the sole starting point in estimating a damages award on the basis of article 6:104 BW. ${ }^{140}$

\subsubsection{Contractual Penalty Clause}

While the question whether the above described tort remedies really contain punitive elements remains undecided, there is no discussion possible about the punitive effect of the contractual penalty clause. The Dutch equivalent of this remedy, the so-called boetebeding, is regulated in articles 6:91 to 6:94 BW. According to article $6: 91 \mathrm{BW}$, the parties to a contract may agree that in case of a breach of contract the debtor is obliged to perform a determined act. ${ }^{141}$ This will usually be monetary damages, but the act can also consist of another performance. Dutch law recognises two functions of the penalty clause, i.e. the above-mentioned assessment of damage function and the incentive function. In so doing, Dutch law resembles French law which also recognises two functions of the penalty clause but differs from the English approach which supports only the assessment function. ${ }^{142}$ The English liquidated damages clause, for that reason, will not be discussed in this chapter. German law also recognises both functions, but only the

136 HR 18 juni 2010, RvdW 2010/771 (Doerga/Ymere), r.o. 3.6; HR 18 juni 2010, RvdW 2010/772 (Setel/AVR), r.o. 3.3.2. In both decisions the Court refers to HR 24 december 1993, NJ 1995/421, m.nt. C.J.H. Brunner; HR 16 juni 2006, NJ 2006/585, m.nt. J.H. Spoor

137 BenGH 24 oktober 2005, A 2004/5, NJ 2006/442, r.o. 11.

138 Benelux Convention on Intellectual Property (Trademarks and Designs) of February 25, 2005.

139 Kortmann \& Sieburgh 2009, p. 271.

140 See on the Dutch decisions Van Boom 2011

141 Schelhaas 2004, p. 503.

142 Schelhaas 2004, p. 504-505. 
incentive penalty clause is laid down in the law ( $\$ 339$ BGB). It thereby takes an intermediate position.

Under Dutch law, article 6:94 BW to be precise, the judge has the power to mitigate or supplement the penalty on request of one of the parties and only when fairness obviously requires such action. ${ }^{143}$ The contractual penalty clause known in Dutch law can be used as an example to contradict the often heard argument that punishment cannot be a function of private law. It is a legal remedy with a clear punitive character, similar to the punitive damages remedy. Another parallel between the two remedies is that punitive damages may also be awarded, at least under American law, if a breach of contract and a tort are constituted by the same act. As explained in section 3.2.1, the classical example of a tortious breach of contract is that of bad faith claim handling by insurers. Interestingly, this theme already receives attention in the European punitive damages debate. ${ }^{144}$ Punitive damages are considered a potentially useful mechanism to deal with wrongful practices of insurers. In the United States, it is common practice that bad faith insurance practices are deterred and punished with punitive damages.

However, as already mentioned in section 9.3.2 above, an important difference between the two remedies should not be neglected: the contractual penalty clause differs from the punitive damages remedy as it is in principle not the judge, but the parties to the contract, who deliberately choose for a contractual penalty clause in their contract and decided on the size of the penalty themselves. Thus, the relevance of the contractual penalty clause in respect of the theme of this chapter is that this remedy illustrates that penal remedies are allowed in Dutch private law. Nevertheless, due to the different characters of the two remedies, i.e. the voluntary contractual penalty clause versus the imperative punitive damages remedy, it is not convincing to state that, since the contractual penalty clause forms part of Dutch private law, the punitive damages remedy should also be allowed.

\subsubsection{Other Non-Compensatory Mechanisms}

There are other relevant mechanisms in Dutch private law that have a noncompensatory function. ${ }^{145}$ The question whether a civil sanction is considered relevant in respect of the theme of this chapter was explained in section 9.2.2 above. Three mechanisms will be described at this point.

The first mechanism is the obligation, laid down in article 6:119 BW, of the debtor who is delayed in the payment of a sum of money (e.g. monetary damages) to pay statutory interest on this sum from the moment he does not comply with his obligation to pay. This means that in case of delay, the creditor is entitled to something more than merely the compensatory sum. Although the Dutch Supreme

143 Schelhaas 2004, p. 504; Van Nispen 2003, p. 35. See, with regard to article 6:94 BW, HR 27 april 2007, NJ 2007/262; HR 16 september 2011, NJ 2012/56, m.nt. T.F.E. Tjong Tjin Tai; HR 13 juli 2012, NJ 2012/459.

144 Smeehuijzen 2012, p. 459-470. See also Smeehuijzen 2009.

145 See for a more complete overview: Kortmann \& Sieburgh 2009, p. 257-278; Geerts et al. 2011, p. $59-62$. 
Court has affirmed that the aim of article $6: 119$ BW is to create legal certainty and manageability of the law, ${ }^{146}$ Geerts et al. state that it might in fact stimulate the debtor to comply with his obligation to pay. ${ }^{147}$ This however does not give article 6:119 BW a punitive character. According to Geerts et al., this is different for article 6:119a BW that implements, in conjunction with article $6: 120(2) \mathrm{BW}$, the European Directive on combating late payment in commercial transactions. ${ }^{148}$ On the basis of these provisions, the debtor who pays late in a commercial transaction is obliged to pay statutory interest that is higher than the interest of article 6:119 $\mathrm{BW}$. The reason for this high interest rate is that it is meant to discourage late payment: ${ }^{149}$

Late payment constitutes a breach of contract which has been made financially attractive to debtors in most Member States by low interest rates on late payments and/or slow procedures for redress. A decisive shift, including compensation of creditors for the costs incurred, is necessary to reverse this trend and to ensure that the consequences of late payments are such as to discourage late payment.

Thus, article 6:119a BW does have a non-compensatory and, according to Geerts et al., even a punitive character. ${ }^{150}$ Note that this Directive has been implemented in all of the Member States. For example, the relevant provision in German law is $\S 288$ BGB. On the basis of $\S 288$ BGB, monetary debtors are obliged to pay interest over the period of delay, so that 'faster payment behaviour' is encouraged; the provision therefore has a clear regulatory function. ${ }^{151}$ As this civil sanction is brought into national law by the legislator of the European Union, it is less relevant for the purpose of this chapter. This sanction is an initiative of the European legislator rather than the national legislator.

The second non-compensatory mechanism in Dutch private law can be found in article 7:625 BW. This provision determines that in case of a delay in the payment of salary, the employer is obliged to increase the salary by a certain percentage. This increase is meant to discourage the employer from paying late and clearly has a law enforcement and punitive function. ${ }^{152}$

A third mechanism worth mentioning at this point cannot be found in substantive private law as such, but it is still relevant for private law judgments. The 'civil judicial penalty payment' 153 is a penalty payment with a similar purpose as the contractual penalty clause, namely an incentive to fulfil one's obligations. ${ }^{154}$ The difference between the two is that the contractual penalty clause forms, as

146 HR 11 februari 2000, NJ 2000/275, m.nt. Bos, r.o. 3.5; HR 14 januari 2005, NJ 2007/481, m.nt. Jac. Hijma, r.o. 3.5.4

147 Geerts et al. 2011, p. 60.

148 Geerts et al. 2011, p. 60, citing Directive 2000/35/EC, which has been replaced by the new Directive 2011/7/EU.

149 Directive 2000/35/EC, recital 16 of the Preamble.

150 Geerts et al. 2011, p. 60.

151 Jansen \& Rademacher 2009, p. 84.

152 Kortmann \& Sieburgh 2009, p. 261-262.

153 Translation derived from Beekhoven van den Boezem 2006, p. 413.

154 Kortmann \& Sieburgh 2009, p. 277. 
agreed by the parties, part of a contract, whereas the penalty payment can be imposed by the civil judge as part of a judgment: if the defendant does not comply with the judgment, he has to pay a penalty payment to the claimant. According to Beekhoven van den Boezem: ${ }^{155}$

A civil judicial penalty payment under Dutch law can best be described as a judicial penalty payment imposed by a civil court at the request of an interested party in order to compel the opposing party to comply with the judgment on the merits.

The penalty payment has a procedural nature and is thus part of procedural law. In that sense, it differs from the earlier described remedies. On the other hand, it is a competence of the civil judge who may bring a non-compensatory element into private law situations. In Dutch law, the relevant provision concerning the socalled dwangsom is article 611 a et seq. of the Code of Civil Procedure. ${ }^{156}$ It is often connected to a civil judgment to do or not to do something, i.e. the mandatory or prohibitory injunction of article 3:296 $\mathrm{BW}$, in order to make this judgment more effective. ${ }^{157}$ There is discussion about the punitive nature of the penalty payment, which in theory has a purely preventive character as it is a warning to influence the opposing party. ${ }^{158}$ However, it is beyond questioning that in fact it does function as a punishment, and it might therefore also have a general preventive effect, once the penalty payment is enforced due to disobedience to the civil judgment. ${ }^{159}$ Penalty payments imposed by Dutch courts can reach fairly large amounts; an example is the case of a 75-year-old man who was convicted for assaulting and stalking his neighbours and was sentenced to pay them $€ 300,000$ (once only) if he would set foot on their property again. ${ }^{160}$

\subsubsection{Germany}

\subsubsection{Basic Principles of the Law of Damages}

Similar to Dutch law, German law has a set of general rules on damages that are applicable irrespective of the basis of liability, for example a tort or breach of contract, which can lead to compensation of either material loss (Vermögensschaden) or immaterial loss (Nichtvermögensschaden). ${ }^{161}$ The primary method to assess the damages award is a concrete calculation of damage, although in some situations, such as the calculation of future loss of income, the judge may abstract from the concrete circumstances. ${ }^{162}$ These general rules have been laid down in $\S 249-255$ BGB. Furthermore, some specific rules on the right to damages in case

155 Beekhoven van den Boezem 2006, p. 413.

156 The Dutch provisions are based on the Benelux Treaty containing a uniform law on penalty payments (Benelux Overeenkomst houdende eenvormige wet betreffende de dwangsom).

157 Kortmann \& Sieburgh 2009, p. 276.

158 Beekhoven van den Boezem 2006, p. 413; Kortmann \& Sieburgh 2009, p. 277.

159 Kortmann \& Sieburgh 2009, p. 277.

160 Rb. Utrecht 28 april 2010, ECLI:NL:RBUTR:2010:BM2510.

161 Von Bar 1996, p. 1-6; Snijders et al. 1996, p. 500; Van Dam 2013a, p. 355; Magnus 2001a, p. 94.

162 Magnus 2001a, p. 96. 
of liability based on tort can be found in $\S 842-845$ BGB. According to $\S 249$ BGB below, the starting point is restitution in kind (Naturalherstellung). ${ }^{163}$ Thus, it is for example preferable that the tortfeasor replaces the thing that he damaged rather than that he compensates for the damage with money. However, in the case of personal injury or property damage, reparation in money is allowed: ${ }^{164}$

(1) A person who is liable in damages must restore the position that would exist if the circumstance obliging him to pay damages had not occurred.

(2) Where damages are payable for injury to a person or damage to a thing, the obligee may demand the required monetary amount in lieu of restoration. When a thing is damaged, the monetary amount required under sentence 1 only includes value-added tax if and to the extent that it is actually incurred.

$\S 251$ BGB states that only if reparation is objectively impossible or not adequate, the liable person has to make good the resulting economic loss in money. In practice, most victims receive monetary compensation, whereas restitution in kind is the exception. ${ }^{165}$ Similar to Dutch law, the objective of the German law of damages is restitutio in integrum and full compensation of the victim's loss. ${ }^{166}$ Again, in principle the victim should receive nothing more than compensation for the loss and may not be enriched by the damages award. ${ }^{167}$ Thus, damages awards focus on the loss of the victim rather than the behaviour of the tortfeasor. ${ }^{168}$ Note that this used to be different in the past. Prior to the introduction of the BGB in 1900 , damages law was dominated by the system of gradation, meaning that not only the loss of the victim but also the degree of fault of the tortfeasor was an important factor in assessing the amount of damages: the graver the fault, the higher the damages award. The drafters of the BGB have however explicitly rejected the system of gradation. ${ }^{169}$ In principle, the law of damages nowadays only has a compensatory function (Ausgleichsgedanke). However, as in the Netherlands and France, in practice the compensatory function is not the only recognised function of the law of damages. Deterrence, for example, is an acknowledged side effect of tort damages (Präventionsgedanke), just as the notion of the continuation of a right (Rechtsfortsetzungsgedanke). ${ }^{170}$ Continuation of a right means that the injured right or legal good survives in a damages claim, which is in conformity with the compensatory and deterrent function. As pointed out by Koziol, safeguarding the duty to compensate 'reinforces the incentive to avoid inflicting damage' and thereby serves the deterrent function. ${ }^{171}$ Although the general idea seems to be that a punitive function (Pönalgedanke) of the law of

163 Jansen \& Rademacher 2009, p. 75; Van Gerven, Lever \& Larouche 2000, p. 754.

164 Translation retrieved via: www.gesetze-im-internet.de/englisch bgb/german civil code.pdf.

165 Magnus 2012, p. 247.

166 Markesinis 1999, p. 675; Ebert 2004, p. 248, 528.

167 Jansen \& Rademacher 2009, p. 76.

168 Magnus 2001a, p. 89-91.

169 Wagner 2012, p. 1404. See also section 7.3.3.

170 Koziol 2012, p. 78-82; Ebert 2004, p. 410-411; Van Gerven, Lever \& Larouche 2000, p. 753.

171 Koziol 2012, p. 80. 
damages is not officially recognised, ${ }^{172}$ as will be further explained below it is difficult to draw a clear line between the deterrent and punitive function of German damages awards, especially immaterial damages. ${ }^{173}$ According to Ebert, deterring sanctions are a recognised part of German private law: ${ }^{174}$

Die Nutzung des Privatrechts zur Verhaltenssteuerung, insbesondere die Abschreckung potentieller Rechtsverletzer vor künftigen Rechtsverletzungen durch die Verhängung spürbarer privatrechtlicher Sanktionen, auch unabhängig von der Existenz eines Schadens oder bewusst über den Ausgleich etwaiger Schäden hinaus, gehört mittlerweile auch in Deutschland zu den erklärten Zielen einerVielzahl privatrechtlicher Rechtsinstitute.

She gives the examples of immaterial damages for personality right infringements or for discrimination in labour situations as well as double damages for infringements of intellectual property rights, which will be discussed below.

In a similar manner, Wagner makes clear that immaterial damages awards in case of personality right infringements serve a preventive rather than a compensatory function and that the relatively substantial awards to achieve this goal point towards the recognition of punitive damages in German tort law: ${ }^{175}$

[...] der Geldausgleich bei Persönlichkeitsverletzungen solle weniger dem Schadensausgleich als vielmehr "der Prävention dienen", weshalb die Entschädigung so hoch anzusetzen sei, daß von ihr ein "echter Hemmungseffekt" für die unautorisierte Vermarktung der Persönlichkeit der Klägerin ausgehe. Nach einer verbreiteten Meinung hat der BGH damit das Institut der punitive damages auch in das deutsche Deliktsrecht eingeführt, sich damit allerdings mindestens so viel Feind 'wie Ehr' gemacht.

Also in Germany there is indeed more and more discussion on the question whether punitive damages would be a good addition to the German law of damages. ${ }^{176}$

The following section will explore the first recognised remedy in German law that includes non-compensatory elements: immaterial damages. This part of German damages law is also seen as 'the traditional battlefield for debates on punitive damages'. ${ }^{177}$

\subsubsection{Immaterial Damages}

This section will take a closer look at German immaterial damages awards and starts with some general remarks. Similar to Dutch law and dissimilar to French and English law, German law does not distinguish between different types of loss

172 Jansen \& Rademacher 2009, p. 76; Magnus 2001a, p. 90; Magnus 2012, p. 246; Koziol 2012, p. 83.

173 Van Gerven, Lever \& Larouche 2000, p. 753; Jansen \& Rademacher 2009, p. 77; Van Dam 2013a, p. 351.

174 Ebert 2004, p. 528.

175 Wagner 2006b, p. 359.

176 Wagner 2006a, p. A 68 - A 105; Koziol 2012, p. 50-57. See also, for example, two dissertations on punitive damages in German law: Müller 2000; Fritz 2004.

177 Jansen \& Rademacher 2009, p. 77. 
for which damages for pain and suffering (Schmerzensgeld) can be granted. ${ }^{178}$ As will be further explained below, German law does, however, make a distinction between Schmerzensgeld and compensation for personality right infringements. ${ }^{179}$ Furthermore, the Germans explicitly accept that immaterial damages serve the functions of compensation (Ausgleich) and satisfaction (Genugtuung), in addition to the preventive function in case of personality right infringements. ${ }^{180}$ According to Markesinis: ${ }^{181}$

\begin{abstract}
As the Grosser Zivilsenat explained in its decision of 6 July 1955 (BGHZ 18, 149), the claim for damages for pain and suffering offers the injured party an appropriate compensation for the depreciation of life (or personality) which is not of a pecuniary kind. But it also takes account of the notion that the doer of damage owes the injured party satisfaction for what he has done to him. It was emphasized in the discussion that 'satisfaction', which forms an integral part of the award for compensation for immaterial damage, must take into account all the relevant circumstances.
\end{abstract}

The acceptance of the satisfaction function of immaterial damages is the result of work of nineteenth century German scholars, according to whom immaterial damages did not have a compensatory function as the payment of a sum of money could not compensate immaterial losses. ${ }^{182}$ Immaterial damages were hence considered a form of punishment, and from this theory the Genugtuungsfunktion developed. The satisfaction function of immaterial damages is also explicitly recognised in the Dutch legal system, whereas the French and English legal system do not openly recognise this function. ${ }^{183}$ The money should help the claimant to overcome negative feelings caused by the wrongdoing. In case of serious wrongdoing - for example grave personality right infringements - the satisfaction function is even said to introduce punitive elements because the behaviour of the tortfeasor rather than the loss of the victim is the primary factor in assessing the award, and because the award can be compared with a criminal law penalty rather than a form of satisfaction. ${ }^{184}$ According to Wagner: ${ }^{185}$

Das Schmerzensgeld diene nicht nur dem Ausgleich des immateriellen Schadens, sondern darüber hinaus der Bestrafung des Täters und der Genugtuung des Opfers.

Although satisfaction is not necessarily synonymous with punishment, as with deterrence and punishment it is difficult to draw a clear line between a satisfaction function and a punitive function. However, Magnus rejects the punitive function and claims that the satisfaction function is an 'extended compensation for the

178 Van Dam 2013a, p. 363

179 Ebert 2004, p. 520.

180 BGH 6 July 1955, BGHZ 18, 149; Stoll 1970, p. 4-5; Van Gerven, Lever \& Larouche 2000, p. 753; Van Dam 2013a, p. 349; Snijders et al. 1996, p. 503; Jansen \& Rademacher 2009, p. 79; Wagner 2006b, p. 382; Koziol 2012, p. 77.

181 Markesinis 1990, p. 303

182 Jansen \& Rademacher 2009, p. 78; Verheij 2002, p. 396.

183 Verheij 2002, p. 389

184 Magnus 2012, p. 252; Markesinis 1990, p. 682; Jansen \& Rademacher 2009, p. 79

185 Wagner 2006b, p. 382 
infringement of immaterial rights' that remain otherwise unprotected. ${ }^{186}$ The satisfactory function of Schmerzensgeld for bodily injury plays a minor role, he argues, which for instance follows from the example that German courts award considerable damages to victims who are in coma and probably no longer feel satisfaction. ${ }^{187}$ Magnus also makes clear that punishment is not an aim of German civil law, even though 'the idea of satisfaction resembles to some extent the consideration that damages serve as penalty or sanction for civil wrong'. ${ }^{188}$ As follows from a recent publication, this may be explained by the fact that he seems to be in favour of a strict public-private divide and is for that reason not in favour of introducing punitive damages in German law. ${ }^{189}$ In a similar manner, the Austrian author Koziol is critical of the introduction of punitive damages in continental Europe. ${ }^{190}$ Koziol also points out that even though accepting the satisfaction function of immaterial damages comes close to accepting private penalties, this function forms part of the compensatory function: ${ }^{191}$

[...] for instance, if more damages for pain and suffering are to be awarded to the victim in the case of gross negligence on the basis of the satisfaction function, this could also be justified to a certain extent according to the compensatory function, since in cases where the damaging action was particularly seriously wrong, the emotional damage inflicted thereby is exacerbated.

In contrast, similar to Wagner mentioned above, Ebert does not see a real difference between punitive damages and compensation for personality right infringements: ${ }^{192}$

Auch ist nicht ersichtlich, warum die Höhe der einem Beklagten drohenden punitive damages unbestimmter und damit schwerer vorhersehbar sein sollte als etwa die Höhe einer Geldentschädigung bei Verletzungen des allgemeinen Persönlichkeitsrechts durch Massenmedien.

Moreover, although the German Supreme Court is of the opinion that the satisfaction function of immaterial damages is still of a private law nature, meaning that damages for pain and suffering have a purely compensatory function, it is at least remarkable that, when compared to other European countries, immaterial damages awards for serious injuries in Germany are rather substantial. ${ }^{193}$ For example, in 2003 a court granted the large sum of $€ 500,000$ plus $€ 500$ per month to (the parents of) a severely handicapped three-year-old child. ${ }^{194}$ Van Dam confirms that this is the highest sum awarded for pain and suffering thus far in

186 Magnus 2012, p. 252.

187 Magnus 2012, p. 252.

188 Magnus 2001a, p. 90.

189 Magnus 2012, p. 257.

190 Koziol 2012, p. 51, 54

191 Koziol 2012, p. 77.

192 Ebert 2004, p. 529.

193 Van Dam 2013a, p. 365.

194 Lindenbergh 2008a, p. 77, citing LG Kiel 11 July 2003, AZ O 13/03. 
Germany. ${ }^{195}$ By way of comparison: the highest sum awarded in the Netherlands is $€ 150,000$, in France $€ 154,000$, and in England $£ 265,000( \pm € 330,000)$. ${ }^{196}$ Interestingly, German courts increase the amount of Schmerzensgeld in case of bad faith insurance practices, which could be seen as a form of punishment. ${ }^{197}$ As explained in section 9.4.1.4 above, it is common practice in the United States that bad faith insurance practices are deterred and punished with punitive damages.

To end with, it is difficult to draw a clear line between a deterrent and satisfactory function of immaterial damages on the one hand and a punitive function on the other hand. As will be explained in the following sections, taking the German approach towards compensation for immaterial loss into account, especially in case of personality right infringements, it is however arguable that such awards do have a punitive function.

\subsection{General Legal Basis}

According to $\S 253$ BGB, Schmerzensgeld can only be awarded if this is provided for by statute. The main legal basis can be found in the second paragraph of this article, stating that in case of 'an injury to body, health, freedom or sexual selfdetermination', reasonable monetary compensation can also be awarded for immaterial loss. In deciding on the amount of Schmerzensgeld in a particular case, German courts can refer to published lists ranging categories of damages (Schmerzensgeldtabellen, comparable to the French barèmes that will be explained in section 9.4.3.1 below). ${ }^{198}$ According to Magnus, if a court has followed these tables of standardised amounts, which is usually the case, it is difficult to qualify damages for pain and suffering as punitive. ${ }^{199}$ Like the Dutch article 6:106 BW, $\S 253$ II BGB forms a closed system of situations that give reason to compensation for immaterial loss. However, the structure of both provisions leaves room for development of the law. This may even be more so the case in Dutch law, as article 6:106(1)(b) BW gives a claimant a right to compensation of immaterial loss in case of physical injury, when his honour or reputation is infringed, or when his person is in another way injured. Although this latter category does not encompass all forms of misfortune that may happen in a person's life, it gives the Dutch judge an option to take infringements of personality rights into account that are not physical nor aimed at a person's honour or reputation. ${ }^{200}$ A comparable broad category cannot be found in the German provision. However, on balance, the difference between the two legal systems seems to be fractional due to the existence in German law of a judge-made right to compensation in case of infringements of the general personality right, which will be further explained below. The exception of $\S 253$

195 Van Dam 2013a, p. 364.

196 Lindenbergh 2008a, p. 77; Van Dam 2013a, p. 364.

197 OLG Nürnberg, 30 April 1997, NJWE-VHR 1997, 179; OLG Frankfurt, 7 January 1999, NJW 1999, 2447; OLG Naumburg, 13 November 2003, NJOZ 2004, 1659; OLG Nürnberg, 22 December 2006, NZV 2007, 301.

198 Ebert 2004, p. 458; Magnus 2012, p. 252; Van Dam 2013a, p. 363

199 Magnus 2012, p. 252.

200 Lindenbergh 2008a, p. 31. 
II BGB used to be incorporated into $\S 847$ BGB and was therefore only applicable to tort cases, but this changed with a reform of the BGB in 2002 leaving it applicable to both breach of contract and tort situations, as long as one of the interests mentioned is violated. ${ }^{201}$ The protected interests of $\S 253$ II BGB are also extended to the area of strict liability, for example in $\S 11$ StVG and $\S 8$ ProdHG. ${ }^{202}$

Apart from $\S 253 \mathrm{BGB}$, the remaining statutory examples are damages for discrimination and harassment, sexual or moral, in labour law situations ${ }^{203}$ as well as damages for ruined package holidays ( $\$ 651 \mathrm{f} \mathrm{BGB}) .{ }^{204}$ As pointed out by Jansen and Rademacher, the first category of damages for discrimination and harassment has a non-compensatory character. ${ }^{205}$ The relevant provision, i.e. $\S 15$ of the German Equal Treatment Act, used to form part of the BGB (formerly $\S 611 \mathrm{a}$ BGB) and implements European Union law in German law. ${ }^{206}$ Thus, as this provision is in line with European Union law and a ruling of the CJEU, to be precise the case of Von Colson and Kamann, it is not a typical German law provision but it nevertheless forms part of German law. As explained in section 7.2.3, the Court decided in the Von Colson and Kamann case that a sanction should 'guarantee real and effective judicial protection' against unlawful discrimination, which must have 'a real deterrent effect on the employer'. ${ }^{207}$ Indeed, $\S 15$ of the Equal Treatment Act, as well as its predecessor $\S 611 \mathrm{a}$ BGB, is seen as a noncompensatory remedy in German private law with a clear preventive function. ${ }^{208}$ Wagner sees this remedy as the so-called cause celèbre of German damages awards with a preventive function based on European legislation. ${ }^{209} \mathrm{He}$ also refers to authors who compare the remedy to the punitive damages remedy and call it a 'Sanktionsvehikel'. ${ }^{210}$ However, according to Jansen and Rademacher, the remedy plays a relatively minor role in German private law: ${ }^{211}$

$[\ldots]$ this sanction primarily serves a regulative purpose: it punishes the employer for his unsocial behaviour. This, however, has to be regarded as an insignificant exception from the fundamental principle of compensation underlying the German law of damages. It is an exceptional rule that was extrinsically brought into German private law by the European legislator and by the ECJ.

201 Koziol 2012, p. 104; Van Dam 2013a, p. 356.

202 Van Dam 2013a, p. 356.

$203 \S 15(1)$ and (2) of the Equal Treatment Act (Allgemeines Gleichbehandlungsgesetz), formerly $\S$ 611a BGB, which implements Directives 76/207/EEC, 2000/43/EC and 2000/78/EC into German law.

204 Magnus 2001a, p. 94.

205 Jansen \& Rademacher 2009, p. 84-85.

206 CJEU 10 April 1984, case 14/83, ECR 1891 (Von Colson and Kamann v. Land NordrheinWestfalen).

207 Von Colson and Kamann v. Land Nordrhein-Westfalen, at $\S 23$.

208 Ebert 2004, p. 521, 528.

209 Wagner 2006b, p. 389.

210 Wagner 2006b, p. 392-393.

211 Jansen \& Rademacher 2009, p. 85. 
Although preventive damages may technically be considered as something else than punitive damages, in practice it is difficult to draw a clear line between the two. Section 6.2.2.6 above already explained that the Commentary to article 10:101 PETL on the nature and purpose of damages for example affirms the statement that the borderline between the aim of prevention and the aim of punishment may be difficult to draw. According to a number of authors, the CJEU in Von Colson and Kamann for example connects a punitive function to the required sanction by ruling that the sanction must cause a real deterrent effect. ${ }^{212}$ Damages for discrimination or harassment on the basis of the German provision are likewise considered to have other purposes than mere compensation. Note that, as explained in section 7.2.5, anti-discrimination law is a legal field in which punitive damages could certainly play a role. In this regard, the American legal system forms an example: there is a relatively high occurrence of punitive damages in American employment discrimination cases, because punitive damages are seen as an important method to prevent discrimination.

\subsection{Das Allgemeine Persönlichkeitsrecht}

One should be aware of the fact that in addition to the above-mentioned bases for immaterial damages awards in German law, there is a judge-made right to compensation of immaterial loss in cases of serious infringements of the general personality right (das allgemeine Persönlichkeitsrecht) created by the German Supreme Court in $1954 .^{213}$ The general personality right is seen as an 'other right' within the meaning of $\S 823(1) \mathrm{BGB}$, the general tort provision that includes a list of protected interests. The right to an effective remedy, i.e. immaterial damages, in case of infringement of this right - which covers all kinds of situations relating to the protection of human dignity and the development of one's personality - was established a few years later in the Herrenreiter case and confirmed in the Ginseng case. $^{214}$ As the right to compensation could not be based on (old) $\S 847 \mathrm{BGB}$, the Court found a basis in articles 1 (the right to human dignity) and 2(1) (the right to free development of one's personality) of the German Constitution. ${ }^{215}$ Like in Dutch law, the requirement of a serious personality right infringement is important: an insignificant infringement is not sufficient. ${ }^{216}$ As will be explained below, this is different in France where the mere infringement - which means even in the absence of fault - of the right to privacy is sufficient for an immaterial damages award.

As in Dutch law, German immaterial damages awards for personality right infringements can be more substantial than those relating to immaterial loss due to personal injury, but this of course depends on the seriousness of the personal

212 Jansen \& Rademacher 2009, p. 85; Behr 2003, p. 142.

213 BGH 25 May 1954, BGHZ 13, 334 (Schacht).

214 BGH 14 February 1958, BGHZ 26, 349 = NJW 58, 827 (Herrenreiter); BGH 19 September 1961, BGHZ 35, 363 (Ginseng); Ebert 2004, p. 495-496; Van Dam 2013a, p. 356; Van Gerven, Lever \& Larouche 2000, p. 147.

215 Van Dam 2013a, p. 186.

216 Van Gerven, Lever \& Larouche 2000, p. 147. 
injury; as was shown in section 9.4.2.2 above, Schmerzensgeld on the basis of $\S 253$ II BGB can also be considerable. ${ }^{217}$ The introduction to this section already explained that compensation for personality right infringements is not similar to compensation for pain and suffering. Rather, according to Von Bar and Drobnig the idea behind it is that without compensation 'breaches of the dignity and honour of people would often remain without sanction with the consequence that legal protection of personality would die'. ${ }^{218}$ Van Dam explains, with reference to a case decided by the German Constitutional Court, that this distinction is also justified on the basis of the preventive effect that is sorted by substantial awards for personality right infringements. ${ }^{219}$ There is of course a connection between these two reasons: without remedies rules will usually have no effect, so that the undesired behaviour that is forbidden by the rule will not be prevented.

In calculating an immaterial damages award, judges should take into account all the circumstances of the case, such as the seriousness and consequences of the injury but also the degree of fault of the tortfeasor. ${ }^{220}$ Especially in case of infringements of the personality right through mass media, courts can take into account 'the gravity of the infringement, fault on the part of the infringer and preventive considerations'. ${ }^{221}$ Wagner pays considerable attention to the preventive function of German immaterial damages awards for personality right infringements, ${ }^{222}$ and also, according to other authors, this preventive function plays an essential role in such cases. ${ }^{223}$ The importance of the preventive function becomes clear in the case of Caroline von Hannover, also known as Caroline I, which was already explained in the introduction to chapter seven: ${ }^{224}$

Eine Verurteilung zur Geldentschädigung ist aber nur dann geeignet, den aus dem Persönlichkeitsrecht heraus gebotenen Präventionszweck zu erreichen, wenn die Entschädigung der Höhe nach ein Gegenstück auch dazu bildet, daß hier die Persönlichkeitsrechte zur Gewinnerzielung verletzt worden sind. Das heißt zwar nicht, daß in solchen Fällen rücksichtsloser Kommerzialisierung der Persönlichkeit eine "Gewinnabschöpfung" vorzunehmen ist, wohl aber, daß die Erzielung von Gewinnen aus der Rechtsverletzung als Bemessungsfaktor in die Entscheidung über die Höhe der Geldentschädigung einzubeziehen ist. Von der Höhe der Geldentschädigung muß deshalb ein echter Hemmungseffekt auch für solche Vermarktung der Persönlichkeit ausgehen.

Thus, a preventive function of immaterial damages is accepted, and also supposedly needed, if the infringement of a personality right resulted in commercially achieved profit aimed for by the defendant. This profit may then be taken into

217 Van Dam 2013a, p. 351; Magnus 2001a, p. 96.

218 Von Bar \& Drobnig 2004, p. 117. See also Koziol 2012, p. 113.

219 Van Dam 2013a, p. 352. See also Von Bar \& Drobnig 2004, p. 117.

220 Magnus 2001a, p. 95; Magnus 2001b, p. 186; Gotanda 2007, p. 517; Behr 2003, p. 130.

221 Magnus 2001a, p. 96.

222 Wagner 2006b, p. 380-386; Wagner 2012, p. 1404.

223 Magnus 2012, p. 252; Amelung 1999, p. 22.

224 BGH 15 November 1994, BGHZ 128, 1 = NJW 1995, 861 (Caroline I), at $\S 865$ 
account as a factor in deciding the amount of damages. Another decisive factor could be the intensity of the infringement:

Als weiterer Bemessungsfaktor kann die Intensität der Persönlichkeitsrechtsverletzung berücksichtigt werden. Dabei ist in Betracht zu ziehen, daß vor allem die Veröffentlichung des erfundenen Exklusiv-Interviews schwer wiegt.

The Court continues that the freedom of press should not be put at risk by disproportionate damages awards. In cases of insignificant injury, courts should always balance the general personality right of the claimant and the right to freedom of expression of the defendant. ${ }^{225}$ However, in the present case, disproportionality is out of question due to the rude commercialisation of Caroline's person:

Weiter gilt es zu berücksichtigen, daß die Geldentschädigung nicht eine Höhe erreichen darf, die die Pressefreiheit unverhältnismäßig einschränkt. Hiervon kann allerdings keine Rede sein, wenn die Presse an einer rücksichtslosen Vermarktung der Person gehindert wird, wie sie hier Gegenstand des Rechtsstreits ist.

The case was referred back to the Court of Appeal in Hamburg, and Caroline received an immaterial damages award of DM 180,000 $( \pm € 100,000){ }^{226}$ As mentioned in the introduction to chapter seven, this sum covers damages for the two later wrongful publications and is one of the highest immaterial damages awards ever imposed for personality right infringements in Germany. Magnus estimates the median for compensation in these cases at $€ 10,000 .^{227}$ It is interesting to see that prevention is explicitly mentioned in Caroline $I$ as a function of immaterial damages for personality right infringements. The preventive effect is since then an important factor in calculating the immaterial damages award, which is also interesting in light of the punitive damages debate: ${ }^{228}$

By introducing the factor of deterrence in cases of infringement of privacy, the BGH arguably crosses the borderline between compensation and punishment and has therefore been criticized for blurring the distinction between civil law and criminal law.

In respect of this debate, section 9.4.2.1 above refers to Wagner, who has made clear that the relatively substantial awards for personality right infringements in German law point towards the recognition of punitive damages in German tort law. Indeed, the deterrent function of immaterial damages awards for personality right infringements becomes evident in specific situations of intentional, calculative and grave misconduct. As explained in section 7.3.2, these are the forms of misconduct that are connected to the punitive damages remedy in the European punitive damages debate.

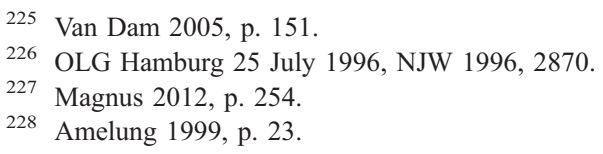




\subsection{Difference between Personality Right Infringements and Personal Injury}

Cases

The previous section has addressed immaterial damages for infringements of the general personality right. The difference, as regards immaterial damages, between personality right infringements and personal injury becomes clear from the abovementioned decision of the German Constitutional Court that was referred to by Van Dam. $^{229}$ This case was about a father and mother who lost their three children in a traffic accident. They suffered immensely from mental and physical harm as a result of their loss, but the initial court deciding their case only awarded half of the immaterial damages they had claimed. Based on what they know about German immaterial damages awards in the case of personality right infringements, the parents went to the Constitutional Court claiming that the decision was in violation of article 3, concerning equal treatment, of the Constitution. Their claim is dismissed. The reasoning of the Court was that the preventive effect of substantial immaterial damages awards in the case of personality right infringements cannot be achieved in case of traffic accidents, as in these cases the award is not paid directly by the tortfeasor but by his insurance company. Magnus also refers to 'the primarily compensatory character' of immaterial damages awards in the case of bodily injury. ${ }^{230}$ This notion is supported by the fact that, as mentioned before, on a regular basis lists with standard categories of immaterial damages, i.e. amounts per bodily injury, that have already been awarded are published to be used as guidance by German courts. ${ }^{231}$ It is important to point out that one might disagree with this reasoning and argue that also in case of bodily injury prevention is an important side effect - although this may be less obvious - since insurance companies worldwide usually pass on the incentive given by the damages award to their clients in the form of an (increased) insurance premium. However, Wagner also makes clear that the preventive function of immaterial damages awards does not play a very significant role in personal injury cases, although he does not completely exclude this function: ${ }^{232}$

Im Bereich des eigentlichen Schmerzensgeldes für Verletzungen von Körper und Gesundheit spielt der Präventionsgedanke bisher keine eigenständige Rolle, d.h. (das heißt, LM) der Gesichtspunkt derVerhaltenssteuerung wird nicht ausdrücklich als Faktor für die Schmerzensgeldbemessung anerkannt.

What does the information provided thus far bring us? At this point, the following conclusion can be drawn: German immaterial damages awards especially - but not only - serve a deterrent function in case of personality right infringements. Furthermore, the German debate on the need for powerful civil sanctions, possibly even punitive damages, seems to originate primarily in these cases. A comparable

229 Van Dam 2013a, p. 351-352, citing BVerfG 8 March 2000, NJW 2000, 2187. See, for other case law of the BVerfG related to personality right infringements, Ebert 2004, p. 502-506.

230 Magnus 2012, p. 252.

231 Van Dam 2013a, p. 363; Magnus 2012, p. 252.

232 Wagner 2006b, p. 382. 
tendency of substantial immaterial damages awards for infringements of honour or reputation can be pointed out in Dutch law, as was shown in section 9.4.1.2 above. Thus, in these specific situations, Dutch and German courts have less difficulty with imposing strong civil sanctions.

\subsubsection{Disgorgement of Profit}

Under German law, the restitution of profit resulting from wrongful behaviour of a tortfeasor is regulated by the law of unjust enrichment. ${ }^{233}$ The law of damages concentrates on the loss of the victim, whereas the profit gained by the tortfeasor is in principle not included. Thus, the German law of damages does not have a general disgorgement of profit provision similar to the Dutch article 6:104 BW. However, in certain specific situations the profit made can be taken into account by the judge calculating the damage. An important example is the infringement of intellectual property rights on the basis of $\S 97(1)$ Urheberrechtsgesetz, the German Copyright Act. ${ }^{234}$ The disgorgement of profit moves away from the general principle of calculating damages on the basis of the actual loss of the victim. Also in case of infringement of antitrust provisions, the profit made by the wrongdoer is a factor that can be taken into account when measuring the damages award. This follows from $\S 33$ and $\S 34$ Gesetz gegen Wettbewerbsbeschränkungen, which is the Antitrust Act. ${ }^{235}$ Furthermore, in case of personality right infringements, German courts have shown that the profit made by for example a tabloid is a factor that can be taken into account when the immaterial damages award is calculated. In addition to satisfaction of the victim that results from the disgorgement of profit from the tortfeasor, this method is justifiable in these situations because of the above-mentioned preventive and perhaps even punitive function of the immaterial damages award. Also in respect of disgorgement of profit, the punitive function of immaterial damages is however disputed; the more generally accepted view is that such awards primarily have a restitutionary purpose. ${ }^{236}$

\subsubsection{Contractual Penalty Clause}

Like Dutch law, German law is familiar with contractual penalty clauses. Although this civil remedy forms part of this overview of German civil sanctions, the remarks made with regard to the Dutch contractual penalty clause also apply to this subsection. It should be emphasised once more that the relevance of the contractual penalty clause in respect of the theme of this chapter is that it illustrates that penal remedies are allowed in German private law. However, the contractual penalty clause is not completely comparable to the punitive damages remedy due to the different characters of the two remedies, i.e. the voluntary contractual penalty clause against the imperative punitive damages remedy. In contrast, other civil

\footnotetext{
233 Magnus 2001a, p. 90; Koziol 2012, p. 65.

234 Jansen \& Rademacher 2009, p. 81; Magnus 2001a, p. 91

235 Magnus 2012, p. 255.

236 Jansen \& Rademacher 2009, p. 77, 80-82.
} 
remedies, such as the immaterial damages award and the possibility to disgorge profit, are more in line with and comparable to the punitive damages remedy.

As mentioned in section 9.4.1.4 above, both the assessment of damage function and the incentive function of the contractual penalty clause is recognised in German law. Only the incentive penalty clause is laid down in the law, in $§ 339$ BGB regulating the Vertragsstrafe. The penalty clause that fixes the amount of damages to be awarded, the so-called Schadensersatzpauschalierung, is also valid under German law but is short of a legal basis. ${ }^{237}$ Most of the rules concerning the Vertragsstrafe are however analogously applicable to this latter form of the contractual penalty clause. Also, the German judge has the power, under $\S 343$ $\mathrm{BGB}$, to mitigate the contractual penalty clause. As indicated by Magnus, the contractual penalty clause is a good example of the recognition of punitive elements in German private law. ${ }^{238}$ However, this particular legal remedy does not seem to play a very important role in the German punitive damages debate, which obviously has to do with the above-mentioned difference in nature with the punitive damages remedy.

\subsubsection{Other Non-Compensatory Mechanisms}

Similar to Dutch law, another non-compensatory mechanism in German law that is relevant for this chapter can be mentioned. An allegedly punitive element in German private law can be found in the case law concerning GEMA, which is an organisation that protects the intellectual property rights of those who are involved in the business of creating music, such as composers. ${ }^{239}$ The German Supreme Court has decided that a person who infringes an intellectual property right of one of the protected members of GEMA has to pay double the license fee he owes the organisation. ${ }^{240}$ The punitive character of this remedy is justified because otherwise potential infringers would have no incentive to comply with the rules. ${ }^{241}$ The legal basis for this mechanism can be found in $\S 54 \mathrm{f}$ and $\mathrm{g}$ Urheberrechtsgesetz. By imposing this form of double damages, the wrongdoer pays for a part of the costs that GEMA has to make to protect its members, even though the wrongdoer did not cause these costs. ${ }^{242}$

Sections 9.4.1 and 9.4.2 above provided an overview of sanctions in Dutch and German private law that are relevant in view of the theme of this chapter. It was seen that civil sanctions that closely resemble the punitive damages remedy are not recognised in the Netherlands and Germany, but civil remedies with non-compensatory elements are. Examples, in both legal systems, are the possibility to disgorge profit that is wrongfully gained by a tortfeasor and the contractual penalty clause.

237 Schelhaas 2004, p. 47.

238 Magnus 2012, p. 252.

239 Schäfer 2002, p. 418; Jansen \& Rademacher 2009, p. 82; Magnus 2012, p. 254.

240 BGH 24 June 1955, BGHZ 17, 376; BGH 10 March 1972, BGHZ 59, 286. See, on the GEMA-case law, Wagner 2006b, p. 376-378; Ebert 2004, p. 546-548.

241 Annex to Green Paper 2005, p. 36.

242 Jansen \& Rademacher 2009, p. 83. 
Moreover, it has become clear that, again in both legal systems, the function of tort damages is not merely compensation. Particularly interesting in this regard are immaterial damages awards which obviously deviate from the principle of full compensation and serve the functions deterrence, satisfaction and even punishment. In Dutch law, lower courts have shown willingness to award substantial immaterial damages in cases of serious wrongdoing. Although the German Supreme Court has made clear that the satisfaction function of Schmerzensgeld is still of a private law nature, meaning that damages for pain and suffering have a purely compensatory function, awards on the basis of $\S 253$ II BGB in cases involving serious injury are remarkably high when compared to surrounding countries. Furthermore, in both legal systems the deterrent and punitive function of immaterial damages is mostly visible in case of serious personality right infringements: such infringements might lead to substantial awards, also in comparison to similar awards for physical injury. It is thus not without reason that within Europe the punitive damages remedy is often connected to situations of intentional, calculative and grave misconduct, for example in the field of personality rights.

To conclude, although tort damages with a clear punitive function are in theory not accepted in both the Netherlands and Germany, especially the practice of awarding substantial immaterial damages shows that courts in both countries in fact recognise a form of tort damages that comes close to preventive and punitive damages. Given the available civil sanctions in the Netherlands and Germany, these legal systems will take an intermediate position on the comparison scale that will be presented in section 9.5. The following subsection will explore the French legal system, which seems to have a rather liberal view on civil sanctions and will therefore be situated more on the punitive side of the scale than the Dutch and German legal system.

\subsubsection{France}

\subsubsection{Basic Principles of the Law of Damages}

French law does not have a general regulation of damages as exists in Dutch and German law. Damages for torts are regulated separately by article $1382 \mathrm{Cc}$ and depend on the interpretation of this tort provision by the courts. The French rules on damages recoverable for a breach of contract can be found in articles 1146 to $1155 \mathrm{Cc}$. These rules are in principle only applicable for breach of contract, but, as the rules on contract are the result of general principles developed by the courts, they are in fact also applicable to non-contractual situations. ${ }^{243}$ Also in French law, a distinction is made between material damage - either actual loss or loss of profit - (dommage patrimonial) which is the loss of 'having' (avoir) and immaterial or moral damage (dommage moral) which is the loss of being (être). ${ }^{244}$ The meaning of the word damage in the general tort provision article $1382 \mathrm{Cc}$ is to be interpreted

243 Van Gerven, Lever \& Larouche 2000, p. 57; Van Dam 2013a, p. 353.

244 Snijders et al. 1996, p. 276; Van Dam 2013a, p. 354, 363. 
by the courts and is therefore almost entirely decided by case law. ${ }^{245}$ In this respect, three requirements have been developed by the courts: (1) someone must have suffered damage; (2) this damage needs to be suffered in respect of a legitimate interest; and (3) the damage has to be sufficiently certain and personal. ${ }^{246}$ Note that some guidance on the calculation of damages can also be found in the above-mentioned provisions relating to breach of contract. ${ }^{247}$

An interesting aspect of French tort law is that it was initially designed to discourage socially undesirable behaviour and only gradually developed into a system that aims at protecting private law interests and compensating loss. ${ }^{248}$ This explains the (covert) recognition, probably even more than in Dutch and German law, of deterrent and punitive elements in French tort law. The French legal system nowadays has a very victim-friendly approach, thereby aiming to compensate as much loss as possible. French tort law is mainly based on the policy approach of distributive justice, meaning that all goods - this includes losses - in society must be distributed, taking into consideration every person's needs and desires. ${ }^{249}$ This also explains why French tort law has quite some strict liability rules, such as the Loi Badinter concerning victims of traffic accidents, which make it easier for a victim to be compensated. Corrective justice, the opposite of distributive justice, is more concerned with regulating conduct without considering the needs of the parties involved. The English tort system is an example of a corrective tort system and focuses primarily on simple fault liability rather than strict liability. The German and Dutch tort systems take a somewhat intermediate position.

As in other continental European legal systems, restitutio in integrum is the point of departure for French courts awarding compensatory damages. ${ }^{250}$ At first sight, full compensation (réparation intégrale) of the victim, and nothing more than that (tout le dommage, mais rien que le dommage), is the only basic principle. $^{251}$ The assessment of damages falls within the discretion of the first and second instance courts. ${ }^{252}$ French courts have a lot of freedom in fixing the amount of the damages award, and the amount cannot be challenged in cassation, as according to the French Supreme Court this is a question of fact and not of law. ${ }^{253}$ The main compensatory function of tort law also follows from the three requirements to hold someone liable on the basis of article $1382 \mathrm{Cc}$ : damage, fault and causation. In fact, these are the three conditions for civil liability in general, that is both contractual and non-contractual liability. ${ }^{254}$ Thus, unlike common law

245 Van Gerven, Lever \& Larouche 2000, p. 803; Van Dam 2013a, p. 353.

246 Van Dam 2013a, p. 353; Snijders et al. 1996, p. 276; Galand-Carval 2001, p. 80.

247 Galand-Carval 2001, p. 79.

248 Van Gerven, Lever \& Larouche 2000, p. 61.

249 Van Dam 2013a, p. 145-146. See on the different justice theories underlying tort law also section 6.2.1.

250 Von Bar 1999, p. 144.

251 Galand-Carval 2001, p. 78; Snijders et al. 1996, p. 278.

252 Borghetti 2009, p. 55.

253 Van Dam 2013a, p. 354.

254 Van Gerven, Lever \& Larouche 2000, p. 58. 
systems, French law does not have the concept of torts that are actionable per se (i.e. a wrong without damage), meaning that sanctioning wrongful conduct plays a lesser role in tort law. Nevertheless, in case someone has not suffered appreciable harm but the harm was for example caused by the violation of an intangible property right, French courts may award nominal damages - the so-called euro symbolique - which also shows that compensation is not the sole purpose of the law of damages. ${ }^{255}$ Rather, the aim of a nominal damages award is the declaration of the victim's infringed right.

Thus, in principle the exclusive function of monetary damages is full compensation or the reparation of harm. ${ }^{256}$ The French Supreme Court is extremely loyal to the principle of full compensation and has even decided that in the assessment of damages, only the harm sustained and not, for example, the degree of culpability of the wrongdoer can be taken into account. ${ }^{257}$ But, although the judge should in principle consider only the 'seriousness of the harm, not the seriousness of the wrong', it appears that French judges use their sovereign power (pouvoir souverain) to take into account circumstances that cannot easily be reconciled with the compensatory approach, such as the behaviour of the tortfeasor, to grant fairly substantial awards. ${ }^{258}$ This practice is for instance based on a broad interpretation of the general tort provision, article $1382 \mathrm{Cc}$, and especially happens in case of very serious faults. The sovereign power applies to the triers of fact, which are not only the courts of first instance but also the courts of appeal, who must assess the size of the damages award in concreto, i.e. on the basis of the facts and concrete circumstances of the case. ${ }^{259}$ It is a very far-reaching power: ${ }^{260}$

The judge is not obliged to specify the elements which have been taken into account in the assessment of damages; he is not bound by any model; he is not obliged to follow the method used by plaintiff or defendant; he can allow one global amount for all the harm sustained (toutes causes de prejudice confondues), or he can split the award.

French courts rarely explain how they have come to a certain damages award: it is enough to point out that the award sufficiently compensates the loss. Because judgments are very concise and lack reasoning or details, and also because the assessment of damage is a matter of fact, it is difficult for the French Supreme Court to quash decisions of the lower courts. Due to the lack of information on the calculation of the award, the highest court can seldom prove that lower courts violated the principle of full compensation. ${ }^{261}$ Thus, French courts are quite easily in a position to award damages which exceed the loss of the victim. Civil liability

255 Van Dam 2013a, p. 349, 354.

256 Van Gerven, Lever \& Larouche 2000, p. 764; Borghetti 2009, p. 56.

257 Van Gerven, Lever \& Larouche 2000, p. 765, citing Cour de cassation, Deuxième chambre civile, 8 mai 1964 (Harang-Martin v. Bonneau).

258 Borghetti 2009, p. 62; Galand-Carval 2001, p. 77; Von Bar \& Drobnig 2004, p. 113; Koziol 2009, p. 284; Von Bar 1999, p. 21.

259 Van Gerven, Lever \& Larouche 2000, p. 804, 812.

${ }^{260}$ Borghetti 2009, p. 63.

261 Borghetti 2009, p. 62; Von Bar 1998, p. 630. 
may then take the form of private punishment, although the covert French method of assessing the damages award makes it difficult to prove that this statement is correct. $^{262}$ In theory, the principle of full compensation is irreconcilable with a punitive function of the law of damages. ${ }^{263}$ Nevertheless, it is generally supported in French legal doctrine that a different function of civil liability than the mere compensatory one is acknowledged in the concept of the private law penalty, the so-called peine privée. This private law penalty may appear in different forms. As will be explained below, both the courts and legal doctrine have been influential in recognising non-compensatory functions in private law, such as deterrence and punishment. ${ }^{264}$ This follows, for instance, from French legislative initiatives that will also be analysed.

To conclude, what is in principle not allowed in French law is an abstract calculation of damage, at least not to a similar extent as in Dutch law: the judge may make comparisons with other damages awards or take into account a damages scale, for example for bodily injuries, as long as these are not decisive. ${ }^{265}$ According to Borghetti, so-called barèmes or standardised amounts of damages are in theory forbidden as they prevent the calculation of damages on the basis of the actual harm suffered and therefore violate the principle of full compensation. Borghetti refers to barèmes as a mechanism that can be used to signal the existence of punitive damages in French law: ${ }^{266}$

Of course, if the use of barèmes were officially recognized, it might be possible to spot the existence of punitive damages and to measure them by comparing the damages actually awarded to the plaintiff in a given case to the "normal" amount of damages which he or she should have received according to the barème, given the type of harm he or she suffered. This, however, is not possible in the current state of the French legal system since the courts, even if they do resort to barèmes, do not say so and of course do not indicate which barème, if any, they have used.

Indeed, it appears that French courts in practice do use barèmes, especially in cases concerning bodily injury. The theoretical rejection of barèmes has less practical value in France due to the existence of a national register with standardised amounts of - material and immaterial - damages for certain types of bodily injury (préjudices corporels). This register, known as the nomenclature Dintilhac, was created in 2005 to promote the uniform compensation of victims throughout the country. ${ }^{267}$ Although the register is still seen as an instrument in progress, it has - for example - already been published on the website of the Supreme Court, is used by the majority of appeal courts as register of reference and

262 Borghetti 2009, p. 56, 62.

263 Galand-Carval 2001, p. 77

264 Van Gerven, Lever \& Larouche 2000, p. 764; Wagner 2012, p. 1404.

265 Van Gerven, Lever \& Larouche 2000, p. 812.

266 Borghetti 2009, p. 63.

267 The report concerning the nomenclature des préjudices corporels was published in July 2005 under the supervision of the president of the second civil chamber of the French Supreme Court, JeanPierre Dintilhac. See for the report: www.ladocumentationfrancaise.fr/var/storage/rapports-publics/ 064000217/0000.pdf. 
has been adopted by several insurers. Thus for certain types of bodily injury, the sovereign power of the court to calculate the damages award is limited. The register distinguishes twenty-seven categories of damage: twenty for the direct victim, including both material and immaterial loss, as well as temporary and permanent injuries, and seven for the indirect victim. ${ }^{268}$

So far the basic principles of French damages law have been introduced. As the structure of this section concerning French law will be more or less the same as that of the previous sections on Dutch and German law, the following section will start by exploring immaterial damages awards.

\subsubsection{Immaterial Damages}

Compensation of immaterial damage is based on a broad interpretation by the French courts of article $1382 \mathrm{Cc}$. Compensation for immaterial loss is not restricted to certain categories as in Dutch and German law and is awarded extensively. It includes all losses that 'consist in a diminution of the victim's well-being', which can refer to both physical and mental well-being. ${ }^{269}$ This probably has to do with the already explained aim of compensating as many victims as possible. The French are quite liberal in awarding compensation for immaterial loss: the number of situations in which immaterial loss can be compensated is wide-ranging. Unlike Dutch and German law, French law distinguishes between different categories of damage for which separate sums of immaterial damages, but also one total amount, can be granted, such as losses due to mental or physical injury, aesthetic damage, loss of leisure, and emotional harm resulting from the death or injury of a loved one. ${ }^{270}$ In this regard, the French legal system resembles the American legal system, which also recognises different categories of damage in immaterial loss cases. $^{271}$ Another example in French law is the infringement of personality rights such as honour and reputation. This category is highly protected in French law, not only by extensive case law developed on the basis of article $1382 \mathrm{Cc}$ but also due to the introduction in 1970 of article 9 Cc (droit au respect de la vie privée), which provides that everyone is entitled to privacy. ${ }^{272}$ The introduction in the civil code of privacy as a separate right has strengthened the protection of personality rights in French law. ${ }^{273}$ The mere infringement of the right to privacy is for example sufficient for an immaterial damages award: the French Supreme Court has decided that a violation of article $9 \mathrm{Cc}$ in itself, therefore even in the absence of fault or actual damage, entitles a victim to compensation. ${ }^{274}$ French courts are

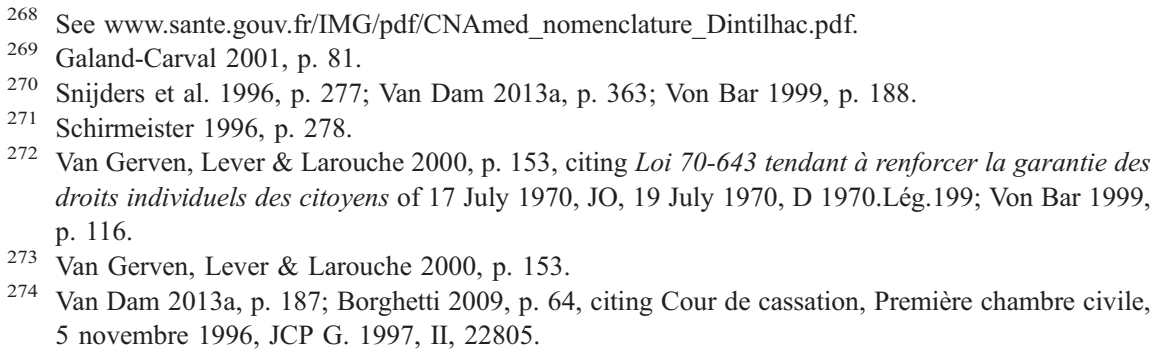


especially strict and willing to grant considerable immaterial damages exceeding the loss of the victim when the tortfeasor intentionally infringed someone's personality right in order to make a profit. ${ }^{275}$ These so-called compensatory awards are allegedly intended to punish the tortfeasor. ${ }^{276}$ Thus, the peine privée function of civil liability especially becomes apparent in the case of immaterial loss due to the intentional and calculative infringement of someone's honour, reputation, privacy and so on, which may give rise to substantial damages awards. ${ }^{277} \mathrm{~A}$ case from 1988 concerning a famous person provides a good example. ${ }^{278}$ When the claimant was eighteen years old, nude pictures were taken of her in a confidential situation. These pictures were later published in a magazine without the woman's consent. The Parisian Court of Appeal awarded FF 250,000 ( $\pm € 40,000)$ in compensatory damages. The award was based on the gravity of the injury and on the profit made by the defendant. Even though immaterial damages are traditionally meant to compensate the victim, such substantial awards cannot be considered purely compensatory and probably have a deterrent and punitive purpose. However, it is difficult to measure the part of an immaterial damages award that exceeds the actual harm, simply because it is difficult to determine the actual harm in cases of immaterial loss. It is nonetheless understood that French case law offers many examples of damages in tort that include a punitive element. ${ }^{279}$ This view has been supported in legal doctrine: ${ }^{280}$

C'est la doctrine, en effet, qui a encouragé les tribunaux à distinguer, parmi les fautes commises, celles qui l'étaient dans un but lucrative, afin de les sanctionner plus durement.

Critical remarks have also been made, for example by Koziol who mentions that even though French courts sometimes estimate - on the basis of the tortfeasor's behaviour - immaterial damages awards that go beyond compensation, these awards are 'clearly not punitive'. ${ }^{281}$

Another particularity of French law is that third parties, the so-called indirect or secondary victims, may also have a right to compensation of immaterial injury, for example grief and sorrow due to the injuries or loss of a loved one. This form of loss is called dommage par ricochet or damage by reflection. ${ }^{282}$ Damage by reflection may not only include immaterial damage but also damage resulting from death, such as funeral costs and loss of income. The circle of persons entitled to

275 Borghetti 2009, p. 64.

276 Galand-Carval 2001, p. 77.

277 Carval 1995, p. 31; Von Bar 1996, p. 606.

278 Cour d'Appel de Paris, Première chambre civile, 4 janvier 1988, D. 1989, 92 (S.A.R.L. Editions des savanes v. Mme B.). See Carval 1995, p. 32; Von Bar \& Drobnig 2004, p. 114.

279 Carval 1995, p. 32, citing Cour d'Appel de Paris, Première chambre civile, 26 avril 1983, D. 1983, 376; Cour d'Appel de Paris, Première chambre civile, 17 décembre 1986, Gaz. Pal. 1987, I, 238 (Henri d'Orléans v. Filipacchi); Cour d'Appel de Paris, Première chambre civile, 4 janvier 1988, D. 1989, 92 (S.A.R.L. Editions des savanes v. Mme B.).

${ }^{280}$ Carval 1995, p. 32.

281 Koziol 2009, p. 284.

282 Van Dam 2013a, p. 353; Snijders et al. 1996, p. 277. 
compensation of such damage is wide, which is the result of a broad interpretation of the requirement of 'personal' damage. ${ }^{283}$

Although compensation of victims is high on the agenda in France, it appears that French immaterial damages awards are not as substantial as in Germany but mediocre, perhaps comparable to the Dutch situation. By 2005, the largest immaterial damages award was $€ 154,000 .^{284}$ This does however not influence the general belief that French immaterial damages awards have non-compensatory purposes, as the sovereign power, the method of assessing damages and the difficulty of measuring the precise immaterial loss give courts the liberty to take into account factors other than the mere loss of the victim. ${ }^{285}$

\subsubsection{Disgorgement of Profit}

The French civil code does not have an article similar to the Dutch article 6:104 BW concerning disgorgement of profit. The French legal system thus resembles the German legal system in this respect. However, because of their sovereign power, in assessing the damages award French judges can take into account the profit that has been wrongfully gained by the tortfeasor. ${ }^{286}$ This might lead to the grant of a non-compensatory award in which the tortfeasor is (partly) deprived of the profit he gained with the wrongdoing. ${ }^{287}$ This especially applies to infringements of intellectual property rights, personality rights and competition law; in these cases, the deterrent and punitive function of damages awards is accepted in French law, albeit in a covert way. ${ }^{288}$ As in Dutch and German law, there are separate legal bases for the disgorgement of profit in French intellectual property law. These mechanisms are considered a form of peine privée and will therefore be explained in the following subsection.

\subsubsection{The Concept of Peine Privée}

As mentioned above, it is generally acknowledged in French legal doctrine that monetary damages can have a deterrent or punitive function in addition to the main compensatory function. This is known as the concept of peine privée or private punishment. $^{289}$ Jault gives the following explanation of this concept: ${ }^{290}$

La peine privée est une sanction civile punitive indépendante de toute idée réparatrice, infligée à l'auteur d'une faute qui lui est moralement imputable, au profit exclusif de la victime qui peut, seule, en demander l'application.

Snijders et al. 1996, p. 277.

${ }^{284}$ Lindenbergh 2008a, p. 77

285 Borghetti 2009, p. 63-64.

286 Van Gerven, Lever \& Larouche 2000, p. 872.

287 Van Gerven, Lever \& Larouche 2000, p. 815-816.

288 Borghetti 2009, p. 60, 64, 66.

289 Van Dam 2013a, p. 352; Borghetti 2009, p. 56. See generally Jault 2005; Carval 1995.

290 Jault 2005, no. 415 . 


\section{According to Van Gerven: ${ }^{291}$}

French legal writing defines an award of damages as a peine privée when the size of the award does not correspond to the amount of harm but is determined by the degree of culpability and aims at the repression of wrongful conduct rather than the compensation of the plaintiff.

As explained in section 9.4.3.1 above, the French Supreme Court has decided that, in assessing damages awards, the focus should be on the loss of the claimant rather than the degree of culpability of the defendant. However, the sovereign power of the French judge to assess damages results in a fairly unlimited freedom to determine the size of damages awards. The sovereign power also gives the judge the possibility to take circumstances into account that deviate from the compensatory approach, such as the nature of the wrongdoing. ${ }^{292}$ This creates room for the concept of peine privée in French law. The different forms of peine privée that exist are considered to bear resemblance to punitive damages, as has been clearly described by Borghetti. ${ }^{293}$

In their explanation of the concept peine privée, both Jault and Van Gerven focus on punishment of the wrongdoer's moral fault or conduct. The punitive function is indeed widely acknowledged: in French legal doctrine several civil remedies that deviate from the principle of full compensation are considered a form of peine privée. For example, a traditional form of the peine privée is the contractual penalty clause (clause pénale), the equivalent of the above-mentioned Dutch boetebeding and German Vertragsstrafe. Also in French law the penalty clause is an important illustration of a civil sanction with a clear punitive function. However, as penalty clauses are only valid in contractual situations and result from a voluntary agreement between the parties to the contract, the parallel with the punitive damages remedy is not clear-cut. ${ }^{294}$ See in this regard the remarks concerning the Dutch and German contractual penalty clause above. But even though this is not the strongest example from the perspective of this book, it will be described briefly at this point. The relevant provision concerning this instrument can be found in article $1152 \mathrm{Cc}$ :

Where an agreement provides that he who fails to perform it will pay a certain sum as damages, the other party may not be awarded a greater or lesser sum.

In order to put an end to the exorbitant penalty clauses that were sometimes imposed by creditors on their debtors, a second paragraph was added to article 1152 Cc in 1975 , allowing courts to alter the penalty: ${ }^{295}$

291 Van Gerven, Lever \& Larouche 2000, p. 766

292 Van Gerven, Lever \& Larouche 2000, p. 766.

293 Borghetti 2009, p. 56-62.

294 Borghetti 2009, p. 57.

295 Borghetti 2009, p. 57. 
Nevertheless, the judge may even of his own motion moderate or increase the agreed penalty, where it is obviously excessive or ridiculously low. Any stipulation to the contrary shall be deemed unwritten.

Other relevant provisions relating to the clause pénale are articles 1226 to 1233 Cc. While Dutch law recognises both the assessment of damage and the incentive function in one single provision (article 6:91 BW), French law is less straightforward. Article $1152 \mathrm{Cc}$ clearly refers to the assessment of damage function, whereas article $1226 \mathrm{Cc}$ underlines the incentive function. Although this divide has caused some discussion, both the judiciary and legal doctrine allows the double function of the clause pénale. ${ }^{296}$

Another form of damages within contract law that bears resemblance to damages with a punitive function is article $1150 \mathrm{Cc}$, which gives a court the discretion to award the full damages caused by a breach of contract in bad faith, free of the foreseeability limitation that would otherwise apply. According to Calleros: ${ }^{297}$

This lifting of the foreseeability requirement must cause some awards for bad-faith breach to blur the line between maximum compensation and punishment.

It is also argued that French courts sometimes award a peine privée in the hidden form of immaterial damages. For example, if someone's personality right is infringed, immaterial damages may be awarded on the basis of article $9 \mathrm{Cc}$. As explained above, the amount of damages for the intentional and calculative infringement of a personality right can be substantial, thereby showing the court's disapproval of the defendant's conduct. ${ }^{298}$ Note that, as mentioned above, the French Supreme Court does not approve of this practice. Nevertheless, this is considered a covert method of lower courts to award damages to a victim that exceed his loss, as is the case with punitive damages.

Forms of the peine privée can also be found outside the civil code. An example is the astreinte, the civil judicial penalty payment comparable to the Dutch dwangsom. ${ }^{299}$ The general rules on the astreinte can be found in a separate act outside the civil code (article 33-36 loi n 91-650 du 9 juillet 1991). A court can impose a penalty payment on a defendant should he fail to comply with his obligations based on the initial court decision. The penalty is usually calculated on a daily basis until the initial obligation is fulfilled. ${ }^{300}$ The astreinte can accompany every judicial decision. ${ }^{301}$ However, although the penalty could be used to motivate a tortfeasor who refuses to pay the damages imposed initially, in practice it is mostly used in the case of breach of either a contract or a statutory duty. Like the contractual penalty clause, the astreinte is an example of a punitive element

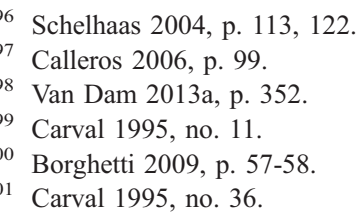

Carval 1995, no. 36 
that is relevant for private law. However, as the astreinte is independent from damages, according to article 34 of the above-mentioned Act, this mechanism is also not entirely comparable to punitive damages. ${ }^{302}$

Another example of the peine privée can be found in articles L. 331-1-3 and L. 331-1-4 of the Intellectual Property Code, which implements the European Directive on the enforcement of intellectual property rights into French law. ${ }^{303}$ In the case of intellectual property right infringements, a court can demand that (part of) the profit made by the wrongdoer should be returned to the claimant, which is in accordance with article 13 of the said Directive. According to Borghetti, this comes 'quite close to' punitive damages, because even though the damages award cannot exceed the profit, the claimant can still receive damages in excess of the actual loss suffered due to the illegal infringement. ${ }^{304}$ Although this might be true in practice, it is difficult to defend a truly punitive function now that recital 26 of the Directive explicitly excludes any non-compensatory function. As stated in section 8.3, Koch for that reason refers to this Directive as an example of European Union legislation excluding punitive damages. Note that, as explained above, a general legal basis for the disgorgement of profit cannot be found in the French civil code as is the case in Dutch law.

To conclude, two more general mechanisms with a punitive function are acknowledged in French private law. Even though these mechanisms are not seen as a typical peine privée, they have a strong resemblance to punitive damages and should therefore be mentioned at this point. ${ }^{305}$ The first mechanism can be found in insurance law. Victims of traffic accidents are highly protected in French law, which includes a compulsory traffic accident compensation scheme, the so-called Loi Badinter. According to article L. 211-13 of the Insurance Code, an insurance company that fails to fulfil its obligation to make a compensation offer to the victim of a traffic accident can be ordered to pay double the legal interest rate, starting from the date that the offer should have been made. This multiple damages award, even though the amount will be relatively small, exceeds the loss of the victim and is for that reason considered a form of (multiple) punishment in French law. As mentioned in section 9.4.1.4 above, bad faith claim handling by insurers receives attention in the European punitive damages debate: based on American law, punitive damages are considered a potentially useful mechanism to deal with bad faith insurance practices. The second relevant mechanism is the civil fine (amende civile), provided for in civil statutes and to be awarded by a civil court as a form of punishment for certain serious wrongs. An important difference with punitive damages is that the fine has to be paid to the treasury. The main example is article L. 442-6 of the Commercial Code, which penalises certain restrictive practices between competitors. This civil fine may not exceed $€ 2$ million, which forms an exception to the general low amount of civil fines in French law. This

302 Borghetti 2009, p. 58.

303 Directive 2004/48/EC.

304 Borghetti 2009, p. 58.

305 Borghetti 2009, p. 60-61 
article is considered a special tort provision supporting private enforcement in the field of competition law. ${ }^{306}$

The recognition of the concept of peine privée as such shows the rather liberal view of the French on civil sanctions. Furthermore, it is widely believed that French lower courts sometimes award civil damages that exceed the loss of the claimant and take into account factors such as the tortfeasor's wrongful behaviour or the profit gained by him. As a similar method is followed by Dutch and German judges, it is difficult to see a real difference between these two legal systems apart from the codification of a general disgorgement of profit provision in Dutch law, i.e. article 6:104 BW; such a general provision cannot be found in French and German law. Moreover, due to the unexplained method that French judges employ in calculating damages awards, it is also difficult to conclude that an award in fact holds a deterrent and punitive element. As a result of the strict reliance - at least in theory - on the principle of full compensation, non-compensatory purposes of damages awards are not always visible and are not recognised by everyone. Therefore, it goes a bit far to suggest that the rather liberal approach to sanctions in French private law shows that the French actually wish to accept the punitive damages remedy. But the legislative developments that will be described in the next subsection do point further in that direction. With regard to the recognition of punitive damages in French law, it is important to point out once more that, also from a private international law perspective, France has a liberal and open attitude towards punitive damages. See in this respect section 8.5 , in which the case Fountaine Pajot of the French Supreme Court was explained. ${ }^{307}$ In this case, the Court held that foreign punitive damages awards are in principle recognisable in France, except for excessive or disproportionate awards. The French attitude from a private international law perspective can be contrasted to, for example, the German attitude. In Germany, the recognition question has also been raised, but it was answered negatively: the German Supreme Court denied the recognition of an American punitive damages award in $1992 .{ }^{308}$

\subsubsection{Punitive Damages Developments in the Legislative Field}

The introduction of punitive damages into French law is a topic of much debate, which goes hand-in-hand with the rather liberal view that some have on the peine privée function of civil liability as well as the increased attention for private enforcement. $^{309}$ The topic has received even more attention with the publication, from 2005 onwards, of three legislative drafts that aim to reform the civil code. All three drafts contain a provision concerning punitive damages, with the idea of sanctioning wrongful behaviour. A profound overview of these drafts in light of

306 French National Report, Competition Law Commission, Congress Geneva 2004, p. 5, retrieved via: commissions.uianet.org/uploads/tx_hhuiacommission/LukeQuestionFrance.pdf.

307 Cour de cassation, Première chambre civile, 1 décembre 2010, 09/13303 (Fountaine Pajot).

308 BGH 4 June 1992, BGHZ 118, 312.

309 Borghetti 2009, p. 68; Mahé 2012, p. 261. 
the punitive damages debate has been provided by Mahé. ${ }^{310}$ The first draft, published in 2005 by a group of academics led by professor Catala, is the AvantProjet du réforme du droit des obligations (Catala Draft) which aims to reform contract law, tort law and prescription law by codifying judge-made law. ${ }^{311}$ The second draft is a proposal initiated by Béteille, a member of the First Legislative Chamber, in 2010 (Béteille Draft). ${ }^{312}$ Like the Catala Draft, this proposal primarily aims to reform tort law by codifying judge made law. The third draft, published by academics and legal practitioners under the supervision of professor Terré in 2011 (Terré Draft), considers tort law and is part of a project that aims at reforming and restructuring the law of obligations. ${ }^{313}$ Thus, both the Catala Draft and the Terré Draft are academic initiatives, whereas the Béteille Draft is a legislative initiative. So far, none of these drafts have become law, but they do considerably contribute to the punitive damages debate in France. It is therefore worthwhile to describe their position towards punitive damages.

Although all three drafts endorse the réparation intégrale principle of civil liability, ${ }^{314}$ they also recognise an important exception to this principle by embracing punitive damages in the following provisions. ${ }^{315}$

\section{Article 1371 Catala Draft:}

One whose fault is manifestly [deliberate], particularly a [lucrative fault], may be ordered to pay punitive damages besides compensatory damages. The judge may direct a part of such damages to the Treasury. The judge must provide specific reasons for ordering such punitive damages and must clearly distinguish their amount from that of other damages awarded to the victim. Punitive damages may not be the subject of a contract or insurance.

Article 1386-25 Béteille Draft:

In cases where the law expressly provides so, when the damage results from a deliberate wrongdoing or a deliberate breach of contract and has lead to an enrichment of the wrongdoer resp. promisor that the sole compensatory damages cannot eliminate, the judge can condemn, by a motivated decision, the inflictor of the damage to the payment, in addition to compensatory damages for the harm suffered in accordance with Article 1386-22, of punitive damages, the amount of which may not stand out twice the amount of the compensatory damages.

According to shares decided by the judge, the punitive damages are respectively paid to the victim and to a fund which purpose is to compensate harm similar to the one suffered by the victim.

310 Mahé 2012, p. 261.

311 'Avant-projet de réforme du droit des obligations (Articles 1101 à 1386 du Code civil) et du droit de la prescription (Articles 2234 à 2281 du Code civil), Rapport à Monsieur Pascal Clément, Garde des Sceaux, Ministre de la Justice', retrieved via: www.justice.gouv.fr/ (search term: Rapport Catala). See Borghetti 2009, p. 69-73; Mahé 2012, p. 263. See further on the Catala Draft Cartwright, Vogenauer \& Whittaker 2009.

312 'Proposition de loi $\S 657$ portant réforme de la responsabilité civile', retrieved via: www.senat.fr/ dossier-legislatif/ppl09-657.html.

313 See Terré 2011.

314 See article 1370 Catala Draft, article 1386-24 Béteille Draft and article 49 Terré Draft.

315 Translations derived from Mahé 2012, p. 262-263. 
When such a fund does not exist, the share of the punitive damages which is not attributed to the victim should be paid to the Treasury.

Article 69 al. 2 Terré Draft:

Subject to any specific provision, the form and amount of the reparation may have a symbolic reach. When the harm is caused by an intentional fault, the judge may condemn the wrongdoer, by an especially reasoned decision, to exemplary damages.

These texts mainly speak for themselves. Whereas both the Catala Draft and the Béteille Draft focus primarily on lucrative faults, the latter is most clear as regards the scope of application and the assessment of the punitive damages award. ${ }^{316}$ The lucrative fault can be defined as 'a wrongdoing, the beneficial consequences of which - for the wrongdoer - are not neutralised by the sole compensation of the harm caused'. 317 The Terré Draft does not aim at lucrative faults but rather suggests the introduction of punitive damages to punish the intentional violation of a person's moral integrity, i.e. someone's dignity, honour, reputation, privacy, etc. $^{318}$ Thus, again the focus seems to be on intentional, calculative and grave misconduct, which are also the forms of misconduct to which the punitive damages remedy is connected in the European punitive damages debate. ${ }^{319}$ As explained before, the categories of wrongful behaviour in which punitive damages could especially play a role in continental Europe are known in American law as the popular punitive damages categories: intentional torts, defamation and financial torts. These three categories cover both intentional and grave wrongdoing, which particularly applies to intentional torts and calculative wrongdoing, for example defamation and fraud. ${ }^{320}$

The report preceding the Béteille Draft observes that lucrative faults are "neither neutralised by civil liability, nor sanctioned by criminal law, ${ }^{321}$ which justifies the introduction of punitive damages but only in certain specific situations, i.e. violations of personality rights, competition law and environmental law. This is probably the reason why the Béteille Draft provision refers to 'cases where the law expressly provides so'. In contrast, the Catala Draft envisages a general punitive damages provision that applies to all lucrative faults. ${ }^{322}$ The discussion regarding the Terré Draft reveals that the recognition of punitive damages would put an end to the already explained covert method of lower judges assessing damages that exceed the loss of the victim. ${ }^{323}$ According to Mahé: ${ }^{324}$

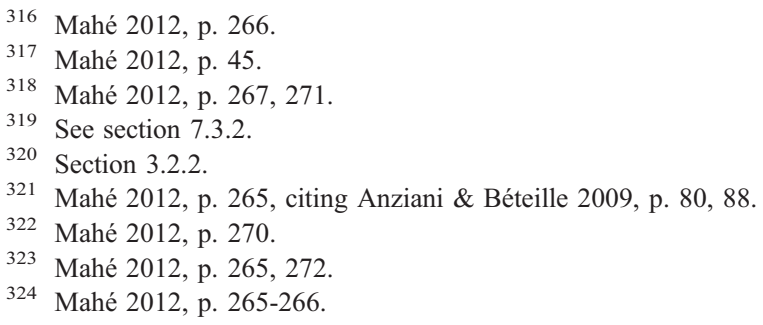


A common perception is that, in response to lacunas in civil and criminal legislation, lower civil judges have, when assessing the award for non-pecuniary losses and exercising thereby their sovereign power of appreciation, taken into account the seriousness of the defendant's conduct getting round the full reparation principle. Codifying punitive damages would end the legal uncertainty created by such covert practices and reel off the law in the books and the law in action.

In conclusion, although none of these punitive damages proposals have the status of law yet, they tell us something about the view on the function of civil liability. It becomes clear that several French academic and legislative initiatives seriously consider punitive damages as an option to strengthen tort remedies, so that lucrative faults and intentional wrongful infringements of personality rights are deterred and punished, and covert methods of awarding non-compensatory damages - as French judges allegedly use - are no longer needed.

Now that an overview of relevant civil sanctions in the Dutch, German and French legal system has been provided, the English legal system will be explored in the following subsection to conclude section 9.4. In the search for civil sanctions, the English approach differs from the Dutch, German or French approach in the sense that a punitive function of private law is generally accepted in England. To be more precise: punitive damages are explicitly accepted in English law, albeit in a more restricted form than in the United States. Compared to the Netherlands, Germany and France, England will therefore be situated on the most punitive side of the comparison scale that will be provided in section 9.5. This of course has to do with the common law foundation of the English legal system, as opposed to the civil law tradition that characterises the other three European legal systems. Keeping in mind that the civil law systems described above allegedly recognise covert forms of punishment - which most likely serves an important deterrent function - in the law of damages, it is especially interesting to see in which particular situations punitive damages are explicitly accepted in the English legal system.

\subsubsection{England}

\subsubsection{Basic Principles of the Law of Damages}

Also in English law, restitutio in integrum and full compensation is the basic principle of the law of damages. ${ }^{325}$ Furthermore, a general distinction is made between material and immaterial loss. The English law of damages is primarily judge made, which explains the absence of codified damages provisions. The main remedy for tortious or contractual liability in English law is compensatory damages. But, in some cases, compensation is not the only or even most important function of a damages award. ${ }^{326}$ Different forms of damages, which all have their own function, exist in English law. ${ }^{327}$ Punitive damages primarily have the function of punishment. Nominal damages are mainly available for torts actionable

325 Rogers 2001, p. 53; Samuel \& Rinkes 1991, p. 24

326 Van Gerven, Lever \& Larouche 2000, p. 741.

327 For an overview of remedies and their functions see Burrows 2004, p. 10 
per se, i.e. when a wrong has been done but no actual loss has resulted from this. The function of nominal damages is to recognise and declare the victim's rights and to vindicate him. Another example is restitutionary damages, a remedy that for example becomes relevant when the defendant is unjustly enriched due to a payment of money by mistake or when he profits from the wrongful behaviour. ${ }^{328}$ Disgorgement of profit is especially applicable in two situations, namely the infringement of intellectual property rights and the breach of a fiduciary duty. ${ }^{329}$

The structure of this section is different from that of the sections on Dutch, German and French law. Disgorgement of profit will for example not be described separately. Under English law, the disgorgement of profit remedy is known as the remedy 'account and award of profits', which clearly falls under the heading of restitutionary remedies. ${ }^{330}$ Although these remedies have a non-compensatory nature, their function is restitution and not punishment. ${ }^{331}$ English law also has another method of both punishing someone who wrongfully gained profit and the disgorgment of the profit, which is by awarding punitive damages: as will be explained below, one of the categories in which punitive damages can be awarded is when the wrongdoer calculated the conduct to make profit.

Furthermore, as already mentioned in section 9.4.1.4, English law does not accept an incentive contractual penalty clause. ${ }^{332}$ Contractual penalty clauses with a punitive aspect that compels the observance of a contractual obligation are considered void. ${ }^{333}$ The main reason given in legal doctrine for this is that such a penalty undesirably forms a punishment between contracting parties, and therefore a violation of the contractual freedom. ${ }^{334}$ Note that this reasoning seems to be consistent with the generally accepted idea that punitive damages are in principle not available under English law for breach of contract, as will be explained in section 9.4.4.3.3 below. The only valid clauses are those with an assessment of damage function, the so-called liquidated damages clause. As this remedy explicitly lacks a punitive function, attention will not be paid to it here. It is however noteworthy that England accepts a form of punitive damages for noncontractual situations but not the contractual penalty clause, whereas the Netherlands, Germany and France do not accept punitive damages but do accept the contractual penalty clause.

The main focus in this section will be on punitive damages, because this remedy epitomises the punitive function of the English law of damages. But, first, attention will be paid to immaterial damages awards and especially aggravated damages, which in theory have a compensatory nature but may also have a deterrent or punitive effect. $^{335}$

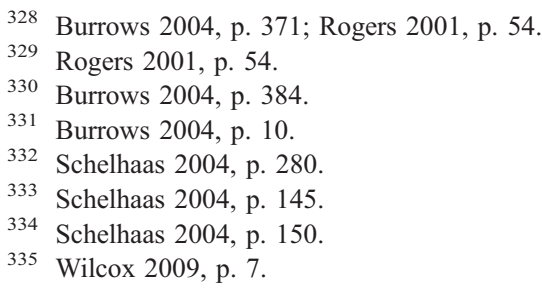




\subsubsection{Immaterial Damages and Aggravated Damages}

Immaterial damages are also awarded by English courts, which make a distinction between damages for pain and suffering, and damages for the loss of amenity (the enjoyment of life). ${ }^{336}$ As already mentioned in section 9.4.2.2 above, the highest sum awarded by an English court for pain and suffering is $£ 265,000$ ( \pm $€ 330,000)$. Furthermore, rather substantial immaterial damages awards may be granted in case of defamation, ${ }^{337}$ i.e. the infringement of someone's personality right by injuring his reputation. This can be in words, pictures, gestures, and other acts. $^{338}$ According to Van Gerven et al.: ${ }^{339}$

In actions of defamation and in any other actions where damages for loss of reputation are involved, the principle of restitutio in integrum has necessarily an even more highly subjective element.

This subjective element can be included in the estimation of loss when the loss cannot be exactly calculated, for example in situations of pain and suffering, future losses and also loss of reputation. In case of defamation, the compensatory damages award has two functions: vindication of the plaintiff to the public and consolation or relief for the plaintiff for the wrong done. ${ }^{340}$ The protection of personality rights, such as privacy, is highly valued by the English, and monetary damages are used as a mechanism to not only compensate the victim but also for reasons of recognition, punishment and deterrence. ${ }^{341}$ Until twenty years ago, these awards used to be very large, up to $£ 600,000$ ( $\pm € 750,000) .{ }^{342}$ However, awards are nowadays smaller due to a possibility given to the Court of Appeal to limit damages awards in section 8 of the Courts and Legal Services Act 1990, as well as reference made by the Court of Appeal to the freedom of speech in article 10 ECHR. $^{343}$ Juries are advised to look into the general amount of damages awarded for immaterial loss in personal injury cases, with a maximum of \pm $£ 200,000( \pm € 250,000)$. But due to the dual function of damages in defamation cases, it could be considered unfair to compare these awards with those awarded in personal injury cases. The maximum amount is therefore not binding. ${ }^{344}$ It is important to point out that the amount of English immaterial damages awards for personal injury is larger than in the Netherlands and France and is within the range of the German awards. ${ }^{345}$

336 Van Dam 2013a, p. 363.

337 Van Gerven, Lever \& Larouche 2000, p. 745; Van Dam 2013a, p. 350.

338 Martin 2003, p. 140.

339 Van Gerven, Lever \& Larouche 2000, p. 745.

340 Van Gerven, Lever \& Larouche 2000, p. 746.

341 Van Dam 2013a, p. 350.

342 Van Dam 2013a, p. 350, citing Sutcliffe v. Pressdram Ltd. [1991] 1 QB 153

343 Van Dam 2013a, p. 350, citing Rantzen v. Mirror Group Newspapers Ltd. and Others [1994] QB 670 , at $\S 692$ : 'The question becomes: could a reasonable jury have thought that their award was necessary to compensate the claimant and to re-establish his reputation.'

344 Van Gerven, Lever \& Larouche 2000, p. 746.

345 Lindenbergh 2008, p. 77. 
The damages awards in defamation cases remind us of a peculiar remedy known in the English legal system, namely aggravated or contemptuous damages. Immaterial damages for personality right infringements are indeed normally awarded under this heading. ${ }^{346}$ As explained in section 9.3.1 above, aggravated damages is a type of compensatory damages that may be awarded when the claimant's feelings of dignity and pride are injured, the defendant's motives, conduct and manner of committing the tort have aggravated the claimant's damage and the damages cannot be calculated precisely. ${ }^{347}$ Injury to the "feelings of dignity and pride': these words are almost always used in decisions with this form of damages. ${ }^{348}$ The injured feelings are independent from pain and suffering, which is a form of loss equivalent to the psychological consequences of personal injuries. Wilcox points out two requirements that have to be fulfilled before a claimant can obtain aggravated damages: ${ }^{349}$

(a) exceptional or contumelious conduct or motive on the part of a defendant in committing the wrong, or, in certain circumstances, subsequent to the wrong; and

(b) mental distress sustained by the claimant as a result.

Thus, the defendant's motives and conduct in committing the wrong or subsequent to the wrong must be exceptionally wrongful, for example malevolence, spite, malice, insolence, or arrogance which injures the claimant's proper feelings. ${ }^{350}$ Furthermore, in order to be able to ask for aggravated damages the wrongdoing must have resulted in mental distress (or: injury to feelings) ${ }^{351}$ of the claimant. Defamation is not the only ground for an award. Other examples of torts for which aggravated damages can been awarded in England are assault and battery, deceit, intimidation, false imprisonment, malicious prosecution, malicious falsehood, unlawful discrimination such as sexual or racial discrimination, trespass to land, and unlawful interference with business. ${ }^{352}$ Given the functions of aggravated damages, the distinction with punitive damages is somewhat difficult to draw. As has also been mentioned in section 9.3.1 above, the American legal system does not even make a distinction and treats the two as synonymous. According to Owen: ${ }^{353}$

[...] punitive damages are distinct from the developed, narrow law of limited 'compensatory' relief ordinarily available in tort, and that punitive damages are assessed in addition thereto to fully restore the rights of victims of aggravated wrongdoing by providing additional relief. Such damages are

346 Aggravated damages are not only awarded in England. The common law countries Canada, Australia and Ireland are also familiar with aggravated damages and distinguish this form of damages from punitive damages. See Sebok \& Wilcox 2009, p. 266.

347 Sebok \& Wilcox 2009, p. 259; Deakin, Johnston \& Markesinis 2008, p. 942.

348 Deakin, Johnston \& Markesinis 2008, p. 943.

349 Sebok \& Wilcox 2009, p. 259, citing the Law Commission Report 1997, Part II, § 1.4, p. 11.

350 Sebok \& Wilcox 2009, p. 259.

351 Law Commission Report 1997, Part I, § 1.8, p. 3.

352 Sebok \& Wilcox 2009, p. 260; Deakin, Johnston \& Markesinis 2008, p. 942.

353 Owen 2012, p. 128. 
'aggravated' beyond normal 'compensatory' amounts in order to restore all stolen freedoms and equality of worth to theft victims by removing all booty held illicitly by the thief.

In England, prior to 1964, a clear line between the two forms of damages also did not exist. But in 1964, in the case of Rookes v. Barnard concerning the tort of intimidation, ${ }^{354}$ a distinction was made and from then on aggravated damages were seen as a way to reflect the wounded feelings of the claimant, whereas punitive damages were meant to punish and deter the defendant's grave wrongful conduct. $^{355}$ In practice, the two still have a lot in common and, although aggravated damages are considered compensatory in nature, the line between satisfaction of the claimant and punishment of the defendant will never be crystal clear. $^{356}$ In respect of the functions of tort damages, note that the difficult borderline between the functions of satisfaction and deterrence, on the one hand, and punishment, on the other hand, has already been addressed in the previous chapters, such as section 6.2.2.6. As pointed out by Sebok and Wilcox, similarities between aggravated and punitive damages are that both categories of damages are available for more or less the same torts, and not for negligence or breach of contract. Moreover, in deciding whether aggravated damages are appropriate, the conduct of the defendant is taken into account, as is the case with the assessment of punitive damages. This is considered justifiable because the only way to find out about the gravity of the claimant's injury is by also looking into the defendant's misconduct. Thus, in assessing the aggravated damages award there is no interest in the misconduct per se; rather, the interest follows from the influence the misconduct has on the claimant's injury. ${ }^{357}$

\subsubsection{Punitive Damages in English Law}

\subsection{Punitive Damages for Torts: the Categories Test}

In the above-mentioned Rookes v. Barnard case, decided in 1964, the House of Lords not only made a distinction between aggravated and punitive damages but also gave three categories in which punitive damages can be awarded for torts.

Almost thirty years later in 1993, in the A.B. v. South West Water Services Ltd. case, the Court of Appeal introduced a second test that needed to be satisfied in order to be entitled to punitive damages, the so-called cause of action test. ${ }^{358}$ Two Law Lords had already made suggestions for this test in the defamation case Cassell \& Co. Ltd. v. Broome. ${ }^{359}$ The test aimed at limiting the number of situations in which punitive damages are available to those causes of action that gave rise to punitive damages prior to the Rookes v. Barnard case. Before 1964, punitive damages had been awarded in cases of malicious prosecution, false

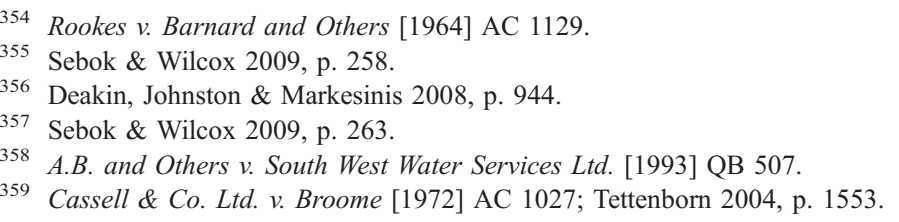


imprisonment, assault and battery, defamation, trespass to land or to goods, private nuisance, and tortious interference with business. Torts that did not satisfy the cause of action test were negligence, deceit, misfeasance in public office, and unlawful discrimination. ${ }^{360}$

Prior to Rookes v. Barnard, there were no particular limitations to award punitive damages for the torts mentioned and, for that reason, the English approach to punitive damages was more or less comparable to the American approach. After Rookes v. Barnard and A.B. v. South West Water Services Ltd., the English position changed and became almost unrecognisably different from that of most American states. These two decisions had a devastating effect on the English practice of awarding punitive damages. ${ }^{361}$ Even though courts were allowed to award punitive damages, they were largely considered 'a regrettable anomaly, grudgingly allowed only in very limited circumstances which openly owed everything to history and nothing to logic'. ${ }^{362}$ This changed when the cause of action test was abolished by the House of Lords in the Kuddus case decided in 2001. ${ }^{363}$ The categories test is again the only test that needs to be satisfied, an approach that is approved by the English government. ${ }^{364}$ Since Kuddus, punitive damages are available for any tort, as long as the categories test has been satisfied. ${ }^{365}$ The focus in this section will therefore be on that test. One additional remark is that punitive damages are generally not available in personal injury cases, even if the injury is severe or the misconduct was grossly negligent. ${ }^{366}$ Although punitive damages can in principle be awarded in all kinds of situations, the main focus is on defamation, false imprisonment and trespass to property; punitive damages are traditionally not awarded for torts that have a primary focus on compensation, most importantly the tort of negligence. ${ }^{367}$ The Rookes v. Barnard categories that give rise to punitive damages for torts as laid down by Lord Devlin are as follows: ${ }^{368}$

(1) When there is oppressive, arbitrary or unconstitutional action by the servants of the government.

Lord Devlin gives the following clarification on this first category: ${ }^{369}$

Where one man is more powerful than another, it is inevitable that he will try to use his power to gain his ends; and if his power is much greater than the other's, he might, perhaps, be said to be using it oppressively. If he uses his power illegally, he must of course pay for his illegality in the ordinary way; but he is not to be punished simply because he is the more powerful. In the case of the

Burrows 2004, p. 418; Wilcox 2009, p. 19.

361 Tettenborn 2004, p. 1552, 1554

362 Tettenborn 2004, p. 1552.

363 Kuddus v. Chief Constable of Leicestershire Constabulary [2002] 2 AC 122.

364 Wilcox 2009, p. 8.

365 Burrows 2004, p. 418; Varuhas 2014, p. 38.

366 Van Dam 2013a, p. 358.

367 Varuhas 2014, p. 38.

368 Rookes v. Barnard, at $\S 1226-1227$.

369 Rookes v. Barnard, at $\S 1226$. 
government it is different, for the servants of the government are also the servants of the people and the use of their power must always be subordinate to their duty of service. It is true that there is something repugnant about a big man bullying a small man and, very likely, the bullying will be a source of humiliation that makes the case one for aggravated damages, but it is not, in my opinion, punishable by damages.

As has been remarked by Wilcox, this category can easily be linked to the first English cases in which punitive damages have been awarded and which also concern abuse of power by the government. ${ }^{370}$ The first category consists of two requirements: (a) oppressive, arbitrary or unconstitutional action, and (b) the action was done by a servant of the government. With regard to the first requirement, it follows from the use of the word 'or' that these are three alternative conditions. Furthermore, in the absence of an oppressive or arbitrary action, the infringement of a constitutional right by a servant of the government does not necessarily give rise to a punitive damages award, because in that case also an actionable tort is needed. ${ }^{371}$ The second requirement 'servant of the government' is to be broadly interpreted and covers those who exercise functions of an executive nature on behalf of the central or local government. ${ }^{372}$ Examples of situations that fall into this category and in which punitive damages have been awarded are false imprisonment, malicious prosecution and several forms of assault by police officers. ${ }^{373}$ The amount of the punitive damages award can be substantial, for example $£ 40,000$ in a case in which police officers had extracted a confession from a claimant by placing a bin bag over his head and $£ 15,000$ (the original award of $£ 200,000$ was reduced on appeal) for false imprisonment and assault. ${ }^{374}$ An interesting table listing cases against the police including the amount of punitive, compensatory and aggravated damages awarded has been published by Wilcox. ${ }^{375}$

(2) When the defendant's conduct has been calculated by him to make a profit for himself which may well exceed the compensation payable to the plaintiff.

With regard to this second category, Lord Devlin explains as follows: ${ }^{376}$

Where a defendant with a cynical disregard for a plaintiff's rights has calculated that the money to be made out of his wrongdoing will probably exceed the damages at risk, it is necessary for the law to show that it cannot be broken with impunity. This category is not confined to moneymaking in the strict sense. It extends to cases in which the defendant is seeking to gain at the expense of the plaintiff some object - perhaps some property which he covets - which either he could not obtain at

370 Wilcox 2009, p. 9, citing Wilkes v. Wood [1763] 98 ER 489; Huckle v. Money [1763] 95 ER 768 and Benson v. Frederick [1766] 97 ER 1130.

371 Wilcox 2009, p. 11

372 Cassell \& Co. Ltd. v. Broome, at $§ 1130$; Burrows 2004, p. 411; Wilcox 2009, p. 11.

373 Burrows 2004, p. 412.

374 Burrows 2004, p. 412, citing Treadaway v. Chief Constable of the West Midlands [1994] WL 1063421 (QB) and Thompson v. Commissioner of Police of the Metropolis [1998] QB 498.

375 Wilcox 2009, p. 40.

376 Rookes v. Barnard, at § 1227. 
all or not obtain except at a price greater than he wants to put down. Exemplary damages can properly be awarded whenever it is necessary to teach a wrongdoer that tort does not pay.

A situation that Lord Devlin explicitly points out as falling into this category is libel, as 'one man should not be allowed to sell another man's reputation for profit'. ${ }^{377}$ However, something more than libelous behaviour resulting in profit is needed, which follows from Cassell \& Co Ltd. v. Broome: ${ }^{378}$

[...] the mere fact that a tort, and particularly a libel, is committed in the course of a business carried on for profit is not sufficient to bring a case within the second category. Nearly all newspapers, and most books, are published for profit. What is necessary in addition is (i) knowledge that what is proposed to be done is against the law or a reckless disregard whether what is proposed to be done is illegal or legal, and (ii) a decision to carry on doing it because the prospects of material advantage outweigh the prospects of material loss. It is not necessary that the defendant calculates that the plaintiff's damages if he sues to judgment will be smaller than the defendant's profit. This is simply one example of the principle. The defendant may calculate that the plaintiff will not sue at all because he has not the money (I suppose the plaintiff in a contested libel action like the present must be prepared nowadays to put at least $£ 30,000$ at some risk), or because he may be physically or otherwise intimidated. What is necessary is that the tortuous act must be done with guilty knowledge for the motive that the chances of economic advantage outweigh the chances of economic, or perhaps physical, penalty.

The reason for these extra requirements is to make sure that the freedom of publishers is safeguarded. In respect of the size of punitive damages awards in case of defamation, the following examples can be mentioned. As the two requirements mentioned in the previous citation were satisfied in the Cassell case, the claimant, who was 'a retired captain in the Royal Navy of unblemished reputation', 379 obtained punitive damages of $£ 25,000$ (which represents an amount of over $£ 245,000$ today $^{380}$ for libelous conduct by an author and his publisher that consisted in holding him responsible for a naval disaster in World War II. An example of a more recent amount of punitive damages in a defamation case is $£ 275,000$, which was reduced to $£ 50,000$ on appeal, in John v. Mirror Group Newspapers Ltd., a case decided in $1997 .^{381}$

To conclude, another situation that may fall into the second category giving rise to punitive damages is wrongful eviction in the relationship between landlord and tenant. ${ }^{382}$ For example, a landlord can unlawfully force his tenant to leave the rented place because he wants it for his own family or for monetary gain. ${ }^{383}$ In fact, punitive damages are more often awarded in these cases than in libel cases. As far as amounts are concerned, punitive damages awards in wrongful eviction cases can range from $£ 100$ to $£ 7,500$. $^{384}$

Rookes v. Barnard, at § 1227.

378 Cassell \& Co. Ltd. v. Broome, at $\S 1079$; Wilcox 2009, p. 12.

379 Cassell \& Co. Ltd. v. Broome, at § 1051.

380 Wilcox 2009, p. 42.

381 Wilcox 2009, p. 42, citing John v. MGN Ltd. [1997] QB 586.

382 Burrows 2004, p. 414; Wilcox 2009, p. 14.

383 Wilcox 2009, p. 15.

384 Wilcox 2009, p. 43. 
(3) Any category in which exemplary damages are expressly authorised by statute.

This category has been added to the first two categories which, according to Lord Devlin, are established as part of the common law. ${ }^{385}$ There is only one statute which expressly authorises punitive damages: the Reserve and Auxiliary Forces (Protection of Civil Interests) Act 1951, s. 13(2). Furthermore, there is discussion on the question whether the terminology 'additional damages' used in the Copyright, Designs and Patents Act 1988, s. 97(2) and the Patents Act 1977, schedule A1, $\S 12$ authorises the awarding of punitive damages. ${ }^{386}$

There have been proposals, although not yet officialised, by the government to replace the terminology in all acts with 'aggravated damages' or 'aggravated and restitutionary damages'. If these suggestions are followed, punitive damages are no longer authorised by statute and become merely a matter of the common law. The reason for this is that the government 'does not intend any further statutory extension of exemplary damages in civil proceedings' and that the term 'additional damages' is not helpful. ${ }^{387}$

\subsection{Other Relevant Factors in the Assessment of Punitive Damages}

Passing the categories test is no guarantee for the plaintiff who has claimed punitive damages. According to Lord Devlin, courts also have to take the next three factors into account. ${ }^{388}$ Firstly, a plaintiff cannot recover punitive damages unless he is the victim of the punishable behaviour. This factor is explained as follows:

The anomaly inherent in exemplary damages would become an absurdity if a plaintiff totally unaffected by some oppressive conduct which the jury wished to punish obtained a windfall in consequence.

This is Lord Devlin's solution to the undesirable windfall effect that a punitive damages award could have on the plaintiff. ${ }^{389}$ Secondly, as the power to award punitive damages constitutes a weapon that can be used in defence of liberty but also against liberty, Lord Devlin asks the courts to moderate punitive damages awards so that the weapon is used with restraint. However, in practice there seems to be 'almost total discretion to award whatever sum is felt necessary to punish the defendant and to set an example to others'. ${ }^{390}$ Thirdly, the means of the parties are relevant in calculating the punitive damages award, just as other mitigating circumstances such as contributory fault of the victim. ${ }^{391}$ According to Lord Devlin:

385 Rookes v. Barnard, at $\S 1227$

386 Burrows 2004, p. 416-417; Wilcox 2009, p. 17-18.

387 Wilcox 2009, p. 18-19.

388 Rookes v. Barnard, at $\S 1227-1228$.

389 See section 4.3.2.3.

390 Burrows 2004, p. 421.

391 Burrows 2004, p. 422. 
The means of the parties, irrelevant in the assessment of compensation, are material in the assessment of exemplary damages. Everything which aggravates or mitigates the defendant's conduct is relevant.

Compare in this regard section 3.3.3, which explains that also in American law the nature of the wrongful conduct and the wealth of the defendant are relevant factors in assessing the punitive damages award. In practice, also in English law, the means of the defendant rather than the means of both parties are especially relevant; the claimant's means are only relevant insofar as they 'affect the culpability of the defendant's behaviour'. ${ }^{392}$ If the defendant is wealthy, punitive damages can be quite substantial. This may for example be so if the defendant is a newspaper in a defamation case. ${ }^{393}$ In addition to these three factors, Lord Devlin has added the 'if, but only if' test: ${ }^{394}$

Thus a case for exemplary damages must be presented quite differently from one for compensatory damages; and the judge should not allow it to be left to the jury unless he is satisfied that it can be brought within the categories I have specified. But the fact that the two sorts of damage differ essentially does not necessarily mean that there should be two awards. In a case in which exemplary damages are appropriate, a jury should be directed that if, but only if, the sum which they have in mind to award as compensation (which may, of course, be a sum aggravated by the way in which the defendant has behaved to the plaintiff) is inadequate to punish him for his outrageous conduct, to mark their disapproval of such conduct and to deter him from repeating it, then it can award some larger sum.

In other words, punitive damages cannot be awarded if the compensatory award is adequate to punish the wrongdoer. According to Wilcox, the 'if, but only if' test emphasises the punitive effect that is already inherent in compensatory damages and avoids double counting. ${ }^{395}$ The decision whether the compensatory award is adequate is left to the discretion of the judge. For example, as explained in $K D v$. Chief Constable of Hampshire: ${ }^{396}$

Exemplary damages may be awarded for oppressive and arbitrary behaviour by police officers when that deserves the exceptional remedy of exemplary damages. But that will only be so where the basic award, including any aggravated damages, is in the circumstances inadequate punishment for the defendant.

The Court eventually decided that a punitive damages award was not necessary as the compensatory award, consisting of an immaterial damages award of $£ 10,000$ for anxiety and injury to feelings plus an additional aggravated damages award of $£ 10,000$, was considered 'adequate both to compensate the claimant and to punish the defendant'. 397

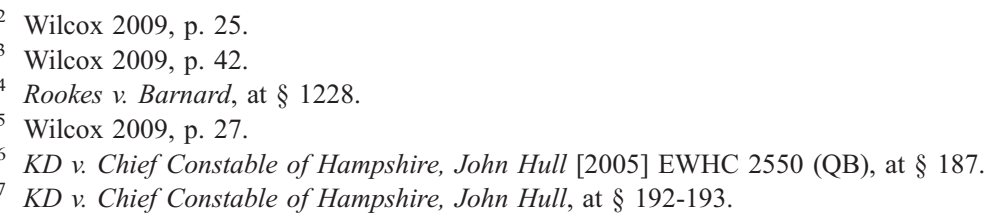


In contrast, the Court in John v. MGN Ltd took a different approach when deciding whether the 'if, but only if' test was satisfied: ${ }^{398}$

The question is, whether the sum which we have awarded for compensatory damages is sufficient to punish the newspaper and deter it and others. In our judgment it is not, since we do not think that this sum adequately reflects the gravity of the newspaper's conduct, or that it would deter it or other national newspapers of a similar character from such conduct in future. An award of exemplary damages is therefore, in our judgment, necessary to meet these two requirements.

Another important factor is the prevention of double punishment for the same offence: if a defendant has already been punished by a criminal law mechanism, punitive damages cannot be awarded. ${ }^{399}$ Compare in this respect section 3.3.4, which explains that, in American law, a criminal conviction does in principle not bar the imposition of punitive damages against the defendant for the same act in a civil lawsuit, and an award of punitive damages is not considered a double jeopardy.

\subsection{Punitive Damages for Breach of Contract?}

In principle, under English law, punitive damages are not available for breach of contract, as contract law primarily concerns the protection of economic interests. ${ }^{400}$ The leading authorities supporting this view are Addis v. Gramophone Co. Ltd. ${ }^{401}$ and Perera v. Vandiyar. ${ }^{402}$ However, some recent decisions give room for the view that this restriction is not absolute. For example, as a result of the abolition of the cause of action test in Kuddus, it might no longer be justifiable to make a distinction between torts and breach of contract as far as it concerns the awarding of punitive damages. ${ }^{403}$ As explained earlier, also under American law, punitive damages are not totally excluded in situations of breach of contract.

\subsection{English Government Rejects Suggestions to Reform Punitive Damages Law}

Awarding punitive damages is an accepted method of giving a punitive function to private law that will most likely remain part of future English law. But, also in English law, the subject is surrounded by controversy. ${ }^{404}$ It has been suggested that the law on punitive damages should be changed or even abolished. In 1997, the Law Commission for England and Wales published a report on 'Aggravated,

398 John v. MGN Ltd. [1997] QB 586, at § 626.

399 Burrows 2004, p. 420; Wilcox 2009, p. 28-30.

400 Burrows 1998, p. 140; Burrows 2004, p. 408; Wilcox 2009, p. 21; Samuel \& Rinkes 1991, p. 26; Law Commission Report 1997, p. 108.

401 Addis v. Gramophone Co. Ltd. [1909] AC 488

402 Perera v. Vandiyar [1953] 1 WLR 672.

403 Burrows 2004, p. 410. See on the introduction of punitive damages for breach of contract in English law also Rowan 2010.

404 Morgan 2012, p. 183; Burrows 2004, p. 424. 
Exemplary and Restitutionary Damages'. ${ }^{405}$ This report gives an outline of the present law as well as suggestions for reform. ${ }^{406}$ The Law Commission stated about the need to reform: ${ }^{407}$

The interpretation given to Rookes $v$ Barnard by the Court of Appeal in AB v South West Water Services Ltd, limiting exemplary damages to wrongs in respect of which they had been held to be available before the decision in Rookes $v$ Barnard, has meant that the availability of exemplary damages is now yet further dictated by what are arguably the accidents of precedent, rather than sound principle. Although it is not inconceivable that the House of Lords could reformulate the law in a way that is more satisfactory, it is surely correct that the present state of the law "cries aloud ... for Parliamentary intervention". The overwhelming majority of our consultees agreed that the current law is in an unsatisfactory state. One consultee spoke for many in stating that the "result of $A B v$ South West Water Services Limited is intolerable in terms of justice, logic and certainty."

The arguments against punitive damages expressed in the consultation paper that preceded the report are the following: ${ }^{408}$

The aim of the law of civil wrongs is to provide compensation for loss; punishment is not a legitimate function of the law of civil wrongs and should take place only within the context of the criminal law; now that non-pecuniary harm is more freely compensatable exemplary damages are no longer necessary; the quantum of exemplary damages is uncertain and indeterminate; exemplary damages constitute an undeserved windfall to the plaintiff; levels of exemplary damages are too high.

In contrast, arguments that plead in favour of punitive damages have also been listed in the report: ${ }^{409}$

Punishment, deterrence and the marking out of conduct for disapproval are legitimate functions of the law of civil wrongs; exemplary damages alert plaintiffs to a method for the effective private enforcement of important rights; criminal, regulatory and administrative sanctions are inadequate; in some situations, compensation is inadequate or artificial, or does not effectively remedy the infringement of certain important interests.

The Law Commission advises that punitive damages should be retained ${ }^{410}$ and gives an extensive list of recommendations in this regard. ${ }^{411}$ It would go too far to explain all the recommendations at this point, especially as the English government has largely ignored the report. Therefore, some of the most important recommendations will be pointed out. The Law Commission, for instance, gives the following important suggestion: ${ }^{412}$

405 Law Commission Report 1997. In 2000, the Irish Law Reform Commission issued a comparable report, retrieved via: www.lawreform.ie/_fileupload/Reports/rAggravatedDamages.pdf.

406 Law Commission Report 1997, parts IV and V.

407 Law Commission Report 1997, p. 93.

408 Law Commission Report 1997, p. 94.

409 Law Commission Report 1997, p. 94.

410 Law Commission Report 1997, p. 104.

411 Law Commission Report 1997, p. 106-107. See for a summary of the main points Burrows 1998, p. 169-171.

412 Law Commission Report 1997, p. 106 
[exemplary damages] may only be awarded where in committing a wrong, or in conduct subsequent to the wrong, the defendant deliberately and outrageously disregarded the plaintiff's rights.

It also advises the legislator to abolish the cause of action test. As explained above, this has been done by the judiciary two years after the publication of the report in the Kuddus case. ${ }^{413}$ Furthermore, according to the Law Commission, the awarding of punitive damages should not be restricted to three categories. Rather, they should be available for any civil wrong except breach of contract. Another recommendation is that punitive damages may only be awarded if other remedies are inadequate to punish the wrongdoer, according to the above-mentioned 'if, but only if' test as established in Rookes v. Barnard. ${ }^{414}$ Lastly, the Law Commission makes clear that it should be the judge and not the jury who determines whether punitive damages should be awarded and what the amount should be.

In 1999, the recommendations on punitive damages made by the Law Commission were rejected by the English government. ${ }^{415}$ In this respect, the government made the following statement: ${ }^{416}$

This Report also made recommendations for legislation on exemplary, or punitive, damages. The Government are grateful to the Law Commission for its important and painstaking work on this subject, and to those who expressed their views during the Law Commission's consultation exercises on the topic. The contending arguments for a complete legislative overhaul of exemplary damages, as recommended by the Law Commission, or abolition as preferred by many commentators, are finely balanced. In the absence of a clear consensus on the issue the Government have decided not to take forward the Law Commission's proposals for legislation on exemplary damages. It may be that some further judicial development of the law in this area might help clarify the issues.

Most importantly, the English government has until now left the categories test intact, thereby leaving a lot of discretion in awarding punitive damages to the courts. The subject nevertheless remains controversial. Wilcox for example suggests that, if one thing could be changed, the categories test should be abolished as, in her opinion and that of 'notable judges and academics', the scope of the categories is by far not clear. ${ }^{417}$ Edelman points out that without a deterrencebased remedy, such as punitive damages, a moral gap would exist in private law. Furthermore, he suggests that the arguments against punitive damages in English law are 'either flawed or incomplete'. ${ }^{418}$ To end with, Janecek recently suggested that the problematic concept of exemplary damages in English common law should be reinterpreted 'as a type of compensatory remedy in order to retain its coherence and normativity.' 419

413 Kuddus v. Chief Constable of Leicestershire Constabulary.

414 Rookes v. Barnard, at $\S 1228$.

415 Burrows 2004, p. 428 and Wilcox 2009, p. 8, citing Hansard (HC Debates), 9 November 1999, col 502.

416 Hansard (HC Debates), 9 November 1999, col. 502, retrieved via: www.parliament.uk.

417 Wilcox 2009, p. 53.

418 Edelman 2008, p. 225.

419 Janecek 2013, p. 191 
It follows from this subsection that - more than in Dutch, German and French law - deterrence and punishment are accepted functions of tort damages in English law. What is most striking is the recognition of a restricted form of punitive damages: such damages can in principle be awarded if the so-called categories test has been passed. In short, punitive damages are recoverable: (1) in case of oppressive, arbitrary or unconstitutional action by servants of the government; (2) in case of calculated conduct resulting in profit for the defendant; or (3) if exemplary damages are expressly authorised by statute. Another striking aspect of English tort damages is that, given the highly valued protection of personality rights in England, the size of immaterial or aggravated damages awards for personality right infringements is substantial, even in comparison to the Netherlands, Germany and France where personality rights are - as was seen - also highly valued and 'protected' by immaterial damages awards. In England, until twenty years ago, awards up to $£ 600,000$ were imposed in cases concerning personality right infringements. Nowadays, a still substantial and non-binding maximum of \pm $£ 200,000$ has been set for such awards. These awards clearly serve the functions of deterrence and punishment, in addition to compensation and recognition of the victim.

Thus, the conclusion should be that, of the four European legal systems studied in this chapter, England is the only legal system that explicitly accepts the punitive damages remedy. Furthermore, although in all four legal systems relatively substantial immaterial damages are awarded in case of serious personality right infringements, English courts seem to have the most liberal view in respect of large amounts.

\subsection{A Comparison Scale of the Legal Systems: From Compensation to Punishment}

The purpose of this chapter is to find an answer to the fifth research question, i.e. which civil sanctions that bear a resemblance to the punitive damages remedy can be pointed out in Dutch, German, French, and English law. Information on the extent to which punitive damages are alien to legal systems in continental Europe (systeemvreemdheid) is helpful in relation to the problem statement. In this chapter, relevant civil sanctions in four European legal systems have been outlined and explained. The result of this analysis can be used in this concluding section, which will present a comparison scale of these legal systems to find out whether each legal system prefers a mere compensatory or perhaps also a punitive approach. The legal systems described in this chapter will thereby be compared to the American legal system, which is obviously on the most punitive side of the scale. For that reason, this section will start with a short repetition of main aspects of the punitive damages remedy in American law. 


\subsubsection{The Position of the American Legal System on the Scale}

Also in the United States, the most important function of civil damages is full compensation of loss. ${ }^{420}$ In addition to that, and this is where the American legal system differs from the majority of jurisdictions, a punitive function of civil damages is explicitly and openly recognised. ${ }^{421}$ If the European systems described above are compared to the American system, it can quite easily be seen that the latter has the most punitive private law. This is mainly the result of the well-known use of punitive damages in that system, also in comparison to other legal systems that allow this civil remedy. Note that the punitive damages remedy is not the only available civil sanction in American law. As mentioned above, a civil remedy with a coercive and punitive function is the liquidated damages clause, in civil law systems known as the contractual penalty clause. In addition, more than the European systems, the American system makes use of so-called statutory civil penalties, meaning that the penalty for violations of a certain statute is fixed rather than calculated by the civil judge. Examples can be found in the Fair Credit Reporting Act and the Telephone Consumer Protection Act. ${ }^{422}$ With regard to statutory civil penalties, the possibility of multiple damages should also be mentioned, for example statutes that allow a court to treble the actual damages award such as the Clayton Antitrust Act mentioned in section 7.2.1.

With reference to chapters two to five, the following aspects of American punitive damages law should be mentioned. Firstly, punitive damages are a wellestablished part of the American legal tradition. Compared to other common law systems in which punitive damages are available, such as Canada, Australia, New Zealand, and England, the most widespread use of the civil remedy is without doubt in the United States. ${ }^{423}$ Even more than in the United States, the use of punitive damages in other countries is 'rare, limited to specific actions and involves relatively modest amounts' ${ }^{424}$ Punitive damages are currently available in almost every American state, although there is great variety among the states as to the circumstances under which such damages may be awarded. Secondly, the civil remedy has several important functions. Punishment and deterrence are considered to be the most important functions. Although the main function of punitive damages is indeed often presented as twofold, one should keep in mind that deterrence can also be seen as the purpose of punishment. This is done, for example, by Posner and other law and economics scholars, as has been explained in section 7.3.1. Another important function is law enforcement. The punitive damages remedy is seen as a procedural mechanism which serves as an incentive for potential plaintiffs to initiate civil litigation and thereby plays an important role in private enforcement, which is the primary method of enforcing laws in the

420 Schwartz 2001, p. 175.

421 Magnus 2001b, p. 186.

422 See Scheuerman 2009.

423 Gotanda 2004, p. 31; Brand 2005, p. 183; Rendleman 2009, p. 4

424 Vidmar \& Wolfe 2009, p. 181. 
United States. This explains why American citizens are also considered private attorney generals who file lawsuits not only for themselves but also in the public interest. Other functions are compensation, especially to satisfy and vindicate the victim, preserving the peace and paying the plaintiff's attorneys fees. Thirdly, although when compared to other legal systems - including England - punitive damages are mostly awarded in the American legal system, punitive damages awards are not as out of control there as is often claimed. In fact, empirical research shows that punitive damages awards are uncommon and that the incidence and size of awards is generally not excessive. Fourthly, although punitive damages are in principle recoverable only for tort actions, American courts in practice award them in all sorts of situations. Contract cases are not excluded: punitive damages may for example be awarded when a breach of contract and an intentional tort are constituted by the same act. Fifthly, the basic requirement for a punitive damages award is the infringement of a legally protected interest. In addition to that, the plaintiff must have suffered actual damage and the behaviour of the wrongdoer must involve an element of major aggravation. Examples of outrageous behaviour are 'spite or malice, or a fraudulent or evil motive on the part of the defendant, or such a conscious and deliberate disregard of the interests of others that his conduct may be called willful or wanton'. ${ }^{425}$ Thus, in addition to the violation of a right and the infliction of actual damage, a certain state of mind of the defendant is needed for punitive damages to be awarded.

The above gives a general insight into the way in which the punitive function of American private law has taken shape. The next subsection will summarise the position of the European legal systems as regards the recognition of civil sanctions that bear a resemblance to the punitive damages remedy.

\subsubsection{The Position of the Four European Legal Systems on the Scale}

The approach in the four legal systems studied will now be classified from punitive to compensatory and compared to the American law of damages which is clearly on the most punitive side of the scale. As in the American legal system, the basic principle of the law of damages in all legal systems is full compensation of loss. This however does not mean that compensation is the only accepted function. Other functions that are recognised as desirable side effects by all the legal systems are satisfaction and deterrence. ${ }^{426}$ But most important in terms of this book, also punitive elements may explicitly or implicitly be present.

Although it is difficult to draw a clear line between a deterrent function on the one hand and a punitive function on the other hand, a certain level of differentiation between the two functions will always be made. According to Van Dam, the preventive and punitive function of tort damages especially plays a role in situations in which criminal law plays a minimal role, such as the protection of

42522 Am. Jur. 2d Damages § 569.

426 Magnus 2001b, p. 185. 
privacy, honour and reputation. ${ }^{427}$ As explained in section 6.2.2.6, this unclear borderline between the deterrent and punitive function has been confirmed in the Commentary to the Principles of European Tort Law. In this respect, reference should also be made to section 7.3.1, which explained that in the European search for powerful civil sanctions, the goals of deterrence and law enforcement seem to prevail. Punishment does not seem to be a goal in itself, as there is a need for stronger civil remedies in specific situations in which the already available remedies do not exert sufficient pressure on wrongdoers. It was seen that the punitive damages remedy has been suggested in this regard, for example by Wagner and Van Boom, as long as it fulfils a preventive rather than a punitive function. ${ }^{428}$ One can recall in this respect the above-mentioned remark that deterrence can also be seen as a purpose of punishment, as has been suggested by Posner: punishment is then not the goal of punitive damages, in itself, but rather a means to an end, namely deterrence. ${ }^{429}$ As explained before, also other American authors support the theory that deterrence should be seen as the leading purpose of punitive damages. ${ }^{430}$ This idea could make the main argument of punitive damages opponents that the punitive function of the civil remedy is inconsistent with continental European legal traditions less valuable. In this view, the advantages of the punitive damages remedy, i.e. deterrence, outweigh disadvantages relating to its punitive function. Although this may be a good theoretical starting point that receives support from law and economics scholars, in practice it is difficult to ignore the punitive aspect of punitive damages awards, as plaintiffs will probably experience the obligation to pay punitive damages primarily as a form punishment.

Of the four European legal systems, the only system that explicitly - meaning both judicially and in legal doctrine - recognises a punitive function of the law of damages is England. In this respect, the English approach can be distinguished from the continental European approach. Punitive damages are available in English law, although not as extensively as in the United States. As explained, Lord Devlin's categories test limits the number of situations in which punitive damages may be awarded. As the English part mainly focused on punitive damages, other English civil sanctions have hardly been described. Note, however, that with regard to awarding immaterial or aggravated damages for personality right infringements, of the four legal systems studied, English courts seem to have the most liberal view in respect of substantial awards in these cases.

The next system to be addressed on the comparison scale is the French legal system. The French attach great value to the traditional principle of full compensation. However, a punitive function of private law has also been recognised in the concept of peine privée. As mentioned above, this concept may take different

\footnotetext{
427 Van Dam 2013a, p. 352.

428 Wagner 2006b, p. 473-474; Van Boom 2006a, p. 35-37. Cf. Koziol who is critical about Wagner's idea: Koziol 2009, p. 289; Koziol 2012, p. 56-57.

429 Kemezy v. Peters, at $\S 34$. See section 7.3.1.

430 Dobbs 1989, p. 858. Section 2.3.3.
} 
forms, such as the clause pénale, the astreinte, the disgorgement of profit based on the Intellectual Property Code, but also in the hidden form of immaterial damages. French courts often award immaterial damages that exceed the loss of the claimant and take into account factors such as the tortfeasor's wrongful behaviour. This is considered a covert, and therefore an implicit, way of awarding damages with a punitive element. Substantial immaterial damages especially occur in cases of personality right infringements. As similar instruments are accepted in the Dutch and German legal systems, it is however difficult to consider the French legal system as the most punitive of the three on this single basis. But the French liberal view on civil sanctions also follows from several developments in the academic and legislative field. Three proposals openly support the introduction of punitive damages in French law and this reason especially makes the conclusion that the French are in a further stage than Germany and the Netherlands justifiable.

Although the Germans do not officially recognise a punitive function of civil damages, the German legal system also implicitly seems to recognise noncompensatory elements and a deviation from the general principle of full compensation. This is for example so in the case of immaterial damages, especially those relating to personality right infringements. ${ }^{431}$ These awards may reach fairly large amounts, especially when compared to other continental European legal systems. This is probably the result of the dual function of immaterial damages, i.e. compensation and satisfaction. The satisfaction function has developed from the idea that, prior to the twentieth century, immaterial damages awards had a punitive function. Although the German Supreme Court considers the present satisfaction function of a private law nature, the borderline between a satisfaction function and a punitive function is not very clear and one could quite easily see a punitive element in some of the immaterial damages awards. Other non-compensatory elements in German law may be found in the disgorgement of profit clauses in the Copyright Act and the Antitrust Act, in the contractual penalty clause of $\S 339$ $\mathrm{BGB}$, and in the case law on GEMA.

The Dutch legal system has similarities with both the German and the French legal system and can probably be situated close to Germany on the scale. According to Magnus, Dutch law does not 'consider punitive purposes in any way an aim of the law of damages even as far as non-pecuniary damage is concerned'. ${ }^{432}$ A punitive function of civil damages is indeed not officially recognised in the Netherlands. However, as stated earlier, punitive elements may occur beneath the surface. For example, similar to German law, satisfaction is also an accepted function of immaterial damages in Dutch law. And although the size of Dutch immaterial damages awards is relatively small in comparison to some other European countries, also Dutch lower courts have shown willingness - albeit infrequently - to award a substantial sum of immaterial damages in case of grave wrongdoing. The examples given in section 9.4.1.2 above are that of a man who received immaterial damages of $€ 150,000$, because he became severally handi-

431 Magnus 2001b, p. 186.

432 Magnus 2001b, p. 186. 
capped due to attempted murder, ${ }^{433}$ and that of the patient who received $€ 136,000$ for being infected with HIV due to medical malpractice. ${ }^{434}$ Questions on the size and efficiency of immaterial damages awards in case of intentional, calculative and grave misconduct have also been brought up in Dutch legal doctrine. One can think of personality right infringements or other grave and serious breaches of private law duties in this respect. This has led to a debate about the need for powerful civil sanctions such as punitive damages. Furthermore, as in French law, punitive elements in private law can be found in the contractual penalty clause (article 6:91 BW) as well as the civil judicial penalty payment. As regards disgorgement of profit, the Dutch civil code has a separate provision for this remedy, namely article 6:104 BW. It was explicitly decided by the Dutch Supreme Court that this provision does not, not even partly, have a punitive character. This rejection of a punitive character of profit disgorgement however does not mean that the remedy in fact has zero punitive effect, especially as the Court made clear that the conduct of the defendant and the level of blameworthiness are factors that should be taken into account when assessing the damages award. In so doing, the Court recognised that compensation of the claimant is not the sole starting point in calculating a damages award on the basis of article 6:104 BW.

\subsection{Concluding Remarks}

To conclude, situated on the punitive side of the comparative scale is the American legal system, followed by England. Both common law systems explicitly recognise the punitive damages remedy. The three remaining legal systems also recognise non-compensatory elements in the law of damages, albeit more implicitly. It is particularly believed that civil remedies may have a deterrent, satisfactory or even punitive aim in certain situations. The most important example in this respect is the personality right infringement, which may lead to immaterial damages that deviate from the general principle of full compensation. In all four legal systems, courts in assessing immaterial damages awards - sometimes seem to be led by considerations that go beyond the principle of full compensation. ${ }^{435}$ The French seem to have the most liberal view on civil sanctions, which also follows from academic and legislative proposals, whereas Germany and the Netherlands take a somewhat intermediate position. A punitive function is not explicitly recognised there, but there are nonetheless signs that the function of civil damages is not merely compensatory. The idea that deterrent and punitive elements in civil damages are de facto recognised in the Dutch, German and French legal system is defensible. The argument that the punitive damages remedy is inconsistent with continental European legal traditions since it is alien to the European system,

433 Lindenbergh 2008a, p. 75, citing Rb. 's-Hertogenbosch 11 april 2007, JA 2007/99.

434 HR 8 juli 1992, NJ 1992/714 (HIV-besmetting).

435 Wurmnest 2012, p. 446. 
especially in relation to the compensatory function of private law, therefore seems to be unfounded and over-simplified. This conclusion is in line with legal history: as was seen in section 6.2.2.1, compensatory and punitive elements were historically combined in the Roman law of delict. Under the influence of canon law and due to the development of a stronger public criminal law from the thirteenth century onwards, the focus slowly shifted from punishment of the wrongdoer to satisfaction of the victim. It is nowadays believed that the function of the immaterial damages award, which was introduced when the law of delict lost its punitive function, is similar to the function of the ancient civil fine. Thus, in view of the historical foundation of tort law, accepting the idea that the punitive damages remedy is not completely alien to the system in continental Europe, as is often suggested, would be an understandable outcome.

Now that all five research questions have been answered, there is a firm foundation to analyse the problem statement adequately, which will be done in the following concluding - chapter ten. 


\section{CHAPTER TEN \\ DOES THE PUNITIVE DAMAGES REMEDY HAVE A FUTURE IN CONTINENTAL EUROPE?}

\subsection{Introductory Remarks}

What happens in the United States will not stay there. This conventional wisdom was presented in the introduction chapter of this book. Now, in the concluding chapter, this wisdom will be reflected upon once more and considered in light of the European punitive damages debate. This book considers the following problem statement: does the punitive damages remedy have a future in continental Europe? As explained in chapter one, the primary objective of this book is to increase the understanding of punitive damages in order to find out whether this civil remedy has a future in continental Europe. Only a correct knowledge of the facts relating to this powerful remedy creates the possibility of answering this question in a fair manner. Because of the long-term American experience with punitive damages law and practice, this book has referred to American law in particular.

Five research questions had to be answered in the previous chapters in order to analyse the problem statement of this book adequately. The first research question, concerning the characteristics of the civil remedy in American law, was addressed in chapters two to five. Research questions two, three and four, concerning the underlying reasons for the non-existence of punitive damages in continental Europe, the causes of the increased European interest in punitive damages and the status quo of punitive damages rejection in Europe, were addressed in chapters six, seven and eight respectively. Chapter nine dealt with the last research question about civil sanctions, especially those that bear a resemblance to the punitive damages remedy, that can be distinguished in Dutch, German, French and English law.

The purpose of this final chapter is not to repeat all concluding observations that have been included in the foregoing chapters. Instead, a number of steps will be taken in order to be able to answer the question whether the punitive damages remedy has a future in continental Europe. To start with, section 10.2 explores two relevant aspects of the European punitive damages debate: the resistance to and the interest in the punitive damages remedy. Section 10.3 concerns the main research results regarding American punitive damages law in order to provide a number of lessons and warnings for European policymakers. To conclude, section 10.4 explores the question whether acceptance of punitive damages in continental Europe is a realistic proposal and gives recommendations on the possible use of this civil remedy. 


\subsection{There is Resistance to, but also Interest in, Punitive Damages in Continental Europe}

\subsubsection{Relevant Aspects of the European Resistance}

To find out whether the punitive damages remedy has a future in continental Europe, a number of issues relating to the European punitive damages debate have been addressed in the second part of this book, i.e. chapters six to nine. These chapters teach that the approach that many, but not all, participants in the European debate have towards the civil remedy is largely negative. In general, two reasons can be pointed out to explain this resistance: (1) the negativity is primarily caused by a number of obstacles that are intrinsic to the civil law tradition, and (2) the negativity is also based on an incorrect perception of the American reality of punitive damages.

In this section, three points of particular interest relating to the first reason will be reflected on, namely the reasons for the non-existence of punitive damages in continental Europe, the status quo of punitive damages rejection in Europe and the fact that the punitive damages remedy is deemed to be alien to continental Europe. The second reason will be analysed in section 10.3. It is essential for participants in the European debate to realise that, even though certain aspects of the civil remedy are also considered controversial in the United States, this powerful remedy still plays an important role in the American civil justice system. But then again, contrary to what is often believed by outsiders, American punitive damages law is not characterised by excessiveness. This means that the European resistance to punitive damages is - at least partly - based on inaccurate arguments. Simultaneously, certain indications in American law support the idea that the introduction of punitive damages in continental Europe is worth considering. In line with the American approach, it is interesting to think about the positive results that the civil remedy might have with regard to law enforcement and certain categories of tortious behaviour, such as intentional, calculative and grave misconduct. As there are serious indications that point towards increased attention for private enforcement in Europe, as well as calls for powerful civil sanctions, it could be useful to have an open and positive attitude towards the punitive damages remedy. The next section will begin by exploring the obstacles to punitive damages in continental Europe.

\subsubsection{The Reasons for the Non-Existence of Punitive Damages: Prohibitive Objections or Not?}

As mentioned above, the European resistance to punitive damages is partly caused by a number of obstacles that are intrinsic to the civil law tradition. The following reasons seem to prevent the existence of punitive damages in civil law systems, including those in continental Europe: (1) the civil remedy is inconsistent with the traditional functions of tort law; (2) there is a fundamental rejection in light of the division between public law and private law; and (3) different views on the role of 
government might explain the absence or presence of punitive damages in a certain legal system. The extensive explanation of this topic that was given in chapter six will not be repeated here. ${ }^{1}$

On the one hand, these reasons can unquestionably be seen as prohibitive objections to the introduction of punitive damages in continental Europe. Punitive damages opponents in the European debate will probably keep availing themselves of these objections, and this is understandable as all objections form part of our legal tradition for a good reason. This indeed means that, at this point in time, continental Europe is not ready for the introduction of punitive damages. On the other hand, it should be made clear that it is possible to put each single objection into perspective. In this respect, the initial impetus will be given in the following subsections with the purpose of stimulating the debate.

\subsection{Problems Relating to the Traditional Functions of Tort Law}

As regards the first reason for the non-existence of punitive damages, the civil remedy seems to be inconsistent with the current accepted functions of tort law in continental Europe. One could doubt, however, whether this argument should really be seen as a prohibitive objection to the introduction of punitive damages. In practice, tort law serves more functions than the traditional compensatory function, and the borderline between these functions (e.g. deterrence or satisfaction as opposed to punishment) is not always crystal clear. ${ }^{2}$ Whereas it is generally accepted that compensation is the primary function of tort law, it is not the sole function. Tort law has a combination of functions and it depends on social and political circumstances and per legal system which functions are predominant. For instance, in the past decennia, the deterrent function has received increased attention. Furthermore, history tells us that the functions of tort law have always been subject to change and are dependent on common desires. Historically, tort law did have a clear punitive character in addition to its compensatory function in both common law and civil law systems. In ancient Roman law there was no real division between public law and private law and a mixed system of criminal law existed. Modern civil law systems have - at least theoretically - surrendered the punitive function of tort law, whereas common law systems have retained it in the form of punitive damages. It has been suggested that, although a punitive function of tort law is theoretically no longer accepted, continental European legal systems might in practice - albeit to a lesser extent - still adhere to the historical approach of combining the functions of punishment and compensation. For example, although the present acceptance of liability for immaterial loss is dogmatically seen as a difference compared to the punitive character of the Roman law of delict, from a functional point of view this difference should be put into perspective. One could argue that the function of the immaterial damages award, which was introduced when the law of delict lost its punitive function, is comparable to the 
function of the ancient civil fine. ${ }^{3}$ Punitive damages would perhaps have still existed in continental Europe if the social and political desires would have been different. In other words, despite their incompatibility with the current functions of tort law, punitive damages could be part of private law in continental Europe if this is considered a proper policy choice. The introduction of punitive damages might deserve reconsideration in light of the European debate concerning private enforcement and calls for powerful civil sanctions. In this respect, a recent remark made by Giesen should be kept in mind, namely that the prohibition to introduce punitive damages into Dutch law hinders the development of private law which is variable by nature and dependent on common desires in a certain period. ${ }^{4}$

\subsection{Problems Relating to the Public-Private Divide}

A similar conclusion can be reached with regard to the second reason for the nonexistence of punitive damages in continental Europe, namely the strict division between public law and private law. Dogmatic arguments against punitive damages relating to the public-private divide are, although justifiably given as reasons for the non-existence of punitive damages in continental Europe, primarily theoretical obstacles that may be overcome in practice. The public-private divide is an extensively debated topic in legal doctrine. The character of the divide has been explained as not only juridical but also political and ideological. It can be seen as a dogmatic solution to deal with the organisation of a certain legal system. As will be further explained in section 10.2.2.1 below, common law lawyers also know this division, but generally seem to find it difficult, unimportant or undesirable to classify legal norms as public or private. They do not let it stand in their way when making certain policy choices. As mentioned in the previous paragraph, an example of such a policy choice is the imposition of punitive damages. In other words: the awarding of punitive damages, for example in the American legal system but also in other common law systems, is first and foremost a choice of policy that is not hindered by the existence of theoretical objections such as the public-private divide. In contrast, the idea in civil law systems that tort law has a compensatory rather than a punitive function is not only based on the theoretical analysis of tort law, as such, but also results from the strict division between public law and private law.

One aspect relating to the public-private divide that is especially put forward by punitive damages opponents as an objection to the introduction of punitive damages is the compatiblility of punitive damages with criminal procedural safeguards, in particular the principle of legality, the ne bis in idem principle, several evidential safeguards, and the general right to a fair trial that has been laid down in article 6 ECHR. ${ }^{5}$ The question whether the punitive damages remedy has a future in continental Europe can obviously not be answered without giving fair consideration to this problem. First the American approach to this issue will be

Section 6.2.2.1.

Giesen 2013, p. 292. Section 7.3.2

Section 6.3.2. 
briefly recapitulated. The lack of safeguards in American punitive damages law is also considered controversial by American critics. Nevertheless, in practice it does not impede the imposition of punitive damages by American courts, as the reason for requiring a high level of protection in criminal law is the threat of criminal punishment for the defendant. Civil sanctions, including punitive damages, are generally considered less severe and less stigmatising than criminal sanctions. The smaller risk of violating the wrongdoer's privacy in civil procedures justifies a smaller degree of protection and therefore the availability of less procedural safeguards in American punitive damages law. With regard to the ne bis in idem principle or the double jeopardy principle, it was seen that a criminal conviction does not bar the imposition of punitive damages by American courts for the same act in a civil lawsuit because the punitive damages claim is distinguishable from the criminal prosecution. To be precise, the criminal sanction is mainly imposed for the wrong done to society, whereas the civil sanction is primarily imposed for the wrong done to the individual plaintiff. The double jeopardy principle cannot be invoked to prevent the imposition of additional civil sanctions, as this principle protects only against the imposition of multiple criminal punishments for the same offence that occur in successive proceedings. The general rule that a punitive damages award cannot be considered a double jeopardy allows the punitive damages remedy to function as a supplement to criminal law sanctions. ${ }^{6}$ Difficulties relating to the principle of legality are removed by the general reform measure in American punitive damages law concerning the clarification of vague standards relevant to questions of measurement, liability and misconduct. ${ }^{7}$ Another reform measure to control punitive damages awards relates to so-called evidential safeguards. Most American states require clear and convincing evidence for punitive damages to be awarded. Furthermore, the defendant is entitled to the privilege of protection against self-incrimination and the defendant who is also charged with a crime is usually protected from selfincrimination by a stay (or: suspension) of the civil procedure, which obliges the claimant to wait until the criminal proceedings are closed. ${ }^{8}$

With reference to section 6.3.2.1, the following should be mentioned about the compatibility of punitive damages with article 6 ECHR. Due to the broad definition of civil obligation in the sense of article 6, paragraph 1 ECHR, it is defensible that punitive damages are to be considered as such. This means that this provision is applicable to the imposition of punitive damages, which gives punitive damages defendants the right to have 'a fair and public hearing within a reasonable time by an independent and impartial tribunal established by law'. ${ }^{9}$ On the basis of three criteria developed by the European Court of Human Rights, it is also defensible to consider the imposition of punitive damages as a criminal charge. Although this should not by itself lead to the conclusion that article 6 ECHR is breached, the additional safeguards of paragraph 2 (presumption of innocence) and

\section{Section 3.3.4}

Section 4.4.1

Section 4.3.2.1

Article 6 § 1 ECHR. 
3 (right to defence) ECHR are then applicable. However, it is thus far quite unclear what the level of protection for potential punitive damages defendants should be, as the Court has not (yet) decided on the criminal charge character of civil fines imposed for non-contractual liability. Should punitive damages one day be introduced in continental Europe, the system of protection has to crystallise. The Court could start by making clear what a less strict treatment, as referred to in the Jussila v. Finland decision, should precisely look like and whether this treatment could also apply to civil sanctions. The Court decided in this case that, in criminal cases that do not carry any significant degree of stigma, for example if a penalty is imposed for violating a legal rule that does not belong to the hard core of criminal law, the safeguards of article 6 ECHR are not fully applicable. ${ }^{10}$

Questions remain in the European discussion concerning compatibility of punitive damages with criminal procedural safeguards. Although this is understandable as the punitive damages remedy is not an accepted civil sanction in continental Europe, it is also a problematic conclusion in light of the question whether the punitive damages remedy has a future in continental Europe. This problem can on the one hand be seen as a prohibitive objection to the introduction of punitive damages. On the other hand, should the introduction of punitive damages one day be seriously considered by legislators within continental Europe, a nuanced approach to this problem similar to that in the United States is worth considering. The Americans deal with this problem by adapting certain criminal safeguards, for example evidential safeguards, and making them fit for punitive damages law. Other safeguards such as the ne bis in idem principle are not considered problematic at all, meaning that the lack of these safeguards cannot in itself impede the imposition of punitive damages. To conclude, for example because of the criticism relating to the confusion of criminal law and tort law and the lack of criminal procedural safeguards, American courts are generally instructed to avoid largely disproportionate awards and impose punitive damages with great caution.

\subsection{Problems Relating to the Role of Government}

The third reason for the non-existence of punitive damages in continental Europe relating to views on the role of government will now be addressed. In this respect, several practical differences between the United States and continental Europe can be put forward as objections to the introduction of punitive damages in the latter area. A first important aspect of the American legal system that is, as was seen, virtually absent in current European legal practice is private enforcement. Citizens who function as private attorneys general are an unknown phenomenon in Europe. However, as will be further explained in section 10.2.2.1, there are serious indications that point towards increased attention for private enforcement in Europe in order to complement public enforcement mechanisms. 
Other aspects of the role of government that directly influence civil litigation and indirectly influence the use of punitive damages concern views on other compensation mechanisms and on government regulation. With regard to the first aspect, private insurance and social security have been developed to a wider extent in Europe than in the United States as alternatives to tort litigation. In Europe, situations involving personal injury are often dealt with by social security or private insurance. This provides a plausible explanation for the underdevelopment of civil litigation in personal injury cases in Europe when compared to the United States. However, one must bear in mind that there is a 'retreat of the European Welfare State' development going on. Also due to financial and economic crises that have captivated the world in the past years, a policy of retrenchment nowadays prevails, meaning, for instance, that social security benefits are being further reduced. This makes compensation via tort law a more appealing compensation mechanism for Europeans. ${ }^{11}$ As regards the second aspect, due to the different perspectives on government regulation, Europeans may not rely on civil litigation and punitive damages to the same extent that Americans do. ${ }^{12}$ The overall picture is that the United States developed a litigation strategy, whereas (countries within) the European Union developed a regulation strategy towards the protection of health and safety in society. However, also in this respect, the retreat of government is noticeable: increased attention is being paid to privatisation and private enforcement, which are developments that are in line with each other. This explains the shift from public to private law enforcement in different areas such as health care, housing, energy supply, information provision concerning financial and health risks, and transport. ${ }^{13}$

Lastly, the unfamiliarity with certain procedural law mechanisms such as contingency fees and class actions allegedly does not facilitate civil litigation in European civil law systems. Not surprisingly, changing ideas are visible in Europe with regard to this point. One can think of the Dutch Act on Collective Settlements Mass Damages (Wet Collectieve Afhandeling Massaschade or WCAM) from $2005,{ }^{14}$ as well as the experiment started by the Dutch legislator in January 2014 to introduce a 'no cure, no pay' system in order to guarantee effective access to court as examples of this. ${ }^{15}$ These are only Dutch examples, but there are also changes at the European level, for instance evident from the recent communication and recommendation of the European Commission concerning the future of collective redress in the European Union. In these documents, the Commission advises the Member States 'to have collective redress systems at national level that follow the same basic principles throughout the Union'. ${ }^{16}$ It thus looks as if American mechanisms such as class actions and contingency fees are slowly

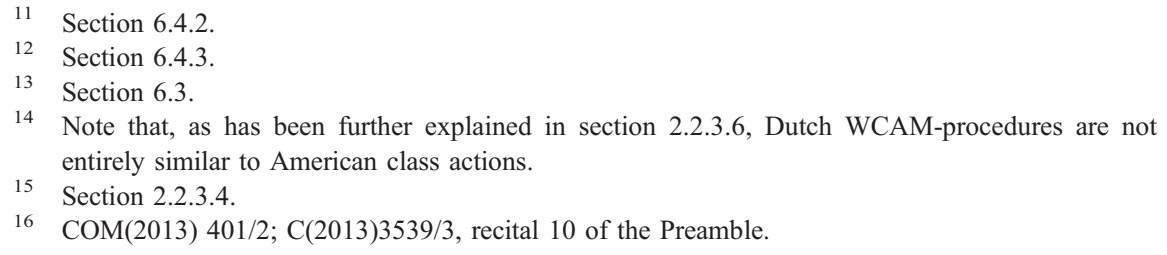

$16 \mathrm{COM}(2013) 401 / 2$; C(2013)3539/3, recital 10 of the Preamble. 
winning ground in Europe, with the purpose of creating a legal climate in which civil litigation is made more easily accessible.

To conclude, several practical differences relating to the role of government can be pointed out between the United States and continental Europe. It is plausible that these differences influence civil litigation and the use of punitive damages. It is however interesting to see - especially in respect of the main focus of this book - that these differences slowly become smaller, for example due to the retreat of government and shifts from public to private law enforcement in Europe. It is therefore debatable whether problems relating to the role of government should still be seen as prohibitive objections to the introduction of punitive damages in continental Europe. It seems, on the contrary, that the possibilities for introducing punitive damages are slowly but surely becoming more realistic.

\subsubsection{What is the Status Quo of Punitive Damages Rejection in Europe?}

In the previous paragraph it was shown that a number of reasons prevent the introduction of punitive damages in continental Europe. Now another relevant objection that has been addressed in this book will be explored: the status quo of punitive damages rejection in Europe. The contemporary, largely negative, approach to punitive damages was illustrated by defining the position of three European institutions: the European Court of Human Rights, the legislator of the European Union and the Court of Justice of the European Union. Furthermore, the European approach towards punitive damages was described from a private international law perspective.

Punitive damages are technically not awarded by the European Court of Human Rights. ${ }^{17}$ In comparison to the legislator of the European Union, as well as the Court of Justice of the European Union, the negative approach to punitive damages of this Court becomes relatively clear. The Court's rejection of the civil remedy follows not only from a number of decisions but also from the Practice Direction on Just Satisfaction claims of 2007. An award of just satisfaction on the basis of article 41 ECHR is clearly meant to compensate applicants for the actual harmful consequences of a human rights violation. Thus far, the Court has not been willing to depart from this traditional compensatory principle. However, as suggested in legal doctrine, there might be room for a broader interpretation of the term 'just satisfaction' in article 41 ECHR on the basis of the wide range of satisfactory measures that have already been granted in international human rights law. At least two recent decisions can be pointed out in which the Court allegedly deviates from the compensatory principle by using the award for just satisfaction as a deterrent or even a punishment. ${ }^{18}$ This idea is supported by the notion that the more grave violations should be sanctioned more severely to achieve credible and effective legal protection. ${ }^{19}$ The introduction of punitive damages is considered an option in

17 Section 8.2.

18 ECtHR 19 June 2012, Krone Verlag GMBH v. Austria, no. 27306/07; ECtHR 25 June 2013, Trévalec v. Belgium, no. 30812/07.

19 Shelton 2005, p. 366. 
this respect, and it is therefore wise to keep an eye on the Court's future interpretation of this term. It is not completely surprising that the punitive damages remedy forms an important sanction in American human rights law. Considerable punitive damages have been awarded in American human rights cases in order to give effect to the international prohibition against torture and deter such gross offences, which might create a precedent for future European human rights cases.

The approach of the legislator of the European Union is, as mentioned above, less straightforward. ${ }^{20}$ It has been described as ambivalent and evidently selfcontradictory. A few examples of the legislator's largely negative approach to punitive damages can be mentioned. First of all, the Rome II Regulation considers punitive damages contrary to public policy. However, it should be noted that this rejection of punitive damages is not absolute as only punitive damages of an excessive nature are considered contrary to public policy. Examples of a negative approach to punitive damages can also be found in the enforcement of intellectual property rights Directive, the Montreal Convention on international carriage by air which is applicable within the European Union, the recent documents of the European Commission in the context of collective redress mentioned in the previous section, and some EU legislative proposals.

But the EU legislator has also shown positivity towards punitive damages, for example in the Green Paper on damages actions for breach of EC antitrust rules. Clearly inspired by the American experience with private enforcement of antitrust law, the legislator has openly and extensively discussed the possible introduction of punitive damages to fight EU competition law infringements and has thereby contributed to the increased attention for the civil remedy throughout Europe. This development follows on the Manfredi judgment in which the CJEU has referred to the possibility to award punitive damages founded on EU competition law, if such damages may be awarded pursuant to similar actions based on national law. ${ }^{21}$ In that case, the Court did not consider punitive damages to be contrary to the European public order. Note, however, that the Commission has taken a more reserved position on punitive damages in the White Paper which followed upon the Green Paper; in this document the focus is on full compensation of victims of anticompetitive behaviour. ${ }^{22}$ At present, private enforcement of EU competition law is still premature, and specific legislative action is required if it is to be taken seriously. ${ }^{23}$ In 2013, the Commission initiated such action with the proposal for a Directive on damages actions for EU competition law infringements, and the communication on quantifying harm in damages actions. Also in these documents, which complement the collective redress initiatives, the sole focus is on compensation. ${ }^{24}$ Nonetheless, in this legislative stage nothing definite has been decided

\section{Section 8.3.}

Manfredi, at $\S 93,99$.

Section 7.2.4.3

Section 7.2.3 and 7.2.4

$24 \operatorname{COM}(2013) 404$ final, article 2. The proposal for a Directive on damages actions is accompanied by an impact assessment report: SWD(2013) 203 final; C(2013) 3440, at § 1.2. The communication on quantifying harm is accompanied by a practical guide: $\operatorname{SWD}(2013)$ 205. See section 7.2.4.4. 
yet in respect of punitive damages. Furthermore, the requirement of effective preventive sanctions for breaches of European Union law, which has been laid down in European anti-discrimination legislation, contributes to the uncertain and inconsistent position of the EU legislator. With regard to national legislators, it should be noted that continental European legal systems in principle fundamentally reject punitive damages. Nevertheless, this subject slowly but surely grabs the attention of national legislators. For example, in France several academic and legislative initiatives seriously consider punitive damages as an option to strengthen tort law.

Just like the EU legislator, the Court of Justice of the European Union does not seem to have a clear position in the punitive damages debate. ${ }^{25}$ On the one hand, the Court has underlined the absence of EU law on punitive damages. On the other hand, the Court has contributed to the ambivalent and self-contradictory attitude of the European Union in respect of punitive damages by creating the requirement, referred to above, that sanctions which may be imposed for breaches of EU law should be 'effective, proportionate and dissuasive'. This formula has become an important tool in a number of European Directives concerning employment discrimination and has been further interpreted by the Court in the context of breaches of EU competition law. Interestingly, even though the formula was probably not originally created for this purpose, it has already been connected to the punitive damages remedy in legal doctrine, for example in the context of intellectual property law, competition law, infringements of personality rights, and discrimination. $^{26}$

The most favorable European approach to punitive damages, at least for punitive damages supporters, can be seen in the area of private international law. ${ }^{27}$ Foreign (in practice: American) punitive damages judgments are generally viewed with hostility by national courts within Europe. Recognition and enforcement of such judgments is difficult as this will usually be considered contrary to a country's public policy. The public policy exception is interpreted in several recognisable ways: the punitive damages award is intolerable due to its criminal function, the award violates the traditional compensatory function of civil damages, or the amount of the award is excessive and disproportionate. Nevertheless, as has also been noticed by others, at least four national courts in different European countries have shown a liberal attitude in respect of the recognition of American punitive damages awards. For example, the French Supreme Court decided in 2010 that foreign punitive damages awards can in principle be recognised in France except if they are disproportionate to the actual damages award and to the wrongdoer's fault. ${ }^{28}$ This increased liberalness has not only been signaled but has also been supported in legal doctrine, in the sense that the hostility towards punitive damages is considered misplaced and the tolerant approach of the liberal courts should form

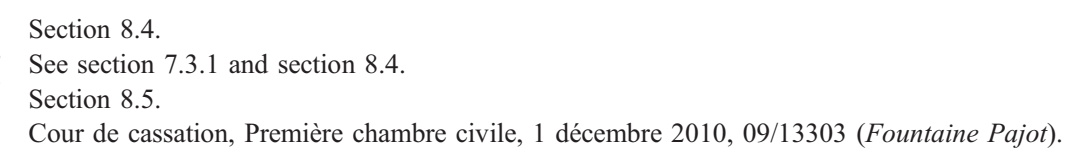


an example to other courts. ${ }^{29}$ The public policy exception still seems to be a high hurdle when it comes to the recognition of punitive damages in continental Europe, but it is perhaps time to change this. In this respect, it fits in well that the public policy concept is perfectly suitable for adaptation if this is required by changing social and political desires.

\subsubsection{What about the Fact that the Punitive Damages Remedy is Deemed to be Alien to the European System?}

The last objection to the introduction of punitive damages that has been discussed in this book relates to the fact that the punitive damages remedy is assumed to be alien to continental European legal systems (systeemvreemdheid), which plays a central role in the European punitive damages debate. Should this argument be seen as a prohibitive objection or can it be put into perspective? Information with regard to the extent to which punitive elements are alien to the European system in private law is necessary for answering the question whether the punitive damages remedy has a future in continental Europe. It is important to become aware of civil sanctions that already exist in private law systems in continental Europe, especially sanctions that bear a resemblance to the punitive damages remedy. The existence thereof could be indicative for policymakers and legislators, in the sense that this renders often heard arguments against punitive damages, such as theoretical and practical obstacles relating to the compensatory function of tort law and the publicprivate divide unfounded. With the purpose of exploring the existence of relevant civil sanctions in five legal systems (the United States, the Netherlands, Germany, France, and England), a so-called comparison scale has been provided in chapter nine. This scale shows that the three continental European legal systems that were studied in this book, i.e. the Netherlands, Germany and France, recognise noncompensatory elements in the law of damages, albeit more implicitly than the United States and England. As both common law systems explicitly recognise the punitive damages remedy, they are situated on the punitive side of the scale. With regard to continental Europe, the French have the most liberal view on civil sanctions, whereas Germany and the Netherlands take an intermediate position. Non-compensatory elements seem to be primarily de facto recognised in Dutch, German and French tort law. It is particularly believed that immaterial damages awards may have a preventive, satisfactory or even punitive aim in certain situations of grave wrongdoing. An example is the infringement of personality rights: immaterial damages that allegedly deviate from the traditional compensatory principle can especially be pointed out - in all three continental European legal systems - in the case of serious personality right infringements. The assessment of compensatory damages by courts is indeed sometimes based on factors that go beyond the principle of compensation, such as the conduct of the defendant and the degree of blameworthiness. This additional focus on the tortfeasor's behaviour means that compensation of the victim is not the only goal in estimating the damages award. One could therefore argue that the argument

29 Nagy 2012, p. 10; Requejo Isidro 2012, p. 329; Parker 2013, p. 431. 
that the punitive damages remedy is not suitable for continental European legal systems because of the above-mentioned notion of systeemvreemdheid, especially in relation to the compensatory function of private law, is unfounded or oversimplified. This conclusion is in line with the above-mentioned historical remarks, i.e. the combination of compensatory and punitive elements in the Roman law of delict. In view of the historical foundation of tort law, accepting the idea that the punitive damages remedy is not entirely alien to the Europen system as is often suggested, would be an understandable outcome.

\subsubsection{Relevant Aspects of the European Interest}

As was shown above, a number of obstacles prevent the introduction of punitive damages in continental Europe. It was also seen that it is possible to put these arguments against punitive damages into perspective. It is, however, not likely that punitive damages opponents will easily accept these qualifications. At this point in time, the obstacles are still mainly seen as prohibitive objections in the European punitive damages debate. Are there perhaps other arguments which should lead to a different conclusion? Despite the above-mentioned obstacles that explain in large part the resistance to punitive damages of many participants in the European debate, at the same time there seems to be growing European attention for the civil remedy. The remedy rouses curiosity throughout Europe and is clearly on the agenda of academics and policymakers, but drastic measures are not taken because of the resistance felt. It therefore seems that Europe stands at the crossroads in respect of punitive damages. This section concerns the causes for the increased interest in punitive damages that can be pointed out in the European punitive damages debate: private enforcement and calls for powerful civil sanctions.

\subsubsection{Private Enforcement}

The first important cause is the increased European attention for private enforcement as a method of enforcing various legal norms. As already mentioned in section 10.2.1.1.3 above, the retreat of government is seen as the main reason for shifts from public to private law enforcement - with an important role for tort law - in areas such as health care, housing, energy supply, information provision concerning financial and health risks, and transport. ${ }^{30}$ The changing view on law enforcement theories can also be seen as one of the reasons for the increased interest in punitive damages in continental European legal systems. Here private enforcement is referred to when law enforcement is a matter of private initiative, i.e. is initiated by a private person (such as a consumer, an entrepreneur or a governmental entity acting as a private person), rather than an initiative of the government (governmental supervisors and regulators, police forces, public prosecutors etc.). The private person uses private law remedies, such as a damages award or an injunction, in order to obtain justice. Whereas private enforcement is a rather unknown concept in Europe, in the United States it is the primary method of enforcing numerous laws. One can think of

30 Rijnhout et al. 2013, p. 173-174. 
securities laws, consumer protection laws, civil rights laws, antitrust laws, and environmental laws as examples of this. To give an example: more than $90 \%$ of antitrust laws are privately enforced in the United States. ${ }^{31}$ An important role is thereby reserved for the punitive damages remedy. The extensive use of the powerful civil remedy in the American legal system in comparison to other legal systems may well be explained by the relatively modest role of the American state and the important position of civil litigation in American society. The punitive damages remedy allegedly works as a procedural mechanism and an incentive for potential plaintiffs to initiate civil litigation, and it thereby contributes to law enforcement as well as deterrence and punishment of tortious misconduct. Thus, we see a traditionally extensive use of private enforcement in the United States, whereas there is limited use of the mechanism in Europe. This may be explained by a different approach towards the distinction between public law and private law or the confusion of criminal law and tort law: common law lawyers seem to put less weight on the public-private divide than civil lawyers do. The public-private divide is also respected in the United States but - in contrast to civil law countries - it does not impede the imposition of punitive damages there. The use of punitive damages is clearly seen as a choice of policy. One could say that the Americans are far more pragmatic in this respect: important policy choices are not hindered by the publicprivate divide. An explanation for this approach might be that the public-private divide has a significant political character: the question whether a certain topic is regulated via private law or public law is not merely juridical but also political.

The public-private divide is considered a typical difference between civil law and common law systems. While it is of fundamental importance in civil law systems, common law systems attach less value to the dogmatic belief. In view of the main focus of this book, it is however important to stress once more that in civil law systems the rather strict public-private divide becomes more and more blurred and law enforcement theories are shifting from the public to the private level. A reason for this shift in Europe is the impact of European Union law and the extension of the effectiveness of European norms in the Member States. Another reason is the retreat of government and the gradual privatisation of European economic markets which results in more regulation of such markets via civil litigation. This already is common practice in the American legal system. The changing view on law enforcement theories can be seen as one of the reasons for the increased European interest in punitive damages. ${ }^{32}$ Due to changing policy views, European policymakers have shown interest in private enforcement to achieve public interest goals. In recent years, private enforcement has become a reemerging term in the European legal debate. Although this debate was initiated in the field of EU competition law, it is no longer merely concentrated there. There is an increased interest in private enforcement in different legal fields on both the European Union and national level, such as intellectual property law, environ-

\footnotetext{
31 Section 7.2.1.
}

32 Section 6.3. 
mental law, human rights law, consumer law, anti-discrimination law, and personality rights. Private enforcement could act as a complement to public enforcement, as the European Commission recently emphasised in the recommendation concerning collective redress: ${ }^{33}$

It is a core task of public enforcement to prevent and punish the violations of rights granted under Union law. The possibility for private persons to pursue claims based on violations of such rights supplements public enforcement.

Indeed, according to law and economics scholars, the ideal enforcement system would be a mix between public and private mechanisms. ${ }^{34}$ Due to lower costs there even is a preference for private enforcement but, as private enforcement alone is not sufficient, reliance on more expensive public enforcement mechanisms is needed. Thus, in line with the American approach to private enforcement, there is increased attention in Europe for a complementary form of law enforcement using private law remedies which, according to contemporary ideas, could perhaps even work better if one has access to powerful civil sanctions such as punitive damages.

\subsubsection{Calls for Powerful Civil Sanctions}

Apart from the increased European attention for private enforcement, there is another important cause of the European interest in punitive damages: the growing attention for the changing functions of tort law on a national level. Compensation, traditionally regarded as the main purpose of tort law, is not the sole purpose. In addition to its compensatory function, tort law nowadays has to fulfil tasks in the field of deterrence and influencing behaviour. Under the influence of law and economics and civilology, i.e. the study of civil law using other disciplines such as economics, psychology and sociology, growing attention is paid to the instrumental function of tort law. The idea is that tort law - if equipped with apt legal remedies - could be used as a mechanism to influence behaviour, deter tortfeasors and enforce tort rules. There seems to be a need to strengthen tort remedies to improve the enforcement of tort law standards and deal with intentional, calculative and grave misconduct, which are keywords to identify the type of wrongdoing that might require powerful civil sanctions. Not surprisingly, this is the type of misconduct for which punitive damages are mostly awarded in the United States; the popular punitive damages categories in American law are intentional torts, defamation and financial torts. ${ }^{35}$ These three categories indeed include intentional and grave wrongdoing, which particularly applies to the intentional torts, as well as calculative wrongdoing, for example defamation and fraud. ${ }^{36}$

Thus, the focus in the European debate is not only on the private enforcement of legal norms in general but on law enforcement within tort law. This development results from the existing idea that the availability of no other form of damages than

\footnotetext{
C(2013)3539/3, recital 6 of the Preamble.

Section 2.3.4.

Section 3.2 .2 .

Section 7.3.2.
} 
compensatory damages to react to serious breaches of private law duties creates a so-called enforcement deficiency. As mentioned before, one could doubt whether it is desirable from the viewpoint of law enforcement and deterrence that the reaction to breaches of private law duties is dominated by the notion of compensation. Important reasons for this doubt are the undercompensation of the victim or ineffective deterrence of the tortfeasor. ${ }^{37}$ In certain specific situations, the available tort remedies allegedly do not exert sufficient pressure on tortfeasors. An example is the infringement of personality rights in a calculative manner, such as publications by tabloids or other violations of a person's name, brand or product with the purpose of making profit. A legal problem that also gives rise to the question whether punitive damages could be of help is bad faith insurance, i.e. insurers who fail to give their clients what they are entitled to. In the United States, deterrence and punishment of bad faith insurance practices by means of punitive damages is common practice. Another example is the situation in which the nature of the wrongdoing is clearly inadmissible. In this respect, one can think of the Dutch cases that were seen in chapters seven and nine: the father who suffered a serious nervous shock as a result of the horrifying murder of his daughter, ${ }^{38}$ the parents who lost their children as a result of grave criminal offences leading to a fatal car accident, ${ }^{39}$ or the mother who was confronted with the murder of her seven-yearold son because her husband had the intention of wounding her. ${ }^{40}$ It has been suggested that private law should respond firmly - i.e. by means of powerful civil sanctions - to such private law infringements. Punitive damages are therefore considered a potential complement to the compensatory damages award.

An important remark in light of this development is that punishment does not seem to be a goal in itself in the search for stronger tort remedies. In contrast, the main focus seems to be on deterrence and law enforcement. In this respect, an important idea developed by law and economics scholars should be mentioned. In the dominant law and economics theory of punitive damages, (specific and general) deterrence is in itself a goal of punishment. ${ }^{41}$ Posner, for instance, suggests that deterrence should be seen as the purpose of punishment. ${ }^{42}$ In other words, punishment is not the main purpose of punitive damages but rather a means to an end: deterrence. European authors like Wagner and Van Boom seem to support the idea that punitive damages can be introduced as long as they fulfil a preventive rather than a punitive function. ${ }^{43}$ But this main focus on deterrence and law enforcement does not mean that the 'real' punitive element receives no attention at all in Europe. Moreover, as mentioned before, it is difficult to ignore the punitive aspect of punitive damages awards, because whichever way you look

37 Section 7.3.1.

38 Rb. Arnhem 29 maart 2006, NJF 2006/252 and subsequent cases Rb. Arnhem 16 mei 2007, NJF 2007/367; Hof Arnhem 26 mei 2009, NJF 2009/311.

39 HR 9 oktober 2009, NJ 2010/387, m.nt. J.B.M. Vranken (Vilt).

40 HR 26 oktober 2001, NJ 2002/216, m.nt. J.B.M. Vranken (Oogmerk).

41 Section 2.3.4

42 Kemezy v. Peters, 79 F.3d 33 (C.A.7 (Ind.) 1996), at § 34.

43 Section 7.3.1 
at it, plaintiffs will probably experience the obligation to pay punitive damages primarily as a punishment. At present, depending on the circumstances of a case, European courts already take into account the nature of the infringement and the degree of blameworthiness in assessing civil damages awards, which gives these awards a punitive character. ${ }^{44}$

\subsubsection{Conclusion}

Thus far the European punitive damages debate has not provided definite answers to the question whether the punitive damages remedy has a future in continental Europe. This is mainly caused by obstacles that are intrinsic to continental European legal traditions and resulting difficulties surrounding the introduction of punitive damages. These obstacles can, on the one hand, be seen as prohibitive objections to the introduction of punitive damages in continental Europe. On the other hand, as was seen in section 10.2.1, it is possible to put each objection into perspective. However, as it is currently unlikely that punitive damages opponents will accept these qualifications, at this point in time the obstacles are still seen as prohibitive objections in the European punitive damages debate.

Although the latter forms an important research result of this book, perhaps even more important for the debate is the conclusion that the punitive damages remedy still rouses curiosity throughout Europe. This gives the chance to elaborate on the question whether the civil remedy has a future in continental Europe. As was seen in the second part of this section, the European attention for punitive damages primarily results from changing policy views, especially the increased interest in private enforcement and calls for powerful civil sanctions. These developments have to be seen in the context of changing European views on the role of government. Inspired by the American experience, legal scholars throughout Europe wonder whether the punitive damages remedy could contribute to realising this ambition. As mentioned in section 10.2.2 above, Europe currently stands at the crossroads in respect of punitive damages. At this intermediate stage, there is both strong interest in and strong resistance to the civil remedy.

Now that this resistance and interest has been analysed, what participants in the European debate can learn from American punitive damages law will now be explored. The purpose of the next section is to safeguard that the European punitive damages debate can be continued properly.

\subsection{Misperceived Ideas of American Punitive Damages Law: Lessons for Continental Europe}

As mentioned above, the primary objective of this book is to increase the understanding of the punitive damages remedy as such, in order to find out whether this civil remedy has a future in continental Europe. Many, but not all, participants in the European punitive damages debate have a largely negative

44 Section 2.3.3. 
opinion of (the introduction of) punitive damages. This negativity is not only caused by a number of obstacles that are intrinsic to the civil law tradition, as was seen in the previous section, but it also results from the fact that outsiders seem to have an incorrect perception of the American reality of punitive damages. This section will focus on misperceived ideas of American punitive damages law, because it is essential that participants in the debate have a correct knowledge of the facts relating to this civil remedy. With reference to chapters two to five, a number of lessons that should be drawn from American punitive damages law and practice will therefore be summarised in this section. As this book explicitly does not want to ignore the fact that also in the United States the punitive damages doctrine is controversial and criticised, ${ }^{45}$ the lessons can also be seen as caveats or warnings that should be kept in mind by European policymakers. These warnings result from the long experience that the Americans have with the legal remedy.

\subsubsection{Lesson One: Powerful Civil Sanction in a Civil Justice System}

The first important lesson that should be drawn from the American legal system is that the punitive damages remedy forms part of a system in which the citizen, civil claims and the civil justice system play a vital role in dealing with everyday problems in society. Participants in the European punitive damages debate should be aware of the fact that the American civil justice system, including powerful civil sanctions such as punitive damages, need to be judged in consideration of the American legal context. The system functions rather well because of the comparatively reserved role for other compensatory and regulatory mechanisms, such as public law enforcement, social security and private insurance. The American civil justice system performs functions that in other modern legal systems, such as those in continental Europe, are primarily dealt with by governmental institutions. This explains why, as mentioned above, public policy is to a great extent privately enforced in the United States. In other words, civil litigation plays an important role in American policymaking.

Punitive damages fit well into American society, which assigns a modest role to the state and a large role to the civil justice system. The law enforcement function of punitive damages is considered a valuable aspect of the civil remedy, which allegedly gives an incentive to private litigants to start a civil lawsuit as private attorneys general. The punitive damages remedy thereby relieves the pressures on the criminal justice system and forms a useful complement to public enforcement mechanisms. ${ }^{46}$ Other accepted functions of punitive damages in view of interests of society in general and of the harmed party in particular are punishment and deterrence of the tortfeasor as well as compensation of the victim. This latter function should be seen in light of the victim's right to seek vindication and redress

\footnotetext{
45 Section 4.3
}

46 Section 2.2.2.2. 
for his injuries. ${ }^{47}$ The punitive damages remedy is not the only available legal instrument that gives an incentive to private litigants to start a lawsuit. The civil remedy forms part of a larger array of elements that facilitate a predominantly wellfunctioning civil justice system, such as adversarial legalism, juries, contingency fees, and class actions. These elements create a legal climate in which civil litigation is made accessible and give a central position to the right to sue, which is an essential right in American society. ${ }^{48}$ Consistent with the American Constitution, each American citizen has the right to hold a wrongdoer who hurts him and thereby causes damage accountable in a civil lawsuit, which may even lead to the imposition of punitive damages. ${ }^{49}$ Of course, Europeans are also aware of their rights in this respect, but the right to sue and trying to hold others responsible for your own bad luck is given more emphasis in the United States than in Europe. It seems very important for Americans to have this right, as they underline it far more often than Europeans do.

As explained in section 10.2.2.1, the imposition of punitive damages in the American legal system is a choice of policy that cannot be impeded by the publicprivate divide. One aspect relating to this divide that is especially put forward by punitive damages opponents is that the remedy has the nature of a civil penalty and is awarded without crimininal procedural safeguards, such as the requirement of proof beyond a reasonable doubt, protection against self-incrimination and double jeopardy. The fact that the public-private divide does not have much practical value for the imposition of punitive damages in the United States can be illustrated by the example that - as shown in section 10.2.1.1.2 - a criminal conviction in principle does not bar the imposition of punitive damages for the same act in a civil lawsuit. In other words, an award of punitive damages is not considered a double jeopardy. With regard to the lack of safeguards, such as the requirement of proof beyond a reasonable doubt and protection against self-incrimination, participants in the European punitive damages debate should remember the following. In order to solve the problem of lack of safeguards relating to the requirement of proof beyond a reasonable doubt, most American states require clear and convincing evidence for punitive damages to be awarded. Furthermore, civil litigants are entitled to the privilege against self-incrimination and the punitive damages defendant, who is also charged with a crime, is usually protected from self-incrimination by a suspension of the civil procedure. This obliges the plaintiff to wait until the criminal procedure is closed.

To conclude, the European approach to the role of government differs greatly from the American approach. ${ }^{50}$ This explains, albeit partly, the conflicting perception of civil litigation and the use of powerful civil sanctions such as punitive damages. However, the causes for the increased European interest in punitive damages that have been explained in the previous section, i.e. private

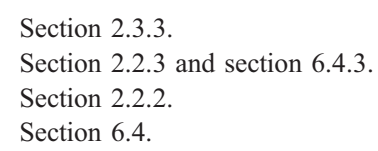


enforcement and powerful civil sanctions, give us reason to believe that it is worthwhile to learn from the American approach. In this respect, it is important that the European punitive damages debate is conducted in the right way and that opponents are informed correctly.

\subsubsection{Lesson Two: The Truth about Excessiveness}

The second lesson that European policymakers should bear in mind is that, although the American civil justice system plays an important role in American society, especially when compared to other legal systems, this does not automatically mean that it is also an excessive and for that reason a malfunctioning system. It is true that the United States has become known as a compensation culture, but this terminology does not necessarily have the negative connotation that it has in Europe. It seems that the idea that many Europeans have of the American civil justice system is not entirely representative. Urban legends concerning American tort cases that are rife but unreal, such as the case concerning the pet in the microwave, do not contribute to a positive picture. ${ }^{51}$ Although tort reformers have put a lot of emphasis on these civil litigation horror stories, empirical research shows that the number of tort actions is not as excessive as is often believed: tort cases form a relatively small percentage of American civil lawsuits and tort damages are generally modest in amount, whereas the majority of tort claims are settled. ${ }^{52}$ Nevertheless, it is important to keep in mind that, even though the American civil justice system is in practice not excessive, there is a noticeable difference between the United States and Europe: the above-mentioned right to sue is a deep-rooted right in American society that - comparatively speaking - is considered more important there than in Europe.

On the basis of other empirical research, it is also safe to state that the criticism relating to the incidence and size of punitive damages awards is almost certainly exaggerated. American legislators and courts have taken the position that punitive damages should be awarded with great caution and that largely disproportionate awards should be avoided. Misunderstandings and misleading information brought forward by media and anti-punitive damages lobbyists contribute to the negative image that consists of the incidence and size of American punitive damages awards. In fact, American courts do not often award punitive damages and the size of these awards is generally not as excessive as many outsiders claim. The relevant data, which has been mentioned before, will be emphasised once more at this point. ${ }^{53}$ Six major studies reviewing punitive damages verdicts from 1985 onwards for example disclose that punitive damages have been awarded in 2 to $9 \%$ of all cases that were won by the plaintiff. With regard to the size of these awards, the median for punitive damages awards was between $\$ 38,000$ and $\$ 52,000$ per award. Furthermore, a close correlation between the amount of compensatory and

\footnotetext{
Section 4.2.2.1

Section 2.2.3.1

53 Section 4.2.2.
} 
punitive damages has been found, which implies that punitive damages are not as unpredictable as often believed. Three reports made in 2005, 2009 and 2011 by the Bureau of Justice Statistics of the U.S. Department of Justice have also contributed to the awareness of application of punitive damages awards. The 2005 report, containing data from 2001, reveals that in that year no more than $356(6 \%)$ of the 6,504 state court civil trials that were won by the plaintiff resulted in punitive damages. In half of the 356 trials, plaintiffs obtained a punitive damages award of $\$ 50,000$ or more. In $41(12 \%)$ of the trials resulting in punitive damages, damages that equaled or surpassed $\$ 1$ million were awarded and in $9(3 \%)$ trials punitive damages of $\$ 10$ million or more were awarded. This report estimates the median for punitive damages at $\$ 25,000$ for the tort cases and $\$ 83,000$ for the contract cases. According to the 2009 report concerning state court tort trials in 2005, punitive damages were awarded in $254(3 \%)$ of the 8,763 tort trials with plaintiff winners; the median punitive damages award in these cases was $\$ 55,000$. The report of 2011 reveals that in 2005 punitive damages were sought in $12 \%$ of the approximately 25,000 tort and contract cases that were concluded in state courts. Punitive damages were awarded in $700(5 \%)$ of the 14,359 cases that were won by the plaintiff. The median award for these 700 cases was $\$ 64,000$, whereas in $13 \%$ of the 700 cases punitive damages of $\$ 1$ million or more were awarded.

With regard to the popular punitive damages categories in American law, participants in the European debate should remember the following. Punitive damages awards are especially rare in legal fields that receive most public, meaning also political, attention: products liability and medical malpractice cases in particular and personal injury cases in general. As mentioned in the previous section, punitive damages are mostly awarded in cases concerning intentional torts (such as battery and assault), defamation and financial torts (such as fraud, bad faith insurance, consumer sales, and discrimination cases), whereas personal injury resulting from negligence, automobile accidents, medical malpractice, and products liability plays a relatively minor role. ${ }^{54}$ The difference can be explained by the aggravating element that is required for the imposition of punitive damages. This aggravating element is probably more often present when the cause of action falls within one of the popular punitive damages categories than in the personal injury cases. Thus, although many outsiders believe otherwise, punitive damages awards play a relatively minor role in cases of personal injury resulting from negligence and accidents, whereas intentional torts, defamation and financial torts are most important. As shown in section 3.2.2, this does not mean that personal injury cases do not play any role in American punitive damages law. But it is important to distinguish between personal injury resulting from negligence and personal injury resulting from intentional behaviour. In the latter category, punitive damages are relatively often awarded, whereas punitive damages awards are uncommon in the first category. 
Thus, although excessive blockbuster awards have been reported, ${ }^{55}$ the conclusion that the incidence and size of American punitive damages awards is not generally excessive can be considered a plausible one. This is an important research result in light of the main focus of this book: the suggestion that American punitive damages awards are excessive is an often suggested misconception that participants in the European punitive damages debate should be aware of. The rejection of punitive damages should not be based on an incorrect perception of the American reality, such as arguments relating to fear for the development of a compensation culture or for exorbitant punitive damages awards. Furthermore, the three categories of wrongful behaviour in which punitive damages could especially play a role in continental Europe are known in American law as intentional torts, defamation and financial torts. This is in line with the calls for powerful civil sanctions in continental European legal systems to improve the enforcement of tort law standards and deal with intentional, calculative and grave misconduct: the three categories include intentional and grave wrongdoing, which particularly applies to the intentional torts, as well as calculative wrongdoing, for example defamation and fraud. An example of a Dutch Supreme Court decision that has provoked discussion as to the question whether there is a need for stronger tort remedies in case of intentional and grave misconduct is the aforementioned Vilt decision concerning the parents who lost their children as a result of grave criminal offences leading to a fatal car accident. ${ }^{56}$

\subsubsection{Lesson Three: Punitive Damages are Generally Awarded with Great Caution}

The third lesson should be drawn from the method applied by American courts to assess punitive damages awards and the legislative and judicial mechanisms to prevent excessive awards. As already mentioned in the previous section, punitive damages are generally awarded with great caution in the United States. Participants in the European debate should be aware of this. A foundational requirement in American law for a punitive damages award is the invasion of a legally protected interest. As a general rule, punitive damages are only recoverable for tort actions, but in practice punitive damages are awarded for all sorts of legal infringements. ${ }^{57}$ However, the sole fact that the defendant committed an unlawful act is not a sufficient basis for a punitive damages award: the unlawful behaviour must also involve a certain element of major aggravation, such as outrageous conduct due to the defendant's evil motive or his reckless indifference to the rights of others. ${ }^{58}$ Lastly, the plaintiff must have suffered actual damage in order to obtain punitive damages. $^{59}$

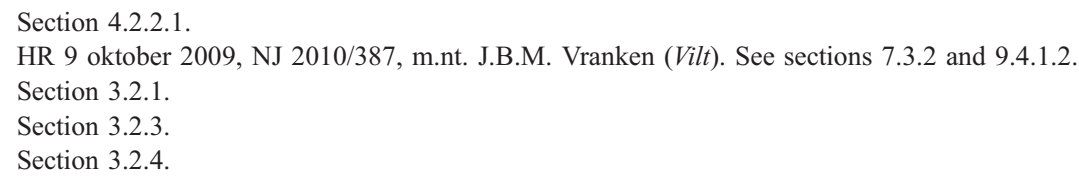


In assessing the amount of a punitive damages award, courts can especially take the following factors into account: the character of the defendant's act, the nature and extent of the harm, profits that the defendant gained due to his unlawful act, and the financial condition of the defendant. Although Europeans might believe otherwise, in the American legal system value is attached to the principle that the award should be reasonable and should not go beyond what is necessary to achieve its goals. This means that there must be a reasonable relation to the harm done to the plaintiff and to the amount of compensatory damages awarded. ${ }^{60}$

If European judges are given the discretion to award punitive damages, it is advisable to look into legislative and judicial methods that are used in the American legal system to prevent excessive and improper awards. Examples of legislative measures with the aim of controlling and limiting the imposition of punitive damages that could be relevant for Europe are: the clarification of vague standards, caps on awards, permitting payment of (part of) the award to the state or state agencies instead of to the plaintiff, separating questions of liability and compensatory issues from punitive damages issues, limiting punitive damages awards to one punishment for a single act or course of conduct, and requiring a higher standard of proof for the recovery of punitive damages in comparison to the recovery of compensatory damages. ${ }^{61}$ In respect of judicial review mechanisms, participants in the European punitive damages debate should specifically be aware of a number of guidelines created by the U.S. Supreme Court to prevent disproportional awards, especially in light of constitutional safeguards relating to excessiveness and due process. Even though the Court has made clear that it is impossible and also undesirable in light of the functions of punitive damages to draw a crystal-clear line between the constitutionally acceptable and the constitutionally unacceptable, the Court has constantly emphasised the need for reasonable punitive damages awards. $^{62}$

Note that an important reason for the necessity of these legislative and judicial reform mechanisms in the United States is the unclear situation that exists because each separate American state has a different punitive damages regime. In other words, there is no real legal unity (rechtseenheid) in American punitive damages law. If punitive damages are introduced in Europe, it could be useful to create legal unity and thereby prevent lack of clarity by using a set of clear and consistent rules. Based on their long experience with the civil remedy, authors from the United States and also England have indeed recommended that Europe should get the theory right before introducing it. ${ }^{63}$ In this respect, a number of recommendations that will be provided in section 10.4 below form a starting point for those who will one day be convinced of the possibility and desirability of introducing punitive damages.

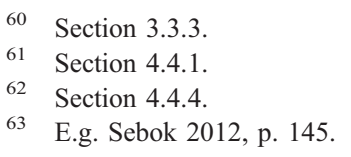




\subsubsection{Lesson Four: Insurability of Punitive Damages, Cause for Concern?}

The fourth and final lesson relates to the insurability of punitive damages. Insurability of punitive damages is often brought forward as an argument against (the introduction of) punitive damages. The availability of insurance and resulting loss spreading allegedly undermines the punitive and deterrent effect of punitive damages awards because the insurer instead of the wrongdoer pays the award (the moral hazard problem). Punitive damages insurance is in that way contrary to good manners and violates public policy, which is the main argument against such insurance. Another argument is that the economic impact of the insurability of punitive damages supposedly leads to increased costs for the insurance industry and to the public at large. The question whether insurance should cover liability for punitive damages is answered differently throughout the United States. ${ }^{64}$ Insurability of punitive damages normally depends upon the importance attached to public policy considerations, the type of defendant (direct or vicarious), and the type of tort (intentional or accidental). Research from 2008 shows that the majority of American states allow the insurability of some form of punitive damages. In this respect, the distinction between punitive damages that are assessed directly against the insured and punitive damages that are assessed vicariously against the assured is important. The majority of states permit the insurability of vicariously assessed punitive damages; only two states prohibit this form of punitive damages insurance. A plausible explanation for this result is that there is no real need to prohibit vicariously assessed punitive damages because public policy considerations, especially those relating to ineffective deterrence, play a lesser role in this category than in that of directly assessed punitive damages. In contrast, the insurability of directly assessed punitive damages is prohibited in twenty states, because the effect of a punitive damages award on the wrongdoer is almost zero if paid by an insurer. Thus, in comparison to vicariously assessed punitive damages, insurance of directly assessed punitive damages is problematic; the latter form of insurance is not allowed in almost half of the American states. Note that even in case the law in a certain state does not prohibit insurance, insurers may explicitly exclude - in full or in part - coverage for punitive damages liability. Some insurers for instance refuse coverage of punitive damages awarded as a result of intentional or calculative wrongdoing. Despite the controversy that has always surrounded the issue, in the past years the availability of insurance for both directly and vicariously assessed punitive damages has grown in the United States.

Participants in the European debate should take the following into account with regard to punitive damages insurance. If the punitive damages remedy is one day introduced in continental Europe, one should - beforehand - think about the insurability question. Whether the insurability of punitive damages is a cause for concern or not is for insurers to decide. They might decide to refuse coverage of punitive damages, for example because this takes away the deterrent effect of the award or because the punitive damages have been awarded as a result of

$64 \quad$ Section 3.4. 
intentional or calculative wrongdoing. This would be an understandable outcome, but that does not mean that refusal of punitive damages insurance is the preferable solution for everyone. The idea that there is no need to prohibit insurance if victims and injurers are rendered better off by it could prevail. In this respect, it is important to remember that in former days the moral hazard argument also played a role in the debate concerning general liability insurance, which has for a long time been seen in a bad light as it was considered invalid and contrary to good manners. ${ }^{65}$ Nowadays, liability insurance is the order of the day in modern legal systems. An important supervising task is thereby granted to insurers: indirect punishment and deterrence of wrongdoers via insurers who give incentives is considered normal and accepted. If insurers take this task seriously, also in Europe punitive damages insurance is not beyond the bounds of possibility.

\subsubsection{Conclusion}

At this point in time, the introduction of punitive damages in continental Europe does not seem to be a workable proposal. The idea simply encounters too much resistance. For example, the negative approach to punitive damages has been confirmed in the recent documents of the European Commission concerning collective redress. ${ }^{66}$ The resistance, which is primarily caused by a number of obstacles relating to the civil law tradition, cannot be easily removed. Nevertheless, an important conclusion of this book is that the possibility and desirability of introducing punitive damages continues to raise questions in the European debate.

Careful judgment is needed in deciding whether the punitive damages remedy should have a future in continental Europe. Participants in the European debate could thereby start with themselves. Probably the most important research result of this book is that the current European resistance to punitive damages is - in addition to the obstacles mentioned above - based on an incorrect perception of the American reality. As the American legal system serves as an example for many participants in the European debate, it is essential to have a correct knowledge of American punitive damages law and practice. The danger of lacking such knowledge is that the rejection of punitive damages is based on inaccurate arguments and therefore unfounded. Although the punitive damages doctrine is also considered controversial in the United States, it has survived several powerful constitutional attacks and still forms an indispensable part of the American civil justice system. Many outsiders have an incorrect perception of the incidence and size of American punitive damages awards (empirical research shows that punitive damages are not as excessive as often believed) and of the popular punitive damages categories (personal injury cases play a relatively minor role, whereas intentional torts, defamation and financial torts are most important). American courts are instructed to award punitive damages with great caution. In this respect,

65 Van Dam 2013b, p. 163. See section 2.2.3.7.

$66 \operatorname{COM}(2013) 401 / 2$, at $\S 3.1 ; \mathrm{C}(2013) 3539 / 3$, at $\S 31$. See section 2.2.3.6 and section 8.3. 
a number of legislative and judicial methods have been incorporated into American punitive damages law to prevent excessive and improper awards. The lessons provided in this section should help to improve the understanding of the punitive damages remedy, so that the required careful judgment can be made in a fair manner.

Based on the relevant aspects relating to resistance to and increased interest in punitive damages in continental Europe (section 10.2), as well as the lessons derived from American punitive damages law (this section), the following concluding - section makes an attempt to predict whether the punitive damages remedy has a future in continental Europe.

\subsection{Concluding Remarks: Punitive Damages in Continental Europe and Gazing into a Crystal Ball}

This concluding chapter has shown that two reasons for the resistance to punitive damages in continental Europe can be pointed out. The negativity is primarily caused by a number of obstacles relating to the civil law tradition. As explained in the first part of section 10.2, the introduction of punitive damages is problematic in light of problems relating to the traditional functions of tort law, the public-private divide and the role of government. These reasons can - on the one hand - be seen as prohibitive objections to the introduction of punitive damages in continental Europe. Punitive damages opponents will probably affirm the idea that all objections form part of continental European legal traditions for a good reason. Furthermore, they will undoubtedly suggest other options than punitive damages to deal with the alleged law enforcement deficiency in continental Europe, the retreating government, and the calls for more powerful civil sanctions. One often heard option is to solve law enforcement deficiencies via public law mechanisms. ${ }^{67}$ Another option is to tackle the problem of our reduced social security system rather than to fall back on the tort system, as has already been suggested by Faure and Hartlief. ${ }^{68}$ A last option is to rely on already existing civil sanctions in order to exert pressure on wrongdoers, for example by raising the level of immaterial damages awards. Despite these obvious drawbacks, given the increased European interest in punitive damages explained in the second part of section 10.2, it is still worthwhile to consider seriously the introduction of punitive damages. But it is difficult - particularly due to the current European resistance as well as the fact that the remedy is deemed to be alien to continental Europe (systeemvreemdheid) - to say anything meaningful about the distant future. The only thing that is left is to gaze into a crystal ball, which would lead to the following conclusion.

The decision to introduce punitive damages is first and foremost a choice of policy. The policy reason to introduce the remedy in continental Europe is twofold: (1) to complement public enforcement mechanisms by providing citizens with a powerful civil sanction in order to privately enforce their rights in different legal fields, such as competition law, environmental law, consumer law, human rights

67 Section 4.3.1.

68 Faure \& Hartlief 1999, p. 2015. 
law, intellectual property law, anti-discrimination law, and personality rights; and (2) to improve the enforcement of tort law standards and deal with specific situations of intentional, calculative and grave misconduct. The choice for punitive damages is a possibility, which does not necessarily mean that this possibility is also realistic. In case the choice for punitive damages is made, it is imaginable to put each single objection into perspective. These solutions certainly have to crystallise and be adapted to the situation, but the initial impetus was given in section 10.2.1.1 with the purpose of stimulating the debate. Should legal systems in continental Europe one day be convinced of the possibility and desirability of introducing punitive damages, a number of guiding principles might come in handy. These recommendations should be read in view of the following American and European words. According to Supreme Court Justice O’Connor: ${ }^{69}$

Punitive damages are a powerful weapon. Imposed wisely and with restraint, they have the potential to advance legitimate state interests. Imposed indiscriminately, however, they have a devastating potential for harm.

Koziol has put it as follows: ${ }^{70}$

Punitive damages do not have to be admitted into the seventh legal heaven but neither would eternal damnation be appropriate. I think they should be condemned to purgatory and after a due period of purification some may graciously be admitted to the first legal heaven.

Both O'Connor and Koziol are prudent, but they do not close the door completely. Perhaps, as long as certain general principles are taken into account, punitive damages could have a future in continental Europe. The following recommendations, which form a start and will need to develop further, should help participants in the European debate to get the theory right and - imaginably - also to overcome difficulties in respect of the introduction of punitive damages:

(1) One of the most important questions is who should initiate the introduction of punitive damages in continental European legal systems. There are two strategies for solving this problem. One option is to give the legislator the sole initial competence to create a set of clear and consistent punitive damages rules. In this way, the legislator could prevent the lack of legal unity (rechtseenheid) that currently exists in American punitive damages law. ${ }^{71}$ Another option is to leave the introduction of punitive damages to the judiciary. While the first option might indeed be attractive for reasons of legal certainty and transparency, the second option gives room to experiment with the size of civil damages awards in case of grave infringements and thereby make a gradual transition towards awarding punitive damages possible. This can be done within the framework of existing legislation, such as the Dutch article 6:106 BW on immaterial loss. As explained in section 9.4.1.2, there are indeed starting points to attribute a punitive function

71 Section 10.3.3. 
to this article. The latter option is preferable as it gives the chance to gain more experience with stronger civil remedies and - because it is less definite - can be reversed more easily is case of persistent opposition. The legislator can of course cancel the experiment prematurely or (refuse to) come into action once the experiment has been finished. ${ }^{72}$

(2) Punitive damages are limited to certain categories of intentional, calculative and grave misconduct. Thus, punitive damages are certainly not available for all sorts of tortious behaviour. Based on the American experience, examples of relevant categories are intentional torts, defamation cases and financial torts. The English legal system might also serve as an example. English law points out specified categories in which punitive damages are recoverable: (1) in the case of oppressive, arbitrary or unconstitutional action by servants of the government, and (2) in the case of calculated conduct resulting in profit for the defendant, or (3) if exemplary damages are expressly authorised by statute.

(3) The decision to award punitive damages as well as the amount of the award falls within the discretion of the civil judge who determines whether there are sufficient factors present to justify a certain punitive damages award. Due to the absence of a jury system in continental European legal systems, the sole discretion of the civil judge speaks for itself.

(4) The punitive damages award bears a reasonable relation to its punitive, deterrent and compensatory function. The award is specifically reasonable in relation to: (a) the wrongful behaviour; (b) the harm done to the plaintiff; (c) the amount of compensatory damages awarded; and (d) other legal penalties that are available for the same conduct. Empirical research shows that in general the median ratio of punitive to compensatory awards remains less than 1:1 in the United States. ${ }^{73}$ The U.S. Supreme Court commented on what constitutes a reasonable relation in the maritime common law case Exxon Shipping Co. v. Baker decided in $2010 .^{74}$ According to the Court, a 1:1 ratio of the punitive damages to the compensatory damages is indeed considered a fair upper limit. $^{75}$ Although this case concerned maritime common law, it gives an indication of the Court's idea with regard to other types of punitive damages cases. This is especially so as the Court established the said ratio in the context of the 'stark unpredictability of punitive awards'. ${ }^{76}$ In assessing the amount of a punitive damages award, the civil judge can take the following factors into account: the character of the defendant's act, the nature and extent of the harm

Cf. the 'no cure, no pay' experiment that the Dutch Minister of Safety and Justice and the Dutch bar recently started for personal injury lawyers, see section 2.2.3.4.

73 Section 4.2.2

74 Exxon Shipping Co. v. Baker, 554 U.S. 471, 128 S.Ct. 2605 (U.S. 2008). See on this case section 4.4.4.3.

75 Exxon, at $\S 473-474$

76 Exxon, at $\S 472$. 
and the financial condition of the defendant. ${ }^{77}$ The possibility of criminal punishment and profits that the defendant gained due to his wrongful act can also influence the size of the punitive damages award.

(5) Certain measures to avoid excessive punitive damages awards are imaginable, such as (a) legislative caps on awards; (b) permitting payment of (part of) the award to the state or state agencies to prevent a windfall for the plaintiff; (c) separating questions of liability and compensatory issues from punitive damages issues; (d) limiting punitive damages awards to one punishment for a single act or course of conduct; and (e) requiring a higher standard of proof for the recovery of punitive damages in comparison to the recovery of compensatory damages.

As mentioned before, it is unlikely that the punitive damages remedy will be introduced in continental Europe in the near future. Even in subfields such as EU competition law and collective redress, where a lot of attention has already been paid to the possible introduction of punitive damages, resistance still seems to dominate the debate. Nevertheless, these recommendations form a starting point for those who will one day be convinced of the possibility and desirability of introducing punitive damages. European policymakers, legislators and courts could pragmatically focus on goals rather than on problems and keep in mind that practical difficulties will remain as long as practice stays the way it is. They should certainly not be led by a fear of excessive civil claims and the rise of a compensation culture. As explained in section 10.3, certain indications in American law support the idea that this is an unfounded attitude. The popular punitive damages categories in American law are the categories in which punitive damages could especially play a role in continental Europe. As explained in section 10.2.2, this is in line with the calls for powerful civil sanctions in continental European legal systems to improve the enforcement of tort law standards and deal with intentional, calculative and grave misconduct.

At present, Europe stands at the crossroads in respect of punitive damages. As there is both strong interest in and strong resistance to punitive damages, it currently finds itself at an intermediate stage as regards the question whether the introduction of the civil remedy is desirable and possible. It is clear that it is difficult, if not impossible, to predict the future. A clear answer to the question whether the punitive damages remedy has a future in continental Europe can therefore not be given at this point. To end with, as two developments point towards an increased need for stronger civil remedies in Europe, it could be useful to have an open attitude towards the punitive damages remedy and focus on the positive effects that this remedy may have. Perhaps it is time to throw objections overboard and start an experimental stage in which the civil judge has more powerful tools to deal with certain forms of tortious behaviour. This might even turn out surprisingly good.

77 Restatement of Torts, $\S 908$. 


\section{NEDERLANDSE SAMENVATTING}

\section{Punitive damages}

Een civiele remedie in het Amerikaanse recht, lessen en caveats voor continentaal Europa

\section{$1 \quad$ Inleidende opmerkingen}

In dit boek staat de vraag centraal of de civielrechtelijke sanctie punitive damages een toekomst heeft in continentaal Europa. Deze vorm van civiele schadevergoeding wordt tot op heden louter erkend in rechtssystemen die behoren tot de common lawtraditie, zoals de Verenigde Staten, Engeland en Wales, Australië en Nieuw-Zeeland. In deze landen kan in bepaalde omstandigheden aan de gedaagde in een civiele procedure, naast een compensatoire schadevergoeding, een extra schadevergoeding in de vorm van punitive damages worden opgelegd. De functies van deze privat trechtelijke boete reiken verder dan bestraffing en preventie alleen; ook het beschermen van het algemeen belang, het faciliteren van privaatrechtelijke handhaving en het compenseren van bepaalde kosten van de eiser, zoals advocaatkosten, behoren tot haar functies. Aangezien claims betreffende punitive damages overwegend in de Verenigde Staten, waar het leerstuk al sinds de achttiende eeuw wordt erkend, worden toegewezen en er op dit gebied een uitgekiend systeem van rechtspraak, doctrine en wetgeving bestaat, refereert dit boek voornamelijk aan het Amerikaanse recht.

De centrale vraag in dit boek is ingegeven door parallelle Europese ontwikkelingen, bestaande uit de toenemende aandacht voor privaatrechtelijke handhaving van, onder meer, het mededingingsrecht, mensenrechten, het consumentenrecht en het intellectuele eigendomsrecht, evenals de roep om steviger sancties ter preventie en bestraffing van ernstige normschendingen binnen het privaatrecht. Deze ontwikkelingen passen zonder aarzeling in het huidige Europese tijdsbeeld, waarin deregulering en privatisering, mondige burgers, een verminderd vertrouwen in de overheid en een tendens om anderen verantwoordelijk te willen houden voor geleden schade meer zichtbaar lijken te worden.

Gelet op de systeemvreemdheid van punitive damages in continentaal Europese rechtssystemen maakt zij geen deel uit van het civielrechtelijke sanctiearsenaal aldaar, en proeft men duidelijke aarzeling bij wetenschappers en beleidsmakers wanneer de vraag aan de orde is of invoering van deze sanctie opportuun is. Een ongefundeerd beeld van 'het onbekende' lijkt een belangrijke reden te zijn waarom deze vraag in het verleden niet zelden negatief werd beantwoord. Dit beeld wekt gevoelens van argwaan en angst op. Meer specifiek wordt het Europese debat tot op de dag van vandaag beïnvloed door angst voor het excessief gebruik van civiele 
procedures wat zal leiden tot een ongewenste claimcultuur, angst voor exorbitante civiele schadevergoedingen, angst voor burgerlijke rechters die zich ongelegitimeerd op het terrein van de strafrechter begeven, et cetera. Nog afgezien van het feit dat angst een slechte raadgever is en zij ons belet stil te staan bij de positieve aspecten van punitive damages als privaatrechtelijk handhavingsmechanisme, lijkt deze angst goeddeels te zijn gebaseerd op onwetendheid en vooropgezette meningen. Het is op zijn minst opmerkelijk te noemen dat in het verleden gedane beweringen over punitive damages nauwelijks door feiten en cijfers werden ondersteund.

De laatste tijd lijkt er echter sprake te zijn van een kentering in het Europese debat en makt de wijdverbreide terughoudendheid steeds vaker plaats voor nieuwe, minder negatieve, ideeën over punitive damages. Wel is nog altijd sprake van onwetendheid die de mogelijkheid voor wetenschappers en beleidsmakers om het debat op de juiste basis te voeren verstoort. De voornaamste doelstelling van dit boek is dan ook het vergroten van het inzicht in werking, reikwijdte en betekenis van de civiele sanctie. Alleen een juiste voorstelling van zaken maakt het immers mogelijk het debat op een goede manier te laten verlopen. Zoals hiervoor aangegeven is daartoe vooral een beroep op het Amerikaanse rechtssysteem gedaan. Een goed begrip van het Amerikaanse punitive damages-recht alsmede van de Amerikaanse context waarin de civiele sanctie functioneert, is niet alleen nuttig maar ook noodzakelijk om een antwoord te kunnen geven op de vraag of zij een toekomst heeft in continentaal Europa. Om deze centrale vraag te kunnen beantwoorden is in dit boek een vijftal onderzoeksvragen aan de orde gekomen. Deze vragen zullen hierna één voor één de revue passeren. Vanzelfsprekend is het onmogelijk om, in het korte bestek van deze samenvatting, uitvoerig in te gaan op alle aspecten van dit boek. De belangrijkste worden daarom aangestipt, en voor nadere uitleg wordt verwezen naar de betreffende hoofdstukken.

\section{Kenmerken van het Amerikaanse punitive damages-recht}

De hoofdstukken twee tot en met vier van dit boek behandelen de voornaamste kenmerken van het Amerikaanse punitive damages-recht. In deze hoofdstukken is niet alleen uitgelegd waarom, wanneer en hoe de civiele sanctie in de Verenigde Staten wordt toegepast, ${ }^{1}$ maar is ook uitvoerig stilgestaan bij een overkoepelend thema in dit verband: de acceptatie en controle van punitive damages. ${ }^{2}$ De onderzoeksresultaten met betrekking tot het Amerikaanse recht zijn vervolgens kort en bondig weergegeven in hoofdstuk vijf. Dit hoofdstuk vormt een tussenconclusie en tevens de overgang van het Amerikaanse debat in de hoofdstukken twee tot en met vier naar het Europese debat in de hoofdstukken zes tot en met negen. Een aantal aspecten springt in het oog.

Zoals hiervoor reeds genoemd, is het in de eerste plaats van belang om de Amerikaanse context waarin punitive damages-claims worden toegewezen te

Hoofdstuk twee en hoofdstuk drie.

Hoofdstuk vier. 
begrijpen. Kennis van de voornaamste kenmerken van deze civiele sanctie is, op zichzelf, niet voldoende om haar werking voor een buitenstaander volledig inzichtelijk te maken. Typerend voor de Verenigde Staten is dat het wordt gezien als een civil justice system, een rechtssysteem waarin burgers worden grootgebracht met het idee dat zij zich kunnen beroepen op het fundamentele recht, ontleend aan de grondwet en de Bill of Rights, om medeburgers ter verantwoording te roepen voor de burgerlijke rechter. Dit right to sue loopt als een rode draad door het Amerikaanse rechtssysteem.

Het wordt gefaciliteerd door een terughoudende overheid enerzijds en een belangrijke positie voor privaatrechtelijke handhaving anderzijds, alsmede (procesrechtelijke) mechanismen zoals class actions en salariëring van advocaten op basis van no cure, no pay. De terughoudende rol van de overheid is een belangrijk aspect in dit verband; hiermee wordt bedoeld een overheid die, althans in vergelijking met overheden in Europa, relatief veel waarde hecht aan de vrijheid en eigen verantwoordelijkheid van het individu en daarom minder snel intervenieert in de maatschappij dan elders gebruikelijk is. De sanctie punitive damages, met als belangrijkste functies bestraffing en preventie, vervult in het Amerikaanse civil justice system een bijzondere, instrumentele functie. Zij makt onderdeel uit van een systeem waarin de burger van grote betekenis is in het, als zogenaamde private attorney general, voorkomen en bestrijden van alledaagse maatschappelijke problemen. In de Verenigde Staten wordt, anders dan in Europa, het overheidsbeleid vooral privaatrechtelijk gehandhaafd. Sterker nog, het is de belangrijkste methode ter handhaving van talloze wetten, zoals securities laws, consumer protection laws, civil rights laws, antitrust laws en environmental laws. Zo bezien vervult de civiele procedure, met punitive damages als een van haar wapens, een regulerende functie, waar dit in Europa vooral door overheidsoptreden gebeurt.

Enige nuancering is echter op haar plaats. Hoewel de Verenigde Staten op dit punt verschilt van Europa zijn civiele procedures in de Verenigde Staten niet in het algemeen excessief of onbeheersbaar. Zo is het aantal claims op basis van onrechtmatige daad betrekkelijk klein; de meeste slachtoffers met lichamelijk letsel komen bijvoorbeeld niet in actie, en degenen die dat wel doen komen vaak tot een schikking. Ook beweringen over het op excessieve wijze toepassen van de civiele sanctie punitive damages door Amerikaanse rechters zijn behoorlijk overdreven. Het zijn vooral de media en anti-punitive damages-lobbyisten die hebben bijgedragen aan mythevorming en een verdraaid beeld van de realiteit. Uit het Amerikaanse recht kan in dit verband een aantal lessen worden getrokken die voor het Europese debat van belang zijn. Wederom zij opgemerkt dat voor een genuanceerd overzicht wordt verwezen naar de hoofdstukken twee tot en met vijf.

Om te beginnen kan een punitive damages-claim alleen worden toegewezen wanneer aan een drietal voorwaarden is voldaan. Er moet, in algemene bewoordingen, sprake zijn van: (1) het schenden van een rechtsnorm die strekt tot bescherming van eisers belang (invasion of a legally protected interest), (2) een verzwarende omstandigheid in het onrechtmatige gedrag van gedaagde (aggravating element) en 
(3) werkelijk geleden schade (actual damage). Bij het beantwoorden van de vraag of in een bepaald geval een bedrag aan punitive damages kan worden toegewezen werpen deze voorwaarden dus een eerste barrière op.

Daarnaast toont empirisch onderzoek aan dat punitive damages globaal gezien zelden worden geclaimd (in ongeveer 10\% van de civiele zaken) en ook zelden worden toegewezen (in minder dan 10\% van de gewonnen civiele zaken). Bovendien gaat het in de meeste gevallen, gelet op de rechtsinbreuk en de schade, om een redelijk - niet excessief - bedrag (gemiddeld tussen \$38,000 en \$ 52,000).

Een ander belangrijk onderzoeksresultaat van dit boek betreft het type zaken waarin punitive damages-claims het vaakst worden toegewezen. Hoewel het theoretische uitgangspunt is dat punitive damages alleen in het geval van een onrechtmatige daad kunnen worden toegewezen, wordt de sanctie in de praktijk in legio andere gevallen toegepast. Dat geldt bijvoorbeeld ook wanneer er sprake is van een contractbreuk, mits deze tevens een onrechtmatige daad oplevert. Ondanks haar ruime toepassingsbereik en in tegenstelling tot wat vaak door buitenstaanders wordt gedacht, komt toewijzing van punitive damages echter relatief weinig voor in zaken die betrekking hebben op lichamelijk letsel als gevolg van nalatigheid (negligence), auto-ongelukken, medische fouten of productaansprakelijkheid. De populaire punitive damages-categorieën zijn: (1) de zogenaamde opzettelijke onrechtmatige daden (intentional torts) zoals aanranding of mishandeling, (2) zaken betreffende de inbreuk van persoonlijkheidsrechten door middel van laster of smaad (defamation) en (3) zaken waarin onder meer fraude, verzekeraars die te kwader trouw zijn in de afhandeling van schadeclaims of discriminatie op de werkvloer aan de orde is (financial torts). Een verklaring voor deze uitkomst is de hiervoor genoemde verzwarende omstandigheid in het onrechtmatige gedrag van de gedaagde die is vereist voor het opleggen van punitive damages. Deze verzwarende omstandigheid is waarschijnlijk vaker aanwezig in de populaire categorieën dan in de letselschade-zaken.

Toch krijgt het leerstuk van punitive damages ook in de Verenigde Staten de nodige kritiek te verduren. Deze kritiek richt zich niet alleen op het strafkarakter van de civiele sanctie die niet met alle mogelijke strafrechtelijke waarborgen is omgeven, maar bijvoorbeeld ook op het gebruik van vage terminologie of de zogenaamde windfall, dat gedeelte van het punitive damages-bedrag dat de eiser ongerechtvaardigd ten deel valt omdat het een preventieve en punitieve functie zou overstijgen. Daarom zijn ook Amerikaanse rechters zich er in het algemeen van bewust dat toekenning van punitive damages redelijk moet zijn, en niet meer moet behelzen dan noodzakelijk is om haar doel te bereiken. Dit bewustzijn is de laatste decennia toegenomen doordat zowel de wetgever als de rechterlijke macht en dan in het bijzonder het Amerikaanse Hooggerechtshof met behulp van diverse controlemechanismen de vinger aan de pols houden. Wat betreft wetgevende technieken kan men bijvoorbeeld denken aan het ophelderen van onduidelijke terminologie, het vaststellen van limieten en het toestaan van betaling van (een deel van) het bedrag aan de staat of aan een slachtofferfonds. Daarnaast heeft het Hooggerechtshof in een reeks uitspraken de grondwettelijkheid van punitive 
damages getoetst en zodoende een kader geschapen waarbinnen lagere rechters kunnen opereren. De voornaamste boodschap van het Hooggerechtshof is dat draconische punitive damages-bedragen niet zijn toegestaan. Integendeel, het bedrag gemoeid met punitive damages dient redelijk te zijn in relatie tot: (a) haar preventieve en bestraffende functie, (b) de aard van het onrechtmatige gedrag, (c) de aard van de schade, (d) de compensatoire schadevergoeding en (e) strafrechtelijke of privaatrechtelijke sancties die in soortgelijke gevallen beschikbaar zijn. Naast deze factoren waarmee de rechter bij het vaststellen van een punitive damages-bedrag rekening dient te houden, kan ook de financiële positie van de gedaagde en eventuele winst die de gedaagde door het onrechtmatige gedrag heeft verkregen de hoogte van het toe te wijzen bedrag beïnvloeden. Het Hooggerechtshof heeft, ten slotte, te kennen gegeven dat het, gelet op de functies van punitive damages, onmogelijk en ook onwenselijk is om een heldere scheidslijn aan te brengen tussen grondwettelijk geaccepteerde en niet-geaccepteerde bedragen.

\section{$3 \quad$ Afwezigheid van punitive damages in continentaal Europa}

Hoewel deze uitleg van de belangrijkste kenmerken van het Amerikaanse punitive damages-recht een onmisbare basis vormt, is het nog niet voldoende om de centrale vraag of de civielrechtelijke sanctie een toekomst heeft in continentaal Europa te kunnen beantwoorden. Daarvoor is het ook noodzakelijk inzicht te krijgen in het Europese debat. Wat zijn bijvoorbeeld de onderliggende redenen voor de afwezigheid van punitive damages in continentaal Europa? Deze vraag is in hoofdstuk zes van dit boek beantwoord. Een aantal traditionele verklaringen voor het niet bestaan van punitive damages kwam naar voren.

De eerste verklaring heeft alles te maken met de functies van het aansprakelijkheidsrecht. In de klassieke oudheid werden aansprakelijkheidsrecht en strafrecht als één geheel gezien. Dit geldt zowel voor landen met een common law-traditie, als voor landen met een civil law-traditie. De civiele boete, ook wel bekend als poena, was destijds een geaccepteerde vorm van bestraffing die gelijkenissen vertoonde met de huidige punitive damages-sanctie. Op zeker moment verloor het aansprakelijkheidsrecht in civil law-rechtssystemen, onder invloed van het kerkelijke recht en door de opkomst van een strikte scheiding tussen publiekrecht en privaatrecht, zijn bestraffende functie en werd de focus verlegd van bestraffing van de dader naar compensatie en genoegdoening van het slachtoffer. Het is echter de vraag of aan deze verlegging van focus niet te zwaar wordt getild. Volgens rechtshistorici verschilt de huidige immateriële schadevergoeding in civil law-rechtssystemen immers qua functie niet veel van de poena zoals die in de klassieke oudheid werd toegepast. In common lawrechtssystemen daarentegen bleef de bestraffende functie van het aansprakelijkheidsrecht naast de compensatoire functie bestaan. Punitieve elementen in het aansprakelijkheidsrecht zouden de facto nog steeds worden geaccepteerd in civil law-rechtssystemen, hetgeen ook de huidige systeemvreemdheid van punitive 
damages zou kunnen relativeren. Gelet op het belang van dit argument in het kader van de centrale vraag, is er in hoofdstuk negen stilgestaan bij punitieve elementen die weliswaar niet de iure maar misschien wel de facto voorkomen in het privaatrecht. Niettemin staat vast dat bestraffing theoretisch gezien geen onderdeel uitmaakt van het aansprakelijkheidsrecht in continentaal Europese rechtsstelsels. Het heersende idee aldaar is dat bestraffing een taak van de overheid is en daarom moet worden overgelaten aan publiekrechtelijke mechanismen zoals het strafrecht en het bestuursrecht. De punitive damages-sanctie wordt daarom als onverenigbaar met de huidige functies van het aansprakelijkheidsrecht gezien.

Een andere verklaring voor de afwezigheid van punitive damages in continentaal Europa hangt sterk samen met de eerste verklaring betreffende de functies van het aansprakelijkheidsrecht en is gelegen in de scheiding tussen het publiekrecht en het privaatrecht. Net als civil law-rechtssystemen erkennen common law-rechtssystemen deze scheiding. Dat de laatste aan een strikte scheiding minder waarde hechten, blijkt echter uit het feit dat het opleggen van punitive damages er niet door wordt gehinderd. In de Verenigde Staten bijvoorbeeld wordt, zoals eerder uitgelegd, het toewijzen van punitive damages gezien als een beleidskeuze, een middel om overheidsbeleid uit te voeren. Dit maakt tevens duidelijk waarom de civiele sanctie in afwezigheid van bepaalde strafrechtelijke waarborgen kan worden gehandhaafd. Zo heeft de double jeopardy rule, in civil law-rechtssystemen ook wel bekend als het ne bis in idem-beginsel, voor Amerikaanse rechters niet veel praktische waarde bij het toewijzen van punitive damages. Het uitgangspunt in het Amerikaanse recht is immers dat een reeds opgelegde strafrechtelijke sanctie het opleggen van een civielrechtelijke sanctie voor dezelfde onrechtmatige gedraging niet kan verhinderen. De ratio van deze algemene regel is dat de civiele sanctie voornamelijk wordt opgelegd voor het onrecht dat de eiser in casu is aangedaan, terwijl de strafsanctie vooral wordt opgelegd voor het onrecht dat de maatschappij is aangedaan. Bovendien maakt deze regel het mogelijk dat de punitive damages-sanctie strafrechtelijke sancties aanvult. Dit aspect van de publiek-privaatscheiding, de onverenigbaarheid met strafrechtelijke waarborgen zoals neergelegd in artikel 6 van het Europees Verdrag voor de Rechten van de Mens (EVRM), wordt in het Europese debat juist veelvuldig als argument tegen invoering van punitive damages gebruikt. Men zou kunnen zeggen dat de Amerikanen op dit vlak pragmatischer zijn dan de Europeanen: belangrijke beleidskeuzes worden niet gehinderd door theoretische obstakels zoals de scheiding tussen publiekrecht en privaatrecht. Een verklaring zou kunnen zijn dat de scheiding een serieus te nemen politiek karakter heeft, dat wil zeggen afhankelijk is van de beleidsagenda van de politiek, en dat de vraag of overheidsregulering langs publiekrechtelijke of privaatrechtelijke weg plaatsvindt niet alleen een juridische, maar ook een politieke vraag is.

De derde verklaring hangt samen met de rol van de overheid. We zagen al dat beleidskeuzes van de overheid de kijk op punitive damages kunnen beïnvloeden. Hierbij is het van belang om niet alleen de sanctie op zichzelf, maar ook de context waarin zij wordt toegepast te begrijpen. Zo is privaatrechtelijke handhaving door 
de burger die als private attorney general functioneert een belangrijk onderdeel van het Amerikaanse civil justice system. In Europa is privaatrechtelijke handhaving weliswaar nog minder goed ontwikkeld, maar staat zij wel meer en meer op de agenda. Een aspect met betrekking tot de rol van de overheid dat tevens invloed heeft op het belang van civiele procedures hangt samen met andere mogelijke vergoedingsmechanismen. In tegenstelling tot de Verenigde Staten is compensatie van slachtoffers via het aansprakelijkheidsrecht een betrekkelijk marginaal fenomeen in Europa, waar het systeem van private verzekeringen en sociale zekerheid een grotere rol speelt bij het compenseren van slachtoffers. Vooral wat betreft de sociale zekerheid is het verschil tussen de Verenigde Staten, waar civiele procedures wel als surrogaat voor de verzorgingsstaat worden gezien, en Europa vrij groot. Zoals eerder aangegeven verschilt de Verenigde Staten ook op het punt van overheidsregulering van Europa. In het Amerikaanse rechtssysteem vervult het civil justice system een belangrijke regulerende functie, terwijl deze functie in Europese rechtsstelsels nog voornamelijk door de overheid wordt vervuld. Dit verschil is in hoofdstuk zes toegelicht aan de hand van een aantal voorbeelden, zoals de mate waarin cultuur een maatschappij kan beïnvloeden en het belang van de eigen verantwoordelijkheid van (mede)burgers.

Een laatste aspect dat de afwezigheid van punitive damages in continentaal Europa mede verklaart hangt samen met de wijze waarop het procesrecht is ingericht. In dit verband is een aantal belangrijke verschillen tussen de Verenigde Staten en Europa aan te wijzen.

$\mathrm{Nu}$ de traditionele redenen voor de afwezigheid van punitive damages in continentaal Europa zijn benoemd, is ook op dit punt enige nuancering op haar plaats. De bezwaren tegen invoering van de civiele sanctie kunnen enerzijds als onoverkomelijk worden beschouwd, anderzijds bestaat voor elk van deze bezwaren wel een oplossing. In de hoofdstukken zeven tot en met negen is verder op dit thema ingegaan, en in paragraaf 2.1.1 van het concluderende hoofdstuk tien is, ter stimulering van het debat, een voorzichtige aanzet tot eventuele oplossingen gegeven.

\section{Toegenomen Europese interesse in punitive damages}

Hoofdstuk zeven betreft de ontwikkelingen die de toegenomen Europese belangstelling voor punitive damages verklaren. Hoewel het niet zonder meer overtuigend is om een toegenomen interesse uit juridische teksten af te leiden en sociaalwetenschappelijk onderzoek veel meer waarde zou hebben, valt niet te ontkennen dat er de laatste tijd sprake is van een zekere kentering in het Europese punitive damages-debat en zijn er steeds vaker positieve geluiden te horen. De ontwikkelingen zijn hiervoor reeds kort aangestipt: (1) een verschuiving van het zwaartepunt van publiekrechtelijke handhaving naar privaatrechtelijke handhaving en (2) de roep om steviger sancties ter preventie en bestraffing van ernstige normschendingen binnen het privaatrecht. 
De toenemende belangstelling voor privaatrechtelijke handhaving is ontstaan in het Europese mededingingsrecht. Geïnspireerd door het Amerikaanse rechtssysteem, waar meer dan $90 \%$ van het mededingingsrecht privaatrechtelijk wordt gehandhaafd, heeft zowel het Hof van Justitie van de Europese Unie als de Europese wetgever een bijdrage geleverd aan de discussie over de mogelijke rol van punitive damages ter handhaving van het mededingingsrecht. Omdat deze civiele sanctie in de Verenigde Staten wordt gezien als belangrijk handhavingsmechanisme, en ook als wapen dat door de burger kan worden ingezet in een civiele procedure, duikt zij bijna vanzelfsprekend op in het Europese debat. Intussen concentreert dit debat zich niet alleen meer op het Europese mededingingsrecht, maar ook op andere terreinen op Europees en nationaal niveau, zoals intellectuele eigendom, milieu, consumenten, anti-discriminatie, persoonlijkheidsrechten en mensenrechten. De Europese Commissie heeft onlangs nog benadrukt dat privaatrechtelijke handhaving een belangrijke aanvulling kan vormen op publiekrechtelijke handhaving. Inderdaad vormt volgens rechtseconomen een combinatie van private en publieke handhaving het ideale handhavingssysteem. Ook de terugtredende overheid en toenemende privatisering, bijvoorbeeld in de gezondheidszorg, huisvesting en energievoorziening, wordt als oorzaak van de aandacht voor privaatrechtelijke handhaving gezien. Een daaraan gerelateerde ontwikkeling is de belangstelling voor public interest litigation, dat wil zeggen civiele procedures met betrekking tot een publiek belang, bijvoorbeeld klimaatverandering of corruptie, gestart door burgers en nongouvernementele organisaties. Ten slotte kan het vervagen van de strikte scheiding tussen publiekrecht en privaatrecht worden genoemd. Deze ontwikkeling hangt nauw samen met de terugtredende overheid en toenemende privatisering.

Ook de roep om steviger sancties in het privaatrecht is het gevolg van veranderende inzichten. Deze verandering speelt zich af op een beperkter terrein dan de zojuist aangehaalde discussie over privaatrechtelijke handhaving, namelijk dat van het aansprakelijkheidsrecht en het schadevergoedingsrecht. Vooral op nationaal niveau is men op zoek naar manieren om ernstige normschendingen te voorkomen en te bestraffen. Doordat de belangrijkste bestaande civiele remedie, de compensatoire schadevergoeding, niet voldoende lijkt opgewassen tegen ernstig wangedrag ontstaat, zo is het idee, een handhavingstekort. Omdat ook publiekrechtelijke sancties niet steeds uitkomst bieden, wordt gezocht naar manieren om het privaatrechtelijke sanctiearsenaal te versterken en zo 'tanden aan het privaatrecht' te geven. Het type normschending dat zich hier voornamelijk voor zal lenen is opzettelijk, calculerend en ernstig wangedrag (intentional, calculative and grave misconduct). Niet toevallig is dit het soort gedrag waarvoor de punitive damages-sanctie primair wordt toegepast in de Verenigde Staten: de populaire categorieën zijn immers de eerdergenoemde intentional torts, defamation, en financial torts. Deze categorieën omvatten zowel opzettelijk en ernstig wangedrag, hetgeen vooral van toepassing is op de eerste categorie, als calculerend wangedrag, wat op de tweede en derde categorie van toepassing is. Vanzelfsprekend raakt deze discussie aan de veelgehoorde vraag naar de hedendaagse functies van het aansprakelijkheidsrecht. Hoewel compensatie als voornaamste functie van het 
aansprakelijkheidsrecht wordt gezien, is zij zeker niet zijn enige functie. Het lijkt beter te zeggen dat het aansprakelijkheidsrecht een combinatie van functies vervult, waarbij de onderlinge rangorde verschilt naargelang de maatschappelijke en politieke omstandigheden. Zo is er niet alleen in de klassieke oudheid, maar ook in de huidige common law-rechtssystemen geopteerd voor een bestraffende functie van het aansprakelijkheidsrecht. En zo is er in de laatste decennia steeds meer Europese aandacht voor de instrumentele functie van het aansprakelijkheidsrecht en daarom dus ook voor punitive damages.

\section{5}

Afwijzing van punitive damages in continentaal Europa: de status quo

In het kader van de centrale vraag of er een toekomst voor punitive damages bestaat in continentaal Europa, is in hoofdstuk zes en zeven van dit boek vastgesteld dat er in het Europese debat zowel weerstand als belangstelling voor punitive damages is. In de daaropvolgende hoofdstukken acht en negen is dit thema verder uitgediept.

Hoofdstuk acht gaat nader in op de gevoelde weerstand, en behandelt de onderzoeksvraag naar de status quo van de afwijzing van punitive damages in continentaal Europa. De Europese benadering van de civiele sanctie is geanalyseerd aan de hand van een aantal voorbeelden. Zo is de positie van drie Europese instituten, te weten het Europese Hof voor de Rechten van de Mens (EHRM), de wetgever van de Europese Unie, en het Hof van Justitie van de Europese Unie (HvJ) bekeken. Tevens is gekeken naar ontwikkelingen binnen het internationaal privaatrecht.

De positie van het EHRM is relatief duidelijk: punitive damages worden door hem niet toegewezen. Wel kan het EHRM op basis van artikel 41 EVRM bij schending van een verdragsnorm een zogenaamde billijke genoegdoening (just satisfaction) toekennen. Deze vorm van schadevergoeding heeft een zuiver compensatoire functie. Toch behoort een ruimere interpretatie van het begrip billijke genoegdoening wellicht tot de mogelijkheden. Dit wordt niet alleen in de doctrine geopperd, ook recente rechtspraak van het EHRM wijst in deze richting. ${ }^{3}$ In enkele uitspraken heeft het Hof een billijke genoegdoening toegewezen waarvan kan worden gezegd dat zij non-compensatoire elementen, zoals preventie en bestraffing, behelst. In hoofdstuk acht is dan ook het standpunt ingenomen dat, hoewel garanties voor de effectieve handhaving van mensenrechten moeilijk te geven zijn, zeker in dit kader de invoering van punitive damages het overwegen waard is. Het EHRM zou zich daarbij kunnen verdiepen in Amerikaanse jurisprudentie, waaruit blijkt dat Amerikaanse rechters al sinds jaar en dag aanleiding zien om ernstige schendingen van mensenrechten te voorkomen en bestraffen door middel van het opleggen van punitive damages.

3 ECtHR 19 June 2012, Krone Verlag GMBH v. Austria, no. 27306/07; ECtHR 25 June 2013, Trévalec v. Belgium, no. 30812/07. 
Minder duidelijk dan de positie van het EHRM is die van de wetgever van de Europese Unie en van het HvJ. Hun benadering van punitive damages wordt in de literatuur ambivalent genoemd. In een aantal documenten, zoals de Rome IIVerordening, heeft de wetgever zich negatief uitgelaten over punitive damages. Daarbij worden de gebruikelijke argumenten aangevoerd die verband houden met de systeemvreemdheid van de civiele sanctie. In het kader van het Europese mededingingsrecht heeft het HvJ zich echter, althans in eerste instantie, niet negatief uitgelaten over punitive damages. Integendeel, in de Manfredi-zaak is bepaald dat schadevergoedingsacties ingesteld bij nationale rechtbanken een belangrijke rol spelen bij de handhaving van het Europese mededingingsrecht. ${ }^{4}$ In deze zaak werd ook stilgestaan bij de mogelijkheid punitive damages toe te wijzen; volgens het $\mathrm{HvJ}$ is dit een optie die niet onverenigbaar is met de Europese openbare orde indien deze vorm van schadevergoeding naar nationaal recht is toegestaan. Zoals bekend is dat in een aantal lidstaten van de Europese Unie, namelijk die met een common law-traditie, al het geval. De wetgever heeft zich nadien in deze discussie, bijvoorbeeld in het witboek over schadevergoedingsacties in het Europese mededingingsrecht, gereserveerder opgesteld met betrekking tot de invoering van punitive damages door zich puur op de compensatoire functie van schadevergoeding te richten. Ook in het recente voorstel voor een richtlijn op dit terrein keert de sanctie niet terug. Ten slotte heeft het HvJ al in 1989, in een andere context, aangegeven dat nationale sancties voor inbreuken op het recht van de Europese Unie 'effectief, proportioneel en ontradend' (effective, proportionate and dissuasive) dienen te zijn. ${ }^{5}$ Dit is een terugkerende formule in Europese wetgeving, zoals anti-discriminatierichtlijnen. ${ }^{6}$ Hoewel met deze formule oorspronkelijk waarschijnlijk niet op punitive damages werd gedoeld, wordt zij daar in de doctrine inmiddels wel aan gekoppeld. Deze ontwikkelingen dragen er waarschijnlijk aan bij dat de uitingen over punitive damages door de wetgever van de Europese Unie en het HvJ ambivalent worden genoemd.

Ontwikkelingen op het terrein van het internationaal privaatrecht, in het bijzonder de erkenning en tenuitvoerlegging van buitenlandse (in de praktijk: Amerikaanse) vonnissen, geven een indruk van de manier waarop nationale rechters in Europa punitive damages beoordelen. In principe worden deze vonnissen in Europa negatief ontvangen, omdat erkenning en tenuitvoerlegging ingaat tegen de openbare orde van nationale rechtssystemen. De openbare ordeexceptie wordt op verschillende manieren uitgelegd, maar steeds hangt de uitleg samen met de traditionele argumenten tegen punitive damages. Zoals gesignaleerd in de literatuur wordt de houding van sommige rechtssystemen echter geleidelijk aan toleranter. Diverse nationale rechters, bijvoorbeeld in Frankrijk, Zwitserland,

4 CJEU 13 July 2006, joined cases C-295/04 to C-298/04, ECR I-6619 (Manfredi and Others), recent bevestigd in CJEU 14 June 2011, case C-360/09, ECR I-05161 (Pfleiderer AG v. Bundeskartellamt); CJEU 6 June 2013, case C-536/11, not yet published (Bundeswettbewerbsbehörde v. Donau Chemie $A G$ and Others).

5 CJEU 21 September 1989, case 68/88, ECR 2965 (Commission v. Greece).

6 Bijvoorbeeld richtlijnen 2000/43/EC; 2000/78/EC; 2002/73/EC. 
Spanje en Griekenland, hebben zich minder negatief of conservatief ten opzichte van erkenning en tenuitvoerlegging van punitive damages-vonnissen uitgelaten. Een belangrijk voorbeeld is een uitspraak van het Franse Hof van Cassatie uit 2010, waarin werd bepaald dat buitenlandse punitive damages-vonnissen in principe kunnen worden erkend en ten uitvoer gelegd in Frankrijk, mits het bedrag aan punitive damages in verhouding staat tot de compensatoire schadevergoeding en tot het wangedrag van de gedaagde. ${ }^{7}$ Volgens verschillende Europese wetenschappers is de huidige vijandigheid jegens punitive damages van nationale rechters misplaatst, en zou de liberale houding van bijvoorbeeld het Franse Hof van Cassatie als voorbeeld voor andere Europese rechters moeten dienen. Een Zwitserse rechtbank was haar tijd ver vooruit en heeft al in 1989 in deze trant geoordeeld, door de openbare orde-exceptie in het kader van buitenlandse punitive damages-vonnissen restrictief uit te leggen. Volgens deze rechtbank moet het creëren van een 'rammelende rechtspositie' (die Schaffung einer hinkenden Rechtslage) die door toepassing van de openbare orde-exceptie in dit soort gevallen ontstaat zo veel mogelijk worden vermeden. Het verhinderen van de erkenning en tenuitvoerlegging van in het buitenland rechtsgeldige en onherroepelijke punitive damages-vonnissen acht zij daarom onwenselijk. ${ }^{8}$ Hoewel de openbare orde-exceptie enerzijds kan worden gezien als een drempel voor de introductie van punitive damages in continentaal Europa, is zij anderzijds een open norm die zich kan en ook moet aanpassen aan het huidige tijdsbeeld en veranderende maatschappelijke en politieke omstandigheden. Op het terrein van het internationaal privaatrecht hebben de hiervoor genoemde nationale Europese rechters hierin het voortouw genomen.

Uit de genoemde voorbeelden in hoofdstuk acht blijkt dat er aanwijzingen zijn dat de in Europa gevoelde weerstand jegens punitive damages, hoewel nog aanwezig, langzaam maar zeker aan het afbrokkelen is.

\section{Bestaande civiele sancties in het Nederlandse, Duitse, Franse en Engelse recht}

In hoofdstuk negen wordt gezocht naar verdere aanknopingspunten wat betreft de in het Europese debat gevoelde belangstelling voor punitive damages. Is de systeemvreemdheid van deze sanctie werkelijk een onoverkomelijk bezwaar? Om deze vraag te kunnen beantwoorden is een overzicht gepresenteerd van bestaande civiele sancties in het Nederlandse, Duitse, Franse en Engelse recht. Informatie met betrekking tot de mate waarin civiele sancties reeds worden geaccepteerd is belangrijk voor het beantwoorden van de vraag of er een toekomst voor punitive damages bestaat in continentaal Europa. Daarom is een zogenaamde 'glijdende schaal' - van compensatoir naar punitief - opgesteld om de verschillen tussen de vier Europese rechtssystemen en het Amerikaanse rechtssysteem aan te geven. De acceptatie van civiele sancties kan een indicatie vormen voor beleids-

Cour de cassation, Première chambre civile, 1 décembre 2010, 09/13303 (Fountaine Pajot). Zivilgericht Basel-Stadt, 1 February 1989, BJM 1991, 31 (S.F. Inc. v. T.C.S. AG), at p. 34 
makers, in die zin dat de gevoelde Europese weerstand jegens punitive damages minder gefundeerd is. Het gaat dan uiteraard vooral om sancties die gelijkenissen vertonen met punitive damages, en daarom heeft de analyse in hoofdstuk negen zich geconcentreerd op de civiele schadevergoeding. Voor een goed overzicht van de behandelde sancties in de betreffende landen wordt verwezen naar hoofdstuk negen.

Van de onderzochte Europese rechtssystemen, erkent alleen het Engelse recht expliciet - een punitieve functie van de civiele schadevergoeding. In Engeland wordt de punitive damages-sanctie immers, in lijn met de common law-traditie, erkend, zij het in beperktere mate dan in de Verenigde Staten. De Engelse benadering komt dan het dichtst bij de Amerikaanse benadering en kan daarom tegelijkertijd worden onderscheiden van de benadering in Nederland, Duitsland en Frankrijk. Een ander opvallend verschil is dat Engelse rechters, in vergelijking met de continentaal Europese rechtssystemen, waar het gaat om de schending van persoonlijkheidsrechten, de hoogste immateriële schadevergoedingen toewijzen.

In continentaal Europa staat het Franse recht het meest liberaal tegenover civiele sancties. Na het Engelse recht is het Franse recht op de glijdende schaal daarom als meest punitief gekwalificeerd. Hoewel het Franse Hof van Cassatie onverkort loyaal blijft aan het uitgangspunt van restitutio in integrum of volledige vergoeding van schade, wordt civiele sancties in de Franse doctrine wél een preventieve en bestraffende functie toegedicht door de erkenning van het concept peine privée. Hieronder wordt, in sommige gevallen althans, ook de immateriële schadevergoeding geschaard. Franse lagere rechters wijken namelijk weleens impliciet - af van het beginsel dat alleen de schade, en niet meer dan de schade, mag worden vergoed. Zo wordt bij het vaststellen van immateriële schadevergoedingen, net als in Nederland en Duitsland overigens, niet alleen de schade van de eiser, maar ook het gedrag van de gedaagde in overweging genomen. Hoe serieuzer de rechtsinbreuk, des te hoger de immateriële schadevergoeding kan uitvallen. Dit ziet men bijvoorbeeld, wederom, in het geval van inbreuken van persoonlijkheidsrechten. Daarnaast is het Franse recht momenteel bijzonder interessant in het kader van het Europese punitive damages-debat. Dit hangt niet alleen samen met de in de vorige paragraaf genoemde tolerante uitspraak van het Hof van Cassatie over erkenning en tenuitvoerlegging van een Amerikaans punitive damages-vonnis. Ook Franse wetenschappers hebben niet stilgezeten, hetgeen sinds 2005 heeft geleid tot drie wetsvoorstellen: het Catala-voorstel, het Béteillevoorstel en het Terré-voorstel. In deze voorstellen is de mogelijkheid opgenomen voor de burgerlijke rechter om punitive damages toe te wijzen wanneer er sprake is van lucratieve fouten of opzettelijke inbreuken van, bijvoorbeeld, persoonlijkheidsrechten. Hoewel deze voorstellen (nog) niet de status van wet hebben gekregen, geven zij aan dat de Franse belangstelling voor punitive damages evident is.

Zowel het Nederlandse als het Duitse recht vertonen overeenkomsten met het Franse recht, in die zin dat door de lagere rechters aan immateriële schadevergoedingen soms een preventieve en bestraffende functie wordt gekoppeld, hetgeen kan leiden tot aanzienlijke bedragen. Wederom is hier vooral sprake van in het geval van ernstige normschendingen en inbreuken op persoonlijkheidsrechten. Omdat 
het punitive damages-debat in beide landen echter nog niet zover gevorderd is als in Frankrijk, nemen deze rechtssystemen op de glijdende schaal een plaats na het Franse recht in.

Van de vier onderzochte Europese landen wordt alleen in Engeland een punitieve functie van de civiele schadevergoeding expliciet erkend. Zoals betoogd in hoofdstuk negen, is het echter verdedigbaar dat een dergelijke functie weliswaar niet de iure maar wel de facto in Frankrijk, Nederland en Duitsland wordt erkend. En het blijft niet bij deze continentaal Europese landen. Naar punitieve elementen in het privaatrecht wordt al geruime tijd door Europese wetenschappers onderzoek gedaan. Uit dit andere onderzoek komt naar voren dat soortgelijke conclusies worden getrokken voor, bijvoorbeeld, Hongarije, Italië, Noorwegen, Zweden, Denemarken, Spanje, Estland en Zwitserland. De systeemvreemdheid van punitive damages in continentaal Europa kan om deze reden worden gerelativeerd, hetgeen ook rechtshistorisch gezien te verklaren valt. Zoals hiervoor aangegeven werd immers in civil law-rechtssystemen een bestraffende functie van het aansprakelijkheidsrecht in de klassieke oudheid erkend en pas later, onder invloed van het kerkelijke recht en door de opkomst van een strikte scheiding tussen publiekrecht en privaatrecht, afgeschaft. Echt afgeschaft is de bestraffende functie van het aansprakelijkheidsrecht volgens rechtshistorici echter nooit, daar zij tegenwoordig door de immateriële schadevergoeding zou worden vervuld.

\section{$7 \quad$ Concluderende opmerkingen}

In het licht van de verschuiving van het zwaartepunt van publiekrechtelijke handhaving naar privaatrechtelijke handhaving, alsmede de roep om steviger sancties ter preventie en bestraffing van ernstige normschendingen binnen het privaatrecht, is de Europese belangstelling voor de civiele sanctie punitive damages de laatste jaren toegenomen. Dit heeft geleid tot de centrale vraag van dit boek of deze sanctie een toekomst heeft in continentaal Europa. Het idee dat de burgerlijke rechter naast een compensatoire schadevergoeding een extra schadevergoeding in de vorm van punitive damages kan opleggen heeft tot dusver voornamelijk negatieve reacties opgeroepen.

De in Europa gevoelde weerstand jegens punitive damages wordt in de eerste plaats veroorzaakt door de hiervoor genoemde traditionele redenen met betrekking tot de functies van het aansprakelijkheidsrecht, de scheiding tussen het publiekrecht en het privaatrecht, en de rol van de overheid. Deze redenen kunnen enerzijds als onoverkomelijke bezwaren worden beschouwd, doch anderzijds bestaat voor elk van deze bezwaren wel een oplossing.

Daarnaast wordt de weerstand veroorzaakt door een ongefundeerd beeld van het Amerikaanse punitive damages-recht. Belangrijke lessen die kunnen worden getrokken uit de ruime Amerikaanse ervaring met de civiele sanctie zijn, onder meer, dat zij niet excessief wordt toegepast, noch qua aantal zaken noch qua hoogte van de bedragen, en in andere gevallen dan doorgaans wordt gedacht. Het voornaamste doel van dit boek was het verminderen van de onwetendheid en de, 
mede hieruit voortkomende, weerstand die nog steeds het Europese punitive damages-debat beheerst. Dit maakt het mogelijk het debat op de juiste wijze te voeren.

Het is momenteel nog te vroeg om een concreet antwoord te geven op de vraag of de civiele sanctie punitive damages een toekomst heeft in continentaal Europa. Ondanks de toenemende belangstelling voor de sanctie, lijkt haar introductie door de nog steeds gevoelde weerstand anno 2014 geen haalbare kaart. De beslissing om punitive damages toe te wijzen is eerst en vooral een beleidskeuze. In ieder geval vraagt deze beslissing om een zorgvuldig afgewogen oordeel met betrekking tot de werking, reikwijdte en betekenis van de civiele sanctie in het Amerikaanse recht. Daarbij wordt verwezen naar de aanbevelingen gegeven in het concluderende hoofdstuk tien van dit boek. In specifiek bepaalde gevallen zou de punitive damages-sanctie, mits op redelijke wijze door de burgerlijke rechter toegepast, het bestaande privaatrechtelijke sanctiearsenaal in continentaal Europese rechtssystemen kunnen aanvullen. Wat betreft de gevallen waarin de sanctie een rol zou kunnen spelen, is aansluiting gezocht bij de eerdergenoemde populaire punitive damagescategorieën in het Amerikaanse recht. Het type normschending dat zich voornamelijk zal lenen voor toepassing van punitive damages is opzettelijk, calculerend en ernstig wangedrag (intentional, calculative and grave misconduct). Dit geldt zowel voor de situaties waarin privaatrechtelijke handhaving als aanvulling op publiekrechtelijke handhaving kan dienen, zoals in het mededingingsrecht, als voor de situaties waarin er vraag is naar steviger sancties binnen het privaatrecht. 


\title{
BIBLIOGRAPHY
}

\author{
Adar 2012 \\ Adar, Y., 'Touring the Punitive Damages Forest: A Proposed Roadmap', ODCC, \\ 2012, p. 301-349.
}

\section{Adriaanse 2007}

Adriaanse, P.C., 'Private handhaving (van het mededingingsrecht) in opmars. Bespreking van het preadvies 'Privaatrechtelijke aspecten van het mededingingsrecht' van mr. W.A.J. van Lierop en mr. H.E. Pijnacker Hordijk voor de Vereniging voor Burgerlijk Recht', NTBR, 2007, p. 314-320.

\section{Adriaanse et al. 2008}

Adriaanse, P.C. et al., 'Het EVRM-kader voor invoering van punitive damages in mededingingszaken. Europese toestanden in het schadevergoedingsrecht?', NTBR, 2008, p. 274-286.

\section{Adriaanse et al. 2008}

Adriaanse, P.C. et al., 'Het EVRM-kader voor invoering van punitive damages in mededingingszaken. Europese toestanden in het schadevergoedingsrecht?', NTBR, 2008, p. 274-286.

\section{Ahsmann 1995}

Ahsmann, M., 'Van 'delictum' tot 'delict': De gemeenschappelijke wortels van strafrecht en privaatrecht', in: A.M. Hol \& C.J.J.M. Stolker (red.), Over de grenzen van strafrecht en burgerlijk recht, Deventer: Kluwer, 1995.

\section{Akkermans et al. 2008}

Akkermans A.J. et al., Slachtoffers en aansprakelijkheid. Een onderzoek naar behoeften, verwachtingen en ervaringen van slachtoffers en hun naasten met betrekking tot het civiele aansprakelijkheidsrecht - Deel II: Affectieschade, Amsterdam: WODC, 2008.

\section{American Jurisprudence 2d}

Retrieved via: Westlaw International online database.

\section{American Law Reports}

Retrieved via: Westlaw International online database. 


\section{Amelung 1999}

Amelung, T.U., 'Damage Awards for Infringement of Privacy - The German Approach', Tul Eur \& Civ L F, 1999, p. 15-47.

\section{Ankaert et al. 2006}

Ankaert, E. et al., Europeesrechtelijke eisen bij de toepassing van bestuurlijke punitieve sancties, Preadviezen Vereniging voor de Vergelijkende Studie van het Recht van België en Nederland, Alphen aan den Rijn: Kluwer, 2006.

\section{Annex to Green Paper 2005}

Commission Staff Working Paper Annex to the Green Paper on Damages Actions for Breach of the EC Antitrust Rules, SEC (2005) 1732.

\section{Annex to White Paper 2008}

Commission Staff Working Paper Accompanying the White Paper on Damages Actions for Breach of the EC Antitrust Rules, SEC (2008) 404.

\section{Annex to White Paper 2008: Impact Assessment}

Commission Staff Working Document Accompanying the White Paper on Damages Actions for Breach of the EC Antitrust Rules: Impact Assessment, SEC (2008) 405.

\section{Anziani \& Béteille 2009}

Anziani, A. \& Béteille, L., Rapport d'information fait au nom de la commission des lois constitutionnelles par le groupe de travail relative à la responsabilité civile, 2009. Retrieved via: www.senat.fr/notice-rapport/2008/r08-558-notice.html.

\section{Asser/Hartkamp \& Sieburgh 2011}

Hartkamp, A.S. \& Sieburgh, C.H., Mr. C. Assers Handleiding tot de beoefening van het Nederlands burgerlijk recht. 6. Verbintenissenrecht. Deel IV. De verbintenis uit de wet, Deventer: Kluwer 2011.

\section{Asser/Hartkamp \& Sieburgh 2013}

Hartkamp, A.S. \& Sieburgh, C.H., Mr. C. Assers Handleiding tot de beoefening van het Nederlands burgerlijk recht. 6. Verbintenissenrecht. Deel II. De verbintenis in het algemeen, tweede gedeelte, Deventer: Kluwer 2013.

\section{Ashurst report 2004}

Waelbroeck, D., Slater, D. \& Even-Shoshan, G., Study on the conditions of claims for damages in case of infringement of EC competition rules - Comparative Report, Brussels: Ashurst, 2004. Retrieved via: ec.europa.eu/competition/antitrust/ actionsdamages/comparative_report_clean_en.pdf. 
Ashworth, A., Principles of Criminal Law, Oxford: Oxford University Press, 2003.

\section{Auby \& Freedland 2006}

Auby, J.-B. \& Freedland, M., 'General Introduction', in: M. Freedland \& J.-B. Auby (eds.), The Public Law/Private Law Divide, Oxford and Portland (OR): Hart Publishing, 2006.

\section{Avraham 2014}

Avraham, R., 'Database of State Tort Law Reforms $\left(5^{\text {th }}\right)$ ', University of Texas School of Law Research Paper No. e555, 2014. Retrieved via: papers.ssrn.com/ sol3/papers.cfm?abstract id $=902711$.

\section{Bailis \& MacCoun 1996}

Bailis, D.S. \& MacCoun, R.J., 'Estimating Liability Risks with the Media as Your Guide: A Content Analysis of Media Coverage of Tort Litigation', Law \& Hum Behav, 1996, p. 419-428.

\section{Backhaus, Cassone \& Ramello 2012}

Backhaus, J.G., Cassone, A. \& Ramello, G.B. (eds.), The Law and Economics of Class Actions in Europe: Lessons from America, Cheltenham: Edward Elgar Publishing, 2012.

\section{Baker 1998a}

Baker, T., 'Reconsidering Insurance for Punitive Damages', Wis L Rev, 1998, p. 101-130.

\section{Baker 1998b}

Baker, T., 'Transforming Punishment into Compensation: In the Shadow of Punitive Damages', Wis L Rev, 1998, p. 211-236.

\section{Baker 2004}

Baker, D.I., 'Revisiting History - What Have We Learned About Private Antitrust Enforcement That We Would Recommend To Others?', Loy Consumer L Rev, 2004, p. 379-408.

\section{Baker, Kritzer \& Vidmar 2008}

Baker, T., Kritzer, H. \& Vidmar, N., 'Jackpot Justice and the American Tort System: Thinking Beyond Junk Science', William Mitchell College of Law Legal Studies Research Paper No. 95, 2008. Retrieved via: Sssrn.com/abstract=1152306.

\section{Balfour 2012}

Balfour, J., 'EU Regulation 261 and Compensation for Delay: The Advocate General's Opinion in the References re Sturgeon', ASL, 2012, p. 377-382. 


\section{Barday 2008}

Barday, S.A., 'Punitive damages, remunerated research, and the legal profession', Stan L Rev, 2008, p. 711-750.

\section{Barendrecht 2002}

Barendrecht, J.M., ‘Aansprakelijkheid en welzijn', NJB 2002, p. 605-617.

\section{Barkhuysen \& Van Emmerik 2006a}

Barkhuysen, T. \& Van Emmerik, M.L., 'Constitutionalisation of Private Law: The European Convention on Human Rights Perspective', in: T. Barkhuysen \& S.D. Lindenbergh (red.), Constitutionalisation of Private Law, Leiden: Koninklijke Brill, 2006.

\section{Barkhuysen \& Van Emmerik 2006b}

Barkhuysen, T. \& Van Emmerik, M.L., 'Rechtsbescherming tegen de overheid en het EVRM', TMA, 2006, p. 130-142.

\section{Barnes 2010}

Barnes, R.D., Outrageous Invasions: Celebrities' Private Lives, Media, and the Law, New York: Oxford University Press, 2010.

\section{Barzaghi 2005}

Barzaghi, A., 'Recognition and Enforcement of United States Judgments in Italy', N Y Int'l L Rev, 2005, p. 61-122.

\section{Basedow 2007a}

Basedow, J. (ed.), Private Enforcement of EC Competition Law, Alphen aan den Rijn: Kluwer Law International, 2007.

\section{Basedow 2007b}

Basedow, J., 'Introduction', in: J. Basedow (ed.), Private Enforcement of EC Competition Law, Alphen aan den Rijn: Kluwer Law International, 2007.

\section{Beekhoven van den Boezem 2006}

Beekhoven van den Boezem, M.B., De dwangsom in het burgerlijk recht (diss. Groningen), Deventer: Kluwer, 2006.

\section{Beer 2008}

Beer, J.M., 'No Win No Fee, of waarom een Engels plantje in Nederlandse bodem niet gedijt', TVP, 2008, p. 136-139.

\section{Beever 2008a}

Beever, A., 'Corrective Justice and Personal Responsibility in Tort Law', OJLS, 2008, p. 475-500. 


\section{Beever 2008b}

Beever, A., 'Justice and Punishment in Tort: A Comparative Theoretical Analysis', in: C.E.F. Rickett (ed.), Justifying Private Law Remedies, Oxford and Portland (OR): Hart Publishing, 2008.

\section{Behr 2003}

Behr, V., 'Punitive Damages in American and German Law, Tendencies towards approximation of apparently irreconcilable concepts', Chi-Kent L Rev, 2003, p. $105-161$.

\section{Behr 2005}

Behr, V., 'Myth and Reality of Punitive Damages in Germany', J L \& Com, 2005, p. 197-224.

\section{Belli 1980}

Belli, M.M., 'Punitive Damages: Their History, Their Use and Their Worth in Present-Day Society', UMKC L Rev, 1980, p. 1-23.

\section{Berch 2010}

Berch, J.J., 'The Need for Enforcement of U.S. Punitive Damages Awards by the European Union', Minn J Int'l L, 2010, p. 55-106.

\section{Bernet \& Ulmer 1994}

Bernet, M. \& Ulmer, N.C., 'Recognition and Enforcement in Switzerland of US Judgments Containing an Award of Punitive Damages', Int'l Bus Law, 1994, p. $272-275$.

\section{Betlem, Rodrigues \& Zijlstra 1999}

Betlem, G., Rodrigues, P.R. \& Zijlstra, S.E., Omkering van Proceslast - Een Onderzoek naar Handhaving van Wetten door de Burger, Den Haag: Boom Juridische uitgevers, 1999.

\section{Blaauw 1988}

Blaauw, R.M., 'De verstraffing van ons privaatrecht; 150 jaar sanctionering van rechtsplichten', in: M.S. Bijleveld (ed.), Recht Vooruit. Opstellen verzameld ter gelegenheid van 150 jaar BW, Deventer: Kluwer, 1988.

\section{Blatt, Hammesfahr \& Nugent 2008}

Blatt, R.L., Hammesfahr, R.W. \& Nugent, L.S., Punitive Damages, A State-ByState Guide to Law and Practice, Eagan (MN): Thomson Reuters/West, 2008.

\section{Bloembergen \& Lindenbergh 2001}

Bloembergen, A.R. \& Lindenbergh, S.D., Schadevergoeding: algemeen, deel 1, Monografieën BW, Deventer: Kluwer, 2001. 


\section{Bolt \& Lensing 1993}

Bolt, A.T. \& Lensing, J.A.W., Privaatrechtelijke boete, Preadvies voor de Nederlandse Vereniging voor Rechtsvergelijking, Deventer: Kluwer, 1993.

\section{Boot 2008}

Boot, J., 'Privaatrecht \& boete. Over double damages bij privaatrechtelijke handhaving van mededinging', $A A, 2008$, p. 200-208.

\section{Borghetti 2009}

Borghetti, J.-S., 'Punitive Damages in France', in: H. Koziol \& V. Wilcox (eds.), Punitive Damages: Common Law and Civil Law Perspectives, Vienna: Springer Verlag, 2009.

\section{Bornstein et al. 2008}

Bornstein, B.H. et al. (eds.), Civil Juries and Civil Justice - Psychological \& Legal Perspectives, New York: Springer Verlag, 2008.

\section{Boukema 2008}

Boukema, H.J., 'Roddel, Schuld \& Boete - Een pleidooi voor stevige schadevergoedingen', $N J B$, 2008, p. 1464-1470.

\section{Boyd \& Ingberman 1999}

Boyd, J. \& Ingberman, D.E., 'Do Punitive Damages Promote Deterrence?', Int'l Rev L \& Econ, 1999, p. 47-68.

\section{Brack 2006}

Brack, A., 'De eenheid van het productenrecht - over de juridische houdbaarheid van de tweedeling food/non-food', TvC, 2006, p. 73-75.

\section{Brand 2005}

Brand, R.A., 'Punitive Damages Revisited: Taking the Rationale for Non-Recognition of Foreign Judgments Too Far', $J$ L \& Com, 2005, p. 181-196.

\section{Braslow 1999}

Braslow, N.T., 'The Recognition and Enforcement of Common Law Punitive Damages in a Civil Law System: Some Reflections on the Japanese Experience', Ariz J Int'l \& Comp L, 1999, p. 285-360.

\section{Bruggeman 2010}

Bruggeman, V., Compensating catastrophe victims - A comparative law and economics approach (diss. Maastricht), Alphen aan den Rijn: Kluwer Law International, 2010. 


\section{Burnham 2006}

Burnham, W., Introduction to the law and legal system of the United States, St. Paul (MN): Thomson/West, 2006.

\section{Burrows 1998}

Burrows, A., Understanding the Law of Obligations - Essays on Contract, Tort and Restitution, Oxford: Hart Publishing, 1998.

\section{Burrows 2004}

Burrows, A., Remedies for Torts and Breach of Contract, Oxford: Oxford University Press, 2004.

\section{Buxbaum 2007}

Buxbaum, H.L., 'Private Enforcement of Competition Law in the United States of Optimal Deterrence and Social Costs', in: J. Basedow (ed.), Private Enforcement of EC Competition Law, Alphen aan den Rijn: Kluwer Law International, 2007.

\section{Calabresi 1970}

Calabresi, G., The Costs of Accidents: A Legal and Economic Analysis, New Haven: Yale University Press, 1970.

\section{Calabresi 2005}

Calabresi, G., 'The Complexity of Torts - The Case of Punitive Damages', in: M.S. Madden (ed.), Exploring Tort Law, New York: Cambridge University Press, 2005.

\section{Calabresi \& Melamed 1972}

Calabresi, G. \& Melamed, A.D., 'Property Rules, Liability Rules, and Inalienability: One View of the Cathedral', Harv L Rev, 1972, p. 1089-1128.

\section{Calandrillo 2010}

Calandrillo, S.P., 'Penalizing Punitive Damages: Why the Supreme Court Needs a Lesson in Law and Economics', Geo Wash L Rev, 2010, p. 774-821.

\section{Calleros 2006}

Calleros, C., 'Punitive Damages, Liquidated Damages, and Clauses Pénales in Contract Actions: a Comparative Analysis of the American Common Law and the French Civil Code', Brook J Int'l L, 2006, p. 67-119.

\section{Cane 1996}

Cane, P., 'Corrective Justice and Correlativity in Private Law', OJLS, 1996, p. 471488. 


\section{Carrington 2004}

Carrington, P.D., 'The American Tradition of Private Law Enforcement', GLJ, 2004, p. 1413-1429.

\section{Cartwright, Vogenauer \& Whittaker 2009}

Cartwright, J., Vogenauer, S. \& Whittaker, S., Reforming the French Law of Obligations - Comparative Reflections on the Avant-projet de réforme du droit des obligations et de la prescription ('the Avant-projet Catala'), Oxford and Portland (OR): Hart Publishing, 2009.

\section{Castermans 2009}

Castermans, A.G., De burger in het burgerlijk recht of De eigenschappen van perensap (oratie Leiden), Den Haag: Boom Juridische uitgevers, 2009.

\section{Carval 1995}

Carval, S., La responsabilité civile dans sa fonction de peine privée, Paris: L.G.D.J., 1995.

\section{Cauffman 2007}

Cauffman, C., 'Naar een punitief Europees verbintenissenrecht. Een rechtsvergelijkende studie naar de draagwijdte, de (grond)wettigheid en de wenselijkheid van het bestraffend karakter van het verbintenissenrecht', TPR, 2007, p. 799-873.

\section{Cauffman 2009}

Cauffman, C., 'Een model voor een Belgische class action? De advocatuur neemt het voortouw', $R W, 2009$, p. 690-708.

\section{Cauffman \& Weyts 2009}

Cauffman, C. \& Weyts, B., 'Privaatrecht en rechtshandhaving', in: A. Scheltema et al., Toezicht op de financiële markt en de energiemarkt, Staatsgeheimen en het strafproces, Rechtshandhaving door het privaatrecht, Preadviezen Vereniging voor de Vergelijkende Studie van het Recht van België en Nederland, Den Haag: Boom Juridische uitgevers, 2009.

\section{Cavalier \& Quéguiner 2007}

Cavalier, G. \& Quéguiner, J.-S., 'Punitive Damages and French Public Policy', 2007. Retrieved via: ssrn.com/abstract $=1174363$.

\section{Cavaliere 2004}

Cavaliere, A., 'Product Liability in the European Union: Compensation and Deterrence Issues', Eur J L \& Econ, 2004, p. 299-318. 


\section{Cavanagh 1987}

Cavanagh, E.D., 'Detrebling Antitrust Damages: An Idea Whose Time Has Come?', Tul L Rev, 1987, p. 777-848.

\section{Cavanagh 2005}

Cavanagh, E.D., 'Antitrust Remedies Revisited', Or L Rev, 2005, p. 147-226.

\section{Cavanagh 2010}

Cavanagh, E.D., 'The Private Antitrust Remedy: Lessons from the American Experience', Loy U Chi L J, 2010, p. 629-649.

\section{Centner 2008}

Centner, T.J., America's Blame Culture. Pointing Fingers and Shunning Restitution, Durham (NC): Carolina Academic Press, 2008.

\section{Chao-Duivis 1990}

Chao-Duivis, M.A.B., 'Vergelding als schadevergoeding', NJB, 1990, p. 513-520.

\section{Chapman \& Trebilcock 1989}

Chapman, B. \& Trebilcock, M., 'Punitive Damages: Divergence in Search of a Rationale', Ala L Rev, 1989, p. 741-829.

\section{Clerk et al. 2006}

Clerk, J.F. et al., Clerk and Lindsell on Torts, London: Sweet \& Maxwell, 2006.

\section{Clermont \& Eisenberg 1992}

Clermont, K.M. \& Eisenberg, T., 'Trial by Jury or Judge: Transcending Empiricism', Cornell L Rev, 1992, p. 1124-1177.

\section{Coase 1960}

Coase, R.H., 'The Problem of Social Cost', J L \& Econ, 1960, p. 1-44.

\section{Coderch 2001}

Coderch, P.S., 'Punitive Damages and Continental Law', ZEuP, 2001, p. 604-616.

\section{Cohen 2005}

Cohen, T.J., 'Punitive Damage Awards in Large Counties, 2001', Report of the Bureau of Justice Statistics, U.S. Department of Justice, Washington DC, 2005. Retrieved via: www.bjs.ojp.usdoj.gov/content/pub/pdf/pdalc01.pdf.

\section{Cohen 2009}

Cohen, T.J., 'Tort Bench and Jury Trials in State Courts, 2005', Report of the Bureau of Justice Statistics, U.S. Department of Justice, Washington DC, 2009. Retrieved via: www.bjs.gov/content/pub/pdf/tbjtsc05.pdf. 


\section{Cohen \& Harbacek 2011}

Cohen, T.H. \& Harbacek, K., 'Punitive Damage Awards in State Courts, 2005', Report of the Bureau of Justice Statistics, U.S. Department of Justice, Washington DC, 2011. Retrieved via: www.bjs.gov/content/pub/pdf/pdasc05.pdf.

\section{Colby 2003}

Colby, T.B., 'Beyond the Multiple Punishment Problem: Punitive Damages as Punishment for Individual, Private Wrongs', Minn L Rev, 2003, p. 583-678.

\section{Colby 2008}

Colby, T.B., 'Clearing the Smoke from Philip Morris v. Williams: the Past, Present, and Future of Punitive Damages', Yale L J, 2008, p. 392-479.

\section{Coleman 1995}

Coleman, J.L., 'The Practice of Corrective Justice', in: D.G. Owen (ed.), Philosophical Foundations of Tort Law, Oxford: Clarendon Press, 1995.

\section{Collignon 2010}

Collignon-Smit Sibinga, A.F., 'Fundamentele rechten in de personenschadepraktijk', TVP, 2010, p. 103-106.

\section{Connor 2000}

Connor, M.F., Taming the Mass Tort Monster, Washington DC: National Legal Center for the Public Interest, 2000.

\section{Cooter 1982}

Cooter, R.D., 'Economic Analysis of Punitive Damages', S Cal L Rev, 1982, p. $79-101$.

\section{Cooter 1989}

Cooter, R.D., 'Punitive Damages for Deterrence: When and How Much?', Ala L Rev, 1989, p. 1143-1196.

\section{Cooter 1997}

Cooter, R.D., 'Punitive Damages, Social Norms, and Economic Analysis', Law \& Contemp Probs, 1997, p. 73-91.

\section{Cooter \& Ulen 2004}

Cooter, R. \& Ulen, T., Law and Economics, Boston: Pearson Addison Wesley, 2004.

\section{Corpus Juris Secundum}

Westlaw online database 2009. 


\section{Corstens \& Borgers 2011}

Corstens, G.J.M. \& Borgers, M.J., Het Nederlands strafprocesrecht, Deventer: Kluwer, 2011.

\section{Cousy \& Vanderspikken 2001}

Cousy, H.A. \& Vanderspikken A., 'Damages under Belgian Law', in: U. Magnus (ed.), Unification of Tort Law: Damages, The Hague: Kluwer Law International, 2001.

\section{Craig \& De Búrca 2011}

Craig, P. \& De Búrca, G., EU Law - Text, cases and materials, Oxford: University Press, 2011.

\section{Cupa 2012}

Cupa, B., 'Scattered Damages: A Comparative Law Study About the Enforcement Deficit of Low-Value Damages and the Class Action Approach', ERPL, 2012, p. 507-540.

\section{Curtin 1985}

Curtin, D., 'Effective Sanctions and the Equal Treatment Directive: The Von Colson and Harz Cases', CMLR, 1985, p. 505-532.

\section{Daniels \& Martin 1990}

Daniels, S. \& Martin, J., 'Myth and Reality in Punitive Damages', Minn L Rev, 1990, p. $1-64$

\section{Danov 2008}

Danov, M., 'Awarding Exemplary (or Punitive) Antitrust Damages in EC Competition Cases with an International Element - The Rome II Regulation and the Commission's White Paper on Damages', ECLR, 2008, p. 430-436.

\section{Dawkins 2008}

Dawkins, P., 'Damage Control: A Glimpse into Punitive Damage Reform', Law and Society Journal at UCSB, 2008, p. 71-88.

\section{Deakin, Johnston \& Markesinis 2008}

Deakin, S., Johnston, A., Markesinis, B., Markesinis and Deakin's Tort Law, Oxford: Clarendon Press, 2008.

\section{De Groot 1980}

De Groot, G.R.J., 'Grenzen aan de mogelijkheden van een abstracte schadeberekening', $V R, 1980$, p. 49-58. 


\section{De Haan 1999}

De Haan, P., Recente ontwikkelingen in de verhouding publiek-/privaatrecht, Amsterdam: Koninklijke Nederlandse Academie van Wetenschappen, 1999.

\section{De Kezel 2013}

De Kezel, E.N.F.M., Asbest, Gezondheid en Veiligheid. Ontwikkelingen in het Aansprakelijkheidsrecht (diss. Utrecht/Gent), Antwerpen: Intersentia, 2013.

\section{Del Rossi \& Kip Viscusi 2009}

Del Rossi, A.F. \& Kip Viscusi, W., 'The Changing Landscape of Blockbuster Punitive Damages Awards', National Bureau of Economic Research Working Paper No. 15571, 2009, p. 1-62.

\section{Developments in the Law 1997}

'Developments in the Law - The Civil Jury', Harv L Rev, 1997, p. 1408-1536.

\section{Dijkshoorn 2012}

Dijkshoorn, W., 'Het privaatrecht is niet geschikt om het algemeen belang te dienen. Nou en?', NJB, 2012, p. 3020-3024.

\section{Dobbs 1989}

Dobbs, D.B., 'Ending Punishment in "Punitive" Damages: Deterrence-Measured Remedies', Ala L Rev, 1989, p. 831-917.

\section{Dorfman 2010}

Dorfman, A., 'What is the point of the tort remedy?', Am J Juris, 2010, p. 105-162.

\section{Dubber 2009}

Dubber, M.D., 'Criminal law between Public and Private Law', 2009, p. 1-18. Retrieved via: ssrn.com/abstract $=1499538$.

\section{Duintjer Tebbens 2009}

Duintjer Tebbens, H., 'Punitive Damages: Towards a Rule of Reason for U.S. Awards and their Recognition Elsewhere', in: G. Venturini \& S. Bariatti (eds.), Liber Fausto Pocar - Volume II: Nuovi strumenti del diritto internazionale privato, Milano: Giuffrè, 2009.

\section{Dupree 2010}

Dupree, T.H., 'Punitive Damages and the Constitution', La L Rev, 2010, p. 421 434.

\section{Ebert 2004}

Ebert, I., Pönale Elemente im deutschen Privatrecht - Von der Renaissance der Privatstrafe im deutschen Recht, Tübingen: Mohr Siebeck, 2004. 


\section{Ebert 2013}

Ebert, I., 'Book Reviews: Lotte Meurkens/Emily Nordin (eds.), The Power of Punitive Damages. Is Europe Missing Out?', JETL, 2013, p. 95-97.

\section{Edelman 2008}

Edelman, J., 'In Defence of Exemplary Damages', in: C.E.F. Rickett (ed.), Justifying Private Law Remedies, Oxford and Portland (OR): Hart Publishing, 2008.

\section{Eggen 2011}

Eggen, J.M., 'Punitive Damages and the Public Health Agenda', in: J.G. Culhane (ed.), Reconsidering Law and Policy Debates - A Public Health Perspective, New York: Cambridge University Press, 2011.

\section{Eisenberg 1998}

Eisenberg, T., 'Measuring the Deterrent Effect of Punitive Damages', Geo L J, 1998, p. 347-357.

\section{Eisenberg et al. 1997}

Eisenberg, T. et al., 'The Predictability of Punitive Damages', J Legal Stud, 1997, p. 623-661.

\section{Eisenberg et al. 2002}

Eisenberg, T. et al., 'Juries, Judges, and Punitive Damages: An Empirical Study', Cornell L Rev, 2002, p. 743-782.

\section{Eisenberg et al. 2006}

Eisenberg, T. et al., 'Juries, Judges, and Punitive Damages: Empirical Analyses Using the Civil Justice Survey of State Courts 1992, 1996, and 2001 Data', J Empirical Legal Stud, 2006, p. 263-295.

\section{Eisenberg et al. 2010}

Eisenberg, T. et al., 'The Decision to Award Punitive Damages: An Empirical Study', J Legal Analysis, 2010, p. 577-620.

\section{Eisenberg, Hans \& Wells 2008}

Eisenberg, T., Hans, V.P. \& Wells, M.T., 'The Relation between Punitive and Compensatory Awards: Combining Extreme Data with the Mass of Awards', in: B.H. Bornstein et al. (eds.), Civil Juries and Civil Justice - Psychological \& Legal Perspectives, New York: Springer Verlag, 2008.

\section{Eisenberg \& Heise 2011}

Eisenberg, T. \& Heise, M., 'Judge-Jury Difference in Punitive Damages Awards: Who Listens to the Supreme Court?', J Empirical Legal Stud, 2011, p. 325-357. 


\section{Eisenberg, Heise \& Wells 2010}

Eisenberg, T., Heise, M. \& Wells, M.T., 'Variability in Punitive Damages: Empirically Assessing Exxon Shipping Co. v. Baker', JITE, 2010, p. 5-26.

\section{Eisenberg \& Wells 1999}

Eisenberg, T. \& Wells, M.T., 'The Predictability of Punitive Damages Awards in Published Opinions, the Impact of $B M W v$. Gore on Punitive Damages Awards, and Forecasting Which Punitive Awards Will Be Reduced', Sup Ct Econ Rev, 1999 , p. 59-86.

\section{Ellis 1982}

Ellis, D.D., 'Fairness and Efficiency in the Law of Punitive Damages', S Cal L Rev, 1982, p. $1-78$

\section{Emaus 2013}

Emaus, J.M., Handhaving van EVRM-rechten via het aansprakelijkheidsrechtOver de inpassing van de fundamentele rechtsschending in het Nederlandse burgerlijk recht (diss. Utrecht), Den Haag: Boom Juridische uitgevers, 2013.

\section{Engelhard et al. 2009}

Engelhard, E.F.D. et al. (red.), Handhaving van en door het privaatrecht, Vijftien bijdragen over handhaving van het privaatrecht en privaatrechtelijke handhaving, Den Haag: Boom Juridische uitgevers, 2009.

\section{Engelhard \& Van Maanen 2008}

Engelhard, E.F.D. \& Van Maanen, G.E., Aansprakelijkheid voor schade: contractueel en buitencontractueel, Monografieën BW, Deventer: Kluwer, 2008.

\section{Englard 2012}

Englard, I., 'Punitive Damages - A Modern Conundrum of Ancient Origin', JETL, 2012, p. 1-20.

\section{Enneking \& De Jong 2014}

Enneking, L. \& De Jong, E., 'Regulering van onzekere risico's via public interest litigation?', $N J B, 2014$, p. 1542-1551.

\section{Fairgrieve \& Howells 2006}

Fairgrieve, D. \& Howells, G., 'General Product Safety - a Revolution Through Reform?', MLR, 2006, p. 59-69.

\section{Faure 2009}

Faure, M.G. (ed.), Tort Law and Economics, Cheltenham: Edward Elgar Publishing, 2009. 


\section{Faure, Fernhout \& Philipsen 2010}

Faure, M., Fernhout, F. \& Philipsen, N., 'No Cure, No Pay and Contingency Fees', in: M. Tuil \& L. Visscher (eds.), New Trends in Financing Civil Litigation In Europe: A Legal, Empirical, and Economic Analysis, Cheltenham: Edward Elgar Publishing, 2010.

\section{Faure \& Hartlief 1999}

Faure, M. \& Hartlief, T., 'Het kabinet en de claimcultuur', NJB, 1999, p. 20072015 .

\section{Faure \& Hartlief 2003}

Faure, M. \& Hartlief, T., 'Social Security versus Tort Law as Instruments to Compensate Personal Injuries: A Dutch Law and Economics Perspective', in: U. Magnus (ed.), The Impact of Social Security Law on Tort Law, Vienna: Springer Verlag, 2003.

\section{Faure \& Hartlief 2012}

Faure, M. \& Hartlief, T., 'Claimcultuur en beloningssystemen', in: W.H. van Boom, I. Giesen \& M. Smit (red.), Civilologie: Opstellen over Empirie en Privaatrecht, Den Haag: Boom Juridische uitgevers, 2012.

\section{Fausten \& Hammesfahr 2012}

Fausten, T. \& Hammesfahr, R., Punitive Damages in Europe: Concern, threat or non-issue, Zurich: Swiss Re, 2012.

\section{Feenstra 1984}

Feenstra, R., Romeinsrechtelijke grondslagen van het Nederlands privaatrecht, Leiden: E.J. Brill/Universitaire Pers, 1984.

\section{Finch 2002}

Finch, M., 'Giving Full Faith and Credit to Punitive Damages Awards: Will Florida Rule the Nation?', Minn L Rev, 2002, p. 497-564.

\section{Flight, Hartmann \& Nauta 2012}

Flight, S., Hartmann, A. \& Nauta, O., Bestuurlijke strafbeschikking en bestuurlijke boete overlast - Evaluatie na drie jaar, Amsterdam: Ministerie van Veiligheid en Justitie/WODC, 2012.

\section{Franken 2009}

Franken, A.C.H., 'Hollandse toestanden', $A V \& S, 2009$, p. 261-262.

\section{Freifield 1935}

Freifield, S., 'The Rationale of Punitive Damages', L J Student B Ass'n Ohio St U, 1935 , p. 5-14. 


\section{Frenk 2007}

Frenk, N., 'Massaschade: de Nederlandse benadering', $A V \& S, 2007$, p. 214-222.

\section{Friedman 1989}

Friedman, D., 'An Economic Explanation of Punitive Damages', Ala L Rev, 1989, p. $1125-1142$.

\section{Fritz 2004}

Fritz, T., Punitive/examplary damages in den USA und ihre Qualifikation als Zivilsache (diss. Münster), 2004.

\section{Galand-Carval 2001}

Galand-Carval, S., 'Damages under French Law', in: U. Magnus (ed.), Unification of Tort Law: Damages, The Hague: Kluwer Law International, 2001.

\section{Galanter 1998a}

Galanter, M., 'Shadow Play: The Fabled Menace of Punitive Damages', Wis L Rev, 1998, p. 1-14.

\section{Galanter 1998b}

Galanter, M., 'An Oil Strike in Hell: Contemporary Legends About the Civil Justice System’, Ariz L Rev, 1998, p. 717-752.

\section{Galanter 2000}

Galanter, M., 'The Conniving Claimant: Changing Images of Misuse of Legal Remedies', DePaul L Rev, 2000, p. 647-665.

\section{Galanter \& Luban 1993}

Galanter, M. \& Luban, D., 'Poetic Justice: Punitive Damages and Legal Pluralism', Am U L Rev, 1993, p. 1393-1463.

\section{Garber \& Bower 1999}

Garber, S. \& Bower, A.G., 'Newspaper Coverage of Automotive Product Liability Verdicts', Law \& Soc'y Rev, 1999, p. 93-122.

\section{Gash 2004}

Gash, J., 'Punitive Damages, Other Acts Evidence, and the Constitution', Utah L Rev, 2004, p. 1191-1277.

\section{Gash 2005}

Gash, J., 'Solving the Multiple Punishments Problem: A call for a National Punitive Damages Registry’, Nw U L Rev, 2005, p. 1613-1686. 


\section{Gash 2011}

Gash, J., 'The End of An Era: The Supreme Court (Finally) Butts Out of Punitive Damages For Good', Fla L Rev, 2011, p. 525-597.

\section{Gash 2012}

Gash, J., 'Understanding and Solving the Multiple Punishments Problem', in: L. Meurkens \& E. Nordin (eds.), The Power of Punitive Damages - Is Europe Missing Out?, Antwerp: Intersentia, 2012.

\section{Geerts et al. 2011}

Geerts et al., Oneerlijke handelspraktijken: praktijkervaringen in België met de sanctie van artikel 41 WMPC, Groningen: Rijksuniversiteit Groningen - Faculteit Rechtsgeleerdheid/WODC, 2011.

\section{Geistfeld 2005}

Geistfeld, M.A., 'Constitutional Tort Reform', Loy L A L Rev, 2005, p. 1093-1120.

\section{Geistfeld 2008}

Geistfeld, M.A., 'Punitive Damages, Retribution, and Due Process', S Cal L Rev, 2008, p. 263-310.

\section{Georgiades 2005}

Georgiades, G., 'Punitive Damages in Europe and the USA: Doctrinal Differences and Practical Convergence', RHDI, 2005, p. 145-163.

\section{Giesen 2009}

Giesen, I., 'Handhaving in, via, door en met het privaatrecht: waar staan we nu?', in: E.F.D. Engelhard et al. (red.), Handhaving van en door het privaatrecht, Vijftien bijdragen over handhaving van het privaatrecht en privaatrechtelijke handhaving, Den Haag: Boom Juridische uitgevers, 2009.

\section{Giesen 2013}

Giesen, I., 'Collectieve actie in Nederland en de EU: and the winner is...', NTBR, 2013, p. 291-292.

\section{Ginsburg \& Kagan 2005}

Ginsburg, T. \& Kagan, R.A., 'Introduction - Institutionalist Approaches to Courts as Political Actors', in: T. Ginsburg \& R.A. Kagan (eds.), Institutions \& Public Law - Comparative Approaches, New York: Peter Lang Publishing, 2005.

\section{Goldberg 2008}

Goldberg, J.C.P, 'Ten Half-Truths about Tort Law', Val U L Rev, 2008, p. 12211276. 


\section{Gordley 1995}

Gordley, J., 'Tort Law in the Aristotelian Tradition', in: D.G. Owen (ed.), Philosophical Foundations of Tort Law, Oxford: Clarendon Press, 1995.

\section{Gotanda 2004}

Gotanda, J.Y., 'Punitive Damages: A Comparative Analysis', Colum J Transnat'l $L, 2004$, p. 391-444.

\section{Gotanda 2007}

Gotanda, J.Y., 'Charting Developments Concerning Punitive Damages: Is The Tide Changing?', Colum J Transnat'l L, 2007, p. 507-528.

\section{Gottlieb 2011}

Gottlieb, E., 'What You Need to Know About... Punitive Damages', New York: Center for Justice \& Democracy, 2011. Retrieved via: www.fairwarning.org/wpcontent/uploads/2011/09/PunitiveDamagesWhitePaper2011F.pdf.

\section{Grabher \& Gamper 2009}

Grabher, G.M. \& Gamper, A. (eds.), Legal Narratives: European Perspectives on U.S. Law in Cultural Context, Vienna: Springer Verlag, 2009.

\section{Green Paper 2005}

Commission Green Paper on Damages Actions for Breach of the EC Antitrust Rules, COM (2005) 672.

\section{Grady 1989}

Grady, M.F., 'Punitive Damages and Subjective States of Mind: A Positive Economic Theory', Ala L Rev, 1989, p. 1197-1225.

\section{Greene, Woody \& Winter 2000}

Greene, E., Woody, W.D. \& Winter, R., 'Compensating Plaintiffs and Punishing Defendants: Is Bifurcation Necessary?', Law \& Hum Behav, 2000, p. 187-205.

\section{Grozev et al. 2009}

Grozev, Y. et al. (eds.), Right to a Fair Trial under the European Convention on Human Rights (Article 6) - Interights Manual for Lawyers, London: Interights, 2009. Retrieved via: www.interights.org/document/106/index.html.

\section{Haak \& VerLoren van Themaat 2005}

Haak, M.F.J. \& VerLoren van Themaat, I.W., De Mogelijkheden voor Civielrechtelijke Handhaving van de Mededingingsregels in Nederland - Een Inventarisatie in Opdracht van het Ministerie van Economische Zaken, Amsterdam: Houthoff Buruma, 2005. Retrieved via: www.houthoff.com/uploads/tx_hhpublications/ 
Mogelijkheden_voor_civielrechtelijke_handhaving_van_de_mededingingsregels_in_ Nederland.PDF.

\section{Halfmeier 2012}

Halfmeier, A., 'Recognition of a WCAM settlement in Germany', NIPR, 2012, p. 176-184.

\section{Hallebeek 2014}

Hallebeek, J., 'Buitencontractuele Aansprakelijkheid aan de Vooravond van de Moderne Samenleving', in: B. Debaenst \& B. Delbecke (red.), Vangnet of Springplank? Het Buitencontractueel Aansprakelijkheidsrecht in een Moderne Samenleving (1804-heden), Brugge: Die Keure, 2014.

\section{Haltom \& McCann 2004}

Haltom, W. \& McCann, M., Distorting the Law - Politics, Media, and the Litigation Crisis, Chicago: University of Chicago Press, 2004.

\section{Hantler, Behrens \& Lorber 2005}

Hantler, S.B., Behrens, M.A. \& Lorber, L., 'Is the "Crisis" in the Civil Justice System Real or Imagined?', Loy L A L Rev, 2005, p. 1121-1199.

\section{Harlow 1980}

Harlow, C., "Public" and "Private" Law: Definition Without Distinction', MLR, 1980, p. 241-265.

\section{Harris 1989}

Harris, A.P., 'Rereading Punitive Damages: Beyond the Public/Private Distinction', Ala L Rev 1989, p. 1079-1116.

\section{Harteveld et al. 2004}

Harteveld, A.E. et al., Het EVRM en het Nederlandse Strafprocesrecht, Deventer: Kluwer, 2004.

\section{Hartlief \& Tjittes 1990}

Hartlief, T. \& Tjittes, R.P.J.L., 'De invloed van verzekeringen op de civiele aansprakelijkheid: privaatrechtelijke aspecten', in: R. van den Bergh et al., De Invloed van Verzekering op de Civiele Aansprakelijkheid, Preadviezen Nederlandse Vereniging voor Burgerlijk Recht, Lelystad: Koninklijke Vermande, 1990.

\section{Hartlief 1997}

Hartlief, T., Ieder draagt zijn eigen schade (oratie Leiden), Deventer: Kluwer 1997. 


\section{Hartlief 2003a}

Hartlief, T., 'De meerwaarde van het aansprakelijkheidsrecht', in: T. Hartlief \& S. Klosse (red.), Einde van het aansprakelijkheidsrecht?, Den Haag: Boom Juridische uitgevers, 2003.

\section{Hartlief 2003b}

Hartlief, T., 'Het recht op smartengeld: burgerwacht of schaamlap?', in: E.M. Hoogervorst et al. (red.), Doel en effect van civielrechtelijke sancties, BW-krant jaarboek 19, Kluwer: Deventer, 2003.

\section{Hartlief 2005}

Hartlief, T., 'Leven in een claimcultuur: wie is er bang voor Amerikaanse toestanden?', $N J B, 2005$, p. 830-834.

\section{Hartlief 2007a}

Hartlief, T., 'Gij zult handhaven!', NJB, 2007, p. 915.

\section{Hartlief 2007b}

Hartlief, T., 'De twee werelden van massaschade' NJB, 2007, p. 2595-2596.

\section{Hartlief 2008a}

Hartlief, T., 'Handhaving in het aansprakelijkheidsrecht. Op weg naar een betere samenleving?', WPNR, 2008, p. 769-777.

\section{Hartlief 2008b}

Hartlief, T., 'Handhaving met Smartengeld', $A V \& S$, 2008, p. 237-247.

\section{Hartlief 2009a}

Hartlief, T., Anno 2010. Beschouwingen over Aansprakelijkheid en Verzekering, Amsterdam: Uitgeverij deLex, 2009.

\section{Hartlief 2009b}

Hartlief, T., 'Wat staat het burgerlijk recht te doen?', NJB, 2009, p. 1553.

\section{Hartlief 2009c}

Hartlief, T., 'De schrik van het burgerlijk recht', NJB, 2009, p. 2253.

\section{Hartlief 2009d}

Hartlief, T., 'Geld zetten op aansprakelijkheidsrecht', TPR, 2009, p. 565-580.

\section{Hartlief 2012a}

Hartlief, T., 'Schadevergoedingsrecht', in: J. Spier et al., Verbintenissen uit de wet en Schadevergoeding, Deventer: Kluwer, 2012. 


\section{Hartlief 2012b}

Hartlief, T., 'Verstraffing van het privaatrecht', NJB, 2012, p. 313.

\section{Hartlief 2012c}

Hartlief, T., 'Smartengeld in Nederland anno 2012: tijd voor een steen in stilstaand water?', in: M. Donkerlo \& M.L.A. van Werkhoven (red.), Smartengeld. Uitspraken van de Nederlandse rechter over de vergoeding van immateriële schade, Den Haag: ANWB Rechtshulp, 2012.

\section{Hartlief 2013}

Hartlief, T., 'Vangnet of springplank? - Een enkele opmerking over de spankracht van het buiten-contractuele aansprakelijkheidsrecht anno 2013', JSAL, 2013, p. 607-628.

\section{Hartlief 2014}

Hartlief, T., 'Over de beperkte betekenis van het privaatrecht bij rampen en crises en een rechtsgebied onder toenemende druk van het publiekrecht', in: E.R. Muller et al., Crises, rampen en recht, Preadviezen Nederlandse Juristen-Vereniging, Deventer: Kluwer 2014.

\section{Hasen 2010}

Hasen, R.L., Remedies, New York: Aspen Publishers, 2010.

\section{Hastie, Schkade \& Payne 1999}

Hastie, R., Schkade, D.A. \& Payne, J.W., 'Juror Judgments in Civil Cases: Effects of Plaintiff's Requests and Plaintiff's Identity on Punitive Damage Awards, Law \& Hum Behav, 1999, p. 445-470.

\section{Hay 1992}

Hay, P., 'The Recognition and Enforcement of American Money-Judgments in Germany - The 1992 Decision of the German Supreme Court', Am J Comp L, 1992, p. $729-750$.

\section{Hay 2005}

Hay, P., Law of the United States - An Overview, Munich: C.H. Beck, 2005.

\section{Hazelhorst 2010}

Hazelhorst, M., 'Private Enforcement of EU Competition Law: Why Punitive Damages Are a Step Too Far', ERPL, 2010, p. 757-772.

\section{Hensler et al. 1991}

Hensler, D.R. et al., Compensation for Accidental Injuries in the United States, Santa Monica (CA): Rand Institute for Civil Justice, 1991. 


\section{Hersch \& Kip Viscusi 2004}

Hersch, J. \& Kip Viscusi, W., 'Punitive Damages: How Judges and Juries Perform', J Legal Stud, 2004, p. 1-36.

\section{Hersch \& Kip Viscusi 2010}

Hersch, J. \& Kip Viscusi, W., 'Punitive Damages by Numbers: Exxon Shipping Co. v. Baker', Sup Ct Econ Rev, 2010, p. 259-280.

\section{Higgins \& Zuckerman 2013}

Higgins, A. \& Zuckerman, A., 'Class Actions in England? Efficacy, Autonomy and Proportionality in Collective Redress', University of Oxford Legal Research Paper Series No. 93, 2013. Retrieved via: papers.ssrn.com/sol3/papers.cfm? abstract_id=2350141.

\section{Hofstede 1998}

Hofstede, G. (ed.), Masculinity and Femininity: The Taboo Dimension of National Cultures, Thousand Oaks (CA): Sage Publications, 1998.

\section{Hofstede 2001}

Hofstede, G., Culture's Consequences: Comparing Values, Behaviors, Institutions and Organizations Across Nations, Thousand Oaks (CA): Sage Publications, 2001.

\section{Hofstede, Hofstede \& Minkov 2010}

Hofstede, G., Hofstede, G.-J. \& Minkov, M., Cultures and Organizations: Software of the Mind, New York: McGraw-Hill, 2010.

\section{Holmes 2004}

Holmes, K., 'Public enforcement or private enforcement? Enforcement of competition law in the EC and UK', ECLR, 2004, p. 25-36.

\section{Hondius 2003}

Hondius, E.H., 'Punitive damages: acceptabel, zij het met mate', NJB, 2003, p. 2019-2020.

\section{Hondius 2009}

Hondius, E.H., 'De tanden van het privaatrecht', in: E.F.D. Engelhard et al. (red.), Handhaving van en door het privaatrecht, Vijftien bijdragen over handhaving van het privaatrecht en privaatrechtelijke handhaving, Den Haag: Boom Juridische uitgevers, 2009.

\section{Honoré 1995}

Honoré, T., 'The Morality of Tort Law - Questions and Answers', in: D.G. Owen (ed.), Philosophical Foundations of Tort Law, Oxford: Clarendon Press, 1995. 


\section{Horwitz 1992}

Horwitz, M.J., The Transformation of American Law 1870-1960 - The Crisis of Legal Orthodoxy, New York: Oxford University Press, 1992.

\section{Howells 2000}

Howells, G.G., 'The Relationship between Product Liability and Product Safety Understanding a Necessary Element in European Product Liability through a Comparison with the U.S. Position', Washburn L J, 2000, p. 305-346.

\section{Howells \& Mildred 1998}

Howells G.G. \& Mildred M., 'Is European Products Liability more protective than the Restatement (third) of Torts: Products Liability?', Tenn L Rev, 1998, p. 985-1030.

\section{Howells \& Wilhelmsson 1997}

Howells G.G. \& Wilhelmsson T., 'EC \& US approaches to consumer protection should the gap be bridged?', YEL, 1997, p. 207-268.

\section{Hubbard 2008}

Hubbard, F.P., 'Substantive Due Process Limits on Punitive Damages Awards: "Morals Without Technique"”, Fla L Rev, 2008, p. 349-399.

\section{Huver et al. 2007}

Huver, R.M.E. et al., Slachtoffers en aansprakelijkheid. Een onderzoek naar behoeften, verwachtingen en ervaringen van slachtoffers en hun naasten met betrekking tot het civiele aansprakelijkheidsrecht - Deel I: terreinverkenning, Amsterdam: WODC, 2007.

\section{Jablonski 2005}

Jablonski, S.R., 'Enforcing U.S. Punitive Damages Awards in Foreign Courts - A Recent Case in the Supreme Court of Spain', J L \& Com, 2005, p. 225-243.

\section{Janecek 2013}

Janecek, V., 'Exemplary Damages: A Genuine Concept?', EJLS, 2013, p. 189-206.

\section{Janke \& Licari 2012}

Janke, B.W. \& Licari, F.-X., 'Enforcing Punitive Damage Awards in France after Fountaine Pajot', Am J Comp L, 2012, p. 775-804.

\section{Janke \& Licari 2013}

Janke, B.W. \& Licari, F.-X., 'Les Conflits de Lois en Matière de DommagesIntérêts Punitifs: L'Expérience de la Louisiane', RLDA, 2013, p. 132-136. Retrieved via: papers.ssrn.com/sol3/papers.cfm?abstract_id=2340477. 


\section{Jansen 2012}

Jansen, N., 'Law of Torts/Delict, General and Lex Aquilia', in: J. Basedow, K.J. Hopt \& R. Zimmermann (eds.), The Max Planck Encyclopedia of European Private Law. Volume II, Oxford: Oxford University Press, 2012.

\section{Jansen \& Rademacher 2009}

Jansen, N. \& Rademacher L., 'Punitive Damages in Germany', in: H. Koziol \& V. Wilcox (eds.), Punitive Damages: Common Law and Civil Law Perspectives, Vienna: Springer Verlag, 2009.

\section{Jault 2005}

Jault, A., La notion de peine privée, Paris: L.G.D.J., 2005.

\section{Jones 1999}

Jones, C.A., Private enforcement of Antitrust Law in the EU, UK and USA, Oxford: Oxford University Press, 1999.

\section{Jones 2004}

Jones, C.A., 'Exporting Antitrust Courtrooms to the World: Private Enforcement in a Global Market', Loy Consumer L Rev, 2004, p. 409-430.

\section{Jurgens \& Van Ommeren 2009}

Jurgens, G.T.J.M. \& Van Ommeren, F.J., De opmars van het onderscheid tussen publiekrecht en privaatrecht in het Engelse recht - Vanuit rechtsvergelijkend perspectief, Den Haag: Boom Juridische uitgevers, 2009.

\section{Kagan 1997}

Kagan, R.A., 'Should Europe Worry About Adversarial Legalism?', OJLS, 1997, p. $165-183$.

\section{Kagan 2001}

Kagan, R.A., Adversarial Legalism - The American Way of Law, Cambridge (MA): Harvard University Press, 2001.

\section{Kagan 2007}

Kagan, R.A., 'American and European Ways of Law: Six Entrenched Differences', in: V. Gessner \& D. Nelken (eds.), European Ways of Law - Towards a European Sociology of Law, Oxford: Hart Publishing, 2007.

\section{Keating 2000}

Keating, G.C., 'Distributive and Corrective Justice in the Tort Law of Accidents', S Cal L Rev, 2000, p. 193-226. 


\section{Keeton et al. 1984}

Keeton, W.P. et al., Prosser and Keeton on Torts, St. Paul (MN): West Group, 1984.

\section{Keirse 2007}

Keirse, A.L.M., 'Nieuwe risico's; wie is er bang voor de magnetron?', NJB, 2007, p. 2418-2425.

\section{Keirse 2009}

Keirse, A.L.M., 'De schadevoorkomingsplicht', in: E.F.D. Engelhard et al. (red.), Handhaving van en door het privaatrecht, Vijftien bijdragen over handhaving van het privaatrecht en privaatrechtelijke handhaving, Den Haag: Boom Juridische uitgevers, 2009.

\section{Kelliher 2008}

Kelliher, D.N., 'Aims and Scope', in: H. Koziol \& R. Schulze (eds.), Tort Law of the European Community, Vienna: Springer Verlag, 2008.

\section{Kenefick 1987}

Kenefick, A.M, 'The Constitutionality of Punitive Damages under the Excessive Fines Clause of the Eighth Amendment', Mich L Rev, 1987, p. 1699-1726.

\section{Kerkmeester 1998}

Kerkmeester, H.O., 'Punitive damages ter veroordeling van een lage veroordelingskans', NJB, 1998, p. 1807-1813

\section{Kilpatrick 2000}

Kilpatrick, C., 'The Future of Remedies in Europe', in: C. Kilpatrick, T. Novitz \& P. Skidmore (eds.), The Future of Remedies in Europe, Oxford and Portland (OR): Hart Publishing, 2000.

\section{Kip Viscusi 1998}

Kip Viscusi, W., 'Why There is No Defense of Punitive Damages', Geo L J, 1998, p. 381-395.

\section{Kip Viscusi \& Born 2005}

Kip Viscusi, W. \& Born, P.H., 'Damages Caps, Insurability, and the Performance of Medical Malpractice Insurance', JRI, 2005, p. 23-43.

\section{Kip Viscusi \& McMichael 2013}

Kip Viscusi, W. \& McMichael, B.J., 'Shifting the Fat-Tailed Distribution of Blockbuster Punitive Damages Awards', Vanderbilt University Law School Research Paper No. 13-18, 2013. Retrieved via: papers.ssrn.com/sol3/papers. cfm?abstract_id=2297577. 


\section{Kircher \& Wiseman 2000a}

Kircher, J.J. \& Wiseman, C.M., Punitive Damages Law and Practice. Volume 1, Eagan (MN): Thomson/West, 2000.

\section{Kircher \& Wiseman 2000b}

Kircher, J.J. \& Wiseman, C.M., Punitive Damages Law and Practice. Volume 2, Eagan (MN): Thomson/West, 2000.

\section{Klaben 1994}

Klaben, M.J., 'Split-Recovery Statutes: The Interplay of the Takings and Excessive Fines Clauses', Cornell L Rev, 1994, p. 104-157.

\section{Klein 1999}

Klein, S.R., 'Redrawing the Criminal-Civil Boundary', Buff Crim L Rev, 1999, p. 679-721.

\section{Klick \& Sharkey 2009}

Klick, J. \& Sharkey, C.M., 'What Drives the Passage of Damage Caps?', New York University Law and Economics Working Paper No. 172, 2009. Retrieved via: papers.ssrn.com/sol3/papers.cfm?abstract_id=1342535.

\section{Klik 1989}

Klik, P., 'Broodje Hond in de Magnetron', NJB, 1989, p. 13.

\section{Koch 2009}

Koch, B.A., 'Punitive Damages in European Law', in: H. Koziol \& V. Wilcox (eds.), Punitive Damages: Common Law and Civil Law Perspectives, Vienna: Springer Verlag, 2009.

\section{Koenig 1998}

Koenig, T.H., 'The Shadow Effect of Punitive Damages on Settlements', Wis L Rev, 1998, p. 169-209.

\section{Koenig \& Rustad 2001}

Koenig, T.H. \& Rustad, M.L., In Defense of Tort Law, New York: New York University Press, 2001.

\section{Kolczynski \& Antas 2013}

Kolczynski, J.P. \& Antas, P.D., 'A copyright holder whose rights have been infringed may claim punitive damages against the perpetrator beyond the actual damage incurred due to the infringement: commentary on Polish Supreme Court judgment of March 8, 2012 (V CSK 102/11)', EIPR, 2013, p. 172-175. 


\section{Kortmann 2009}

Kortmann, J., The Tort Law Industry (oratie Amsterdam UvA), Amsterdam: Vossiuspers UvA, 2009.

\section{Kortmann \& Sieburgh 2009}

Kortmann, J. \& Sieburgh, C., 'Handhaving door Nederlands privaatrecht', in: A. Scheltema et al., Toezicht op de financiële markt en de energiemarkt, Staatsgeheimen en het strafproces, Rechtshandhaving door het privaatrecht, Preadviezen Vereniging voor de Vergelijkende Studie van het Recht van België en Nederland, Den Haag: Boom Juridische uitgevers, 2009.

\section{Koziol 2001}

Koziol, H., 'Damages under Austrian Law', in: U. Magnus (ed.), Unification of Tort Law: Damages, The Hague: Kluwer Law International, 2001.

\section{Koziol 2008}

Koziol, H., 'Punitive Damages - A European Perspective', La L Rev, 2008, p. 741764.

\section{Koziol 2009}

Koziol, H., 'Punitive Damages: Admission into the Seventh Legal Heaven or Eternal Damnation? Comparative Report and Conclusions', in: H. Koziol \& V. Wilcox (eds.), Punitive Damages: Common Law and Civil Law Perspectives, Vienna: Springer Verlag, 2009.

\section{Koziol 2010}

Koziol, H., Grundfragen des Schadenersatzrechts, Vienna: Jan Sramek Verlag, 2010 .

\section{Koziol 2012}

Koziol, H., Basic Questions of Tort Law from a Germanic Perspective, Vienna: Jan Sramek Verlag, 2012.

\section{Koziol et al. 2005}

Koziol, H. et al., European Group on Tort Law 2005, Principles of European Tort Law, Text and Commentary, Vienna: Springer Verlag, 2005.

\section{Koziol \& Schulze 2008}

Koziol, H. \& Schulze R., 'Conclusio', in: H. Koziol \& R. Schulze (eds.), Tort Law of the European Community, Vienna: Springer Verlag, 2008.

\section{Koziol \& Wilcox 2009}

Koziol, H. \& Wilcox, V. (eds.), Punitive Damages: Common Law and Civil Law Perspectives, Vienna: Springer Verlag, 2009. 


\section{Krauss 2007}

Krauss, M.I., 'Punitive Damages and the Supreme Court: A Tragedy in Five Acts', Cato Sup Ct Rev, 2007, p. 315-334.

\section{Kroes 2006}

Kroes, N., More private antitrust enforcement through better access to damages: an invitation for an open debate - Opening speech at the conference 'Private enforcement in EC competition law: the Green Paper on damages actions', Speech/06/158, Brussels, 9 March 2006.

\section{Kuklin 1989}

Kuklin, B., 'Punishment: the civil perspective of punitive damages', Clev St L Rev, 1989, p. 1-118.

\section{Lahe 2011}

Lahe, J., 'Punitive Damages in Estonian Tort Law?', JETL, 2011, p. 280-293.

\section{Landes \& Posner 1975}

Landes, W.M. \& Posner, R.A., 'The Private Enforcement of Law', J Legal Stud, 1975, p. 1-46.

\section{Landes \& Posner 1987}

Landes, W.M. \& Posner, R.A., The Economic Structure of Tort Law, Cambridge: Harvard University Press, 1987.

\section{Landsman 1988}

Landsman, S., Readings on Adversarial Justice: The American Approach to Adjudication, St. Paul (MN): West Publishing, 1988.

\section{Landsman et al. 1998}

Landsman, S. et al., 'Proposed Reforms and Their Effects. Be Careful What You Wish For: The Paradoxical Effects of Bifurcating Claims for Punitive Damages', Wis L Rev, 1998, p. 297-342.

\section{Langton \& Cohen 2008}

Langton, L. \& Cohen, T.H., 'Civil Bench and Jury Trials in State Courts, 2005', Report of the Bureau of Justice Statistics, U.S. Department of Justice, Washington DC, 2008. Retrieved via: bjs.ojp.usdoj.gov/content/pub/pdf/cbjtsc05.pdf.

\section{Laplante 2004}

Laplante, L.J., 'Bringing Effective Remedies Home: The Inter-American Human Rights System, Reparations, and the Duty of Prevention', NQHR, 2004, p. 347-388. 


\section{Larsen 1993}

Larsen, S., 'Validity, construction, and application of statutes requiring that percentage of punitive damages awards be paid directly to state or courtadministered fund', 16 ALR 5th 129, 1993. Retrieved via: American Law Reports, Westlaw International online database.

\section{Law Commission Report 1997}

Report of the Law Commission for England and Wales, Aggravated, Exemplary and Restitutionary Damages, Law. Com. no. 247, 1997. Retrieved via: lawcommission.justice.gov.uk/docs/lc247_aggravated_exemplary_and_restitutionary_ damages.pdf.

\section{Lawson \& Marland 2011}

Lawson, R. \& Marland, T., 'The Montreal Convention 1999 and the Decisions of the CJEU in the Cases of IATA and Sturgeon - in Harmony or Discord?', ASL, 2011, p. 99-108.

\section{Lew 2007}

Lew, J.D.M., 'When Should International Arbitrators Award Punitive Damages?', in: A.W. Rovine (ed.), Contemporary Issues in International Arbitration and Mediation The Fordham Papers 2007, Leiden: Martinus Nijhoff Publishers, 2007.

\section{Lemmens 2003}

Lemmens, K., 'The Protection of Privacy between a Rights-Based and a FreedomBased Approach: What the Swiss Example can teach us', MJ, 2003, p. 381-403.

\section{Licari 2011}

Licari, F.-X., 'La compatibilité de principe des punitive damages avec l'ordre public international: une décision en trompe-l'œil de la Cour de cassation?', Recueil Dalloz, 2011, p. 423-427. Retrieved via: ssrn.com/abstract=1820963.

\section{Lillich 1993}

Lillich, R.B., 'Damages for Gross Violations of International Human Rights Awarded by US Courts', Hum Rts Q, 1993, p. 207-229.

\section{Lindenbergh 1995}

Lindenbergh, S.D., 'Smartegeld, geen straf: (on)mogelijkheden van punitive damages in het schadevergoedingsrecht', Nemesis, 1995, p. 126-132.

\section{Lindenbergh 1998}

Lindenbergh, S.D., Smartengeld (diss. Leiden), Kluwer: Deventer, 1998. 


\section{Lindenbergh 2003}

Lindenbergh, S.D., 'Doeleinden en effecten van civielrechtelijke sancties', in: E.M. Hoogervorst et al. (red.), Doel en effect van civielrechtelijke sancties, BW-krant jaarboek 19, Kluwer: Deventer, 2003.

\section{Lindenbergh 2006}

Lindenbergh, S.D., 'Damages in Tort', in: J.M. Smits (ed.), Elgar Encyclopedia of Comparative Law, Cheltenham: Edward Elgar Publishing, 2006.

\section{Lindenbergh 2008a}

Lindenbergh, S.D., Smartengeld - tien jaar later, Deventer: Kluwer, 2008.

\section{Lindenbergh 2008b}

Lindenbergh, S.D., 'PETL: Remedies, Damages', AV\&S, 2008, p. 221-228.

\section{Lindenbergh 2008c}

Lindenbergh, S.D., Schadevergoeding: algemeen, deel 1, Monografieën BW, Deventer: Kluwer, 2008.

\section{Lindenbergh 2010}

Lindenbergh, S.D., 'Fundamental Rights in Private Law: Anchors or Goals in a Globalizing Legal Order? ', in: M. Faure \& A. Van der Walt, Globalization and Private Law: The Way Forward, Cheltenham: Edward Elgar Publishing, 2010.

\section{Litwiller 2002}

Litwiller, L., 'Has the Supreme Court Sounded the Death Knell for Jury Assessed Punitive Damages? A Critical Reexamination of the American Jury', USF L Rev, 2002, p. 411-472.

\section{Lokin 2003}

Lokin, J.H.A., 'Doel en effectiviteit van civielrechtelijke sancties in het Romeinse recht', in: E.M. Hoogervorst et al. (red.), Doel en effect van civielrechtelijke sancties, BW-krant jaarboek 19, Kluwer: Deventer, 2003.

\section{Long 1977}

Long, J.D., 'Should Punitive Damages be Insured?', JRI, 1977, p. 1-20.

\section{Lundmark 1996}

Lundmark, T., 'The Restatement of Torts (Third) and the European Product Liability Directive, J Int'l L \& Pract, 1996, p. 239-270.

\section{Magnus 2001a}

Magnus, U., 'Damages under German Law', in: U. Magnus (ed.), Unification of Tort Law: Damages, The Hague: Kluwer Law International, 2001. 


\section{Magnus 2001b}

Magnus, U., 'Comparative Report on the Law of Damages', in: U. Magnus (ed.), Unification of Tort Law: Damages, The Hague: Kluwer Law International, 2001.

\section{Magnus 2003}

Magnus, U. (ed.), The Impact of Social Security on Tort Law, Vienna: Springer Verlag, 2003.

\section{Magnus 2006}

Magnus, U., 'Tort Law in General', in: J.M. Smits (ed.), Elgar Encyclopedia of Comparative Law, Cheltenham: Edward Elgar Publishing, 2006.

\section{Magnus 2010}

Magnus, U., 'Why is US Tort Law so Different?', JETL, 2010, p. 102-124.

\section{Magnus 2012}

Magnus, U., 'Punitive Damages and German Law', in: L. Meurkens \& E. Nordin (eds.), The Power of Punitive Damages - Is Europe Missing Out?, Antwerp: Intersentia, 2012.

\section{Mahé 2012}

Mahé, C.B.P., 'Punitive Damages in the Competing Reform Drafts of the French Civil Code', in: L. Meurkens \& E. Nordin (eds.), The Power of Punitive Damages Is Europe Missing Out?, Antwerp: Intersentia, 2012.

\section{Mallor \& Roberts 1999}

Mallor, J. \& Roberts, B.S., 'Punitive Damages: On the Path to A Principled Approach?', Hastings L J, 1999, p. 1001-1014.

\section{Mann 1992}

Mann, K., 'Punitive Civil Sanctions: The Middleground between Criminal and Civil Law', Yale L J, 1992, p. 1795-1873.

\section{Markel 2009a}

Markel, D., 'Retributive Damages: A Theory of Punitive Damages as Intermediate Sanction', Cornell L Rev, 2009, p. 239-340.

\section{Markel 2009b}

Markel, D., 'How Should Punitive Damages Work?', U Pa L Rev, 2009, p. 13831484.

\section{Markel 2010}

Markel, D., 'Punitive Damages and Private Ordering Fetishism', U Pa L Rev, 2010, p. 283-304. 


\section{Markesinis 1990}

Markesinis, B.S., A Comparative Introduction to the German Law of Torts, Oxford: Clarendon Press, 1990.

\section{Martin 2003}

Martin, E.A. (ed.), Oxford Dictionary of Law, Oxford: Oxford University Press, 2003.

\section{McGovern 2010}

McGovern, F.E., 'Punitive Damages and Class Actions', La L Rev, 2010, p. 435462.

\section{McGregor 1997}

McGregor, H., McGregor on Damages, London: Sweet \& Maxwell, 1997.

\section{McKown 1995}

McKown, J.R., 'Punitive Damages: State Trends and Developments', Rev Litig, 1995, p. 419-463.

\section{McQuillan et al. 2007}

McQuillan, L.J. et al., Jackpot Justice - The True Cost of America's Tort System, San Francisco: Pacific Research Institute, 2007. Retrieved via: www.pacificresearch.org.

\section{Mead 1995}

Mead, S., 'Punitive Damages and the Spill Felt Round the World: A U.S. Perspective', Loy L A Int'l \& Comp L J, 1995, p. 829-860.

\section{Melnick 2005}

Melnick, R.S., 'Deregulating the States: The Political Jurisprudence of the Rehnquist Court', in: T. Ginsburg \& R.A. Kagan (eds.), Institutions \& Public Law - Comparative Approaches, New York: Peter Lang Publishing, 2005.

\section{Merritt \& Barry 1999}

Merritt, D.J. \& Barry, K.A., 'Is the Tort System in Crisis? New Empirical Evidence', Ohio St L J, 1999, p. 315-398.

\section{Merryman \& Pérez-Perdomo 2007}

Merryman, J.H. \& Pérez-Perdomo, R., The Civil Law Tradition - An Introduction to the Legal Systems of Europe and Latin America, Stanford (CA): Stanford University Press, 2007. 


\section{Meurkens 2012a}

Meurkens, L., 'The Punitive Damages Debate in Continental Europe: Food for Thought', in: L. Meurkens \& E. Nordin (eds.), The Power of Punitive Damages Is Europe Missing Out?, Antwerp: Intersentia, 2012.

\section{Meurkens 2012b}

Meurkens, L., 'Epilogue', in: L. Meurkens \& E. Nordin (eds.), The Power of Punitive Damages - Is Europe Missing Out?, Antwerp: Intersentia, 2012.

\section{Meurkens \& Nordin 2012}

Meurkens, L. \& Nordin, E. (eds.), The Power of Punitive Damages - Is Europe Missing Out?, Antwerp: Intersentia, 2012.

\section{Milutinović 2010}

Milutinović, V.M., The 'Right to Damages' under EU Competition Law: from Courage v. Crehan to the White Paper and Beyond, European Monographs, Alphen and den Rijn: Kluwer Law International, 2010.

\section{Moore \& Kip Viscusi 2001}

Moore, M.J. \& Kip Viscusi, W., Product Liability Entering the Twenty-First Century - the U.S. Perspective, Washington DC: Brookings Institution Press, 2001.

\section{Morgan 2005}

Morgan, B., 'The Internationalization of Economic Review of Legislation: NonJudicial Legalization?', in: T. Ginsburg \& R.A. Kagan (eds.), Institutions \& Public Law - Comparative Approaches, New York: Peter Lang Publishing, 2005.

\section{Morgan 2012}

Morgan, J., 'Reflections on Reforming Punitive Damages in English Law', in: L. Meurkens \& E. Nordin (eds.), The Power of Punitive Damages - Is Europe Missing Out?, Antwerp: Intersentia, 2012.

\section{Morris 1931}

Morris, C., 'Punitive Damages in Tort Cases', Harv L Rev, 1931, p. 1173-1209.

\section{Mukheibir 2007}

Mukheibir, A., The Wages of Delict - Compensation, Satisfaction, Punishment? (Diss. Amsterdam UvA), 2007.

\section{Mulder 2009}

Mulder, J.D.W.E., Compensatie na geweld. Wie krijgen er een vergoeding van het Schadefonds Geweldsmisdrijven en wat zijn de effecten van zo'n financiële vergoeding, Tilburg: Intervict/PrismaPrint, 2009. 


\section{Mulder 2010}

Mulder, J.D.W.E., 'Hoe schadevergoeding kan leiden tot gevoelens van erkenning en gerechtigheid. Lessen uit de praktijk van het Schadefonds Geweldsmisdrijven', NJB, 2010, p. 293-296.

\section{Mulder 2013}

Mulder, J.D.W.E., Compensation. The Victim's Perspective (diss. Tilburg), Oisterwijk: Wolf Legal Publishers, 2013.

\section{Müller 2000}

Müller, P., Punitive Damages und deutsches Schadensersatzrecht (diss. Augsburg), De Gruyter: Berlin, 2000.

\section{Nagy 2012}

Nagy, C.I., 'Recognition and Enforcement of US Judgments Involving Punitive Damages in Continental Europe', NIPR, 2012, p. 4-11.

\section{Nater-Bass 2003}

Nater-Bass, G., 'U.S.-Style Punitive Damages Awards and their Recognition and Enforcement in Switzerland and Other Civil-Law Countries', DAJV Newsletter, 2003, p. $154-160$.

\section{Nebbia 2008}

Nebbia, P., 'Damages actions for the infringement of EC competition law: compensation or deterrence?', ELR, 2008, p. 23-43.

\section{Nezar 2011}

Nezar, A., 'Reconciling Punitive Damages with Tort Law's Normative Framework', Yale L J, 2011, p. 678-723.

\section{Nieuwenhuis 2009}

Nieuwenhuis, J.H., 'De geboorte van het recht uit de geest van de tragedie', $R M$ Themis, 2009, p. 233-235.

\section{Nordin 2011}

Nordin, E. 'Private Straffen in het Contractenrecht Beschouwd vanuit het Perspectief van Artikel 6 EVRM', in: J. Rozie, A. Van Oevelen \& S. Rutten (red.), Toetsing van Sancties door de Rechter, Antwerp: Intersentia, 2011.

\section{Nordin 2014}

Nordin, E., De Schadevergoeding in het Aansprakelijkheidsrecht: tussen Compensatie en Handhaving (diss. Antwerpen), Antwerpen: Universiteit Antwerpen, 2014. 


\section{Noussia 2010}

Noussia, K., 'Punitive Damages in Arbitration: Panacea or Curse?', J Int Arb, 2010, p. 277-294.

\section{Ogus \& Visscher 2010}

Ogus, A.I. \& Visscher, L.T., 'A Law and Economics Perspective on Injunctive Relief', MJ, 2010, p. 32-47.

\section{Oliphant 2008}

Oliphant, K., 'The Nature and Assessment of Damages', in: H. Koziol \& R. Schulze (eds.), Tort Law of the European Community, Vienna: Springer Verlag, 2008.

\section{Oliphant 2012}

Oliphant, K., 'Cultures of Tort Law in Europe', JETL, 2012, p. 147-157.

\section{Ortega González 2012}

Ortega González, A., 'Punitive Damages for Cartel Infringements: Why Didn’t the Commission Grasp the Opportunity?', in: L. Meurkens \& E. Nordin (eds.), The Power of Punitive Damages - Is Europe Missing Out?, Antwerp: Intersentia, 2012.

\section{Ostoni 2005}

Ostoni, L., 'Italian Rejection of Punitive Damages in a U.S. Judgment', $J L \&$ Com, 2005, p. 245-262.

\section{Owen 1976}

Owen, D.G., 'Punitive Damages in Products Liability Litigation', Mich L Rev, 1976, p. 1257-1371.

\section{Owen 1982}

Owen, D.G., 'Civil Punishment and the Public Good', S Cal L Rev, 1982, p. 103-121.

\section{Owen 1989}

Owen, D.G., 'The Moral Foundations of Punitive Damages', Ala L Rev, 1989, p. 705-739.

\section{Owen 1994}

Owen, D.G., 'A Punitive Damages Overview: Functions, Problems and Reform', Vill L Rev, 1994, p. 363-413.

\section{Owen 1995}

Owen, D.G., 'Why Philosophy Matters to Tort Law', in: D.G. Owen (ed.), Philosophical Foundations of Tort Law, Oxford: Clarendon Press, 1995. 


\section{Owen 2005}

Owen, D.G., Products Liability Law, St. Paul (MN): Thomson/West, 2005.

\section{Owen 2010}

Owen, D.G., ‘Aggravating Punitive Damages', U Pa L Rev, 2010, p. 181-194.

\section{Owen 2012}

Owen D.G., 'Punitive Damages as Restitution', in: L. Meurkens \& E. Nordin (eds.), The Power of Punitive Damages - Is Europe Missing Out?, Antwerp: Intersentia, 2012.

\section{Ozmis \& Tzankova 2012}

Ozmis, D. \& Tzankova, I.N., 'De evaluatie van de WCAM: de kernthema's uitgelicht', TCR, 2012, p. 33-42.

\section{Paijmans 2013}

Paijmans, B.M., De zorgplicht van scholen: de grondslag en reikwijdte van de civielrechtelijke zorgvuldigheidsnorm van scholen jegens leerlingen (diss. Utrecht), Deventer: Kluwer, 2013.

\section{Parker 2013}

Parker, M., 'Changing Tides: the Introduction of Punitive Damages into the French Legal System', Ga J Int'l \& Comp L, 2013, p. 389-432.

\section{Paulis 2007}

Paulis, E.P., 'Policy Issues in the Private Enforcement of EC Competition Law', in: J. Basedow (ed.), Private Enforcement of EC Competition Law, Alphen aan den Rijn: Kluwer Law International, 2007.

\section{Pennings 2006}

Pennings, F., 'Social Security', in: J.M. Smits (ed.), Elgar Encyclopedia of Comparative Law, Cheltenham: Edward Elgar Publishing, 2006.

\section{Polinsky 1989}

Polinsky, A.M., An Introduction to Law and Economics, Boston (Ma): Little, Brown \& Co., 1989.

\section{Polinsky \& Shavell 1998a}

Polinsky, A.M. \& Shavell, S., 'Punitive Damages: An Economic Analysis', Harv L Rev, 1998, p. 869-962. 


\section{Polinsky \& Shavell 1998b}

Polinsky, A.M. \& Shavell, S., 'Punitive Damages', in: P. Newman (ed.), The New Palgrave Dictionary of Economics and the Law, London: MacMillan Reference, 1998. Retrieved via: www.law.harvard.edu/programs/olin_center/papers/pdf/214.pdf.

\section{Polinsky \& Shavell 2005}

Polinsky, A.M. \& Shavell, S., 'The Theory of Public Enforcement of Law', Harvard Law School John M. Olin Center for Law, Economics and Business Discussion Paper No. 529, 2005. Retrieved via: 1sr.nellco.org/harvard_olin/529.

\section{Polsky \& Markel 2010}

Polsky, G.D. \& Markel, D., 'Taxing Punitive Damages', Va L Rev, 2010, p. 12951360.

\section{Posner 1972a}

Posner, R.A., 'A Theory of Negligence', J Legal Stud, 1972, p. 29-96.

\section{Posner 1972b}

Posner, R.A., Economic Analysis of Law, Boston (Ma): Little, Brown \& Co., 1972.

\section{Practice Direction on Just Satisfaction Claims 2007}

Practice Direction ECtHR of 28 March 2007. Retrieved via: www.echr.coe.int/NR/ rdonlyres/8227A775-CD37-4F51-A4AA-1797004BE394/0/PracticeDirectionsJustSatifactionClaims2007.pdf.

\section{Priest 1989}

Priest, G.L., 'Insurability and Punitive Damages', Ala L Rev, 1989, p. 1009-1035.

\section{Priest 1991}

Priest, G.L., 'The Modern Expansion of Tort Liability: Its Sources, its Effects and its Reform', JEP, 1991, p. 31-50.

\section{Quarta 2008}

Quarta, F., 'Recognition and Enforcement of U.S. Punitive Damages Awards in Continental Europe: The Italian Supreme Court's Veto', Hastings Int'l \& Comp L $R, 2008$, p. 753-782.

\section{Redish \& Mathews 2004}

Redish, M.H. \& Mathews, A.L., 'Why Punitive Damages are Unconstitutional', Emory L J, 2004, p. 1-54.

\section{Reed \& Fitzpatrick 2006}

Reed, A. \& Fitzpatrick, B., Criminal Law, London: Sweet \& Maxwell, 2006. 


\section{Reimann 2003}

Reimann, M., 'Product Liability in a Global Context: the Hollow Victory of the European Model', ERPL, 2003, p. 128-154.

\section{Rendleman 2009}

Rendleman, D., 'Common Law Punitive Damages: Something for Everyone?', U St Thomas L J, 2009, p. 1-24.

\section{Requejo Isidro 2009}

Requejo Isidro, M., 'Punitive Damages from a Private International Law Perspective', in: H. Koziol \& V. Wilcox (eds.), Punitive Damages: Common Law and Civil Law Perspectives, Vienna: Springer Verlag, 2009.

\section{Requejo Isidro 2012}

Requejo Isidro, M., 'Punitive Damages: How Do They Look Like When Seen From Abroad?', in: L. Meurkens \& E. Nordin (eds.), The Power of Punitive Damages - Is Europe Missing Out?, Antwerp: Intersentia, 2012.

\section{Report U.S. Census Bureau 2008}

DeNavas-Walt, C., Proctor, B.D. \& Smith, J.C., Income, Poverty, and Health Insurance Coverage in the United States: 2007, U.S. Census Bureau Report, Washington DC: U.S. Government Printing Office, 2008. Retrieved via: www. census.gov/prod/2008pubs/p60-235.pdf.

\section{Report U.S. Census Bureau 2011}

DeNavas-Walt, C., Proctor, B.D. \& Smith, J.C., Income, Poverty, and Health Insurance Coverage in the United States: 2010, U.S. Census Bureau Report, Washington DC: U.S. Government Printing Office, 2011. Retrieved via: www. census.gov/prod/2011pubs/p60-239.pdf.

\section{Report U.S. Census Bureau 2012}

DeNavas-Walt, C., Proctor, B.D. \& Smith, J.C., Income, Poverty, and Health Insurance Coverage in the United States: 2011, U.S. Census Bureau Report, Washington DC: U.S. Government Printing Office, 2012. Retrieved via: www. census.gov/hhes/www/hlthins/hlthins.html.

Report U.S. Census Bureau: Statistical Abstract of the United States 2012 U.S. Census Bureau, Statistical Abstract of the United States: 2012, Section 3 Health and Nutrition, Washington DC: U.S. Government Printing Office, 2011. Retrieved via: www.census.gov/compendia/statab/.

\section{Restatement of Torts}

Restatement (Second) of Torts 1979. 


\section{Rhee 2012}

Rhee, R.J., 'A Financial Economic Theory of Punitive Damages', Mich L Rev, 2012, p. 33-88.

\section{Rijnhout et al. 2013}

Rijnhout, R. et al., 'Beweging in het aansprakelijkheidsrecht', NTBR, 2013, p. 171184.

\section{Robbennolt 2002a}

Robbennolt, J.K., 'Determining Punitive Damages: Empirical Insights and Implications for Reform', Buff L Rev, 2002, p. 103-203.

\section{Robbennolt 2002b}

Robbennolt, J.K., 'Punitive Damage Decision making: The Decisions of Citizens and Trial Court Judges', Law \& Hum Behav, 2002, p. 315-341.

\section{Robinette 2008}

Robinette, C.J., 'Peace: a Public Purpose for Punitive Damages?', Charleston L Rev, 2008, p. 327-344.

\section{Rogers 2001}

Rogers, W.V.H., 'Damages under English Law', in: U. Magnus (ed.), Unification of Tort Law: Damages, The Hague: Kluwer Law International, 2001.

\section{Rogers 2006}

Rogers, W.V.H., Winfield and Jolowicz on Tort, London: Sweet \& Maxwell, 2006.

\section{Romero 2008}

Romero, L.M., 'Punitive Damages, Criminal Punishment, and Proportionality: The Importance of Legislative Limits', Conn L Rev, 2008, p. 109-160.

\section{Rouhette 2007}

Rouhette, T., 'The Availability of Punitive Damages in Europe: Growing Trend or Nonexistent Concept?', DCJ, 2007, p. 320-342.

\section{Rowan 2010}

Rowan, S., 'Reflections on the Introduction of Punitive Damages for Breach of Contract', OJLS, 2010, p. 495-517.

\section{Rubin 1998}

Rubin, E.L., 'Punitive Damages: Reconceptualizing the Runcible Remedies of Common Law', Wis L Rev, 1998, p. 131-155. 


\section{Rubin \& Shepherd 2008}

Rubin, P.H. \& Shepherd, J.M., 'The Demographics of Tort Reform', RLE, 2008, p. 591-620.

\section{Rustad 1998}

Rustad, M.L., 'The Incidence, Scope, and Purpose of Punitive Damages', Wis L Rev, 1998, p. 15-69.

\section{Rustad 2008}

Rustad, M.L., 'The Uncert-Worthiness of the Court's Unmaking of Punitive Damages', Charleston L Rev, 2008, p. 459-519.

\section{Rustad \& Koenig 1993}

Rustad, M. \& Koenig, T., 'The Historical Continuity of Punitive Damages Awards: Reforming the Tort Reformers', Am UL Rev, 1993, p. 1269-1333.

\section{Ryan 2003}

Ryan, P.S., 'Revisiting the United States Application of Punitive Damages: Separating Myth from Reality', ILSA J Int'l \& Comp L, 2003, p. 69-93.

\section{Samoy et al. 2013}

Samoy, I. et al., 'De dynamiek van het schadevereiste (1804-heden)', in: B. Debaenst \& B. Delbecke (red.), Vangnet of Springplank? Het Buitencontractueel Aansprakelijkheidsrecht in een Moderne Samenleving (1804-heden), Brugge: Die Keure, 2014.

\section{Samuel 2001}

Samuel, G., Law of Obligations and Legal Remedies, London: Cavendish Publishing, 2001.

\section{Samuel \& Rinkes 1991}

Samuel, G. \& Rinkes, J., The English law of obligations - in comparative perspective, Nijmegen: Ars Aequi Libri, 1991.

\section{Schäfer 2002}

Schäfer, C., 'Strafe und Prävention im Bürgerlichen Recht', AcP, 2002, p. 397-434.

\section{Schäfer \& Müller-Langer 2009}

Schäfer, H-B. \& Müller-Langer, F., 'Strict Liability versus Negligence', in: M.G. Faure (ed.), Tort Law and Economics, Cheltenham: Edward Elgar Publishing, 2009.

\section{Schkade, Sunstein \& Kahneman 2000}

Schkade, D., Sunstein, C.R. \& Kahneman, D., 'Deliberating About Dollars: The Severity Shift', Colum L Rev, 2000, p. 1139-1176. 


\section{Scarso 2009}

Scarso, A.P., 'Punitive Damages in Italy', in: H. Koziol \& V. Wilcox (eds.), Punitive Damages: Common Law and Civil Law Perspectives, Vienna: Springer Verlag, 2009.

\section{Schelhaas 2004}

Schelhaas, H.N., Het Boetebeding in het Europese Contractenrecht (diss. Utrecht), Deventer: Kluwer, 2004.

\section{Scheltema 2012}

Scheltema, M.W., Effectiviteit van privaatrechtelijke regulering: is dat meetbaar? (oratie Rotterdam), Den Haag: Boom Juridische uitgevers, 2012.

\section{Scheuerman 2008}

Sheuerman, S.B., 'Two Worlds Collide: How the Supreme Court's Recent Punitive Damages Decisions Affect Class Actions', Baylor L Rev, 2008, p. 880-940.

\section{Schirmeister 1996}

Schirmeister, F.C., Amerikaanse toestanden in het schadevergoedingsrecht - De vergoeding van letselschade in de Verenigde Staten (diss. Amsterdam VU), Lelystad: Koninklijke Vermande, 1996.

\section{Schirmeister 2003}

Schirmeister, F.C., 'Punitive Damages: Amerikaanse lessen voor Nederland?', in: E.M. Hoogervorst et al. (red.), Doel en effect van civielrechtelijke sancties, BW-krant jaarboek 19, Kluwer: Deventer, 2003.

\section{Schuijt 2003}

Schuijt, G.A.I., 'Smartengeld wegens aantasting eer en goede naam of privacy', Mediaforum, 2003, p. 50-51.

\section{Schlueter 2005a}

Schlueter, L.L., Punitive Damages. Volume 1, LexisNexis, 2005.

\section{Schlueter 2005b}

Schlueter, L.L., Punitive Damages. Volume 2, LexisNexis, 2005.

\section{Schoenbrod et al. 1996}

Schoenbrod D. et al., Remedies: Public and Private, St. Paul (MN): West Publishing, 1996.

\section{Schwartz 1982}

Schwartz, G.T., 'Deterrence and Punishment in the Common Law of Punitive Damages: A Comment', S Cal L Rev, 1982, p. 133-153. 


\section{Schwartz \& Magarian 1990}

Schwartz, V.E. \& Magarian, L., 'Challenging the Constitutionality of Punitive Damages: Putting Rules of Reason on an Unbounded Legal Remedy', Am Bus L J, 1990, p. 485-497.

\section{Schwartz 2001}

Schwartz, G., 'Damages under US law', in: U. Magnus (ed.), Unification of Tort Law: Damages, The Hague: Kluwer Law International, 2001.

\section{Sebok 2003}

Sebok, A.J., 'Introduction: What does it mean to say that a remedy punishes?' Chi-Kent L Rev, 2003, p. 3-15.

\section{Sebok 2007}

Sebok, A.J., 'Punitive Damages: From Myth to Theory', Iowa L Rev, 2007, p. 9571036.

\section{Sebok \& Wilcox 2009}

Sebok, A.J. \& Wilcox, V., 'Aggravated Damages', in: H. Koziol \& V. Wilcox (eds.), Punitive Damages: Common Law and Civil Law Perspectives, Vienna: Springer Verlag, 2009.

\section{Sebok 2014}

Sebok, A.J., 'Normative Theories of Punitive Damages: The Case of Deterrence', Benjamin N. Cardozo School of Law Research Paper No. 431, 2014. Retrieved via: papers.ssrn.com/sol3/papers.cfm?abstract_id=2437529.

\section{Sein 2007}

Sein, K., 'Should Estonian Law Provide for an Award of Punitive Damages?', Juridica International, 2007, p. 46-54.

\section{Seiner 2008}

Seiner, J.A., 'The Failure of Punitive Damages in Employment Discrimination Cases: A Call for Change', Wm \& Mary L Rev, 2008, p. 735-796.

\section{Seiner 2012}

Seiner, J.A., 'Punitive Damages, Due Process, and Employment Discrimination', Iowa L Rev, 2012, p. 473-519.

\section{Sharkey 1996}

Sharkey, L.M., 'Judge or Jury: Who Should Assess Punitive Damages?', U Cin L Rev, 1996, p. 1089-1139. 


\section{Sharkey 2003}

Sharkey, C.M., 'Punitive Damages as Societal Damages', Yale L J, 2003, p. 347-453.

\section{Sharkey 2005}

Sharkey, C.M., 'Revisiting the Noninsurable Costs of Accidents', Md L Rev, 2005, p. 409-460.

\section{Sharkey 2008}

Sharkey, C.M., 'Crossing the Punitive-Compensatory Divide', in: B.H. Bornstein et al. (eds.), Civil Juries and Civil Justice - Psychological \& Legal Perspectives, New York: Springer Verlag, 2008.

\section{Sharkey 2009}

Sharkey, C.M., 'The Exxon Valdez Litigation Marathon: A Window on Punitive Damages', U St Thomas L J, 2009, p. 25-54.

\section{Sharkey 2010}

Sharkey, C.M., 'Federal Incursions and State Defiance: Punitive Damages in the Wake of Philip Morris v. Williams', Willamette L Rev, 2010, p. 449-478.

\section{Sharkey 2012}

Sharkey, C.M., 'Economic Analysis of Punitive Damages: Theory, Empirics, and Doctrine', New York University Law and Economics Working Paper No. 12-02, 2012. Retrieved via: ssrn.com/abstract $=1990336$.

\section{Sharkey \& Klick 2007}

Sharkey, C.M. \& Klick, J., 'The Fungibility of Damage Awards: Punitive Damage Caps and Substitution', Florida State University Law and Economics Paper No. 912256, 2007. Retrieved via: ssrn.com/abstract $=912256$.

\section{Shavell 1979}

Shavell, S., 'On Moral Hazard and Insurance', QJE, 1979, p. 541-562.

\section{Shavell 1987}

Shavell, S., Economic Analysis of Accident Law, Cambridge (Ma): Harvard University Press, 1987.

\section{Shavell 2004}

Shavell, S., Foundations of Economic Analysis of Law, Cambridge (Ma): Harvard University Press, 2004.

\section{Shea Adams \& Bourgeois 2006}

Shea Adams, C.M. \& Bourgeois, M.J., 'Separating Compensatory and Punitive Damage Award Decisions by Trial Bifurcation', Law \& Hum Behav, 2006, p. 11-30. 


\section{Sheinman 2003}

Sheinman, H., 'Tort Law and Corrective Justice', L \& Phil, 2003, p. 21-73.

\section{Scheuerman 2009}

Scheuerman, S.B., 'Due Process Forgotten: The Problem of Statutory Damages and Class Actions', Mo L Rev, 2009, p. 103-152.

\section{Shelton 2005}

Shelton, D., Remedies in International Human Rights Law, Oxford: Oxford University Press, 2005.

\section{Sibon 2013}

Sibon, A.S., 'Enforcing Punitive Damages Awards in France: Facing Proportionality Within International Public Policy', 2013. Retrieved via: papers.ssrn.com/ sol3/papers.cfm?abstract_id=2382817.

\section{Sieburgh 2010}

Sieburgh, C.H., 'Gerechtigheid en rechtshandhaving', WPNR, 2010, p. 388-395.

\section{Six 2006}

Six, J.P.H., 'Amerikaanse toestanden? Een poging tot demystificatie', PIV-Bulletin, 2006, p. 3-5.

\section{Slok \& Van 1990}

Slok, W.M.K. \& Van, A.J., 'De Privaatrechtelijke boete en artikel 6:106 Nieuw BW', NJB 1990, p. 1823-1829.

\section{Smeehuijzen 2009}

Smeehuijzen, J.L., 'Schadevergoeding wegens onzorgvuldige afwikkeling van letselschade-vorderingen', NTBR, 2009, p. 328-341.

\section{Smeehuijzen 2012}

Smeehuijzen, J.L., 'Some Tentative Thoughts on Punitive Damages in Case of Bad Faith Claim Handling by Insurers', in: L. Meurkens \& E. Nordin (eds.), The Power of Punitive Damages - Is Europe Missing Out?, Antwerp: Intersentia, 2012.

\section{Snijders et al. 1996}

Snijders et al., Toegang tot buitenlands vermogensrecht, Gouda: Quint, 1996.

\section{Spencer 2006}

Spencer, A.B., 'Due Process and Punitive Damages: the Error of Federal Excessiveness Jurisprudence', S Cal L Rev, 2006, p. 1085-1154. 


\section{Spier 2012}

Spier, J., 'Algemene Inleiding', in: J. Spier et al., Verbintenissen uit de Wet en Schadevergoeding, Deventer: Kluwer 2012.

\section{Spruit 2001}

Spruit, J.E., Cunabula iuris - Elementen van het Romeinse privaatrecht, Deventer: Kluwer, 2001.

\section{Spruit \& Feenstra 1989}

Spruit, J.E. \& Feenstra, R., Textux Iuris Romani, Deventer: Kluwer, 1989.

\section{Stocker 2003}

Stocker, F.T., 'The Problem With Punitive Damages', in: F.T. Stocker (ed.), I Pay, You Pay, We All Pay - How the Growing Tort Crisis Undermines the U.S. Economy and the American System of Justice, Arlington (VA): Manufacturers Alliance/MAPI, 2003.

\section{Stoll 1970}

Stoll, H., 'Penal Purposes in the Law of Tort', Am J Comp L, 1970, p. 3-21.

\section{Stolker 1995}

Stolker, C.J.J.M., 'Straffen met privaatrecht - of juist verzoenen?', in: A.M. Hol \& C.J.J.M. Stolker (red.), Over de grenzen van strafrecht en burgerlijk recht, Deventer: Kluwer, 1995.

\section{Stolker 2003}

Stolker, C.J.J.M, 'Smartengeld: willen we niet veel te veel?' RM Themis, 2003, p. 307-309.

\section{Sturley 2010}

Sturley, M.F., 'Vicarious Liability for Punitive Damages', La L Rev, 2010, p. 501527

\section{Sugarman 2000}

Sugarman, S.D., 'A Century of Change in Personal Injury Law', Cal L Rev, 2000, p. 2403-2436.

\section{Sunstein et al. 2002}

Sunstein, C.R. et al., Punitive Damages - How Juries Decide, Chicago: University of Chicago Press, 2002.

\section{Sunstein, Kahneman \& Schkade 1998}

Sunstein, C.R., Kahneman, D. \& Schkade, D., 'Assessing Punitive Damages (with Notes on Cognition and Valuation in Law)', Yale L J, 1998, p. 2071-2153. 


\section{Sykes 1988}

Sykes, A.O., 'The Boundaries of Vicarious Liability: An Economic Analysis of the Scope of Employment Rule and Related Legal Doctrines', Harv L Rev, 1988, p. 563-609.

\section{Tak 2008}

Tak, P.J.P., 'Methods of Diversion Used by the Prosecution Services in the Netherlands and other Western European Countries', Resource Material Series no. 74, Tokyo: UNAFEI, 2008, p. 53-64. Retrieved via: www.unafei.or.jp/english/ pdf/RS_No74/No74_07VE_Tak.pdf.

\section{Ten Wolde \& Peters 2013}

Ten Wolde, M.H. \& Peters, N., 'De Wet collectieve afwikkeling massaschade: wat is zij waard in het buitenland?', NTBR, 2013, p. 3-14.

\section{Terré 2011}

Terré, F., Pour une réforme du droit de la responsabilité civile, Paris: Dalloz, 2011.

\section{Tettenborn 2004}

Tettenborn, A., 'Punitive Damages - A View from England', San Diego L Rev, 2004, p. $1551-1573$.

\section{Towers Watson 2010}

Towers Watson Update on U.S. Tort Cost Trends 2010. Retrieved via: www. towerswatson.com/assets/pdf/3424/Towers-Watson-Tort-Report-1.pdf.

\section{Triadafillidis 2002}

Triadafillidis, C.D., 'Anerkennung und Vollstreckung von "punitive damages"Urteilen nach Kontinentalem und insbesondere nach griechischem Recht', IPRax, 2002, p. 236-238.

\section{Twerski 1994}

Twerski, A.D., 'Punitive Damages Awards in Product Liability Litigation: Strong Medicine or Poison Pill?', Vill L Rev, 1994, p. 353-362.

\section{Tzankova 2005}

Tzankova, I.N., Strooischade: Een verkennend onderzoek naar een nieuw rechtsfenomeen, Allen Overy Onderzoeksreeks, Den Haag: SDU, 2005.

\section{Tzankova 2007}

Tzankova, I.N., Toegang tot het recht bij massaschade (diss. Tilburg), Deventer: Kluwer, 2007. 


\section{Tzankova 2012}

Tzankova, I.N., 'Funding of Mass Disputes: Lessons from the Netherlands', $J$ L Econ \& Pol'y, 2012, p. 549-591.

\section{Tzankova \& Lunsingh Scheurleer 2009}

Tzankova, I.N. \& Lunsingh Scheurleer, D., 'The Netherlands', Annals AAPSS, 2009, p. 149-160.

\section{Tzankova, Plomp \& Raats 2013}

Tzankova, I.N., Plomp, M.J. \& Raats, T., 'Handhaven en Balanceren: een Tussenstand van Privaatrechtelijke Handhaving in Europa, $M \& M, 2013$, p. 178186.

\section{Van den Bergh \& Keske 2007}

Van den Bergh, R. \& Keske, S., 'Private Enforcement of European Competition Law: Quo Vadis?', ERCL, 2007, p. 468-486.

\section{Van Boom 2006a}

Van Boom, W.H., Efficacious Enforcement in Contract and Tort (oratie Rotterdam), Den Haag: Boom Juridische uitgevers, 2006.

\section{Van Boom 2006b}

Van Boom, W.H., 'Compensating and Preventing damage: is there any future left for tort law?', 2006. Retrieved via: papers.ssrn.com/sol3/papers.cfm?abstract_id=942710.

\section{Van Boom 2007a}

Van Boom, W.H., 'On the Intersection between Tort Law and Regulatory Law - A Comparative Analysis', in: W.H. van Boom, M. Lukas \& C. Kissling (eds.), Tort and Regulatory Law, Vienna: Springer Verlag, 2007.

\section{Van Boom 2007b}

Van Boom, W.H., 'Effectuerend Handhaven in het Privaatrecht', NJB, 2007, p. 982-991.

\section{Van Boom 2008}

Van Boom, W.H., 'Iets over handhaving in het privaatrecht', WPNR, 2008, p. 765-769.

\section{Van Boom 2011}

Van Boom, W.H., 'Twee arresten over 'winstafroming' ex artikel 6:104 BW, AA, 2011, p. 118-125.

\section{Van Boom \& De Jong 2014}

Van Boom, W.H. \& De Jong, M., 'Het Experiment resultaatgerelateerde beloning verwachtingen over werking en doelbereiking', TVP, 2014, p. 69-76. 


\section{Van Boom, Giesen \& Smit 2012a}

Van Boom, W.H., Giesen, I. \& Smit, M. (red.), Civilologie: Opstellen over Empirie en Privaatrecht, Den Haag: Boom Juridische Uitgevers, 2012.

\section{Van Boom, Giesen \& Smit 2012b}

Van Boom, W.H., Giesen, I. \& Smit, M., 'Civilologie en de Vaart der Privaatrechtelijke Volkeren', in: W.H van Boom, I. Giesen \& M. Smit (red.), Civilologie: Opstellen over Empirie en Privaatrecht, Den Haag: Boom Juridische Uitgevers, 2012.

\section{Van Boom, Giesen \& Verheij 2013}

Van Boom, W.H., Giesen, I. \& Verheij, A.J. (red.), Capita Civilologie: Handboek Empirie en Privaatrecht, Den Haag: Boom Juridische Uitgevers, 2013.

\section{Van Buuren, Jurgens \& Michiels 2011}

Van Buuren, P.J.J., Jurgens, G.T.J.M. \& Michiels, F.C.M.A., Bestuursdwang en dwangsom, Deventer: Kluwer, 2011.

\section{Van Dam 2007}

Van Dam, C., 'European Tort Law and the Many Cultures of Europe', in: T. Wilhelmsson (ed.), Private Law and the Many Cultures of Europe, Alphen aan den Rijn: Kluwer Law International, 2007.

\section{Van Dam 2009}

Van Dam, C., 'Who is Afraid of Diversity? Cultural Diversity, European Cooperation, and European Tort Law', KLJ, 2009, p. 281-308.

\section{Van Dam 2011a}

Van Dam, C., 'Tort Law and Human Rights: Brothers in Arms on the Role of Tort Law in the Area of Business and Human Rights', JETL, 2011, p. 221-254.

\section{Van Dam 2011b}

Van Dam, C., 'Air Passenger Rights after Sturgeon', ASL, 2011, p. 259-274.

\section{Van Dam 2013a}

Van Dam, C., European Tort Law, Oxford: Oxford University Press, 2013.

\section{Van Dam 2013b}

Van Dam, C., 'Gronden van Nietigheid en Vernietigbaarheid', in: J. Hijma et al., Rechtshandeling en Overeenkomst, Deventer: Kluwer, 2013.

\section{Van der Heijden 2001}

Van der Heijden, E.M., 'Punitive damages en de calculerende schadeveroorzaker', NJB, 2001, p. 1749-1756. 


\section{Van der Heijden 2010}

Van der Heijden, M.-J., 'Class Actions/les actions collectives', EJCL, 2010. Retrieved via: www.ejcl.org/143/abs143-18.html.

\section{Van Gerven et al. 1998}

Van Gerven, W. et al., Tort Law - Scope of Protection, Oxford: Hart Publishing, 1998.

\section{Van Gerven 2001}

Van Gerven, W., 'Substantive Remedies for the Private Enforcement of EC Antitrust Rules before National Courts', in: C.D. Ehlermann \& I. Atanasiu (eds.), European Competition Law Annual 2001: Effective Private Enforcement of EC Antitrust Law, Oxford: Hart Publishing 2001.

\section{Van Gerven 2007}

Van Gerven, W., 'Private Enforcement of EC Competition Rules in the ECJ Courage v. Crehan and the Way Ahead', in: J. Basedow (ed.), Private Enforcement of EC Competition Law, Alphen aan den Rijn: Kluwer Law International, 2007.

\section{Van Gerven, Lever \& Larouche 2000}

Van Gerven, W., Lever J. \& Larouche, P., Tort Law, Oxford: Hart Publishing, 2000 .

\section{Van Harinxma thoe Slooten 2003}

Van Harinxma thoe Slooten, L.R., 'Toegang tot het recht tegen de media (televisie, pers en radio)', NJB 2003, p. 1991-2002.

\section{Van Hooijdonk \& Eijsvoogel 2009}

Van Hooijdonk, M. \& Eijsvoogel, P., Litigation in the Netherlands, The Hague: Kluwer Law International, 2009.

\section{Vanleenhove 2012}

Vanleenhove, C., 'Punitive Damages and European Law: Quo Vademus?', L. Meurkens \& E. Nordin (red.), The Power of Punitive Damages - Is Europe Missing Out?, Anwerp: Intersentia 2012.

\section{Vanlerberghe 2011}

Vanlerberghe, B., 'De toetsing van sancties door de rechter: algemeen kader', in: J. Rozie, A. Van Oevelen \& S. Rutten (red.), Toetsing van Sancties door de Rechter, Antwerp: Intersentia, 2011.

\section{Vansweevelt \& Weyts 2009}

Vansweevelt, T. \& Weyts, B., Handboek Buitencontractueel Aansprakelijkheidsrecht, Antwerpen: Intersentia, 2009. 


\section{Van Maanen 1999}

Van Maanen, G.E., De Zutphense juffrouw en de ontrouwe bediende van Lindenbaum, Nijmegen: Ars Aequi, 1999.

\section{Van Maanen 2012}

Van Maanen, G.E., 'Algemene inleiding', in: J. Spier et al., Verbintenissen uit de wet en Schadevergoeding, Deventer: Kluwer, 2012.

\section{Van Maanen, Townend \& Teffera 2008}

Van Maanen, G.E., Townend, D. \& Teffera, A., 'The Dutch 'Cellar Hatch' Judgment as a Landmark Case for Tort Law in Europe: A Brief Comparison with English, French and German Law with a Law and Economics Flavour', ERPL, 2008, p. 871-889.

\section{Van Maanen \& Van Dam 2010}

Van Maanen, G.E. \& Van Dam, C., 'The Development of Road and Railway Accident Law in The Netherlands', in: W. Ernst (ed.), The Development of Traffic Liability, Cambridge: Cambridge University Press 2010.

\section{Van Maanen \& Lindenbergh 2011}

Van Maanen, G.E. \& Lindenbergh, S.D., EVRM en Privaatrecht: Is Alles van Waarde Weerloos?, Preadviezen Nederlandse Vereniging voor Burgerlijk Recht, Deventer: Kluwer, 2011.

\section{Van Nispen 2003}

Van Nispen, C.J.J.C., Sancties in het vermogensrecht, Monografieën Nieuw BW, Deventer: Kluwer, 2003.

\section{Van Schaik 1999}

Van Schaik, R., 'De calculerende pers. Smartengeld bij onrechtmatige perspublicaties', Mediaforum, 1999, p. 169-173.

\section{Van Tiggele-Van der Velde 2009}

Van Tiggele-Van der Velde, N., Onverkwikkelijke afwikkeling van schade - Een (zelfstandige) grond voor schadeplichtigheid? (oratie Nijmegen), Nijmegen, 2009.

\section{Varuhas 2014}

Varuhas, J.N.E., 'The Concept of 'Vindication' in the Law of Torts: Rights, Interests and Damages', OJLS, 2014, p. 1-40.

\section{Verheij 1997}

Verheij, A.J., 'Punitive damages, immateriële schade en fundamentele rechtsbeginselen', $A A, 1997$, p. 71-81. 


\section{Verheij 2002}

Verheij, A.J., Vergoeding van immateriële schade wegens aantasting in de persoon (diss. Amsterdam VU), Nijmegen: Ars Aequi Libri, 2002.

\section{Verheij 2013a}

Verheij, A.J., 'Wil de Hoge Raad plegers van bijzonder ernstige normschendingen steviger aanpakken?', $A V \& S, 2013$, p. 3-4.

\section{Verheij 2013b}

Verheij, A.J., 'Immuniteiten in het burgerlijk recht: handhaven of aanpassen?', in: R.J.B. Schutgens et al., Immuniteiten. Het recht opzijgezet? Preadviezen Nederlandse Juristen-Vereniging, Deventer: Kluwer 2013.

\section{Verkerk 2010}

Verkerk, R., Fact-finding in Civil Litigation - A Comparative Perspective (diss. Maastricht), Antwerp: Intersentia, 2010.

\section{Vidmar 1999}

Vidmar, N., 'Juries Don't Make Legal Decisions! And Other Problems: A Critique of Hastie et al. on Punitive Damages', Law \& Hum Behav, 1999, p. 705-714.

\section{Vidmar et al. 2006}

Vidmar, N. et al., Brief of Neil Vidmar et al. as Amici Curiae in Support of Respondent, Philip Morris v. Williams, 127 S Ct 1057 (2007) (no. 05-1256).

\section{Vidmar \& Wolfe 2009}

Vidmar, N. \& Wolfe, M.W., 'Punitive Damages', Annu Rev Law Soc Sci, 2009, p. 179-199.

\section{Vidmar \& Holman 2010}

Vidmar, N. \& Holman, M., 'The Frequency, Predictability and Proportionality of Jury Awards of Punitive Damages in State Courts in 2005: A New Audit', Suffolk U L Rev, 2010, p. 855-895.

\section{Visscher 2005}

Visscher, L.T., Een rechtseconomische analyse van het Nederlandse onrechtmatigedaadsrecht (diss. Rotterdam), Den Haag: Boom Juridische uitgevers, 2005.

\section{Visscher 2009}

Visscher, L.T., 'Tort Damages', in: M.G. Faure (ed.), Tort Law and Economics, Cheltenham: Edward Elgar Publishing, 2009. 


\section{Visscher 2012}

Visscher, L.T., 'The Law and Economics of Punitive Damages', in: L. Meurkens \& E. Nordin (eds.), The Power of Punitive Damages - Is Europe Missing Out?, Antwerp: Intersentia, 2012.

\section{Von Bar 1996}

Von Bar, C., Gemeineuropäisches Deliktsrecht. Band I, Munich: Verlag C.H. Beck, 1996.

\section{Von Bar 1998}

Von Bar, C., The Common European Law of Torts, Vol. 1: The core areas of tort law, its approximation in Europe, and its accommodation in the legal system, Oxford: Oxford Clarendon Press, 1998.

\section{Von Bar 1999}

Von Bar, C., Gemeineuropäisches Deliktsrecht. Band II, Munich: Verlag C.H. Beck, 1999.

\section{Von Bar 2000}

Von Bar, C., The Common European Law of Torts, Vol. 2: Damage and damages, liability for and without personal misconduct, causality, and defences, Oxford: Oxford University Press, 2000.

\section{Von Bar 2009}

Von Bar, C., Principles of European Law. Non-Contractual Liability Arising out of Damage Caused to Another, Munich: Sellier European Law Publishers, 2009.

\section{Von Bar \& Clive 2009}

Von Bar, C. \& Clive, E. (eds.), Principles, Definitions and Model Rules of European Private Law. Draft Common Frame of Reference (DCFR), Volume 4, Munich: Sellier European Law Publishers, 2009.

\section{Von Bar \& Drobnig 2004}

Von Bar, C. \& Drobnig, U., The Interaction of Contract Law and Tort and Property Law in Europe - A Comparative Study, Munich: Sellier European Law Publishers, 2004.

\section{Von Mehren \& Murray 2007}

Von Mehren, A.T. \& Murray, P.L., Law in the United States, Cambridge: Cambridge University Press, 2007.

\section{Wagner 2005}

Wagner, G. (ed.), Tort Law and Liability Insurance, Vienna: Springer, 2005. 


\section{Wagner 2006a}

Wagner, G., Neue Perspektiven im Schadensersatzrecht - Kommerzialisierung, Strafschadensersatz, Kollektivschaden, Gutachten A zum 66. Deutschen Juristentag Stuttgart 2006, Munich: C.H. Beck, 2006.

\section{Wagner 2006b}

Wagner, G., 'Prävention und Verhaltenssteuerung durch Privatrecht - Anmaßung oder legitime Aufgabe?', AcP, 2006, p. 352-476

\section{Wagner 2012}

Wagner, G., 'Punitive Damages', in: J. Basedow, K.J. Hopt \& R. Zimmermann (eds.), The Max Planck Encyclopedia of European Private Law. Volume II, Oxford: Oxford University Press, 2012.

\section{Wansink 2006}

Wansink, J.H., De algemene aansprakelijkheidsverzekering, Deventer: Kluwer, 2006.

\section{Wells 2010}

Wells, M.L., 'A Common Lawyer's Perspective on the European Perspective on Punitive Damages', La L Rev, 2010, p. 557-578.

\section{Wester-Ouisse \& Thiede 2012}

Wester-Ouisse, V. \& Thiede, T., 'Punitive Damages in France: A New Deal?', JETL, 2012, p. 115-122.

\section{Weyts 2006}

Weyts, B., 'Lucratieve fouten in het aansprakelijkheids- en verzekeringsrecht. The winner takes it all', $R W, 2006$, p. 1641-1652.

\section{Weyts 2011}

Weyts, B., 'Punitieve elementen in het buitencontractueel aansprakelijkheidsrecht', in: J. Rozie, A. Van Oevelen \& S. Rutten (red.), Toetsing van Sancties door de Rechter, Antwerp: Intersentia, 2011.

\section{White 2003}

White, G.E., Tort Law in America - An Intellectual History, Oxford: Oxford University Press, 2003.

\section{White Paper 2008}

Commission White Paper on Damages Actions for Breach of the EC Antitrust Rules, COM (2008) 165. 


\section{Widiss 1994}

Widiss, A.I., 'Liability Insurance Coverage for Punitive Damages? Discerning Answers to the Conundrum Created by Disputes Involving Conflicting Public Policies, Pragmatic Considerations and Political Actions', Vill L Rev, 1994, p. 455-503.

\section{Wilcox 2009}

Wilcox, V., 'Punitive Damages in England', in: H. Koziol \& V. Wilcox (eds.), Punitive Damages: Common Law and Civil Law Perspectives, Vienna: Springer Verlag, 2009.

\section{Wils 2010}

Wils, W.P.J., 'The Increased Level of EU Antitrust Fines, Judicial Review, and the European Convention on Human Rights', WC, 2010, p. 5-29. Retrieved via: ssrn. com/author $=456087$.

\section{Wissink \& Van Boom 2001}

Wissink, M.H. \& Van Boom, W.H., 'Damages under Dutch Law', in: U. Magnus (ed.), Unification of Tort Law: Damages, The Hague: Kluwer Law International, 2001 .

\section{Wright 1995}

Wright, R.W., 'Right, Justice, and Tort Law', in: D.G. Owen (ed.), Philosophical Foundations of Tort Law, Oxford: Clarendon Press, 1995.

\section{Wurmnest 2012}

Wurmnest, W., 'Damages', in: J. Basedow, K.J. Hopt \& R. Zimmermann (eds.), The Max Planck Encyclopedia of European Private Law. Volume I, Oxford: Oxford University Press, 2012.

\section{Yeazell 2008}

Yeazell, S.C., Civil Procedure, New York: Aspen Law \& Business, 2008.

\section{Yeung 2006}

Yeung, K., 'Competition Law and the Public/Private Divide', in: M. Freedland \& J.-B. Auby (eds.), The Public Law/Private Law Divide, Oxford and Portland (OR): Hart Publishing, 2006.

\section{Zimmermann 1992}

Zimmermann, R., The Law of Obligations, Roman Foundations of the Civilian Tradition, Deventer: Kluwer, 1992.

\section{Zippro 2009}

Zippro, E.-J., Privaatrechtelijke Handhaving van Mededingingsrecht (diss. Leiden), Deventer: Kluwer, 2009. 


\section{Zipursky 2005}

Zipursky, B.C., 'A Theory of Punitive Damages', Tex L Rev, 2005, p. 105-171.

\section{Zipursky 2012}

Zipursky, B.C., 'Palsgraf, Punitive Damages, and Preemption', Harv L Rev, 2012, p. $1757-1797$.

\section{Zwalve 1995}

Zwalve, W.J., 'De autonomie van strafrecht en civiel recht', in: A.M. Hol \& C.J.J. M. Stolker (red.), Over de grenzen van strafrecht en burgerlijk recht, Deventer: Kluwer, 1995. 



\section{TABLE OF CASES}

\section{Courts of the United States}

\section{Federal Courts}

United States District Courts

Roginsky v. Richardson-Merrell, Inc., 254 F.Supp. 430 (D.C.N.Y. 1966) Filartiga v. Pena-Irala, 577 F.Supp. 860 (D.C.N.Y. 1984)

St. Paul Mercury Ins. Co. v. Duke University, 670 F.Supp. 630 (M.D.N.C. 1987) McBride v. General Motors Corp., 737 F.Supp. 1563 (M.D.Ga. 1990) Xuncax v. Gramajo, 886 F.Supp. 162 (D.Mass. 1995)

Engle v. R.J. Reynolds, 122 F.Supp.2d 1355 (S.D.Fla. 2000)

Todd v. Roadway Exp., Inc., 178 F.Supp.2d 1244 (M.D.Ala. 2001)

Varboncoeur v. State Farm Fire and Cas. Co., 356 F.Supp.2d 935 (S.D.Iowa 2005)

Ray v. Allergan, Inc., 863 F.Supp.2d 552 (E.D.Va. 2012)

United States Courts of Appeals

United States v. Carroll Towing Co., 159 F.2d 169 (C.A.2 1947)

Northwestern Nat. Cas. Co. v. McNulty, 307 F.2d 432 (C.A.Fla. 1962)

Roginsky v. Richardson-Merrell, Inc. (appeal), 378 F.2d 832 (C.A.N.Y. 1967)

Globus v. Law Research Service, Inc., 418 F.2d 1276 (C.A.N.Y. 1969)

deHaas v. Empire Petroleum Co., 435 F.2d 1223 (C.A.Colo. 1970)

David by Berkeley v. Pueblo Supermarket of St. Thomas, 740 F.2d 230 (C.A. Virgin Islands 1984)

Transgo, Inc. v. Ajac Transmission Parts Corp., 768 F.2d 1001 (C.A.9 1985)

McKinnon v. Kwong Wah Restaurant, 83 F.3d 498 (C.A.1 (Me.) 1996)

Kemezy v. Peters, 79 F.3d 33 (C.A.7 (Ind.) 1996)

F.T.C. v. Febre, 128 F.3d 530 (C.A.7 (Ill.) 1997)

Thorne v. Welk Inv., Inc., 197 F.3d 1205 (C.A.8 (Mo.) 1999)

Arizona v. Asarco Llc, 733 F.3d 882 (C.A.9 (Ariz.) 2013)

United States Supreme Court

The Amiable Nancy, 16 U.S. 546, 1818 WL 2445 (U.S.N.Y. 1818)

Day v. Woodworth, 54 U.S. 363, 1851 WL 6684 (U.S. Mass. 1851)

Missouri Pac. Ry. Co. v. Humes, 115 U.S. 512, 6 S.Ct. 110 (U.S. 1885)

Gertz v. Robert Welch, Inc., 418 U.S. 323, 94 S.Ct. 2997 (U.S.Ill. 1974)

Aetna Life Ins. Co. v. Lavoie, 475 U.S. 813, 106 S.Ct. 1580 (U.S. Ala. 1986)

Pennzoil Co. v. Texaco, Inc., 481 U.S. 1, 107 S. Ct. 1519 (U.S.N.Y. 1987)

Bankers Life and Cas. Co. v. Crenshaw, 486 U.S. 71, 108 S.Ct. 1645 (U.S. 1988) 
Browning-Ferris Industries of Vermont, Inc. v. Kelco Disposal, Inc., 492 U.S. 257, 109 S.Ct. 2909 (U.S.Vt. 1989)

United States v. Halper, 490 U.S. 435, 109 S.Ct. 1892 (U.S.N.Y. 1989)

Pacific Mut. Life Ins. Co. v. Haslip, 499 U.S. 1, 111 S.Ct. 1032 (U.S.Ala. 1991) TXO Production Corp. v. Alliance Resources Corp., 509 U.S. 443, 113 S.Ct. 2711 (U.S.W.Va. 1993)

Honda Motor Co., Ltd. v. Oberg, 512 U.S. 415, 114 S.Ct. 2331 (U.S.Or. 1994) BMW of North America, Inc. v. Gore, 517 U.S. 559, 116 S.Ct. 1589 (U.S.Ala. 1996)

Hudson v. United States, 522 U.S. 93, 118 S.Ct. 488 (U.S.Okl. 1997)

Cooper Industries, Inc. v. Leatherman Tool Group, Inc., 532 U.S. 424, 121 S.Ct. 1678 (U.S.Or. 2001)

State Farm Mut. Auto. Ins. Co. v. Campbell, 538 U.S. 408, 123 S.Ct. 1513 (U.S. 2003)

Philip Morris USA v. Williams, 549 U.S. 346, 127 S.Ct. 1057 (U.S.Or. 2007) (Philip Morris)

Exxon Shipping Co. v. Baker, 554 U.S. 471, 128 S.Ct. 2605 (U.S. 2008)

Philip Morris USA Inc. v. Williams, 556 U.S. 178 (U.S. Or. 2009)

National Federation of Independent Business v. Sebelius, 132 S.Ct. 2566 (U.S. 2012)

State Courts

State Trial Courts

Genay v. Norris, 1 Bay 6, 1 S.C.L. 6, 1784 WL 26 (S.C. Com. Pl. Gen. Sess. 1784) Liebeck v. McDonald's Restaurants, P.T.S., Inc., 1995 WL 360309 (N.M. Dist. 1994)

Cynthia Robinson v. R.J. Reynolds Tobacco Co., 2008 CA 000098 (Fla. 2014)

State Courts of Appeals

Wisner v. S.S. Kresge Co., 465 S.W.2d 666 (Mo.App. 1971)

Runyon v. Superior Court, 187 Cal.App.3d 878 (Cal.App.4.Dist. 1986)

City of Los Angeles v. Shpegel-Dimsey, Inc., 198 Cal.App.3d 1009 (Cal.App.2. Dist. 1988)

Ellerin v. Fairfax Sav., F.S.B., 337 Md. 216, 652 A.2d 1117 (Md. 1995)

Barton v. Chicago and North Western Transp. Co., 325 Ill.App.3d 1005, 757 N.E.2d 533, 258 Ill.Dec. 844 (Ill.App. 1 Dist. 2001)

Seitzinger v. Trans-Lux Corp., 40 P.3d 1012 (N.M.App. 2001)

State Supreme Courts

Coryell v. Colbaugh, 1 N.J.L. 77, 1791 WL 380 (N.J. 1791)

Fay v. Parker, 53 N.H. 342, 1872 WL 4394 (N.H. 1872)

Bass v. Chicago \& N.W. Ry. Co., 42 Wis. 654, 1877 WL 7100 (Wis. 1877)

Wise v. Daniel, 221 Mich. 229, 190 N.W. 746 (Mi. 1922)

Escola v. Coca Cola Bottling Co. of Fresno, 24 Cal.2d 453, 150 P.2d 436 (CA. 1944) 
Greenman v. Yuba Power Products, Inc., 59 Cal.2d 57, 377 P.2d 897, 27 Cal.Rptr. 697 (CAL. 1963)

Lazenby v. Universal Underwriters Ins. Co., 18 McCanless 639, 214 Tenn. 639, 383 S.W.2d 1 (Tenn. 1964)

Beggs v. Universal C.I.T. Credit Corp., 409 S.W.2d 719 (Mo. 1966)

Montoya v. Moore, 77 N.M. 326, 422 P.2d 363 (N.M. 1967)

City of Minneapolis v. Richardson, 307 Minn. 80, 239 N.W.2d 197 (MINN 1976)

Wangen v. Ford Motor Co., 97 Wis.2d 260, 294 N.W.2d 437 (Wis. 1980)

Gryc v. Dayton-Hudson Corp., 297 N.W.2d 727 (Minn. 1980)

Sieben v. Sieben, 231 Kan. 372, 646 P.2d 1036 (Kan. 1982)

Freeman v. Anderson, 279 Ark. 282, 651 S.W.2d 450 (Ark. 1983)

Micari v. Mann, 126 Misc.2d 422, 481 N.Y.S.2d 967 (N.Y.Sup. 1984)

Tuttle v. Raymond, 494 A.2d 1353 (Me. 1985)

Fernandez v. Curley, 463 N.W.2d 5 (Iowa 1990)

Honeywell v. Sterling Furniture Co., 310 Or. 206, 797 P.2d 1019 (Or. 1990)

Kirk v. Denver Pub. Co., 818 P.2d 262 (Colo. 1991)

Hodges v. S.C. Toof \& Co., 833 S.W.2d 896 (Tenn. 1992)

Gordon v. State, 608 So.2d 800 (Fla. 1992)

Hopewell Enterprises, Inc. v. Trustmark Nat. Bank, 680 So.2d 812 (Miss. 1996)

Ford v. Uniroyal Goodrich Tire Co., 267 Ga. 226, 476 S.E.2d 565 (Ga. 1996)

Fust v. Attorney General for the State of Mo., 947 S.W.2d 424 (Mo. 1997)

Life Ins. Co. of Georgia v. Johnson, 701 So.2d 524 (Ala. 1997)

Farmers Ins. Exchange v. Shirley, 958 P.2d 1040 (Wyo. 1998)

Alexander v. Meduna, 47 P.3d 206 (Wyo. 2002)

Dardinger v. Anthem Blue Cross \& Blue Shield, 98 Ohio St.3d 77, 781 N.E.2d 121

(Ohio 2002)

Evans ex rel. Kutch v. State, 56 P.3d 1046 (Alaska 2002)

DeMendoza v. Huffman, 334 Or. 425, 51 P.3d 1232 (Or. 2002)

Cheatham v. Pohle, 789 N.E.2d 467 (Ind. 2003)

Williams v. Philip Morris Inc., 340 Or. 35, 127 P.3d 1165 (Or. 2006)

Williams v. Philip Morris Inc., 344 Or. 45, 176 P.3d 1255 (Or. 2008) (on remand) Williams v. RJ Reynolds Tobacco Co., 351 Or. 368, 271 P.3d 103 (Or. 2011)

Aleo v. SLB Toys USA, Inc., 466 Mass. 398, 2013 WL 4849097 (Mass. 2013)

\section{Courts of the Netherlands}

\section{Rechtbanken}

Rb. Amsterdam 28 juni 2000, NJ 2000/621

Rb. 's-Hertogenbosch 7 november 2003, NJF 2004/34

Rb. 's-Gravenhage 26 oktober 2005, NJF 2006/33

Rb. Utrecht 17 januari 2006, NJF 2006/131

Rb. Arnhem 29 maart 2006, NJF 2006/252

Rb. 's-Hertogenbosch 11 april 2007, JA 2007/99

Rb. Arnhem 16 mei 2007, NJF 2007/367

Rb. Groningen 5 december 2007, NJF 2008/62 
Rb. Utrecht 28 april 2010, ECLI:NL:RBUTR:2010:BM2510

Rb. Utrecht 8 februari 2012, ECLI:NL:RBUTR:2012:BW1631

\section{Gerechtshoven}

Hof Amsterdam 13 september 1990, NJ 1991/334

Hof Arnhem 7 december 1999, VR 2000/90

Hof Amsterdam 1 juni 2006, NJ 2006/461 (DES)

Hof Amsterdam 25 januari 2007, NJ 2007/427 (Dexia)

Hof Amsterdam 31 mei 2007, NJF 2007/348

Hof 's-Gravenhage 24 februari 2009, NJ 2010/55, m.nt. E.A. Alkema

Hof Amsterdam 29 april 2009, NJ 2009/448 (Vie d'Or)

Hof Arnhem 26 mei 2009, NJF 2009/311

Hof Amsterdam 29 mei 2009, NJ 2009/506 (Shell)

Hof Amsterdam 15 juli 2009, JOR 2009/325 (Vedior)

Hof 's-Gravenhage 30 augustus 2011, ECLI:NL:GHSGR:2011:BS8801

Hof Amsterdam 17 januari 2012, NJ 2012/355 (Converium)

\section{Hoge Raad der Nederlanden}

HR 5 november 1965, NJ 1966/136, m.nt. G.J. Scholten (Kelderluik)

HR 30 mei 1975, NJ 1976/572, m.nt. B. Wachter

HR 30 oktober 1987, NJ 1988/277, m.nt. LWH

HR 1 november 1991, NJ 1992/58 (K/Staat)

HR 8 juli 1992, NJ 1992/714 (HIV-besmetting)

HR 24 december 1993, NJ 1995/421, m.nt. C.J.H. Brunner

HR 11 februari 2000, NJ 2000/275, m.nt. Bos

HR 17 november 2000, NJ 2001/215, m.nt. ARB (Druijff/B.C.E. Bouw)

HR 27 april 2001, NJ 2002/91, m.nt. C.J.H. Brunner

HR 26 oktober 2001, NJ 2002/216, m.nt. J.B.M. Vranken (Oogmerkarrest)

HR 22 februari 2002, NJ 2002/240, m.nt. J.B.M. Vranken (Taxibus)

HR 20 september 2002, NJ 2004/112, m.nt. J.B.M. Vranken (Coma)

HR 9 juli 2004, NJ 2005/391, m.nt. JBMV (Groninger Oudejaarsrellen)

HR 14 januari 2005, NJ 2007/481, m.nt. Jac. Hijma

HR 16 juni 2006, NJ 2006/585, m.nt. J.H. Spoor

HR 27 april 2007, NJ 2007/262

HR 5 december 2008, NJ 2009/387, m.nt. J.B.M. Vranken

HR 9 oktober 2009, NJ 2010/387, m.nt. J.B.M. Vranken (Vilt)

HR 18 juni 2010, RvdW 2010/771 (Doerga/Ymere)

HR 18 juni 2010, RvdW 2010/772 (Setel/AVR)

HR 16 september 2011, NJ 2012/56, m.nt. T.F.E. Tjong Tjin Tai

HR 15 juni 2012, NJ 2012/394

HR 29 juni 2012, NJ 2012/410 (Blauw oog)

HR 13 juli 2012, NJ 2012/459 


\section{Courts of Germany}

\section{Landgerichte}

LG Kiel 11 July 2003, AZ O 13/03

\section{Oberlandesgerichte}

OLG Hamburg 25 July 1996, NJW 1996, 2870

OLG Nürnberg, 30 April 1997, NJWE-VHR 1997, 179

OLG Frankfurt, 7 January 1999, NJW 1999, 2447

OLG Naumburg, 13 November 2003, NJOZ 2004, 1659

OLG Nürnberg, 22 December 2006, NZV 2007, 301

\section{Bundesgerichtshof}

BGH 25 May 1954, BGHZ 13, 334 (Schacht)

BGH 24 June 1955, BGHZ 17, 376

BGH 6 July 1955, BGHZ 18, 149

BGH 14 February 1958, BGHZ 26, $349=$ NJW 58, 827 (Herrenreiter)

BGH 19 September 1961, BGHZ 35, 363 (Ginseng)

BGH 10 March 1972, BGHZ 59, 286

BGH 4 June 1992, BGHZ 118, 312

BGH 15 November 1994, BGHZ 128, 1 = NJW 1995, 861 (Caroline I)

BGH, NJW 1996, 984 (Caroline II)

BGH, NJW 1996, 1128; BGHZ 131, 332 (Caroline III)

BGH, NJW 1996, 985 (Caroline's son)

BGH 8 May 2000, NJW-RR 2000, S. 1372f., 1372

Bundesverfassungsgericht

BVerfG 8 March 2000, NJW 2000, 2187

\section{Courts of France}

\section{Cours d'Appel}

Cour d'Appel de Paris, Première chambre civile, 26 avril 1983, D. 1983, 376

Cour d'Appel de Paris, Première chambre civile, 17 décembre 1986, Gaz. Pal. 1987, I, 238 (Henri d'Orléans v. Filipacchi)

Cour d'Appel de Paris, Première chambre civile, 4 janvier 1988, D. 1989, 92 (S.A.R.L. Editions des savanes v. Mme B.)

Cour d'Appel de Poitiers, Première chambre civile, 26 février 2009, 07/02404

Cour de cassation

Cour de cassation, Deuxième chambre civile, 8 mai 1964 (Harang-Martin v. Bonneau)

Cour de cassation, Première chambre civile, 5 novembre 1996, JCP G. 1997, II, 22805 
Cour de cassation, Première chambre civile, 1 décembre 2010, 09/13303 (Fountaine Pajot)

\section{Her Majesty's Courts of Justice of England and Wales}

Court of King's Bench

Wilkes v. Wood [1763] 98 ER 489

Huckle v. Money [1763] 95 ER 768

Benson v. Frederick [1766] 97 ER 1130

High Courts of Justice

Treadaway v. Chief Constable of the West Midlands [1994] WL 1063421 (QB)

KD v. Chief Constable of Hampshire, John Hull [2005] EWHC 2550 (QB)

Courts of Appeal

Perera v. Vandiyar [1953] 1 WLR 672

Halford v. Brookes [1991] 1 WLR 428

Sutcliffe v. Pressdram Ltd. [1991] 1 QB 153

A.B. and Others v. South West Water Services Ltd. [1993] QB 507

Rantzen v. Mirror Group Newspapers Ltd. and Others [1994] QB 670

John v. MGN Ltd. [1997] QB 586

Thompson v. Commissioner of Police of the Metropolis [1998] QB 498

Supreme Court of the United Kingdom

Addis v. Gramophone Co. Ltd. [1909] AC 488

Rookes v. Barnard and Others [1964] AC 1129

Cassell \& Co. Ltd. v. Broome [1972] AC 1027

Macfarlane v. Tayside Health Board [2000] 2 AC 59

Kuddus v. Chief Constable of Leicestershire Constabulary [2002] 2 AC 122

\section{Courts of Italy}

Tribunale di Torre Annuziata

Tribunale di Torre Annunziata, Sezione Stralcio, 24 febbraio 2000

Tribunale di Torre Annunziata, Sezione Stralcio, 14 marzo 2000

Corte Suprema di Cassazione

Corte di Cassazione, 19 gennaio 2007, 1183, affirming Corte di Appello di Venezia, 15 ottobre 2001, 1359, Giur. It., II, 2002, 1021

\section{Courts of Poland}

Supreme Court of the Republic of Poland

Supreme Court Poland, 8 March 2012, V CSK 102/11 


\section{Courts of Spain}

\section{Tribunal Supremo}

Tribunal Supremo, 13 noviembre 2001, Exequátur No. 2039/1999 (Miller Import Corp. v. Alabastres Alfredo, S.L.)

\section{Courts of Switzerland}

Zivilgerichte

Zivilgericht Basel-Stadt, 1 February 1989, BJM 1991, 31 (S.F. Inc. v. T.C.S. AG)

\section{Benelux Court of Justice}

BenGH 24 oktober 2005, A 2004/5, NJ 2006/442

\section{Court of Justice of the European Union}

CJEU 5 February 1963, case 26/62, ECR 1 (Van Gend en Loos NV Algemene Transport- en Expeditie Onderneming v. Nederlandse Administratie der Belastingen) CJEU 10 April 1984, case 14/83, ECR 1891 (Von Colson and Kamann v. Land Nordrhein-Westfalen)

CJEU 10 April 1984, case 79/83, ECR 1921 (Harz v. Deutsche Tradax GmbH) CJEU 21 September 1989, case 68/88, ECR 2965 (Commission v. Greece)

CJEU 19 June 1990, case C-213/89, ECR I-2433 (R. v. Secretary of State for Transport, ex parte: Factortame Ltd. and Others) (Factortame I)

CJEU 8 November 1990, case C-177/88, ECR I-3941 (Dekker v. Stichting Vormingscentrum voor Jong Volwassenen)

CJEU 13 March 1991, case C-377/89, ECR I-1155 (Cotter and McDermott v. Minister for Social Welfare and Attorney General)

CJEU 25 July 1991, case C-208/90, ECR I-4269 (Emmott v. Minister for Social Welfare and the Attorney General)

CJEU 19 November 1991, joined cases C-6/90 and C-9/90, ECR I-5357 (Francovich and Bonifaci v. Italy)

CJEU 2 August 1993, case C-271/91, ECR I-4367 (Marshall v. Southampton and South West Hampshire Area Health Authority)

CJEU 5 March 1996, joined cases C-46/93 and C-48/93, ECR I-1029 (Brasserie du pêcheur SA v. Germany and R. v. Secretary of State for Transport, ex parte: Factortame Ltd. and Others (Factortame III))

CJEU 22 April 1997, case C-180/95, ECR I-2195 (Nils Draehmpaehl v. Urania Immobilienservice $\mathrm{OHG}$ )

CJEU 8 March 2001, joined cases C-397/98 and C-410/98, ECR I-1727 (Metallgesellschaft and Hoechst v. Commissioners of Inland)

CJEU 20 September 2001, case C-453/99, ECR I-6297 (Courage Ltd. v. Crehan)

CJEU 10 January 2006, case C-344/04, ECR I-0403 (IATA and ELFAA) 
CJEU 13 July 2006, joined cases C-295/04 to C-298/04, ECR I-6619 (Manfredi and Others)

CJEU 17 September 2007, case T-201/04, ECR II-3601 (Microsoft Corp. v. Commission)

CJEU 8 July 2008, case T-99/04, ECR II-1501 (AC-Treuhand AG v. Commission) CJEU 23 April 2009, joined cases C-378/07 to C-380/07, ECR I-3071 (Kiriaki Angelidaki and Others).

CJEU 19 November 2009, joined cases C-402/07 and C-432/07, ECR I-10923 (Sturgeon and Others)

CJEU 14 June 2011, case C-360/09, ECR I-05161 (Pfleiderer AG v. Bundeskartellamt)

CJEU 18 October 2011, case C-406/09, ECR I-09773 (Realchemie Nederland BV v. Bayer CropScience $A G$ )

CJEU 27 June 2012, case T-167/08, not yet published (Microsoft Corp. v. Commission II)

CJEU 23 October 2012, joined cases C-581/10 and C-629/10, not yet published (Nelson and Others v. Deutsche Lufthansa AG and TUI Travel and Others v. Civil Aviation Authority)

CJEU 6 June 2013, case C-536/11, not yet published (Bundeswettbewerbsbehörde v. Donau Chemie AG and Others)

CJEU 11 September 2014, case C-565/12, not yet published (LCL Le Crédit Lyonnais SA v. Fesih Kalhan)

\section{European Court of Human Rights}

ECtHR 8 June 1976, Engel and Others v. The Netherlands, no. 5100/71, 5101/71, 5102/71, 5354/72, 5370/72

ECtHR 27 February 1980, Deweer v. Belgium, no. 6903/75

ECtHR 25 March 1983, Minelli v. Switzerland, no. 8660/79

ECtHR 24 October 1983, Silver and Others v. The United Kingdom, no. 5947/72, 6205/73, 7052/75; 7061/75; 7107/75; 7113/75; 7136/75

ECtHR 21 February 1984, Öztürk v. Germany, no. 8544/79

ECtHR 24 February 1994, Bendenoun v. France, no. 12547/86

ECtHR 13 July 1995, Miloslavsky v. The United Kingdom, no. 18139/91

ECtHR 16 September 1996, Gaygusuz v. Austria, no. 17371/90

ECtHR 25 September 1997, Aydin v. Turkey, no. 23178/94

ECtHR 1 April 1998, Akdivar and Others v. Turkey, no. 21893/93

ECtHR 24 April 1998, Selçuk and Asker v. Turkey, nos. 23184/94 and 23185/94

ECtHR 24 July 1998, Menteş and Others v. Turkey, no. 23186/94

ECtHR 18 February 1999, Hood v. The United Kingdom, no. 27267/95

ECtHR 21 May 2003, Janosevic v. Sweden, no. 34619/97

ECtHR 10 February 2004, B.B. v. The United Kingdom, no. 53760/00

ECtHR 24 June 2004, Von Hannover v. Germany, no. 59320/00

ECtHR 27 July 2004, Ikincisoy v. Turkey, no. 26144/95

ECtHR 25 October 2005, Blake v. The United Kingdom, no. 68890/01 
ECtHR 26 September 2006, Wainwright v. the United Kingdom, no. 12350/04 ECtHR 23 November 2006, Jussila v. Finland, no. 73053/01

ECtHR 18 September 2009, Varnava and Others v. Turkey, nos. 16064/90, 16065/ 90, 16066/90, 16068/90, 16069/90, 16070/90, 16071/90, 16072/90 and 16073/90 ECtHR 23 November 2010, Greens and M.T. v. the United Kingdom, nos. 60041/ 08 and $60054 / 08$

ECtHR 7 February 2012, Von Hannover v. Germany (no. 2), nos. 40660/08 and 60641/08

ECtHR 19 June 2012, Krone Verlag GMBH v. Austria, no. 27306/07

ECtHR 23 October 2012, Hadzhiev v. Bulgaria, no. 22373/04

ECtHR 25 June 2013, Trévalec v. Belgium, no. 30812/07

ECtHR 3 June 2014, López Guió v. Slovakia, no. 10280/12

\section{Inter-American Court of Human Rights}

Myrna Mack-Chang v. Guatemala (2003) 101 Inter-Am.Ct.H.R (ser. C) 



\section{CURRICULUM VITAE}

Lotte Meurkens was born on 30 August 1982 in Tilburg, the Netherlands. She attended grammar school at the Stedelijk Gymnasium in Breda, the Netherlands. In September 2001, she started studying law at Utrecht University, where she joined the editorial board of the faculty journal Juncto and passed her propaedeutic exam in July 2002. While continuing her studies at Maastricht University (September 2002 - July 2008), she was an intern at a first instance court and a law firm, and obtained master of laws degrees in European law and Dutch private law. After graduation until September 2012, Lotte worked as a junior researcher at the private law department of Maastricht University. Besides writing her dissertation under supervision of professor Hartlief and professor Van Maanen, she taught courses in Dutch and European private law, was a member of the Ius Commune Research School, and was co-editor of 'The Power of Punitive Damages - Is Europe Missing Out?' (Antwerp: Intersentia, 2012). From January 2009 until August 2011, she was editorial secretary of the Dutch Journal of Civil Law (Nederlands Tijdschrift voor Burgerlijk Recht). In 2009 and 2011, she was a visiting researcher at three law schools in the United States (University of South Carolina, Duke University North Carolina, and Yeshiva University New York). Since September 2013, Lotte has worked as a private law teacher and researcher at Maastricht University. 
